\title{
Geotechnical analysis of large volcanic landslides: The La Orotava events on Tenerife, Canary Islands.
}

\author{
A dissertation submitted to the \\ TECHNICAL UNIVERSITY OF CATALONIA \\ for the degree of \\ Doctor of Sciences (Geologic)
}

presented by

Marcel Hürlimann

\begin{abstract}
Supervisors:
Dr. A. Ledesma

Dep. of Geotechnical Engineering and Geosciences, Technical University of Catalonia Dr. J. Martí

Institute of Earth Sciences 'Jaume Almera', Spanish Research Council
\end{abstract}

\author{
Barcelona
}

October, 1999 


\title{
Geotechnical analysis of large volcanic landslides: The La Orotava events on Tenerife, Canary Islands.
}

\author{
Marcel Hürlimann
}

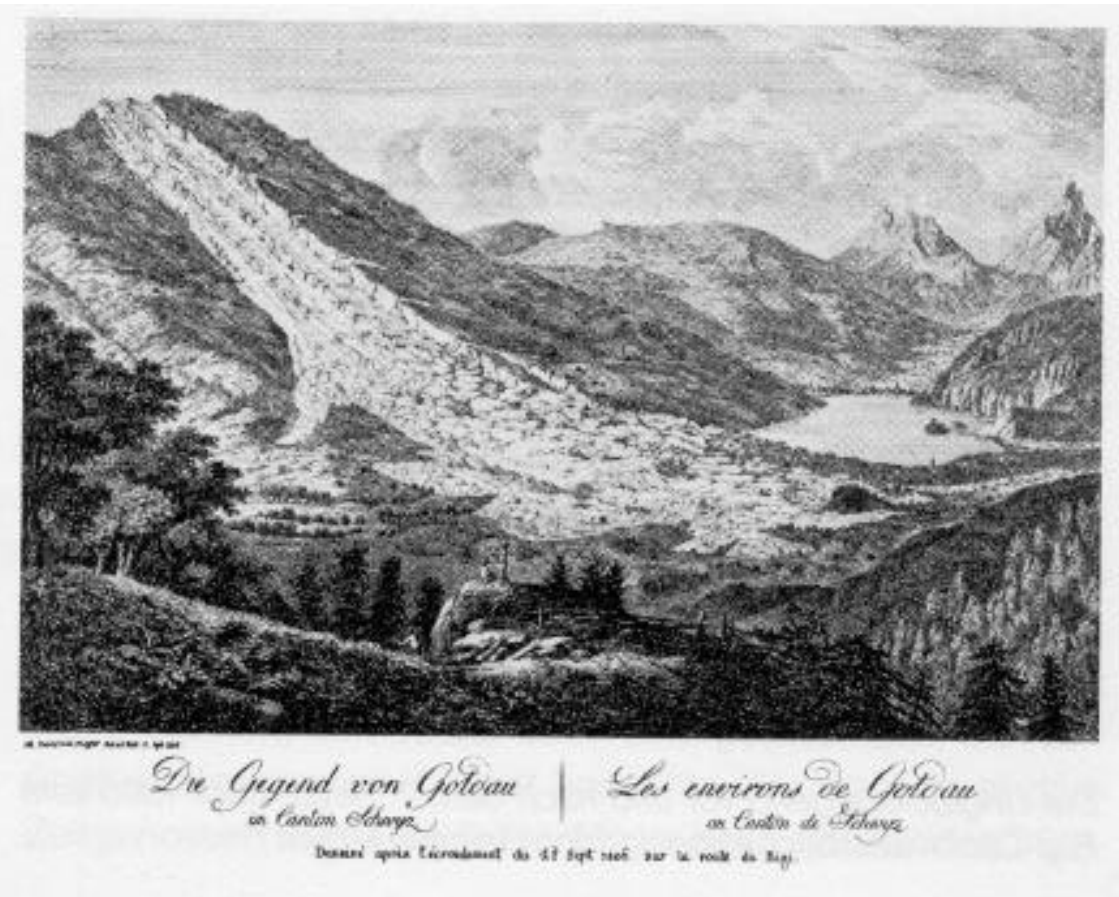

"Getöse, Krachen und Geprassel erfüllt wie tief brüllender Donner die Luft - erschüttert jedes lebende Ohr und Herz, und tönt im Wiederhall von tausend Bergesklüften noch grässlicher."

Schuttbuch des Goldauer Bergsturzes (Dr. Karl Zay, 1807) 


\section{ACKNOWLEDGEMENTS}

This study was supervised by Alberto Ledesma from the Department of Geotechnical Engineering and Geosciences, School of Civil Engineering, 'Universitat Politècnica de Catalunya' (UPC) and Joan Martí from the Institute of Earth Sciences 'Jaume Almera', Spanish Research Council (CSIC). I owe many thanks to them and my Ph.D. would not have been the same without their continuous support and encouragement. To combine the ideas of an engineer and a volcanologist was not always easy, but the inter-disciplinary structure certainly improved the results of this work.

I am very grateful to many people at the Department of Geotechnical Engineering and Geosciences (UPC) and the Institute of Earth Sciences 'Jaume Almera' (CSIC) who helped me in various ways.

Special thanks to Antonio Lloret, Tomás Pérez and José Álvarez who introduced me into the design and handling of the apparatuses of the geotechnical laboratory and to Ignasi Queralt who carried out the $\mathrm{X}$-ray analyses.

I want to extend my thanks to the many colleagues who joined me during the Ph.D. including Silvia Zafrilla, Arnau Folch, Carles Soriano, Elisenda Turon, Dioni Cendon, Giray Ablay, Fernando Resta and François Legros at the CSIC and Joan Rius, Mauricio Barrera, Luciano Costa and José Moya at the UPC.

Special thanks are due to Josep-Oriol García for his contribution to the mobility analysis and laboratory work.

José-Manuel Navarro and the staff of the 'Consejo Insular de Aguas del CABILDO Tenerife' are appreciated for facilitating the visits of some water tunnels on the island and giving many useful hints on the underground geology around the La Orotava valley.

Luis García-Cacho is thanked for many helpful discussions on volcanic landslides and making the bathymetric and topographic data available. Francisca Gómez is acknowledged the preparation of some GIS data.

This study was supported by several financial sources. In the first place, I acknowledge to the Swiss National Science Foundation and also to the Spanish Research Council (CSIC) / the Swiss Federal Institute of Technology Zurich for paying my salary and travelling expenses. Additional help came from the Werner Steiger Foundation and the EC contract EV5V-CT-0283 / the CICYT project AMB960498-C04.

I would also like to express gratitude to my parents Karl and Ida and to my brothers Stefan and Guido who motivated my university education and assisted me generously. To my beloved Nieves, all my thankfulness for her faith in me and unconditioned support. 


\section{TABLE OF CONTENTS}

ABSTRACT vii

LIST OF FIGURES viii

LIST OF TABLES X xii

1 INTRODUCTION 1

1.1 Hazards from large volcanic landslides 1

1.2 Problem 1

1.3 Test site 2

1.4 Goals 2

1.5 Thesis structure 3

2 STATE OF THE ART

2.1 Terminology of mass movements 5

$\begin{array}{ll}2.2 & \text { Examples of large landslides }\end{array}$

2.3 Causes of large landslides $\quad 11$

$\begin{array}{lll}\text { 2.3.1 Non-volcanic factors } & 13\end{array}$

Morphologic factors 13

Geologic factors 13

Hydrologic and hydrogeological factors $\quad 14$

Sea level changes $\quad 14$

Tectonic seismicity 14

$\begin{array}{ll}\text { 2.3.2 Volcanic factors } & 16\end{array}$

Explosive eruptions 17

Dike intrusion $\quad 17$

Caldera collapse episode 18

Volcanic seismicity 19

Hydrothermal activity 21

Stress regime 22

$\begin{array}{lll}\text { 2.3.3 Geotechnical considerations } & 23\end{array}$

Progressive failure 23

Undrained loading $\quad 24$

3 SITE INVESTIGATION 25

3.1 Introduction 25

3.2 The Canary Islands $\quad 26$

3.3 Tenerife Island 31

$\begin{array}{lll}\text { 3.3.1 Geological evolution } & 32\end{array}$

\begin{tabular}{ll} 
3.3.2 & Morphologic features \\
\hline
\end{tabular}

$\begin{array}{lll}3.3 .3 & \text { Volcanic activity } & 36\end{array}$

$\begin{array}{lll}3.4 & \text { Geomorphologic analysis } & 38\end{array}$

$\begin{array}{lll}3.4 .1 & \text { Tenerife Island } & 39\end{array}$

3.4.2 Northern flank of Tenerife 41

3.4.3 The La Orotava valley area 47

$\begin{array}{lll}3.5 & \text { Geologic analysis } & 65\end{array}$

$\begin{array}{lll}3.6 & \text { Assumed preslide conditions } & 77\end{array}$

$\begin{array}{lll}3.7 & \text { Conclusions } & 79\end{array}$ 
$\begin{array}{llr}4.1 & \text { Introduction } & 83\end{array}$

4.2 Methodology 86

4.2.1 Sampling $\quad 86$

4.2.2 Analysis of mineralogy, chemistry and microstructure 94

$\begin{array}{ll}\text { 4.2.3 Geotechnical analysis } & 94\end{array}$

Soil characterisation 95

Consolidation tests 95

Direct shear test 96

Ring shear test 99

Triaxial test 99

$\begin{array}{lll}4.3 & \text { Results } & 102\end{array}$

4.3.1 Analysis of mineralogy, chemistry and microstructure 102

Mineralogical and chemical analysis $\quad 102$

Microstructure 108

4.3.2 Geotechnical tests 113

Soil characterisation $\quad 113$

Consolidation tests $\quad 115$

Direct shear tests $\quad 120$

Ring shear test 131

Triaxial tests 132

$\begin{array}{llr}4.4 \text { Conclusions } & 148\end{array}$

5 STABILITY ANALYSIS

5.1 Introduction 151

$\begin{array}{lll}5.2 & \text { Mechanisms applied } & 152\end{array}$

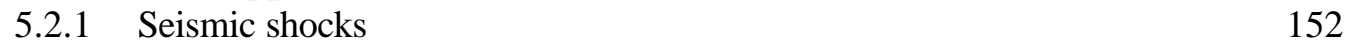

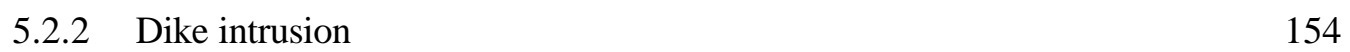

5.2.3 Caldera collapse event 155

$\begin{array}{llr}5.3 & \text { Approaches } & 155\end{array}$

5.3.1 Global limit analysis 155

Limit Equilibrium Method 156

Upper Bound Method $\quad 159$

$\begin{array}{ll}\text { 5.3.2 Continuum analysis } & 161\end{array}$

Finite Difference Method 162

Finite Element Method 163

$\begin{array}{lll}5.4 & \text { Model description } & 164\end{array}$

$\begin{array}{lll}\text { 5.4.1 Global limit analysis } & 165\end{array}$

$\begin{array}{ll}5.4 .2 \text { Continuum analysis } & 167\end{array}$

$\begin{array}{llr}5.5 & \text { Results } & 169\end{array}$

$\begin{array}{lll}\text { 5.5.1 Global limit analysis } & 170\end{array}$

Limit Equilibrium Method $\quad 170$

Upper Bound Method 177

$\begin{array}{ll}\text { 5.5.2 Continuum analysis } & 182\end{array}$

Finite Difference Method 182

Finite Element Method 183

$\begin{array}{llr}5.6 \text { Conclusions } & 190\end{array}$ 
6 MOBILITY ANALYSIS 193

$\begin{array}{llr}6.1 & \text { Introduction } & 193\end{array}$

$\begin{array}{lll}6.2 & \text { Model description } & 195\end{array}$

$\begin{array}{lll}6.3 & \text { Results } & 197\end{array}$

$\begin{array}{lll}6.4 & \text { Conclusions } & 200\end{array}$

7 CONCLUSIONS 201

8 REFERENCES 205

APPENDIX 1: PUBLICATIONS ARISING FROM THIS THESIS 219 


\section{ABSTRACT}

Large volcanic landslides are one of the most hazardous of geological processes. They have occurred about once every 25 years during the last 500 years, and are a serious risk for the population due to their great volume and mobility. In spite of their destructive potential there are few comprehensive studies analysing large landslides on volcano flanks, and the mechanisms of such mass movements are not yet resolved. Within the last few years, several hypotheses concerning the potential causes of volcanic landslides have been proposed including processes such as dike intrusion, volcanic spreading, hydrothermal alteration, seismic shocks and caldera collapse events.

Tenerife exhibits three large subaerial valleys originated by giant flank failures with ages ranging from Upper Pliocene to Middle Pleistocene. The northern submarine flank of the island is characterised by a voluminous apron of landslide debris. The La Orotava valley has been selected for analysis due to the amount of available data concerning its structure and evolution, and has been used as a test site to validate new assumptions that could be applied to other volcanic areas.

The site investigation has revealed that the present morphology of the La Orotava valley was formed by two different failures: one in the western sector and the other in the eastern sector. The mechanical stability of the preslide volcano flank was strongly reduced by geologic, morphologic, climatic and volcanological factors which play a fundamental role in the initiation of the landslides. Widespread residual soils (paleosols) might have acted as potential slip surfaces, while deep erosive canyons probably evolved into the lateral limits of the failures. A high coastal cliff and a humid climate have also contributed to the critical stability conditions. The location of the landslide amphitheatre is perpendicular to the active Dorsal rift zone and adjacent to the Las Cañadas caldera, both important influences on the stability of the volcano slopes. On Tenerife, the relationship between large volcanic landslides and vertical caldera collapses is supported by a temporal coincidence of at least two failures with caldera collapse events.

The mechanical behaviour of a residual soil sampled in the La Orotava valley has been analysed. Red coloured residual soils are generally located at the top of phonolitic pyroclastic deposits and are proposed as potential slip surfaces due to their very weak behaviour and their flat, homogeneous characteristics. They represent the only planar surface within the succession making up the volcano slopes. Their weak mechanical behaviour is characterised by volumetric collapse during shearing, a substantial reduction of shear strength for high normal stresses, and a significant increase of pore water pressure during undrained loading. The last feature is fundamental to the stability of volcano flanks since it strongly reduces the soil strength. Earthquakes, common processes in active volcanic areas, and saturated conditions can generate high excess pore pressures indicating the importance of regional climate and seismicity.

The stability analysis has considered three different mechanisms: 1) ground acceleration due to seismicity - including both tectonic earthquakes and volcano-tectonic seismic shocks produced by caldera collapse; 2) horizontal stress due to dike intrusion, and; 3) vertical shear stress due to caldera collapse. The results indicate that ground acceleration principally decreases the mechanical stability of volcano flanks, enabling failure. Horizontal stresses due to dike intrusion can also influence slope stability, but preferably act as a preparing factor destabilising the slope, and not as a final triggering mechanism. The 3D numerical simulations show the significant effect of deeply incised canyons creating high shear stress at their base.

Applying the results to the La Orotava events, the following scenario is assumed: First, deep narrow canyons, weak residual soils, humid climate, coastal cliff and persistent dike intrusion have significantly reduced the mechanical stability of the volcano slope and determined the limits of the failing mass. Then, seismicity generated by the caldera collapse episode at the end of the Guajara cycle at $\sim 0.56 \mathrm{Ma}$ triggered the catastrophic landslides.

The results of the mobility analysis show the important influence of water on the runout distances of landslides. Subaqueous drag forces reduce the velocity, while hydroplaning effects strongly increase the runout distance. For Tenerife, the model indicates that a sliding mass can advance great distances, tens of kilometres away from the island, at water depths exceeding $3000 \mathrm{~m}$, as can be observed in the bathymetric data. 


\section{LIST OF FIGURES}

Figure 2.1: Mobility versus volume of non-volcanic and volcanic landslides..................................... 6

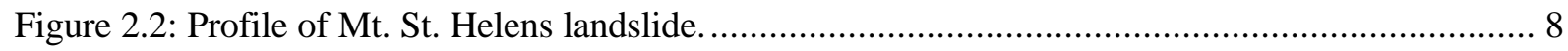

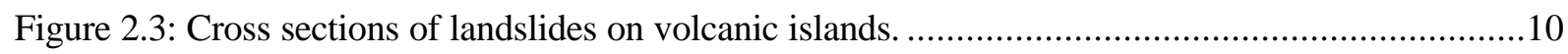

Figure 2.4: Influence of slope angle on the failure of 55 Quarternary volcanoes. .................................13

Figure 2.5: Variation of peak horizontal acceleration coefficient (PHAC) with epicentre distance for

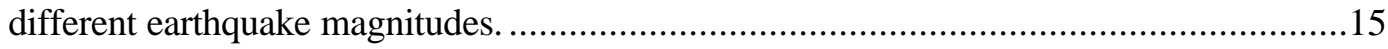

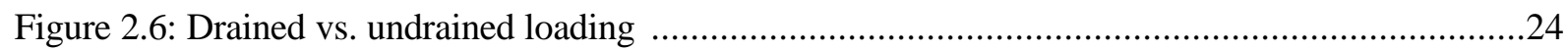

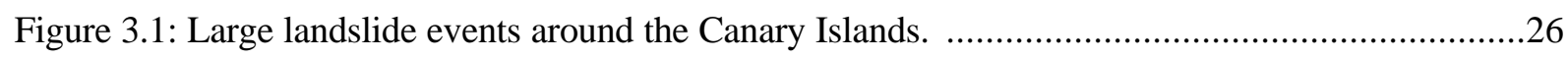

Figure 3.2: Simplified tectonic framework and structural axes of the Canary Islands.........................28

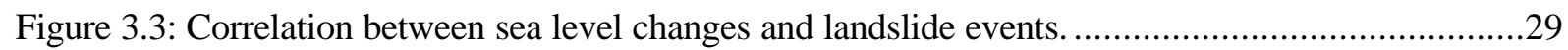

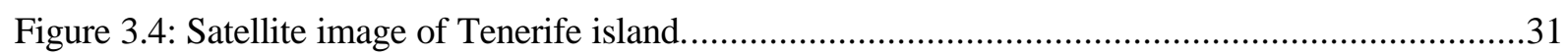

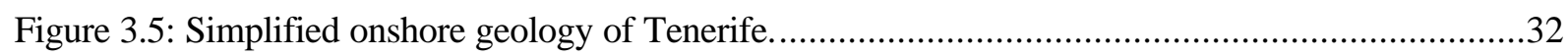

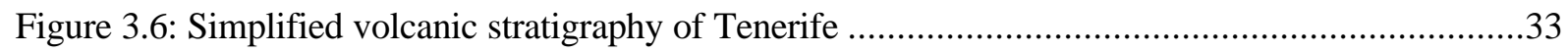

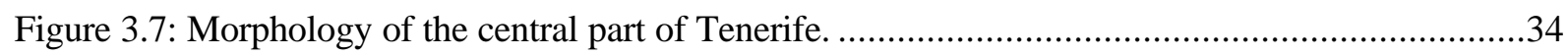

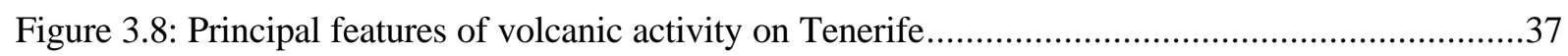

Figure 3.9: Subaerial slope inclination versus altitude computed using GIS......................................39

Figure 3.10: Simplified profiles of the flanks of Tenerife island .......................................................

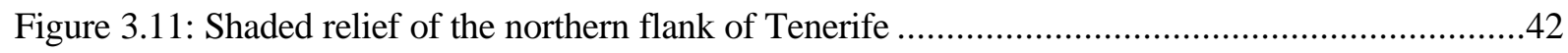

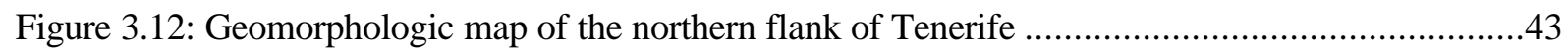

Figure 3.13: Idealised longitudinal geological cross section through the north flank of Tenerife. ...........45

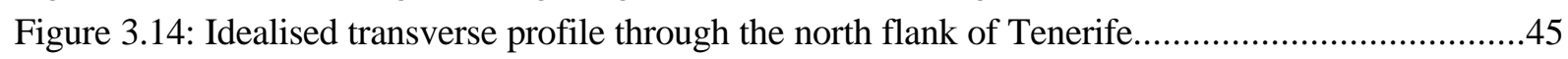

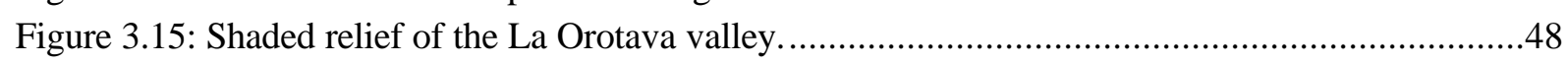

Figure 3.16: Longitudinal topographic profiles of the La Orotava valley ...........................................49

Figure 3.17: Transverse topographic profiles of the La Orotava valley.............................................49

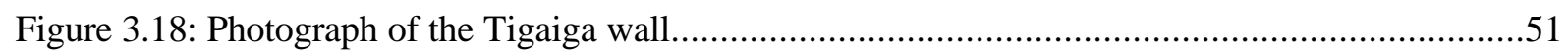

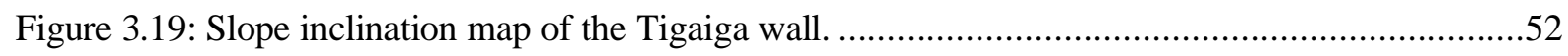

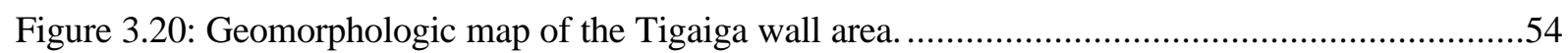

Figure 3.21: Photograph of the St. Ursula wall and Los Organos area ..............................................56

Figure 3.22: Slope inclination map of the St. Ursula wall and the Los Organos area.............................57

Figure 3.23: Photograph of sub-vertical wall in the Los Organos ...................................................58

Figure 3.24: Photograph of sub-vertical wall in the Los Organos area.................................................58

Figure 3.25: Geomorphologic map of the St. Ursula wall and the Los Organos area...........................60

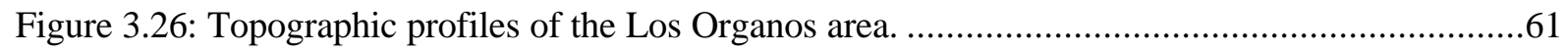

Figure 3.27: Simplified geomorphologic map of the La Orotava valley. ..............................................62

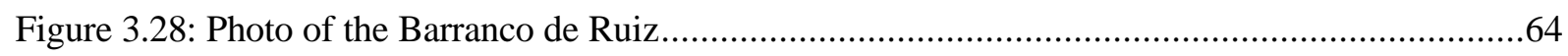

Figure 3.29: Geochronological data in the La Orotava valley area. .................................................67

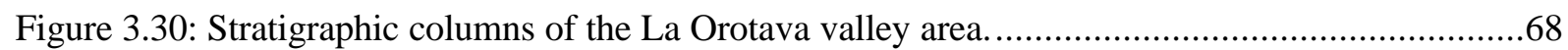

Figure 3.31: Simplified geological map of the La Orotava valley area................................................. 70

Figure 3.32: Rose diagram of dip directions of the materials composing the Tigaiga massif.................71

Figure 3.33: Rose diagram of dip directions of deposits composing the Los Organos area ...................72

Figure 3.34: Simplified geologic cross sections of the La Orotava valley..........................................73

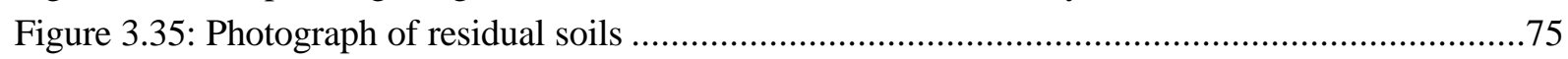

Figure 3.36: Simplified geologic column indicating the formation of residual soils. ............................76

Figure 3.37: Morphologic features characterising the preslide conditions of the La Orotava valley area.77 
Figure 4.1: Tentative model of the bonding in residual soils after Vaughan et al. (1988).....................84

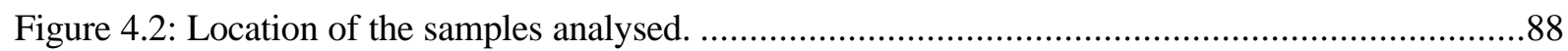

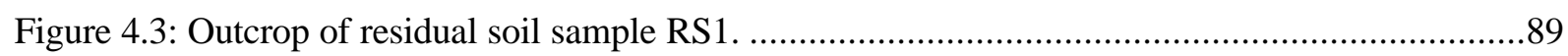

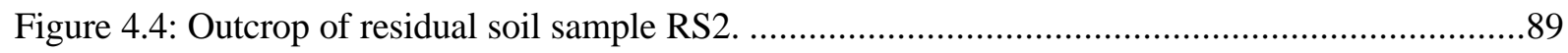

Figure 4.5: Location of the samples of the valley filling breccia EL1 and EL2 …............................90

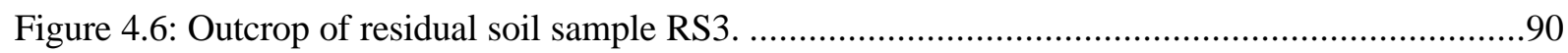

Figure 4.7: Outcrop of the valley filling breccia MO1 at Playa de Fajana............................................91

Figure 4.8: Outcrop of the valley filling breccia MO2 at Punta el Gundastés....................................91

Figure 4.9: Location of the breccia sample BR1 near Los Organos. ...................................................92

Figure 4.10: Outcrop of breccia sample BR2 near La Ladera. ......................................................92

Figure 4.11: Hand sample BI1 representing a baked phonolitic pyroclastic deposit...........................93

Figure 4.12: Photograph indicating the contact between the phonolitic pyroclastic deposit and the upper

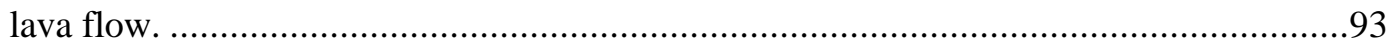

Figure 4.13: Photograph of the small shear test apparatus SHEAR1 …..........................................98

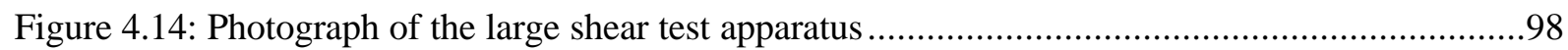

Figure 4.15: Triaxial test apparatus TRIAX1 for cell pressure up to $1700 \mathrm{kPa}$..............................101

Figure 4.16: Triaxial cell of TRIAX2 apparatus for cell pressure up to $5000 \mathrm{kPa}$............................101

Figure 4.17: $\mathrm{Fe}_{2} \mathrm{O}_{3}$ - content versus $\mathrm{SiO}_{2}$-content for the twelve hand samples using XRF...............103

Figure 4.18: $\mathrm{Rb}$ - content versus $\mathrm{SiO}_{2}$ - content for the twelve hand samples using XRF. ..................105

Figure 4.19: X-ray diffractograms of the twelve samples divided into three groups.............................107

Figure 4.20: ESEM photograph showing the open microstructure of the intact soil..........................109

Figure 4.21: ESEM - photograph showing the compacted microstructure of the broken soil .............109

Figure 4.22: ESEM photograph showing a bonding between two particles in the intact soil ..............110

Figure 4.23: ESEM photograph showing a bonding between two particles in the intact soil ..............110

Figure 4.24: ESEM photograph showing a bridge tike bonding between two particles in the intact soil111

Figure 4.25: ESEM photograph showing a zoom of a bridge -like bonding between two particles in the intact soil.

Figure 4.26: ESEM -photograph showing a failed, bridge - like bonding between two particles in the broken soil .112

Figure 4.27: Particle size distribution curves of the residual soil samples. .......................................113

Figure 4.28: Vertical strain - time curves for different vertical stresses due to first time loading. .......115

Figure 4.29: Creep effect during the secondary compression phase over an extended duration. ..........116

Figure 4.30: Primary compression (a) and secondary compression (b) versus vertical stress.............117

Figure 4.31: Void ratio versus vertical stress from three oedometer tests on undisturbed samples. .....118

Figure 4.32: Void ratio vs. vertical stress of undisturbed and remoulded specimens using standard oedometer tests.

Figure 4.33: Results of direct shear test reloading the same initially undisturbed specimen in apparatus SHEAR1

Figure 4.34: Determination of the shear strength values carried out by the drained direct shear test. ..121

Figure 4.35: Stress - strain curves for undisturbed specimens from direct shear tests using SHEAR2.

Figure 4.36: Horizontal strain versus $\tau / \sigma_{\mathrm{n}}{ }^{\prime}$ ratio for different normal stresses and both undisturbed and remoulded specimens.

Figure 4.37: Horizontal strain versus shear stress and void ratio during direct shear test of an undisturbed specimen with normal load of 5.197 MPa.

Figure 4.38: Mohr-Coulomb failure planes for different shear strengths obtained from tests in the SHEAR1 apparatus. 
Figure 4.39: Mohr-Coulomb failure planes for the different shear strengths obtained from tests in the SHEAR2 apparatus.

Figure 4.40: Mohr-Coulomb failure planes obtained from peak shear strength values and the calculated angle of friction

Figure 4.41: Failure zone of undisturbed specimen after a direct shear test.....................................130

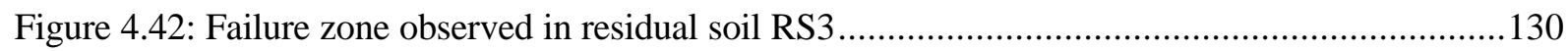

Figure 4.43: Shear strength versus horizontal displacement during ring shear tests ..........................131

Figure 4.44: Void ratio versus effective confining stress during confining pressure phase of triaxial tests using TRIAX2.

Figure 4.45: Void ratio vs. mean effective stress during failure phase of undrained and drained triaxial tests.

Figure 4.46: Undrained triaxial tests on undisturbed specimens at low effective confining stress obtained from TRIAX1.....

Figure 4.47: Drained triaxial tests on undisturbed specimens at low effective confining stress obtained from TRIAX1.

Figure 4.48: Stress paths of undrained triaxial tests on undisturbed specimen using TRIAX1...........137

Figure 4.49: Stress paths of drained (dashed lines) and undrained (solid lines) triaxial tests on undisturbed specimen using TRIAX1.....

Figure 4.50: Undrained triaxial tests on undisturbed specimens at high effective confining stress obtained from TRIAX2.

Figure 4.51: Drained triaxial tests on undisturbed specimen at high effective confining stress obtained from TRIAX2.

Figure 4.52: Stress paths of undrained triaxial tests on undisturbed specimen applying low and high confining pressures.

Figure 4.53: Stress paths of drained (dashed line) and undrained (solid line) triaxial tests on undisturbed specimen applying low and high confining pressures.

Figure 4.54: Peak and residual strengths obtained from drained (CD) and undrained (CU) triaxial tests on undisturbed specimen.

Figure 4.55: Void ratio vs. effective confining stress of undisturbed (RS1-T-CUII) and remoulded (RS1-T-CUIr) specimens during isotropic compression

Figure 4.56: Comparison between undrained triaxial tests on undisturbed (straight line) and remoulded (dashed line) specimens.

Figure 4.57: Stress path of undrained triaxial tests on undisturbed (straight line) and remoulded (dashed line) specimen.

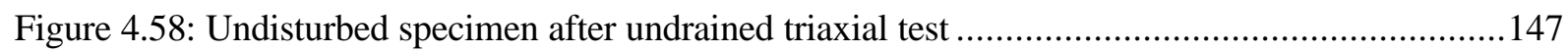

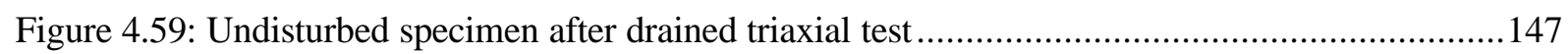

Figure 5.1: Application of the three mechanisms analysed in this study.........................................153

Figure 5.2: External forces and geometric parameters used in LEM2 ..........................................157

Figure 5.3: External forces and geometric parameters used in UBM. ............................................160

Figure 5.4: Geometry of the 2D models used in the global limit stability analysis .............................166

Figure 5.5: Meshes of the 2D models used in the FD (a) and FEM (b) analysis.................................167

Figure 5.6: Mesh of the 3D FEM-model representing the simplified preslide morphology of the La

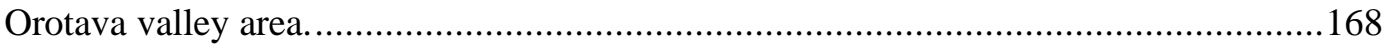

Figure 5.7: Influence of slope angle (a) and $L_{o n} / L_{\text {off }}$-ratio (b) on the stability of volcano slopes using LEM.

Figure 5.8: Influence of material property (a) and level of water table (b) on the stability of a common

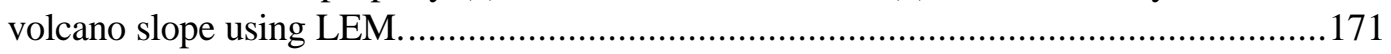

Figure 5.9: Typical circular failure surfaces for a simplified volcano slope using LEM. ...................172 
Figure 5.10: Influence of horizontal seismic acceleration, $a$, and, inclination of the water table, $\beta$, on the stability of a simplified volcano slope using LEM

Figure 5.11: Influence of magma overpressure, $P_{m o}$, owning to dike intrusion on the stability of volcano slopes using LEM.

Figure 5.12: Stability analysis for the La Orotava valley using LEM. .

Figure 5.13: Typical circular failure surfaces for the simplified preslide La Orotava model using LEM.176

Figure 5.14: Influence of average ground acceleration, $a$, on the stability of a common volcano slope using UBM.....

Figure 5.15: Influence of horizontal stress owning to dike intrusion on the stability of volcano slopes using UBM.

Figure 5.16: Influence of vertical shear stress due to caldera collapse on the stability of volcano flanks using UBM.

Figure 5.17: Comparison of the destabilising influence of the three mechanisms using UBM. 180

Figure 5.18: Destabilising influence of combinations of external mechanisms using UBM.................181

Figure 5.19: Shear stress distribution and intensity corresponding to a horizontal stress due to dike intrusion (a) and caldera collapse with a vertical shear stress (b).

Figure 5.20: Zoom of the zones corresponding to elements in which yielding may occur. 183

Figure 5.21: Influence of horizontal stress due to dike intrusion and vertical shear stress due to caldera collapse on the stress field of the volcano flank. 184

Figure 5.22: Distribution and intensity of Von Mises shear stresses in the entire model after the application of external mechanisms. 185

Figure 5.23: Zoom of the distribution and intensity of Von Mises shear stresses after the application of external mechanisms

Figure 5.24: Distribution of Von Mises shear stresses in the 3D FEM model applying a horizontal stress due to dike intrusion.

Figure 5.25: Distribution and intensity of Von Mises shear stresses in the upper part of the 3D model applying dike intrusion.

Figure 5.26: Transverse section through deep, narrow canyon with calculated distribution and intensity of Von Mises shear stresses.

Figure 6.1: Topography of Tenerife and bathymetry of the northern offshore slopes........................194

Figure 6.2: Forces acting on a subaqueous sliding mass.

Figure 6.3: Topographic / bathymetric profile indicating the main morphologic sections of the northern slopes of Tenerife.

Figure 6.4: The effect of the drag forces on the landslide mobility 198

Figure 6.5: The effect of hydroplaning on the landslide mobility 199 


\section{LIST OF TABLES}

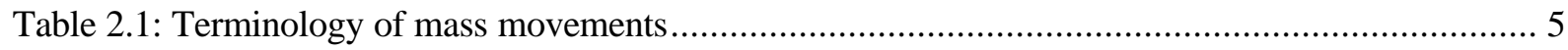

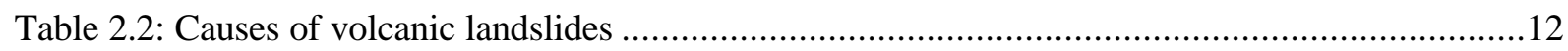

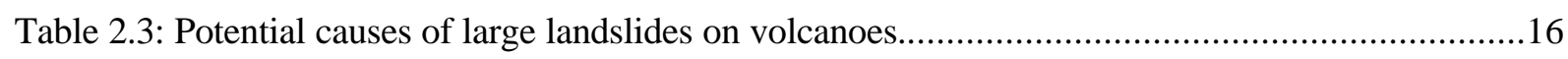

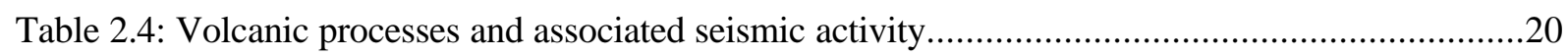

Table 3.1: Large landslide events detected around the Canary Islands ..............................................27

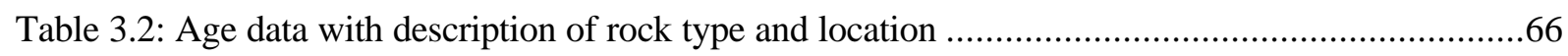

Table 4.1: Samples studied during the geochemical and geotechnical analyses.....................................86

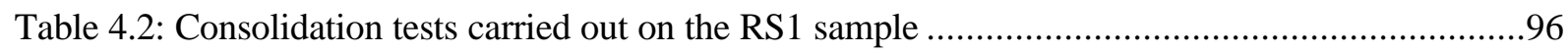

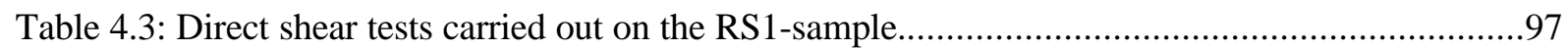

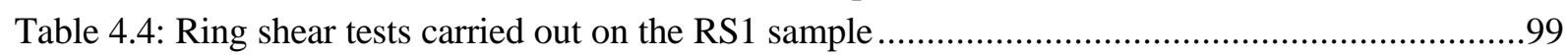

Table 4.5: Test conditions and type of apparatus during the triaxial tests .......................................100

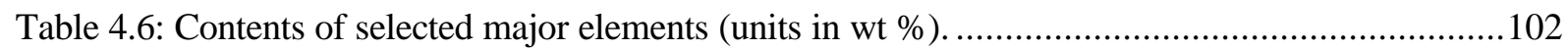

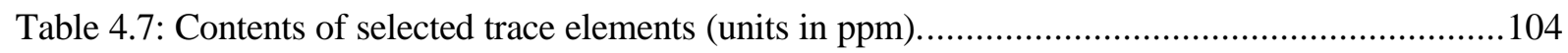

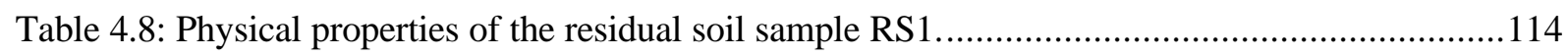

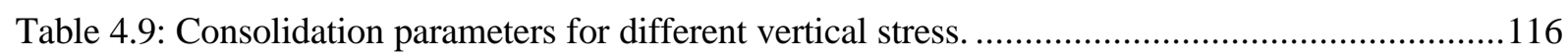

Table 4.10: Stress-strain parameters obtained from the oedometer tests on undisturbed specimens.....118

Table 4.11: Shear strengths for three different normal stresses using SHEAR1. ................................121

Table 4.12: Shear strengths for different normal stresses using SHEAR2 ......................................123

Table 4.13: Angle of friction and cohesion for the three shear strengths obtained from SHEAR1

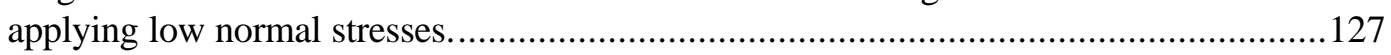

Table 4.14: Angle of friction and cohesion for the three shear strengths obtained from SHEAR2

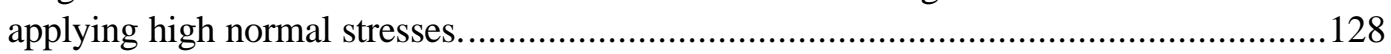

Table 4.15: Residual shear strength and friction angles obtained from the ring shear tests. ...............131

Table 4.16: Permeability values obtained in triaxial cells and applied cell pressure, back pressure (inlet)

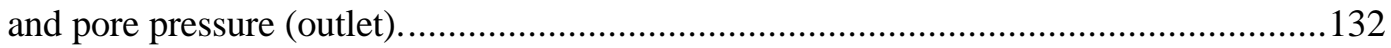

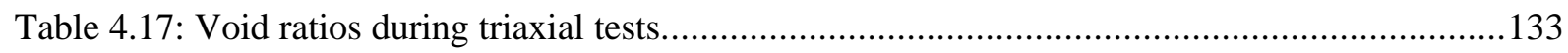

Table 4.18: Peak and residual stress obtained from drained and undrained triaxial tests for undisturbed

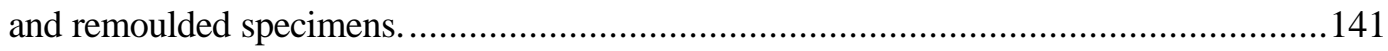

Table 4.19: Peak and residual angles of friction obtained from CU and CD-tests. .............................142

Table 4.20: Calculation of the apparent friction angle and estimate of the pore pressure parameter $A$ for

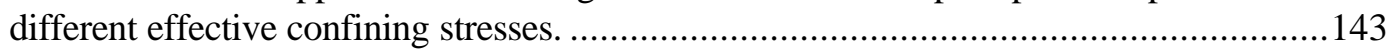

Table 5.1: Agents analysed during the stability calculations and approaches applied........................151

Table 5.2: Modelling sequences during the FD analysis indicating the applied stress, material property

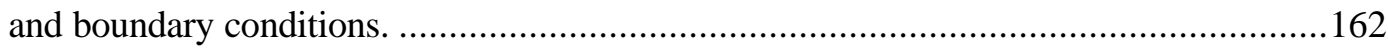

Table 5.3: Modelling sequences during the FEM analysis indicating the applied stress, material property

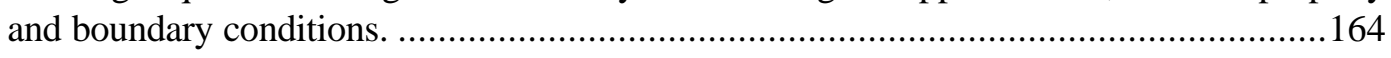

Table 5.4: Definition of the standard geometric parameters used in the preliminary calculations of LEM

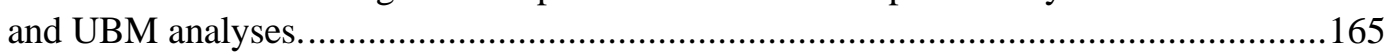

Table 5.5: Definition of the standard material parameters used for the LEM and UBM. ....................166 


\section{INTRODUCTION}

\subsection{Hazards from large volcanic landslides}

Large volcanic landslides are one of the most hazardous geological processes. Their volumes can exceed tens or even hundreds of cubic kilometres covering areas as large as $1000 \mathrm{~km}^{2}$. Moreover, their velocity easily surpasses $100 \mathrm{~m} / \mathrm{sec}$ and runout distances greater than 100 $\mathrm{km}$ have been observed. After the 1980 eruption and associated debris avalanche at Mount St. Helens (Voight et al., 1981), the analysis of large volcanic landslides gained worldwide attention and their importance has been repeatedly demonstrated by disastrous events, which claimed thousands of lives (e.g. Nevados de Huascarán in 1970; Plafker and Ericksen, 1978 or Nevado de Ruiz in 1985; Pierson and Janda, 1994). Recent studies show that large volcanic landslides are a common process during the evolution of large stratovolcanoes (Siebert, 1984; Ui et al., 1986). Large-scale failures have been observed world-wide at several hundred volcanoes and have occurred about every 25 years during the last 500 years (Siebert, 1992; McGuire, 1996b; Voight and Elsworth, 1997).

The occurrence of large volcanic landslides represents different hazards for the neighbouring population. The direct hazards include not only the debris avalanche and associated lahars, but also the possibility of explosive eruptions and lateral blasts which can be triggered by the opening of the magma conduit due to the decompression caused by slope failure (e.g. Mt. St. Helens or Bezymianny; Siebert et al., 1987). In addition to these direct hazards, large landslides at coastal or oceanic volcanoes can produce tsunamis and affect areas far away from the volcano.

\subsection{Problem}

Many causes refering to large volcanic landslides have been proposed, but their explanation in mechanical terms has not been resolved yet. Generally, failure of natural slopes occurs only if the slope angle exceeds the friction angle of the soil or rock, assuming zero cohesion and no external forces. Friction angles of the majority of materials composing volcanoes are assumed to have values between 30 and 40 degrees (Voight et al., 1983; Iverson, 1995; Voight and Elsworth, 1997) and have a negligible cohesion. Therefore, they build stable slopes from a geomechanical point of view. However, many large landslides in volcanic areas are characterised by failure surfaces with a small inclination and a gentle slope angle. The giant Hawaiian landslides, for example, are assumed to slide over a failure surface probably inclined less than 10 degrees and slope angles prior to failure are likely less than $12^{\circ}$ and almost certainly less than $19^{\circ}$ (e.g. Dieterich, 1988, Iverson, 1995).

An additional feature increasing the difficulty of the analysis of large volcanic landslides is the scale effect. Failures at volcanoes can involve up to $20 \%$ of the whole edifice and surpass the volumes of non-volcanic landslides by two or three orders. Conventional causes such as groundwater pore pressures are not able to initiate such giant mass movements with failure lengths and widths of several kilometres (Hürlimann et al., 1997).

Hence, there must exist significant external forces that enable the failure of volcano flanks. These external forces are commonly generated by volcanic or tectonic processes. The destabilising effects of volcanic activity are very complicated, while the tectonic processes mainly include seismic shocks. Explosive and effusive eruptions, magma injection, hydrothermal alteration, volcanic spreading, caldera collapse episodes and volcanic or volcano-tectonic tremors are often related to each other and are characterised by many direct and indirect influences on the stability of volcanoes.

Detailed, comprehensive geotechnical studies analysing the stability of volcano flanks are not common and analyses including a mechanical approach hardly exist. The causes of large volcanic landslides have not yet been resolved and many hypotheses have been proposed without geotechnical data. 


\subsection{Test site}

The La Orotava valley has been selected as test site of the geotechnical analysis. The valley is located at the northern flank of Tenerife and covers an area of more than $100 \mathrm{~km}^{2}$. The origin of the La Orotava and the two other valleys located on the island has been a controversy since the last century. Their landslide origin, however, is supported by recent bathymetric studies that have identified voluminous landslide deposits on the northern and south-eastern submarine slopes of Tenerife (Watts and Masson, 1995; Teide-Group, 1997).

Apart form the analysis of the La Orotava events, many stability calculations have been carried out for general volcano slopes in order to facilitate the application of the results to other locations with volcano instabilities. Therefore, the landslide events in the La Orotava valley have been used as a practical case trying to establish general rules that can be applied to other volcanoes.

\subsection{Goals}

The main goals of this work is to answer three fundamental questions refering to large volcanic landslides:

1) 'Why such large mass movements can occur?'

2) 'Where is the failure located?'

3) 'When does failure occur?'

The first question evaluates the potential causes of large volcanic landslides and investigates the significant features influencing on the mechanical stability of volcanoes.

The second point analyses the morphologic and geologic features, which destabilise the volcano flank and may evolve into the limits of the landslide. The definition of potential weak layers composing the volcano and creating potential slip surfaces of the failures is another aim concerning this second question.

The third question concerning the timing of the failure is perhaps the most difficult to answer. If large volcanic landslides have to be predicted, a wide range of disciplines as distinct as geotechnics, material science, fluid mechanics, seismology, volcanology and geodesy must be brought together. In this work, this point is only studied marginally and without the aim of establishing an exact predictive timing.

Another aim of the study is the improvement of the insights regarding to the natural examples that have occurred in the La Orotava valley. The potential causes of the large volcanic landslides occurred in the valley and the chronological, geological and morphological evolution of the valley are two important topics of this research. On the other side, the evaluation of the influence of the volcanic and tectonic activity on the initiation of the failures is an additional objective.

Moreover, another aim is the application of the results obtained from the study of the La Orotava events to other locations. The determination of common roles and critical features concerning volcano stability is an important point of the study.

At last, the understanding of the dynamics and an explanation refering to the great mobility of large volcanic landslides on oceanic islands is another aim. 


\subsection{Thesis structure}

After some introductory statements, it follows the State-of-the-art refering to large landslides in general and to large volcanic landslides in particular. In addition, the potential causes of large failures at volcano flanks are reviewed.

The Chapters 3 to 6 contain the main part of the text and are structured as in a standard geotechnical analysis of mass movements. The four Chapters include the site investigation, the laboratory analysis, the stability analysis and the mobility analysis. Each Chapter starts with a short introduction and ends with some conclusions related to the Chapter.

\section{Chapter 3: Site investigation.}

The site investigation gives first an overview of the landslide events occurred around the Canary Islands. Second, it describes the geology, morphology and volcanic activity of Tenerife. Then, the results of the geomorphologic analysis concerning the whole island are presented including the northern subaerial and submarine flank of Tenerife and specially the La Orotava valley. The following geologic analysis mainly focuses on the La Orotava valley and its adjacent areas. At the end, the inferred preslide conditions are explained. Although the site investigation has been performed on Tenerife, some of the findings are proposed to be common in other locations.

\section{Chapter 4: Laboratory analysis.}

The laboratory analysis can be divided into two test programmes both of them studying a residual soil (paleosol) found in the La Orotava valley which has been considered a potential zone for the slip surface. First, the results of the mineralogical analysis, chemistry and microstructure of this soil are described and second, geomechanical parameters of the material are explained using the results obtained from the geotechnical tests. A special interest is focussed on the bonding or cementation of the soil which is a particular feature of this material.

\section{Chapter 5: Stability analysis.}

This Chapter provides an overview of the analytical and numerical models used in the study of the stability of volcano flanks. First, global limit equilibrium models have been used to carry out a quantitative study calculating a global factor of safety of the volcano flank, and second, the numerical continuum models based on Finite Element and Finite Differences have been employed to perform a study computing the stress-strain field inside the flank.

Chapter 6: Mobility analysis.

Large volcanic landslides on oceanic islands are characterised by a huge mobility. This Chapter analyses this particular feature incorporating novel ideas such as hydroplaning or drag forces into well-known mobility models.

Finally, some concluding remarks and ideas refering to future works are presented. Then, the reference list and an Appendix including the publications arising from this thesis are completing the text. 


\section{STATE OF THE ART}

\subsection{Terminology of mass movements}

Slope movements can be classified in many ways, each one having some usefulness in emphasising features appropriate to the recognition, avoidance, control, correction, or other purpose for the classification. The classification of Varnes (1978) listed in Table 2.1 is one of the most used and complete in its way.

Generally, large volcanic mass movements are classified as 'slides' including translational slides and rotational slumps. Slumps are slow-moving, rotational failures, deeply rooted in the volcanic edifice and are characterised by only a slight disruption of the structural coherence. Such type of failure has principally been found on the Hawaiian ridge (Moore et al., 1989; Moore et al., 1994). Translational slides often evolve into avalanches or flows. The term debris avalanches is rather usual for such events and was introduced after the 1980 eruption of Mount St. Helens and its associated destructive sector collapse (Voight et al., 1981; Voight et al., 1983; Glicken, 1996). Debris avalanches are rapid moving, more superficial failures than slumps and form amphitheatre-like scars and extensive deposits. The movement is characterised by flowage in a dry or wet state, or both, and the initial massive sliding blocks disintegrate into fragments ranging in size from small particles to blocks of hundreds of meters.

If the debris avalanche has a large water content, its matrix may continue to flow downslope as a lahar after its coarser parts have come to rest. Lahar is an Indonesian word describing mudflows and debris flows that originate from the slopes of a volcano. Both types have an extremely great mobility, can flow at velocities exceeding $100 \mathrm{~m} / \mathrm{sec}$ and travel over 100 kilometres from a volcano.

In summary, the most common types of large mass movements occurring at volcanoes can be described by the classification of Varnes (1978) as translational or rotational slides and flows. Sometimes the same event can start as a slide, then evolve to a debris avalanche and ending as a lahar (Iverson et al., 1997; Mothes et al., 1998). Hereafter the general term 'landslide' is used for all types of mass movements.

Table 2.1: Terminology of mass movements (after Varnes, 1978)

\begin{tabular}{|c|c|c|c|c|c|}
\hline \multirow{3}{*}{\multicolumn{3}{|c|}{ TYPE OF MOVEMENT }} & \multicolumn{3}{|c|}{ TYPE OF MATERIAL } \\
\hline & & & \multirow[t]{2}{*}{ BEDROCK } & \multicolumn{2}{|c|}{ ENGINEERING SOILS } \\
\hline & & & & $\begin{array}{l}\text { Predominantly } \\
\text { coarse }\end{array}$ & $\begin{array}{l}\text { Predominantly } \\
\text { fine }\end{array}$ \\
\hline \multicolumn{3}{|l|}{ FALLS } & Rock fall & Debris fall & Earth fall \\
\hline \multicolumn{3}{|c|}{ TOPPLES } & Rock topple & Debris topple & Earth topple \\
\hline \multirow{3}{*}{ SLIDES } & Rotational & \multirow{2}{*}{$\begin{array}{l}\text { Few } \\
\text { units }\end{array}$} & Rock slump & Debris slump & Earth slump \\
\hline & \multirow[t]{2}{*}{ Translational } & & Rock block slide & Debris block slide & Earth block slide \\
\hline & & Many units & Rock slide & Debris slide & Earth slide \\
\hline \multicolumn{3}{|c|}{ LATERAL SPREADS } & Rock spread & Debris spread & Earth spread \\
\hline \multirow{2}{*}{\multicolumn{3}{|c|}{ FLOWS }} & Rock flow & Debris flow & Earth flow \\
\hline & & & (deep creep) & \multicolumn{2}{|c|}{ (soil creep) } \\
\hline \multicolumn{3}{|c|}{ COMPLEX } & of two or more $p$ & incipal types of mo & ment \\
\hline
\end{tabular}




\subsection{Examples of large landslides}

In contrast to large volcanic landslides, non-volcanic failures of similar scale occur more frequently and diverse studies refering to such events have been published in historic times. However, there is not a big amount of comprehensive geotechnical works analysing large landslides since the majority of landslide studies focuses on shallow, small-scale event.

Figure 2.1 shows some geometric relations of volcanic and non-volcanic landslides indicating the volume and the mobility of the events. The mobility is represented by the H/D-ratio where $\mathrm{H}$ is the vertical height and $\mathrm{D}$ is the runout distance. Lower H/D-ratios indicate a greater mobility and vice versa. A clear relationship between higher volumes and greater mobility can be seen which confirms this well-known correlation between volume and runout distance (Heim, 1932; Hsü1 1975; Corominas, 1996). Figure 2.1 shows that the volcanic landslides are generally more voluminous than the non-volcanic ones, and that mass movements on volcanoes are characterised by an enormous mobility and great runout distances. Moreover, the graph indicates that landslides on volcanic islands surpass the maximum volume of terrestrial volcanic events by one or two magnitudes. Maximum volumes exceeding $1000 \mathrm{~km}^{3}$ have been detected around the Hawaiian archipelago (Moore et al., 1989; Moore et al., 1994).

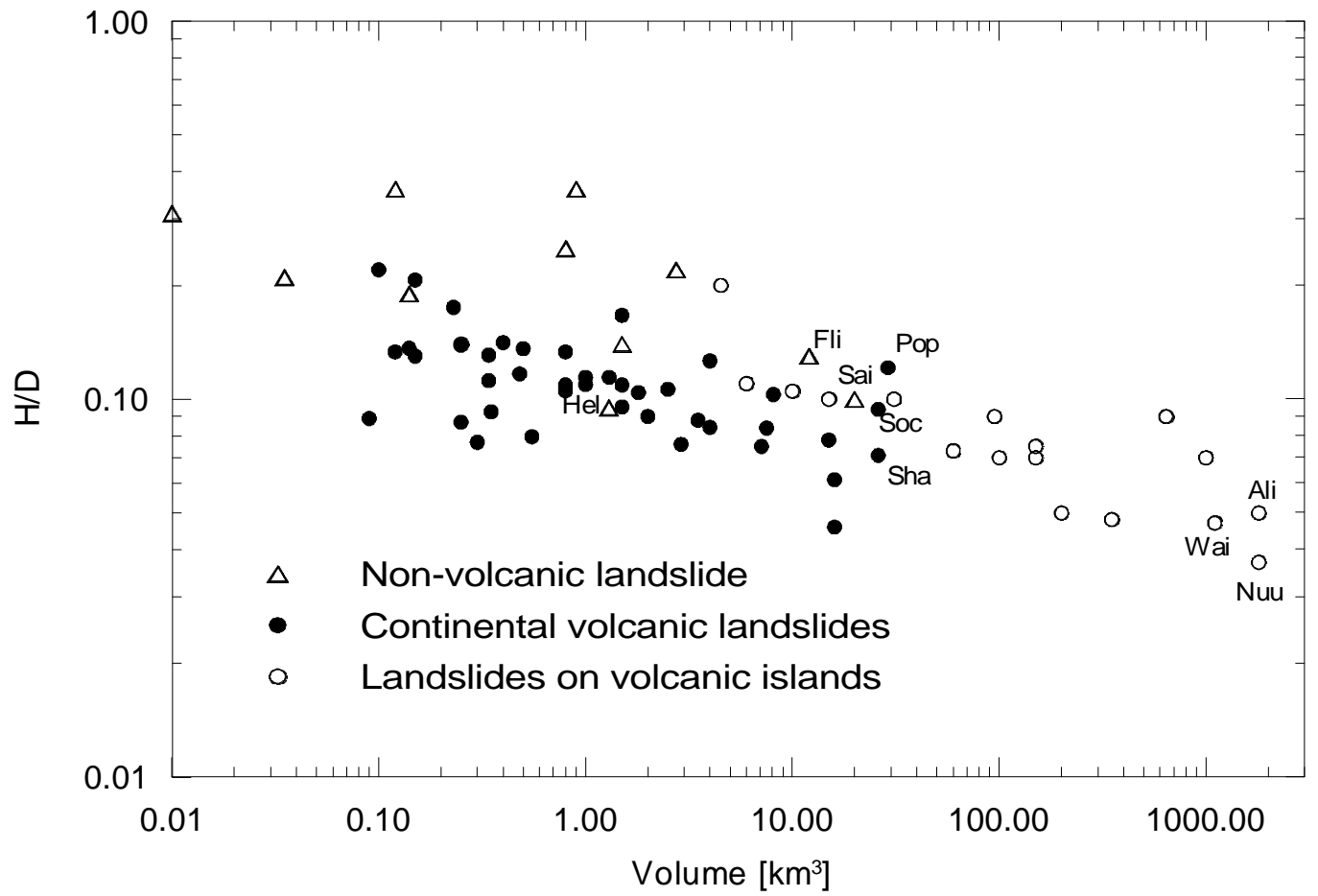

Figure 2.1: Mobility versus volume of non-volcanic and volcanic landslides. Sai: Saidmarreh, Fli: Flims, Hel: Mt. St. Helens, Sha: Shasta, Soc: Socompa, Pop: Popocatepetl, Ali: Alika, Wai: Wailau, Nuu: Nuuanu. Data after Hsü(1975), Harrison and Falcon (1937), Ui (1983), Siebert (1984), Moore et al. (1989), Lipman et al. (1988) Urgeles et al.(1997,1999).

In the following, some non-volcanic large landslides will be described, and afterwards the most important volcanic events at terrestrial volcanoes and volcanic islands will be presented.

The classic landslide at Elm, Switzerland, in 1881 is perhaps the best observed historical event of its kind and was comprehensively investigated just after the catastrophe (Buss and Heim, 1882; Heim, 1932). The failure was caused by quarry activity at the base of the slope, occurred after recent heavy 
rains and involved two rockslides that overrun the village of Elm. While the study of these events has mainly focussed on the high mobility, the failure mechanisms have only been analysed marginally.

After the Vaiont Dam catastrophe in Italy, which occurred on October 2, 1963, and caused at least 1800 casualties, several geotechnical hypotheses about the failure mechanisms of large landslides have been proposed. There, actively creeping for at least 3 years took place before the slope failed suddenly within the Malm formation consisting thin-bedded limestone intercalated with clays (Bromhead, 1992). The failure occurred in association with a rise in the reservoir level, but the superposed effect of artesian groundwater conditions, progressive failure or pore fluid vaporisation may also have been involved (Skempton, 1966; Voight, 1978c). The slide involved a total volume of material of $0.25 \mathrm{~km}^{3}$ which drove the water over the dam generating a huge wave.

The Flims, Switzerland, rockslide in prehistoric epoch with an estimated volume of $12 \mathrm{~km}^{3}$ (Heim, 1932) is assumed to be one of the largest landslides ever occurred in mountainous terrain. A huge block of Jurassic limestone having a thickness of $600-800 \mathrm{~m}$ slid on a bedding plane with a dip of $11-16^{\circ}$ and dammed the Rhine valley along $11 \mathrm{~km}$. The Rhine has now cut a canyon through the landslide deposit and the scarps of this canyon show that the mass had moved almost as a single unit and not as completely fragmented (Goguel, 1978).

Another enormous prehistoric landslide is the Saidmarreh event in southwestern Iran (Harrison and Falcon, 1937; Watson and Wright, 1967). Involving a total volume of about $20 \mathrm{~km}^{3}$, it had been considered to be the largest subaerial non-volcanic landslide known on earth. The failure with a width of about $5 \mathrm{~km}$, a length of $15 \mathrm{~km}$ and a thickness of about $300 \mathrm{~m}$ occurred at a slope composed of limestone dipping about $20^{\circ}$ and resting on thin bedded sequence of marl and limestone. The immediate trigger of the landslide is stated to have been an earthquake, but evidence simply notes that the region is seismically active (Watson and Wright, 1967).

After the Elm event, the second classical historic landslide in the Swiss Alps is the Goldau event in 1806 (Heim, 1932; Zehnder, 1988). The Goldau or Rossberg rockslide involved massive ‘

conglomerate layers, 60 to $120 \mathrm{~m}$ thick, that slid on marls dipping between 11 and $300^{\circ}$. A total volume of about $0.04 \mathrm{~km}^{3}$ slid off after heavy rains, covered the village of Goldau and killed more than 400 persons.

There are many other large landslide events that have occurred in historic times, but the majority of them have not been analysed properly. The mechanics of the failures have not been studied, and we often only know where and when they occurred and how many fatalities were caused. The study of large landslides is a young research topic and scientific analyses started at the end of the last century. Heim's masterpiece 'Bergsturz und Menschenleben' (Heim, 1932) was the beginning of several fundamental overviews published in this century and refering to landslides (e.g. Voight, 1978b; Eisbacher and Clague, 1984; Dikau et al., 1996).

Large volcanic landslides can exceed several cubic kilometres in volume and generally surpass the volumes of non-volcanic events by two or three orders of magnitude (Figure 2.1). Recent studies indicate that catastrophic failures have occurred world-wide at several hundred volcanoes (Ui et al., 1986; Siebert et al., 1987). Siebert (1992) calculated that large volcanic landslides have taken place globally by an average of four times a century during the past 500 years, which was commented to be an underestimated frequency concerning the big amount of failures during this century (McGuire, 1996b). Moreover, it is assumed that $75 \%$ of the Andean volcanoes with heights in excess of $2500 \mathrm{~m}$ have experienced one or more failures (Francis, 1994), and more than 100 events have been observed at Japanese Quaternary volcanoes (Inokuchi, 1988).

The most important historic eruptions associated with large volcanic landslides occurred on Mount St. Helens in 1980, on Bezymianny Volcano in 1956, on Bandai Volcano in 1888 and on Unzen in 1792 (Gorshkov, 1959; Moriya, 1980; Lipman and Mullineaux, 1981; Voight et al., 1983; Siebert et al., 1987). The best documented and analysed event is the one which was associated with the climatic eruption of Mt. St. Helens on May 18, 1980 (Lipman and Mullineaux, 1981; Voight et al., 1981; Voight et al., 1983; Voight et al., 1985; Glicken, 1996). The destructive failure was preceded by several months of magma intrusion and associated large-scale deformation of the volcano flank. The collapse started with a 5.2 magnitude earthquake (Endo et al., 1981) and the north slope began to slide 
northwards along a previously formed fracture system. A slide block I (Figure 2.2) failed within seconds producing a lateral blast by the explosion of exposed magma and hydrothermal chambers (Voight et al., 1981). At the same time the retrogressive failure continued in the unstable crown behind of slide block I and caused the failure of two additional slide blocks II and III. The multiple slope failures led to the development of an enormous debris avalanche that travelled downward in pulses involving material with a volume of about $2.5 \mathrm{~km}^{3}$ and burying an area of about $60 \mathrm{~km}^{2}$ (Voight et al., 1981; Voight et al., 1983; Glicken, 1996).

The event at Bezymianny is assumed to have occurred similar to the one at Mt. St. Helens including retrogressive failures that produced a landslide event with a total volume of about $0.8 \mathrm{~km}^{3}$ (Gorshkov, 1959; Siebert et al., 1987). At Bandai, the landslide included a total volume of about $1.5 \mathrm{~km}^{3}$ and covered an area of $34 \mathrm{~km}^{2}$. The volcano flank failed probably in a retrogressive sequence including three main stages during a phase of several phreatic eruptions (Moriya, 1980; Siebert et al., 1987; Voight and Elsworth, 1997). In contrast, the landslide at Unzen in 1972 is assumed to be caused by the saturation of the volcano by hydrothermal waters and intense seismicity (Siebert et al., 1987). The debris avalanche of about $0.34 \mathrm{~km}^{3}$ entered the sea and generated a catastrophic tsunami that caused about 15000 fatalities.

Other examples of catastrophic landslides on volcanoes have been taken place without associated explosive eruptions, but have also caused thousands of casualties. The landslide at Nevados Huascará, Peru, in 1970 caused an estimated 18000 fatalities. The event was triggered by the strong 7.7 magnitude earthquake situated $130 \mathrm{~km}$ to the west off the coast of Peru. The mass movement originated as a rock and ice fall on the sheer west face of the peak and incorporated a total volume on the order of 0.05 to $0.1 \mathrm{~km}^{3}$. In 1962, a similar event with a smaller volume killed about 4000 people. Both failures were finally developed into lahars characterised by extreme velocities and large horizontal runout distances.

At Nevado del Ruiz volcano, Colombia, a small explosive eruption in 1985 melted the ice cap at the summit and generated a large lahar $\left(0.017 \mathrm{~km}^{3}\right)$ causing more than 20000 casualties (Pierson and Janda, 1994). Similar recent examples, but without fatalities, were observed at Mt. St. Helens in 1982 and 1983 and at Redoubt volcano, Alaska, in 1989 causing lahar-type mass movements with volumes up to $0.034 \mathrm{~km}^{3}$.

At the Mt. Rainier, more than 55 large mass movements occurred during the Holocene and future events present significant risks to local communities (Crandell, 1971). The mass movements include debris avalanches and lahars with volumes up to $3 \mathrm{~km}^{3}$ and runout distances of more than $100 \mathrm{~km}$ such as the well known Osceola mudflow (Vallance and Scott, 1997).

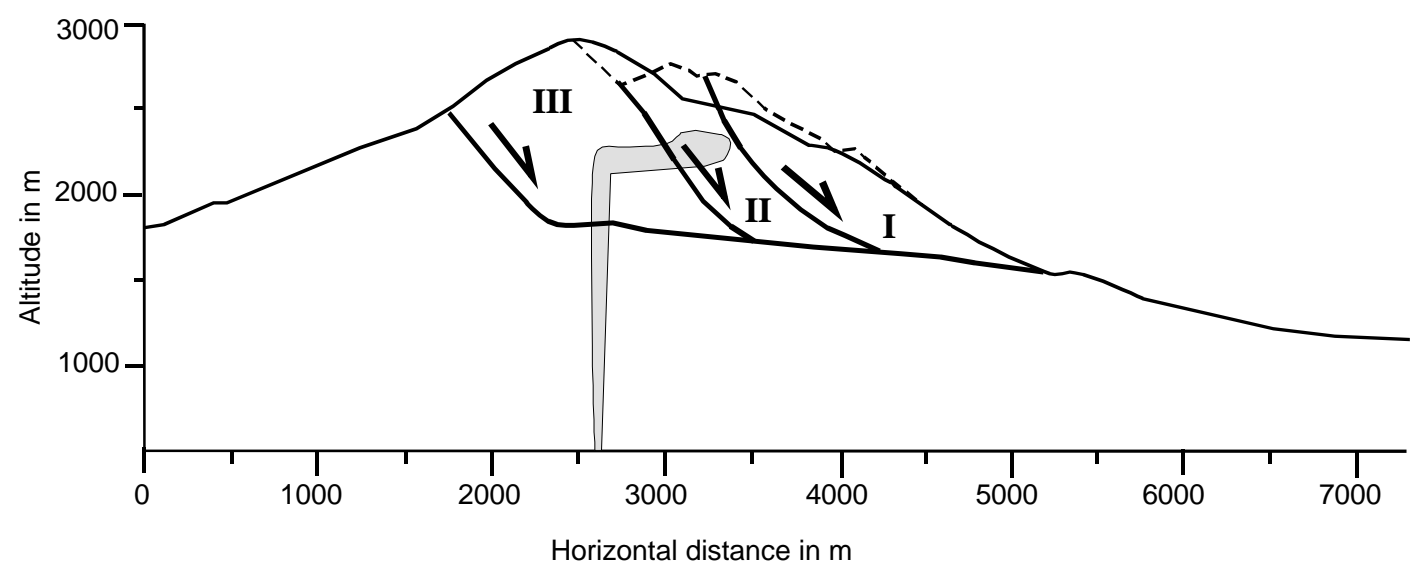

Figure 2.2: Profile of Mt. St. Helens landslide. Dashed line indicates the preslide topography. Thick lines show the failure surfaces and the approximate boundaries of the three slide blocks. Grey shaded area indicates the dome intrusion (after Voight et al., 1983) 
Recent submarine geophysical techniques have enabled the detection of many extensive landslide deposits on the sea floor around volcanic islands caused by giant slope failures. The major amount of such events have been identified around the Hawaiian archipelago (Moore, 1964; Lipman et al., 1988; Moore et al., 1989; Garcia and Hull, 1994; Moore et al., 1994; Moore et al., 1995), but also around the Canary Islands (Holcomb and Searle, 1991; Watts and Masson, 1995; Masson, 1996; Urgeles et al., 1997; Carracedo et al., 1999; Urgeles et al., 1999), La Rúnion Island (Chevallier and Bachelery, 1981; Duffield et al., 1982; Léat et al., 1989; Labazuy, 1996), Stromboli (Kokelaar and Romagnoli, 1995), St. Augustine Island (Begé and Kienle, 1992; Siebert et al., 1995; Waythomas, 1997), Ritter Island (Johnson, 1987), Tristan da Cunha (Holcomb and Searle, 1991), Martinique (Semet and Boudon, 1994), Cape Verde (Elsworth and Day, 1999) and others.

Most of these studies, however, have focussed on the description of the offshore bathymetric data including the accumulation zone of the landslides and an analysis of the mechanics of the failures mostly lacks. Only the Hilina event on Mauna Loa, Hawaii, and the Piton de la Fournaise failures on La Rénion have been investigated more comprehensively, because both events are characterised by active displacements currently measured. The Hilina event, a typical slump, is an enormous, active creeping landslide that involves most of the southeast flank of Kilauea volcano (Figure 2.3). The slump covers about $5200 \mathrm{~km}^{2}$, is about $100 \mathrm{~km}$ wide and $40 \mathrm{~km}$ long and has an inferred maximum depth of $5 \mathrm{~km}$ (Moore et al., 1989). Its location on an active volcano induces that the mass movement is influenced by sustained magmatic, seismic and hydrothermal activity. The head scarp of the slump is located adjacent to the active East Rift zone and the Kilauea caldera.

The recurrent landslides on Piton de la Fournaise volcano were defined as debris avalanches and include at least three different events (Labazuy, 1996). A total volume of $550 \mathrm{~km}^{3}$ was estimated for the entire submarine accumulation zone. The multiple failures cut a huge amphitheatre into the volcano edifice with lateral scarps of heights between 100 and $300 \mathrm{~m}$. The amphitheatre lies between two rift zones and the large Enclos caldera is located at its head (Figure 2.3a). Recent magma intrusions and flank eruptions provoked seaward displacements of the materials filling the amphitheatre and a big part of the volcanic edifice (Duffield et al., 1982).

The examples of the Hilina and Piton de la Fournaise landslides have not only been selected due to their big amount of data, but also because of the volcanic setting adjacent to the failures which are similar to the one on Tenerife. The La Orotava valley events and both of the described examples are characterised by the presence of an important rift zone and of a collapse caldera. 

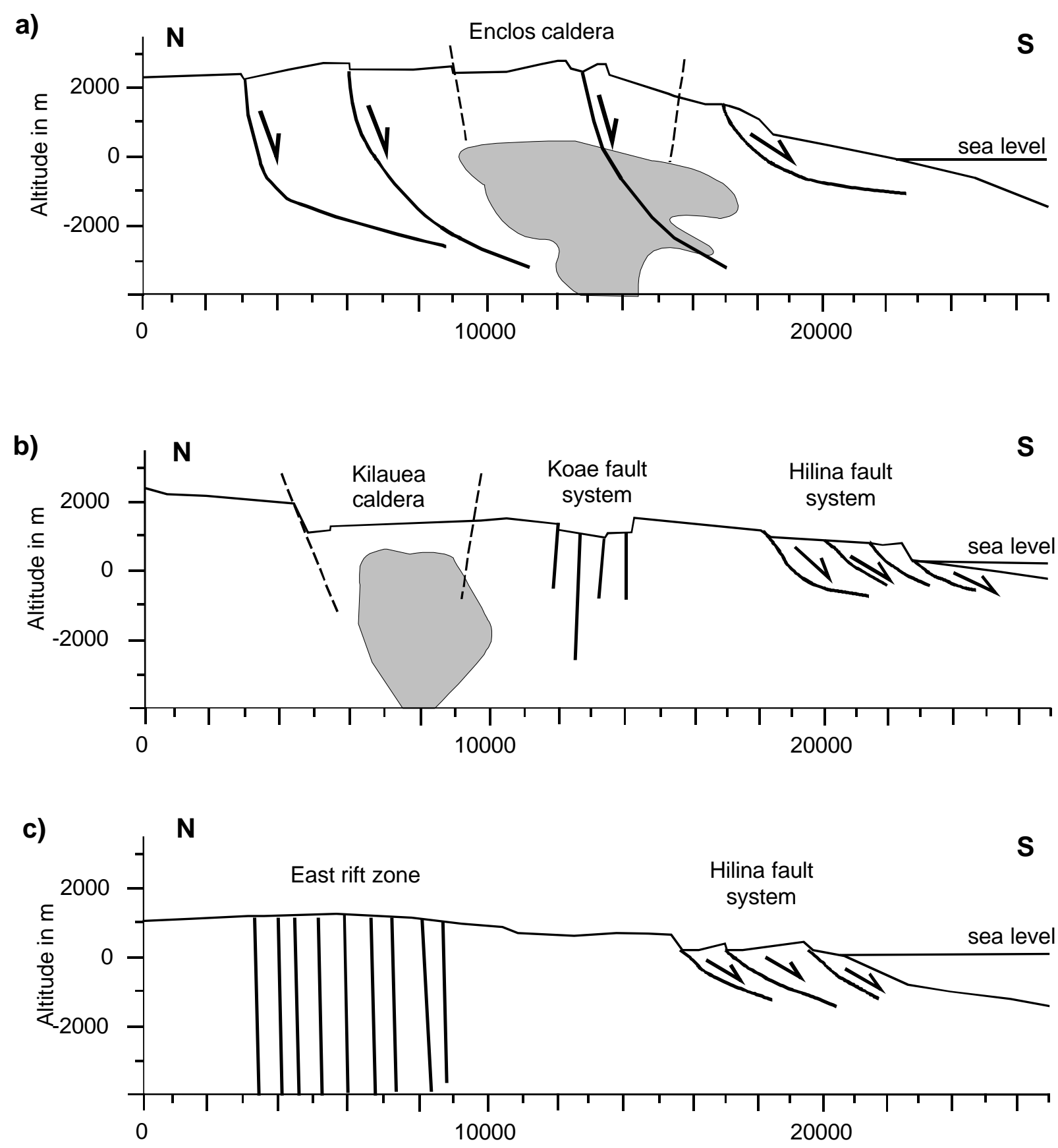

Horizontal distance in $\mathrm{m}$

Figure 2.3: Cross sections of landslides on volcanic islands. a) Piton de la Fournaise on La Rénion with Enclos caldera, (b) Hilina landslide with Kilauea caldera, and (c) Hilina landslide with east rift zone. Arrows indicate slope movements. Dashed lines represent the inferred ring faults of the calderas, thick solid lines show intruding dikes and grey-shaded area indicates the magma chamber. Modified from Duffield et al. (1982). 


\subsection{Causes of large landslides}

Generally, large landslides originate either by increasing the destabilising forces (driving forces) or by reducing the strength of the materials involved, or both. The causes of slope failures include: 1) preparing factors; and 2) triggering mechanisms. Landslides can have several preparing factors destabilising the natural slope, but only one mechanism finally triggering the failure. By definition a trigger is an external stimulus such as intense rainfall, a seismic shock or another mechanism that causes a near immediate response in the form of a landslide by rapidly increasing of the stresses or by reducing the strength of slope materials (Turner and Schuster, 1996). On the other hand the preparing factors or destabilising processes can include geological, morphological, physical and human components and can affect the slope stability over days, weeks or even years.

Large non-volcanic landslides mainly have many preparing factors including geologic features such as bedding and foliation, rock alteration from weathering, the history of previous motions, hydrologic or climatologic variations and morphologic features, amongst others. On the other side, the triggering mechanisms of such large events include strong and/or long-lasting rainfalls, rapid snow melts, strong earthquakes or a combination of different factors (Heim, 1932; Voight, 1978c; Eisbacher and Clague, 1984; Turner and Schuster, 1996).

In contrast, the causes of large volcanic events are more complex due to the influence of volcanic activity. The volcanic activity produces many different processes destabilising directly or indirectly the natural slopes. These processes include explosive or effusive eruptions, volcanic or volcano-tectonic tremors, magma intrusion in form of dikes, sills or domes, inflation or deflation of the magma chamber, hydrothermal alteration and caldera collapse episodes. The complexity of factors influencing on the mechanical stability of volcanic slopes can been seen in Table 2.2, where non-volcanic and volcanic agents are listed. In this study, however, only some of these factors have been studied including agents of point 1 (morphologic and geologic features), point 2 (e.g. earthquakes) and point 3 (pore fluid pressure enhancement and changes in structure).

In the following Sections the most important causes will be described dividing into non-volcanic and volcanic causes. Sometimes, the division between non-volcanic and volcanic causes is diffuse because they are often correlated with each other. Hydrothermal alteration can be taken as such an example since the hydrogeological setting with the existence of water and the volcanic activity generating heat and gas are two indispensable factors for this process. Another example are the seismic shocks which can be caused by a tectonic, volcano-tectonic or volcanogenic origin. 
Table 2.2: Causes of volcanic landslides (after Voight and Elsworth, 1997).

\section{Inherent causes}

- Initial composition

- Texture : loose, porous, weak materials are slide-prone

- Bedding attitude relative to slope face

- Layering sequences in relation to strength and permeability

- Discontinuity systems : faults, joints, dikes, bedding planes

- Slope forming process history, movement history : bedding slip and fault slip history and orientation of movement

- Initial physicochemical setting conditions of weathering and alteration

- History of seismicity and seismic damage

- Ambient (seasonal) groundwater conditions

\section{Increase of shear stress}

- Removal of lateral or underlying support of slopes

- Erosional processes producing, steepening, or undercutting natural slopes

- Prior mass movements

- Phreatic explosion near base of slope

- Static loading

- Natural deposition : slope or river sedimentation volcanic sedimentation (tephra, lava)

- Weight of water added by natural precipitation or by exsolved volatiles

- Seepage pressure and joint water pressures

- Magma pressure

- Swelling pressures in expansion clays

- Dynamic loading

- Regional or local tectonic earthquakes

- Vibrations from volcanic earthquakes, explosion and eruptive processes

- Vibrations from adjacent, rapidly moving landslides

- Increase of surface slope

- Magma intrusion related deformation (cryptodomes)

- Regional tectonics (slow or episodic change)

- Slope changes due to depositional processes

\section{Reduction of shear strength}

- Physicochemical factors

- Hydrothermal alteration

- Softening of clays

- Hydration of clay minerals

- Ion exchange of clays

- Weathering

- Solution of grain cement

- Decomposition of organic materials

- Physicochemical fracturing

- Pore fluid pressure enhancement

- Heavy rainfall or rapid snowmelt

- Changes in groundwater flow regime

- Pore-pressure changes in aquifers adjacent to magma intrusion, due to poroelastic

deformation, thermal expansion, or separation of gas from magma chambers

- Pore-pressure changes due to hydrothermal processes

- Thermal expansion of pore fluid due to frictional slip

- Vibration induced pore fluid pressure rise

- Shear deformation induced pressure rise

- Consolidation seepage induced by surcharge

- Base level change in reservoirs, lakes or oceans

- Flow boundary condition changes (e.g. iced or plugged flow egress points)

- Enhanced glacier melting due to increased geothermal flux

- Changes in structure

- Disturbance, remoulding

- Particle reorientation due to slip or dynamic loading ; peak to residual strength loss

- Grain collapse in altered, weakened tephra deposits

- Fracturing and loosening of valley walls, stress relief etc.

- Deep seated fracturing associated with magma intrusion, stress relief, geothermal processes, physiochemical alteration

- Adjustments to groundwater flow paths; slope drainage enhanced or impeded 


\subsubsection{Non-volcanic factors}

\section{Morphologic factors}

The slope angle has traditionally been assumed to be one of the most important morphologic features which influences the stability of the volcano flanks. The slope angles of 55 Quaternary volcanoes, which have undergone major slope failure, are shown in Figure 2.4. Large landslides appear most likely when the slope angle exceeds $20^{\circ}$, but mass movements on volcano flanks with an inclination of less than $10^{\circ}$ have also been observed (Siebert, 1984). While the events with slope inclinations of about $30^{\circ}$ mainly occurred at steep-sided stratovolcanoes, the events with a slope angle of about $10^{\circ}$ are characteristic for volcanic islands. In addition, the comparison of the elevation above base of 845 Holocene volcanoes with that of volcanoes which have suffered large landslide events suggests that failure can occur with edifice heights as low as $500-1000 \mathrm{~m}$. The most critical height of volcanic edifices, however, seems to be between 1000 and $1500 \mathrm{~m}$ (Siebert, 1984).

Similar results revealed the analysis of 55 rock avalanches exceeding volumes greater than $10^{6} \mathrm{~m}^{3}$ in mountainous terrains (Hermanns and Strecker, 1999). This study suggests that vertical relief contrasts between the breakaway zone and the toe of the failure must exceed a threshold of $400 \mathrm{~m}$ and slope inclinations must be steeper than $20^{\circ}$.

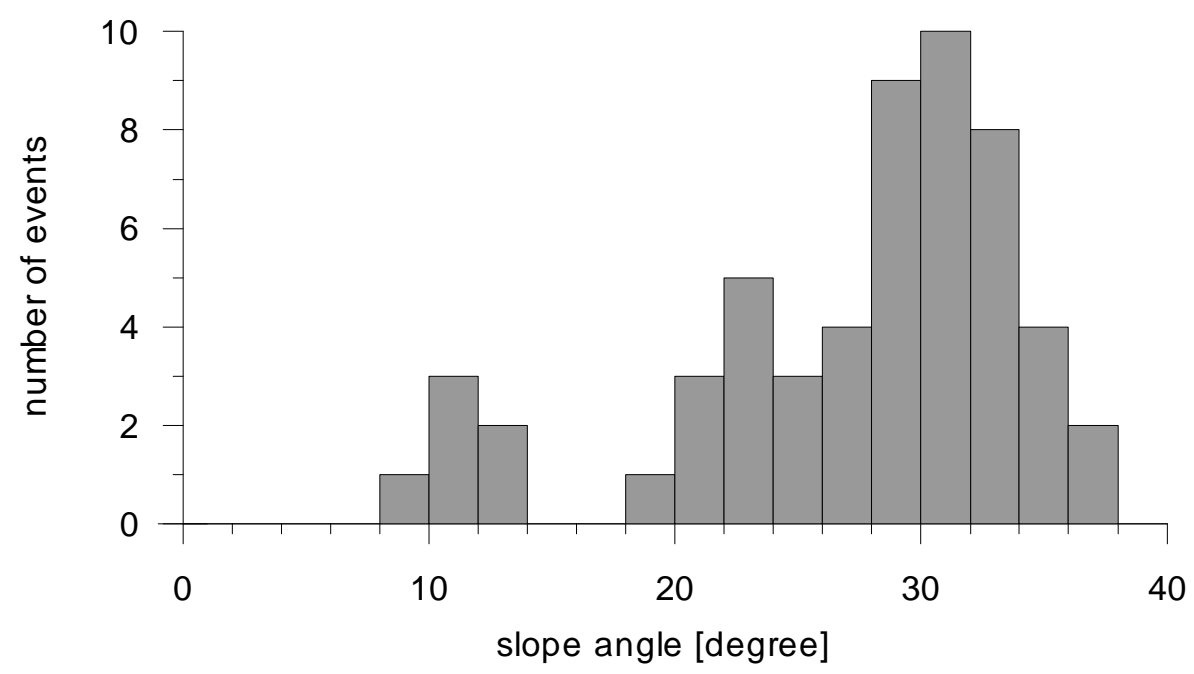

Figure 2.4: Influence of slope angle on the failure of 55 Quarternary volcanoes (after Siebert, 1984).

\section{Geologic factors}

The geologic setting including texture, bedding, discontinuities or weathering conditions strongly influences on the stability of natural slopes (e.g. Pearce and O'Loughlin, 1985). The orientation of rock layering and discontinuities, or bedding planes, exfoliation joints and cleavage dipping slope outwards often encourage mass movements, and long-term weathering decreases the frictional resistance of the rock. However, the mechanical properties of the materials composing volcanoes are not well known and geotechnical studies on volcanic deposits hardly exist. Nevertheless, some potential weak layers destabilising the volcano flanks have been proposed by several authors. Weak pyroclastic rocks were detected at Bandai or Stromboli within the volcano slopes (Siebert, 1984) or at the contact with the basement (Van Wyk de Vries and Francis, 1997). Hyaloclastite deposits as a potential slip surface have been proposed for the events on La Rénion and Kilauea volcano (Duffield et al., 1982) and the destabilising effect of a ductile layer of olivine cumulates is another factor found on Hawaiian volcanoes (Clague and Denlinger, 1994). 
Eisbacher and Clague (1984) defined water saturated pyroclastic deposits and fractured lava flows as soil and rock types with high risk of landslide initiation and described different cases in the western hemisphere: the Dusty Creek landslide in 1963 with a poorly consolidated tuff breccia and columnar jointed dacites, the Pylon Peak event in 1975 with weakly consolidated pyroclastic rocks or the Guatemala landslides in 1976 at steep slopes of Pleistocene pumice deposits.

\section{Hydrologic and hydrogeological factors}

The relationship between the climate and the groundwater system is a fundamental point in the stability analysis of natural slopes. There is increasing evidence that water plays an important role in the stability conditions of volcanic edifices, as it does in non-volcanic slopes. Pore water pressure controls the strength of the material and thus the slope stability mechanics. The significant effect of pore fluid pressure in the initiation of landslides has mainly been constrained for non-volcanic events (e.g. Iverson et al., 1997), while only theoretical models have been applied to those associated with volcanic events (Elsworth and Voight, 1995; Day, 1996; Voight and Elsworth, 1997). In volcanic environment, hydrothermal alteration does not only play a major role in increasing susceptibility to failure, but the common association of lateral collapse events with phreatic explosions supports a significant involvement by hydrothermal pore fluids in the failure process (McGuire, 1996b). The effects of volcanic activity on the pore fluid pressures and the hydrothermal alteration are the topic of many recent and running research projects and will be discussed in the Section refering to volcanic factors later in this Chapter.

\section{Sea level changes}

Many of the largest landslide events are located on volcanic islands (Figure 2.1) and the destabilising effect of sea level changes on the stability of the volcanic edifice has been proposed by different authors (Bray, 1977; Firth et al., 1996; McGuire, 1996a; McGuire et al., 1997; Ablay and Hïlimann, 1999). The principal origins of sea level changes are twofold: 1) the global climatic variations with the associated increase of the ice sheets; and 2) the vertical movement of the volcanic island due to magma loading and unloading. The construction and destruction of the volcanic edifice applies a vertical stress to the lithosphere deforming the oceanic crust upwards or downwards. The resulting flexural moat in the oceanic crust can have a depth of up to $2500 \mathrm{~m}$ as in Tenerife (Watts et al., 1997) or $1000 \mathrm{~m}$ as in Gran Canaria (Funck and Schmincke, 1998).

The correlation between mechanical stability of oceanic islands and sea level fluctuations is complex and the destabilising factors include many different processes such as sea wave erosion at the coast, sea water loading onto the submarine volcano flank or pore pressure changes. The most important factor, however, plays the suggested relationship between large rapid sea level changes and its influence on the volcanic activity (McGuire et al., 1997).

\section{Tectonic seismicity}

Seismicity in volcanic terrains can have tectonic, volcanic or volcano-tectonic origins. Often a clear distinction between tectonic and volcanic earthquakes is difficult. In contrast to purely tectonic dynamics, where all seismic failures can be ascribed to double-couple systems of shear forces acting on two orthogonal planes, the seismic source at active volcanoes may be highly complex, since it often involves interactions between gas and liquid or liquid and solid (Ekströn, 1994; Ferrucci, 1995). However, while the tectonic shocks can be characterised by shear failures, the volcanic shocks are generally tensional failures. 
Here, a short overview of the tectonically induced seismicity and its influence on slope stability will be given, while a detailed description of the volcanogenic and volcano-tectonic seismicity will be presented in Section 0 concerning volcanic factors.

Strong tectonic earthquakes are assumed to be the most frequent triggering mechanism of large landslides in mountainous terrains characterised by ongoing tectonism (Plafker and Ericksen, 1978; Eisbacher and Clague, 1984; Crozier, 1992; Schuster et al., 1992; Jibson and Keefer, 1993; Tibaldi et al., 1995; Hermanns and Strecker, 1999). Every year, small- or large-scale slope failures occur due to tectonic seismicity (Albini and Vogt, 1992) and the catastrophic earthquakes at Northridge in 1994 and at Kobe in 1995 are only two examples to illustrate the hazard of tectonically induced landslides (Harp and Jipson, 1996; Okimura et al., 1996).

The destabilising effects of an earthquake on a natural slope mainly depend on the geologic underground, the magnitude of the tremor and the epicentre distance (Okamoto, 1984; Kramer, 1996). The study of 40 historic tectonic earthquakes and the landslides associated with these events revealed the maximum distance from the epicentre to cause slope failure as a function of magnitude (Keefer, 1984). The results indicate that the occurrence of landslide events decreases exponentially for higher epicentre distances. This feature can be explained by the use of geotechnical earthquake engineering, where the influence of a seismic shock on a natural slope is generally calculated by the acceleration released. Using a peak acceleration attenuation relationship, a maximum horizontal acceleration coefficient (PHAC) can be estimated for different magnitudes and distances to the epicentre. A nearsource attenuation with worldwide data is shown in Figure 2.5 applying the component for hard-rock sites (Campbell and Bozorgnia, 1994). The graph indicates that the PHAC increases logarithmically with proximity to the epicentre and linearly with increasing magnitude. Therefore, to have a PHAC high enough to exceed the stability limit of the volcano slopes and to trigger a landslide it is necessary to have either a close, moderate earthquake or a distal one of large magnitude. The significant influence of the epicentre distance on the acceleration magnitude can be verified by comparing an earthquake occurring at a distance of $50 \mathrm{~km}$ with a tremor at a distance of $5 \mathrm{~km}$. Assuming a magnitude of 5.0 for both events, the distant earthquake produces a PHAC of 0.01, in contrast to the proximal tremor, which generates a PHAC of 0.29 . This suggests that adjacent and shallow volcanogenic or volcano-tectonic earthquakes are much more favourable to produce large slope failures at volcano flanks than a distal purely tectonic tremor.

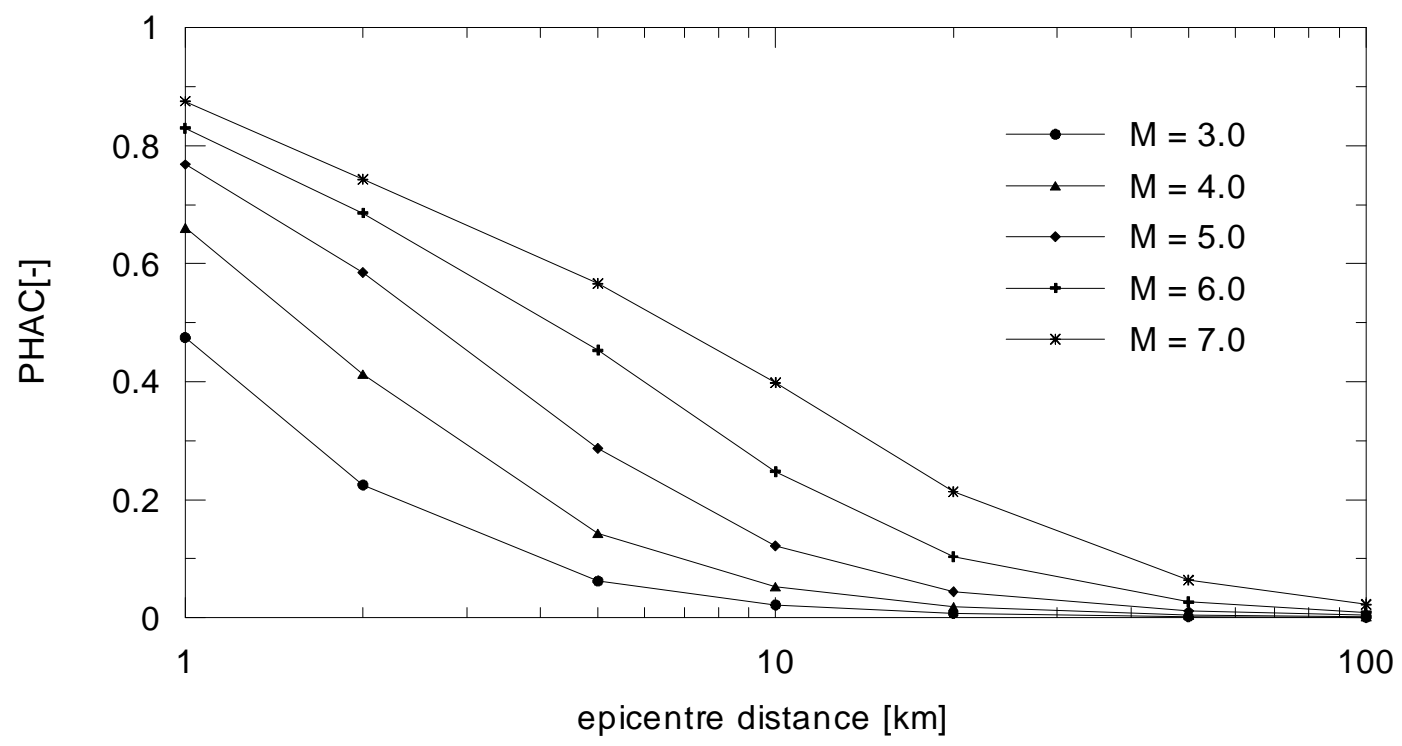

Figure 2.5: Variation of peak horizontal acceleration coefficient (PHAC) with epicentre distance for different earthquake magnitudes (after Campbell and Bozorgnia, 1994). 


\subsubsection{Volcanic factors}

Since the Mt. St. Helens event in 1980 the influence of volcanic activity on the stability of volcano flanks has intensively been studied. The complex interactions due to active volcanism have originated many potential theories refering to the significant mechanisms provoking a failure, but the relationship between landslide triggers and volcanic activity has not yet been resolved. A summary of some proposed causes concerning large volcanic landslides is listed with examples and references in Table 2.3. Each of these processes will be described in the following Sections.

Table 2.3: Potential processes generating large landslides on volcanoes.

\begin{tabular}{|c|c|c|}
\hline process & example & reference \\
\hline explosive eruption & Bezymianny, Bandai & Siebert et al. $(1984,1987,1992)$ \\
\hline dike intrusion / 'rifting' & $\begin{array}{l}\text { Hawaii } \\
\text { Mt. Etna } \\
\text { Canary Islands } \\
\text { Cape Verde }\end{array}$ & $\begin{array}{l}\text { Dvorak et al. (1986) } \\
\text { Dieterich (1988) } \\
\text { Iverson (1995) } \\
\text { Elsworth and Voight (1995) } \\
\text { McGuire et al. (1990,1991) } \\
\text { Carracedo (1994) } \\
\text { Elsworth and Day (1999) }\end{array}$ \\
\hline dome intrusion & Mt. St. Helens & Voight et al. $(1981,1983)$ \\
\hline inflation of magma chamber & $\begin{array}{l}\text { Hawaii } \\
\text { La Rúnion } \\
\text { Mt. Etna }\end{array}$ & $\begin{array}{l}\text { Denlinger and Okubo (1995) } \\
\text { Duffield et al. (1982) } \\
\text { Lo Giudice and Rasa (1992) }\end{array}$ \\
\hline $\begin{array}{l}\text { seismic shocks (tectonic, } \\
\text { volcano-tectonic or volcanic) }\end{array}$ & $\begin{array}{l}\text { Mt. St. Helens } \\
\text { Nevados Huascará } \\
\text { Mt. Etna }\end{array}$ & $\begin{array}{l}\text { Voight et al. (1981, 1983) } \\
\text { Plafker and Ericksen (1978) } \\
\text { Montalto et al. (1996) }\end{array}$ \\
\hline caldera collapse event & Tenerife & Martíet al. (1997) \\
\hline volcanic spreading & $\begin{array}{l}\text { Mt. Etna, Central Costa Rica } \\
\text { Mombacho (Nicaragua) }\end{array}$ & $\begin{array}{l}\text { Borgia et al. (1990, 1992, 1994) } \\
\text { vanWyk deVries and Francis (1997) }\end{array}$ \\
\hline hydrothermal alteration & $\begin{array}{l}\text { Nevado del Ruiz } \\
\text { Mt. Rainier } \\
\text { Mt. Pelé }\end{array}$ & $\begin{array}{l}\text { Lóez and Williams (1993) } \\
\text { Frank (1995) } \\
\text { Zlotnicki et al. (1998) }\end{array}$ \\
\hline
\end{tabular}




\section{Explosive eruptions}

Failures related to explosive eruptions have been the first large volcanic landslides in being classified (Siebert et al., 1987). Historic eruptions have been studied and the associated slope failures were divided into the following two types of landslides distinguishing between the magmatic activity during the eruption:

I. 'Bandai-type', characterised by steam explosions without eruption of juvenile products

II. 'Bezymianny- type', characterised by a magmatic explosion

However, Siebert et al. (1987) concluded that additional factors have played an important or the most important role in the majority of the analysed cases and that often a combination of processes or conditions have caused the failure. A good example of this hypothesis is the Mt. St. Helens event, where the slope failure produced the eruption, not vice versa. Therefore, the idea proposed by Siebert et al. (1987) represents more a classification of large slope failures at stratovolcanoes than a definite cause of the landslides. This is verified by the fact that the authors defined an additional type of large volcanic landslides: an 'Unzen- type' occurring without related explosive eruption but with associated seismic shocks.

Finally, Siebert et al. (1987) classified historic eruptions with associated partial failure of the volcanic edifice. The majority has been defined on one hand by type I including the events at Bezymianny, 1956; Mt. St. Helens, 1980; Shiveluch, 1854 and 1964, Augustine 1883, amongst others and on the other hand by type II including the events at Bandai, 1888 or Ritter Island, 1888. A slope failure related to the Unzen-type has only been documented at Unzen, 1792, and at Chaos Crags, ca. 1650 (Siebert et al., 1987).

\section{Dike intrusion}

Most volcanic eruptions are supplied with magma through fractures. Magma filled fractures, frozen or fluid, are referred to as dikes when they are sub-vertical and as sheets when they are inclined (Gudmundsson et al., 1999). Only a small part of all dikes reaches the surface (feeder dikes) and provokes an eruption.

Where repeated dike intrusion is favoured by extensional tectonics, so that it occurs along a persistent linear axis, the process is commonly called 'rifting'. The theory of volcanic rift zones was determined on the Hawaiian Ridge and was defined as flank-preferential intrusive-eruptive zones that converge at the summit caldera or central zone of a volcano (Léat et al., 1989).

From a geotechnical point of view, the intrusion of dikes into bedrock influences in many forms on the mechanical stability of volcanoes. Generally, the principal factors caused by dike intrusion can be divided into:

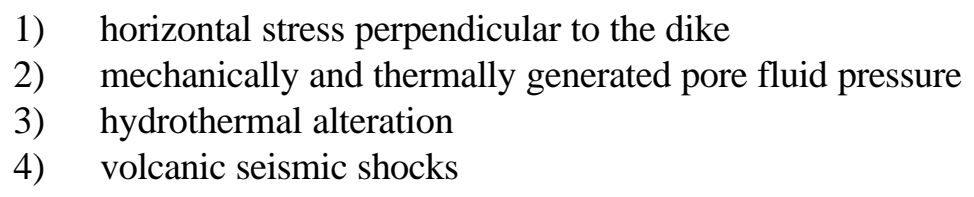

Point 2 includes the pressurisation of pore fluids due to magmatic intrusion and is perhaps one of the most complicated processes related to volcanic slope stability (e.g. Elsworth and Voight, 1992). It depends not only on the mechanical and thermal strains but also on the related processes such as hydrothermal activity, hydrofracturing or seismic shocks (Elsworth and Voight, 1995; Voight and Elsworth, 1997). 
Dike intrusion or rifting are suggested to be the principal causes of large slope failures especially on Hawaiian volcanoes (Dvorak et al., 1986; Elsworth and Voight, 1995; Iverson, 1995; Voight and Elsworth, 1997), but also at Mt. Etna (McGuire et al., 1990; McGuire et al., 1991), La Rúnion (Chevallier and Bachelery, 1981; Léat et al., 1989), the Canary Islands (Carracedo, 1994) or Cape Verde (Elsworth and Day, 1999). Continuous measurements of the deformations along zones affected by persistent dike intrusion may give an idea of the influence of the horizontal stress acting on the adjacent slope and are being carried out at many sites. At Kilauea volcano, an average horizontal displacement rate of $0.5 \mathrm{~m}$ per year has been observed between 1970 and 1989 (Denlinger and Okubo, 1995), and at Mt. Etna an average rate of $0.93 \mathrm{~m}$ per year has been detected between $1983-1985$ and $0.4 \mathrm{~m}$ per year between 1981 - 1989 (McGuire et al., 1991).

The study of 30 landslides occurred at volcanic edifices revealed that the axes of the failure amphitheatres often show a preferred orientation normal to the dominant direction of the dike intrusion (Moriya, 1980; Siebert, 1984). On volcanic islands, a similar feature has also been observed correlating the landslide events with the axis of the rift zones. Failures perpendicular to a rift zone or failures located between two rift zones are the most common cases. Examples of the first case have been described in the Hawaiian archipelago (Dvorak et al., 1986; Dieterich, 1988), the Canary Islands (Carracedo, 1994) and at Stromboli, Italy (Romagnoli and Tibaldi, 1994); and the second case have been detected at Piton de Fournaise, La Rénion (Léat et al., 1989), el Golfo, Hierro (Carracedo, 1994) and Valle de Bove, Mt. Etna (McGuire et al., 1990; McGuire et al., 1991).

Dikes represent only one form on how magma can intrude into the volcanic rocks, and there exist many other intruding styles such as domes or sills. The Mt. St. Helens event is the most common example of a volcano failure that has been affected by dome intrusion (Voight et al., 1981). Deformation measurements from the summit point above the dome during the week before the catastrophic failure occurred gave horizontal values of about 2.5 meters per day and vertical values of about 1 meter per day (Moore and Albee, 1981; Paul and Gratier, 1987 ).

Inflation or deflation of the magma chamber are other processes related to magma movements and are proposed to be an important agent to the slope stability in Hawaii (Denlinger and Okubo, 1995), La Rúnion (Duffield et al., 1982) and Mt. Etna (Lo Giudice and Rasa, 1992).

\section{Caldera collapse episode}

Caldera collapse episodes are cataclysmic infrequent events, which form large subcircular depressions up to $100 \mathrm{~km}$ in diameter generated by the collapse of overlying roof rock into a shallow magma chamber typically accompanied by voluminous eruptions of pyroclastic materials (Williams and McBirney, 1979; Druitt and Sparks, 1984).

The destabilising effects during a caldera collapse episode are complex and include many different processes. The most important mechanical influences on the stability of the volcano flank can be summarised as:

1) changes of the stress field due to pre-eruption inflation of the magma chamber and associated magma intrusion

2) hydrothermal alteration caused by point 1

3) shear stress along the ring fault caused by the vertical collapse of the roof into the decompressed magma chamber

4) seismic shocks caused by both the shear stresses on the ring fault mentioned in point 3 and the associated explosive eruption

5) accumulation of eruptive products on the volcano slopes

On Tenerife, a relationship between caldera collapse episodes and large-scale slope failures has been proposed due to the temporal coincidence of at least two caldera collapses with giant volcanic landslides (Martíet al., 1997). 
There exist data on several caldera collapse episodes during historic times. In the following, two different events will be described in a brief mode explaining the most important features refering to the caldera collapse and the destabilising effects.

The caldera collapse episode on Fernandina, Galapagos Islands, in 1968 is the best documented event and the only one with seismic records (Filson et al., 1973). The episode started with small seismic shocks about one month before the collapse occurred. Some flank eruptions during the last three weeks were observed, before a major eruption initiated the vertical caldera collapse that took place during 9 days from $11^{\text {th }}-19^{\text {th }}$ June. A strong seismic activity with earthquakes of maximum magnitudes up to 5.0 was recorded during the vertical collapse episode. The total subsided area covers about $8 \mathrm{~km}^{2}$ and the entire length of the boundary fault is assumed to be $10.5 \mathrm{~km}$. The caldera floor had dropped as a whole several hundreds of meters without altering a large tuff cone in its centre. The subsidence reached a maximum of $350 \mathrm{~m}$ in one corner. However, along about $3.5 \mathrm{~km}$ of the boundary fault much less than $200 \mathrm{~m}$ was measured (Filson et al., 1973).

The century's most voluminous eruption and the resulting caldera collapse at Mt. Katmai, Alaska, during June 1912 was recently studied using seismographic data (Abe, 1992). A sequence of moderate seismic activity began five days before the first eruption. The main eruptive phase lasted 60 hours and yielded about $15 \mathrm{~km}^{3}$ of solid volume producing about $30 \mathrm{~km}^{3}$ of eruption products (Hildreth, 1983). Approximately half of the volume is represented by ash-fall units and the other half by pyroclastic flow deposits. During this phase, the formerly cone-shaped volcano collapsed, leaving in its place a caldera 3 $\mathrm{km}$ in diameter and nearly $1 \mathrm{~km}$ deep. Strong seismicity was detected during the main eruption and the related collapse including 14 shocks with magnitudes between 6.0 and 7.0.

Two other significant caldera collapse episodes have been reported during the past 150 years. The basaltic volcano Askja in the central part of Iceland collapsed in 1875 during a gigantic explosive eruption and at Kilauea, Hawaii, important events occurred in 1868 and 1924. In 1924, the Kilauea caldera subsided $85 \mathrm{~m}$ and doubled its diameter due to a submarine eruption more than $50 \mathrm{~km}$ to the east.

Recently, significant unrest at large caldera systems have occurred in three locations of the world: Long Valley (USA), Campi Flegrei (Italy) and Rabaul (Papua New Guinea).

\section{Volcanic seismicity}

Two main sources of seismic shocks in the vicinity of volcanoes can be distinguished (Hoblitt et al., 1997): 1) those generated by the movement of magma or by formation of cracks through which magma can move, and those resulting from gas explosions within a conduit; 2) seismic shocks that result from readjustments of a volcanic edifice following eruption or movement of magma. While the first category is assumed to include pure volcanogenic tremors, the second category can be defined as volcano-tectonic earthquakes. Seismic shocks belonging to the first category rarely have Richter magnitudes greater than 5.0 and generally have foci at depths of less than $10 \mathrm{~km}$. The relationship between volcanic activity and earthquakes of category 2 is less well understood. Few quantitative data are available concerning the maximum magnitude of such earthquakes, although events larger than magnitude 5 have been observed.

A summary of seismic events associated with volcanic or volcano-tectonic processes is listed in Table 2.4 including the recorded or estimated magnitudes of the events. Seismicity associated to large explosive eruptions has been described many times, but the exact relationship between eruption and seismicity is not always clear. However, magnitudes during eruptions rarely exceed 6 (Abe, 1992) and generally range from 4 to 5 (Okada, 1983). Data on the seismicity related to the historic eruptions at Bandai in 1888, Unzen in 1792, Bezymianny in 1956, Shiveluch in 1964 and Mt St. Helens in 1980 have been published recently and show, that maximum magnitudes are about 5.0 (Gorshkov and Dubik, 1970; Okada, 1983; Voight et al., 1983; Siebert et al., 1987). The epicentre depths are normally located within the volcanic structures in depth ranging from about 1 to $5 \mathrm{~km}$. 
Table 2.4: Volcanic and volcano-tectonic processes and associated seismic activity (References see text).

\begin{tabular}{|c|c|c|c|}
\hline process & location & year & magnitude \\
\hline \hline explosive eruption $^{\mathrm{v}}$ & Unzen & 1792 & 5.0 \\
& Bandai & 1888 & 5.3 \\
& Bezymianny & 1956 & 5.0 \\
& Shiveluch & 1964 & 5.5 \\
& Mt St. Helens & 1980 & 5.2 \\
\hline rifting - slumping $^{\text {vt }}$ & Kilauea, Hawaii & 1975 & 6.6 \\
& & 1983 & 7.2 \\
\hline inflation or deflation of $^{\text {magma chamber }}{ }^{\text {vt }}$ & Long Valley, California & 1980 & 6 \\
& Campi Flegrei, Italy & $1983 / 84$ & 4.2 \\
\hline caldera collapse event $^{\text {vt }}$ & Katmai, Alaska & 1912 & 7.0 \\
& Sakurajima, Japan & 1914 & 6.7 \\
& Fernandina & 1968 & 5.2 \\
& Piton de la Fournaise & 1986 & 3.3 \\
\hline
\end{tabular}

v: volcanogenic shock

vt: volcano-tectonic shock

Earthquakes with magnitudes of 6.6 (Kalapana earthquake in 1975) and 7.2 (Kaoiki earthquake in 1983) have occurred at the Hilina fault system on Kilauea volcano, Hawaii (Eissler and Kanamori, 1987; Elsworth and Voight, 1995). These earthquakes may have been related to the movement along the head scarp of a large gravitational slump, which may have been caused by forceful dike intrusion along an active rift zone (see Figure 2.3). Therefore, the earthquakes are provoked by a combination of volcanic processes, large creeping mass movements and tectonic mechanisms and should correctly be defined as tectonic or volcano-tectonic shocks.

Earthquakes with a volcano-tectonic origin have also been detected adjacent to calderas mainly provoked by inflation or deflation of the magma chamber. A sequence of seismic shocks that occurred near the Long valley caldera, California, in 1980 included four events of magnitude 6+, which may have been triggered by magmatic intrusion (Julian, 1983; Aki, 1984). In the Campi Flegrei, Italy, the inflation of the magma chamber provoked in 1983 and 1984 seismic activity of maximum magnitudes of 4.2 in a depth between 2 and $4 \mathrm{~km}$ (Dvorak and Berrino, 1991).

However, the highest magnitudes associated with a volcanic process have been reported during caldera collapse episodes. These catastrophic events produce very strong earthquakes of mainly volcano-tectonic origins. The only available seismic records referring to a caldera collapse event is the collapse episode on Fernandina in the Galapagos Islands in 1968 (Filson et al., 1973). In spite of the modest event some 75 earthquakes with magnitudes up to 5.0 occurred. For the century's largest caldera collapse event in 1912 at Mount Katmai, Alaska, a study has been carried out and origin times, epicentre locations and surface-wave magnitudes could have been calculated. During the two days of strong seismic activity, 14 earthquakes had a magnitude equal or greater than 6.0 and the largest earthquake had a magnitude of 7.0 (Abe, 1992). A similar case to the Katmai event and one of the largest earthquakes of possible volcano-tectonic origin occurred adjacent to the caldera of Sakurajima volcano, Japan, in 1914 (Abe, 1992). There the earthquake had a focal depth of $13 \mathrm{~km}$ and a magnitude of 6.7. Another volcano-tectonic event represents the pit-crater collapse at the Piton de la Fournaise in 1986 , which incorporated a total collapsing volume of only $\sim 0.01 \mathrm{~km}^{3}$ provoking a swarm of seismic shocks with maximum magnitudes of 3.3 (Hirn et al., 1991). 
Volcanic spreading may also generate volcano-tectonic earthquakes with high magnitudes. However, observations or data refering to such types of seismic shocks have not been found in literature.

In summary, earthquakes directly associated with movement or eruption of magma seldom exceed a magnitude of about 5.0, while seismic shocks which have volcano-tectonic origins can reach high magnitudes up to about 7.0. However, as seen in Figure 2.5, the destabilising influence of seismic shocks on natural slopes not only depends on the magnitude of the event, but also on the epicentre distance. Therefore, volcano-tectonic earthquakes related to a vertical caldera collapse or to large-scale creep movements along rift zones (slumping) are the most critical seismic shocks refering to the stability of volcanoes. The high magnitude and the vicinity to the volcano flank convert such earthquakes to perfect candidates of potential triggering mechanisms of large volcanic landslides.

\section{Hydrothermal activity}

Hydrothermal alteration is the reaction of rocks or minerals by hot water and other fluids. The liquid is normally heated by magma or in association with magma (Gardner et al., 1995). Hydrothermal alteration of the volcanic material can reduce the shear strength and thus could play an important role in the volcano stability. Hot water and other fluids heated by magma change the material properties of the surrounding rocks and are able to weaken even hard, compact lava flows into unsound material.

Hydrothermal alteration has been described in several landslide events as an important factor contributing to the slope instability. The exposure of extensively altered pyroclastic rocks after the failure of volcanic cones in Japan (Moriya, 1980), weakening of major portions of the Mount St. Helens cone prior to its failure (Voight et al., 1981) and hydrothermal alteration at Nevado del Ruiz volcano (Lṕez and Williams, 1993), Mt. Pelé (Zlotnicki et al., 1998) and Mt. Rainier (Crandell, 1971; Frank, 1995; Crowley and Zimbelman, 1997; Vallance and Scott, 1997) are only some events found in volcanological literature. Other examples of hydrothermal activity associated with failures of volcano flanks are described on St. Lucia and Dominica in the Lesser Antilles islands, where Fumaroles are located along the head scarp of the rotational slides (Roobol et al., 1983).

On the other side, pore fluid pressures generated by hydrothermal systems may also influence on the mechanical stability of volcanoes. The relationship between these two factors is complex depending on many different parameters, but natural examples and theoretical models have illustrated the significant effect of pressurisation due to hydrothermal alteration on the initiation of large volcanic landslides (Day, 1996; Day et al., 1997; Voight and Elsworth, 1997). Enhanced fluid pressures and fracturing induced by shallow magma intrusion and hydrothermal alteration have been mentioned for the Mt. St. Helens event (Voight et al., 1981) and for the collapse at Bezymianny volcano (Siebert, 1984). 


\section{Stress regime}

The local stress field in a volcanic edifice is mainly controlled by two different features: 1) the regional tectonic stress regime; and 2) the gravitational stress regime which is mainly influenced by the general morphology of the volcano and modified by local topographic anomalies. This theory was supported by Finite Element Methods modelling the Hawaiian volcanic rift zones (Dieterich, 1988) as well as by studying the eruptive fissure and feeder-dike disposition at Mount Etna (McGuire and Pullen, 1989). Numerical analyses of the effects of regional stresses on the mechanical stability of Stromboli and Vesuvius volcano have revealed the significant influence of a strike-slip stress regime (Russo et al., 1996; Russo et al., 1997). Similar studies have been carried out for the active intraplate volcanoes Marion, Tristan da Cunha and La Rúnion and have shown that the stress field inside the volcanic edifice strongly depends on the applied regional stresses and the selected magmatic pressure in the magma chamber (Chevallier and Verwoerd, 1988).

One specific phenomenon generated by the stress field of the volcanic edifice is spreading. The influence of gravitational spreading on the stress regime of volcanoes and the potential destabilising mechanisms have been analysed numerically (Van Wyk de Vries and Metala, 1998) and also at the Mt. Etna (Borgia et al., 1992), at the Mombaco volcano, Nicaragua (Van Wyk de Vries and Merle, 1996; Van Wyk de Vries and Francis, 1997) and at the central Costa Rica volcanic range (Borgia et al., 1990; Borgia, 1994). The model of volcano spreading assumes a radial displacement away from the volcanic centre, unbuttressed on a weak and incoherent basement (e.g. clay-rich layer for Mt. Etna), due to the loading of the edifice. Van Wyk de Vries and Merle (1996) showed that several relations between volcano geometry, mechanical properties and life-time of the volcano predict the spreading potential and the relative hazard of a large-scale failure. 


\subsubsection{Geotechnical considerations}

Failure mechanisms related to large-scale landslides might be different from those involved in medium- and small-scale events for which many geomechanical models have been proposed. Thus, a size/scale effect is probably important when analysing large slope failures. However, it is reasonable to make use of standard models and strategies as a starting point to study large volcanic landslides. This study has applied standard geotechnical approaches studying the mechanisms of large volcanic landslides.

Two phenomena that have been observed in small to medium failures could also be very important in large ones and have been considered in detail in this Section: 1) progressive failure, and 2) undrained loading.

\section{Progressive failure}

Almost every description of large historical landslides refers to some aspects of time-dependent deformation before the sudden initiation of the failure occurred. Creep-like movements seem to precede most of the large landslides and have been observed prior to many events such as Frank, Hope, Gros Ventre, Elm or Vaiont (Buss and Heim, 1882; Mathews and McTaggart, 1978; Voight, 1978c; Voight, 1978a; Bromhead, 1992). The causes-effect relationship of such creeping are proposed to be twofold: 1) the progressive reduction of strength (e.g. Skempton, 1966); and 2) the pore fluid vaporisation due to frictional heating (e.g. Habib, 1976).

The influence of slow displacements along existing bedding planes and the resulting reduction of the shear strength to the residual strength has first been mentioned by Skempton (1966) after the Vaiont catastrophe. The residual strength is a minimum value of soil strength and is generated at large displacements along existing slip surfaces. A laboratory research on the strength reduction due to constant displacements along slip planes showed that strength reduction occurs in a transitional sense for materials with a clay fraction between 25 to $50 \%$ (Skempton, 1985; Tika and Hutchinson, 1999). The residual strength is generally not relevant to first-time slides in previously unsheared soils, but in old landslides, in bedding shears of folded strata and in sheared joints or faults.

The evolution of a creeping mass strongly depends on the pore fluid pressure changes associated with the movement. Due to its complexity and the lack of data refering to natural examples, this argument was investigated almost always theoretically (Habib, 1976; Voight and Faust, 1982; Voight et al., 1985) and an application has hardly been carried out (Goguel, 1978). Generally, these authors follow the suggestion that heat due to sliding friction can transform pore water into vapour and thus change the pore fluid pressure. Applying the effective stress principles, this change affects directly on the strength of the material and can decrease the apparent coefficient of kinetic friction. Because slow creep movements produce little fluid pressure enhancement, however, most of the studies have focused on the dynamic problem of landslides, rather than the static problem, which cause the initial movement. A recent publication intended to adapt this frictional heating theory to creeping motion over long periods of time using a theoretical approach (Davis et al., 1990).

Progressive slope failure should be taken into account during the analysis of large volcanic landslides because creeping movements, saturated conditions and heat transfer are common features in volcano flanks. Especially the reduction of material strength caused by slow movements can be applied to materials composing volcanic edifices, since significant displacements exist in volcanic terrains due to magma intrusion or the local and regional stress regime. Evidence for these processes might be the creeping slumps at submarine volcano flanks such as the one at Kilauea (Denlinger and Okubo, 1995) or aborted lateral collapses along rift zones such as the one at el Hierro (Day et al., 1997). 


\section{Undrained loading}

The difference between drained and undrained loading is fundamental in geotechnics and strongly influences on the stability of natural slopes (e.g. Lambe and Whitman, 1979). The two distinct loading conditions mainly depend on the pore fluid pressure, $\mathrm{P}_{\mathrm{w}}$. Undrained conditions occur whenever external loads change at a rate much faster than the rate at which the induced pore pressure can dissipate and, consequently, the water pressure in the voids increases. Such conditions generally require both a fast loading mechanism such as seismic shocks and saturated conditions. On the other side, drained conditions exist when the pore pressures caused by external loads can dissipate and remain constant. A drained loading occurs in dry conditions and/or slow loading mechanisms.

The key point of this concept is that undrained loading conditions can significantly reduce the material strength due to an increase of pore water pressure. Figure 2.6 illustrates the fundamental differences of drained and undrained loading using the data obtained from standard triaxial tests. The result of the drained test indicates a slow and/or 'dry' loading and is characterised by a high material strength, while the result of the undrained test has a much lower strength representing a fast loading of saturated material.

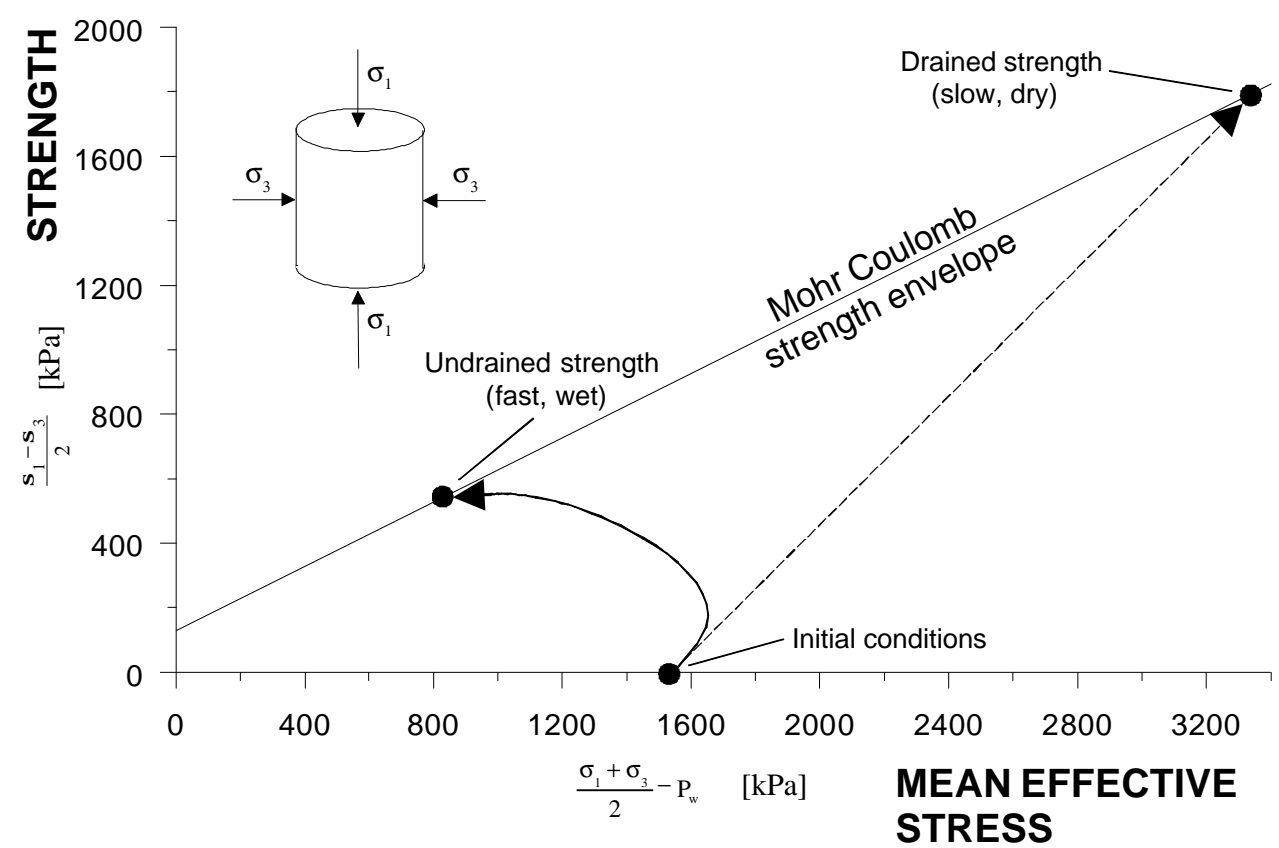

Figure 2.6: Drained (dashed line) vs. undrained loading (solid line) illustrated by two stress paths of triaxial tests. Dots represent initial and final stress conditions of the tests. $x$-axis indicates the mean effective stress applied to the samples during the tests and $y$-axis shows the material strength (deviator stress). Inset illustrates how the stress vectors are defined during triaxial tests.

In summary, undrained loading is an important feature studying the initiation of large volcanic landslides, since the two conditions seismic shocks and saturated material are frequently certain in volcanic terrains.

In this study, the effect of undrained loading on the behaviour of a common soil found on Tenerife has been investigated in detail. It is proposed as one of the most important mechanism producing large volcanic landslide on the island and may be applied to volcano collapses at other locations. 


\section{SITE INVESTIGATION}

\subsection{Introduction}

Site investigations are essential in geotechnical analyses of mass movements. Landslides in volcanic terrains are commonly characterised by complex geologic and morphologic settings due to the existence of many constructive and destructive processes caused by volcanic activity. Thus, a comprehensive analysis of the test site is fundamental in order to define the preslide conditions and to understand the evolution of the landslide. In this study, the landslide events of the La Orotava valley located at the northern flank of Tenerife have been selected as main test site. On Tenerife there are three important landslide amphitheatres - the valleys of Güimar, La Orotava and Icod - being the La Orotava valley the one which has been considered to be the most appropriate location to study the mechanisms of large volcanic landslides.

The landslide origin of the La Orotava and the two other valleys on Tenerife have not yet been proved definitively and the controversy about the evolution of these large depressions has divided the scientists in different groups. The discussion on the origin of the large valleys on Tenerife already started in the last century when some naturalists proposed theirs ideas (Von Humboldt, 1814; Buch, 1825; Lyell, 1855). One of the oldest theories suggests a volcanic explosion as the main mechanism of the valleys formation. A big explosion like the one of Krakatau, Vesuvius or Santorini caused a volcanic depression and formed the valleys (Hausen, 1956; Fúster et al., 1968). This theory was especially supported referring to the Icod valley and the Las Cañadas caldera. Ridley (1971) has distinguished between the Icod valley which has typical volcanic collapse features, and both the La Orotava valley and the Güimar valley which have been caused by the migration of magma towards the volcano flanks and failed by a 'trap-door' type mechanism. Another theory explains the origin of the valleys by a combination of lava accumulation and fluvial erosion. Repeated lateral accumulation of volcanic material combined with constant fluvial erosion has produced a lateral expansion of narrow canyons into wide valleys (Fritsch and Reiss, 1868; Palacios, 1994). Today, the most accepted theory suggests that large landslides originated the valleys. This theory has recently been confirmed by two bathymetric studies (Watts and Masson, 1995; Teide-Group, 1997).

Several potential causes have been proposed to explain the initiation of the landslide events. These include: the persistent rift activity along the structural axis of the island causing gravitational landsliding (Carracedo, 1994), the 'trap-door' mechanism proposed by Ridley (1971) or an impermeable, volcanic breccia acting as 'lubricating level' and thus destabilising the volcano flanks (Coello, 1973; Bravo Bethencourt and Bravo, 1989; Ancochea et al., 1999). Recently, the hypothesis of the caldera collapse episode as a potential trigger of the large landslides has been suggested by Martí et al. (1997).

The chapter is divided into four main parts. The first part includes the explanation of the geological setting of the Canary Islands in a short form and extensively the one of Tenerife. This part shows that large slope failure is a common phenomenon in the Canary archipelago. In the second part of this chapter, the results of the geomorphologic analysis are presented including information on the whole island of Tenerife, on its northern flank and in detailed form on the La Orotava valley. The third part refers to the geologic study and field surveys carried out at the La Orotava valley area and includes data on geochronology, hydrogeology, lithology, volcanism etc. In addition, some geotechnical observations will be explained focussing on the material strengths of the volcanic deposits found in the test site. In this study, the morphology of the test site will be described prior to the geology, but many results are correlated with each other. Finally, all of them will be summarised in the last part of the Chapter describing the assumed preslide conditions.

The main objective of this chapter is to determine the preslide geologic and morphologic conditions of the La Orotava valley area and the extension of the large landslides. The characterisation of the morphological and geological features favouring the initiation of the slides is another objective. Moreover, the temporal and local relationship between landsliding and volcanic activity is also a principal aim. 


\subsection{The Canary Islands}

The Canarian archipelago contains seven islands and is located in the eastern Atlantic Ocean near the African coast. Large landslides are common morphologic features on these volcanic islands and in the $90^{\text {th }}$ several submarine deposits derived from giant failures of volcano flanks have been detected using swath bathymetric and side-scan sonar data (Figure 3.1). A summary of the large landslides till now detected in the Canary Islands is listed in Table 3.1, containing a total of seventeen events on four islands. The majority of these mass movements have been defined as debris avalanches which have failed at the slopes of shield volcanoes, but significant collapses with post-shield ages have also been observed. Generally, the construction of a volcanic island implies a fist stage with a fast growth of a basaltic shield volcano and a second stage with the slow formation of a composite stratovolcano.

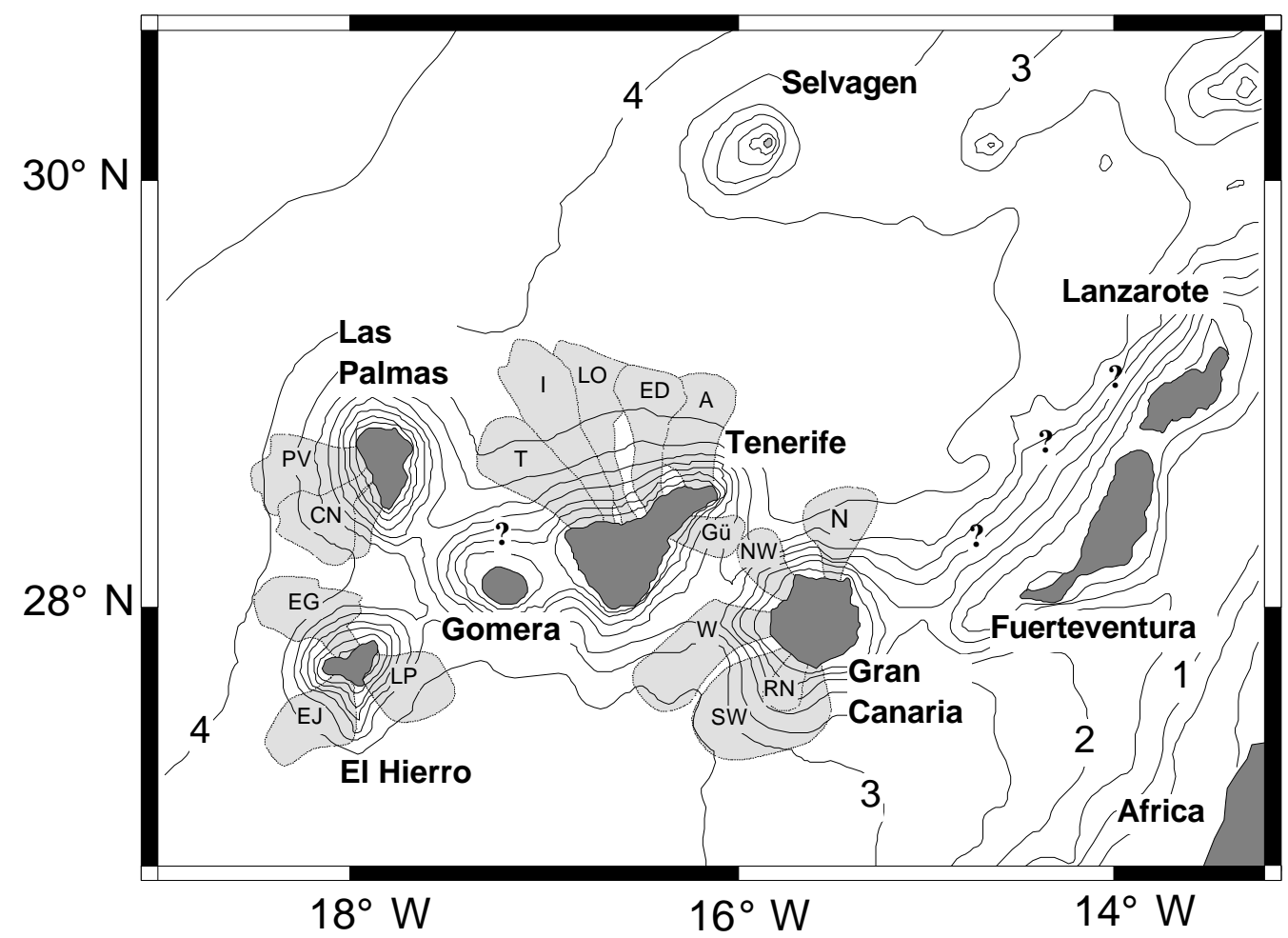

Figure 3.1: Large landslide events around the Canary Islands. Tenerife: Gü for Güimar, A for Anaga, ED for East Dorsal, LO for La Orotava, I for Icod and T for Teno; Gran Canaria: N for North, NW for Northwest, W for West, SW for Southwest and RN for Roque Nublo; Las Palmas: PV for Playa de la Veta complex and CN for Cumbre Nuevo; El Hierro: EG for El Golfo, EJ for El Julán and LP for Las Playas. Contour lines in km below sea level. Modified from Ablay and Hürlimann (1999).

On El Hierro exist three subaerial amphitheatres generated by the El Golfo event in the northwest, the Las Playas or San Andrés event in the southeast and the El Julán event in the southwest including each of them hundreds of cubic kilometres (Holcomb and Searle, 1991; Day et al., 1997; Soler, 1997; Urgeles et al., 1997; Gee et al., 1999). On Gran Canaria, four giant slide scars truncate the shield (Funck and Schmincke, 1998), while a small debris avalanche has been described from the post-shield Roque Nublo centre (García et al., 1994). On La Palma, the complex subaerial escarpment at the western side of the island has been generated by multiple landslide events forming a huge submarine 
debris apron with the Cumbre Nueva event and the Playa de la Veta complex (Carracedo et al., 1999; Urgeles et al., 1999). On Tenerife, two major failures with shield ages have been detected: one in the Anaga and the other in the Teno peninsula (Watts and Masson, 1995; Watts and Masson, 1998; Cantagrel et al., 1999). During the post-shield stage, four different events have affected the northern side of the island and one have failed at the southern flank (Watts and Masson, 1995; Teide-Group, 1997; Ablay and Hürlimann, 1999; Cantagrel et al., 1999). Around the two oldest Canary Islands (Lanzarote and Fuerteventura) and around Gomera no submarine surveys have been carried out and hence no deposits have been found. However, large sector collapses might have occurred on these islands, too.

Table 3.1: Large landslide events detected around the Canary Islands (References see text).

\begin{tabular}{|l|c|c|c|c|}
\hline island & landslide & $\begin{array}{c}\text { amphitheatre } \\
\text { orientation }\end{array}$ & $\begin{array}{c}\text { age } \\
{[\mathrm{Ma}]}\end{array}$ & $\begin{array}{c}\text { volume } \\
{\left[\mathrm{km}^{3}\right]}\end{array}$ \\
\hline \hline Gran Canaria & North & N & $12-14$ & $>60$ \\
\hline & Northwest & NW & 14 & - \\
\hline & West & W & $>14$ & - \\
\hline & Southwest & SW & - & - \\
\hline Tenerife & Roque Nublo & SW & 3.5 & 20 \\
\hline & Teno & N & $5.6-6.3$ & - \\
\hline & Anaga & NNW & $>4.5$ & - \\
\hline & old post-shield' & NNW & $3.0-2.3$ & $560-650$ \\
\hline & East Dorsal & NNW & $<0.56$ & $25-100$ \\
\hline & Güimar & SE & - & - \\
\hline & La Orotava & NNW & $0.73-0.56$ & $80-130$ \\
\hline La Palma & Icod & N & 0.17 & 80 \\
\hline & Cumbre Nueva & WSW & 0.560 & $95-200$ \\
\hline El Hierro & Playa de la Veta & W & $0.8-1.0$ & 650 \\
\hline & El Golfo & NW & $0.136-0.021$ & $150-180$ \\
\hline & El Julán & SW & 0.16 & - \\
\hline & Las Playas & SE & $0.882-0.545$ & - \\
& San Andrés (aborted) & SE & $0.545-0.176$ & - \\
\hline
\end{tabular}

The analyses of the spatial distribution and the temporal occurrence of all the slides occurred around the archipelago indicate several interesting points. It seems that regional tectonics, climate and sea level changes may have influenced large-scale slope failures.

The first observation is that the spatial distribution of the landslide amphitheatres on the Canary Islands may depend on the regional tectonic framework and the structural axes of the islands. Many amphitheatre orientations are located either perpendicularly to the main structural axis of the island or limited by two important axes. Especially the first relationship is quite common for large volcanic landslides (Siebert, 1984) and has been proposed for the events in the Canary Islands (Carracedo, 1994).

The Canary Islands' region is affected by various fault systems (Figure 3.2). These can be divided into two types of families: the Atlantic family and the African family (Mezcua et al., 1992; Araña, 1995). The fractures of the African family generally contain ENE-WSW and NNE-SSW orientations. The ENE-WSW trend coincides with one of the two main axes on Tenerife and has a perpendicular orientation to the majority of the landslide events on this island. The Atlantic family has a principal orientation of WNW-ESE and trends parallel to the transform faults of the Middle-Atlantic Ridge. In some case this trend is shown by the existence of a main NW-SE strike-slip fault system, which could be the prolongation of the transforming fracture zones crossing the ocean floor from the Middle-Atlantic 
Ridge and loose definition approaching to the continents (Araña, 1995). On Tenerife this NW-SE orientation coincides with a second structural axis limiting the spatial landslide distribution to the west. On Gran Canaria the amphitheatre of the Roque Nublo debris avalanche is perpendicular to one of the main structural arrangements of the island as well with this NW-SE direction (García et al., 1994). On El Hierro with its particular triangular silhouette and triple star shaped structural alignments, the axes define the subaerial limits of all the three slope failures. Moreover, on Las Palmas the two landslide escarpments are perpendicular to the rift zone on the island with a $\mathrm{N}-\mathrm{S}$ orientation (Carracedo et al., 1999).

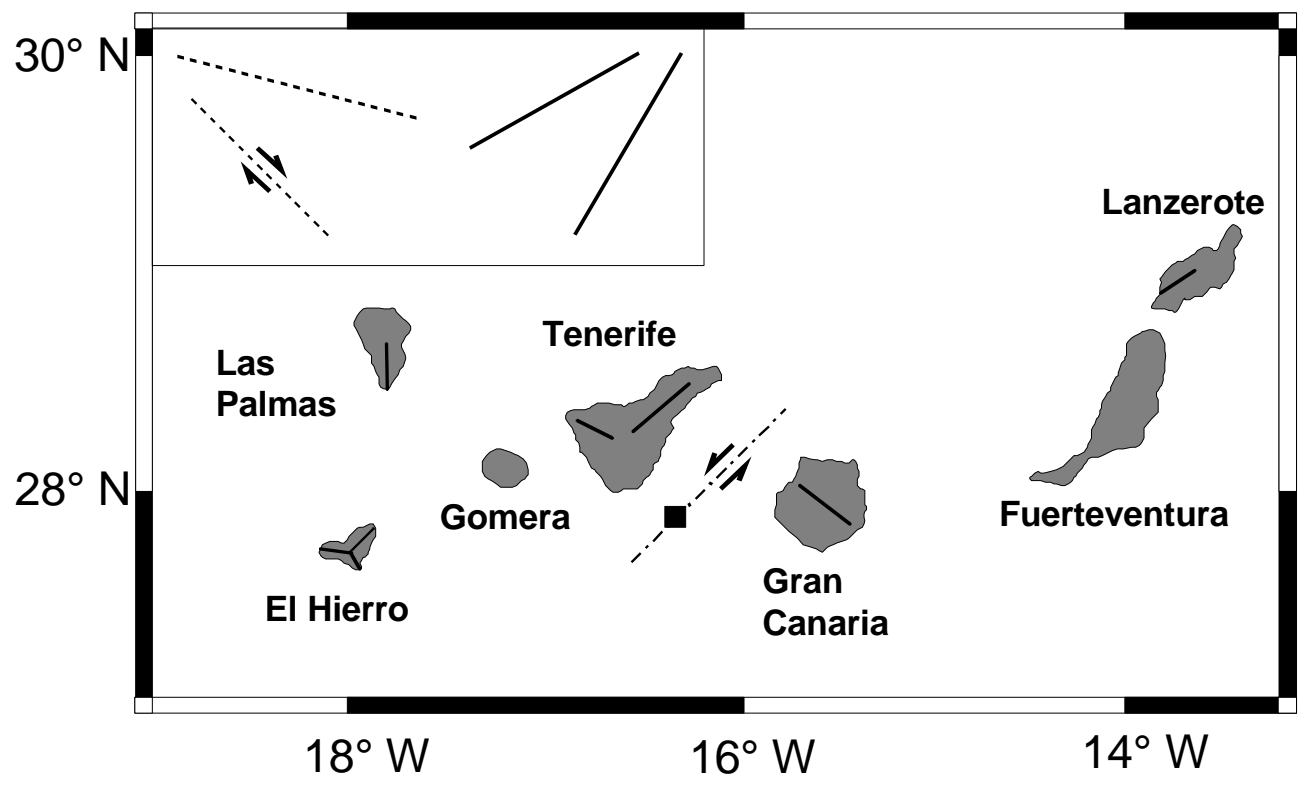

Figure 3.2: Simplified tectonic framework and structural axes of the Canary Islands. Solid lines show structural axes and dashed-pointed line indicates the strike-slip faults, which caused the 1989 earthquake (black box for the epicentre location). Inset illustrates the alignments of the African family (solid lines) and of the Atlantic family (dashed lines).

The second important observation refering to the spatial distribution of the landslide events is the relationship between the climatic conditions on the islands and the locations of the amphitheatres.

Generally, the climate of the Canary Islands can be determined as semiarid-subhumid. The islands have a stable weather with constant trade winds from the north to northeast. These winds, in addition to the orographic effect, induce mainly the precipitation of the area (Ecker, 1976; Palacios, 1994). Additionally, there is a temperature inversion at an altitude of about $1500 \mathrm{~m}$ a.s.l., which strongly influences the vertical distribution of rainfall, creating the characteristic 'mar de nubes' (sea of clouds) in heights ranging from 800 to $1500 \mathrm{~m}$ a.s.l. with maximum precipitation rates (Marzol, 1988). Conditions of atmospheric instability can generate clouds up to $2000 \mathrm{~m}$ a.s.l., which surpass the mountain ridges slightly to the southern part and can originate precipitation at the upper parts of the southern slopes. Maximum mean precipitation recorded on Tenerife is about $1000 \mathrm{~mm}$, while as much as $1800 \mathrm{~mm}$ has been observed on the northern side of the island (Ecker, 1976). In summary, the maximum precipitation rates in the Canary Islands obtain the north to northeastern parts of the islands located between 800 and $1500 \mathrm{~m}$ a.s.l. and in minor importance the highest areas of the south to southwestern parts. On the other side, precipitation is higher in the western islands than in the eastern islands, where the trade winds cannot discharge their humidity due to the absence of large orographic systems. All these features can be seen in the Satellite Image of the Canary Islands where the humid, wet parts of the islands are shown by the green colour due to intense vegetation (Instituto Geográfico Nacional, 1988). A relationship between humid areas and large landsliding has been proposed for the Tenerife events (Hürlimann et al., 1999b) and has also been observed for the giant slope failures around 
the Hawaiian Islands (Moore et al., 1994). On Tenerife, this hypothesis matches unconditionally since all of the amphitheatres are located in the humid north and northeastern parts of the island. On Gran Canaria exists a very dry part in the south where no amphitheatre has been detected, while the most humid area is located in the north to northeast where a huge landslide event has occurred. A correlation between climate and landslide initiation is difficult on Las Palmas and El Hierro, since these western islands are characterised by all in all wetter climates.

On the other hand, the climate may also have influenced on the temporal occurrence of landsliding on the archipelago. Generally, the basic situation of the climate has not been changed since the Pleistocene and the changes of the precipitation rate have always been related to the climatic changes of the Western Sahara (Selby, 1985; Lomoschitz, 1995). Three important periods of high precipitation and several humid intervals have been proposed within the Quaternary. The three periods of higher precipitation have been determined at 0.3 Ma B.P., from 0.125 to 0.09 Ma B.P. and around 8500 a B.P.. The shorter humid intervals occurred several times between 40000 to 10000 a B.P. and represent short climatic changes. A comparison between these climatic data and the ages of the landslides (Table 3.1) does not reveal a clear correlation, but additional, detailed data on climatic changes in the Canary Islands area and exact ages of the large failures might help to find a relationship. Such a relationship would be realistic since precipitation rates and the associated hydrogeological conditions are significant factors in the initiation of the many slope failures (e.g. Turner and Schuster, 1996). Rainfall-induced landslides are a common phenomenon on the Canary Islands and have been investigated e. g. in the Tirajana depression (Lomoschitz, 1995). However, such mass movements are generally of a small scale and related to short, strong rainfalls caused by the occasional arrival of the polar front in winter or by tropical depressions in summer and not related to longer climatic changes.

Finally, the temporal relationship between sea level changes and large failures of volcano flanks in the Canary Islands has been analysed (Figure 3.3). The main causes of sea level fluctuations are first, the global climatic variations with the associated increase of the ice sheets and second, the vertical movement of the volcanic island.

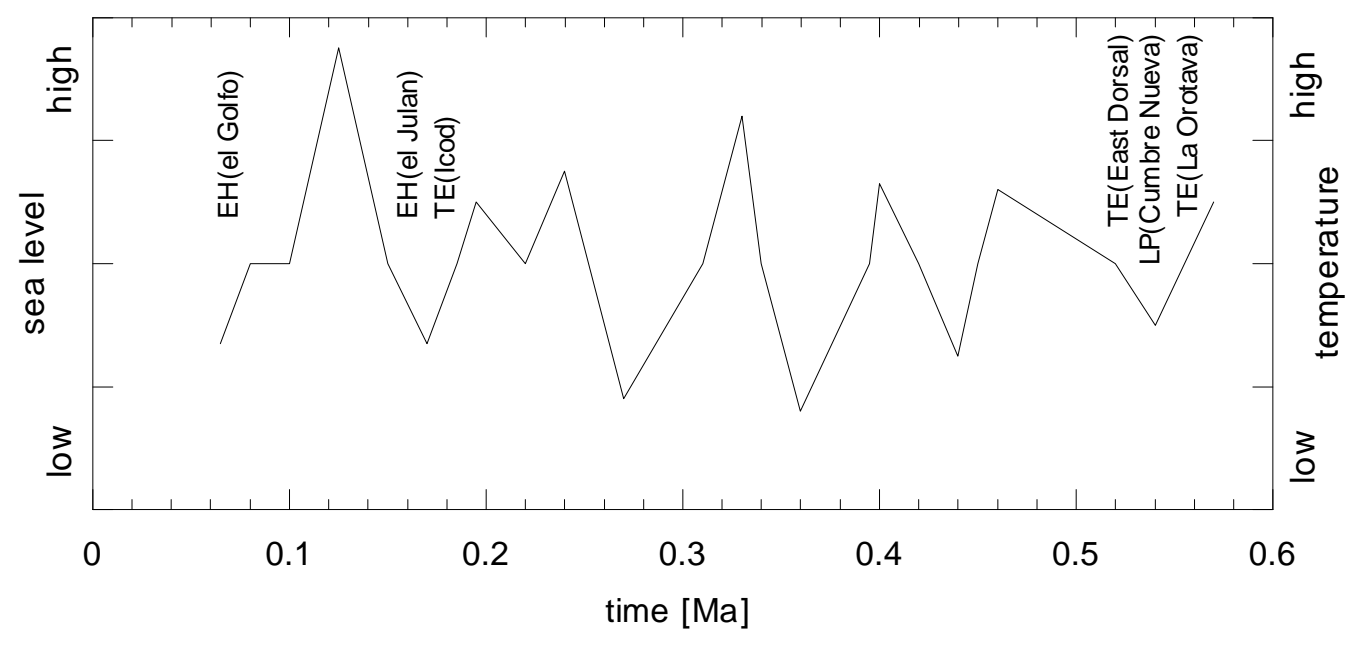

Figure 3.3: Correlation between sea level changes and landslide events. Sea level changes simplified from temperature data by Winograd et al. (1997).

Here, the sea level changes caused by the glaciations avoiding the vertical movement of volcanic islands have been studied including worldwide data (Haq et al., 1987; Winograd et al., 1992), data collected on the Atlantic coast of Africa (Giresse, 1987) and data of the Canary Islands (Lietz and Schmincke, 1975; Meco et al., 1992). Haq et al. (1987) determined three significant fallings of the sea level with previous maximums during the last 3 million years. The first time has occurred between 3.0 and 2.8 Ma with a descent of about $140 \mathrm{~m}$, the second time between $1.8 \mathrm{Ma}$ and $1.6 \mathrm{Ma}$ with a falling of about $90 \mathrm{~m}$ and the third time between $0.76 \mathrm{Ma}$ and $0.8 \mathrm{Ma}$ with a descending of about $90 \mathrm{~m}$. 
Comparing these data with the ages of the landslides in Table 3.1 a relationship between large failures of volcano flanks and sea level changes can be seen. The first descent between 3.0 and 2.8 Ma can be related to the huge 'old post shield' landslide complex on Tenerife and the third falling between $0.76 \mathrm{Ma}$ and 0.8 Ma correlates with the assumed age of the Las Playas event on El Hierro. The sea level changes during the last $600 \mathrm{ka}$ are better constrained (Winograd et al., 1992; Winograd et al., 1997) and the temperature variations have been modified into a graph plotting sea level changes versus time (Figure 3.3). Then, six landslide events can be associated with large cooling phases and thus with fallings of the sea level: at about 0.55 Ma the La Orotava and East Dorsal events on Tenerife (Ablay and Hürlimann, 1999) as well as the Cumbre Nueva landslide on La Palma (Carracedo et al., 1999), at about 0.17 Ma the Icod landslide on Tenerife (Watts and Masson, 1995) and the EL Julán event on El Hierro (Urgeles et al., 1997) and at about $60 \mathrm{ka}$ the El Golfo debris avalanche on El Hierro (Urgeles et al., 1997).

On the other hand, uplift or subsidence of the island can change the level of the coastline of a volcanic island (Watts et al., 1997). Vertical movements caused by volcanism are common features during the evolution of volcanic islands. The continuous magma loading of the growing edifice applies a vertical stress to the lithosphere. Therefore, the oceanic crust deforms under the additional weight and creates a flexural moat. In the case of Tenerife the island rises almost $8000 \mathrm{~m}$ above the expected depth of the oceanic crust and consequently represents an enormous load on the lithosphere. The flexural moat in the oceanic crust has a depth of about $2500 \mathrm{~m}$ (Watts et al., 1997). A similar flexure of a maximum depth of $1000 \mathrm{~m}$ has been detected in Gran Canaria (Funck and Schmincke, 1998). However, the vertical movement due to magma loading is a slow process and has a much minor influence than the faster sea level changes caused by climatic changes.

As explained in Chapter 2, the sea level changes produce many direct and indirect influences on the stability of volcanic islands. Some of them will be analysed mechanically during the stability analysis in Chapter 5. However, the interaction between sea level changes and volcanic activity proposed by McGuire et al. (1997) is assumed to be the most important feature causing large-scale failures on volcanic islands and inducing the correlation shown in Figure 3.3. 


\subsection{Tenerife Island}

Tenerife is the largest of the seven Canary Islands and has a total surface of $2057 \mathrm{~km}^{2}$. The shape of the island can be compared with a triangle oriented to the northeast (Figure 3.4). The population of the island exceeds $600^{\prime} 000$ persons which can be the double or triple during tourist's high season. There are two major towns on Tenerife: Santa Cruz de Tenerife in the northeast and Puerto de la Cruz in the north. The vegetation of the island is very variable including humid subtropical forests in the north to dry, desert-like areas in the south. The landscape of the island is characterised by old deeply eroded volcanic ranges at the eastern and western extremities, a quite smooth part with gully erosion in the south to southwestern zones, two recent volcanic ridges oriented NNW-SSE and NE-SW, respectively, and a central volcanic complex with two huge stratovolcanoes. Figure 3.4 shows a satellite image of Tenerife taken by Landsat 5 (Sensor T.M.) located at an altitude of $705 \mathrm{~km}$. There exist three valleys originated by large landslide events: the La Orotava and Icod valleys in the north and the Güimar valley in the southeast.

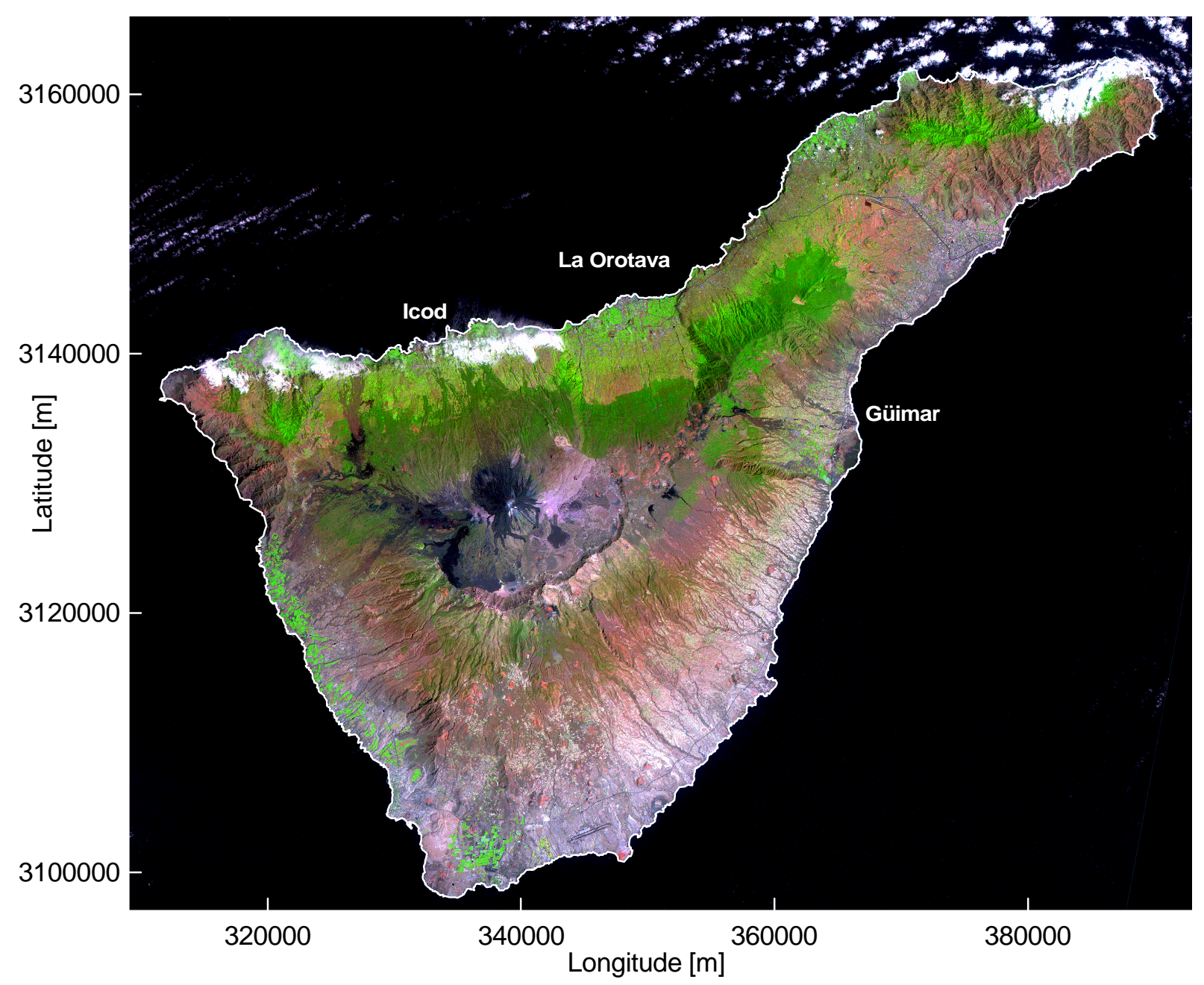

Figure 3.4: Satellite image of Tenerife island. 


\subsubsection{Geological evolution}

The geologic evolution of Tenerife is summarised in a geological map (Figure 3.5) and in stratigraphic columns (Figure 3.6). The onshore geology began in the Late Miocene with the growth of several mafic shield volcanoes. Three eroded remains of these shields can still be found on the island: in the western extremity the Teno massif, in the eastern extremity the Anaga massif and in the southern part of the island the Roque del Conde massif. The age of this shield phase constituting about $90 \%$ of the total volume of the island has been proposed to be between 6.0 and 4.5 Ma (Fúster et al., 1968; Abdel-Monem et al., 1972; Ancochea et al., 1990).

Towards the end of the shield phase started the construction of a large volcanic complex in the central part of the island. The sequences of this volcanic complex - called the Las Cañadas edifice (LCE) - are distinguished into two main groups: a dominantly mafic Lower Group with ages ranging from $3 \mathrm{Ma}$ to $2.1 \mathrm{Ma}$ and a felsic Upper Group with ages between 1.59 Ma and 0.179 Ma (Martí et al., 1994). The Upper Group is subdivided into three formations called Ucanca (ranging from 1.59 to 1.18 Ma), Guajara (850 - $570 \mathrm{ka}$ ) and Diego Hernández (370 - $179 \mathrm{ka}$ ) characterised by thick sequences of phonolitic lavas and pyroclastics. Each of these volcanic cycles started with predominantly mafic volcanism and finished with a voluminous $\left(5-15 \mathrm{~km}^{3}\right)$ pyroclastic eruption. The associated vertical caldera collapses have been proposed at 1.02, 0.56 and $0.18 \mathrm{Ma}$, respectively, forming a multiple depression called Las Cañadas caldera (Martí et al., 1994). Chronological data and the distribution of pyroclastic rocks suggest that the Lower Group started in the southeastern central part (Fúster et al., 1994; Huertas et al., 1994) and the focus of the Upper Group activity migrated then northeast (Araña, 1971; Martí et al., 1994; Bryan et al., 1998; Ancochea et al., 1999).

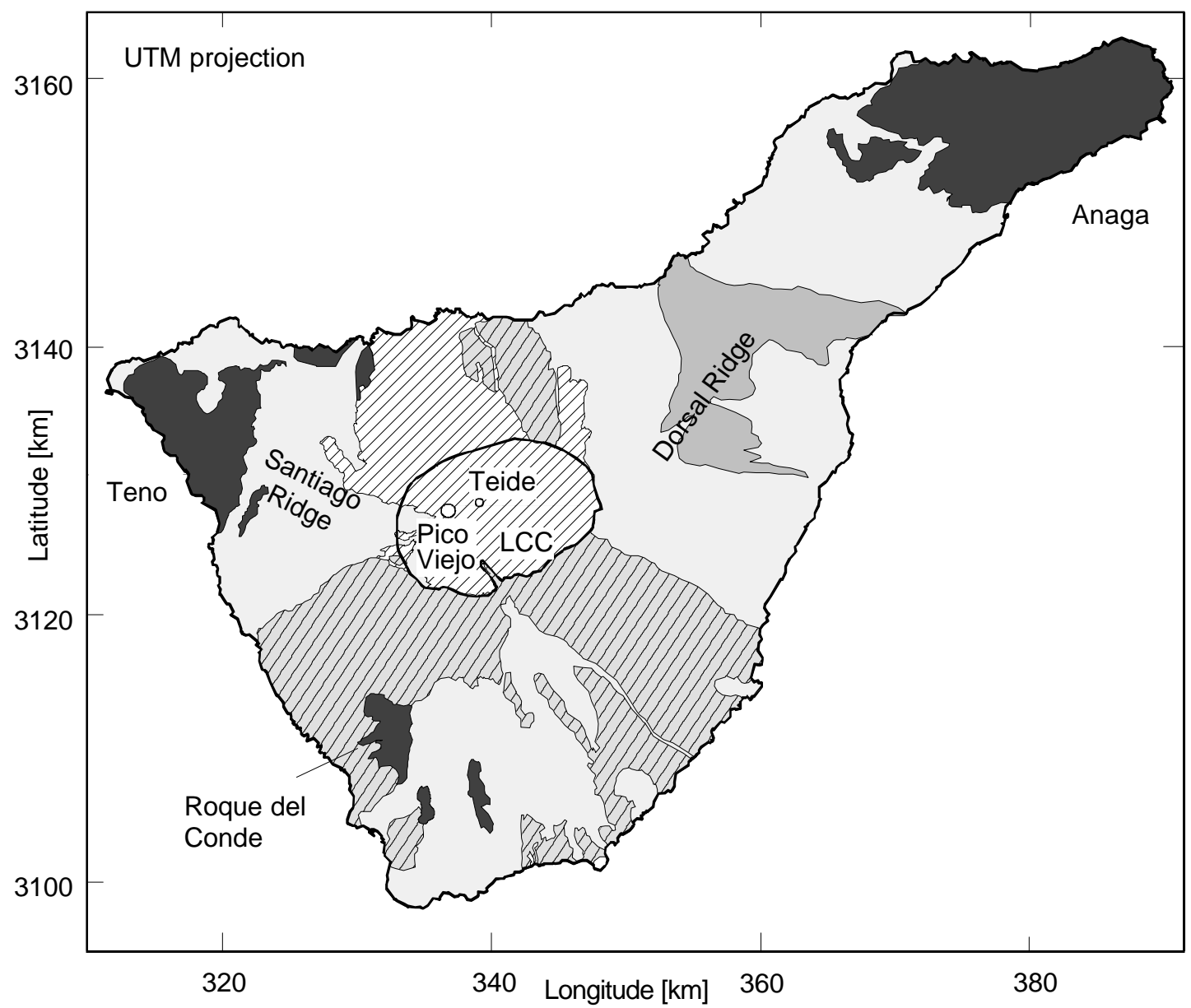

Figure 3.5: Simplified onshore geology of Tenerife. Colour shades as defined in Figure 3.6. Thick solid line indicates the extension of the Las Cañadas caldera (LCC). 
Since the last caldera forming event at $0.179 \mathrm{Ma}$ the volcanic activity has built the huge Teide-Pico Viejo complex located inside the Las Cañadas caldera (LCC). It comprises mainly intermediate to felsic lavas erupted from the two stratocones Teide and Pico Viejo which have both experienced summit collapses associated with young phonolitic eruptions (Ablay, 1997; Ablay and Martí, 1999).

Additionally, about $2 \mathrm{Ma}$ ago have started basaltic eruptions along the two structural axes of the island: the NW-SE orientated Dorsal Ridge and the NNW-SSE orientated Santiago Ridge. These prominent rift zones are characterised by monogenetic cones constructed on sub-parallel basaltic fissure systems concentrated near the crests of the rifts. The Dorsal rift zone can be divided into two different sections: 1) the central, old section, and 2) the western and eastern sections with younger ages. The central section is at least 1.8 Ma old (Féraud et al., 1985) whereas the western and eastern sections are covered by younger volcanics with ages younger than $0.5 \mathrm{Ma}$. The age of the Santiago Ridge is poorly constrained but probably of the same age than the young Dorsal Ridge sections. The two rift zones intersect the LCC and can be connected through the intra-caldera Teide-Pico Viejo vent system (Ablay and Martí, 1999). Flank volcanism has also occurred in the southern part of the island. However, this southern volcanic zone is a broad area of basaltic fissure vent systems on the lower to middle flank of the LCE and differs from the other two well defined rift zones (Martí et al., 1996; Bryan et al., 1998).

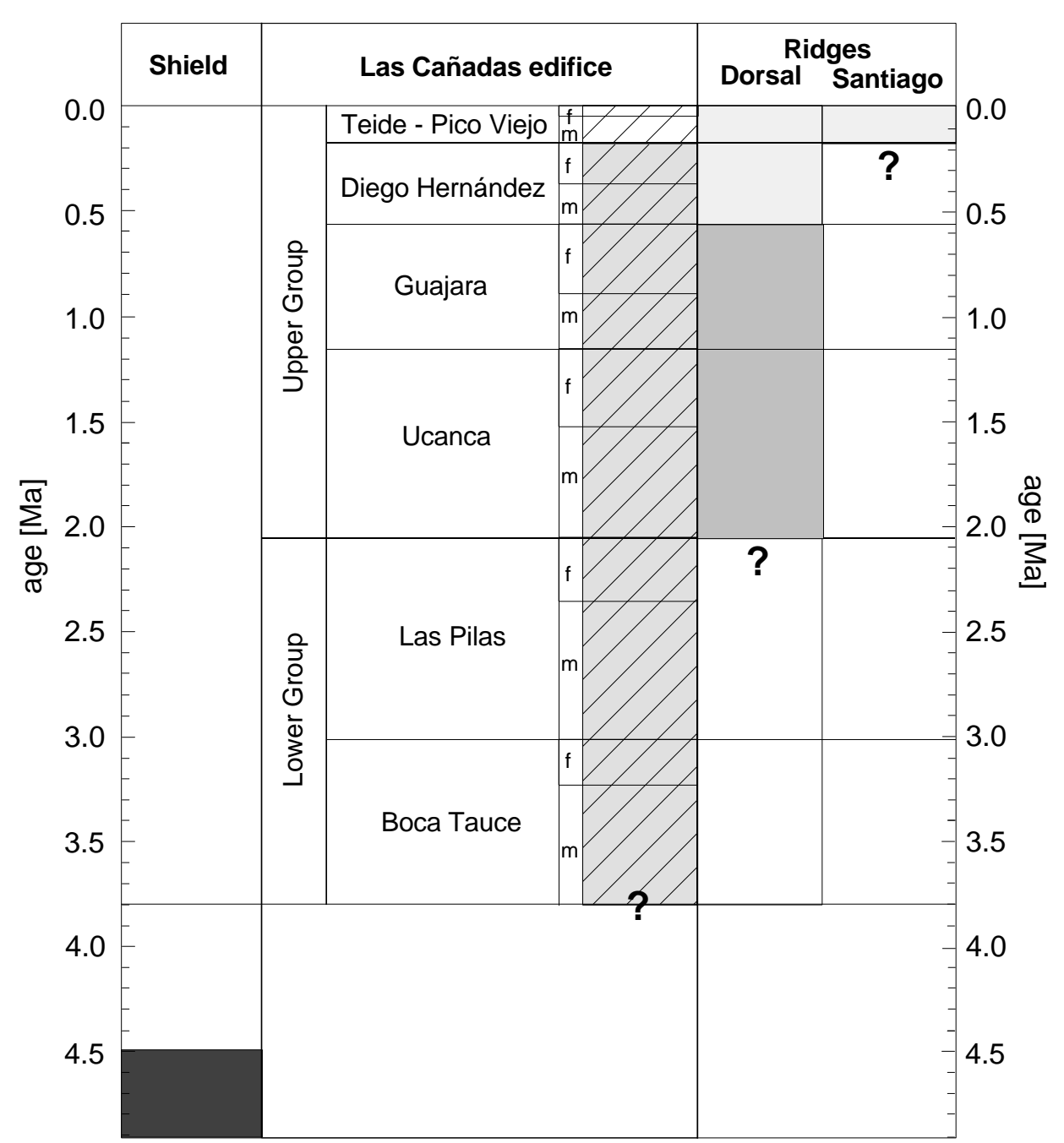

Figure 3.6: Simplified volcanic stratigraphy of Tenerife. ' $m$ ' for mafic and 'f' for felsic. 


\subsubsection{Morphologic features}

The geomorphology of volcanic terrains results from a combination of constructive and destructive processes. On Tenerife, the principal constructive feature is the huge $3718 \mathrm{~m}$ high stratovolcano Teide located on the top of the LCE. Additional morphologic features are the two structural axes with steep sided flanks, the smooth southern slopes flattened by the phonolitic pyroclastic deposits of the LCE and the deeply eroded remnants of the shield volcanoes especially exposed at the Teno and Anaga peninsulas. Apart form these features the morphology of the island is mainly characterised by two major destructive processes: first, large scale landsliding and second, caldera collapse episodes. Both processes have chiefly modified the morphology of the central part of Tenerife (Figure 3.7) and have strongly influenced on the evolution of the whole island. The LCE has been affected by multiple caldera collapse episodes forming a large elliptical depression called Las Cañadas caldera. The LCC is open towards the north and bounded to the south and east by high walls up to $500 \mathrm{~m}$. The total length of the visible caldera wall is about $27 \mathrm{~km}$. The northern and western caldera walls are absent or covered by recent lavas except for an isolated segment called La Fortaleza forming part of the Tigaiga massif. The spur-formed Roques de García adjacent to the south wall divides the LCC into two sectors. A lower sector including the Ucanca caldera and a higher sector containing the Guajara and the Diego Hernández calderas (Figure 3.7).

At the northern flank of Tenerife the Tigaiga massif separates the Icod and La Orotava valleys, which are amphitheatres derived from large slope failures (Bravo, 1962; Coello, 1973; Navarro and Coello, 1989; Ablay and Hürlimann, 1999). A third amphitheatre, called Güimar valley, is located at the southeastern flank perpendicular to the Dorsal Ridge. All of these escarpment areas include subaerial extensions of more than $100 \mathrm{~km}^{2}$ and many tourist resorts and villages are settled on theirs floors. Whereas the Icod valley is almost completely filled by recent lava flows, the La Orotava and Güimar valleys are only partly infilled by postslide materials and high lateral scarps up to $600 \mathrm{~m}$ can be observed. In the Güimar valley the amount of filling volcanics is especially in the upper part very limited. Consequently, the head scarp towards the Dorsal Ridge is characterised by strong fluvial erosion forming deep barrancos and alluvial fans in the valley floor.

Comparing the chronology of these two major geologic processes, there exists a relationship between the inferred ages of the landslide valleys and the caldera collapse episodes (Martí et al., 1997). The age of the Icod landslide is assumed to have occurred at $0.17 \mathrm{Ma}$ (Watts and Masson, 1995) coinciding with the ending of the Diego Hernández cycle at about 0.179 Ma (Mitjavila and Villa, 1993). The age estimate of the La Orotava valley ranges from 0.78 to $0.57 \mathrm{Ma}$ (Ancochea et al., 1990; Martí et al., 1997) coinciding with the Guajara collapse at about 0.56. The age of Güimar valley is poorly constrained.

Opposite page:

Figure 3.7: Morphology of the central part of Tenerife. Suggested limits of landslides (thick dashed lines). Caldera wall: visible (solid line), buried (dashed) and absent (dotted). Limits of the three vertical caldera collapses (thin dashed line). 


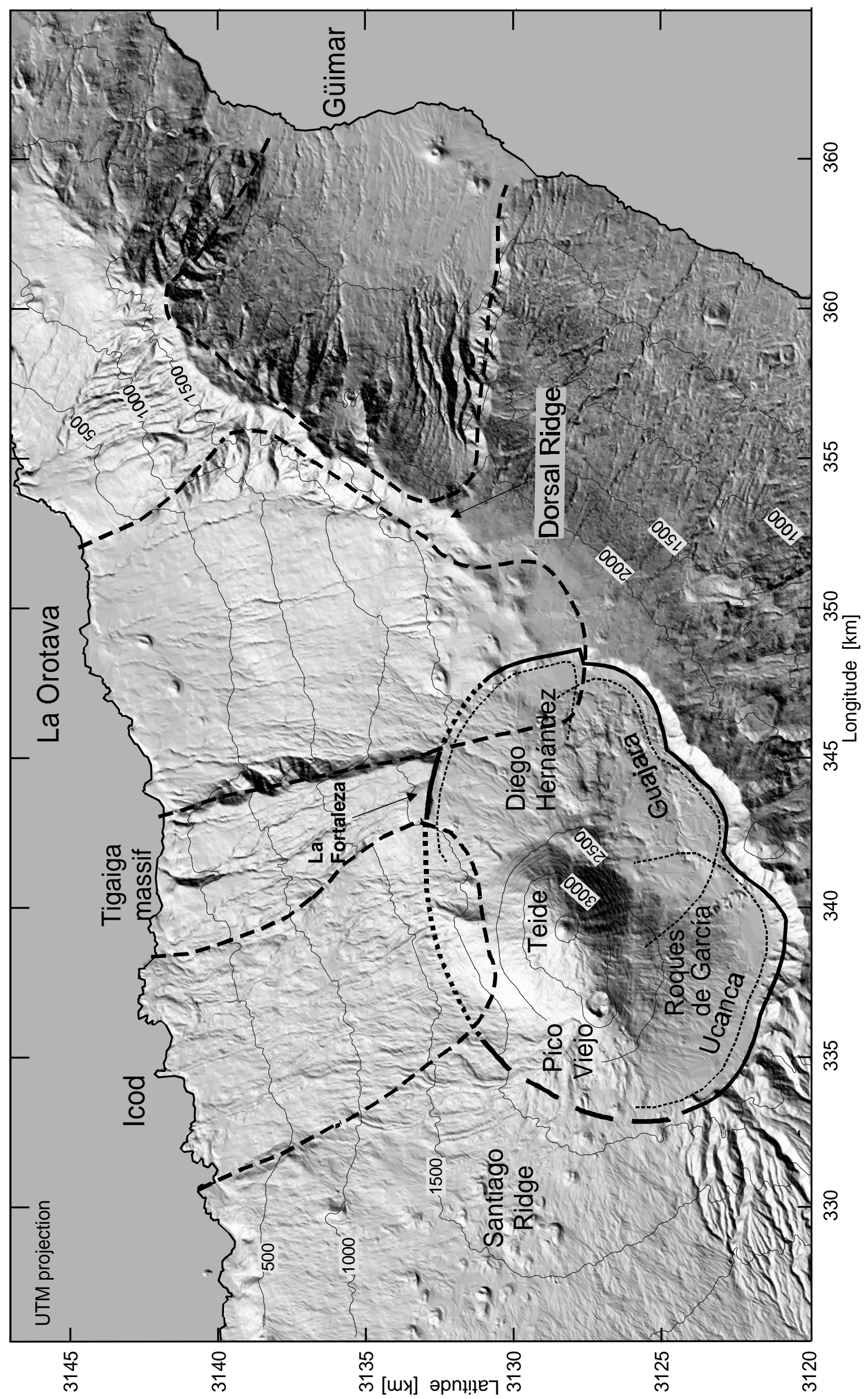


At present, the extension of the Icod valley and the origin of the LCC are one of the major uncertainties of the geological evolution of Tenerife. The principal problem is the location of the head scarp of the Icod landslide: One hypothesis proposes this breakaway zone at the lower northern flank of the Teide stratovolcano excluding the LCC into the failure (Hürlimann et al., 1997; Martí et al., 1997; Martí, 1998; Hürlimann et al., 1999a) and the other suggests the head scarp at the southern caldera wall including the LCC (Navarro and Coello, 1989; Watts and Masson, 1995; Watts and Masson, 1998; Ancochea et al., 1999; Cantagrel et al., 1999). Initially, Watts and Masson (1995) joined together the Icod and La Orotava failures and proposed that this giant landslide also included the LCC. The southern caldera wall was interpreted as the slide headwall, while the Tigaiga massif was explained as a detached slide block. The landsliding interpretation of Watts and Masson (1995) was criticised by Martí (1998) who pointed out that the Icod and La Orotava valleys have different ages and are thus likely to be the products of different landslide events. He also gave the volcanological arguments for the Las Cañadas caldera having formed by multiple vertical collapse events. Watts and Masson (1998) accepted the hypothesis of multiple landslides but restated a landslide origin for the LCC in order to explain the disparity between the modest volumes of the valleys and the huge volume of offshore deposits. They described additional data which allowed them to recognise two different landslides: one from the La Orotava valley and the other from the Icod valley. But, the Icod landslide was still related to the formation of the Las Cañadas caldera. A similar model has been proposed by Ancochea et al. (1999), assuming that the LCC has been formed by repeated landslide events to the north.

During this study a model inferring a simultaneous occurrence of lateral flank failures and vertical caldera collapses has been established (Hürlimann et al., 1997; Martí et al., 1997; Ablay and Hürlimann, 1999; Hürlimann et al., 1999a; Hürlimann et al., 1999c; Hürlimann et al., 1999d). The model proposes a mechanical relationship of these two processes according to which the Icod valley has been formed by landsliding and the LCC by multiple vertical caldera collapse episodes. According to this model, the head of the Icod valley would be located at the northern slopes of the Teide - Pico Viejo volcano complex.

\subsubsection{Volcanic activity}

In this Section, the most important volcanic features of the central part of Tenerife will be described in order to recognise the volcanic processes that may have influenced on the formation of the large landslides. A comparison between the spatial distribution of both the landslide amphitheatres and the volcanic features may help to improve the understanding of the initiation of large slope failures. In addition, other destabilising processes associated with the volcanism on Tenerife will be described.

The main volcanic features adjacent to the landslide escarpments are the Las Cañadas caldera and the two rift zones (Figure 3.7 and Figure 3.8). The LCC is a huge depression measuring $16 \times 9 \mathrm{~km}$ situated at an altitude of about $2000 \mathrm{~m}$ a.s.l. The two landslide amphitheatres Icod and La Orotava valley intersect the caldera at the northern and at the northeastern border, respectively. Both of them have incorporated large sections of the LCC truncating the caldera limits along distances greater than 5 $\mathrm{km}$. An important fact for the stability of the volcano flank is the downfall distance of the volcano roof during a caldera collapse. The subsidence distance strongly influences the magnitudes of both the shear stresses generated along the ring faults and the associated seismic shocks (see Chapter 2). The total subsidence of the Las Cañadas collapse episodes is not completely constrained but likely exceed 1000 $\mathrm{m}$. The maximum height of the caldera wall near Guajara peak is about $600 \mathrm{~m}$ and two drillholes inside the caldera show that more than $500 \mathrm{~m}$ of mafic and intermediate lavas from the postcaldera Teide-Pico Viejo complex occupy the central-eastern part of the caldera (Servicio de Planificación Hidráulica, 1992).

On the other side, the two rift zones clearly influence the spatial distribution and extensions of the landslide valleys. Especially, the Dorsal Ridge with its persistent magma injection seems to have affected the stability of the volcano flanks adjacent to this active rift zone. The head scarps of both the Güimar and the La Orotava valley are located along the Dorsal Ridge and slope failure has occurred 
perpendicular to it. Inside the LCC the intra-caldera Teide-Pico Viejo vent system connects the two rift zones (Ablay and Martí, 1999) and may have affected the initiation of the Icod landslide.

Inflation or deflation of shallow magma chambers may have been associated with volcano instabilities during the evolution of the LCE (Martí et al., 1994). The preslide slopes of the Icod and La Orotava valleys adjacent to the magma chamber might have been destabilised by such processes (Hürlimann et al., 1999d).

Processes of hydrothermal alteration are not well constrained in the central part of the island. There exist two locations with important hydrothermally altered rocks inside the LCC, both of them however with very limited extensions. One is situated adjacent to the Teide crater where some fumaroles can be observed and the other is located at Roques de García.

Data on the seismic activity on Tenerife are very scarce. A local network of seismographic stations has been installed in 1975 and until the 5.2 magnitude earthquake in 1989 (Figure 3.2) only very little activity has been recorded. Historically, however, important earthquakes related to volcanic eruptions have occurred (Mezcua et al., 1992). On Tenerife two moderate earthquakes with intensities of about VII (M.S.K.) took place in 1706 and 1909. Generally, the seismic activity on the island is moderate and with low magnitudes $(M \leq 5)$ and chiefly related to volcanic processes (Canas et al., 1995). Additionally, it can be mentioned that the Spanish Ministry of Public Works has defined a critical seismic acceleration coefficient of $0.04 \mathrm{~g}$ for the design of buildings on the whole island of Tenerife (BOE, 1995).

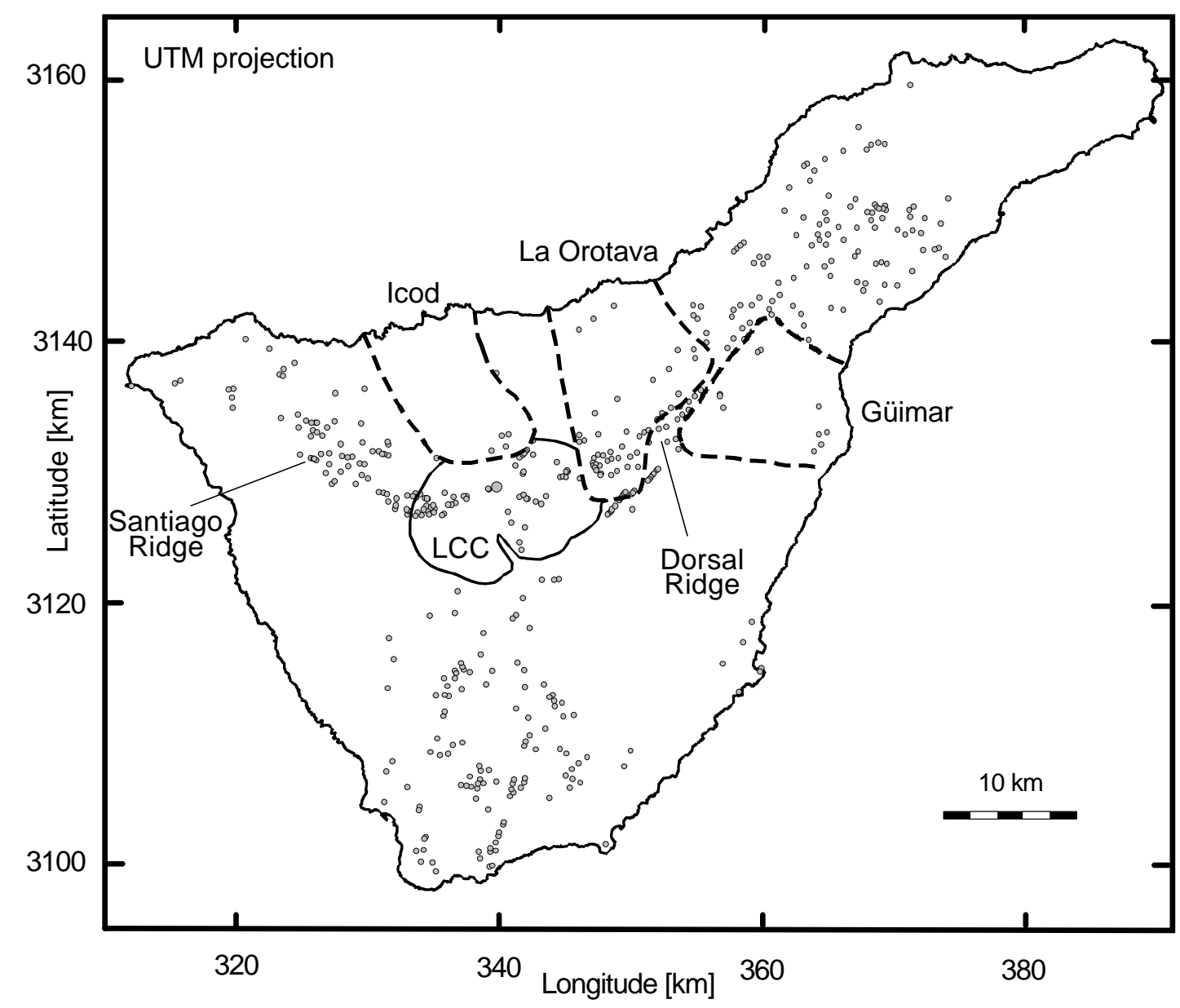

Figure 3.8: Principal features of volcanic activity on Tenerife. Dashed lines show the suggested limits of the large landslides. Solid line indicates the extension of the Las Cañadas caldera. Dots show the eruptive vents indicating the two principal structural axes on the island. 


\subsection{Geomorphologic analysis}

Volcanic landforms are characterised by a geomorphological evolution differing from other landforms originated in sedimentary rocks. Both constructional and destructional processes due to the volcanic activity generate the morphology in volcanic terrains.

In this study, the geomorphologic analysis has been divided into three parts. The first part has studied the geomorphology of the whole island in order to create simplified morphologic profiles of the volcano flanks. Afterwards, these profiles have been used at the beginning of the numerical stability analysis (see Chapter 5). The second part has analysed the northern submarine and subaerial flank of Tenerife and describes the occurrence of the different slope failures during the evolution of the island. At last, the third part has focused on the morphology of the La Orotava valley area and analyses in detail the geomorphologic features of the largest subaerial amphitheatre on Tenerife.

The methods have been similar in all parts including the study of Digital Elevation Models (DEM) using Geographic Information Systems (GIS), the interpretation of aerial photographs, the analysis of existing geological data and field surveys. Subaerial and especially submarine morphologies have been analysed using different DEMs. In total three DEMs have been imported and studied using different GIS-tools:

- Two topographic DEMs:

One with a pixel size of $100 \mathrm{~m}$ created from the topographic maps with the scale of $1: 200 ' 000$, and

another with a pixel size of $25 \mathrm{~m}$ prepared from the 1:50'000 maps. Both sets of maps have been published by the Spanish 'Instituto Geográfico Nacional'.

- One bathymetric DEM with pixel size of $100 \mathrm{~m}$ containing swath bathymetric data obtained during the 1995 Teide cruise of the Spanish research vessel Hespérides (Teide-Group, 1997).

The GIS-tools applied during this study include: 1) the statistical analysis of GRID-coverages containing cells with computed morphologic information, 2) mapping shaded reliefs containing different illuminated conditions, 3) contour mapping; and, 4) building or stacking of topographic profiles (ESRI, 1998).

The subaerial morphologic features have also been studied by means of the interpretation of aerial photographs. Two different sets of photographs have been used:

- black and white aerial photographs from 1987 with the scale of $1: 18^{\prime} 000$

- colour aerial photographs from 1992 with the scale of $1: 50$ '000

The photo interpretation has mainly focussed on three surface characteristics: 1) the hydrological features including the drainage network and the watersheds, 2) the significant morphological features including different types of scarps, marine cliffs etc. and 3) volcanic features including cones, lava flows etc. 


\subsubsection{Tenerife Island}

A geomorphic analysis of the entire island has been carried out using GIS. The definition of an idealised volcano flank similar to the natural slopes on Tenerife not affected by large-scale slope failure has been the main objective of this part of the geomorphologic analysis.

During the first step the subaerial part of the present island morphology has been divided into two types of zones: one characterised by a 'regular, natural' evolution without the influence of significant geomorphologic changes and the other characterised by the occurrence of important geomorphologic processes such as landslide events and caldera collapse episodes. Finally, the zones formed during a 'regular, natural' evolution have been analysed comprehensively excluding the two peninsulas Anaga and Teno with their deeply incised morphologies. The study area has been divided into a northern part including the north flanks between Teno and Icod valley, the top of the Tigaiga massif and the zone between La Orotava valley and Anaga and a south part including the southern slopes west of Güimar valley and the zone between this amphitheatre and Anaga.

The DEM of the island with a pixel size of $100 \mathrm{~m}$ has been smoothed to avoid the influences of insignificant morphologic features such as small erosional barrancos and volcanic cones. At last the analysed GRID coverage has contained cells with a pixel distance of $250 \mathrm{~m}$ and the total number of cells inside the study area has been $19^{\prime} 735$. Therefore, a total area of about $1250 \mathrm{~km}^{2}$ has been analysed which represent about $60 \%$ of the total surface of the island. Each cell has been linked to two values indicating the mean elevation and the mean slope angle of the cell. To simplify the analysis these two values have been classified. The elevation has been separated into classes with steps of $250 \mathrm{~m}$ starting at sea level and finishing at $2500 \mathrm{~m}$ a.s.1.. The slope angle has been divided into classes with steps of 5 degrees. Since the two classified values have been linked, they have allowed a statistical analysis for the different study sections incorporating information about slope angle and elevation.

Figure 3.9 illustrates the results of this analysis plotting the average slope inclination for the northern and southern part of the island at each altitude. Additionally, an average value of both parts has been calculated characterising a global slope of Tenerife Island. The results show a very different morphology up to an altitude of about $500 \mathrm{~m}$. Within this elevation the slope angle in the northern part has an average value of about $17^{\circ}$ whereas the computed value in the southern part is only $7^{\circ}$. The zones higher than about $500 \mathrm{~m}$ illustrate a uniform slope angle in both parts of the island with an average value of about $11^{\circ}$. A similar slope inclination has been proposed for the volcanoes not affected by large-scale landslides in Hawaii. There, the island flanks slope probably less than $12^{\circ}$ and almost certainly less than $19^{\circ}$ (Mark and Moore, 1987; Iverson, 1995).

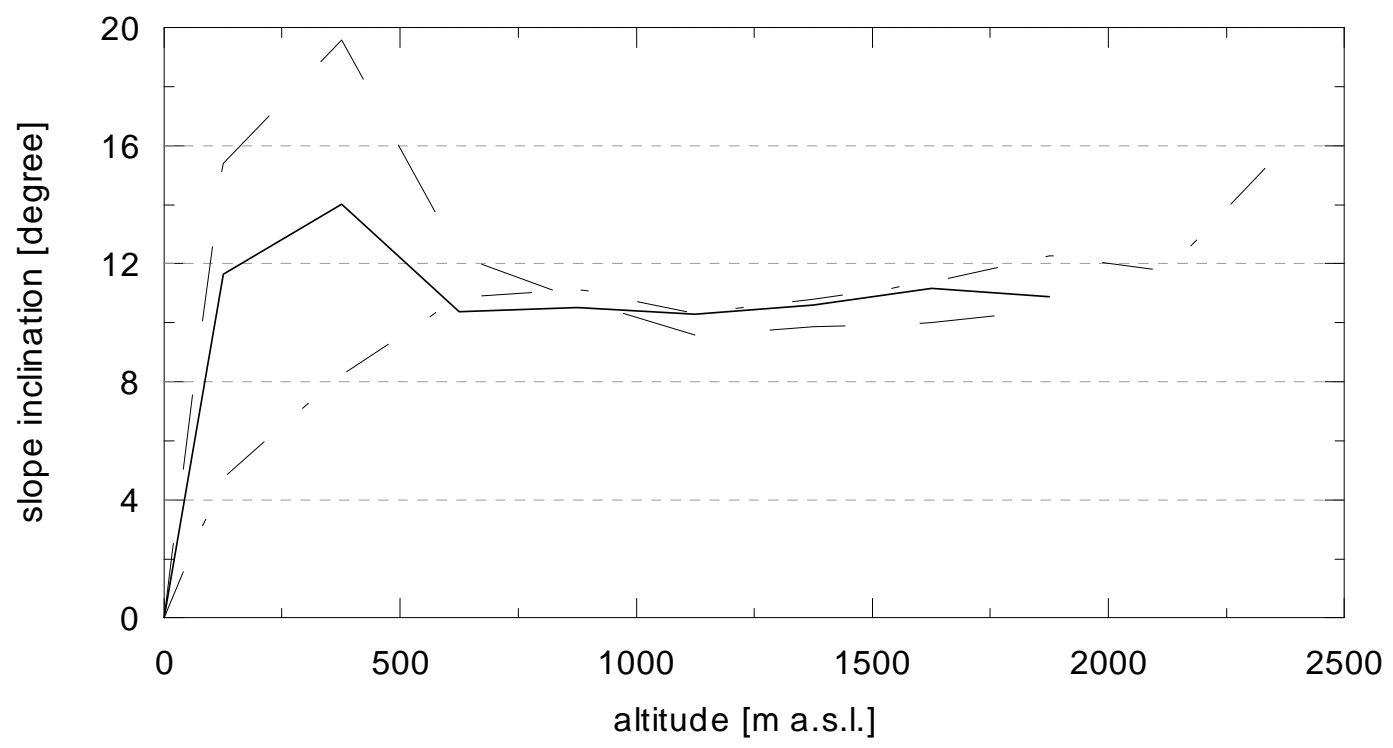

Figure 3.9: Subaerial slope inclination versus altitude computed using GIS. Northern flank (dashed line), southern flank (dash - dot line) and average values (solid line). 
The slope angle vs. altitude data plotted in Figure 3.9 can also be illustrated by topographic profiles of the southern and northern volcano flanks. Figure 3.10 shows the simplified slope profiles unifying the subaerial part obtained from the GIS-analysis with the submarine part as interpreted from the available bathymetric data (Watts and Masson, 1995; Teide-Group, 1997).

Generally, the subaerial island slopes on Tenerife are similar on the northern and southern side. Only within the first $500 \mathrm{~m}$ a.s.l. exist some strong differences. The idealised northern slope starts at sea level with a steep and high coastal cliff, whereas the southern slopes are smooth near the coastline. This coastal cliff in the north may be formed by the influence of sea wave erosion due to constant winds arriving from north to northeast. Additionally, the southern flank of Tenerife are covered by large pyroclastic deposits flattening the morphology (Bryan et al., 1998) and only insignificant sea wave erosion alters the coast.

The morphology of the submarine flanks of Tenerife has been interpreted in several recent works (Watts and Masson, 1995; Teide-Group, 1997; Ablay and Hürlimann, 1999). Here, the main results will be summarised refering to Ablay and Hürlimann (1999) for the northern slopes and to the data published by the Teide-Group (1997) for the southern slopes. The northern submarine slopes can be divided into three different sections. Near the coast exists a relatively smooth 1 to $2 \mathrm{~km}$ wide erosional submarine platform down to about $-100 \mathrm{~m}$ and with an inclination of about $6^{\circ}$. Beyond this insular shelf lies a 100 to $600 \mathrm{~m}$ high steep slope with inclinations ranging from $4^{\circ}$ to $16^{\circ}$. The morphology deeper than about $-600 \mathrm{~m}$ can be defined as a convex slope with gradients of about $6^{\circ}$ for depths less than $1600 \mathrm{~m}$, gradients of about $4^{\circ}$ for depth ranging from -1600 to $-2400 \mathrm{~m}$ and gradients of about $2^{\circ}$ at a depth of about $-3500 \mathrm{~m}$. The southern offshore slope starts with an smooth insular shelf and changes the morphology at the shelf's edge into a steep slope down to a depth of -800 to $-1800 \mathrm{~m}$ and with gradients of $15-16^{\circ}$. Beyond this steep slope are located slopes with gradients of about $3^{\circ}$.

The abrupt submarine changes of slope inclination near the sea level are common features on volcanic islands. In Hawaii (Mark and Moore, 1987) and on Réunion Island (Lénat et al., 1989) this marked slope change is assumed to be the result of volcanic activity, including: 1) the chilling effect of water, that tends to increase the effective viscosity of lava flows, 2) the surf action, which causes the spreading of the lava flows after entering the sea; and, 3) the bouyant effect of the water on the propagation of the lava flow, which may be the most important process. On Tenerife, the platform and steep submarine slope may have been formed by a combination of these processes and additional accumulation of material eroded by the important erosion due to sea waves. Coastal platforms formed by marine abrasion have been found around many ocean islands (Nunn, 1995).

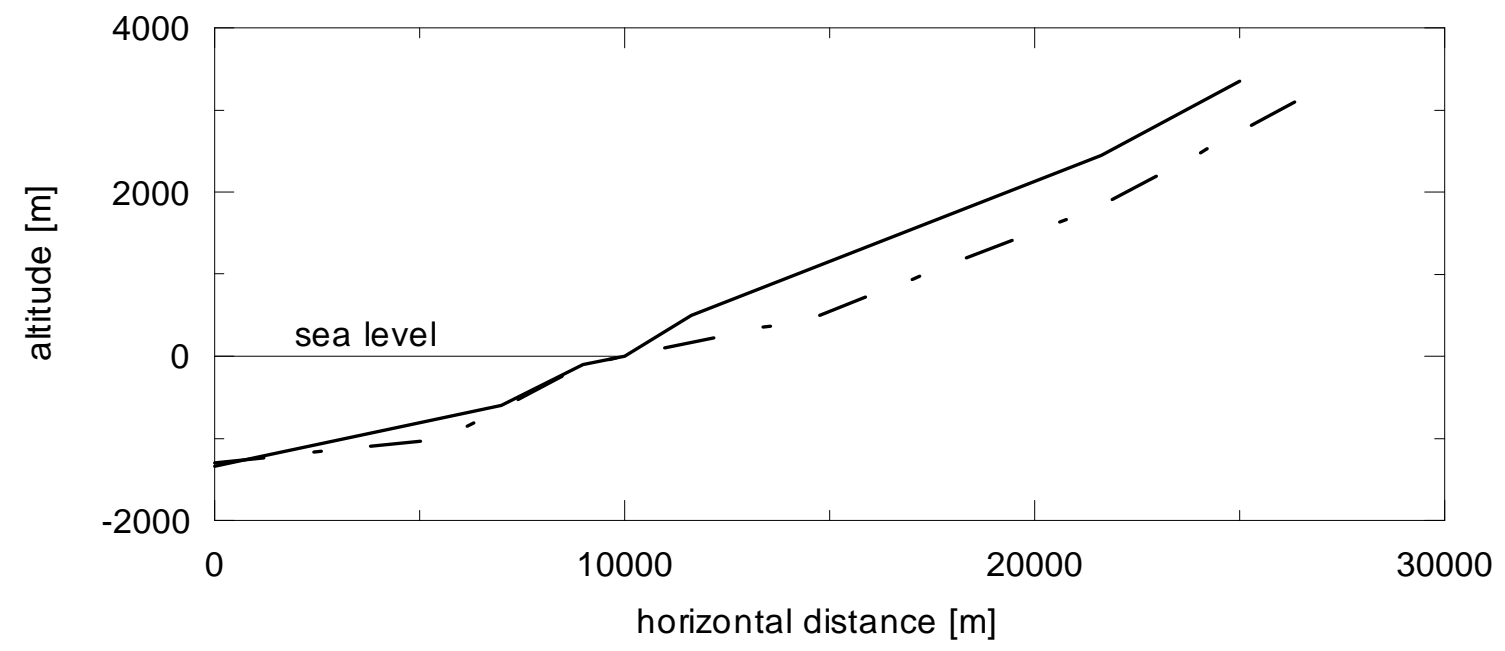

Figure 3.10: Simplified profiles of the flanks of Tenerife island. Morphology of northern slopes (straight line) and of southern slopes (dash - dot line). Vertical exaggeration: 2x. 


\subsubsection{Northern flank of Tenerife}

The morphology of the La Orotava valley is strongly related to the evolution of the north flank of Tenerife. During the post-shield stage the northern submarine and subaerial slopes have been affected by at least four episodes of large landslide events: an old landslide episode and the three young events Icod, La Orotava and East Dorsal. Hereafter, a short summary of the morphology of the north flank of Tenerife will be given starting with the submarine zones and ending with the subaerial areas. A complete overview of the results obtained from the morphologic study of the north flank of Tenerife will be published in the paper by Ablay and Hürlimann (1999).

Figure 3.11 shows a combined shaded relief and contour map of the northern flank of Tenerife computed by the DEMs with pixel size of $100 \mathrm{~m}$. The submarine zone of the shaded relief illustrates a wide undulating region representing the North Tenerife debris apron located between the offshore extensions of the Teno and Anaga massifs characterised by deeply incised terrain.

Generally, the morphology of the study area shows three different surface features associated with the large landslide events: 1) onshore amphitheatres, 2) offshore troughs located near to the island; and, 3) lobes in the distal part of the debris apron.

The determination of the exact onshore extensions of the landslide amphitheatres has been complicated by postslide materials filling the original escarpments. Finally, the tentative limits of the slope failures have been defined as illustrated in Figure 3.12 using the available geologic and morphologic data. Apart from the giant failures which have originated the valleys of Icod and La Orotava, a third large landslide event has been inferred to be located at the eastern part of the Dorsal Ridge forming the East Dorsal amphitheatre. The existence of the East Dorsal event is not only supported by the morphologic study (Ablay and Hürlimann, 1999), but also by geological evidences obtained from the water tunnels in the east Dorsal area (Navarro, 1998).

The seawards offshore continuation of the landslide amphitheatres is characterised by three submarine troughs (Figure 3.11): the Icod trough adjacent to the Icod valley, the La Orotava trough adjacent to the La Orotava valley and the East Dorsal trough adjacent to the eastern termination of the Dorsal Ridge where the East Dorsal amphitheatre has been assumed to be. The landslide troughs are channel-shaped features bordered by sub-vertical walls up to $600 \mathrm{~m}$ high and lengths between 5 and 20 $\mathrm{km}$. In the distal part of the debris apron in a depth of about $3500 \mathrm{~m}$ b.s.l. three deposit lobes have been identified: the Icod lobe, the La Orotava lobe and the East Dorsal lobe. The lobes are characterised by steep ridges at the lateral margins, arcuate transverse ridges and hummocks up to $300 \mathrm{~m}$ high. Hummocks and lateral margins or levées are typical features described at many subaerial volcanic debris avalanches (e.g. Glicken, 1996) and non-volcanic mass movements (Corominas, 1995), and the transverse ridges can be interpreted as pressure ridges formed by material pilling up behind the deposit front.

Two supplementary morphologic features detected by the bathymetric/topographic data and already mentioned in the previous Sections are the shallow coastal platform and the steep onshore cliff (Figure 3.11 and Figure 3.12). The north Tenerife platform is characterised by water depths of less than $200 \mathrm{~m}$ and an average value of less than $100 \mathrm{~m}$. A clear difference in the platform width can be observed between the two sections adjacent to Teno and Anaga characterised by an average width of about 4500 $\mathrm{m}$ and the central part of the north flank corresponding to the post-shield complex where the platform is narrow and the average width is about $1600 \mathrm{~m}$. This variance may determine the lateral extension of the old post-shield landslide episodes occurred in the LCE materials deposited between the old shields volcanoes Teno and Anaga. The onshore cliff along the shores is a good morphologic feature indicating the existence and extension of large slope failures. Steep cliffs with heights up to $500 \mathrm{~m}$ (e.g. northern side of Tigaiga massif) can be detected at the volcano slopes not affected by large landslides during recent times. In contrast the present, coastal cliffs inside the La Orotava and the Icod valley are generally smaller than $50 \mathrm{~m}$. 


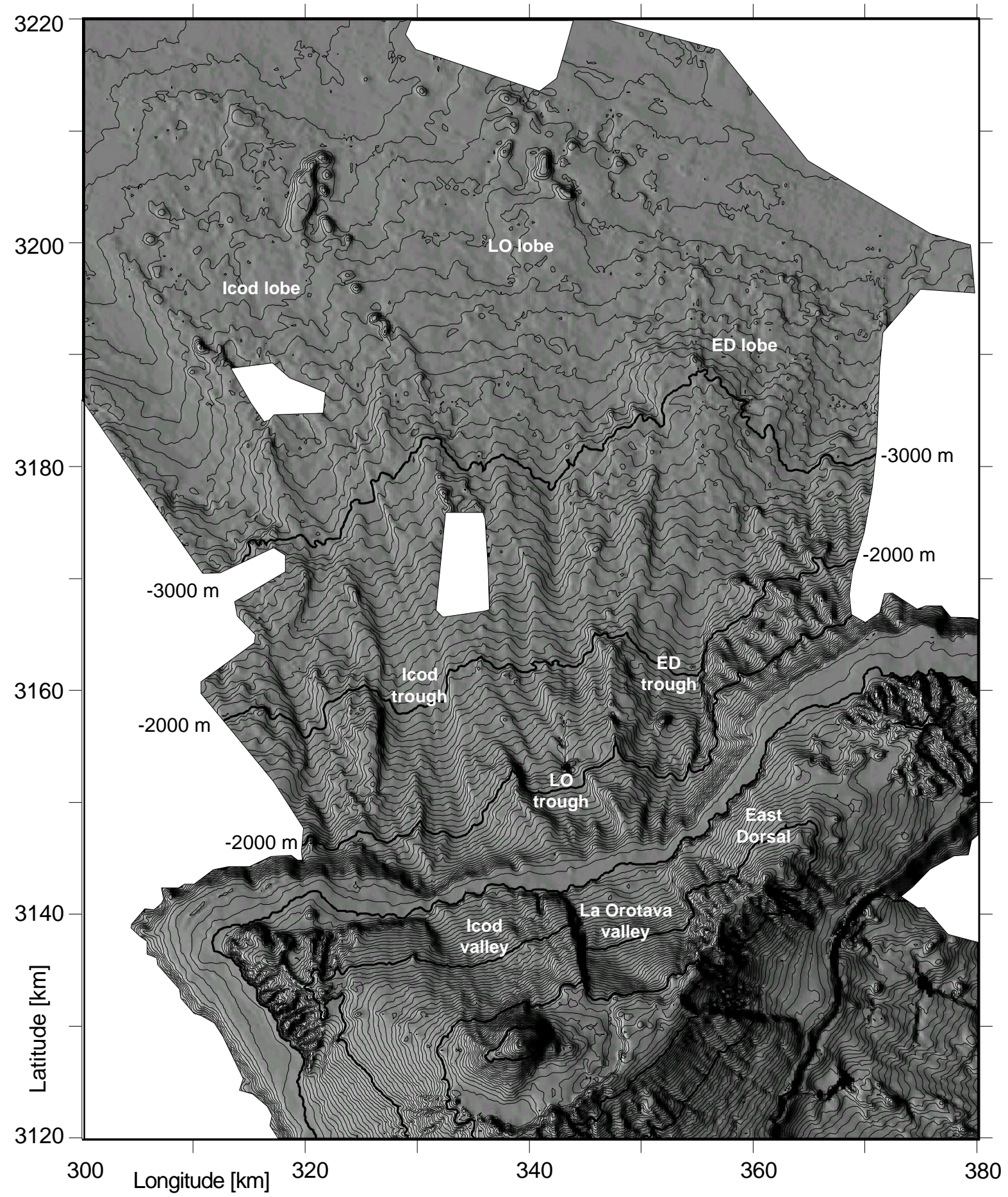

Figure 3.11: Shaded relief of the northern flank of Tenerife. Contour lines in $50 \mathrm{~m}$. LO for La Orotava and ED for East Dorsal.

A geomorphologic map (Figure 3.12) covering the area of Figure 3.11 illustrates a detailed view of the landslide limits and surface forms of the north flank of Tenerife. The most important geomorphologic areas and features have been drawn including the three landslide events Icod, East Dorsal and La Orotava. 


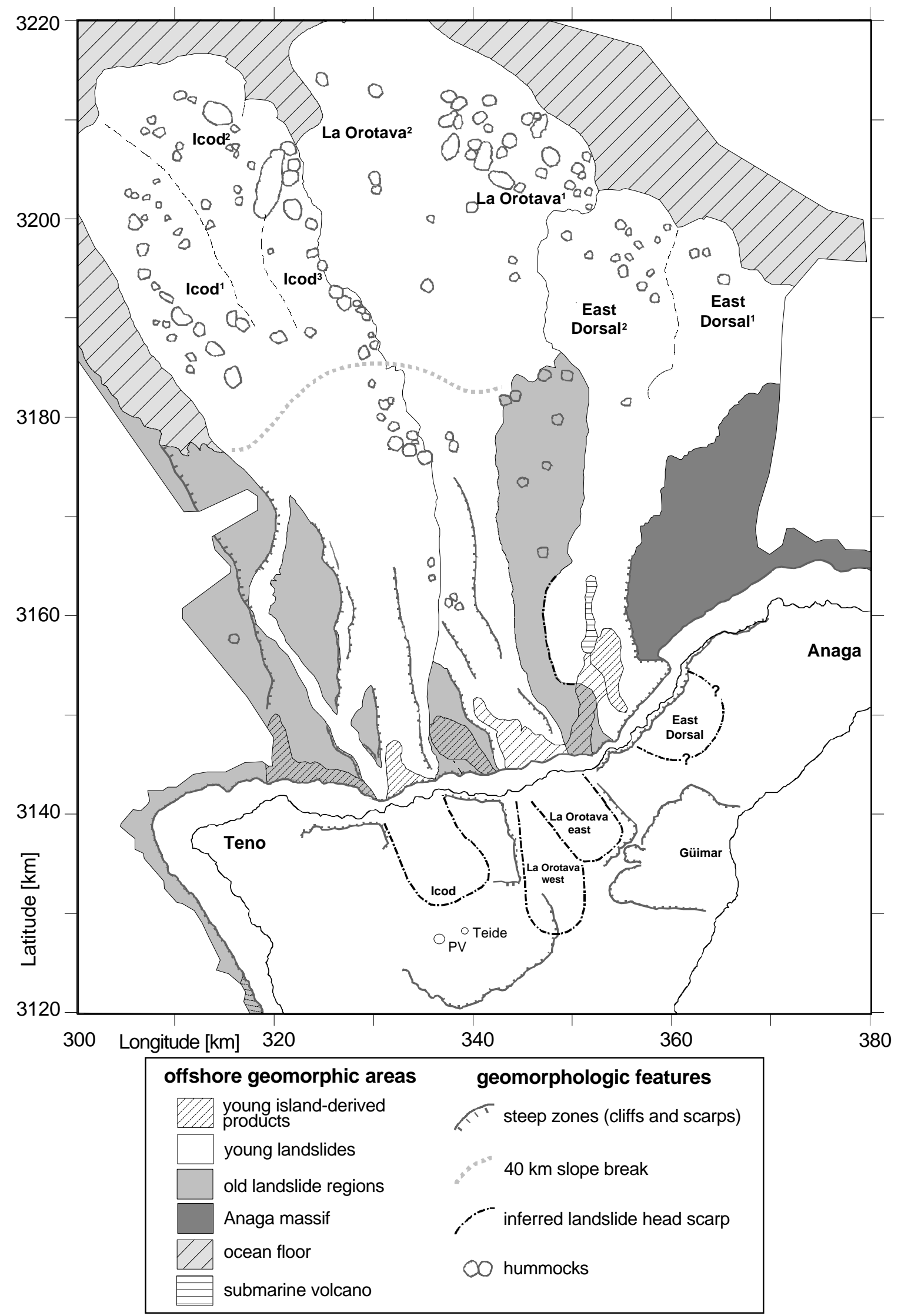

Figure 3.12: Geomorphologic map of the northern flank of Tenerife. Modified from Ablay and Hürlimann (1999). 
In total three young post-shield landslides have been assumed. Two of them have been interpreted to comprise multiple failures including the La Orotava landslide events and the East Dorsal events. The Icod slide has been assumed to incorporate only one failure with a single breakaway zone.

The Icod landslide includes the subaerial Icod valley, the Icod trough and the Icod lobe with three different sub-lobes. The existence of sub-lobes can be interpreted as an accumulation process characterised by several pulses. Each pulse may have deposited one sub-lobe. The Icod lobe is overlying the La Orotava lobe to the east and therefore of younger age, which is consistent with the onshore chronology.

The East Dorsal landslides comprise an onshore as well as an offshore breakaway zone, the East Dorsal trough and the East Dorsal lobe. The onshore breakaway zone is assumed to underlie the eastern part of the Dorsal Ridge while the offshore failure scarp is located at the west border of the East Dorsal trough. The East Dorsal lobe is divided into two sub-lobes each of them formed from an impulse of the onshore and offshore material, respectively.

The La Orotava landslides involve the La Orotava valley, the La Orotava trough and the La Orotava lobe. A structural relationship between the trough walls and those of the onshore La Orotava valley is suggested by their spatial correlation and corresponding orientations. The morphology of the La Orotava valley is attributed to a combination of two failures. This explains the contrasting slope orientations and headwall strike directions of the eastern and western valley sectors and the nonparallelism of the bounding walls. The east La Orotava slide is inferred to have affected the eastern sector of the valley. Failed material is inferred to have travelled northwest along the La Orotava trough. This is suggested by the coincidence in the orientations of the east walls of the valley and trough, and the slope direction of the eastern valley floor. Further down slope, the disappearance of the main La Orotava trough is attributed to its burial beneath the Icod landslide. Muted ridges within the Icod landslide trending parallel to the La Orotava trough are interpreted as the attenuated longitudinal fabric of the east La Orotava slide. The west La Orotava failure is inferred to have affected the western sector of the valley, probably contemporaneous with the east La Orotava event. The west La Orotava slide is inferred to have entered the trough used or formed previously by the east La Orotava slide then turned north to exit the trough, forming the sub-lobe La Orotava ${ }^{2}$ (Figure 3.12).

In addition to these young post-shield events exists an old post-shield landslide complex. The deposits of this landslide complex characterised by hummocky surface are illustrated as 'old landslide regions' in Figure 3.12 and encompass an area $35 \mathrm{~km}$ wide extending from the coast to about $40 \mathrm{~km}$ offshore. The down slope limits of the hummocky terrain together with the correlative slope break at $-2100 \mathrm{~m}$ to $-2200 \mathrm{~m}$ occurring within the Icod and La Orotava slides are inferred to mark the front of the old post-shield deposits (Figure 3.13). 
Figure 3.13 illustrates a schematic interpretative cross section trough the north flank of Tenerife. The inferred geometries of older and younger post-shield landslide deposits and failure surfaces are projected onto an idealised, slope-normal section. This section starts at the top in the Las Cañadas caldera and includes down slope the Tigaiga massif, the onshore steep zone, the offshore coastal platform and the submarine debris apron.

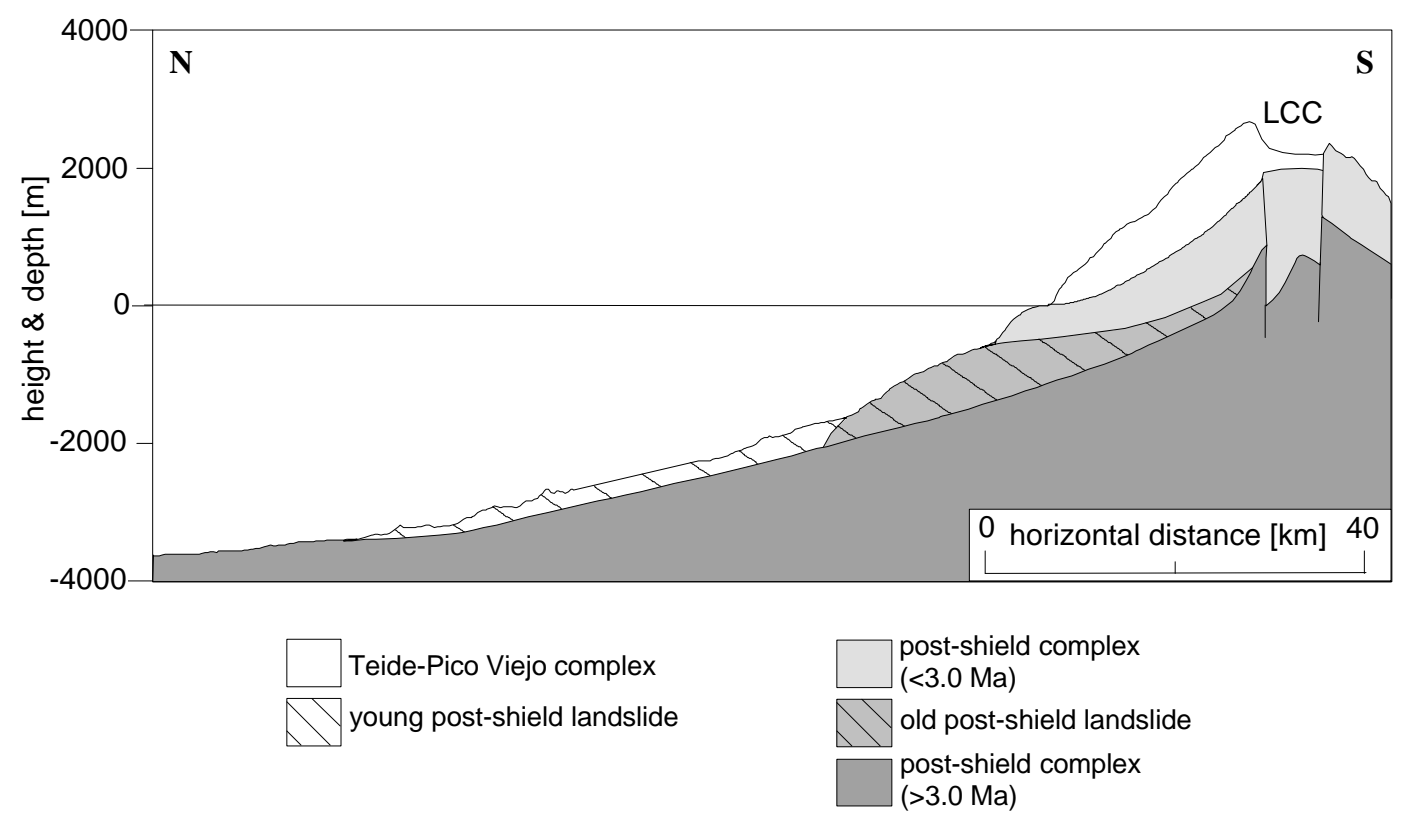

Figure 3.13: Idealised longitudinal geological cross section through the north flank of Tenerife. LCC indicates the Las Cañadas caldera

Figure 3.14 shows an idealised transverse profile through the north flank of Tenerife illustrating the three young post-shield failures East Dorsal, La Orotava and Icod and also the assumed failure surface of the old post-shield failure complex. The breakaway zone of this landslide complex might have been partly submarine and partly subaerial ranging from the west border of Anaga along the Dorsal Ridge and the Santiago Ridge to the east border of Teno.

W

E

Icod La Orotava East Dorsal

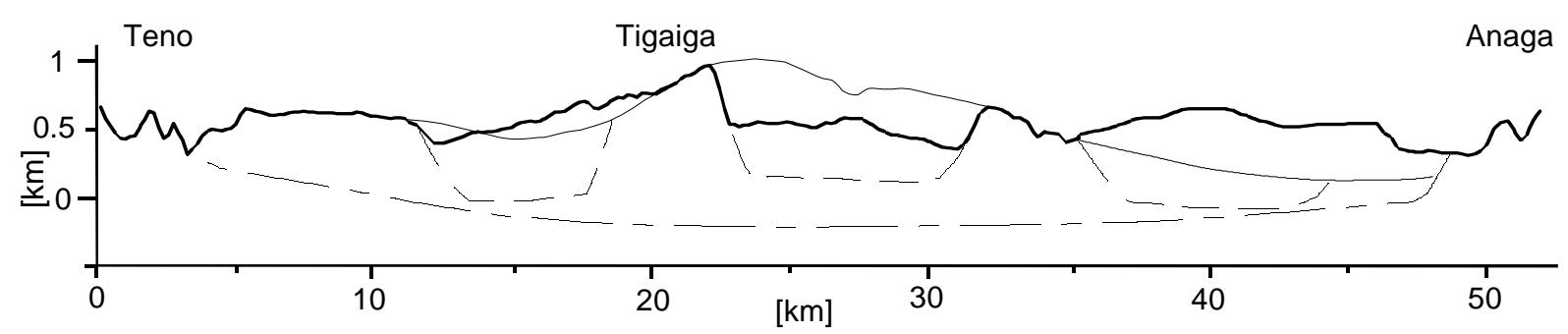

Figure 3.14: Idealised transverse profile through the north flank of Tenerife. Solid thick line indicates the present topography and thin solid line shows the assumed topography previous to the three young post-shield slides Icod, La Orotava and East Dorsal. Thin dashed lines illustrate the inferred failure surfaces of the young post-shield slides and thin dashed-dotted line indicates the failure surface of the old post-shield slide complex. 
While the ages of the Icod and La Orotava landslides (about $179 \mathrm{ka}$ and $560 \mathrm{ka}$ ) have been estimated in previous studies (e.g. Ancochea et al., 1990; Watts and Masson, 1995; Martí et al. 1997), the ages of the East Dorsal and the old post-shield landslides have been inferred analysing the available geologic and morphologic data. No constraints on the age of the East Dorsal event are available other than the observation that it covers the La Orotava lobe and is therefore younger than $560 \mathrm{ka}$. Age constraints of the old post-shield events offered by platform geometry and onshore geochronological data (Carracedo, 1975; Ibarrola et al., 1993) suggest that the most likely age is between 2.3 and $3.0 \mathrm{Ma}$ with the age of 3.0 Ma assumed to be more possible due to the platform width adjacent to the Tigaiga massif.

The failure of a major part of the north flank of Tenerife at about 3.0 Ma is inferred to have formed a large amphitheatre with its axis and deepest point at the western sector of the present La Orotava valley (Figure 3.14). Erosional products and later post-shield volcanics have been accumulated within this huge depression. The rebuilding of the LCE is suggested to have involved the piling up of volcanics against the headwall of the amphitheatre, which explains the northwest sloping morphology of the Tigaiga massif and its oblique truncation by the sea.

An important fact in each landslide study is the volume of material involved. There are two modes to calculate the landslide volumes: 1) volume estimates refering to the deposit; and 2) volume estimates concerning the breakaway zone. However, the volume of the deposit is generally about 20 to $25 \%$ greater than the volume of the breakaway zone due to rupture of the massive rock mass into debris (Voight, 1978c; Nicoletti, 1991). A recent example of an observed volcanic landslide event indicates that the Mt. St. Helens debris avalanche has increased its volume about $20 \%$ during its transportation phase (Voight et al., 1981). Volume estimates for the entire debris apron have been proposed by Watts and Masson (1995) and Teide-Group (1997). Here, each landslide episode has been calculated separately including on the one hand the volumes of the lobes and on the other hand the volumes of the amphitheatres (Ablay and Hürlimann, 1999). The most voluminous event with a total amount of material exceeding 500 or even $600 \mathrm{~km}^{3}$ has been attributed to the old post-shield landslide episode that probably incorporated many single events. The three young post-shield events East Dorsal, La Orotava and Icod have all of them volumes of about $100 \mathrm{~km}^{3}$. Thus, a total volume of the debris apron can be suggested as about $900 \mathrm{~km}^{3}$ coinciding quite well with the estimates of $1000 \mathrm{~km}^{3}$ by Watts and Masson (1995) and $1200 \mathrm{~km}^{3}$ by Teide-Group (1997). However, both of them excluded the existence of a huge old post-shield landslide episode and hence proposed other facts in order to justify the volume difference between the debris apron and the young post-shield amphitheatres including only about $210 \mathrm{~km}^{3}$. Watts and Masson $(1995,1998)$ have defended the disparity in volume by inferring that the Las Cañadas caldera was emptied through the Icod valley. However, the geometries of the offshore deposits, Icod valley and Las Cañadas caldera argue against this. Moreover, detailed gravity studies of central Tenerife by Camacho et al., (1991) and Ablay and Kearey (1999) suggest that the headwall of the Icod valley does not equate with the southern Las Cañadas caldera wall, but is located further to the north beneath Teide. On the other hand, Teide-Group (1997) has suggested that the proximal part of the debris apron comprises slump deposits derived from the outer edge of the shallow submarine platform, while distal parts comprise debris flow deposits derived from the slumps. However, the observation that the central section of the platform is relatively narrow compared to that adjacent to the shields is better explained by its younger age than by failures from its seaward edge. The prominent lobes and troughs developed on the debris apron show clear connections to the young landslide valleys and are better interpreted as young post-shield debris avalanches derived from the onshore valleys. 


\subsubsection{The La Orotava valley area}

The morphology of the La Orotava valley has been studied including the lateral scarps, the coast line, the Dorsal Ridge area and the valley floor (Figure 3.15). In addition, a detailed geomorphological analysis has been carried out for the two areas, where the preslide deposits crop out: 1) the St. Ursula wall and the Los Organos area in the east; and, 2) the Tigaiga wall in the west.

The La Orotava valley is the largest visible landslide amphitheatre on Tenerife and is bordered by two characteristic lateral escarpments: the eastern Santa Ursula wall and the western Tigaiga wall (Figure 3.15) Both scarps are very steep and have maximum heights of about $500 \mathrm{~m}$ in the middle parts. In contrast to the Santa Ursula wall, which is characterised by a slightly convex morphology with a general NNW-SSE direction, the Tigaiga wall has a linear N-S orientation with an opening at the lower end. At the head of the valley to the south, the Dorsal Ridge with a SW-NE direction extends to heights ranging from $1900 \mathrm{~m}$ in the eastern parts to $2300 \mathrm{~m}$ in the western parts. The width of the valley reaches almost $10 \mathrm{~km}$ at the coast and increases continuously towards the upper areas. The longitudinal distance varies between about $9 \mathrm{~km}$ in the eastern part to $14 \mathrm{~km}$ in the middle/western parts (Figure 3.16). At the south-western limit of the valley (el Portillo) exists a connection to the Las Cañadas Caldera, which is characterised by a plateau-like morphology.

The La Orotava amphitheatre can be divided in three parts: 1) a rather uniform lower part up to an altitude of about $500 \mathrm{~m}, 2$ ) an irregular upper part higher than $500 \mathrm{~m}$; and, 3) a quite rough and complex head wall area. The lower part is characterised by a small slope inclination, especially in the centre of the valley. At the coast, where the tourist resort 'Puerto de la Cruz' is located, the barranco deposits and recent lava flows have formed a significant delta. The higher part of the La Orotava valley is characterised by an irregular morphology due to lava accumulation and fluvial erosion. In the centre of the valley exists a steep zone located between 500 and $800 \mathrm{~m}$. The head wall of the valley presents a complex morphology. In the eastern sector where preslide deposits crop out, the fluvial erosion has formed a well developed, rough relief characterised by deeply eroded barrancos and catchments. In the central sector, adjacent to the observatory station 'Izaña', the morphology is affected on one hand by the pyroclastic accumulation of the volcanic cones along the Dorsal Ridge flattening the upper part of the La Orotava valley and on the other hand by fluvial erosion forming deep gullies. The western sector of the amphitheatre's head wall is open to the Las Cañadas caldera and the surface morphology is influenced by the lava flows coming out from the caldera into the valley. 


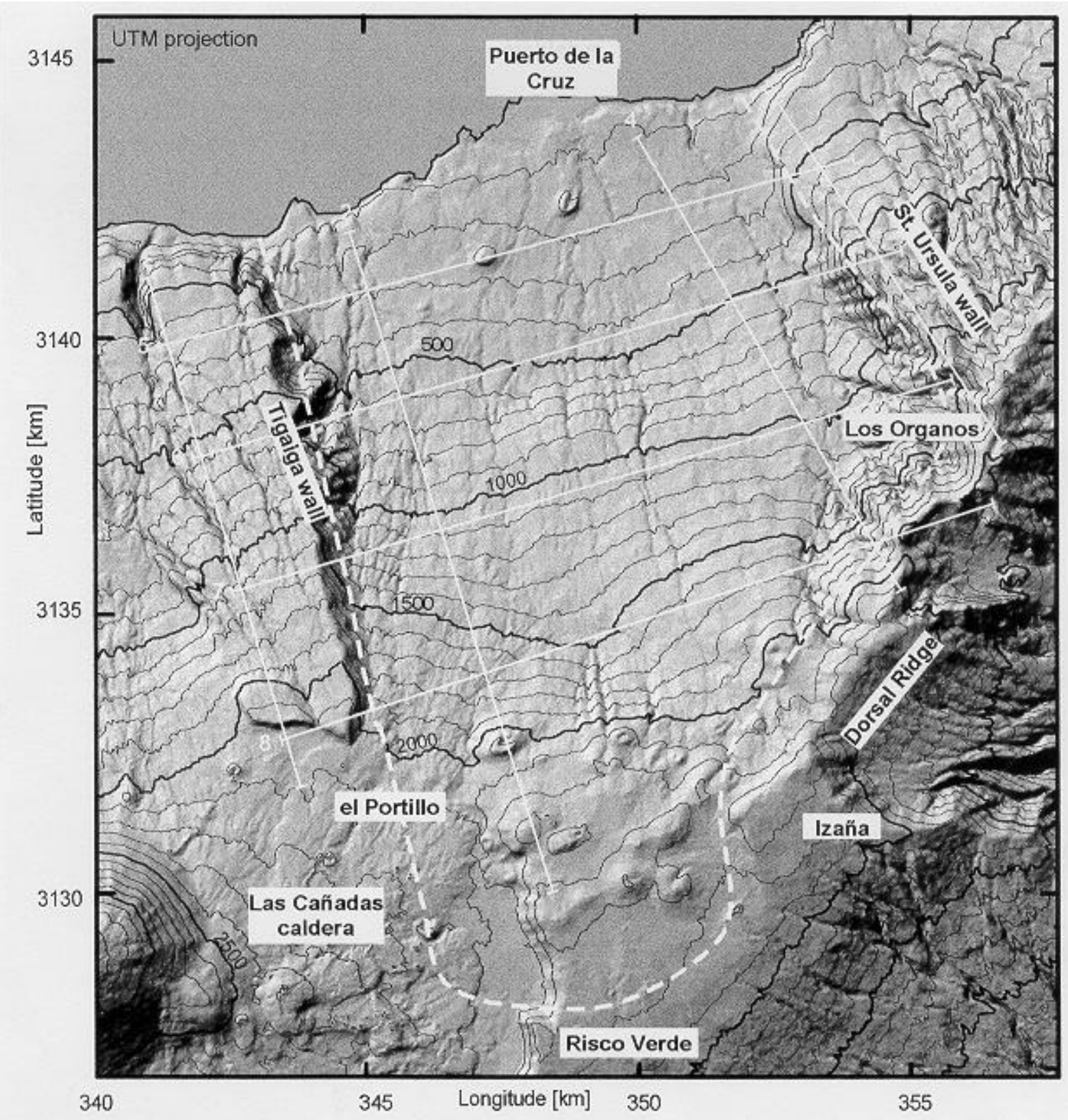

Figure 3.15: Shaded relief of the La Orotava valley. The contour interval is $100 \mathrm{~m}$. White solid lines show the topographic profiles presented in Figure 3.16 and Figure 3.17. Thick dashed line indicates the inferred extension of the landslide amphitheatre.

Longitudinal and transverse profiles of the morphology affected and not affected by the landslide events have been drawn (Figure 3.16 and Figure 3.17). The longitudinal profiles of the morphology not affected by the landslides show a significant coastal cliff of heights up to $500 \mathrm{~m}$, especially at the Tigaiga massif (Figure 3.16b, profile 3). This high coastal cliff lacks inside the La Orotava valley and thus indicates the extension of the landslide amphitheatres. The slopes above the cliffs are characterised by average seawards inclinations of about $11^{\circ}$ on the Tigaiga massif and about $13^{\circ}$ at the St. Ursula side. The longitudinal sections inside the valley have a concave morphology at the east side and a linear shape in the western part. Transverse profiles show the smooth valley floor (Figure 3.17, profile 5) and the irregular morphology in the upper part of the valley (Figure 3.17, profile 8). 
a)

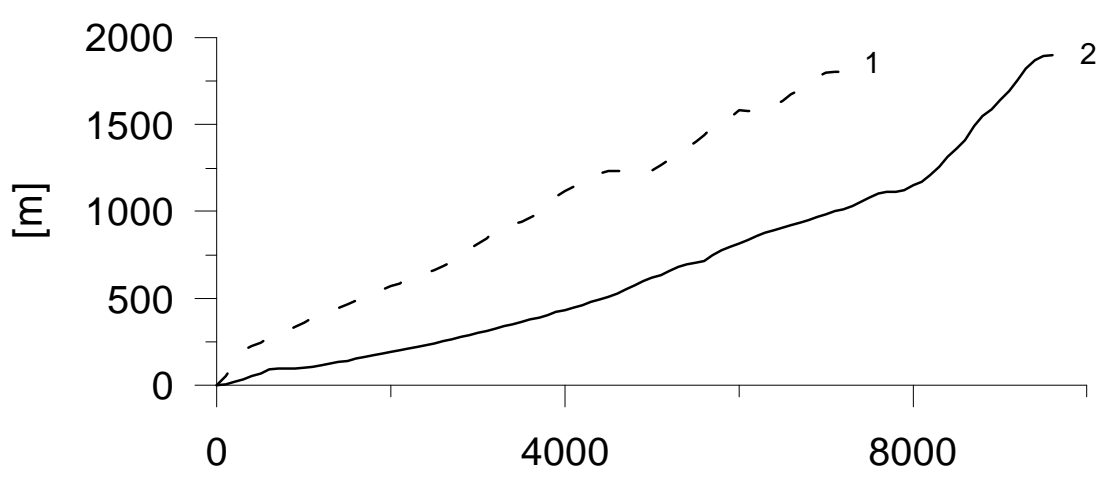

b)

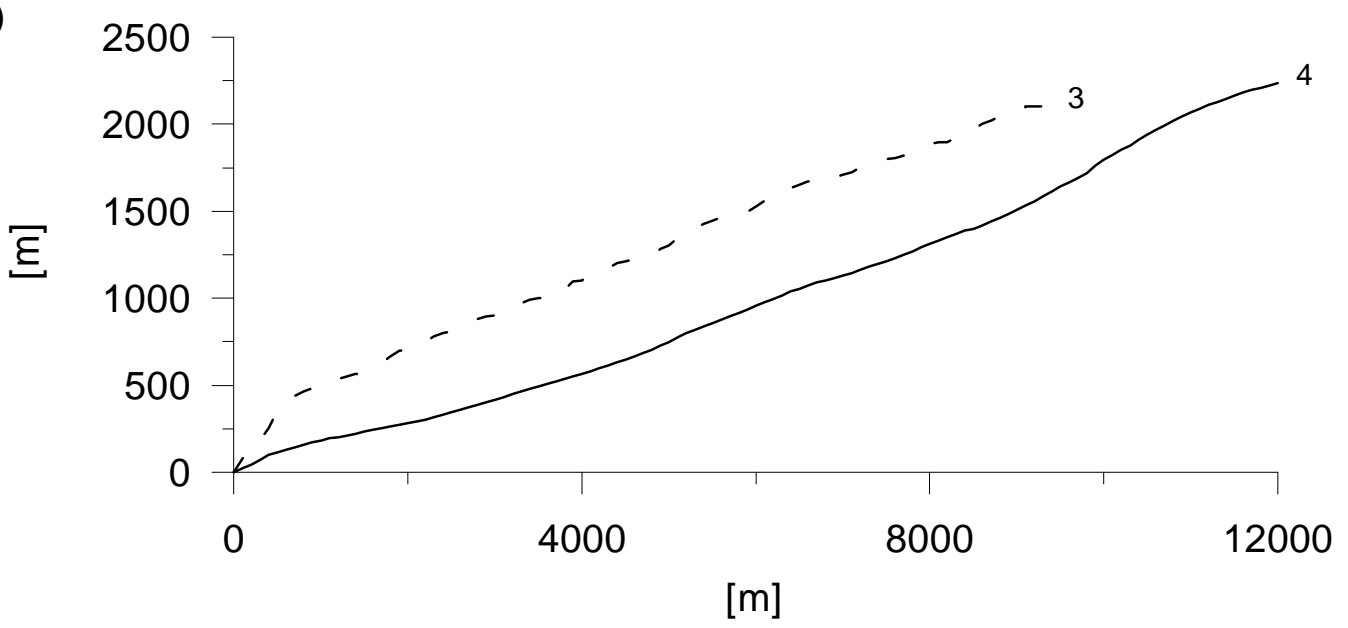

Figure 3.16: Longitudinal topographic profiles 1 to 4 of the areas affected (straight line) and not affected (dashed line) by the landslide events. a) Eastern part of the La Orotava valley near Santa Ursula wall and b) western part of the valley near Tigaiga wall. Vertical exaggeration is 2. Locations are indicated in Figure 3.15.

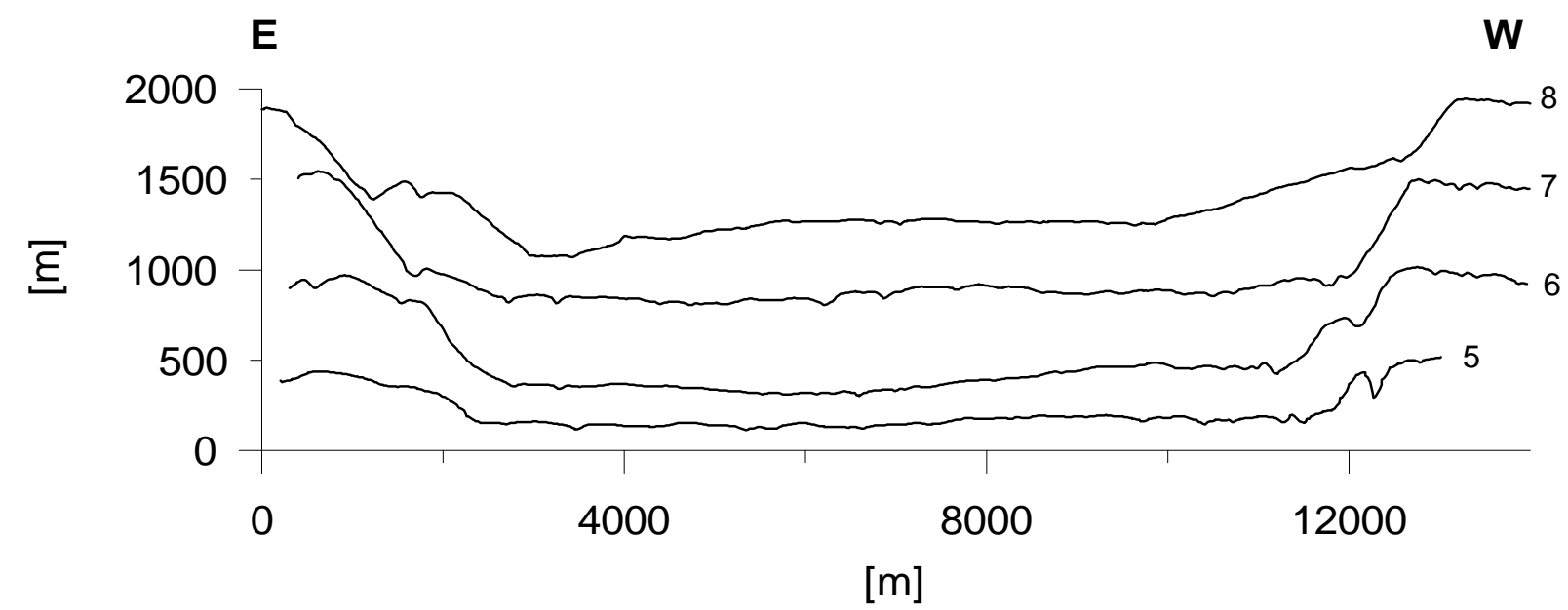

Figure 3.17: Transverse topographic profiles 5 to 8 of the La Orotava valley. Vertical exaggeration is 2. Locations are indicated in Figure 3.15. 
In the next step, the lateral scarp areas have been analysed comprehensively. First, the results obtained from the geomorphologic study of the western Tigaiga wall will be presented and then the eastern scarp area including the St. Ursula wall and the zone of Los Organos will be explained.

At the beginning an extensive study of the slope inclinations of both scarps have been performed using GIS-tools as explained in Section 3.4.1. The DEM with a pixel size of 25 meters has been incorporated into the GIS. Then, a new DEM (called 'DEM10') with a pixel size of $10 \mathrm{~m}$ has been generated using a triangulated irregular network and linearly interpolation, and the areas of the two lateral scarps have been clipped out of the DEM10. Finally, the Tigaiga wall DEM has contained 380'990 cells and the St. Ursula - Los Organos DEM 364'762 cells. In the next step, the slope angle of each cell of the DEMs has been computed and analysed by the Arc/Info module GRID (ESRI, 1998). The objectives of these calculations have been on one side the determination of the general morphology of the lateral walls and on the other side the detection of small open scarps indicating failure zones of the large landslides. Moreover, the spatial distribution of the slope angles in the DEMs gives necessary data to check the results obtained from the interpretation of the aerial photographs. At last, the cells of the DEMs have been divided into four different classes of slope angles each of them shaded by a different colour:

$$
\begin{array}{ll}
\text { I. } & 0-30 \text { degrees } \\
\text { II. } & 30-40 \text { degrees } \\
\text { III. } & 40-50 \text { degrees } \\
\text { IV. } & 50-90 \text { degrees }
\end{array}
$$

$$
\begin{aligned}
& \text { (white shaded) } \\
& \text { (light-grey shaded) } \\
& \text { (dark-grey shaded) } \\
& \text { (black shaded) }
\end{aligned}
$$

In the second part, a geomorphologic map of each lateral escarpment zone has been established using the results of the GIS modelling, the aerial photograph interpretations and field observations. General features refering to mass wasting, accumulation processes, fluvial erosion etc. have been incorporated in these maps and geomorphologic zones have been determined for the entire study area.

First, the results concerning to the Tigaiga wall area will be presented. The Tigaiga wall is a more than $10 \mathrm{~km}$ long sub-vertical scar limiting the La Orotava valley to the west. Its height constantly increases from the top at La Fortaleza to the middle part reaching there a maximum height of about 500 $\mathrm{m}$ (Figure 3.18). In the lower part the wall slightly decreases its height and terminates abruptly at the coast, where the steep coastal cliff falls down from an altitude of about $500 \mathrm{~m}$ to sea level. The upper part of the Tigaiga wall is characterised by sparse, grassy vegetation with some pines while the part below about $1500 \mathrm{~m}$ is mainly covered by dense vegetation. Several open scarps can be seen in the wall indicating the inclination of layers composing the Tigaiga massif. These layers generally are formed by sound, resistant material (lava flows) in comparison to weak deposits (pyroclastics) not able to create a vertical relief (Chorley, 1984; Gerrard, 1988). In the lower part near the coastline, these layers are subhorizontally while their dip increases towards the higher zones running almost parallel at the top of the massif near La Fortaleza (Figure 3.18).

In Figure 3.19 the results of the GIS-modelling are illustrated analysing the slope inclinations of the Tigaiga wall. The section of the DEM studied is limited in the longitude between the UTM coordinates 342.6 and $346 \mathrm{~km}$ and in the latitude between the coordinates 3132 and $3143 \mathrm{~km}$. The top of the Tigaiga massif is characterised by a smooth relief with slope angles less than $30^{\circ}$ except of some erosional gullies. At La Fortaleza a very steep scarp towards the south indicates the caldera wall of the LCC. The south sector of the Tigaiga wall located higher than about $1500 \mathrm{~m}$. comprises mainly slope angles of 30 to $40^{\circ}$ with some areas with inclinations up to $50^{\circ}$. In the middle part of the wall, where the horizontal width of the scar is greatest, the spatial distribution of the slope angles is very inhomogeneous including quite smooth zones (inclination less than $30^{\circ}$ ) and very steep zones (inclinations higher than $50^{\circ}$ ). The northern sector of the Tigaiga wall with its general NNW- SSE orientation clearly differs from the southern sector with its $\mathrm{N}-\mathrm{S}$ orientation. The northern sector is characterised by very steep zones in the higher areas of the escarpment including large scars with slope angles higher than $50^{\circ}$ and smooth zones at the foot of the escarpment. An average slope angle of $33.5^{\circ}$ has been calculated for the entire Tigaiga wall and a maximum value of $70.8^{\circ}$ located in the open scars of the northern sector. 


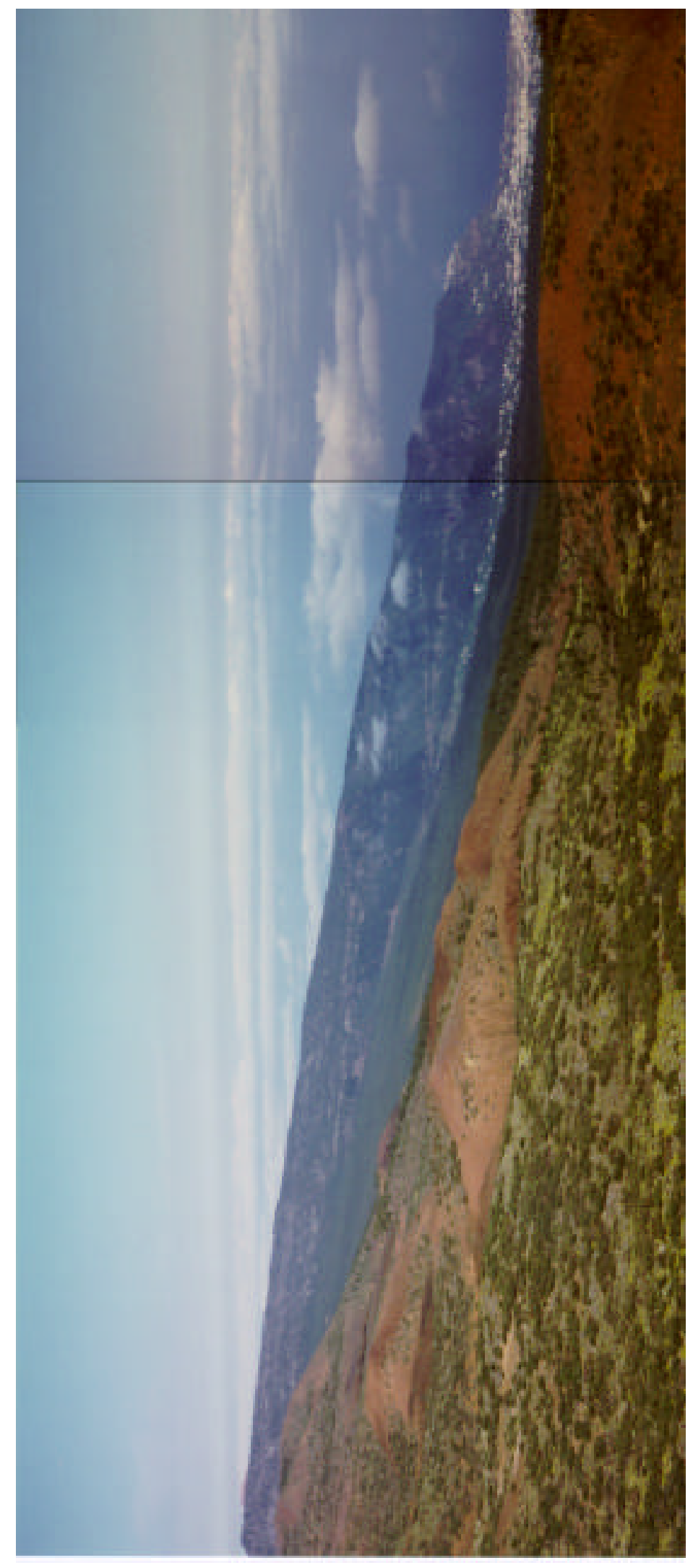

Figure 3.18: Photograph of the Tigaiga wall taken from the Dorsal Ridge in NWW direction. 


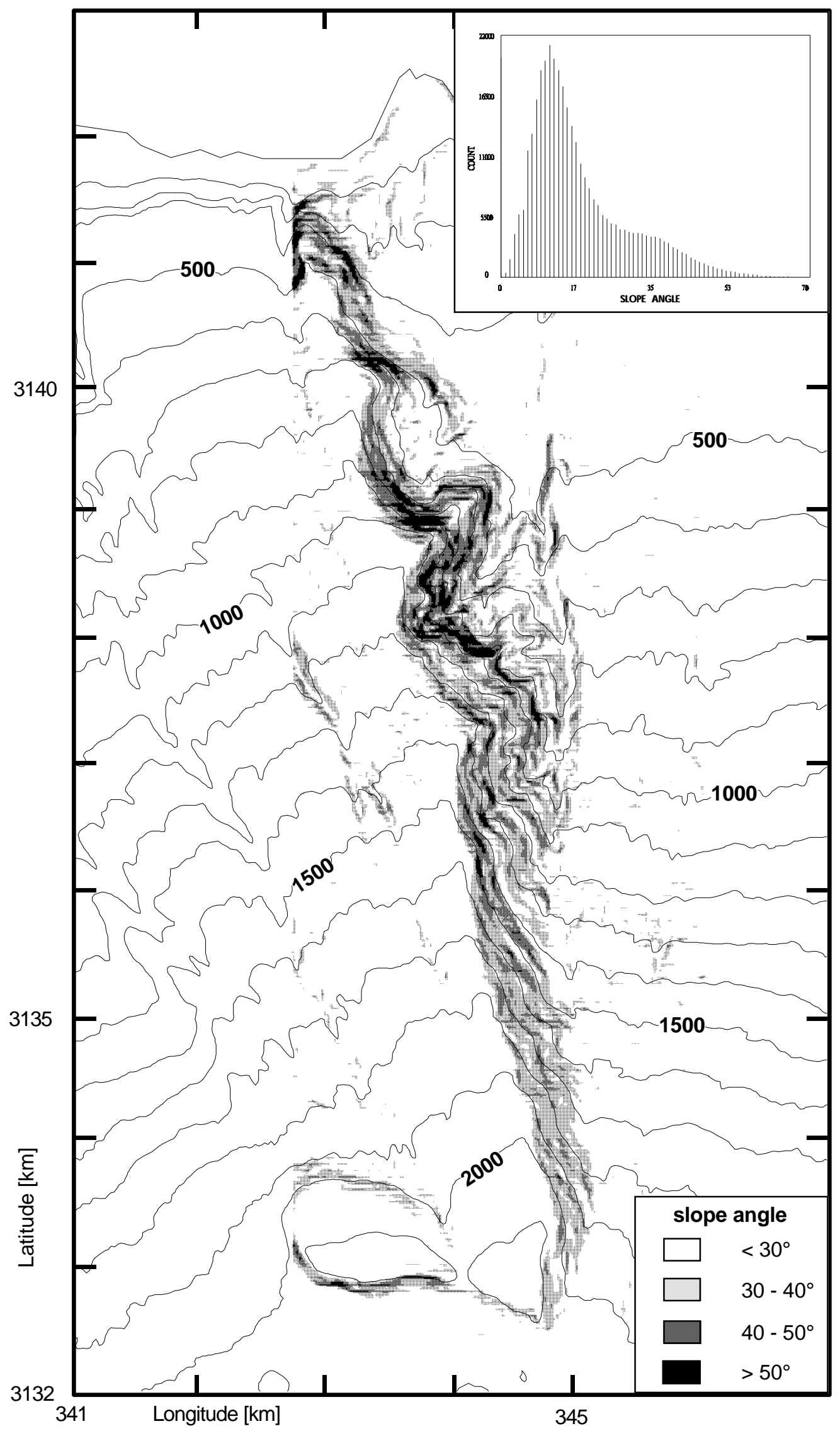

Figure 3.19: Slope inclination map of the Tigaiga wall. Contour lines in $100 \mathrm{~m}$. Inset shows overall distribution of slope angles in the DEM (number of cell vs. slope angle). 
A geomorphologic map is shown in Figure 3.20 incorporating the results obtained from the GISmodelling, the interpretations of the aerial photographs, field observations and geologic data.

The Tigaiga wall has been divided into two different morphologic units, while the zones adjacent to the wall have been divided into four units. The two units characterising the morphology of the wall are separated by the magnitude of the postslide mass wasting processes that have affected the original lateral scarp generated by the large La Orotava slide: on the one side minor processes and on the other side significant processes. Significant postslide mass wasting processes including major secondary landslides have changed the relief of the lower sector of the original Tigaiga wall. In contrast, the morphology of the upper part of the wall has only been affected by minor fluvial erosion. This area is characterised by a quite continuous east dipping relief inclined by about $35^{\circ}$. In the lower part of the Tigaiga wall, the secondary, postslide landslides have formed two very marked arcuate escarpments located between Risco de Miguel and Corona as well as two linear scarps adjacent to el Lance (Figure 3.20). The breakaway zones of the two arcuate escarpments are characterised by circular morphologies with large open scars in theirs highest zones. Such features are quite typical for rotational slope failures. The material involved into these secondary landslides exceeding $1 \mathrm{~km}^{3}$ has been transported seawards and the deposition has been started at the foot of the slope. A submarine continuation of the accumulation zone has been observed by the bathymetric data (Figure 3.12) and by the existence of slide deposits in the active coastal cliff up to $2 \mathrm{~km}$ east of Punta de Gundastés. Therefore, the extension of the secondary landslide deposits in the underground may surpass the eastern border defined at the surface in Figure 3.20. The causes of the secondary slope failures may have been the critical stability conditions of the lateral escarpment generated by the large La Orotava slide and the following erosional processes undercutting this high scarp. An important point is that only the lower part of the Tigaiga wall has been affected by secondary slides. This part is characterised by higher precipitation and a wetter micro-climate than the upper part caused by the temperature inversion at an altitude of about $1500 \mathrm{~m}$.

The study of the drainage network has shown the particular northwest sloping morphology of the Tigaiga massif differing from the general N-S orientation of the La Orotava valley floor that has already been explained in the previous Section 3.4.2. At the foot of the Tigaiga wall exist a deeply incised barranco draining almost the entire lateral escarpment area and entering into the sea east of the Punta el Gundastés as the Barranco de la Calera. This deep gully has a N-S orientation starting at the connection of the valley with the Las Cañadas caldera and may indicate the original western limit of the large western La Orotava landslide.

The coastal cliff is characterised by an active and a passive sector. The active marine cliff runs almost along the whole coast while the passive one is limited to the coastal part of the Tigaiga massif (Palacios, 1989; Palacios, 1990). There, previous marine abrasion during an epoch of higher sea levels has formed a huge cliff with heights up to $400 \mathrm{~m}$ and very steep slopes.

Opposite page:

Figure 3.20: Geomorphologic map of the Tigaiga wall area. Contour lines in $50 \mathrm{~m}$. Legend see below.

geomorphologic features

barranco
marine cliff (active)
marine cliff (passive)
$\begin{aligned} & \text { headscarp of secondary } \\ & \text { landslide }\end{aligned}$

\section{geomorphologic areas}

valley wall:

significant mass wasting processes

minor mass wasting processes

other areas:

postslide volcanics

mainly preslide volcanics

deposit of secondary landslide

sandy/scree deposit 


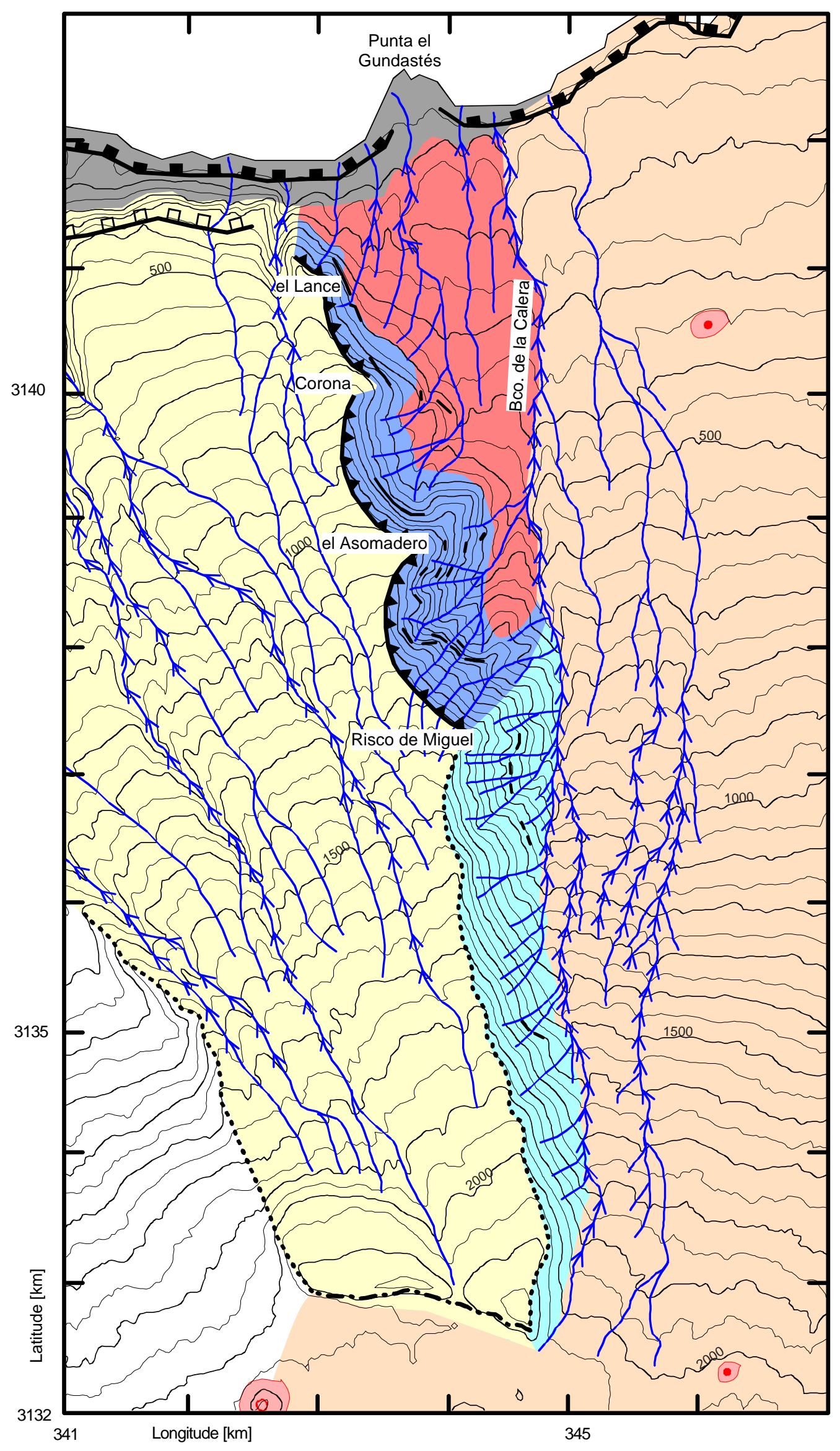


In the next step the eastern valley limit has been studied using the same methods as for the western valley limit. The area studied includes both the NW-SE oriented and about 5 kilometre long St. Ursula wall and the complex Los Organos area located to the northwest of the central part of the Dorsal Ridge.

Figure 3.21 shows a photograph of the eastern valley limit taken from the Tigaiga wall to the northeast. The lower sector of eastern valley limit (St. Ursula wall) is characterised by scarce vegetation, a rocky terrain and erosional canyons running down the slopes while the central sector is covered by dense pine forest and characterised by a quite smooth relief. In the highest sector adjacent to the Dorsal Ridge (Los Organos area), a rough morphology is visible with almost no vegetation and many open scars (located in the shadow). The changes of the vegetation due to the temperature inversion are similar to the ones observed in the Tigaiga wall. However, the vegetation cover is generally poorer in the St. Ursula wall since its location is not directly exposed to the winds coming generally from the north to northeast. The height of the St. Ursula wall increases constantly form the coast to the central part where it reaches a maximum height of about $500 \mathrm{~m}$. Then the escarpment continues with a similar height up to the Los Organos area characterised by its heterogeneous relief. The maximum altitude of the study area can be found at the top of the Dorsal Ridge with $2000 \mathrm{~m}$. In contrast to the Tigaiga wall, no linear areas of open scars indicating the inclination of some layers are visible. In the St. Ursula wall, the open scars are distributed in a speckled mode indicating no general trend and thus inferring more homogeneous geologic deposits composing the escarpment.

The slope angles in each cell of the DEM has been computed using GIS and the final results are shown in Figure 3.22. The section of the DEM studied includes the longitude interval between the UTM coordinates 353 and $357 \mathrm{~km}$ and the latitude interval between the coordinates 3135.5 and $3142.5 \mathrm{~km}$. The slope inclination map clearly determines the steep valley limits forming two different axes of steep zones: one with a NW-SE orientation indicating the St. Ursula wall and the other with a NE-SW orientation representing the escarpments of the Los Organos area. The orientation of very steep zones with slope angles higher than $50^{\circ}$ confirm the directions of these two axes. Therefore, the results of the slope angle map shows that the St. Ursula wall and the Los Organos area are situated perpendicularly. Additionally, a histogram indicating the overall distribution of slope inclination in the DEM is shown in the inset of Figure 3.22. In contrast to the histogram computed for the Tigaiga wall (Figure 3.19) the distribution of the eastern valley limit is more homogeneous. The mean slope angle of the study area is about $22^{\circ}$ and a maximum value of $73.5^{\circ}$ has been computed. Focussing only on the St. Ursula wall an average slope angle of $34.9^{\circ}$ has been calculated.

The GIS-modelling in addition to the interpretations of the aerial photographs and the field surveys have shown that the largest open scarp is located in the Los Organos area near the picnic place La Caldera (coordinates: 354200/3135150). This sub-vertical wall with a length of about $200 \mathrm{~m}$ and a height of almost $100 \mathrm{~m}$ faces northwest and may indicate the location of the head scarp of the eastern La Orotava landslide (Figure 3.23 and Figure 3.24). Other significant scarps with similar orientations but minor magnitude have been observed in the Los Organos area and confirm this hypothesis. A common hillslope evolution characterised by fluvial erosion and small mass wasting processes can be rejected to have formed such large vertical walls (Chorley, 1984; Gerrard, 1988). The location of this inferred head scarp can be seen in the upper part of the longitudinal profile crossing the eastern area of the valley (profile 2 in Figure 3.16a).

All these observations combined with the submarine morphology (Figure 3.11) infer that the eastern La Orotava landslide has failed in a sector limited by the St. Ursula wall as lateral escarpment and by the vertical walls at Los Organos as head scarp. The general direction of the large landslide movement can be assumed to be to the northwest coinciding with the bathymetric data, too. This fact is also supported by the study of the hydrological pattern and the orientations of deep, narrow canyons which will be presented later in this Chapter. 


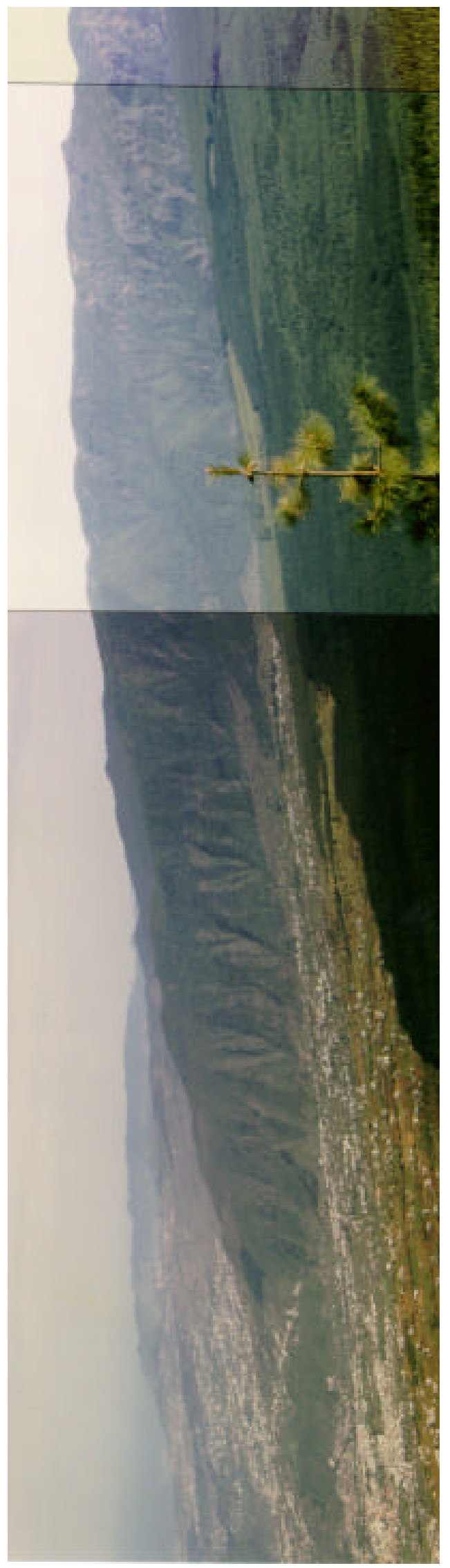

Figure 3.21: Photograph of the St. Ursula wall and Los Organos area taken from the Tigaiga wall in NE direction. 


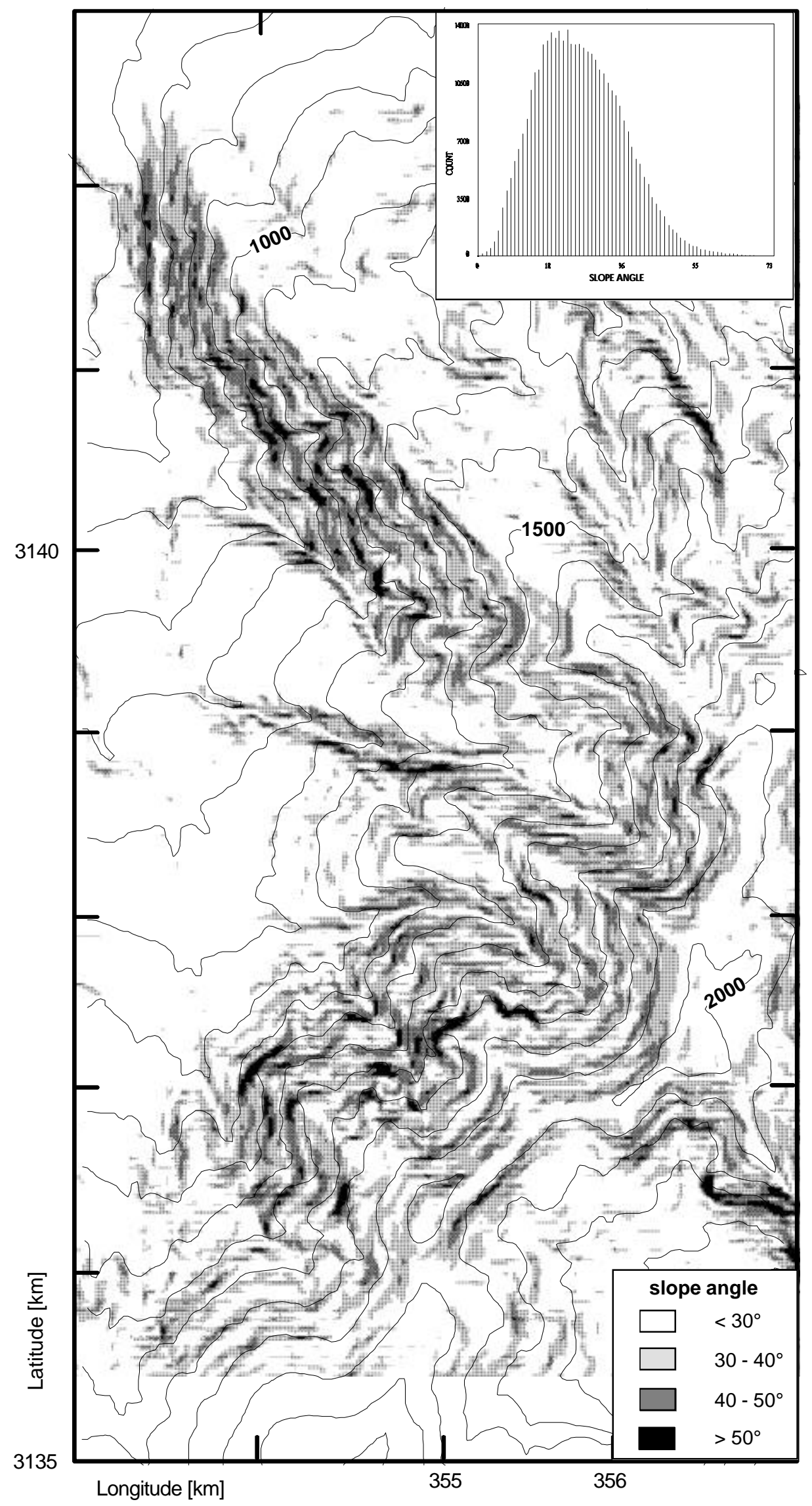

Figure 3.22: Slope inclination map of the St. Ursula wall and the Los Organos area. Contour lines in $100 \mathrm{~m}$. Inset shows overall distribution of slope angles in the DEM (number of cell vs. slope angle). 


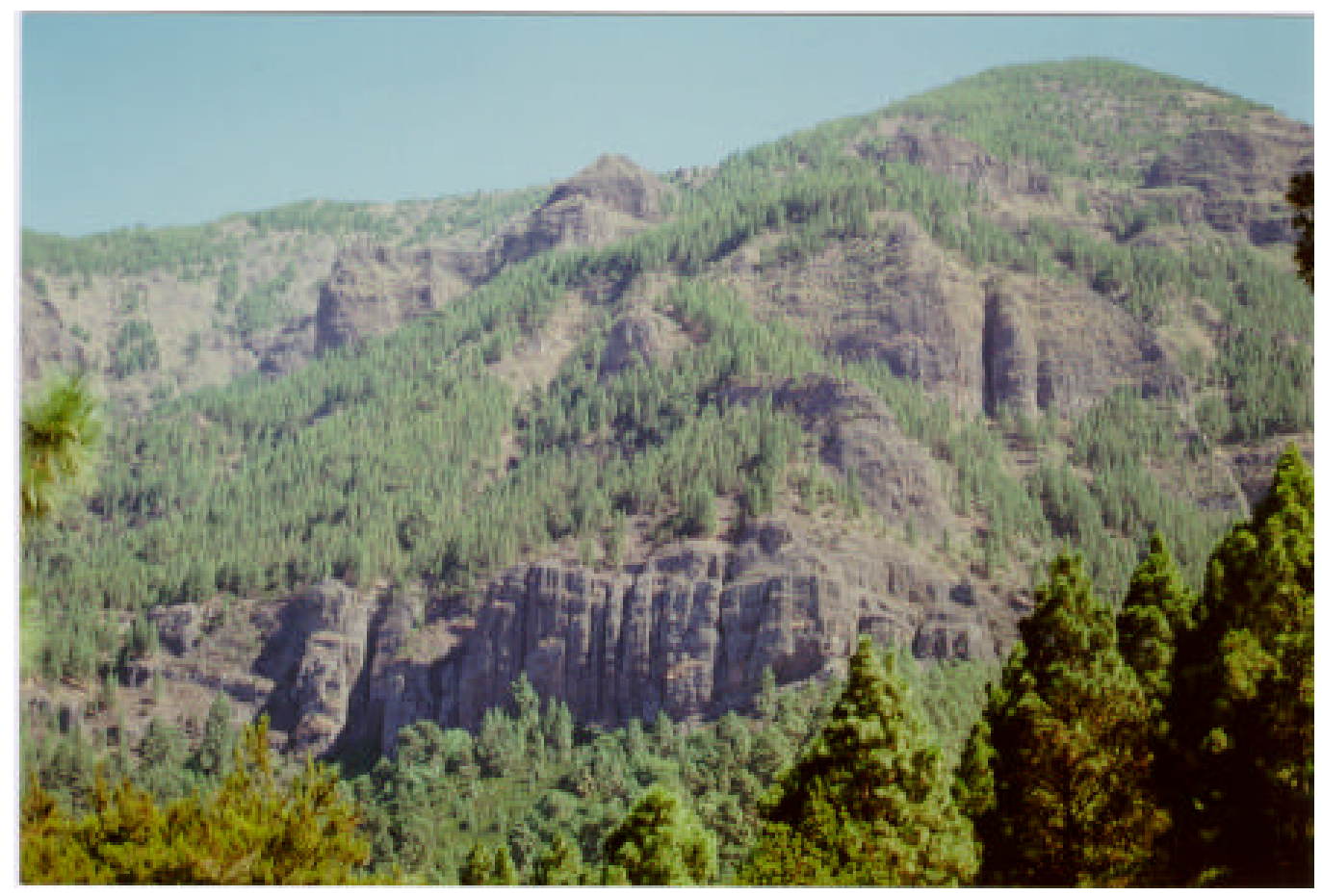

Figure 3.23: Photograph of sub-vertical wall in the Los Organos area assumed to be the head scarp of the eastern La Orotava landslide (overview).

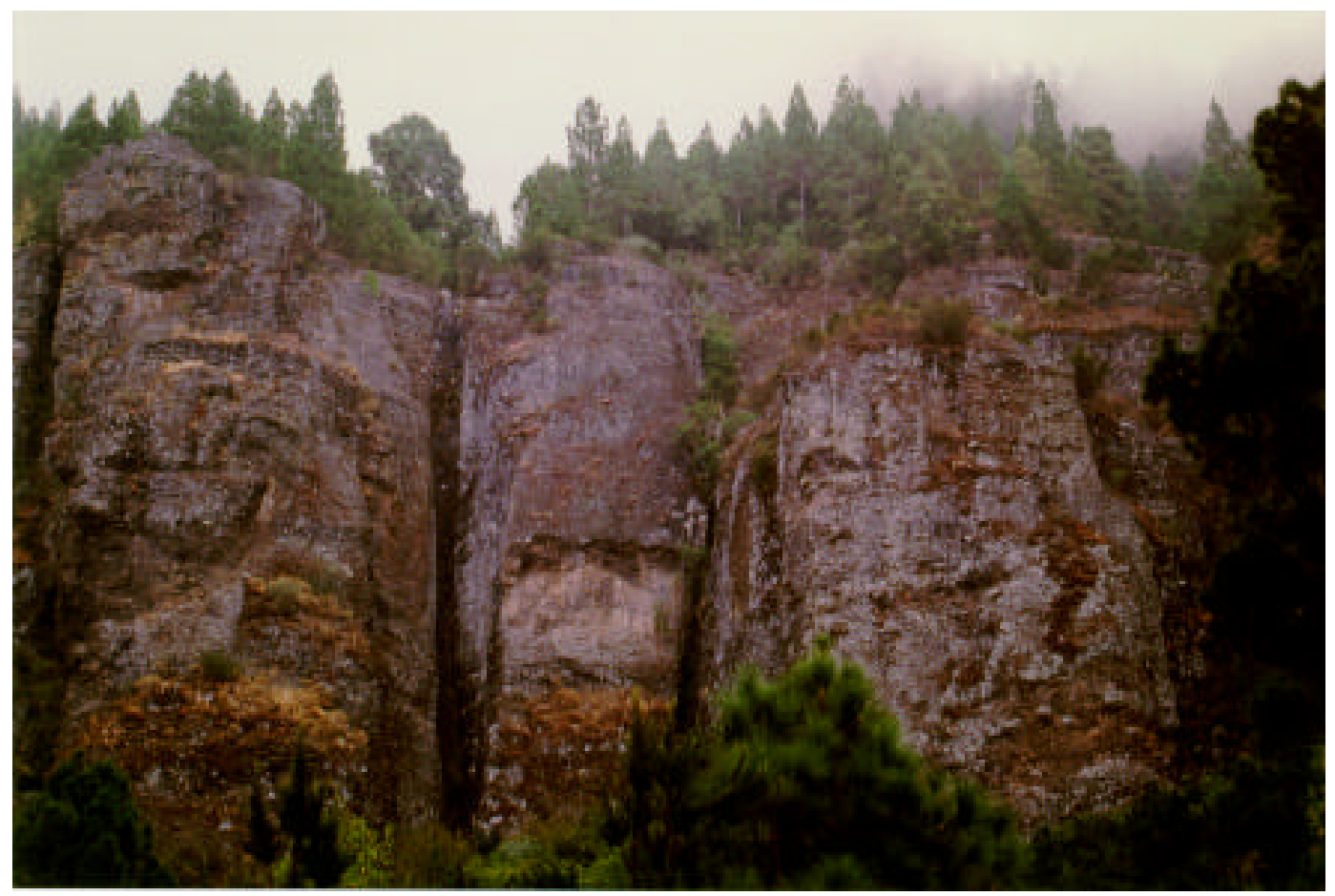

Figure 3.24: Photograph of sub-vertical wall in the Los Organos area assumed to be the head scarp of the eastern La Orotava landslide (zoom). 
The results obtained from the GIS-modelling have been combined with the ones achieved from the interpretation of aerial photographs and field observations in order to create a geomorphologic map of the eastern valley limit (Figure 3.25).

The study area is divided into four different units: two units characterising the valley walls (St. Ursula wall and Los Organos area) and two units representing the resting zones of the study area. As done in the Tigaiga wall, the two units describing the valley walls have been classified refering to the magnitude of mass wasting processes that have affected the slopes. Because no secondary landslides (major processes) have been detected in this area, the two units have been defined as zones affected by intermediate and minor mass wasting processes. The zones classified by minor processes have only been modified by slight fluvial erosion and thus might correspond quite well to the morphology represented by the original landslide amphitheatre. The regions classified by this unit are the main part of the St. Ursula wall and the front sides of the bulges located in the Los Organos area. These regions are characterised by many large open scars with NW-SE direction in the St. Ursula wall and NE-SW direction in the Los Organos area. The zones classified by intermediate mass wasting processes mainly include the three large catchments of the Los Organos area that have been formed by significant erosional processes. There, the fluvial erosion strongly altered the original landslide headwall and large open scars hardly exist. The two units characterising the resting zones of the study area include: 1) the recent postslide volcanics affected by fluvial erosion principally covering the valley floor and the zones east to the St. Ursula wall; and, 2) scree/sandy deposits that have been detected at the foot of steep slopes.

In contrast to the Tigaiga wall many volcanic cones are located adjacent to or within the St. Ursula wall and the Los Organos area. Pyroclastics and lava flows derived from these eruptive centres have changed the original landslide amphitheatre simultaneously to the mass wasting processes described above. Especially the two large cones situated in the west and northwest of Roque Gordo (Figure 3.25) have changed the morphology in this area and actually cover parts of the valley floor. Additionally, lava flows derived from the eruptive vents located at the top of the St. Ursula wall have mostly covered the lower part of the wall flowing over the lateral escarpment into the La Orotava valley. One of these flows has formed a big bulge at el Pinito piling up a big amount of lava layers.

The drainage network in the study area shows similar gully erosion at the foot of the St. Ursula wall as observed at the Tigaiga wall. The lava accumulation of the two mentioned cones near Roque Gordo has separated the main gully in the upper part into three different patterns that join in the Barranco de la Arena in the coastal zone. The drainage network of the large catchments in the Los Organos area is characterised by a clear dendritic pattern indicating the significant fluvial erosion.

The coastal cliff can be divided into an active sector along the whole coast with abrasion heights up to maximal $20 \mathrm{~m}$ and a passive sector outside the valley with heights up to $250 \mathrm{~m}$.

Opposite page:

Figure 3.25: Geomorphologic map of the St. Ursula wall and the Los Organos area. Contour lines in 50 m. Legend see below.

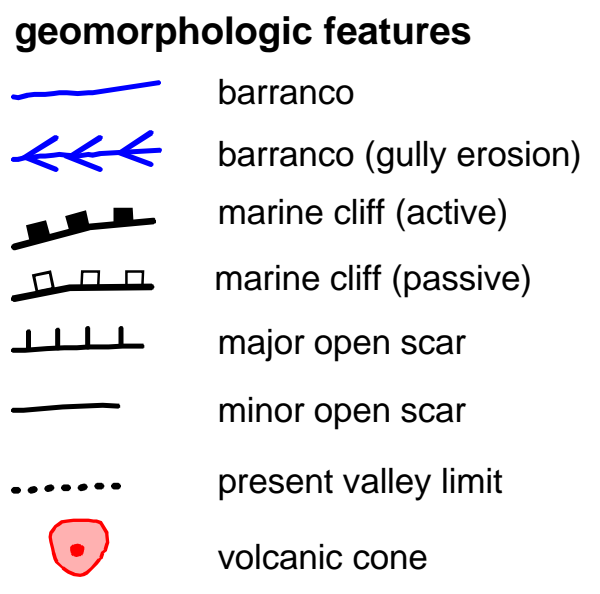

\section{geomorphologic areas}

valley walls:

intermediate mass wasting processes

minor mass wasting processes

\section{other areas:}

postslide volcanics

sandy/scree deposit 


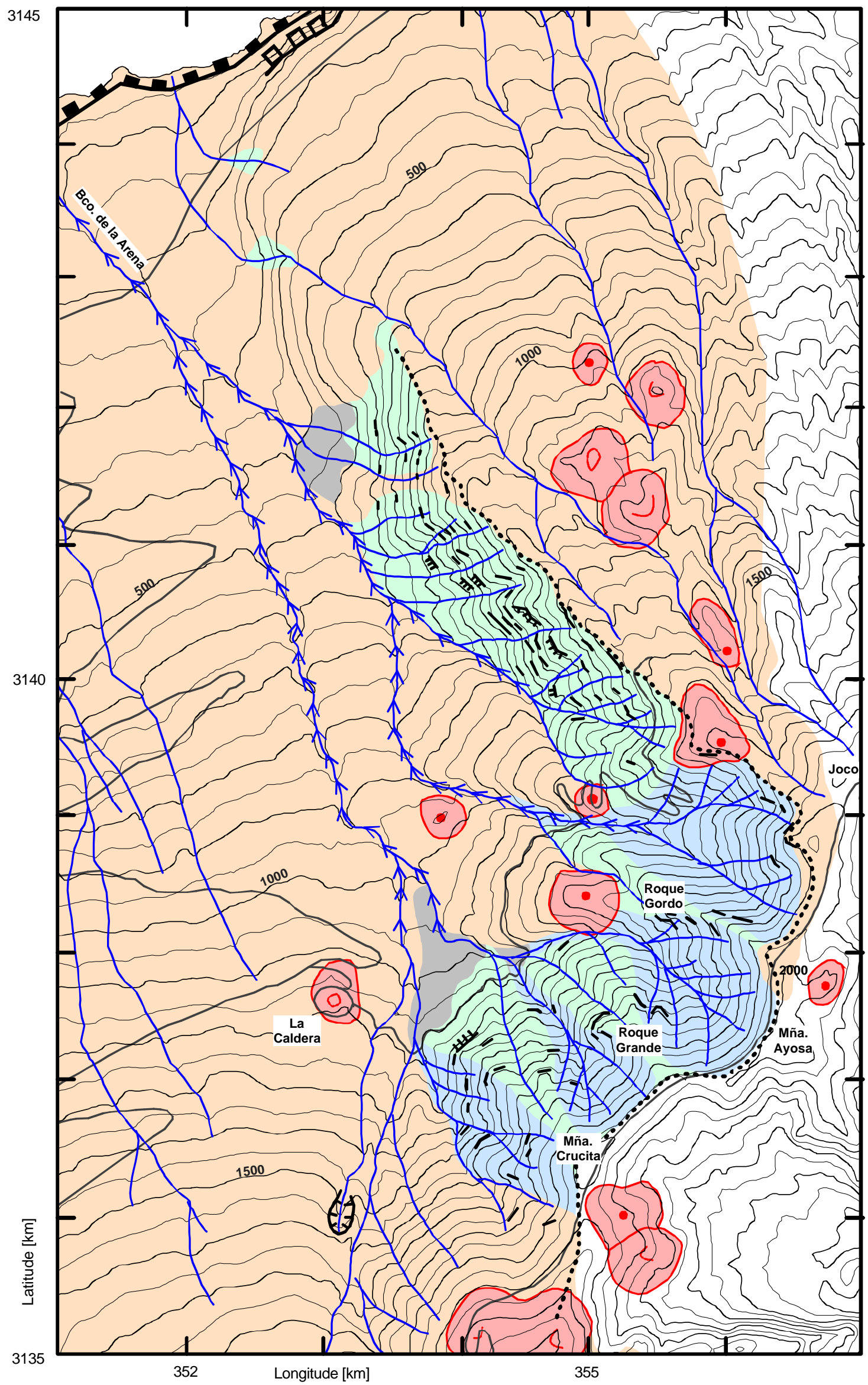


In order to study the morphologic particularities of the Los Organos area, two types of topographic profiles have been created and compared. On the one hand, longitudinal profiles have been drawn along the ridges that have been defined in Figure 3.25 as areas with minor mass wasting processes including the ridge of Montaña Crucita, the ridge of Roque Grande and the ridge of Roque Gordo. On the other hand, longitudinal profiles have been drawn inside the three fluvial catchments that have been defined in Figure 3.25 as areas with intermediate mass wasting processes. Figure 3.26 shows the two types of profiles and indicates the morphologic differences between ridges, fluvial catchments and the top of the St. Ursula wall. The profile of the St. Ursula wall infers the morphology previous to the large La Orotava landslides, while the profiles of the ridges represent the morphology affected by the large slope failure and minor posterior erosion. A clear slope break is visible indicating the assumed location of the head scarp of the eastern La Orotava landslide. This sector of steep slopes has an average inclination of almost $40^{\circ}$ and includes at its bottom the sub-vertical walls of the Los Organos area previously mentioned (Figure 3.23 and Figure 3.24). The profiles of the catchments indicate the same head scarp area, but strongly affected by fluvial erosion. The slopes in these zones have a quite linear profile with an average slope angle of 30 degrees.

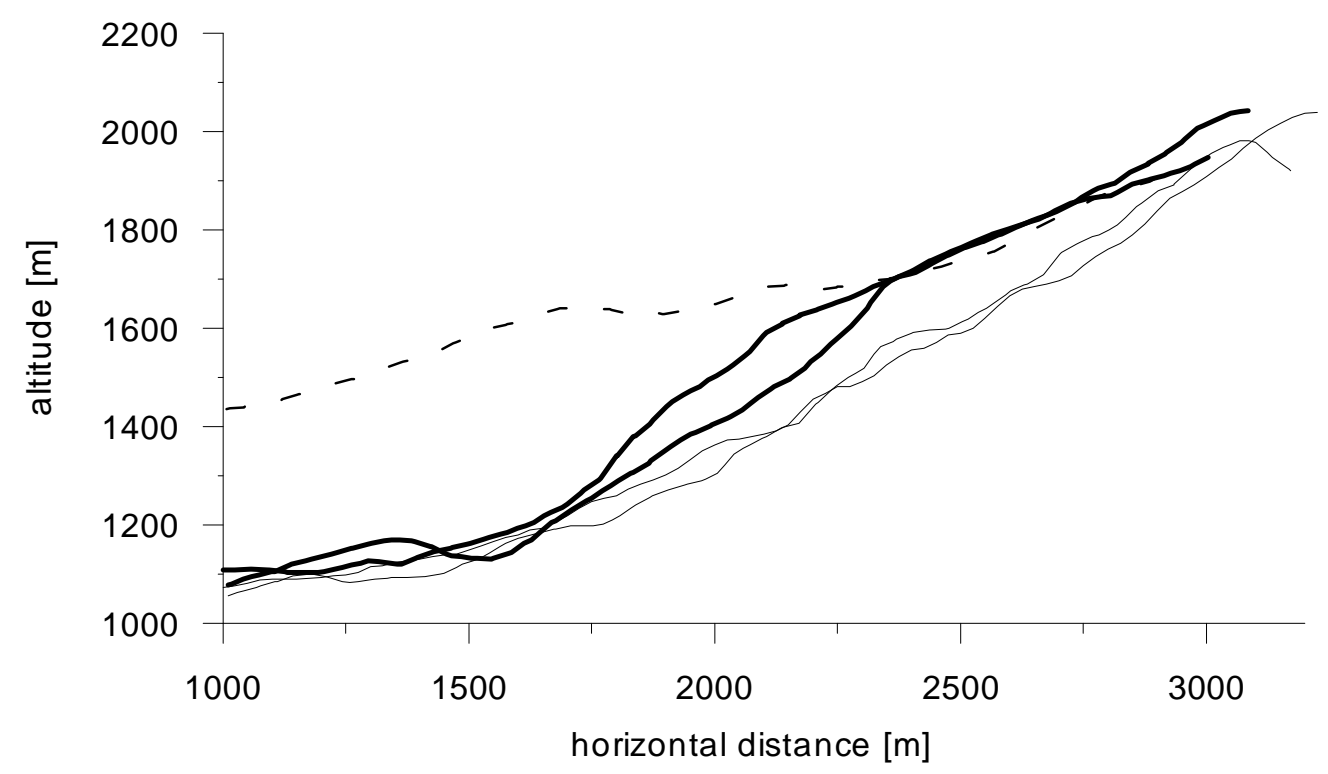

Figure 3.26: Topographic profiles of the Los Organos area. Thick lines indicate the morphology of the ridges and thin lines the one of the catchments. The dashed line shows the top of St. Ursula wall.

Finally, the geomorphology of the entire La Orotava valley will be described including the main results of the previous sections and descriptions of additional morphologic features relevant for the study of the large landslide events. A summary of all the morphologic features is given in a general geomorphologic map of the La Orotava valley area defining the inferred limits of the two large landslides (Figure 3.27).

As mentioned in previous sections, the coastal cliff is a good morphologic feature to define the extension of the large landslide events. In the case of the La Orotava slides, high and steep coastal cliffs have been detected outside the valley at the Tigaiga massif and at the St. Ursula side (Figure 3.27). These cliffs contain an old, passive scarp located at an altitude of 200 to $400 \mathrm{~m}$ and a young, active scarp with a height of tens of metres. Inside the La Orotava valley, only the small active cliff is visible since the high cliff has been removed by the large landslide events. 


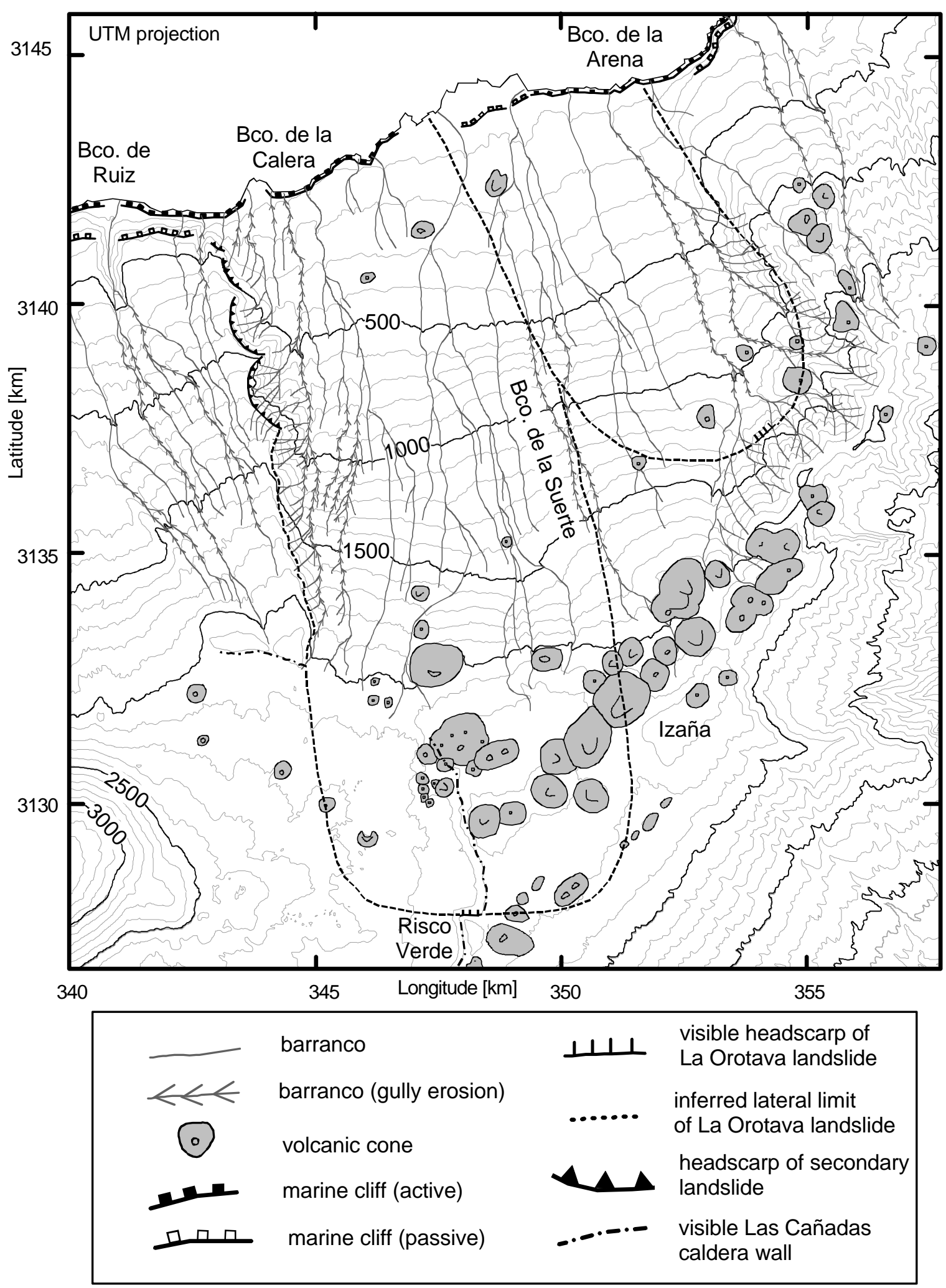

Figure 3.27: Simplified geomorphologic map of the La Orotava valley. 
The morphology of the head wall of the La Orotava valley represents the breakaway zone of the large slope failures and comprises the Los Organos area in the east, a central part characterised by many recent volcanic cones and the western area including the northeast sector of the Las Cañadas caldera. There are two morphologic features defining the locations of the landslide head scarps. The large sub-vertical wall at Los Organos is assumed to indicate the head scarp of the eastern landslide and the northwards facing wall at Risco Verde may denote the head scarp of the western slide (Figure 3.27). The scarp at Risco Verde is characterised by a geologic unconformity in the caldera wall (Martí et al., 1994) and has a perpendicular position to the Tigaiga wall. A similar perpendicular situation can be observed for the eastern landslide between the directions of the Los Organos scarp and the St. Ursula wall. In addition, the extension of the western head scarp is limited to the east by a steep westwards facing slope west of Izaña (Figure 3.15 and Figure 3.7). Moreover, an arcuate smooth slope break connecting the scarps at Risco Verde and Izaña can be assumed in Figure 3.7 and in the aerial photographs.

The drainage network inside the La Orotava valley can be divided into three sectors: two lateral sectors including one in the west adjacent to the Tigaiga wall and another in the east adjacent to the St. Ursula wall, and a central sector occupying a large part of the valley floor from Izaña at $2300 \mathrm{~m}$ a.s.l. down to Puerto de la Cruz (Figure 3.27). All of the sectors are characterised by a generally parallel hydrologic pattern with NNW-SSE orientation in the eastern sector and N-S orientation in the western sector. Each sector comprises one or two principal barrancos with gully erosion. The most important gullies are the Barranco de la Calera at foot of Tigaiga massif, the Barranco de la Arena at the St. Ursula wall and the Barranco de la Suerte in the central part. Similar canyons but with greater depths have been observed outside the valley limits on the Tigaiga massif and in the west of the St. Ursula wall. Such deep, narrow canyons have been formed by fluvial erosion and are common surface features on Tenerife and on others oceanic islands such as Hawaii (Nunn, 1995). They can reach depths of more than $300 \mathrm{~m}$ and especially occur in the areas not affected by large landslide events. The Barranco de Ruiz incised into the Tigaiga massif (Figure 3.27) is an excellent example of this morphologic feature. Since the beginning of the Upper Group, fluvial erosion has cut a very deep canyon into the volcanic deposits mainly composed of lava flows and phonolitic pyroclastic flow deposits (Figure 3.28). Such deep, narrow canyons not only reduce the lateral strength of the slope by their existence, but also increase shear stress at their base, reducing therefore safety conditions (Hürlimann et al., 1999b). Thus, the lateral limits of large volcanic landslides may have been developped along these canyons.

The morphologic onshore and offshore observations of the north flank of Tenerife and the assumption of deep, preslide canyons located at the Tigaiga wall, the St. Ursula wall and in the central part of the valley encourage the hypothesis of two major landslide events limited by deep, narrow canyons. A western slide with the head scarp at Risco Verde and an eastern slide with its breakaway zone in the Los Organos area (Figure 3.27). 


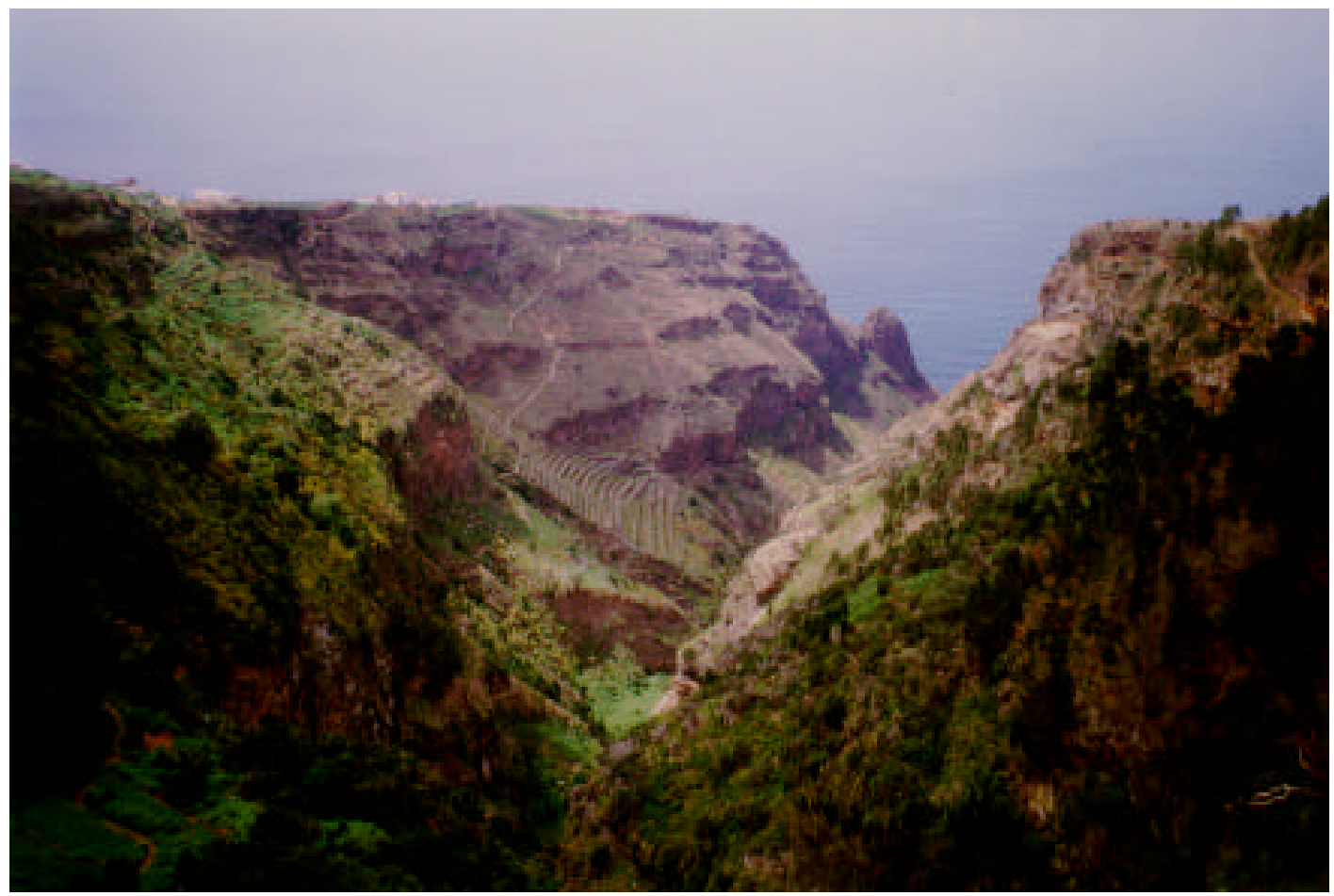

Figure 3.28: Photo of the Barranco de Ruiz, a deep, narrow canyon eroded into the Tigaiga massif. Photo taken from Icod el Alto to the north. 


\subsection{Geologic analysis}

The geological analysis has focussed on the La Orotava valley area, since the geologic evolution of Tenerife has already been described in Section 3.3. Especially the eastern and western valley limits composed of preslide deposits have been studied, but also the valley floor, the Dorsal Ridge and parts of the Las Cañadas caldera have been included into the geologic study.

The geological analysis of landslides in volcanic areas differs from landslides in other areas in several aspects. Especially the fact, that a significant postslide deposition can occur, must be taken into account. In the case of the La Orotava valley, volcanic materials associated with the postslide volcanic activity have filled a great part of the landslide amphitheatre.

The available data of subaerial and underground geology have been carefully analysed containing geological maps at a scale of 1:25000 (IGME, 1988a), geochronological data (Abdel-Monem et al., 1972; Carracedo, 1975; Féraud et al., 1985; Ancochea et al., 1990; Ibarrola et al., 1993; Martí et al., 1994), information obtained from the water galleries (Servicio de Planificación Hidráulica, 1991; Navarro and Braojos, 1991; Servicio de Planificación Hidráulica, 1994), interpretation of aerial photographs and field observations.

In the first part, the geochronological data will be presented. Then, the general geology of the La Orotava valley area will be explained including the zones of the Tigaiga massif and the eastern valley limit. In the next part, the information of both the underground geology and the hydrogeology will be explained. Finally, some general comments on the geomechanical behaviour of the volcanic materials found in the study area will be given and the geological characteristics of a weak layer that may have acted as potential slip surface will be described.

In addition, geochemical and mineralogical information of volcanic materials sampled in the La Orotava valley area has been obtained from energy dispersive X-ray fluorescence and X-ray diffraction technique. The results of a total of twelve samples achieved from these analyses will be presented in the next Chapter (Laboratory analysis).

The data from 6 different works with a total amount of 28 samples have been selected out of the big amount of geochronological studies carried out on Tenerife (Abdel-Monem et al., 1972; Carracedo, 1975; Féraud et al., 1985; Ancochea et al., 1990; Ibarrola et al., 1993; Martí et al., 1994). The data chosen refer to the La Orotava valley area and have strongly improved the understanding of the geologic evolution of the valley. All the age data selected are listed in Table 3.2 including information on the corresponding geologic sequence, the rock type, the location name and the reference cited. The coordinates of the 28 samples have been imported into the GIS and theirs exact positions have been calculated. Figure 3.29 shows the positions of the age data located inside or adjacent to the La Orotava valley. Most of the samples are situated at the Tigaiga massif. This large remnant between the Icod and the La Orotava valley is mainly composed of materials with ages of the Upper Group sequence Guajara (age data ranging from 0.93 to $0.56 \mathrm{Ma}$ ). Some older materials of Ucanca or Lower Group ages have been found at the base of the massif (age data ranging from 2.28 to $1.03 \mathrm{Ma}$ ), and several isolated areas of phonolitic pyroclastic flow deposits with Diego Hernández ages have been sampled at its top (age data of $0.37,0.27$ and $0.17 \mathrm{Ma})$. Only one data $(0.78 \mathrm{Ma})$ exits at the eastern limit of the valley determining the age of a lava flow from a volcanic cone located to the east of the St. Ursula wall, overflowing the lower part of the wall and depositing its material on the valley floor (Figure 3.24). Four age data have been found along the Dorsal Ridge: one refering to a dike ( $0.43 \mathrm{Ma})$ and three concerning lava flows $(0.56,0.81$ and $1.54 \mathrm{Ma})$. Inside the valley limits exist three age data: one of a young basaltic flow in the upper part of the valley (0.05), another of a phonolitic clast in a breccia deposit at the coast $(0.73 \mathrm{Ma})$ and a data without exact location obtained from a phonolitic flow interbedded by two different breccia deposits that have been found in a water gallery of the La Orotava valley (2.3 $\mathrm{Ma})$. 
Table 3.2: Age data with description of rock type and location

\begin{tabular}{|c|c|c|c|c|}
\hline sequence & rock type & location & age $[\mathrm{Ma}]$ & reference \\
\hline Young Dorsal & basaltic flow & La Orotava & 0.05 & 1 \\
\hline Diego Hernández & non welded pyroclastics & La Fortaleza & 0.17 & 4 \\
\hline Diego Hernández & basaltic flow & Tigaiga massif*, km 14.1 & 0.27 & 1 \\
\hline Diego Hernández & welded phonolitic flow & La Fortaleza & 0.37 & 1 \\
\hline Young Dorsal & basaltic dike & Dorsal Ridge & 0.43 & 5 \\
\hline Young Dorsal & trachybasaltic flow & Fuente de Joco & 0.56 & 1 \\
\hline Guajara & phonolitic flow & Fuentes del Bardo & 0.56 & 2 \\
\hline Guajara & trachybasaltic flow & Barranco de Ruiz, 555m & 0.56 & 2 \\
\hline Guajara & phonolitic flow & Tigaiga massif*, km 16 & 0.67 & 3 \\
\hline Guajara & phonolitic flow & $\begin{array}{l}\text { Tigaiga wall, Fuente de } \\
\text { Mesa }\end{array}$ & 0.69 & 2 \\
\hline Guajara & phonolitic block in breccia & Playa de Los Roques & 0.73 & 2 \\
\hline Guajara & phonolitic flow & San Juan de la Rambla & 0.77 & 2 \\
\hline Old Dorsal & basaltic flow & Mirador de Humboldt & 0.78 & 1 \\
\hline Guajara & trachytic flow & $\begin{array}{l}\text { Tigaiga massif*, } \\
\mathrm{km} 12.85\end{array}$ & 0.80 & 1 \\
\hline Guajara & trachytic flow & Tigaiga wall, $1410 \mathrm{~m}$ & 0.80 & 2 \\
\hline Old Dorsal & basaltic flow & Dorsal road, km 27.8 & 0.81 & 1 \\
\hline Guajara & trachyphonoliltic flow & Tigaiga massif*, km 16.3 & 0.83 & 2 \\
\hline Guajara & basaltic flow & $\begin{array}{l}\text { Road C-820, km 56, } \\
\text { above Playa de Socorro }\end{array}$ & 0.84 & 3 \\
\hline Guajara & phonolitic flow & Tigaiga massif*, $\mathrm{km} 12.3$ & 0.93 & 1 \\
\hline Ucanca & trachybasaltic flow & Tigaiga massif*, km 13 & 1.03 & 3 \\
\hline Ucanca & basaltic flow & el Terreno & 1.10 & 1 \\
\hline Ucanca & ignimbrite & San Juan de la Rambla & 1.24 & 1 \\
\hline Ucanca & phonolitic flow & Tigaiga massif*, km 12 & 1.35 & 3 \\
\hline Old Dorsal & basaltic flow & Montaña Izana & 1.54 & 3 \\
\hline Lower Group & submarine basaltic flow & San Juan de la Rambla & 2.23 & 2 \\
\hline Lower Group & trachybasaltic flow & Barranco de Ruiz & 2.26 & 2 \\
\hline Lower Group & $\begin{array}{l}\text { trachybasaltic flow, } \\
\text { just above breccia deposit }\end{array}$ & Gallery 'Los Ajos' & 2.28 & 2 \\
\hline Lower Group & phonolitic flow & $\begin{array}{l}\text { water gallery in } \mathrm{La} \\
\text { Orotava valley }\end{array}$ & 2.3 & 6 \\
\hline
\end{tabular}

* road form Los Realejos to Icod de los Vinos

1: Ancochea et al. (1990)

2: Ibarrola et al. (1993)

3: Abdel-Monem et al. (1972)

4: Martí et al. (1994)

5: Féraud et al. (1985)

6: Carracedo (1975) 
Several interesting facts refering to the chronological evolution of the La Orotava valley have been found in Table 3.2 and Figure 3.29. An age estimate of the La Orotava landslides can be established comparing the data of the valley limits with the data inside the valley floor. On the basis of the youngest lava flows cut by the valley and the oldest flows occupying the valley, the age of the valley has been estimated as between 0.78 and $0.56 \mathrm{Ma}$ (Ancochea et al., 1990). In addition, the phonolitic clast found within the breccia at the coastline (Playa de los Roques) has an age of $0.73 \mathrm{Ma}$ (Ibarrola et al., 1993), which reduces the maximum age of the valley. Martí et al. (1997) proposed that the age of the La Orotava valley coincides with the vertical collapse which has terminated the Guajara cycle at about 0.56 Ma. They verified their hypothesis, because the valley does not contain any pyroclastic products of the Guajara formation (0.85-0.56 Ma), which are widespread across the island. So, the age of the La Orotava slides can be assumed to have occurred between 0.73 and $0.56 \mathrm{Ma}$ with the termination of the Guajara cycle at $0.56 \mathrm{Ma}$ as the most possible age.

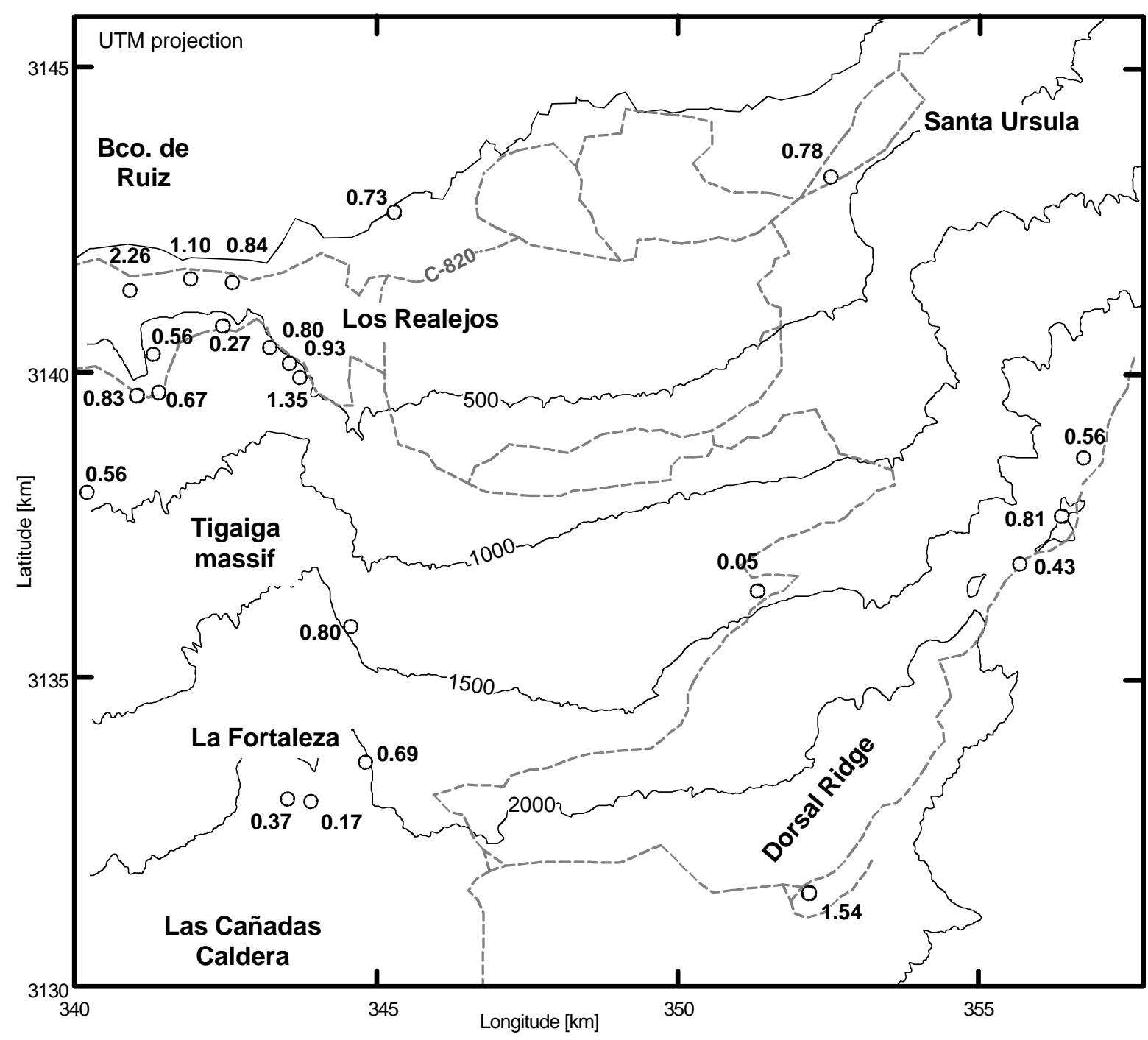

Figure 3.29: Geochronological data in the La Orotava valley area. Ages are given in Ma. Dashed lines indicate roads. Contour lines are in $500 \mathrm{~m}$. 
The stratigraphic column refering to the geologic evolution of Tenerife Island (Figure 3.6) has been specified for the La Orotava valley area (Figure 3.30) using the existing geochronological and geological data.

The products deriving from the Las Cañadas edifice and from the Dorsal Ridge have been divided each of them into two main sequences: the preslide deposits and the postslide deposits. The age of the La Orotava landslides have been assumed to be at the end of the Guajara cycle at about $0.56 \mathrm{Ma}$. Therefore, the simplified stratigraphy of the La Orotava valley area includes four different deposits: 1) the preslide Las Cañadas edifice deposits containing Lower Group materials and the two Upper Group cycles Ucanca and Guajara, 2) the postslide Las Cañadas edifice deposits comprising the Diego Hernández cycle and the Teide-Pico Viejo formation, 3) the preslide Dorsal Ridge materials called Old Dorsal Ridge; and, 4) the postslide Dorsal Ridge materials called young Dorsal Ridge. Additionally, two different breccia deposits have been incorporated into the stratigraphic columns: an old preslide breccia and a young postslide breccia.

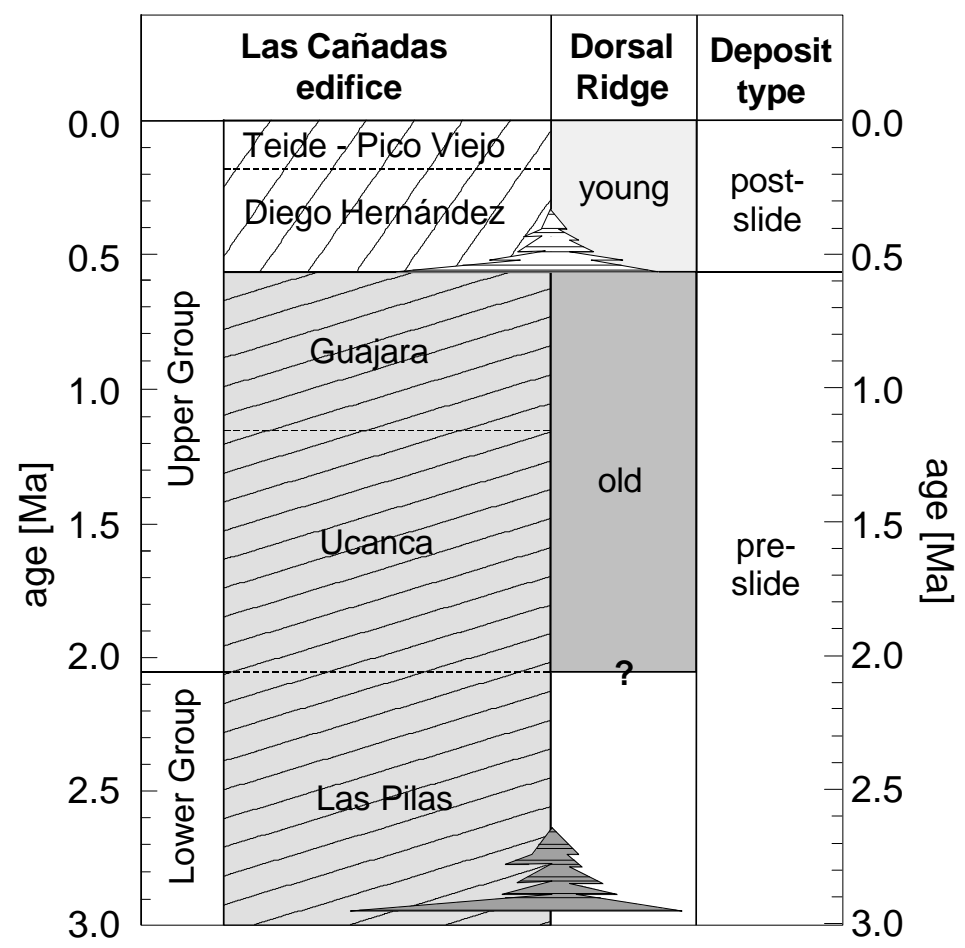

Figure 3.30: Stratigraphic columns of the La Orotava valley area.

In the following, the importance of the two breccias as significant layers in the evolution of the La Orotava valley will be explained. The exact origin of these breccias has not yet been resolved and there exist many geologic descriptions about this particular deposits sometimes called 'Mortalon' (Coello, 1973; IGME, 1988b; Coello and Bravo, 1989; Navarro and Coello, 1989; Carracedo, 1994; Palacios, 1994). Generally, these authors have described one thick widespread breccia deposit without distinguishing it into a younger and an older layer as proposed here. Coello (1973) calculated a maximum thickness of the entire breccia sequence of more than $450 \mathrm{~m}$ studying the water galleries cut into the La Orotava valley. He described the entire deposit as a volcanic breccia. Furthermore, the breccia deposit has been interpreted as material related to a major flank failure (Bravo, 1962; Navarro and Coello, 1989) or as an altered, plastically deformable, clay-rich explosive breccia (Carracedo, 1994). In this study, both the old and the young breccia have been assumed to be deposits composed of different poligenic layers formed mainly by mass wasting processes. A similar origin has recently been proposed for a breccia layer detected in the boreholes drilled into the filling materials of the large landslide escarpment on La Palma (Carracedo et al., 1999). There, the breccia has been defined as a collapse-filling sedimentary deposits containing alluvial and scree deposits. 
The old breccia is reported to underlie a wide region of the north flank of Tenerife extending from the eastern part of the Dorsal ridge to the Icod valley in the west (Coello, 1973). It contains coarse subangular to sub-rounded clasts of predominantly mafic lithologies supported by a clayey matrix (Coello and Bravo, 1989). A trachybasaltic flow overlying the breccia at the base of the Tigaiga massif has yielded an age of $2.28 \mathrm{Ma}$ (Ibarrola et al., 1993) and an age data of a phonolitic flow located above the breccia in a water gallery of the La Orotava valley has given $2.3 \mathrm{Ma}$, constraining the minimum age of the breccia at about $2.3 \mathrm{Ma}$. The reported distribution of the breccia is consistent with a relationship to the old post-shield landslide whose deposits have been identified by the bathymetric data of the north flank of Tenerife (Section 3.4.2). The old breccia is thus interpreted as erosional products occupying the amphitheatre of the post-shield landslide that may have occurred at about 3.0 Ma.

The young breccia crops out in the coastal cliffs of the La Orotava valley and has also been encountered in water galleries intersecting the valley floor (Carracedo, 1975; Ibarrola et al., 1993). The coastal outcrops are located in the western part of the valley between Punta el Gundastés and Punta Piedra Gorda. There, these breccia-like materials mainly include materials of mass wasting processes derived from the La Orotava slide amphitheatre. The field observations have indicated that these breccia layers contain alluvial products of the valley fill, valley head and lateral scarps, small-scale secondary landslide deposits and autoclastic, hyaloclastitic and peperitic lava facies. In addition, some phonolitic pyroclastic deposits with Diego Hernández age are interbedded between the young breccia constraining its age between 0.37 and $0.179 \mathrm{Ma}$ (see Figure 3.30). A supplementary age data of the young breccia offers a phonolitic clast inside the deposit with $0.73 \mathrm{Ma}$ (Ibarrola et al., 1993) verifying the maximum age of the breccia. The mass wasting processes originating the young breccia started just after the large landslide events and have continued with great importance till an erosional equilibrium has been established. This fact explains why the breccia deposits are always the first materials filling the landslide amphitheatres and why they reduce their importance stratigraphically upwards. A similar stratigraphic sequence has been detected in other landslide valleys on Tenerife (Servicio de Planificación Hidráulica, 1991) and on La Palma (Carracedo et al., 1999).

The analysis of the geochronological data in addition to the study of the geological maps (IGME, 1988a), the interpretation of aerial photographs and field surveys have provided a simplified geological map of the study area (Figure 3.31). The resulting map reveals that the postslide volcanic activity has covered the main part of the original landslide amphitheatre and the preslide deposits only crop out along the lateral valley limits and in the eastern part of the Dorsal Ridge. Almost the entire valley floor is covered by postslide lavas flowing down from eruptive vents located along the Dorsal Ridge (mafic) or inside the Las Cañadas caldera (intermediate to phonolitic). In the northwestern part of the valley several isolated areas of phonolitic pyroclastic flow deposits associated with the Diego Hernández cycle have been observed. Additionally, three historic intermediate lava flows derived from isolated eruptive cones are located in the lower part of the valley. At Risco Verde exits a significant unconformity in the materials composing the caldera wall. Only postslide deposits of Diego Hernández age crop out north of the Risco Verde, while mainly preslide deposits of Guajara and Ucanca ages crop out to the south (Martí et al., 1994).

In the following, the two lateral limits composed of preslide materials will be described. First, the results of the geological study at the Tigaiga massif will be presented, and second the ones at the St. Ursula wall and Los Organos area will be described.

The geology of the Tigaiga wall is mainly composed of thick sequences of phonolitic to intermediate lava flows with Guajara ages. These lava flows are interbedded with phonolitic pyroclastic deposits and residual soil layers. The soil layers are generally located at the top of the phonolitic pyroclastic deposits and characterised by their red colour. The dips and dip directions of the deposits have been measured in the outcrops of the Tigaiga wall and indicate a general dip direction to NNE (Figure 3.32). This coincides with the assumed centre of the Guajara edifice located in SSW direction inside the Las Cañadas caldera (Bryan et al., 1998) and the proposed preslide prolongation of the Tigaiga massif to the east illustrated in Figure 3.13. Below the large Guajara sequences, the basement of the Tigaiga massif is formed by phonolitic pyroclastic deposits and lava flows of Ucanca ages, mafic to intermediate lava flows of Lower Group and as lowest detected material the old breccia. At the top of the Tigaiga massif exist some isolated phonolitic pyroclastic deposits associated with the Diego Hernández caldera collapse 
episode. Finally, it can be assumed, that the western La Orotava slide has failed in the same materials as those composing the present Tigaiga massif.

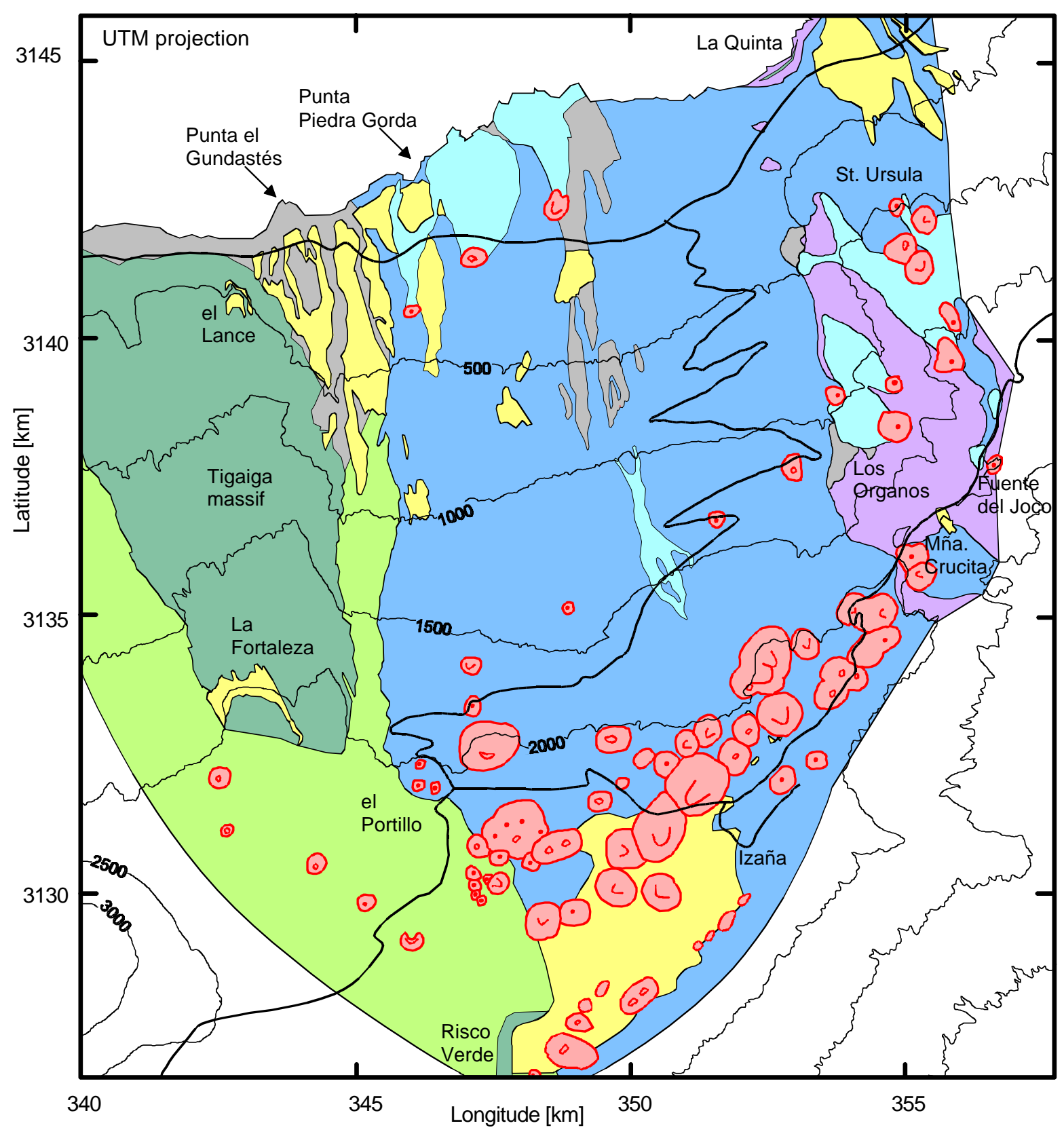

postslide Dorsal Ridge (intermediate/phonolitic)

\section{postslide Dorsal Ridge} (basaltic)

preslide Dorsal Ridge postslide $\mathrm{DH}$ phonolitic pyroclastic deposit

preslide Las Cañadas edifice deposit

postslide Las Cañadas

edifice deposit

Figure 3.31: Simplified geological map of the La Orotava valley area. Thick line shows roads. Contour lines are in $500 \mathrm{~m}$. 


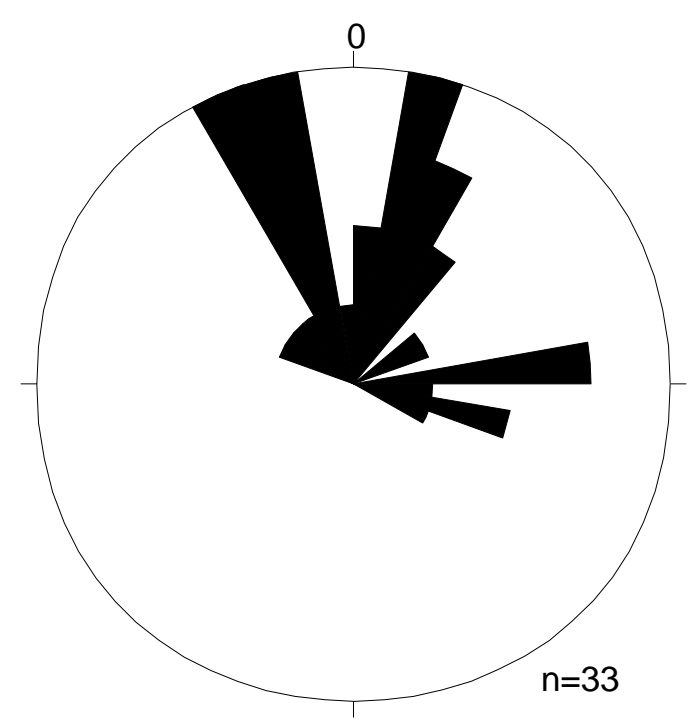

Figure 3.32: Rose diagram of dip directions of the Guajara materials composing the Tigaiga massif. Dip classes are in $10^{\circ}$.

In contrast to the geology of the Tigaiga massif, the geology of the St. Ursula wall and the Los Organos area is very homogeneous. The main sequences are composed of porphyritic basaltic breccia deposits. The exposed materials contain textural features which suggest a strong volcanic activity characterised by high eruption rates and the fast growth of a new volcanic edifice. Beds of thin lava flows, lava breccias and sedimentary deposits originated by both dry and wet small-scale mass movements (hyperconcentrated flows, lahars etc.) have been found in the Los Organos area. This infers the proximity of the eruptive centre, while the St. Ursula wall is mainly composed of thicker lava flows interbedded with less volcanoclastic materials. The measurements of dips and dip directions of the materials indicate two interesting facts. First, the dips measured in the Los Organos area range from 14 to $40^{\circ}$ indicating a steep sided volcanic edifice. Second, the situation of the eruptive centre inferred by the dip directions (Figure 3.33) may have been situated near Montaña Crucita (see Figure 3.24) slightly inside the Güimar valley. This location coincides with the results obtained from the study of the dike distributions along the Dorsal Ridge (Day, 1997) and the geologic data achieved from the water galleries (Navarro, 1998). The construction of this large mafic stratovolcano has been occurred during the Old Dorsal Ridge stage because of the $0.81 \mathrm{Ma}$ age data of a basaltic flow composing this edifice (Ancochea et al., 1990) and may occurred simultaneously with the principal formation of the Tigaiga massif during Guajara cycle. Some phonolitic pyroclastic deposits interbedded with preslide mafic lavas derived from the Dorsal Ridge have been detected at the coastline outside of the La Orotava valley near La Quinta (Figure 3.31). These preslide materials are stratigraphically located below the mafic materials composing the topmost deposits at St. Ursula, so that they have early Guajara or Ucanca ages.

The preslide deposits composing the St. Ursula wall are partly covered by postslide lava flows proceeding from eruptive vents located outside the La Orotava valley (Figure 3.31). Extensive zones at the lower part of the St. Ursula wall are hidden by basaltic lavas flowing over the lateral scarp into the valley. Another, smaller lava flow with intermediate composition descends the lateral escarpment in a higher zone and at the base of the Los Organos area there are two small strombolian cones with some associated intermediate lava flows of limited extension. The age of one of the basaltic lava flows at the lower part of the St. Ursula wall have been determined at 0.78 Ma (Ancochea et al., 1990). 


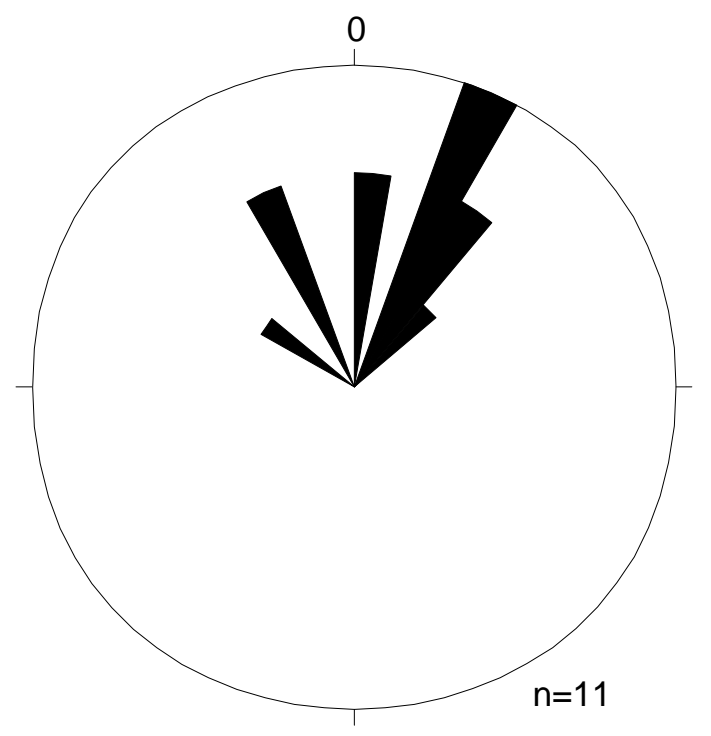

Figure 3.33: Rose diagram of dip directions of deposits composing the Los Organos area. Dip classes are in $10^{\circ}$.

One of the most important stratigraphical units of this study have been the phonolitic pyroclastic deposits. They have significantly helped to improve the understanding of the evolution of the La Orotava valley. These deposits are covering large parts of the island and theirs ages can be related in most cases to one of the three Upper Group cycles defined by the geochronological study of the Las Cañadas caldera walls (Martí et al., 1994).

In the La Orotava area exist several locations with significant phonolitic pyroclastic deposits which have contributed to the determination of the age and the extension of the landslide amphitheatre. The most important fact can be found in the valley floor, where widespread areas are covered by phonolitic pyroclastic deposits (Figure 3.31). All of these deposits are related to the Diego Hernández cycle, so that since they must have been accumulated after the large La Orotava slides at the end of the Guajara cycle. Additional phonolitic pyroclastic deposits related to the Diego Hernández cycle crop out outside the valley limits as topmost layers at St. Ursula, el Lance, La Fortaleza, between Risco Verde and Izaña and at several parts along the Dorsal Ridge. In contrast, in-situ phonolitic pyroclastic deposits associated to the Guajara cycle can only be found outside the valley limits. Three locations with Guajara deposits have been found during the field surveys: 1) at the Tigaiga massif both in the Barranco de Ruiz and in the Tigaiga wall, 2) at the coastal cliff of La Quinta; and, 3) at the Dorsal Ridge at Fuente del Joco (Figure 3.31). The deposits at La Quinta might be of an earlier cycle since no exact age data have been determined in this area. At 'Fuente del Joco', the trachybasaltic lava flow overlaying the phonolitic pyroclastic deposit has an age of $0.56 \mathrm{Ma}$ (Ancochea et al., 1990), thus the pyroclastic deposit has to be related to the Guajara cycle. Additionally, also the phonolitic pyroclastic deposits of Ucanca age have only been found outside of the valley limits (at the Tigaiga massif). In conclusion, the phonolitic pyroclastic deposits indicate that only the deposits with Diego Hernández age are located inside the valley limits, while the pyroclastic deposits of Guajara and Ucanca ages are limited to the areas located outside of the La Orotava valley.

The underground geology of the La Orotava valley area has been studied using the data of the water galleries dug in volcano slopes (Coello, 1973; Coello and Bravo, 1989; Servicio de Planificación Hidráulica, 1991; Navarro and Braojos, 1991; Servicio de Planificación Hidráulica, 1994). Because the morphologic analysis has revealed the lateral limits and parts of the head scarps of the two landslide events, the underground geology has been studied in order to define the lower limits and the continuations of the missing parts of the head scarps. The young breccia has been a key material for the 
estimate of the lower limit since it marks the first postslide deposit filling the landslides amphitheatres. However, its impermeable behaviour has caused that the majority of the water galleries stop when they arrive to this hydrogeological barrier. So, only a few data exist on the contact of the preslide and postslide deposits in the underground giving some estimates on this limit and on the thickness of the breccia layer (e.g. Coello, 1973).

Finally, two cross sections have been drawn indicating the simplified underground geology of the western and eastern part of the La Orotava valley (Figure 3.34). Both parts present a similar geology comprising preslide and postslide deposits as defined in Figure 3.30. Above the basement containing mafic Old Dorsal Ridge materials lie two other preslide materials: the old breccia related to the filling of the amphitheatre of the old post-shield landslides (Ablay and Hürlimann, 1999) and preslide LCE deposits (Carracedo, 1975). The postslide valley-filling deposits mainly include the young breccia, the Young Dorsal Ridge materials and especially in the western part postslide LCE deposits containing Diego Hernández and Teide-Pico Viejo materials. The depth of the slip surface can be assumed to be at the lower limit of the young valley filling breccia. Exact data on this limit do not yet exist and thus the thickness of La Orotava slides can only be approximated. Based on the morphological and geological analyses performed, the total thickness of the failures certainly has exceeded $500 \mathrm{~m}$ and maximum values up to $1000 \mathrm{~m}$ cannot be excluded.
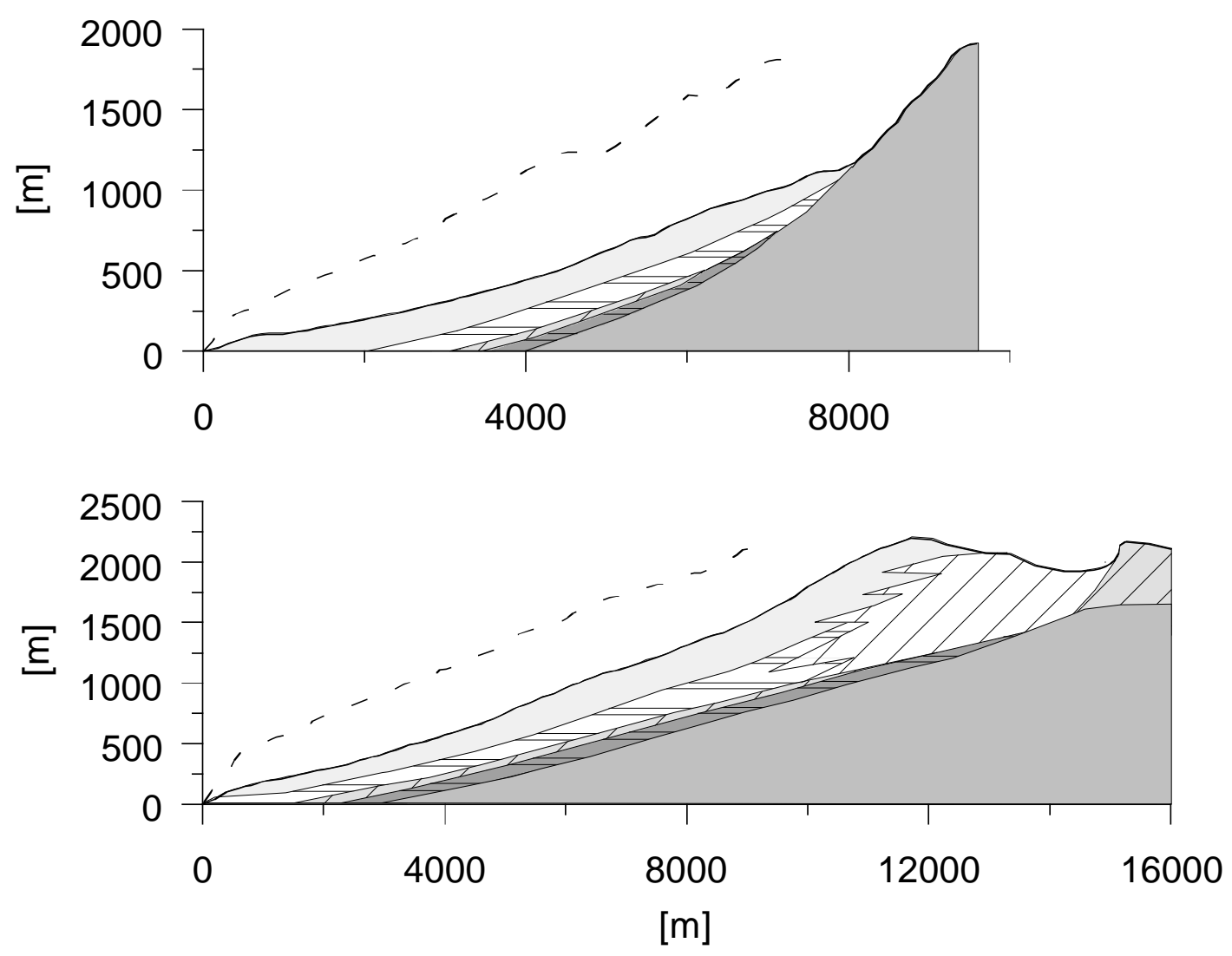

Figure 3.34: Simplified geologic cross sections of the La Orotava valley. (a) Eastern part and (b) western part. Geological shades as shown in Figure 3.30. Dashed line shows the inferred preslide topography. Similar locations as profile 2 and 4 in Figure 3.14. Vertical exaggeration is 2.

In addition, the underground continuation of the breakaway zones has been determined studying the lithological changes from postslide filling materials to preslide deposits in the water galleries. So, the head scarp of the eastern La Orotava slide at the Los Organos wall could be prolonged about 3 kilometres to the west (Servicio de Planificación Hidráulica, 1991). Similar contacts between old preslide materials and deposits filling the escarpments have been observed between Risco Verde and 
Izaña. There, the unconformity at Risco Verde could be extended in the underground to the east (Navarro, 1998) indicating the north facing head scarp of the western La Orotava slide. Afterwards, this area of the western landslide amphitheatre has been filled by a large amount of postslide volcanic materials with Diego Hernández age (Figure 3.34).

The water tunnels drilled in the La Orotava valley also reveal important information referring to the hydrogeological conditions. These data represent the present situation influenced by the large water amount consumed by the population and the tourist sector and not coincide with the situation half a million years ago. But, the hydrogeological studies carried out on Tenerife have strongly improved the understanding of the hydrogeological processes in volcanic terrains (Ecker, 1976; Custodio, 1989; Servicio de Planificación Hidráulica, 1991; Navarro and Braojos, 1991).

The hydrogeology in volcanic terrains is characterised by a complex system depending on 1) the original composition of the deposits, 2) secondary processes such as alteration or compacting; and, 3) fracturing caused by dike intrusion or other volcano-tectonic processes. The present hydrogeological conditions in the La Orotava valley area can be simplified as follows. Apart from some perched water tables situated close to the ground surface, the great mass of water resources is found in a general zone of saturation above an impermeable basement. The lower limit of this saturated zone is defined by the breccia deposits previously mentioned.

The upper limit of the phreatic surface before the exploitation is difficult to estimate. However, the Hydrologic Plan of Tenerife proposed, that it was relatively close to the ground surface, or even cut through it in some areas and that water therefore surged naturally at these points (Navarro and Braojos, 1991). And that could be the position of the water table prior to the landslide events.

From a geotechnical point of view, the slopes in the study area are mainly composed of 1) hardened and molten lava flows, 2) welded and non-welded pyroclastic deposits; and, 3) secondary reworked deposits of any origin. In general, volcano flanks comprise a complex and irregular stratigraphy and contacts are not so clear as in slopes formed by sedimentary rocks.

Molten lava from a volcano or other type of eruptive vent moves downhill by gravity. The movement is determined by its viscosity which increases as the lava cools in contact with the underlying surface and the air above. So, the base and top of a lava flow cool rapidly and develops an irregular surface containing fractures, bubbles and lava breccias. The interior of a hardened lava flow is normally quite coherent and compact. The development of a columnar structure as a result of shrinkage during cooling is quite common. The thickness of lava flows changes downhill and often becomes thinner on the lower part of the volcano flank.

Welded and non-welded pyroclastic deposits can be originated by mafic and salic eruptions and mainly include tephra and ignimbrite deposits. Tephra consists of particles of rock that were expelled by the pressure of gasses previously dissolved in the molten magma. The particles can be as small as silt (volcanic ash) or as large as tens of meters. Deposits of tephra cover the ground in a layer of varying thickness with little or no internal structure. The pyroclastic deposits from upwards eruptions tend to be thicker and coarser grained close to the eruptive vent from which the particles were erupted and thinner as well as finer outwards from the vent. Ignimbrites are formed by the deposition and consolidation of hot ash flows, pyroclastic flows or nuées ardentes. The deposit is made up of glass shards, crystals and lithic fragments, commonly in that order of decreasing abundance. In some cases the existence of a kind of flow structure resulting from the parallel arrangement of the larger glass particles can be observed. Ignimbrite deposits can be considerable and thick even kilometres or tens of kilometres from the vent and generally comprise a flat plateau-like surface.

Secondary deposits can include alluvial deposits on the lower flanks of the volcano caused by erosion and redeposition of tephra, residual soils generated by in-situ weathering and scree/sand deposits formed by small-scale mass wasting processes.

The field survey carried out in the La Orotava valley has revealed that widespread residual soils (also called paleosols) might have been potential slip surfaces for large landslides. In contrast to the solid lava flows and quite hard ignimbrites, residual soil layers interbedding these strata seem to be characterised by a particular geotechnical behaviour (see Chapter 4). Red coloured residual soils are 
generally located at the top of pyroclastic deposits produced by explosive eruptions of phonolitic magmas. The flat tops of phonolitic pyroclastic deposits (or ignimbrites) represent the only planar surfaces within the deposits composing the volcano slopes. In Tenerife, extensive deposits have been found within the central part of the island either subaerially exposed or covered by recent lavas. These occur in regions adjacent to the Las Cañadas caldera which are covered by pyroclastic deposits related to explosive eruptions from the Las Cañadas edifice (e.g. IGME, 1988a; Navarro and Braojos, 1991; Bryan et al., 1998). Weathering processes change the phonolitic pyroclastic deposit into a residual soil which is later covered by a lava flow, further modifying the soil by thermal processes. The result of these processes is the occurrence of widespread red residual soils, several decimetres thick, representing the weakest material found on the island. The residual soils are characterised by a particular geotechnical behaviour (see Chapter 4) strongly influenced by their double cementation. This cementation or bonding is caused first by the lithification processes during the deposition of the hot ignimbrite and second by the thermal alteration by the lava flow covering the weathered ignimbrite deposit.

A photograph of residual soil layers interbedded between lava flows is shown in Figure 3.35 and detailed photographs of residual soils are presented in Chapter 4 (Figure 4.3, Figure 4.4 and Figure 4.5) where the geomechanical behaviour of such a residual soil has been comprehensively analysed. A typical geologic column describing the residual soil is illustrated in a simplified mode in Figure 3.36.

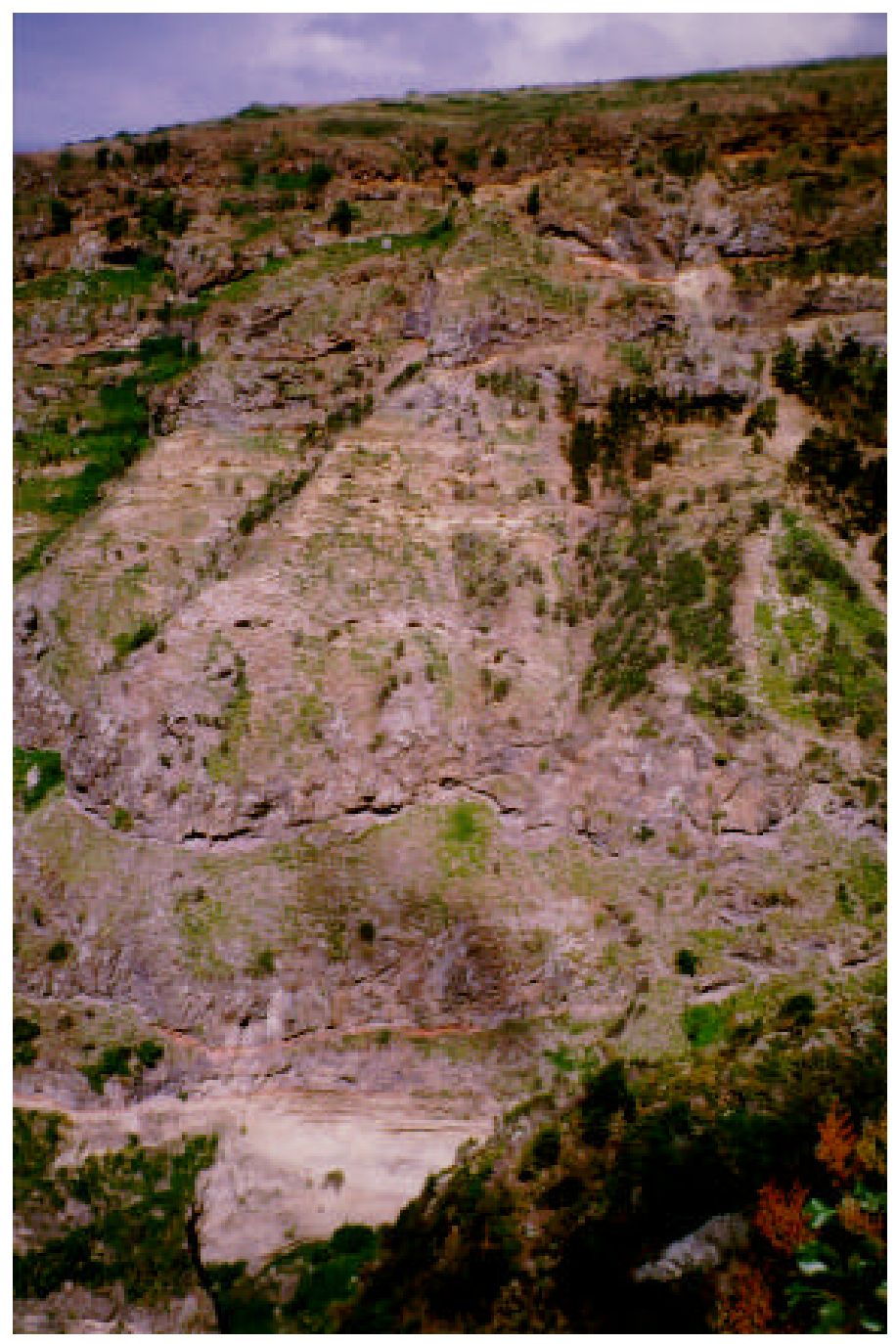

Figure 3.35: Photograph of residual soils (red coloured) interbedded between lava flows (grey-brown) and ignimbrites (white-brown). The stratigraphy represents the preslide LCE deposits cropping out in the Barranco de Ruiz (Tigaiga massif). 


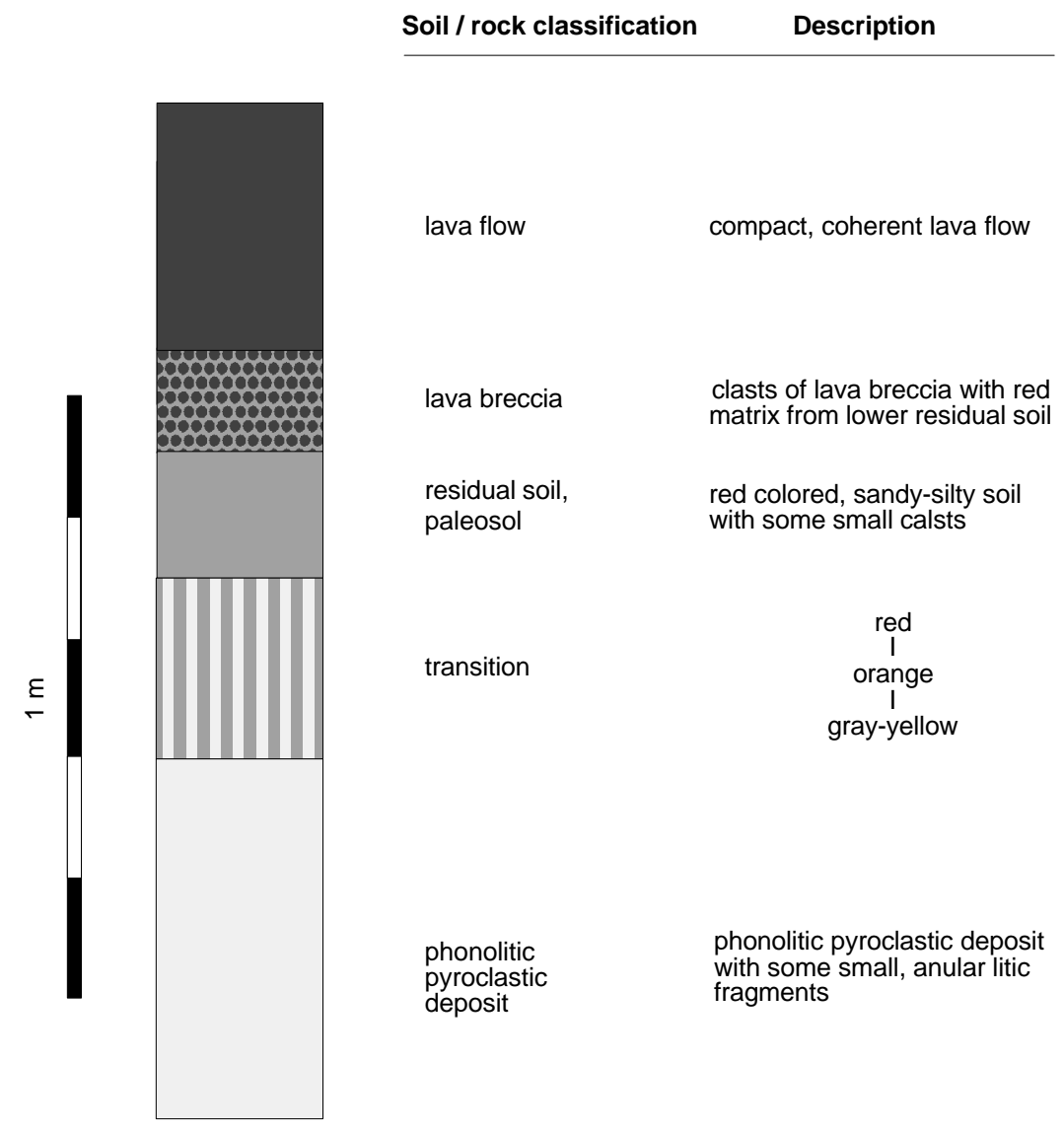

Figure 3.36: Simplified geologic column indicating the formation of residual soils.

The geologic column of Figure 3.36 contains three main zones: the lower phonolitic pyroclastic deposit, the upper lava flow and the soil layer interbedded between these strata. The lower zone is a grey-yellow coloured ignimbrite deposit. The upper zone of the ignimbrite deposit has been affected on one side by weathering processes and on the other side by thermal alteration caused by the upper lava flow creating a red to orange coloured transition zone. The thickness of this transition zone depends both on the duration of the weathering and the temperature of the upper lava flow, but rarely exceeds half a meter. The lower limit of the lava flow contains a lava breccia. The contact of the hot lava and the soil has formed sometimes a thin layer of yellow-green coloured layer, which is a common feature of volcanic (hydro-) thermal alteration (see Figure 4.12 in Chapter 4). The lava flow on the top of the section is generally coherent and compact.

The field surveys have shown that there exist other weak materials such as clayey-silty alluvial deposits in the La Orotava valley area but the residual soils are the only deposits with regional extension. Alluvial deposits have been found locally and thus are less efficient to act as a slip surface of a landslide with an extension of several kilometres. Moreover, the homogeneous flat top of the ignimbrites and therefore of the residual soils is quite unique for volcanic deposits and support the hypothesis that these residual soils are the perfect candidate of the failure surface of the large landslides.

Two studies of shallow landslides in volcanic terrains have confirmed the results obtained in this work and indicate the critical failure contacts in similar volcanic deposits. A study of rain-induced, shallow landslides in Dominica, West Indies, showed the significant influence of the contact between a porous topsoil and a lower low-permeable deposit (Rouse et al., 1986). From the analysis of numerous landslides, the key failure plane could be defined at the base of the residual soil at the soil/rock interface. Similar characteristics has been found in shallow mass movements in volcanic soils in Japan (Kitamura et al., 1988). All the landslides occurred at the contact between the upper residual topsoil and the lower, widely spread pyroclastic flow deposits with a plateau like topography. 


\subsection{Assumed preslide conditions}

In order to define the models for the stability analysis the preslide morphologic and geologic conditions of the La Orotava valley area has been assumed. The simplified preslide conditions have been established using the data containing all the available geologic and morphologic information of previous studies, the results obtained from the morphologic and geologic analysis and observations of the field work.

The preslide morphology of the La Orotava valley has mainly been influenced by the volcanic activity along the Dorsal Ridge and in the Las Cañadas caldera. A chain of volcanic edifices is assumed to be situated along the Dorsal Ridge as indicated in Figure 3.37. The two major ones are a large mafic stratovolcano in the eastern sector of the Dorsal Ridge and the huge Guajara edifice inside the Las Cañadas caldera (Servicio de Planificación Hidráulica, 1991; Martí et al., 1994). The deposits of the two large volcanoes may have generated a canyon or depression in the centre of the actual amphitheatre (Bco. de la Suerte) dividing the whole area geologically and morphologically into two sectors. In addition to this central canyon, others narrow barrancos may have been formed at the contacts of the different volcanoes (Bco. de la Calera and Bco. de la Arena). These canyons would correspond to ravines created by fluvial erosion, oriented from the Dorsal Ridge towards the sea and characterised by depths exceeding $100 \mathrm{~m}$. This characteristic is consistent with the morphology found nowadays in the Tigaiga massif and other areas not affected by the landslide events. The canyons may have evolved into the lateral limits of the landslides since they provide an easy for such processes (Hürlimann et al., 1999).

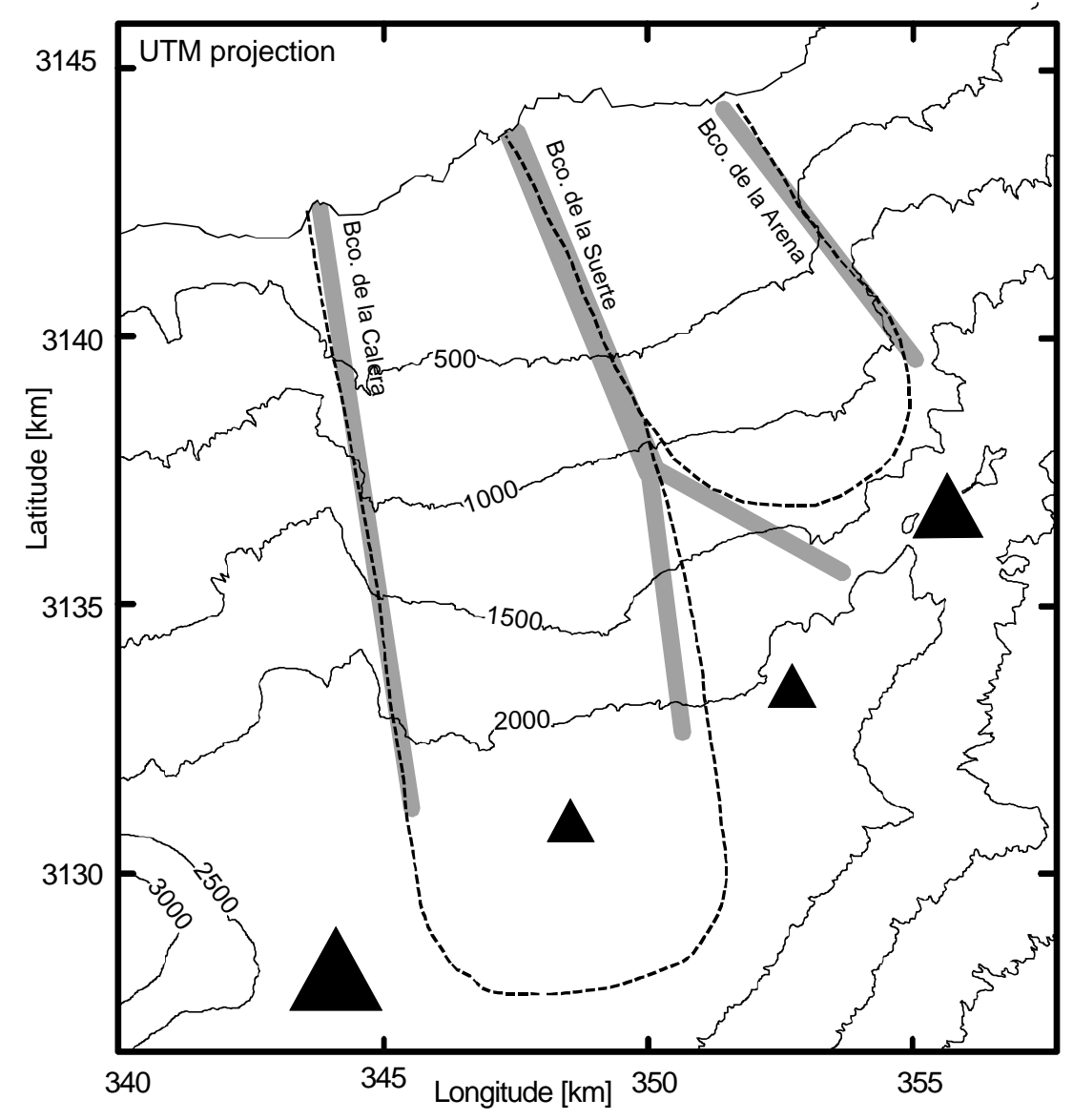

Figure 3.37: Morphologic features characterising the preslide conditions of the La Orotava valley area. Dashed lines indicate the assumed landslide limits, thick grey lines show the preslide canyons and triangles indicate the major preslide volcanic edifices. 
The high coastal cliff today visible at both sides out of the amphitheatre is an important morphologic feature and may have been extended along the entire preslide coast of the La Orotava valley area.

The preslide geology of the La Orotava valley area can be divided into two main sections. The western part has been composed of intermediate to phonolitic lavas and phonolitic pyroclastics belonging to the LCE. The western part has mainly been consisted of mafic materials derived from the large stratovolcano in the east sector of the Dorsal Ridge and additional eruptive vents along this rift zone (Figure 3.37). Some layers of phonolitic pyroclastics related to the LCE have been interbedded between the mafic materials, too. The residual soils formed above these widespread phonolitic pyroclastic deposits may have played a fundamental role in the initiation of the large landslide events. Weak residual soils interbedded between sound materials have covered the entire area of the slide extensions and therefore may have been acted as slip surface of the large landslide events.

Before the formation of the La Orotava slides between 0.73 and $0.56 \mathrm{Ma}$ the volcanism of the island has been characterised by a very high activity. Strong magma intrusion and the formation of volcanic edifices have affected the Dorsal Ridge. In the central part of the island the huge Guajara edifice has been constructed and formed a volcano with a height similar to the present Teide - Pico Viejo complex. This high volcanic activity around the La Orotava valley has strongly influenced the stability of the volcano flank. Many different destabilising processes associated with the volcanism has affected the natural slopes including the accumulation of new volcanic material, changes of the stress in the slope due to magma injections, fracturing of the bedrock, pore pressure changes, hydrothermal alteration and seismic shocks especially caused by the caldera collapse terminating the Guajara cycle. 


\subsection{Conclusions}

The site investigation has included a comprehensive geologic and morphologic analysis of the large landslide events that have formed the La Orotava valley. In addition, other large volcanic slides on Tenerife and in the Canary Islands have been studied marginally in order to improve the general understanding of the mechanics of such destructive mass movements.

During the last years a total of seventeen large landslide events have been detected around the Canarian archipelago due to bathymetric surveys. The islands of Tenerife (seven events), Gran Canaria (five events), el Hierro (three events) and La Palma (two events) have been strongly affected by this geologic phenomenon. The analysis of these seventeen events has revealed several interesting and novel conclusions. First, there exists a strong correlation between the structural axes on the islands and the breakaway zones of large volcanic landslides. The majority of the failures has occurred perpendicularly to the main structural axis or has been limited by two axes. Second, a spatial relationship between areas characterised by a humid climate and a higher probability of large landslide occurrence has been detected. Most of the large failures have taken place in the wettest parts of the islands. This fact can be seen in a perfect way on Tenerife, where all of the seven landslide events have occurred in the wet north and northeast parts of the island. Third, a temporal relationship between sea level fallings and the occurrence of large landslides have been observed. Most of the events with exact age data could have been correlated to a significant descent of the sea level. At last eight of the seventeen landslides have been associated with such a sea level falling and better age data of other landslide events would certainly strengthen this relationship.

On Tenerife a total of seven large landslide events has been detected. Two slide events have occurred during the shield stage at the north of Teno and Anaga, and five events have taken place during the postshield phase (old slide complex, Icod, La Orotava, East Dorsal and Güimar). The central north flank of Tenerife, where the La Orotava valley is located, has been affected by the old post-shield slide complex with a volume exceeding $500 \mathrm{~km}^{3}$ and the three young post-shield landslides Icod, La Orotava and East Dorsal with volumes of about $100 \mathrm{~km}^{3}$ each of them. The causes of the failures have not yet been resolved but the volcanic activity definitely have played a significant role. The caldera collapse episodes of the Las Cañadas edifice in the central part of the island have strongly influenced on the mechanical stability of the volcano flanks. This fact is verified by a temporal relationship between the landslide ages of the La Orotava and Icod valley and the two caldera collapse episodes Guajara and Diego Hernández. On the other side, the Dorsal Ridge characterised by persistent dike intrusion may have played an additional significant role in the initiation of the large failures. The breakaway zones of all of the postshield landslide events are located near this active rift zone.

In this study the La Orotava valley has been selected as main test site due to the data available and its location adjacent to the Dorsal Ridge and the Las Cañadas caldera. The La Orotava valley is the largest visible amphitheatre on Tenerife with a width of almost $10 \mathrm{~km}$ and a length of up to $14 \mathrm{~km}$. The valley is bordered by high, lateral escarpments and filled by a big amount of postslide volcanic materials. The subaerial and submarine morphologic analysis and the study of the subaerial and underground geology have revealed that two different landslide events have generated the La Orotava valley: one in the eastern part of the valley with a failure movement to the northwest and the other in the western part with a failure direction to the north. Morphologically, this can be verified by the contrasting slope orientations and headwall strike directions of the eastern and western valley sectors, the non-parallelism of the bounding walls and the two submarine accumulation lobes. Geologically, the hypothesis of two different slide events has been intensified by the different materials composing the two lateral limits of the valley and the assumed preslide geologic conditions. In the eastern part of the valley the preslide deposits are characterised by mainly mafic lava flows and volcanoclastic materials derived from a large stratovolcano and other smaller cones situated along the Dorsal Ridge. In contrast, the preslide deposits of the western part are composed of thick sequences of phonolitic to intermediate lava flows interbedded with thinner layers of phonolitic pyroclastics all of them derived from the Las Cañadas edifice. 
Several morphologic and geologic facts have constrained the limits of the two landslide events. The steep, coastal cliff is an important morphologic feature determining the lateral extension of the slides at the coastline. Before the occurrence of the failures, this coastal cliff has been extended along the entire coastline with heights up to $500 \mathrm{~m}$. Nowadays, this high cliff is missing inside the La Orotava valley and remnants of it occur outside of the amphitheatre at the Tigaiga massif and the east Dorsal Ridge. The steep, coastal cliff may have been the seawards limit of the landslide events, since the base of the subaerial volcano flank was unbuttressed due to its truncation by marine erosion.

The lateral limits of the amphitheatre are characterised by two sub-vertical escarpments composed of preslide materials and with heights of up to $500 \mathrm{~m}$. In the west there is the Tigaiga wall with a length of about $10 \mathrm{~km}$ and in the east is the St. Ursula wall with a length of about $5 \mathrm{~km}$. The morphologic analysis of the present hydrologic network and the assumed preslide conditions suggest that deep narrow canyons may have existed in the locations of these lateral walls. An additional canyon or depression may have developed in the central part of the valley dividing it into two sectors. The large landslides are assumed to have exploited these lateral weaknesses and have developed the lateral limits along these barrancos. Deep narrow canyons are a typical morphologic feature on Tenerife in areas not affected by large failures, are characterised by depths exceeding $200 \mathrm{~m}$ and are formed by fluvial erosion.

The head walls of the two large landslide events could have been determined during the geological and morphological analyses. The exact location of the breakaway zone of the western slide has been difficult to define since the amphitheatre is filled in this sector by a huge pile of postslide volcanics. However, morphologic features, a geological unconformity in the Las Cañadas caldera wall and the underground geology obtained from the water tunnels let assume that the head scarp of the western slide is located at the top of the Dorsal Ridge between Risco Verde and Izaña. The failure has truncated the northeast sector of the Las Cañadas caldera and thus has generated the particular unconformity in the caldera wall at Risco Verde dividing preslide materials in the south from postslide materials in the north. The breakaway zone of the eastern La Orotava slide is located in the Los Organos area slightly to the north of the Dorsal Ridge. There, high sub-vertical walls exposed in the preslide materials have been detected during the morphologic analysis and are inferred to be the head scarps of the failure. A westward prolongation of this breakaway zone has been observed in the underground geology obtained from the water tunnels.

The definition of the basal slip surface has been the most critical step during the site investigation because of the lack of exact data. The data on the underground geology obtained from the water tunnels mostly terminate at an impermeable breccia layer found in depths of 200 to $300 \mathrm{~m}$. This thick breccia layer can be divided into two different units: an old unit infilled the old post-shield landslide complex at about 3.0 Ma and a young unit. The young breccia unit is the oldest postslide deposit and has been formed by mass wasting processes filling the large landslide amphitheatre created by the La Orotava events. The thickness of the young breccia is not known but may involve 200 to $300 \mathrm{~m}$. Therefore, the total thickness of the postslide materials filling the original landslide amphitheatre may reach $500 \mathrm{~m}$ in some sectors of the valley and a total thickness of the entire failed material has reached $1000 \mathrm{~m}$.

The field surveys carried out in the La Orotava valley has revealed that widespread residual soils (also called paleosols) might have been potential slip surfaces for the large landslides. Red coloured residual soils are generally located at the top of pyroclastic deposits produced by explosive eruptions of phonolitic magmas. The flat tops of phonolitic pyroclastic deposits represent the only planar surfaces within the materials composing the volcano slopes. Furthermore, the residual soils are the only weak layer with regional extensions. The soils are characterised by a particular cementation caused by thermal alteration and may have acted as failure surfaces of the large landslides due to their weak mechanical behaviour.

In conclusion, the large volcanic landslides of the La Orotava valley may have been slab-shaped, transitional failures bordered laterally by deep narrow canyons, seawards by a steep coastal cliff, at the head by an active rift zone with persistent dike intrusion and at the bottom by a weak residual soil layer. Slab-shaped mass movements are common slide types in fractured, bedded rocks under tension (O'Leary, 1991). 
The causes of the two La Orotava landslides are complex and include geologic, morphologic, climatic and volcanic factors. The accumulation of new volcanic material on the slope caused by the fast growth of volcanic edifices and the horizontal pressure from the Dorsal rift zone have changed the stress field of the volcano flank and has reduced its global stability. Simultaneously, fluvial erosion has cut deep, narrow canyons along the contacts of these volcanic edifices and marine erosion has formed a steep and high cliff along the coastline. These two morphologic features have reduced the stability of the volcano slope laterally and towards the sea. Moreover, the humid climate in the north part of Tenerife and in the La Orotava valley area has generated saturated hydrogeological conditions with high pore water pressures and a residual soil layer may have acted as the failure surface of the landslides. Finally, a destructive caldera collapse episode has occurred at the end of the Guajara cycle at about $0.56 \mathrm{Ma}$ and the strong seismicity associated with this collapse is inferred to have triggered the two La Orotava landslides. 


\section{LABORATORY ANALYSIS}

\subsection{Introduction}

The site investigation carried out in the La Orotava valley has revealed the existence of a potential weak layer in which the slip surface of the large volcanic landslides may have been occurred. Widespread residual soils (or paleosols) are assumed to be the weakest material in the volcano flank with a sufficient large extension to cause a failure plane destabilising a sector of the volcano slope of some kilometres in width and length. In this Chapter the results of a comprehensive laboratory study will be presented analysing such a residual soil.

Residual soils are products of rock weathering without transportation as sediments but accumulation in place. Among the factors influencing the rate of weathering and the nature of the products are climate (temperature and rainfall), time, type of parent rock, vegetation, drainage and bacterial activity (Blight, 1988). The extreme humid climate at the northern flank of Tenerife and especially around the Tigaiga massif together with the relative weakness of the phonolitic pyroclastic deposits (in comparison with resistant lava flows) favour the development of residual soils.

In contrast to sedimentary soils, the residual soils are not well studied and the understanding of volcanic residual soils is even less known. In this study, a residual soil which has been formed above a phonolitic pyroclastic deposit and covered by a lava flow, has been analysed. Geotechnical studies on similar materials are very rare, because the construction of large buildings or civil engineering works, which require a geotechnical analysis, is very limited on soils originated from these materials. Hazard zonation maps generally interdict important infrastructures on such deposits due to the probability of future pyroclastic flow events. At Vesuvius, Italy, a general geotechnical analysis of volcanic soils covering the historic sites of Pompeii and Herculaneum (Rippa, 1997) and a comprehensive study of a homogeneous volcanic tuff found in the centre of the city of Naples (Aversa and Evangelista, 1998) have been carried out. Moreover, a volcanic agglomerate in the Canary Islands has been analysed due to the construction of water dams (Uriel and Serrano, 1973; Uriel and Serrano, 1974; Serrano, 1976). The same cause has also led to an extensive research on phonolitic pyroclastic deposits in New Zealand (Moon, 1993a; Moon, 1993b). On Tenerife, a study of volcanic soils near La Laguna has been carried out providing information on clayey lake deposits which has been formed due to accumulation of transported volcanic material and intense weathering processes (Gonzalez de Vallejo et al., 1981). However, the majority of the geotechnical studies on volcanic residual soils have been performed on soils generated above volcanic ashes or basaltic lava flows (Koizumi and Ito, 1963; Wallace, 1973; Rouse et al., 1986; Hobbs et al., 1988; Kitamura et al., 1988; O'Rourke and Crespo, 1988; Sridharan, 1988; Belloni, 1989; Maccarini et al., 1989; Thrall and Bell, 1989; Wesley, 1990; Sudhakar, 1995; Zhu and Anderson, 1998) and not on a soil generated on a phonolitic pyroclastic deposit as in this study. Consequently, the analysis carried out in this work is unique and tests on similar materials are very scarce. This fact should be kept in mind comparing the results with other ones obtained from different residual soils.

The stress - strain and strength behaviour of residual soils clearly differ from the one of sedimentary soils. The most important features that influence on the mechanical behaviour of residual soils include void ratio, density and bonding effects all of them almost independent of the stress history (Vaughan, 1988; Blight, 1997). Other factors are the relict structure and possible discontinuities of the parent rock and also the great variability of weathering products originating weak mineral grains or agglomerations of grains. However, the small effect of the stress history is the major difference to sedimentary soils which mainly depend on this factor.

One of the particular characteristics of residual soils is the presence of bonds between particles. These bonds represent a component of strength and stiffness that is variable because of different bonding minerals and differences in weathering processes. In general, bonds can be provided by a wide range of agents, such as silicates, iron oxides, precipitation of calcite cement etc. A bonded soil (also 
called cemented soil) can be described as a mixture of soil particles and a matrix, which connects these particles. The bonding matrix can have different origins depending on the structure of the parent rock, weathering processes or thermal heating. The strong bonding of some volcanic residual soils may be explained by lithification processes during the deposition of the parent rock (phonolitic pyroclastic deposits, tuff etc.). A very important fact from a mechanical point of view is that once the bonding is broken by loading or strain, it is irrecoverable and the soil strength decreases.

A simplified interpretation of the bonding behaviour in residual soils has been postulated by Vaughan et al. (1988) and will be shortly described. They propose that the different consolidation curves between undisturbed and remoulded samples are caused by the bond strength, that exists in the undisturbed sample and misses in the remoulded specimen. Figure 4.1 illustrates the tentative model of the stress-strain behaviour of bonded soils defining both the bond stress and the bond strength. The stress applied to the bonded sample is partially carried by the bonds and is called the bond stress. This bond stress is a function of the difference in the void ratios of the remoulded and undisturbed soil, $\mathrm{e}_{\mathrm{UD}}$ and $\mathrm{e}_{\mathrm{RM}}$. On the other hand, the total stress that can be carried by the bonds of an undisturbed material is defined as the bond strength.

At the beginning of the test during phase 'A' the compression of the bonded sample is less than that of the remoulded sample. The bond stress increases with increasing stress values. The first yield represents the stress at which some of the bonds start to fail. Up to this point the bond strength remains constant, since no bonds have been broken. During phase 'B' decreases the bond strength due to the higher stress and strain, which break more and more bonds. Simultaneously, the bond stress still increases. The second yield occurs, when the decreasing bond strength becomes equal to the increasing bond stress. Thereafter, during stage ' $\mathrm{C}$ ', both the bond strength and the bond stress decrease in a matching manner. The two curves of undisturbed and remoulded samples should coincide, when the bonding has been completely destroyed.

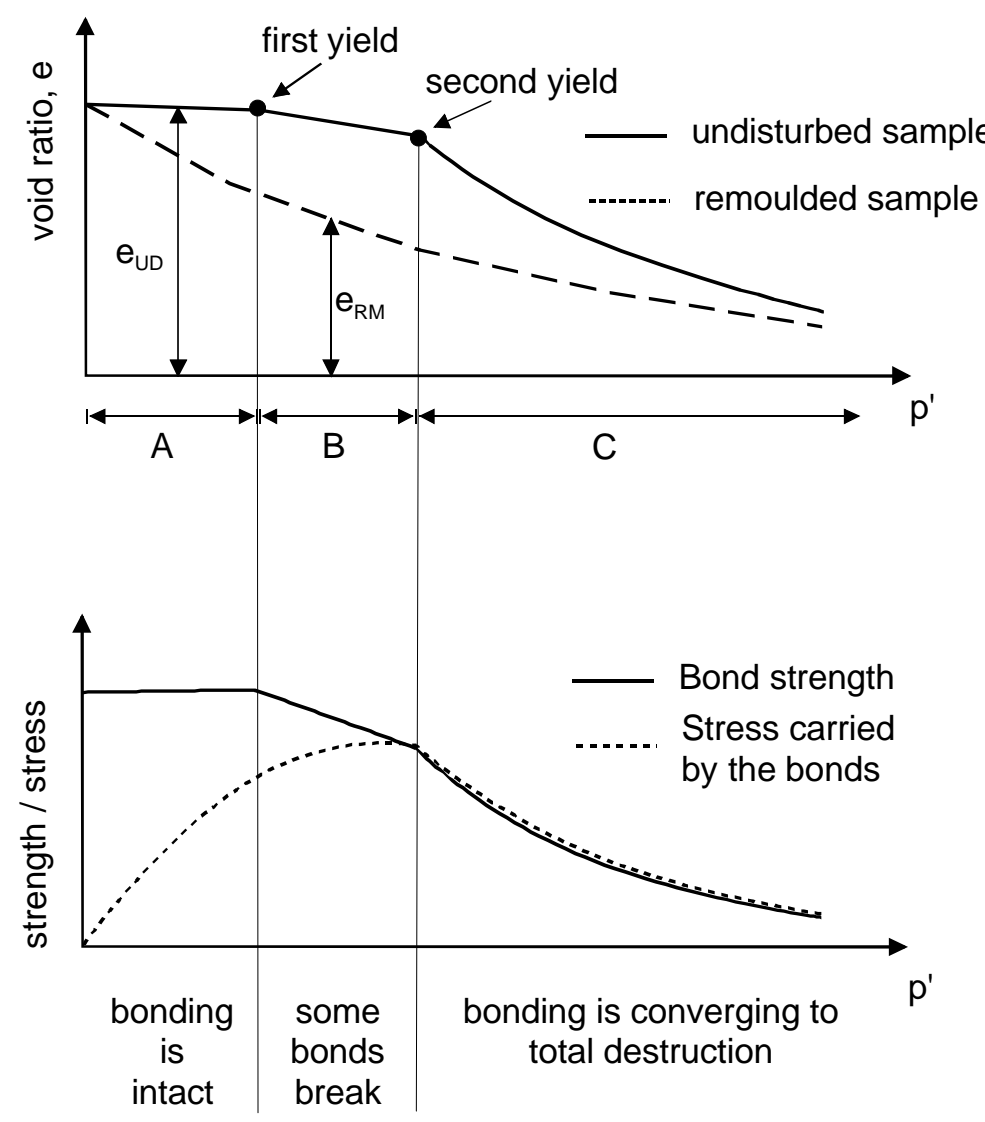

Figure 4.1: Tentative model of the bonding in residual soils after Vaughan et al. (1988). 
In the analysis of large volcanic landslides - or large landslides in general - a supplementary, very important fact has to be taken into account. Due to the enormous thickness of the large volcanic landslide occurred on Tenerife - assumed as several hundreds of meters - the overburden stress exceeds that of common shallow slides by at least two orders of magnitudes. Therefore, the stresses applied to the soil mass at the slip surface would surpass $1 \mathrm{MPa}$ for a material density of about $2500 \mathrm{~kg} / \mathrm{m}^{3}$. This significant scale effect has to be incorporated into the geotechnical study of deep seated landslides, since the mechanical behaviour of materials confined by high stresses clearly differs from normally confined materials (Petley and Allison, 1997). In this study, effective confining stresses up to $15 \mathrm{MPa}$ have been applied during the laboratory tests and some novel and unique results refering to the strength behaviour of volcanic residual soils have been achieved.

Finally, the test programme carried out during this work has included: 1) Standard geotechnical tests such as oedometer tests, ring shear tests, direct shear tests and triaxial tests; and, 2) an analysis of the mineralogy, chemistry and microstructure using X-ray fluorescence, X-ray diffraction technique and environmental scanning electron microscopy. The main objective of this chapter is to determine the mechanical behaviour of the residual soil analysed in this study. Particular attention has been paid to the bonding effect and its influence on the geotechnical behaviour of the soil. The aim of the mineralogical and geochemical analyses of twelve samples collected in the La Orotava valley area has been to obtain a general insight of the composition of the samples and to improve the understanding of the geological settings in the region. 


\subsection{Methodology}

\subsubsection{Sampling}

Two types of samples have been collected during the geological field survey in the La Orotava valley area: 1) small hand-samples in order to study their mineralogy and chemistry; and, 2) block samples which have also been analysed by geotechnical laboratory tests and the environmental scanning electron microscopy.

In total twelve samples of different geological deposits have been analysed. Information about the sample type, data refering to its location and the tests carried out are summarised for each sample in Table 4.1. Moreover, the locations of the samples are illustrated in a topographic map of the La Orotava valley (Figure 4.2), and overviews of each outcrop are given by photographs in Figure 4.3 to Figure 4.12. In addition to the twelve hand-samples used for the geochemical and mineralogical analysis, block-samples of the three residual soils (RS1, RS2 and RS3) have been collected in order to carry out mechanical tests. The residual soils have been sampled in block size, protected and brought to the geotechnical laboratory of the UPC, where the samples are kept in a humid room of a constant humidity of $90 \%$ and a temperature of $25^{\circ} \mathrm{C}$.

Table 4.1: Samples studied during the geochemical and geotechnical analyses

\begin{tabular}{|c|c|c|c|c|c|c|}
\hline abbreviation & sample type & location & $\begin{array}{c}\mathrm{X} \text {-coordinate } \\
{[\mathrm{m}]}\end{array}$ & $\begin{array}{c}\text { Y-coordinate } \\
{[\mathrm{m}]}\end{array}$ & $\begin{array}{c}\text { altitude } \\
{[\mathrm{m}]}\end{array}$ & $\begin{array}{c}\text { test carried } \\
\text { out }{ }^{1)} \\
\end{array}$ \\
\hline $\mathrm{RS} 1$ & residual soil & $\begin{array}{l}\text { Piedra de los } \\
\text { Pastores }\end{array}$ & 344330 & 3135710 & 1650 & $\begin{array}{c}\text { XRF/XRD } \\
\text { ESEM } \\
\text { GEOT }\end{array}$ \\
\hline RS2 & residual soil & Tres Pinos & 343270 & 3138220 & 1155 & $\begin{array}{l}\text { XRF/XRD } \\
\text { GEOT }\end{array}$ \\
\hline RS3 & residual soil & Mirador Sergio & 344610 & 3135160 & 1188 & $\begin{array}{l}\text { XRF/XRD } \\
\text { GEOT }\end{array}$ \\
\hline MO1 & valley filling breccia & Playa de Fajana & 344680 & 3142280 & 10 & XRF/XRD \\
\hline MO2 & valley filling breccia & $\begin{array}{c}\text { Punta el } \\
\text { Gundastés }\end{array}$ & 343730 & 3142440 & 15 & $\mathrm{XRF} / \mathrm{XRD}$ \\
\hline BR1 & $\begin{array}{l}\text { preslide } \\
\text { breccia }\end{array}$ & Los Organos & 353930 & 3137490 & 1210 & XRF/XRD \\
\hline $\mathrm{BR} 2$ & $\begin{array}{c}\text { preslide } \\
\text { breccia }\end{array}$ & La Ladera & 355440 & 3139420 & 1490 & $\mathrm{XRF} / \mathrm{XRD}$ \\
\hline EL1 & $\begin{array}{l}\text { valley filling breccia } \\
\text { (matrix) }\end{array}$ & el Lance & 343260 & 3141550 & 120 & $\mathrm{XRF} / \mathrm{XRD}$ \\
\hline EL2 & $\begin{array}{l}\text { valley filling breccia } \\
\text { (block) }\end{array}$ & el Lance & 343260 & 3141550 & 120 & XRF/XRD \\
\hline BI1b & $\begin{array}{c}\text { phonolitic pyroclastic } \\
\text { deposit (bottom) }\end{array}$ & $\begin{array}{c}\text { Barranco de } \\
\text { Ruiz }\end{array}$ & 340760 & 3140980 & 238 & XRF/XRD \\
\hline BI1t & $\begin{array}{c}\text { phonolitic pyroclastic } \\
\text { deposit (top) }\end{array}$ & $\begin{array}{c}\text { Barranco de } \\
\text { Ruiz }\end{array}$ & 340760 & 3140980 & 238 & XRF/XRD \\
\hline $\mathrm{BI} 2$ & $\begin{array}{l}\text { baked phonolitic } \\
\text { pyroclastic deposit }\end{array}$ & $\begin{array}{l}\text { Barranco de } \\
\text { Ruiz }\end{array}$ & 340760 & 3140980 & 202 & XRF/XRD \\
\hline
\end{tabular}

1) XRF: X-ray fluorescence

XRD: $\quad \mathrm{X}$-ray diffraction technique

ESEM: environmental scanning electron microscope

GEOT: geotechnical laboratory tests 
Three residual soil samples (RS1, RS2 and RS3) have been collected at various locations on the Tigaiga massif. The origin of these common and widespread soil layers on Tenerife are explained in Chapter 3 (Site investigation). RS1-sample is situated near the site called 'Piedra de los Pastores' inside the eastern Tigaiga wall, which represents the western lateral scarp of the La Orotava valley. The outcrop lays along the forestry road starting from the C-821 near 'el Portillo' and continuing to the top of the Tigaiga massif. The unit sampled is a red coloured, about $1 \mathrm{~m}$ thick residual soil formed at the top of a phonolitic pyroclastic deposit and covered by a thick lava flow (Figure 4.3). The RS2-sample has been collected on the top of the Tigaiga massif near the location called 'Tres Pinos' and is characterised by its greyish colour, which is rather unusual for residual soils observed on the island (Figure 4.4). Local geochemical effects and the extremely humid conditions in this area may explain this feature. RS3-sample is located at the site called 'Mirador Sergio' taking the forestry road which starts at the picnic place 'Pedro Gonzalez' and continues up to the Tigaiga massif (Figure 4.5). The sample contains several fault planes dipping towards the east, outwards of the Tigaiga wall and typical slickenslides are visible. A photograph of the RS3-sample is shown in Figure 4.42 (Section of the laboratory results) with the red coloured soil and the black slickenslides.

Two samples have been selected from the matrix of young post-shield valley filling breccias (MO1 and MO2). The samples have been collected from the so-called 'Mortalón' deposit (IGME, 1988) outcropping at the coast in the western part of the La Orotava valley (see Chapter 3). The MO1-sample is located at the beach called 'Playa de Fajana' (Figure 4.7) and has been collected from the same deposit which has been dated with an age > 0.73 Ma (Ibarrola et al., 1993). The sampled unit, which can be classified as a massive, poorly sorted, volcanic breccia, contains a grey - reddish matrix and polymict clasts. MO2-sample has been collected at the site called 'Punta el Gundastés' which is a delta composed of alluvial deposits, volcanic materials and deposits of small-scale landslides. The unit of sample MO2 contains a reddish matrix and poorly sorted, monomict clasts (Figure 4.8).

Two samples of the matrix of mafic breccias (BR1 and BR2) have been collected in the southeastern part of the La Orotava valley driving along the forestry road which starts at the picnic place 'La Caldera' near Aguamansa. These breccias are preslide deposits and form the head wall and also parts of the lateral scarp of the eastern La Orotava landslide event. The BR1-sample has been taken from a large block fallen down of the vertical wall at Los Organos which may be the head scarp of the LOe landslide. The sampled unit can be classified as a very massive, volcanic breccia with a brown-grey matrix and poorly sorted monomict clasts (Figure 4.9). The BR2-sample is situated at the location called 'La Ladera' which is still assumed to be inside the same head scarp of the LOe landslide. The outcrop is a lithic rich, thinly bedded breccia deposit with monomict, basaltic clasts ranging from granule to boulder size (Figure 4.10).

Additionally, two samples from small-scale, secondary landslide deposits near the village Los Realejos have been analysed (EL1 and EL2). Both samples have been collected at the same outcrop along the road C-820 from Puerto de la Cruz to Icod. The EL1-sample has been taken from a large block of a phonolitic pyroclastic deposit within the deposit and EL2 has been taken from a red coloured, sandy layer of the same deposits (Figure 4.6). 


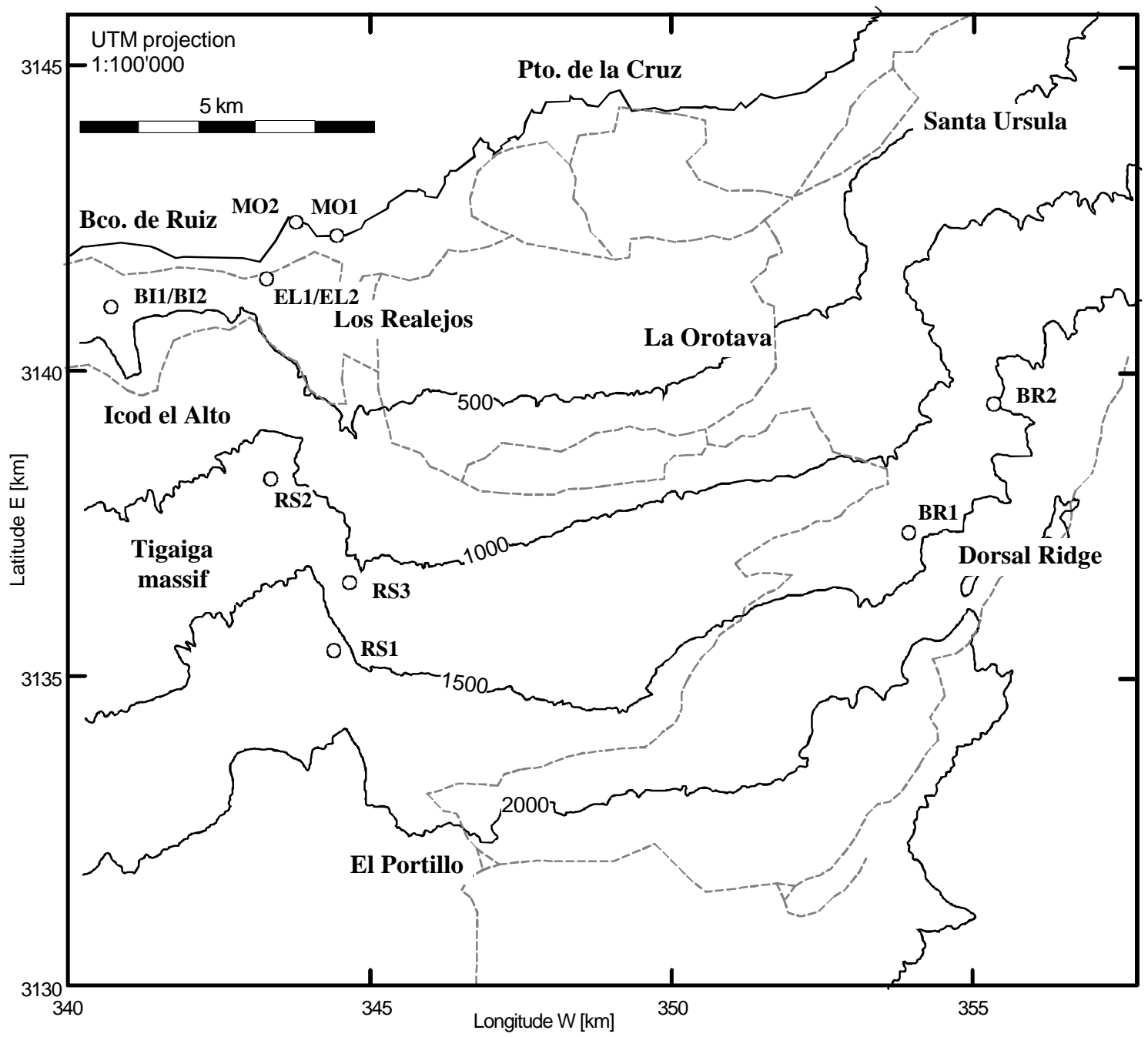

Figure 4.2: Location of the samples analysed shown in a topographic map of the La Orotava valley. Grey dashed line indicates roads. Interval of the contour lines is $500 \mathrm{~m}$.

At last, three samples of phonolitic pyroclastic deposits with different grades of baking (thermal alteration) have been collected in the 'Barranco de Ruiz' which is a deeply incised canyon in the Tigaiga massif (BI1t, BI1b and BI2). The samples are located along the walking path from the picnic place at the road C-820 to the village Icod el Alto. Baked phonolitic pyroclastic deposits are common deposits on Tenerife and are characterised by their red colour. These deposits can be compared with residual soils since their original material and the thermal alteration due to the covering of lava flow is the same. However, the weathering processes are missing and thus have avoided the formation of a residual soil above the phonolitic pyroclastic deposit. BI1t and BI1b have been taken from the same phonolitic pyroclastic deposits (Figure 4.11). BI1t represents the topmost zone strongly baked due to thermal alteration and BI1b represents the lower zone with almost no influence of thermal alteration. The BI2sample has been collected of the small, grey - yellowish layer characterising the contact between the upper lava flow and the lower phonolitic pyroclastic deposit, which is totally affected by the thermal alteration (Figure 4.12). 


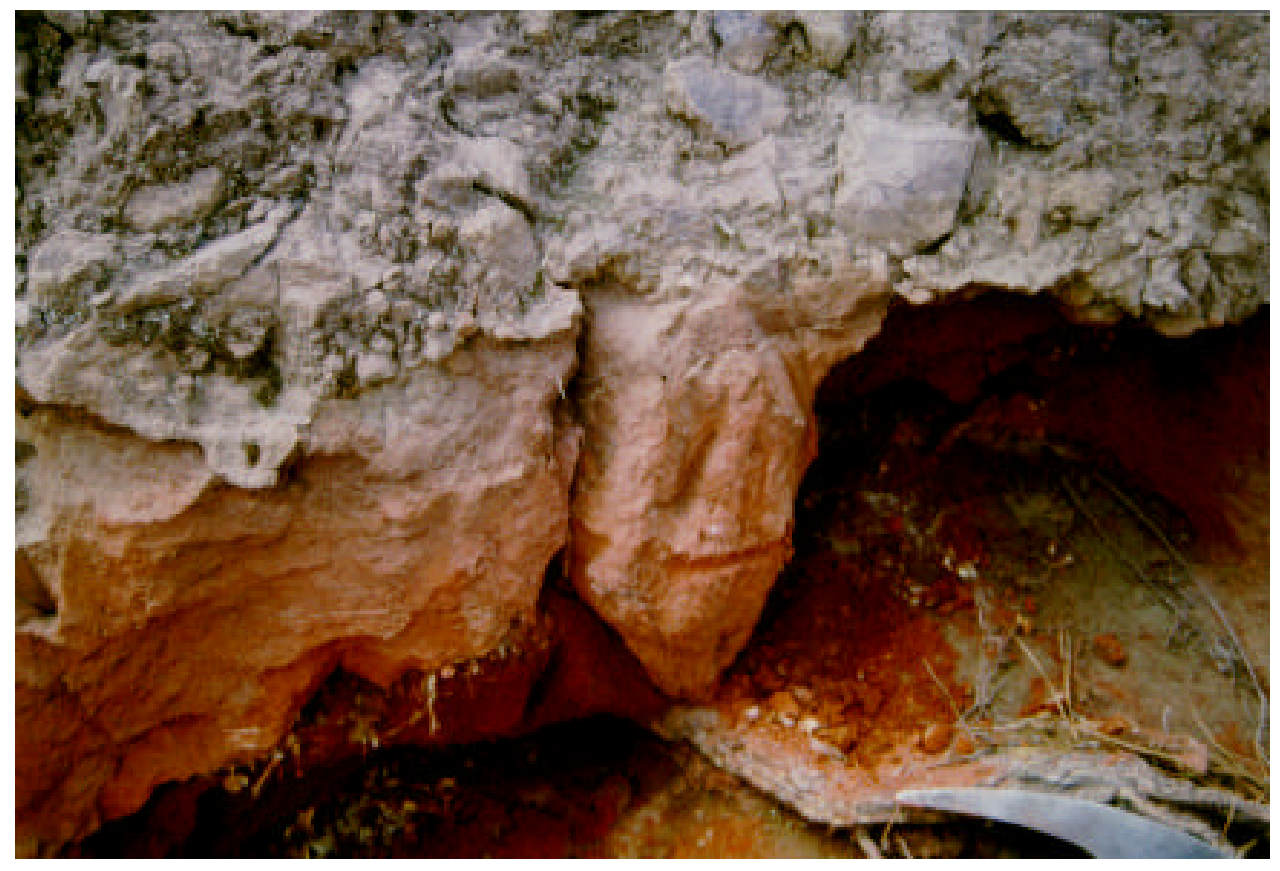

Figure 4.3: Outcrop of residual soil sample RS1. The reddish soil layer is covered and baked by a thick lava flow.

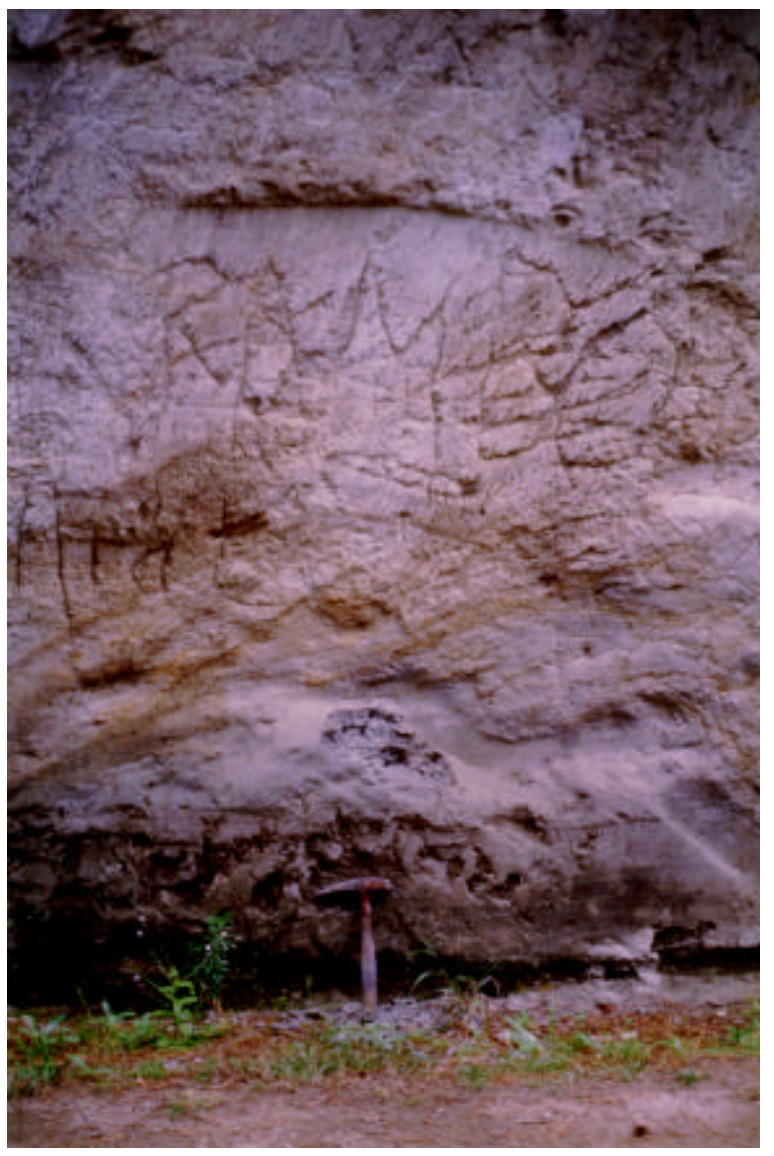

Figure 4.4: Outcrop of residual soil sample RS2. The greyish soil layer is located in one of the most humid parts of the island. 


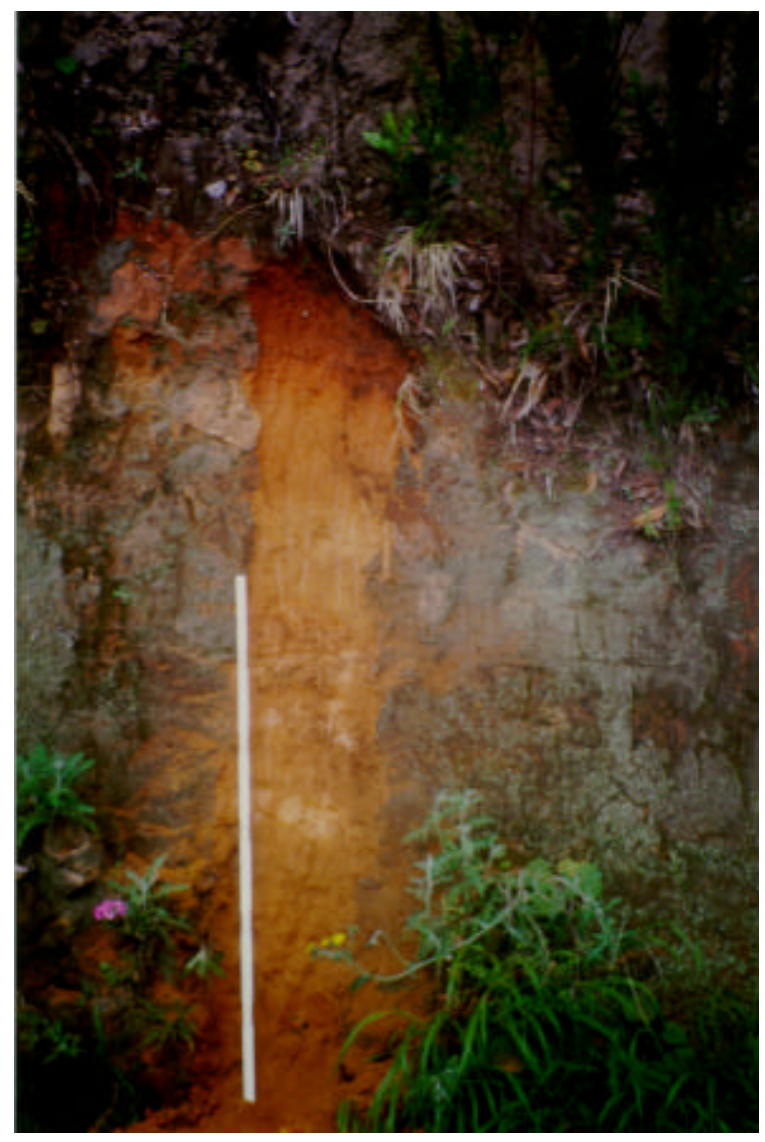

Figure 4.5: Outcrop of residual soil sample RS3. The reddish soil layer is located above the yellow phonolitic pyroclastic deposit and covered by a lava flow. The alteration from the top to the bottom is clearly visible due to the change of colour (reddish for strongly altered and yellow for slightly altered phonolitic pyroclastic deposit).

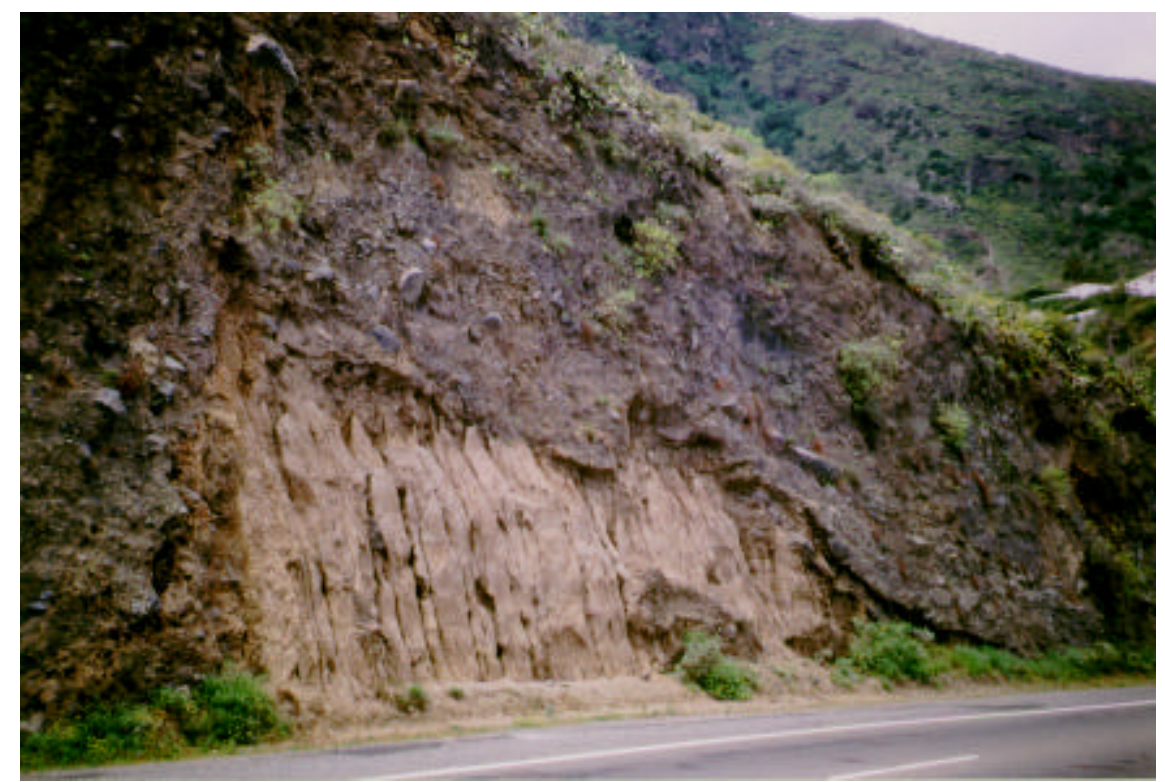

Figure 4.6: Location of the samples of the valley filling breccia EL1 and EL2. The deposit has been generated by a postslide small scale landslide event. EL1 has been taken from the large block of a phonolitic pyroclastic deposit situated in the middle of the deposit. EL2 has been sampled from the matrix of the deposit. 


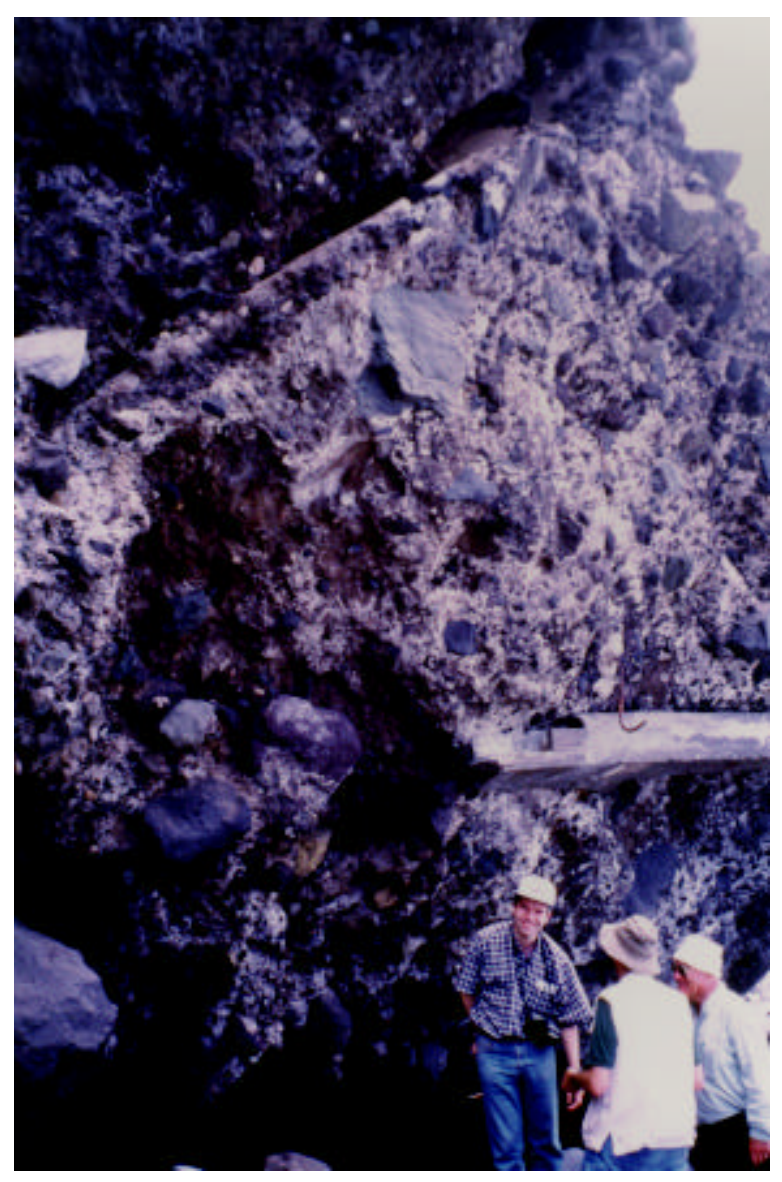

Figure 4.7: Outcrop of the valley filling breccia MO1 at Playa de Fajana. The sample has been taken from the matrix of the breccia. The white colour of the deposits are salt minerals due to evaporation of sea water.

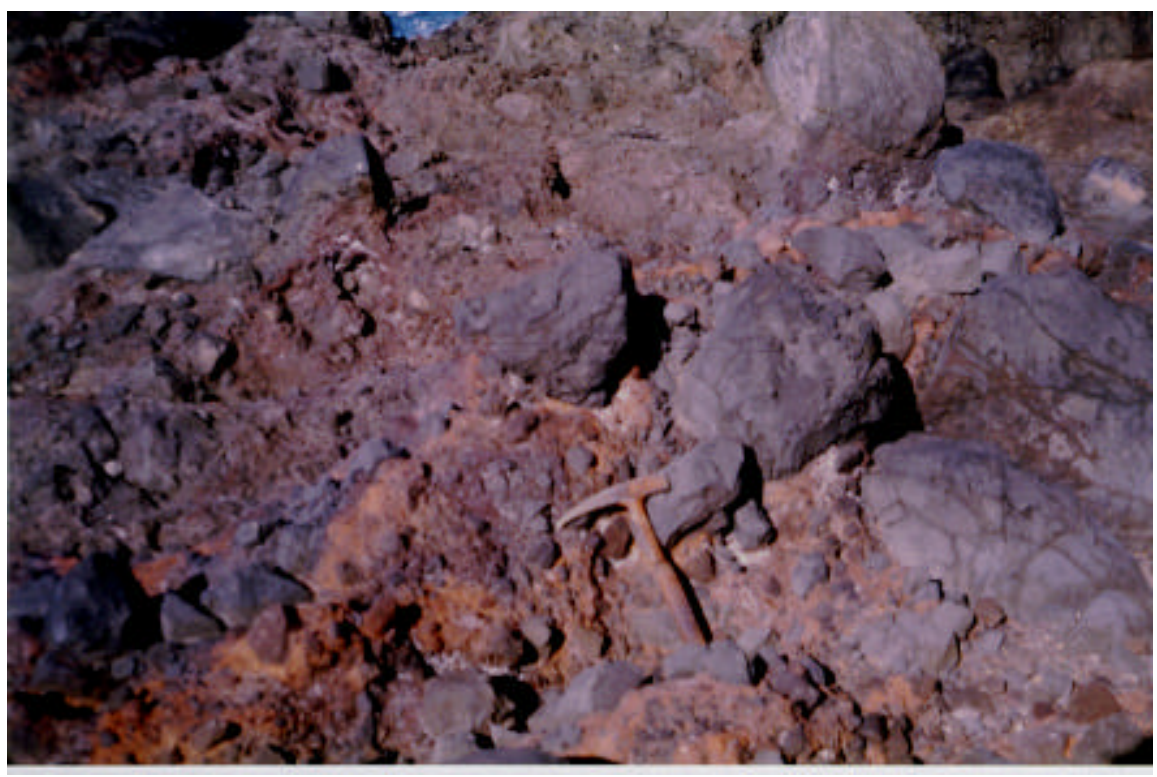

Figure 4.8: Outcrop of the valley filling breccia MO2 at Punta el Gundastés. The sample has been taken from the reddish matrix in the front of the photo. 


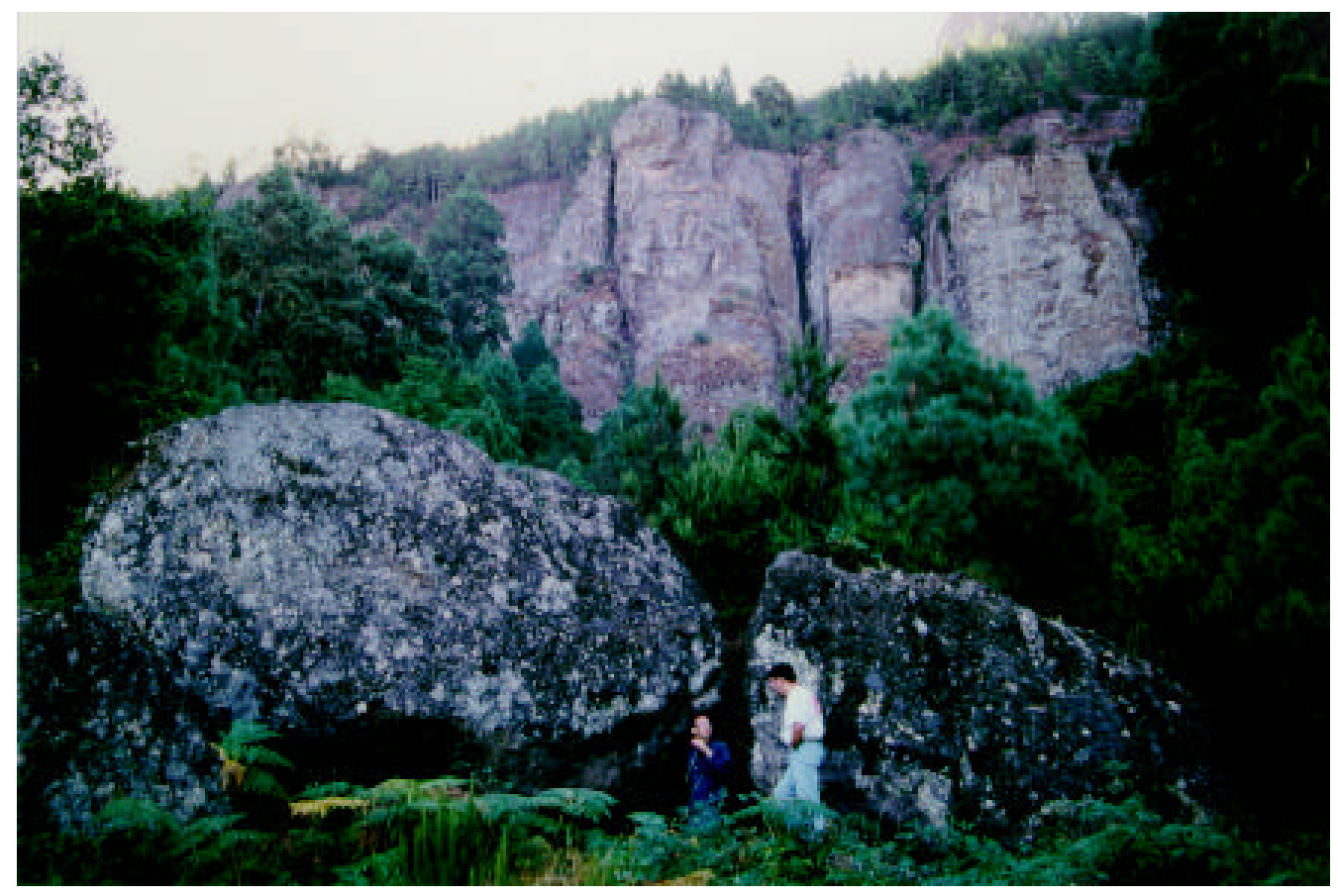

Figure 4.9: Location of the breccia sample BR1 near Los Organos. The sample has been taken from the block fallen out of the vertical wall.

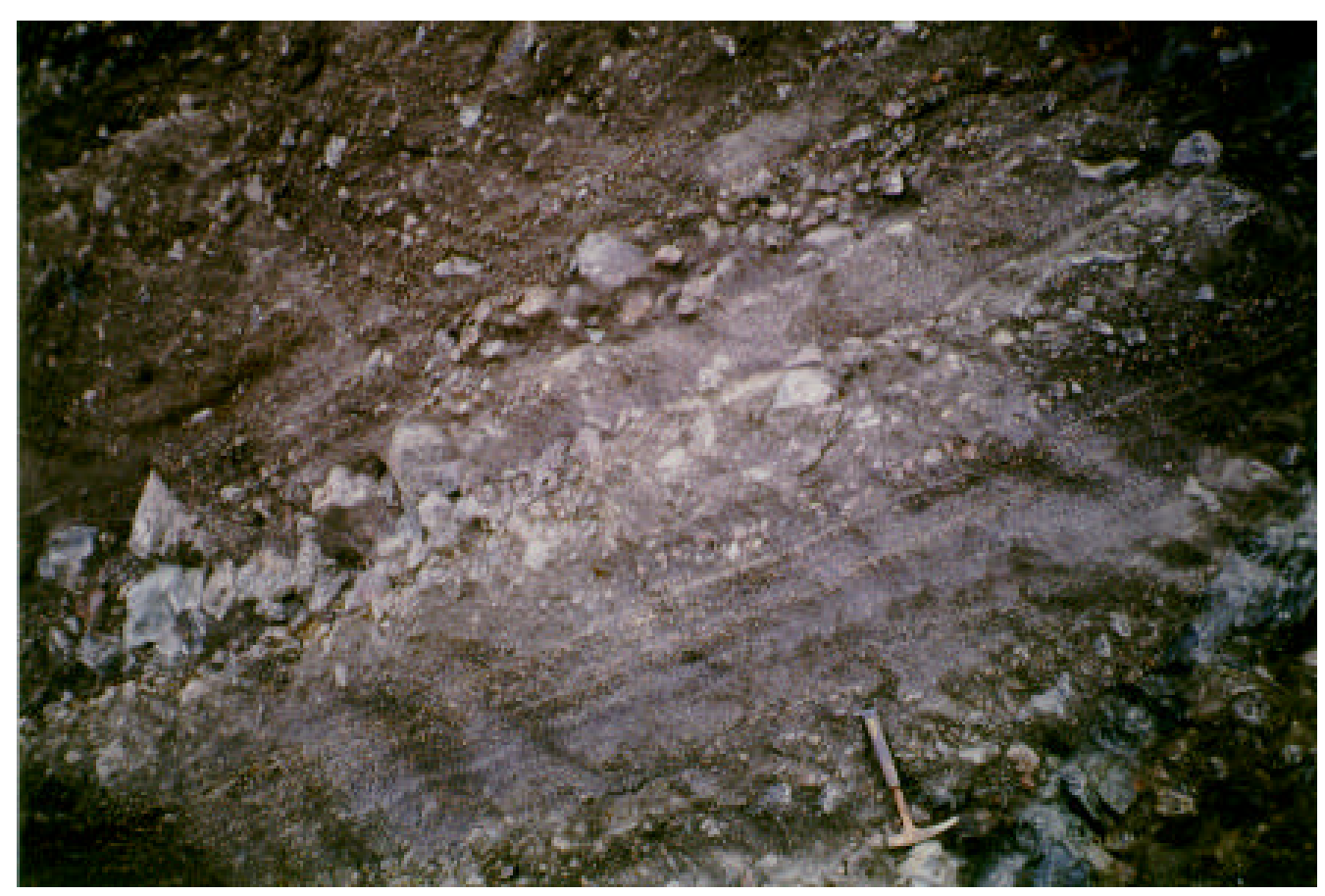

Figure 4.10: Outcrop of breccia sample BR2 near La Ladera. 


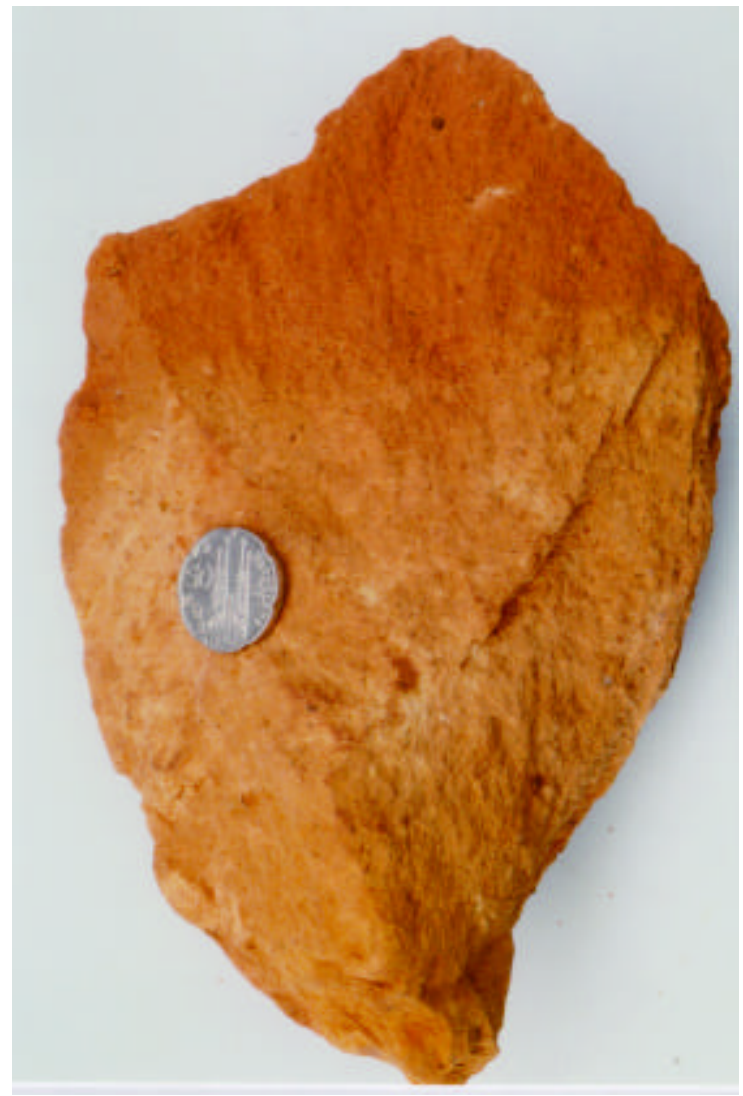

Figure 4.11: Hand sample BI1 representing a baked phonolitic pyroclastic deposit. BI1t has been taken from the upper, reddish part of the sample with a maximum thermal alteration. BI1b has been taken from the lower part with minor effects of thermal alteration.

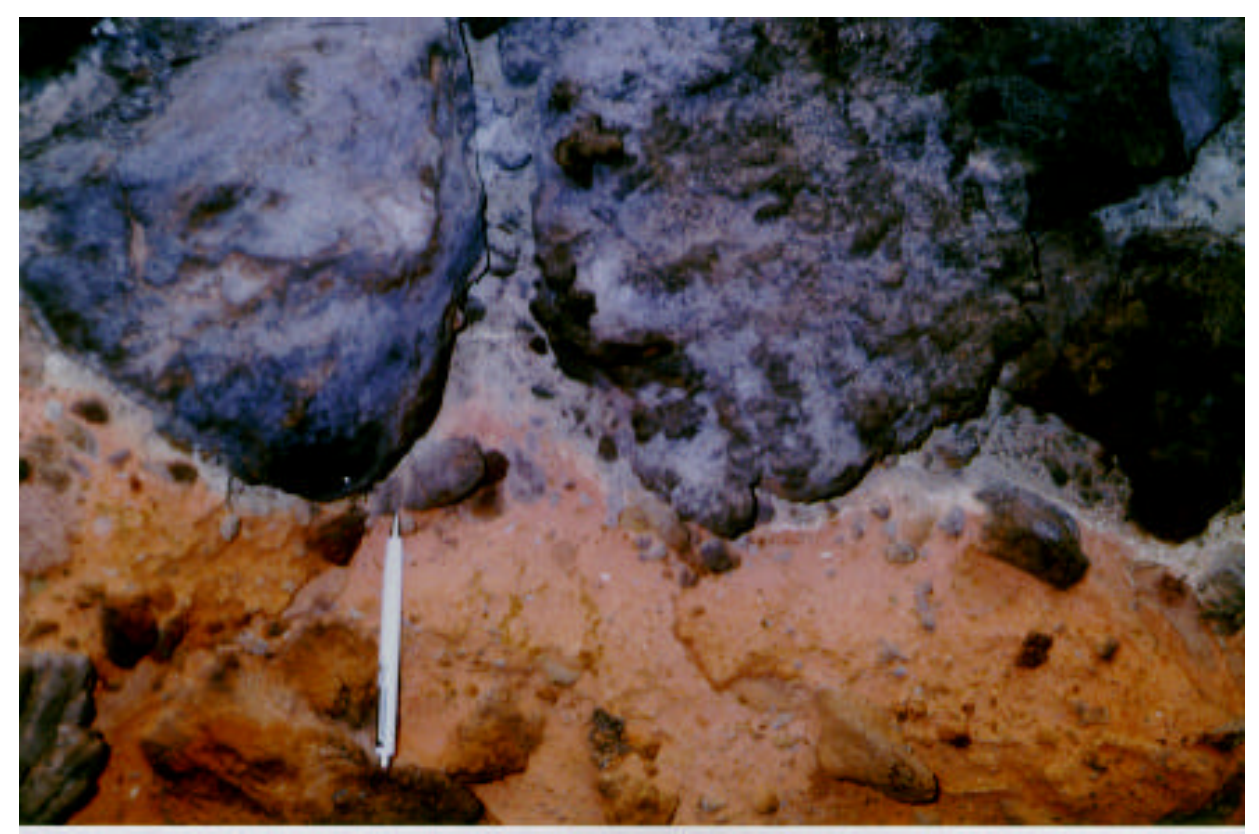

Figure 4.12: Photograph indicating the contact between the phonolitic pyroclastic deposit and the upper lava flow. Sample BI2 has been taken from the grey - yellow part at the top of the sample. 


\subsubsection{Analysis of mineralogy, chemistry and microstructure}

Two different methods have been applied to determine the mineralogical and whole-rock composition of the fine fraction of the twelve samples. First, using energy dispersive X-ray fluorescence (XRF) the chemistry of the samples has been analysed qualitatively and quantitatively. Second, X-ray diffraction technique (XRD) has been employed to characterise the mineralogy of the samples and to determine their mineral phases present.

$\mathrm{X}$-ray fluorescence is nowadays the analytical technique most widely used in the determination of the trace and major element chemistry of soil and rock samples. The major elements are the elements which predominate in any rock analysis and theirs concentrations are given as a weight per cent [wt \%] of the oxide. The trace elements are defined as those elements which are present at less than the $0.1 \%$ level and theirs concentrations are expressed in parts per million [ppm] of the element. Using XRF, up to 80 elements over a wide range of sensitivities and in concentrations from as low as a few parts per million to $100 \%$ can be analysed. It is a rapid method and large numbers of precise analyses can be made in a relative short time. XRF is capable of measuring all elements from beryllium (atomic number 4) to uranium (atomic number 92). Different corrections have to be made for instrumental errors and for the effects of sample composition on x-rays intensities. Alternatively, the x-rays may be detected without being separated into different sequences, using a detector, which measures energy as well as intensity of the x-rays. The major elements are determined using one $\mathrm{x}$-ray tube whereas trace elements are determined using one or more different tubes. On the other hand, X-ray diffraction technique is a versatile, non-destructive analytical method for identification and quantitative determination of the various crystalline forms, known as mineral 'phases', of compounds present in solid materials and powders. Applying XRD the results can be illustrated graphically by diffraction pattern or 'diffractograms'. The identification of the mineral phases is achieved by comparing the x-ray diffraction pattern obtained from the analysed sample with an internationally recognised database containing reference patterns for more than 70,000 mineral phases. XRF and XRD have been carried out for the matrix of the samples, which has been remoulded and air-dried in order to analyse the dry powder.

Additionally, the microstructure of the residual soil sample RS1 has been analysed using an environmental scanning electron microscope (ESEM). Microstructure has been proposed as an important factor in the strength of clay-rich sedimentary soils and preliminary studies of pyroclastic materials seems to confirm this idea (Moon, 1993b; Rippa, 1997). In contrast to the macrostructure of the soil, which can be observed without magnification, the microstructure reveals information about cementation and pea contact arrangements. Therefore, ESEM technique can lead to a better understanding of the engineering properties and is especially useful for bonded soil. In this study, two different specimens of the residual soil RS1 have been analysed using ESEM: First, a specimen of the undisturbed soil with an intact structure, and then a specimen of the soil with a broken bonding after carrying out a triaxial test with large confining stress. The aim of the ESEM analysis has been a general comparison of the microstructure and the bonding of the two samples rather than the recognition of specific minerals or a detailed study of the microstructural patterns.

\subsubsection{Geotechnical analysis}

In this study the geotechnical behaviour of the residual soil sample RS1 has been analysed comprehensively, while the soil characterisation has been carried out for the samples RS2 and RS3. After characterising and classifying the soil, standard laboratory tests including consolidation tests, direct shear tests, ring shear tests and triaxial tests have been carried out to determine the mechanical properties of the soil. An important topic during this research has been the study of the bonding effect of the residual soil. The mechanical behaviour of residual soils depends not just on the initial porosity and stress history, but mainly on the bonds between particles. The influence of bonding can only be detected 
if a set of tests under different values of vertical stress (direct shear test) and confining stress (triaxial test) is carried out for the same soil sample. Moreover, the comparison between undisturbed and remoulded specimens may improve the understanding of the bonding effect on the mechanical behaviour of the soil. Therefore, the effect of the bonds on the stress-strain behaviour has been studied using consolidation tests, direct shear tests and triaxial tests on undisturbed and remoulded specimens.

\section{Soil characterisation}

At the beginning of a geotechnical study, the general characteristics of the sample must be analysed to describe and classify the soil. The density of the soil, the density of the solids, the water content, the porosity, the void ratio, the permeability, the particle size distribution and the Atterberg limits are common properties characterising soils. All of these parameters have been obtained for the RS1-sample. Additionally the particle size distributions have been determined for the samples RS2 and RS3, respectively.

First, the natural density and the water content of the soil mass have been measured. Then, using the volume of the sample the dry density and the void ratio have been calculated. Moreover, the specific gravity of the solids has been determined during this step. Second, the particle size distribution for the coarse-grained part of the soil has been obtained performing a sieve analysis. A sample of dry soil has been mechanically shaken through a series of sieves and the percentage retained or passed through each sieve has been weighted. This analysis is impracticable for fine-grained soil particles, which has been separated by sedimentation. A first estimate of the permeability has been calculated using data of the particle size distribution. Moreover, the Atterberg limits have been determined using the fine fraction of the soil sample. The liquid limit has been analysed by the Casagrande apparatus and the plastic limit by rolling the soil into a pencil shape. Finally, the soil has been classified by the Unified Soil Classification System, USCS, which was adopted in 1969 by the American Society for Testing and Materials as a Standard Method for Classification of Soils for Engineering Purposes (Wagner, 1957).

\section{Consolidation tests}

In the consolidation tests (also called oedometer tests) stress is applied to the sample along the vertical axis. Only vertical strain is permitted and therefore the axial strain is equal to the volumetric strain. The major difficulty with the oedometer test is the side friction, which can be minimised by an appropriate thickness-diameter ratio. This should be kept as small as practicable, usually $1: 3$ to $1: 4$. The consolidation tests can be used to obtain values of the primary and secondary compression. Till the primary compression is reached (normally in less than one hour) dissipation of the pore water occurs and afterwards, during the secondary compression, the vertical deformation is caused by the timedependent stress-strain properties of the mineral skeleton. Results of the primary compression can be applied to the consolidation theory and a vertical strain value can be determined.

In this study, information refering to the consolidation of the soil has been obtained from two different types of data: 1) Data from the oedometer tests carried out in the standard oedometer apparatus; and, 2) data acquired during the consolidation phase of the direct shear tests. All the specimens, that have been undergone consolidation tests, are illustrated in Table 4.2 describing the size of the specimen (illustrated by the height, $\mathrm{H}_{\text {spec }}$, and the diameter, $\mathrm{D}_{\text {spec }}$ ), the apparatus and the vertical stresses applied. A range of vertical stress is given for the specimens that have undergone reloading.

Three oedometer tests in the standard oedometer apparatus have been performed using undisturbed specimens of the RS1-sample. The specimens have been prepared with a diameter of $50 \mathrm{~mm}$ and a initial height of $20 \mathrm{~mm}$. The loading history of the three specimens has been the same, but the initial time of soaking has been changed for each specimen. At last, the stresses applied have been defined as $10 \mathrm{kPa}-20 \mathrm{kPa}-50 \mathrm{kPa}-100 \mathrm{kPa}-200 \mathrm{kPa}-400 \mathrm{kPa}-800 \mathrm{kPa}-1600 \mathrm{kPa}$ for the loading phase and $800 \mathrm{kPa}-400 \mathrm{kPa}$ for the unloading phase. One sample (RS1-O-UD2) has been loaded up to 2400 $\mathrm{kPa}$. Information about the effect of the water has been obtained from different times of saturation. The specimen RS1-O-UD1 has been saturated from the beginning, the specimen RS1-O-UD2 at $100 \mathrm{kPa}$ 
and the specimen RS1-O-UD3 at $400 \mathrm{kPa}$. To analyse the bonding effect of the undisturbed specimens an additional oedometer test has been carried out for a remoulded, soaked specimen (RS1-O-RM1). This specimen has been prepared so, that the void ratio and moisture content of the sample have been the same as the one of sample RS1-O-UD1. The remoulded specimen has been undergone the same loading history as the undisturbed one. Additional information of the consolidation behaviour has been obtained from the consolidation phase during direct shear tests before applying the horizontal shear stress. Especially, data on the stress-strain regime related to high vertical stresses have been achieved during the consolidation phase of the direct shear tests. The cylindrically shaped, undisturbed specimens have been analysed inside the small shear apparatus, called SHEAR1, applying vertical stresses up to $600 \mathrm{kPa}$ and in the large shear apparatus, called SHEAR2, applying vertical stresses up to $15593 \mathrm{kPa}$.

In addition, the behaviour of the second compression of the soil has been studied by a long lasting consolidation test, also called creep test. The creep test has been performed on a undisturbed specimen with a high vertical stress of $2.598 \mathrm{MPa}$ inside the SHEAR2 apparatus (specimen RS1-O-UDVI).

Table 4.2: Consolidation tests carried out on the RS1 sample

\begin{tabular}{|l|c|c|c|}
\hline specimen & $\begin{array}{c}\mathrm{H}_{\text {spec }}-\mathrm{D}_{\text {spec }} \\
{[\mathrm{cm}]}\end{array}$ & $\begin{array}{c}\text { vertical stress applied } \\
{[\mathrm{kPa}]}\end{array}$ & type of apparatus \\
\hline \hline RS1-O-UD1 & $2.0-5.0$ & $10-1600$ & Oedometer \\
\hline RS1-O-UD2 & $2.0-5.0$ & $10-2400$ & Oedometer \\
\hline RS1-O-UD3 & $2.0-5.0$ & $5-1600$ & Oedometer \\
\hline RS1-O-RM1 & $2.0-5.0$ & $10-1600$ & Oedometer \\
\hline RS1-D-UD0 & $2.6-5.0$ & $200-600$ & SHEAR1 \\
\hline RS1-D-UDI & $3.2-7.0$ & 5197 & SHEAR2 \\
\hline RS1-D-UDII & $3.7-7.0$ & 5197 & SHEAR2 \\
\hline RS1-D-UDIII & $3.7-7.0$ & 10395 & SHEAR2 \\
\hline RS1-D-UDIV & $3.7-7.0$ & 15593 & SHEAR2 \\
\hline RS1-D-UDV & $3.6-7.0$ & $2598-10395$ & SHEAR2 \\
\hline RS1-D-UDVI & $3.2-7.0$ & 2598 & SHEAR2 (creep) \\
\hline RS1-D-RM1 & $3.2-7.0$ & 5197 & SHEAR2 \\
\hline RS1-D-RM2 & $3.2-7.0$ & 10394 & SHEAR2 \\
\hline RS1-D-RM3 & $3.7-7.0$ & 15591 & SHEAR2 \\
\hline
\end{tabular}

\section{Direct shear test}

In the direct shear test the sample is located in a split cylindrical metal box. The upper or lower part of the box can be displaced, whereas the other part is fixed. At the upper and lower ends porous stones allow drainage of the sample during the test. A vertical load is transferred to the sample by means of a loading plate on top of the upper porous stone. This load generates the normal stress for which the shear strength is to be measured. During the test, the complete sample is submerged under water.

The tests carried out in this study are called consolidated-drained shear tests in order to obtain the drained shear strength of the soil. The word 'consolidated' defines the consolidation at the start of the test and the word 'drained' means that the excess pore pressure is equal to zero at all times. The tests run at a slow rate to permit the dissipation of the excess pore pressure. Normally, the displacement rate has been maintained constant during the whole test with values between $0.05 \mathrm{~mm} / \mathrm{min}$ and 0.005 $\mathrm{mm} / \mathrm{min}$. The direct shear test has been carried out in three steps: First, after trimming an undisturbed specimen from the block sample, it has been installed in the shear apparatus and soaked during one day. Second, a normal stress has been applied to the specimen and the consolidation data have been collected during the following day. Third, the specimen has been sheared to failure and the horizontal/vertical displacements as well as the shear stress has been measured. 
This work has analysed the shear strengths of the soil using two different shear box apparatuses. A small one for normal stress up to $600 \mathrm{kPa}$ (hereafter called SHEAR1) and a large one for normal stress up to $15.59 \mathrm{MPa}$ (hereafter called SHEAR2). This unusual high value is necessary analysing large volcanic landslides, since their overburden loading exceeds the one of shallow slides by at least two magnitudes and refers to a different part of the stress-strength envelope in the Mohr-Coulomb criterion. The SHEAR1 apparatus is an equipment from Mecánica Científica and SHEAR2 is a modification of a standard equipment designed and built during this study. Photographs of the two apparatuses are shown in Figure 4.13 and Figure 4.14, respectively. In the SHEAR1 apparatus shear tests have been carried out applying three different normal stresses $(200,400$ and $600 \mathrm{kPa})$. The three shear tests have been realised for an undisturbed specimen. First, the peak shear strength and the constant volume shear strength have been obtained applying the horizontal stress in one direction. Then, the specimen has been cycled to additional displacement and sheared again to provide a measurement of the residual shear strength (applying the horizontal stress in the other direction and returning the sheared part of the specimen to the initial position). This procedure has been repeated for the two other stresses using the same specimen.

Additional direct shear tests have been carried out in the larger shear box apparatus (SHEAR2) applying normal stresses ranging from 2.598 MPa to $15.591 \mathrm{MPa}$. Due to the large vertical loading and the horizontal displacement limit of the shear box only the measures of the first run, peak shear strength have produced realistic values using SHEAR2. So, there does not exist neither constant volume shear strength nor residual shear strength values. In order to estimate the residual shear strength for high normal stresses some tests have been carried out with remoulded specimens of fine soil particles. The remoulded specimen has contained only fine particles with diameters smaller than $0.425 \mathrm{~mm}$ passed through the standard sieve No. 40 (ASTM series). Finally, three specimens have been prepared by soaking and compacting the fine particles up to the desired natural density.

Table 4.3: Direct shear tests carried out on the RS1-sample.

\begin{tabular}{|c|c|c|c|}
\hline specimen & $\begin{array}{c}\text { applied normal stress } \\
{[\mathrm{kPa}]}\end{array}$ & type shear test & type of apparatus \\
\hline \hline \multirow{3}{*}{ RS1-D-UD0 } & 200 & first run and recycled & SHEAR1 \\
\cline { 2 - 4 } & 400 & first run and recycled & SHEAR1 \\
\cline { 2 - 4 } & 600 & first run and recycled & SHEAR1 \\
\hline \multirow{2}{*}{ RS1-U-UDI } & 5197 & first run and recycled & SHEAR2 \\
\cline { 2 - 4 } & 10394 & first run and recycled & SHEAR2 \\
\cline { 2 - 4 } & 10394 & first run and recycled & SHEAR2 \\
\hline RS1-D-UDII & 5197 & first run and recycled & SHEAR2 \\
\cline { 2 - 4 } & 10394 & first run and recycled & SHEAR2 \\
\hline RS1-D-UDIII & 10394 & first run failure & SHEAR2 \\
\hline RS1-D-UDIV & 15591 & first run failure & SHEAR2 \\
\hline RS1-D-UDV & 10394 & first run failure & SHEAR2 \\
\hline RS1-D-UDVI & 2598 & first run failure & SHEAR2 \\
\hline RS1-D-RMI & 5197 & first run failure & SHEAR2 \\
\hline RS1-D-RMII & 10394 & first run failure & SHEAR2 \\
\hline RS1-D-RMIII & 15591 & first run failure & SHEAR2 \\
\hline
\end{tabular}




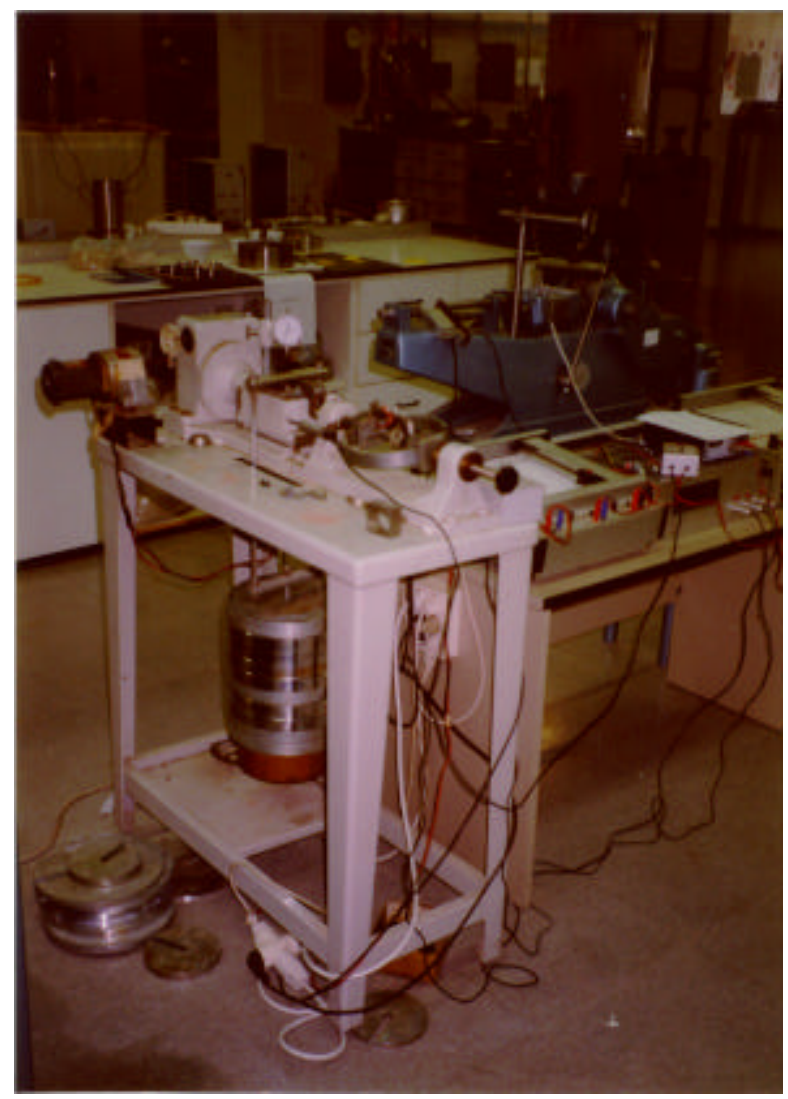

Figure 4.13: Photograph of the small shear test apparatus SHEAR1 used during the geotechnical study.

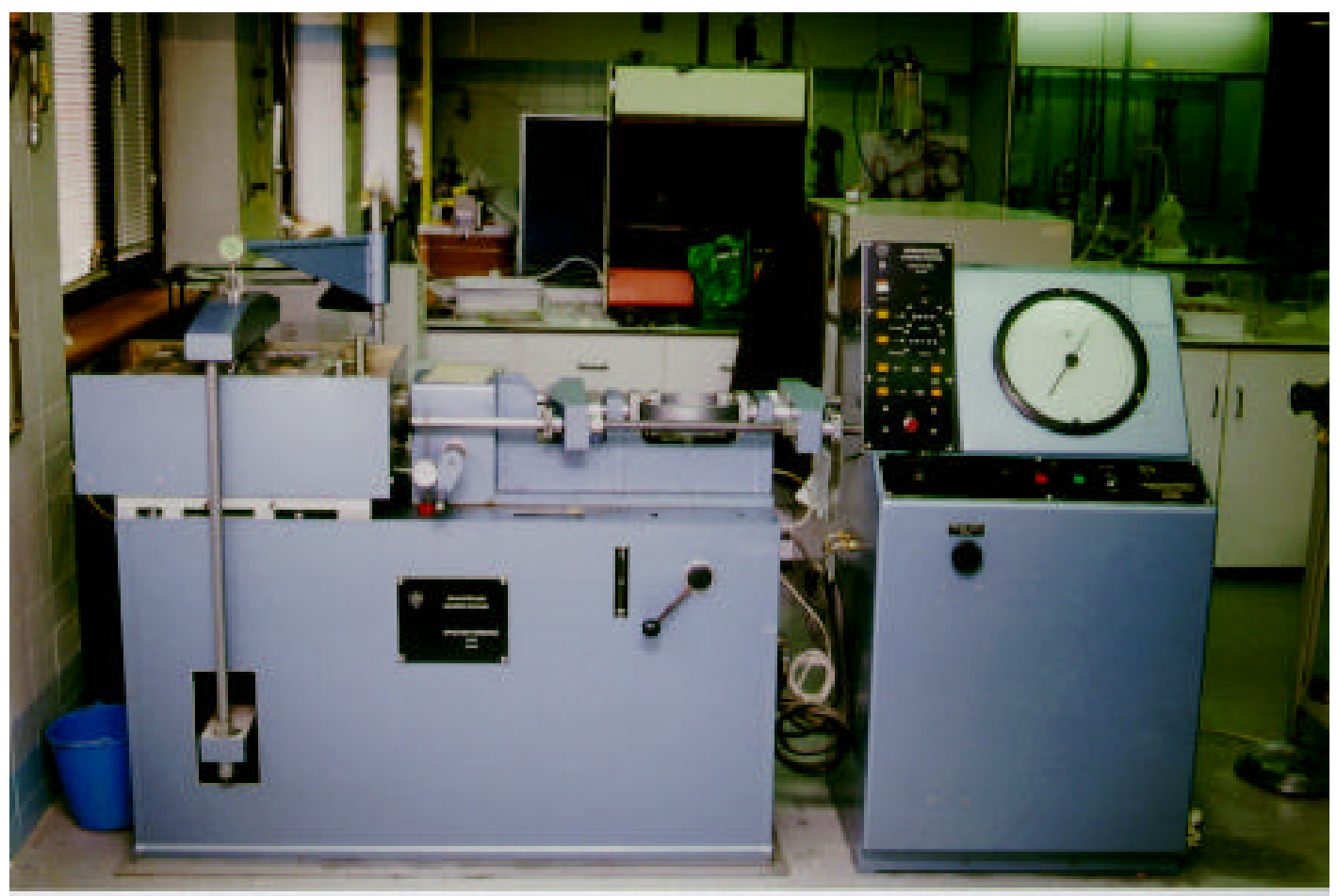

Figure 4.14: Photograph of the large shear test apparatus SHEAR2 used during the geotechnical study. 


\section{Ring shear test}

The ring shear test is similar to the direct shear test with the advantage that prolonged deformation will not cause a reduction of the contact area between the upper and lower parts of the specimen as it occurs in the direct shear test. Hence, the ring shear test is a common apparatus to measure the residual strength after large displacements. The apparatus used in this study is a Bromhead type ring shear apparatus from Whykeham Farrance Engineering Ltd. The specimens analysed have been remoulded fines of the RS1 sample passing through sieve No. 40 with a diameter smaller than $0.425 \mathrm{~mm}$. The ring shear tests have been carried out in three steps: First, the remoulded specimen has been installed in the apparatus and soaked during one day. Second, a normal stress has been applied to the specimen and third, the specimen has been sheared by a slow displacement rate of about $0.048 \mathrm{~mm} / \mathrm{min}$. The conditions during the tests have been maintained drained. In total five ring shear tests have been carried out applying normal stresses ranging form 200 to $600 \mathrm{kPa}$ (Table 4.4).

Table 4.4: Ring shear tests carried out on the RS1 sample

\begin{tabular}{|c|c|}
\hline specimen & $\begin{array}{c}\text { applied normal stress } \\
{[\mathrm{kPa}]}\end{array}$ \\
\hline \hline RS1-R-RM1 & 300 \\
\hline RS1-R-RM2 & 400 \\
\hline RS1-R-RM3 & 200 \\
\hline RS1-R-RM4 & 500 \\
\hline RS1-R-RM5 & 600 \\
\hline
\end{tabular}

\section{Triaxial test}

In comparison to the direct shear test and the ring shear test, the triaxial test allows to measure the stress-strain behaviour in relation to pore pressure changes and therefore to effective stresses. During the triaxial test the cylindrical specimen is encased in a rubber membrane and placed in a water-filled pressure cell. The ends of the specimen are connected in such a way that during drained tests the volume of the escaped water can be measured and pore pressure can be determined in undrained tests. The cell pressure provides the minor principal stress, $\sigma_{3}$, and the force imposed by the loading ram combined with the cell pressure produces the major principal stress, $\sigma_{1}$. After saturation of the soil specimen, the specimen is first subjected to a confined pressure. Then, in the second phase of the test the axial stress is increased until the specimen fails. Using the convention of Lambe (Lambe and Whitman, 1979), all the plots in the section of the results include mean effective stresses, p', and deviatoric stresses, q, defined as

$$
\begin{aligned}
& \mathrm{p}=\frac{\left(\sigma_{1}+\sigma_{3}\right)}{2} \\
& \mathrm{p}^{\prime}=\frac{\left(\sigma_{1}+\sigma_{3}\right)}{2}-\mathrm{u} \\
& \mathrm{q}=\frac{\left(\sigma_{1}-\sigma_{3}\right)}{2}
\end{aligned}
$$

, where $\mathrm{u}$ is the pore water pressure in the specimen. Two different apparatuses have been used in this study: 1) A small apparatus for cell pressures up to $1700 \mathrm{kPa}$ (hereafter called TRIAX1) which is known as standard GDS stress-path system including a Bishop-Wesley hydraulic cell with two GDS 
digital hydraulic actuators; and, 2) a large apparatus for cell pressures up to $5000 \mathrm{kPa}$ (hereafter called TRIAX2) which has been designed and built during this study. Photographs of both apparatuses are shown in Figure 4.15 and Figure 4.16, respectively.

Two types of tests have been carried out in this study. On the one hand, the soil has been analysed by consolidated-undrained tests (abbreviated CU-tests) in order to obtain the undrained shear strength of the soil as well as the increase of pore water pressure in the specimen. On the other hand, consolidateddrained tests (abbreviated CD-tests) have been carried out in order to achieve the drained shear strength as well as the volumetric strain behaviour of the soil during drained failure.

For the size of the undisturbed and cylindrical specimens have been selected the common dimensions of $38 \mathrm{~mm}$ in diameter and $76 \mathrm{~mm}$ in length using the TRIAX1 apparatus and $50 \mathrm{~mm}$ in diameter and $100 \mathrm{~mm}$ in length using the TRIAX2 apparatus. After saturation and measurements of the permeability using back-pressure technique and a constant axial flow rate, the soil specimen has been consolidated with back pressures ranging from $100 \mathrm{kPa}$ to $800 \mathrm{kPa}$ and cell pressures between 800 and 5000 (see Table 4.5). The specimen has been considered saturated when the pore-water pressure B parameter has been equal or greater than 0.95 (Lambe and Whitman, 1979). Applying a low back pressure in TRIAX1 in order to receive a high effective confined stress has required a $\mathrm{CO}_{2}$ - treatment of the specimen before installing into the cell (carried out for specimen RS1-T-CU4). Once consolidated, the specimens have been subjected to drained loading with open back pressure or undrained loading with closed back pressure at a constant deformation rate of about $3 \mathrm{~mm}$ per hour (strain controlled conditions). The tests have generally terminated at a minimum axial strain of about $16 \%$ for undrained tests and of $20 \%$ for drained tests. Due to the large deformations, all results refering to the stresses and strengths include the correction of the failing area.

Table 4.5: Test conditions and type of apparatus during the triaxial tests

\begin{tabular}{|c|c|c|c|c|c|}
\hline specimen & Test & $\begin{array}{c}\text { cell pressure } \\
{[\mathrm{kPa}]}\end{array}$ & $\begin{array}{c}\text { back pressure } \\
{[\mathrm{kPa}]}\end{array}$ & $\begin{array}{c}\text { effective confining } \\
\text { stress } \\
{[\mathrm{kPa}]}\end{array}$ & type of apparatus \\
\hline \hline RS1-T-CU1 & $\mathrm{CU}$ & 1100 & 500 & $600(588)^{*}$ & TRIAX1 \\
\hline RS1-T-CU1r & $\mathrm{CU}$ & 1100 & 500 & 600 & TRIAX1 \\
\hline RS1-T-CU2 & $\mathrm{CU}$ & 1200 & 300 & $900(851)^{*}$ & TRIAX1 \\
\hline RS1-T-CU3 & $\mathrm{CU}$ & 1100 & 800 & 300 & TRIAX1 \\
\hline RS1-T-CU3r & $\mathrm{CU}$ & 1100 & 800 & 300 & TRIAX1 \\
\hline RS1-T-CU4 & $\mathrm{CU}$ & 1650 & 100 & 1550 & TRIAX1 \\
\hline RS1-T-CUI & $\mathrm{CU}$ & 4000 & 500 & 3500 & TRIAX2 \\
\hline RS1-T-CUIr & $\mathrm{CU}$ & 4000 & 500 & 3500 & TRIAX2 \\
\hline RS1-T-CUII & $\mathrm{CU}$ & 5000 & 500 & 4500 & TRIAX2 \\
\hline RS1-T-CD1 & $\mathrm{CD}$ & 800 & 500 & 300 & TRIAX1 \\
\hline RS1-T-CD2 & $\mathrm{CD}$ & 1400 & 500 & 900 & TRIAX1 \\
\hline RS1-T-CD3 & $\mathrm{CD}$ & 1650 & 100 & 1550 & TRIAX1 \\
\hline RS1-T-CD4 & $\mathrm{CD}$ & 1100 & 500 & 600 & TRIAX1 \\
\hline RS1-T-CDI & $\mathrm{CD}$ & 4000 & 500 & 3500 & TRIAX1 \\
\hline
\end{tabular}

exact measured values are in brackets 


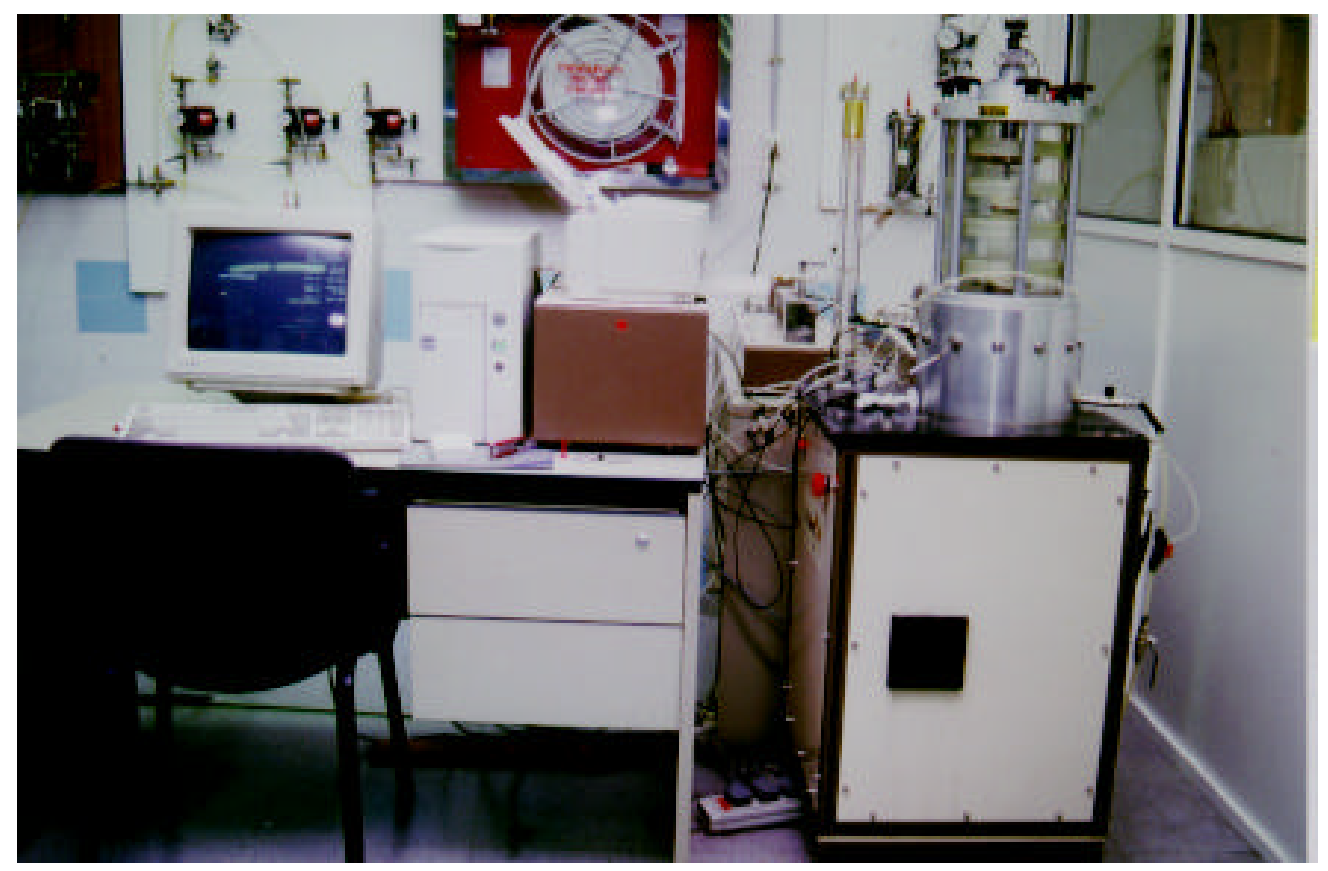

Figure 4.15: Triaxial test apparatus TRIAX1 for cell pressure up to $1700 \mathrm{kPa}$.

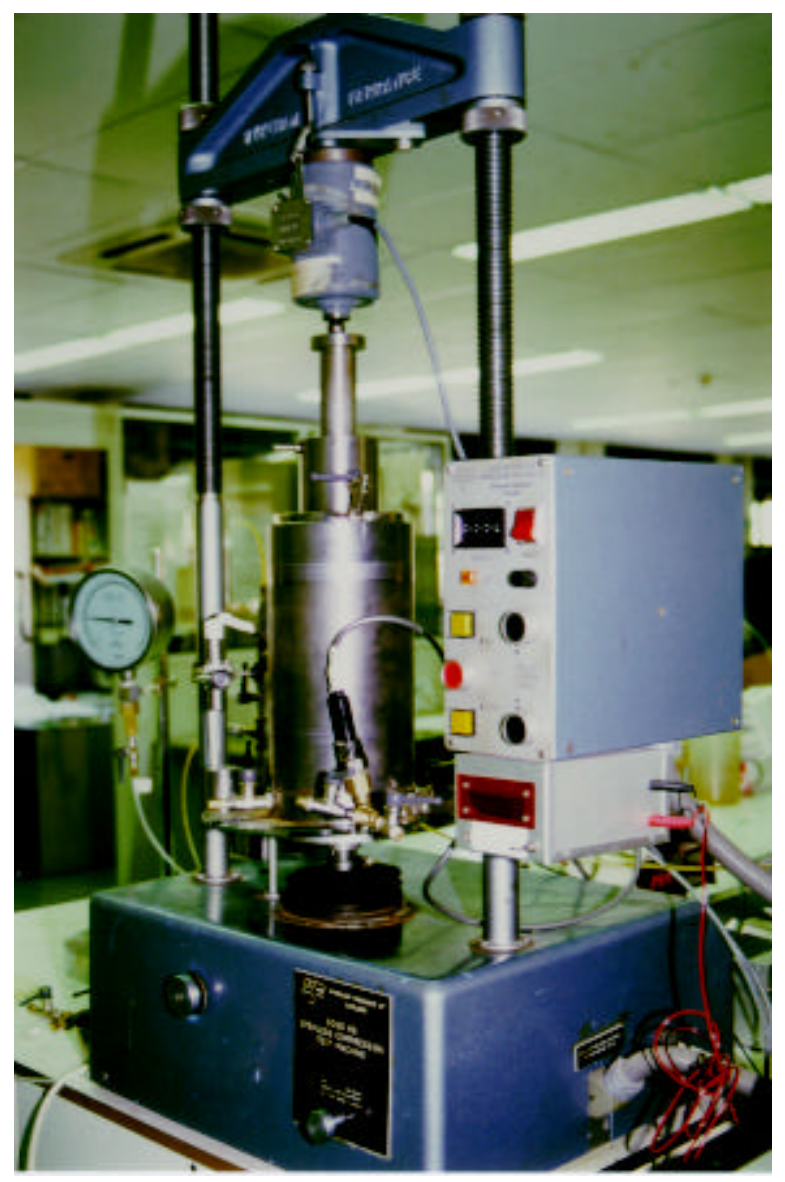

Figure 4.16: Triaxial cell of TRIAX2 apparatus for cell pressure up to $5000 \mathrm{kPa}$. 


\subsection{Results}

\subsubsection{Analysis of mineralogy, chemistry and microstructure}

\section{Mineralogical and chemical analysis}

The twelve samples have been analysed first using the energy dispersive X-ray fluorescence in order to determine the sample chemistry and second using the X-ray diffraction technique to characterise the mineralogy of the samples. The results of the X-ray fluorescence analysis are listed below indicating the contents of selected major elements (Table 4.6) and selected trace elements (Table 4.7) of the twelve samples.

Table 4.6: Contents of selected major elements (units in wt \%).

\begin{tabular}{|c|c|c|c|c|c|c|c|}
\hline Sample & $\mathrm{SiO}_{2}$ & $\mathrm{Fe}_{2} \mathrm{O}_{3}$ & $\mathrm{CaO}$ & $\mathrm{TiO}_{2}$ & $\mathrm{~K}_{2} \mathrm{O}$ & $\mathrm{Cl}$ & $\mathrm{Al}_{2} \mathrm{O}_{3}$ \\
\hline \hline \multirow{2}{*}{$\mathrm{R} 1$} & 44.6 & 14.45 & 4.37 & 2.92 & 0.71 & - & - \\
\cline { 2 - 8 } & 42.8 & 15.80 & 4.72 & 3.35 & 0.81 & - & - \\
\hline \multirow{2}{*}{$\mathrm{R} 2$} & 42.7 & 15.20 & 1.18 & 3.96 & 0.95 & 0.27 & - \\
\cline { 2 - 8 } & 42.5 & 14.81 & 1.14 & 4.05 & 1.01 & 0.24 & - \\
\hline \multirow{2}{*}{ RS3 } & 45.32 & 14.14 & 1.21 & 3.64 & 1.48 & 0.02 & 24.43 \\
\cline { 2 - 8 } & 45.32 & 14.05 & 1.19 & 3.67 & 1.43 & 0.01 & 24.95 \\
\hline \multirow{2}{*}{ MO2 } & 49.0 & 9.38 & 5.85 & 2.00 & 1.45 & 0.69 & - \\
\cline { 2 - 8 } & 48.8 & 9.70 & 5.94 & 2.12 & 1.53 & 0.63 & - \\
\cline { 2 - 8 } & 48.3 & 6.65 & 3.72 & 1.36 & 1.93 & 2.92 & - \\
\hline \multirow{2}{*}{ BR1 } & 49.5 & 6.68 & 3.60 & 1.36 & 2.08 & 2.80 & - \\
\cline { 2 - 8 } & 44.06 & 13.83 & 7.21 & 3.37 & 0.76 & - & 17.2 \\
\hline \multirow{2}{*}{ BR2 } & 45.24 & 12.24 & 7.77 & 3.08 & 0.9 & - & 17.8 \\
\cline { 2 - 8 } & 45.14 & 11.89 & 7.69 & 3.05 & 0.85 & - & 18.14 \\
\hline \multirow{2}{*}{ EL1 } & 51.98 & 9.22 & 3.6 & 2.12 & 1.78 & 0.16 & 19.41 \\
\cline { 2 - 8 } & 52.14 & 9.18 & 3.22 & 2.08 & 1.71 & 0.18 & 19.17 \\
\hline \multirow{2}{*}{ EL2 } & 47.22 & 6.44 & 0.55 & 1.57 & 0.94 & 0.05 & 27.77 \\
\cline { 2 - 8 } & 46.7 & 6.37 & 0.46 & 1.57 & 0.99 & 0.05 & 25.78 \\
\hline \multirow{2}{*}{ BI1t } & 52.14 & 5.6 & 1.26 & 1.34 & 2.57 & 0.6 & 26.34 \\
\cline { 2 - 8 } & 51.71 & 5.39 & 1.22 & 1.34 & 2.53 & 0.6 & 24.49 \\
\cline { 2 - 8 } & 53.04 & 5.42 & 0.96 & 1.26 & 2.92 & 0.16 & 23.04 \\
\hline \multirow{2}{*}{ BIb } & 52.94 & 5.42 & 1.1 & 1.29 & 2.67 & 0.19 & 19.78 \\
\hline & 58.71 & 4.11 & 1.7 & 1.12 & 3.54 & 0.54 & 19.84 \\
\hline
\end{tabular}


In the following, the twelve samples have been divided into four different groups to simplify the interpretation of the data. The four groups are:

1) residual soils

2) basaltic breccias

3) valley filling breccias

4) phonolitic pyroclastic deposits (including sample RS1, RS2 and RS3)

(including sample BR1 and BR2)

(including sample MO1, MO2 and EL1)

(including sample EL2, BI1b, BI1t and BI2)

The analysis of the major elements of the samples has revealed several interesting points. First, the $\mathrm{SiO}_{2}$ - content is very low for the residual soils formed above phonolitic pyroclastic flow deposits, which have an $\mathrm{SiO}_{2}$ - content usually in the range of $55-65 \%$. The $\mathrm{SiO}_{2}$ - content of the soil group is similar to the one of the basaltic breccias. This particular feature may be explained by the effect of weathering processes and also by the percolation from the basaltic lava covering the residual soils. Secondly, the phonolitic pyroclastic deposits are characterised by low $\mathrm{SiO}_{2}$ - contents and only the BI2 sample can be classified as a typical phonolitic pyroclastic deposit. Normally, the $\mathrm{SiO}_{2}$ - contents in ignimbrites ranges from about $55 \%$ to about $65 \%$. Refering to the ignimbrites on Tenerife, the lowest $\mathrm{SiO}_{2}$ - content has been assumed to be at about $55 \%$ and the maximum content of $\mathrm{Fe}_{2} \mathrm{O}_{3}$ at about $6 \%$ (Ablay, 1997; Bryan et al., 1998). Thirdly, the valley filling breccias are located in an intermediate domain representing the wide variety of these deposits each of them generated by one or several mass wasting events of different materials.

Figure 4.17 illustrates graphically the $\mathrm{Fe}_{2} \mathrm{O}_{3}$ - content versus the $\mathrm{SiO}_{2}$ - content and shows an overall decreasing of the $\mathrm{Fe}_{2} \mathrm{O}_{3}$ - content for increasing $\mathrm{SiO}_{2}$ - contents.

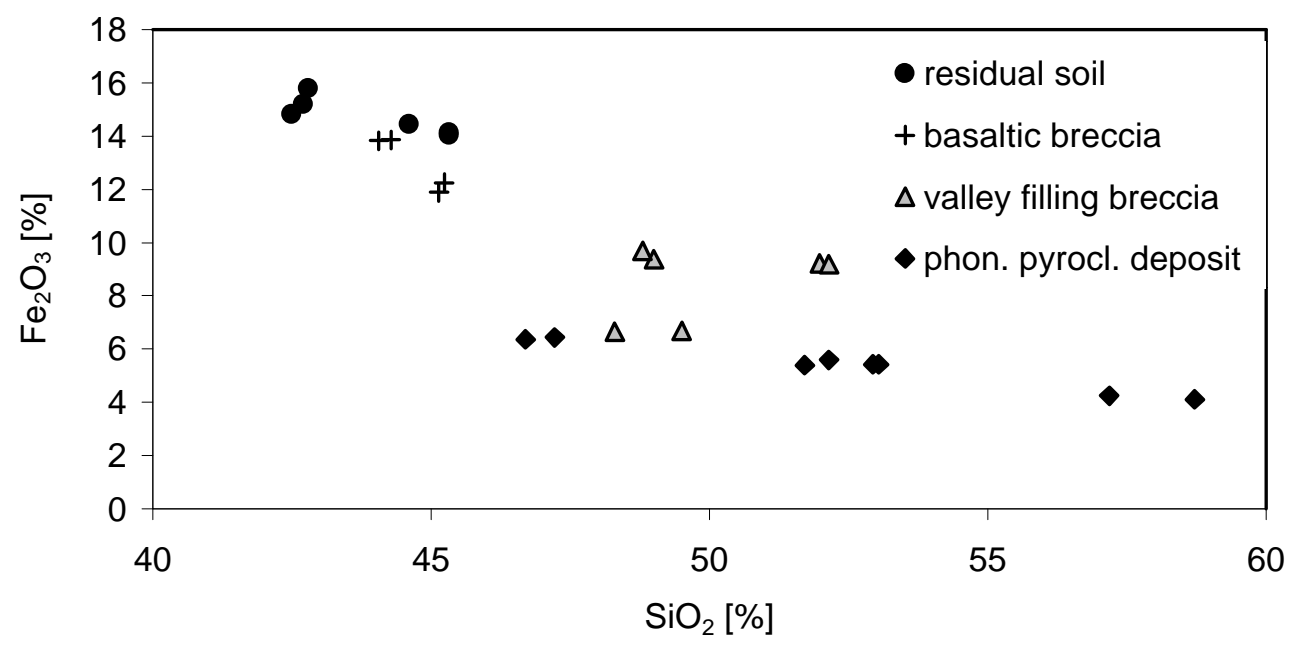

Figure 4.17: $\mathrm{Fe}_{2} \mathrm{O}_{3}$ - content versus $\mathrm{SiO}_{2}$-content for the twelve hand samples using XRF.

The analysis of the contents of the selected trace elements has confirmed the heterogeneous nature of the twelve samples. Even within the same group exists a significant variance of content of some elements. The RS3 - sample, for example, clearly differs from the two other residual soils and especially its $\mathrm{Ce}$ - and Nd - contents exceed the ones of RS1 and RS2. However, some general conclusions can be done refering to some specific trace elements. Focussing on the $\mathrm{Ni}$ - content, a clear difference between the phonolitic pyroclastic deposits with zero or close to zero contents and the other samples with higher contents can be seen. A similar contrast is shown by the $\mathrm{Zr}$ - contents which are much higher for the phonolitic pyroclastic deposit group than for the other groups. 
Table 4.7: Contents of selected trace elements (units in ppm).

\begin{tabular}{|c|c|c|c|c|c|c|c|c|c|c|c|c|c|c|c|}
\hline sample & $\mathrm{Ni}$ & $\mathrm{Zn}$ & $\mathrm{Br}$ & $\mathrm{Rb}$ & $\mathrm{Sr}$ & $\mathrm{Zr}$ & $\mathrm{Nb}$ & $\mathrm{La}$ & $\mathrm{Ce}$ & $\operatorname{Pr}$ & $\mathrm{Nd}$ & $\mathrm{Sm}$ & $\mathrm{Mn}$ & $\mathrm{Cu}$ & As \\
\hline \multirow[t]{2}{*}{ RS1 } & & & 8 & 30 & & & 62 & 125 & 39 & 2 & & & & - & - \\
\hline & 123 & & 6 & 20 & & 636 & 66 & 112 & 117 & 17 & & 11 & - & & - \\
\hline \multirow[t]{2}{*}{ RS2 } & & & & & & & & & & & & & & & - \\
\hline & 124 & 1 & & & & 60 & & 36 & 71 & & & & & & - \\
\hline \multirow[t]{2}{*}{ RS3 } & 81.7 & 40.1 & 0.4 & 9.6 & 434.8 & 541.3 & 137.4 & 94.8 & 224.9 & 23.5 & 91.4 & 9.8 & 3132 & 71.1 & 1.3 \\
\hline & 54.4 & 4.7 & 0.5 & 8.1 & 430.9 & 533.5 & 136.3 & 97 & 182.3 & 23.9 & 82.5 & 5 & 2677 & 73.3 & 1.5 \\
\hline \multirow[t]{2}{*}{ MO1 } & 69 & 126 & 32 & 50 & 191 & 466 & 49 & 111 & 128 & 20 & & & & & - \\
\hline & 75 & & 2 & 50 & 37 & 467 & 4 & 114 & 124 & 2 & & & & & - \\
\hline \multirow[t]{2}{*}{ MO2 } & 49 & & & 61 & & 571 & 62 & 147 & 169 & 24 & & & & & \\
\hline & 49 & & & & & 591 & & 142 & 100 & & & & & & - \\
\hline \multirow[t]{2}{*}{ BR1 } & 113.2 & 86.2 & 0.7 & 25.7 & 669 & 274.8 & 70.1 & 56.5 & 118.7 & 15.4 & 53 & & 207 & 80.3 & 2.3 \\
\hline & 57.4 & 0.5 & 0.7 & 26.9 & 679.8 & 286.9 & 72.4 & 55.1 & 118.8 & 16.2 & 44. & & 2014 & 106 & 1.8 \\
\hline \multirow[t]{2}{*}{ BR2 } & 55 & 103.5 & 0.6 & 19.2 & 1010 & 358.2 & 81.9 & 82.2 & 154.4 & 15.2 & & & 2247 & & 2.2 \\
\hline & 52.1 & 9.1 & 0.5 & 19.6 & 1028 & 360.4 & 82.9 & 82.9 & 152.6 & 18.2 & 60.7 & 3.9 & 202 & 5.1 & 1.5 \\
\hline \multirow[t]{2}{*}{ EL1 } & 4.3 & 131.7 & 0.5 & 59.4 & 761.8 & 536.8 & 132.2 & 88 & 173.2 & 30.1 & 60.1 & 15 & 2200 & 4.1 & 1.7 \\
\hline & 55.8 & 119.5 & 0.7 & 64.9 & 700.5 & 560.5 & 133 & 94.7 & 169.7 & 24.3 & 65.4 & 12.3 & 2259 & 53.4 & 0.7 \\
\hline \multirow[t]{2}{*}{ EL2 } & 0 & {$[117.0$} & 0.4 & 71.0 & 474 & 940.7 & 252.3 & 199.1 & 276.6 & 18.2 & 123 & & 2218 & & 2.4 \\
\hline & 5.2 & 130.9 & 0.3 & 49.1 & 315.5 & 979.6 & 262.1 & 183.5 & 297.4 & 20.7 & & & 2526 & 30.8 & 1.8 \\
\hline \multirow[t]{2}{*}{ BI1t } & 0 & 231.6 & 0.9 & 69.4 & 356.6 & 747.4 & 220.9 & 101.6 & 240.3 & 22 & 58.2 & 10.4 & 2302 & & 0.2 \\
\hline & 0 & 230.5 & 0.9 & 72.4 & 361.8 & 773.5 & 219.4 & 94.3 & 226.6 & 15.5 & & + & 1987 & 35.1 & 1.9 \\
\hline \multirow[t]{2}{*}{ BI1B } & 0 & 270.3 & 0.6 & 85.4 & 204.1 & 853 & 261.6 & 109.3 & 246.2 & 22.5 & 63.8 & 10 & 2500 & 0 & 1.5 \\
\hline & 0 & 294 & 0.5 & 81.9 & 222 & 863 & 259.9 & 104.8 & 266.3 & 18.3 & 61 & 7.9 & 2314 & 10.9 & 0.5 \\
\hline \multirow[t]{2}{*}{ BI2 } & 0 & 129.4 & 1.1 & 71.2 & 556.8 & 822.3 & 192.2 & 110 & 237.6 & 24 & 74.1 & & 2465 & 4.8 & 1.3 \\
\hline & 0 & 135 & 0.9 & 73.5 & 558.4 & 768.5 & 181.8 & 113.7 & 219.7 & 24.7 & 74.1 & 15.4 & 1991 & 31 & 1 \\
\hline
\end{tabular}

During the analysis of the contents of the trace elements, some common trace elements of volcanic material have been compared with the $\mathrm{SiO}_{2}$ - content. In Figure 4.18 the $\mathrm{Rb}$ - content has been selected and plotted versus the $\mathrm{SiO}_{2}$ - content. A clear increasing trend of the $\mathrm{Rb}$ - content can be seen for higher $\mathrm{SiO}_{2}-$ content. This trend coincides with other geochemical data achieved from volcanic materials on Tenerife and of other locations (Bauer et al., 1973; Ablay, 1997; Bryan et al., 1998). 


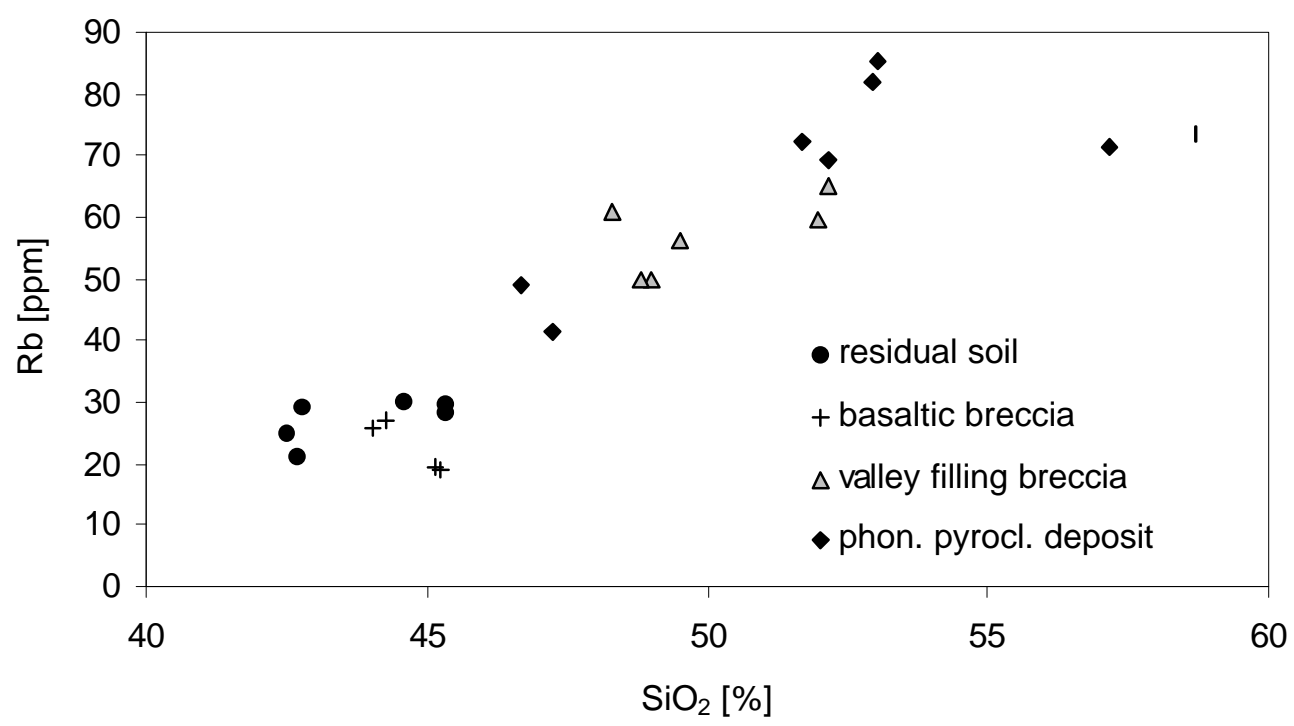

Figure 4.18: $\mathrm{Rb}$ - content versus $\mathrm{SiO}_{2}$ - content for the twelve hand samples using XRF.

To summarise the XRF - analysis, the samples can be characterised by a high content of metals and a low content of silica. The large metallic content may explain the high density of the solids that has been achieved by the geotechnical study $\left(\mathrm{G}_{\mathrm{s}}=2.965\right.$ for the RS1 sample). The analysis of the data from a geotechnical point of view has not revealed any significant feature of important elements. For example, the gypsum and the calciumoxide contents are quite low, which indicates that the samples have no swelling characteristics. A curious feature which occurs especially in volcanic areas located near the sea, has been detected by the $\mathrm{Br}$ - and $\mathrm{Cl}$ - content. The two samples of valley filling breccias MO2 and MO1 contain a very high $\mathrm{Br}$ - and $\mathrm{Cl}$ - content which can be explained by the spray of seawater due to their coastal location. However, $\mathrm{Br}$ - and $\mathrm{Cl}$ - contents may also be justified by a possible alteration of the phonolitic pyroclastic deposits. Phonolitic pyroclastic deposits are normally formed by pyroclastic flows associated with phreatomagmatic eruptions, which can be induced by mixing of sea water and magma in the magma chamber.

Additionally the samples have been analysed by X-ray diffraction and for each sample a diffractogram has been achieved. The results of the XRD analysis are shown graphically in Figure 4.19 and the most important minerals are indicated in the diffraction patterns. During this analysis, the twelve samples are divided into three different groups. The residual soil group and the phonolitic pyroclastic deposit group are the same as in the XRF analysis and the third group consists of all types of breccias:

1) residual soils

2) valley filling breccias and basaltic breccias

3) phonolitic pyroclastic deposits (including sample RS1, RS2 and RS3)

(including sample MO1, MO2, EL1, BR1 and BR2)

(including sample EL2, BI1b, BI1t and BI2)

Generally, the main objective of an X-ray analysis during a geotechnical investigation is the detection of the amount of clay minerals in the samples. However, the results have shown that the twelve samples analysed during this study are not characterised by high clay contents. The X-ray diffractograms indicate that the samples contain only a small or even no clay content (Figure 4.19). The most common 
clay mineral detected is called halloysite and appears especially in the RS2, MO2 and EL2 samples. Halloysite minerals are frequently present in residual soils and occur primarily in youthful soils from volcanic deposits (Jiméez, 1963; Dixon and Weed, 1989). Halloysite is the product of the transformation of the two-layered kaolinitic clay minerals (Millot, 1970), which can be described as

$$
\text { Kaolinite } \Leftrightarrow \text { Halloysite } \Leftrightarrow \text { disordered Kaolinites }
$$

Because of the relationships described above the structural composition of halloysite is similar to that found in the common kaolinite minerals. The main difference being that halloysites normally occur in a partly or fully hydrated form with a structural formula given as

$$
(\mathrm{OH})_{8} \mathrm{Al}_{4} \mathrm{Si}_{4} \mathrm{O}_{10} * \mathrm{nH}_{2} \mathrm{O}
$$

,where $\mathrm{n}$ may be equal to zero, two or four (Attewell and Farmer, 1976). From the geotechnical point of view the halloysites are classified as sheet silicate minerals, but are not platy in shape and generally do not give low peak or residual strength. Their stability depends on the degree of hydration, with the partly hydrated forms $(n=2)$ being the least stable, though the water does not influence significantly on mechanical behaviour (Vaughan, 1988). Usually, the soils with a large amount of halloysite have a very high plasticity, low permeability and display sensitivity to drying and also to manipulation (Blight, 1997). The specific gravity of halloysite in the form with two $\mathrm{H}_{2} \mathrm{O}$ molecules is given as 2.55 . In contrast to the halloysite the highly expansive mineral montmorillonite is not detected.

In addition to the halloysite mineral, other clay or clay-like minerals with minor content have been detected in some samples. Most of them belong to the group of sheet silicates defined as 'mica'. The minerals of the mica group are characterised by low hardness and by perfect basal cleavage, readily splitting into thin, tough, somewhat elastic laminae or plates (Lambe and Whitman, 1979). The mica mineral biotite has been determined in the phonolitic pyroclastic deposit samples. Biotite is a widely distributed and important rock forming mineral and has a similar composition as the mica mineral phlogopite, which has also been detected in some samples. Biotite and phlogopite contain to the primary mica minerals, since they are already formed in the magma. They differ from the secondary mica minerals which are products of weathering. From a geotechnical point of view, however, both primary and secondary mica minerals belong to the group of sheet silicates and are characterised by a similar mechanical behaviour (Lambe and Whitman, 1979). In Figure 4.19 the peaks of the halloysite and biotite minerals are located in the diffractograms. The peak called 'clays' indicates the position which represents an estimate of the total amount of clay minerals in the sample.

The most frequent, not clayey mineral detected in the twelve samples is the feldspar (especially the albite mineral) which is characterised by the highest peaks in the diffractograms. Other important minerals found in almost every sample are amphibols, pyroxenes and hematites.

Finally, an important fact should be kept in mind interpreting the results of the XRD analysis. The sample locations are near the surface and far away from the areas of volcanic activity, so that hydrothermal alteration has not affected the geological units sampled. However, hydrothermal alteration and its significant effect on the formation of clay minerals is a very important process influencing the mineralogy of the volcanic material (Frank, 1995; Crowley and Zimbelman, 1997). Studies at the volcanoes of the Cascade Range have shown that smectite and kaolin (either as disordered kaolinite or halloysite) are the most common clay-mineral groups in the fumarole areas. Such clay minerals generated by hydrothermal alteration can significantly weaken the volcano flank and prepare slope failure. At the Mount Rainier, for example smectite, kaolin, jarosite, alunite and silica phases, with lesser illite, gypsum and pyrite have been found within a debris avalanche main scarp (Frank, 1995). 
a)

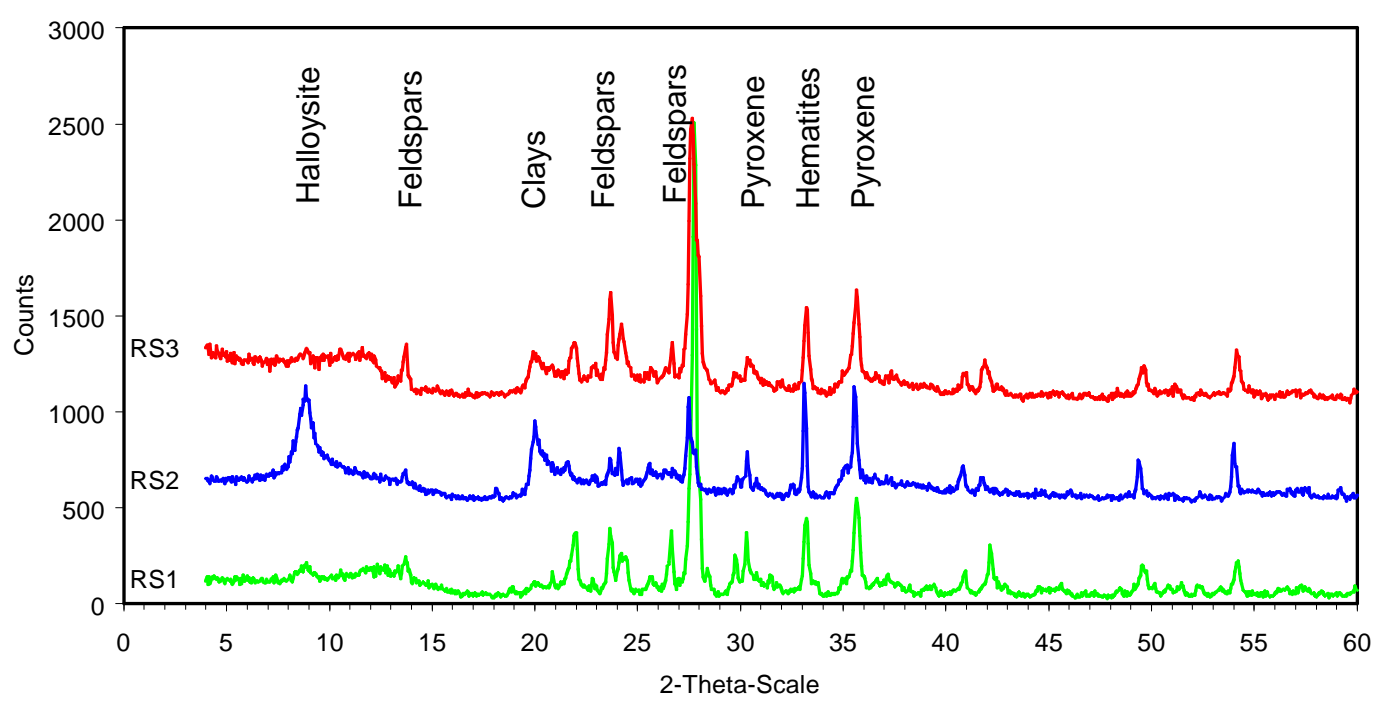

b)

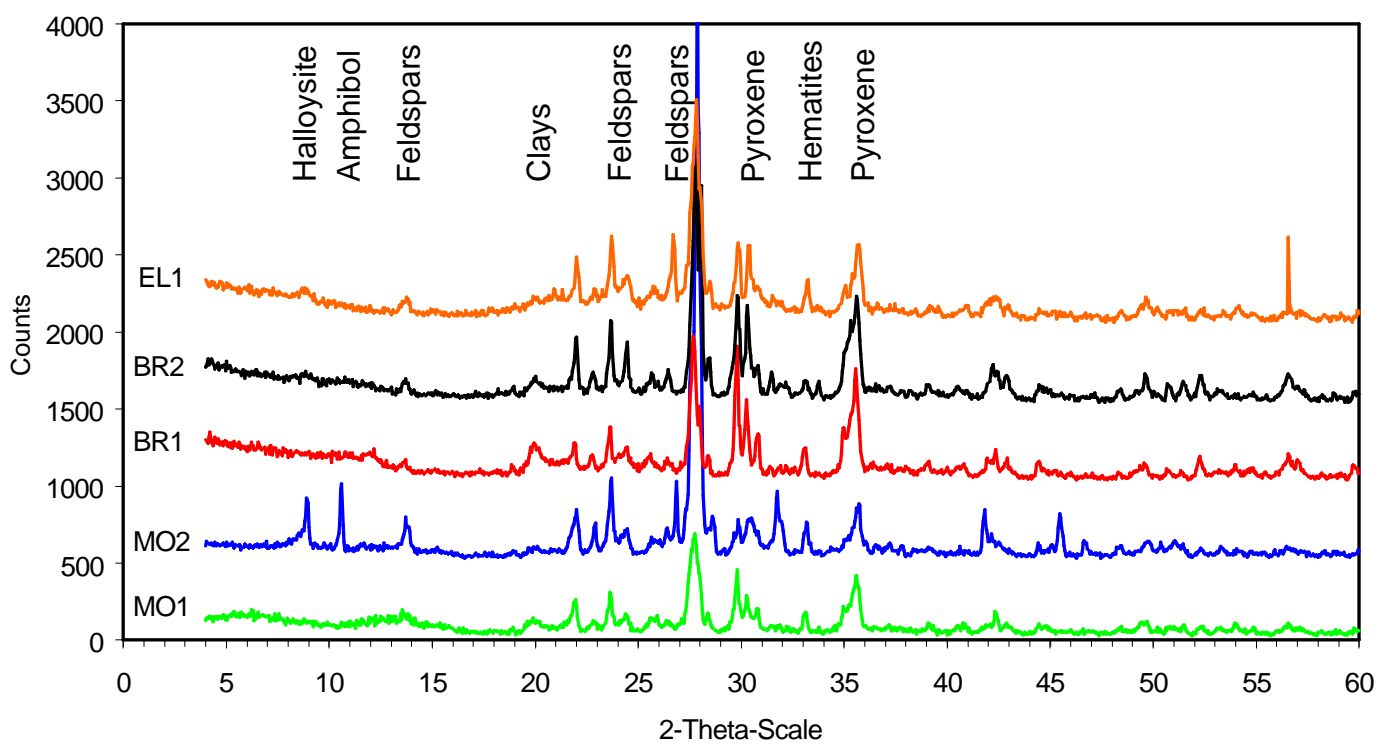

c)

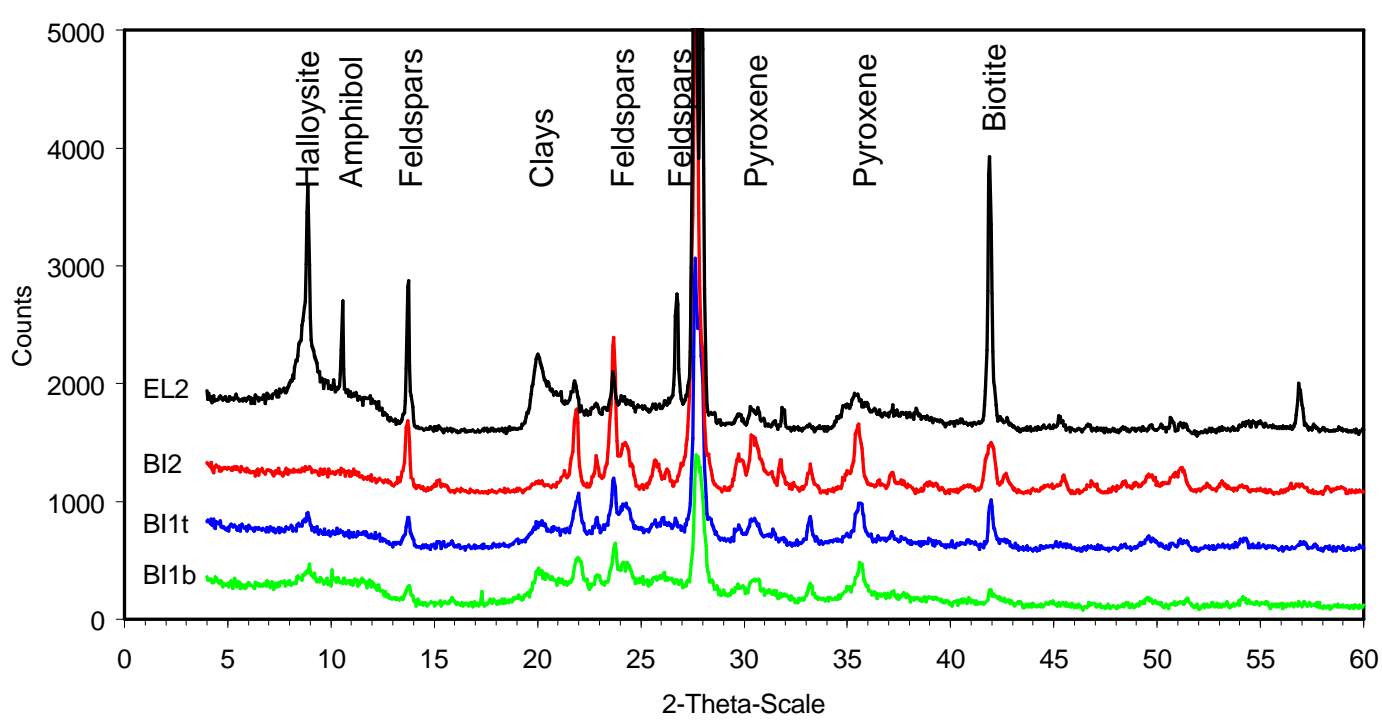

Figure 4.19: X-ray diffractograms of the twelve samples divided into three groups: a) Residual soils, b) breccias, and c) ignimbrites. 


\section{Microstructure}

Two samples have been analysed using an environmental scanning electron microscope (ESEM). Both of the samples have been taken from the residual soil RS1. One from the intact soil as it has been sampled in the field and the other from a specimen which has been failed during a triaxial test applying high confining pressure.

First, the microstructure of the two samples has been studied according to the terminology proposed for the description of volcanic ash material (Heiken and Wohletz, 1985) and to the microstructural analysis of residual soils (Blight, 1997). Figure 4.20 shows the microstructure of the intact soil with an open fabric organisation of generally rounded particles. Large macro-voids are visible and only a small amount of a homogeneous groundmass can be detected. The larger particles are surrounded by fragmentary material and an amorphous coverage which can only be detected by a higher magnification (e.g. Figure 4.24). A similar coverage of the soil particles has been seen in other volcanic residual soils and has been described as 'viscous gel' (Wallace, 1973). The microstructure of the broken soil is illustrated in Figure 4.21. The microfabric organisation is much denser than in the intact soil and the large macro-voids disappeared. The majority of the particles consists of fragmentary material and only some large particles can be assumed. The overall assemblage of the particles is very compacted due to the high stress applied to the soil.

Second, the bonding of the soil has been observed. Figure 4.22, Figure 4.23 and Figure 4.24 show three different types of contacts which have been detected between the individual soil particles. In general, the ESEM analysis has revealed that many different forms of bonds can exist in the same soil sample. Some of them are characterised by an homogeneous, amorphous contact between two, preferably rounded clasts as shown in Figure 4.22 or Figure 4.23, and others are characterised by a heterogeneous contact consisting of tubes, flakes or plate - like bridge between the clasts (Figure 4.24). A zoom of such a bridge between two soil particles is illustrated in Figure 4.25 and clearly indicates the heterogeneous origin of the bond which is formed by an amorphous mass, small grains and some crystals. On the other hand, yielded bonds have been detected in the broken soil sample after applying high stresses. Figure 4.26 shows an example of a contact between two particles, which have been broken during the loading. The relicts of the contact are still visible and only the weakest part of the bridge between the clasts has failed. 


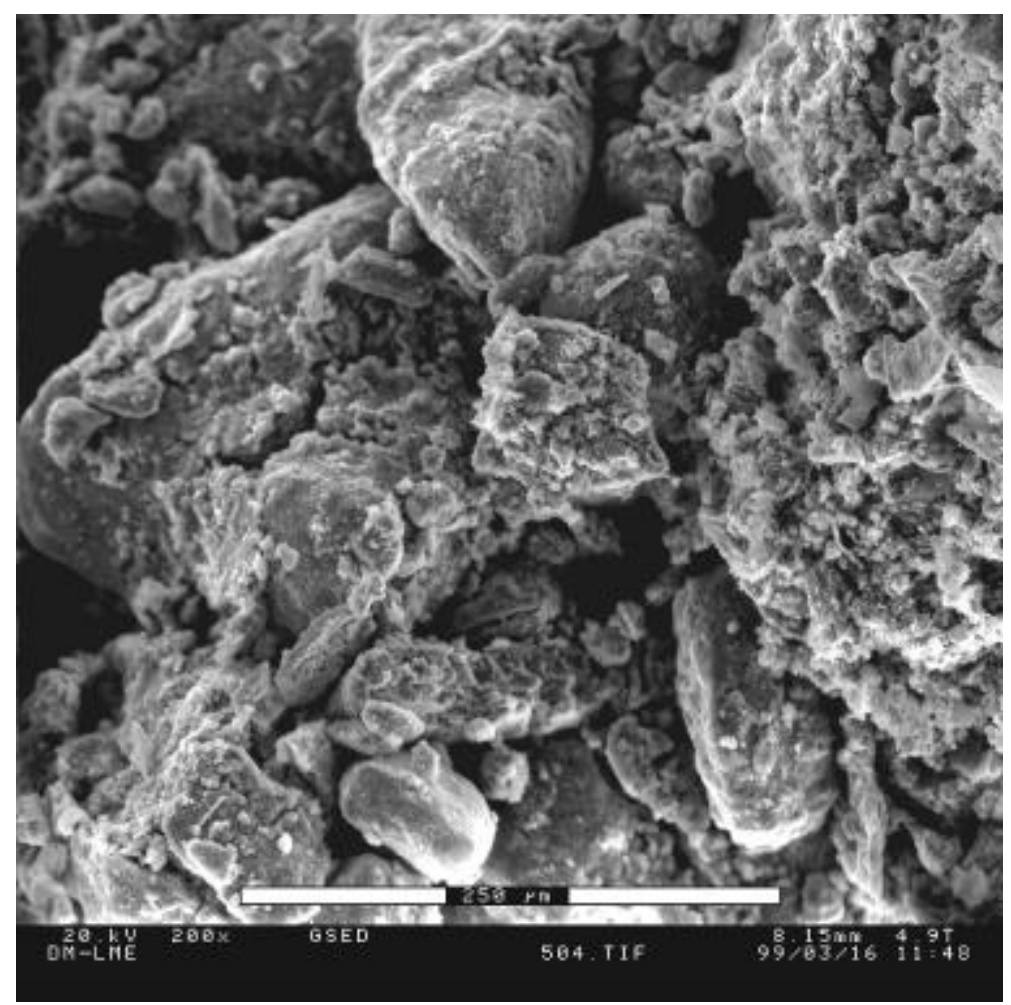

Figure 4.20: ESEM photograph showing the open microstructure of the intact soil (magnification = 200x).

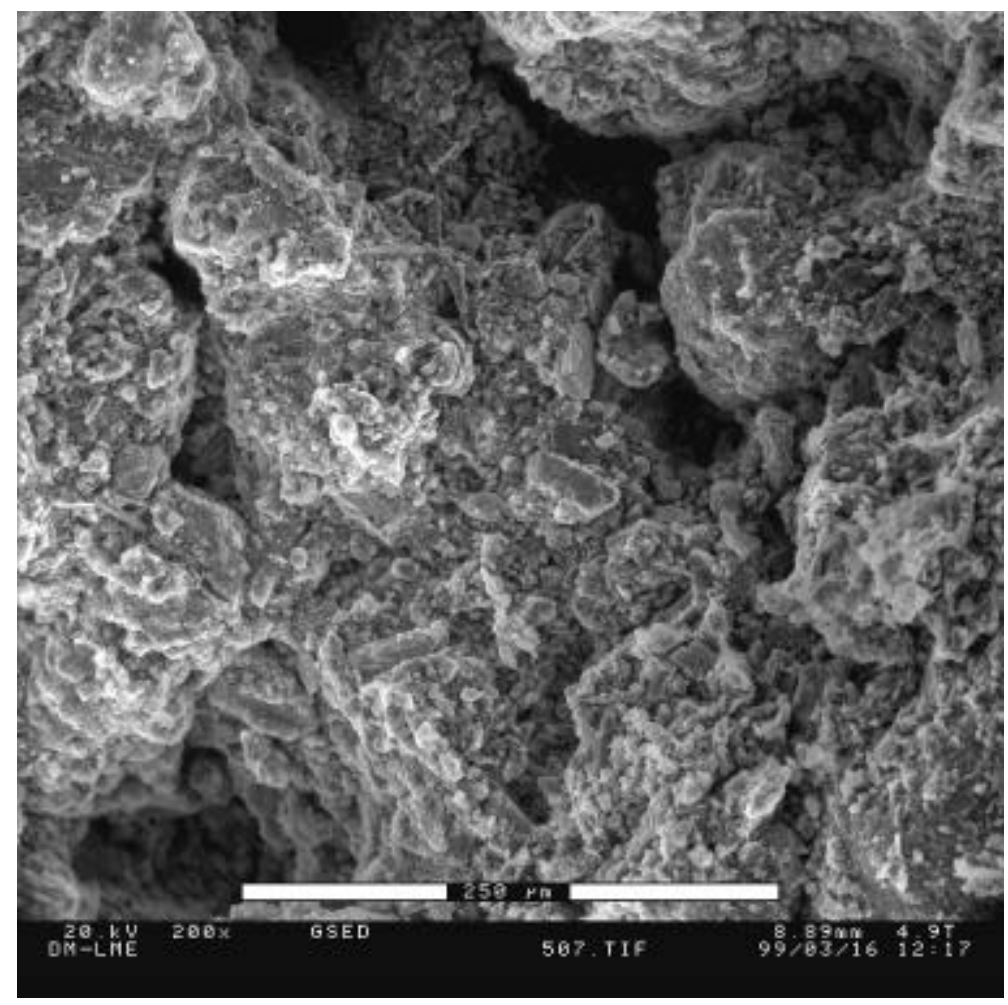

Figure 4.21: ESEM photograph showing the compacted microstructure of the broken soil (magnification $=200 x$ ). 


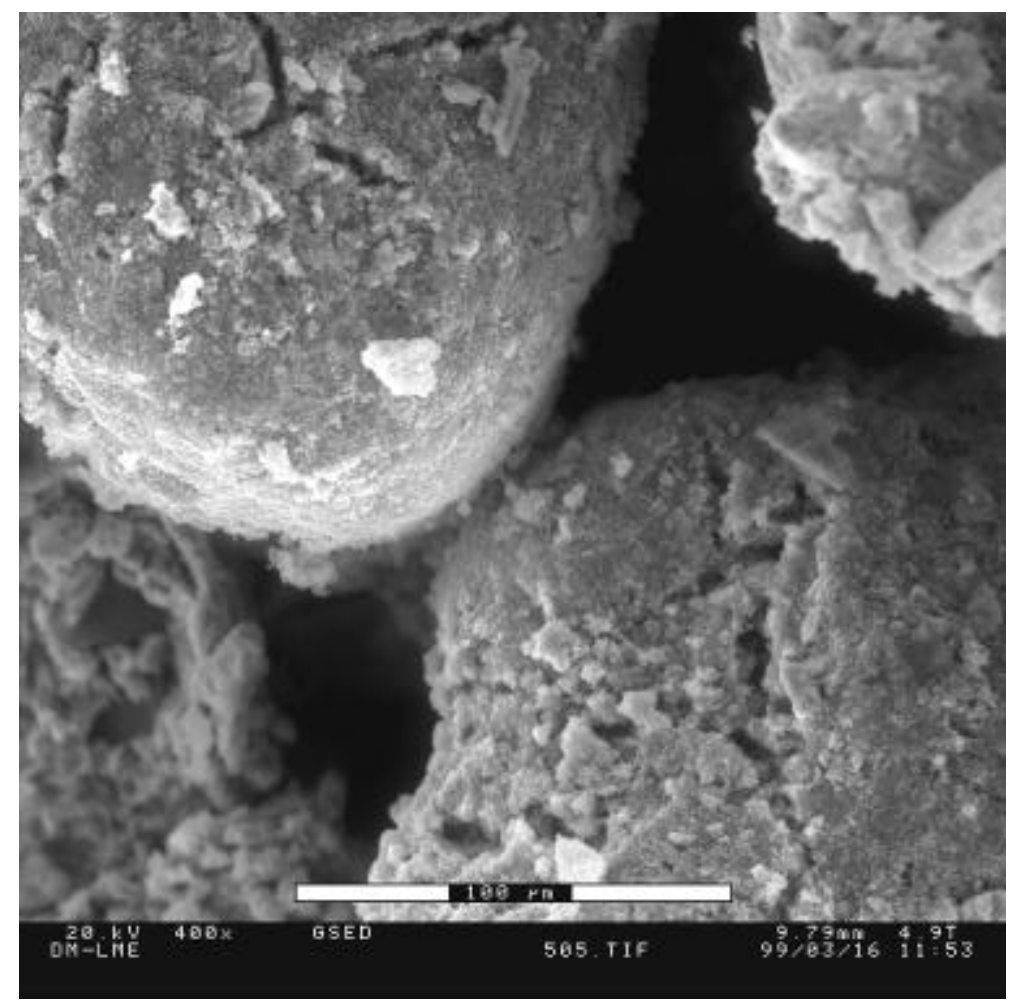

Figure 4.22: ESEM - photograph showing a bonding between two particles in the intact soil (magnification $=400 \mathrm{x}$ ).

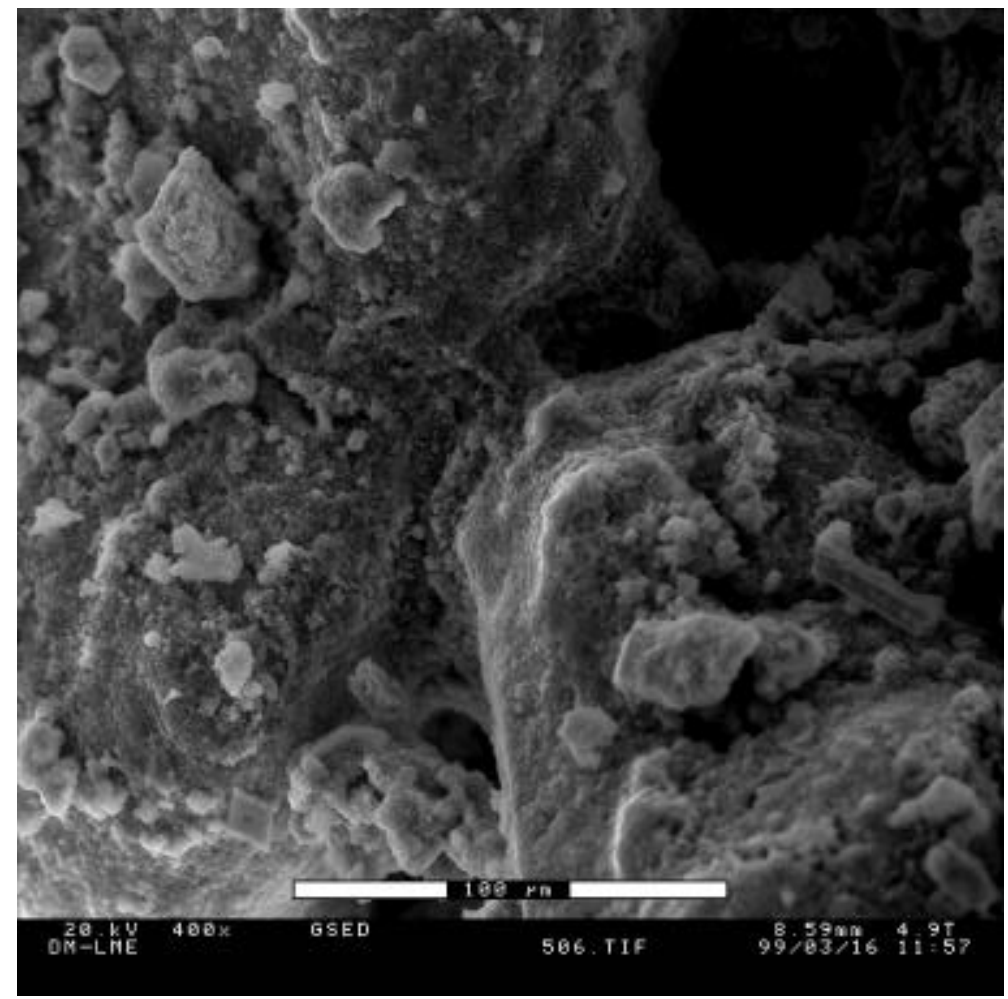

Figure 4.23: ESEM - photograph showing a bonding between two particles in the intact soil $($ magnification $=400 \mathrm{x})$. 


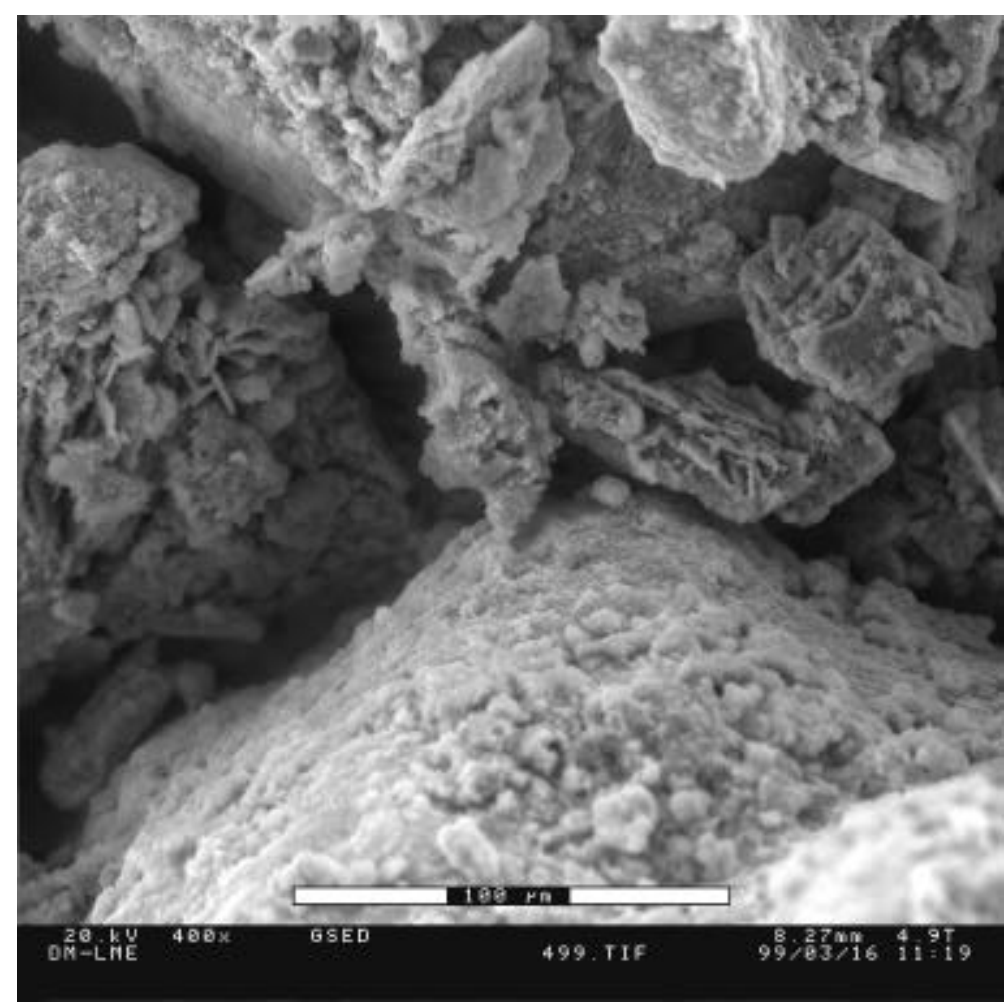

Figure 4.24: ESEM - photograph showing a bridge - like bonding between two particles in the intact soil $($ magnification $=400 \mathrm{x}$ ).

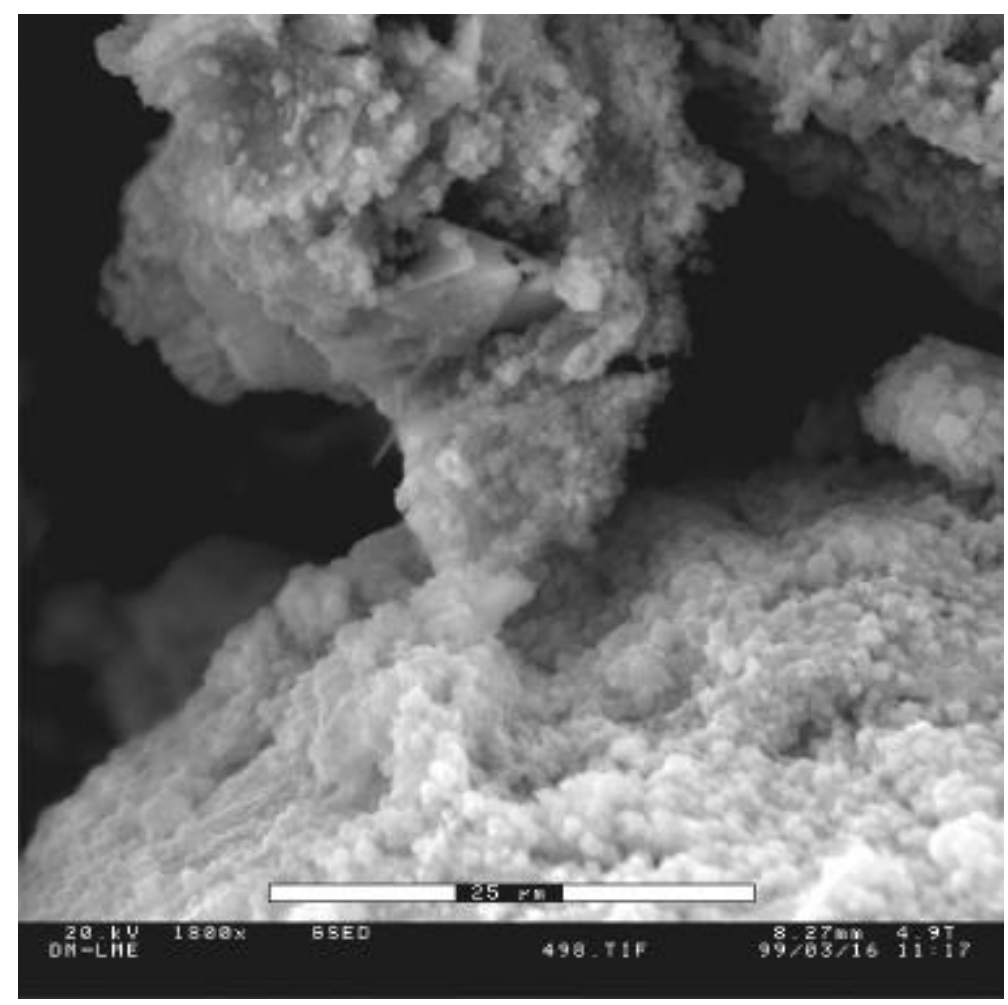

Figure 4.25: ESEM - photograph showing a zoom of a bridge - like bonding between two particles in the intact soil $($ magnification $=1800 x)$. 


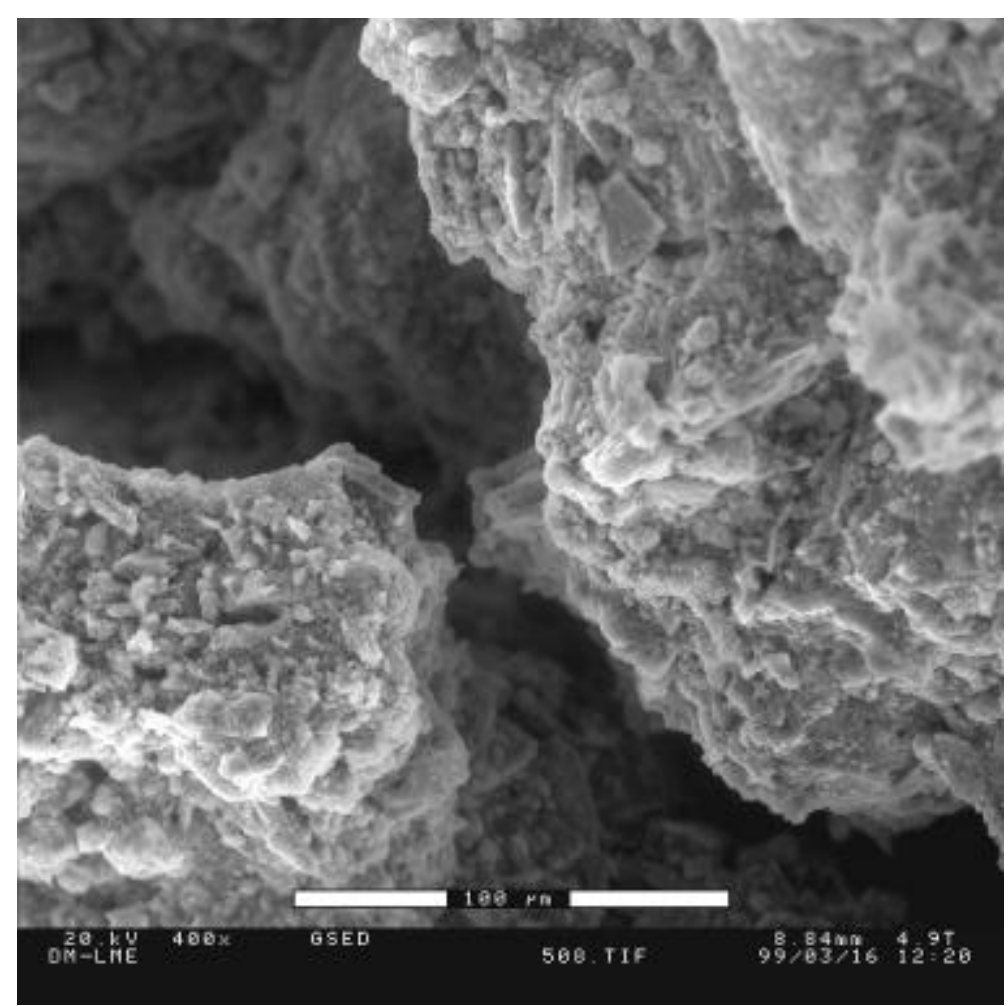

Figure 4.26: ESEM - photograph showing a failed, bridge - like bonding between two particles in the broken soil (magnification $=400 x$ ). 


\subsubsection{Geotechnical tests}

\section{Soil characterisation}

The particle size distribution curves of the residual soil samples RS1, RS2 and RS3 are shown in Figure 4.27. Generally, the curves represent soils with sandy - (silty) characteristics, some gravel components and a small clay fraction. RS1 sample is characterised by generally coarser particles than RS2 and RS3 though the percentage of the clay fraction is similar for all the three soils. A comparison of these results with published data on volcanic residual soils indicates that the residual soils analysed contain very low clay contents. Typical values for clay contents of residual soils range from 20 to $80 \%$ although in most cases it reaches more than $50 \%$ (Gonzalez de Vallejo et al., 1981). Therefore, it can be said that the three residual soils have undergone only a short time of weathering and reached an early phase within the weathering sequence.

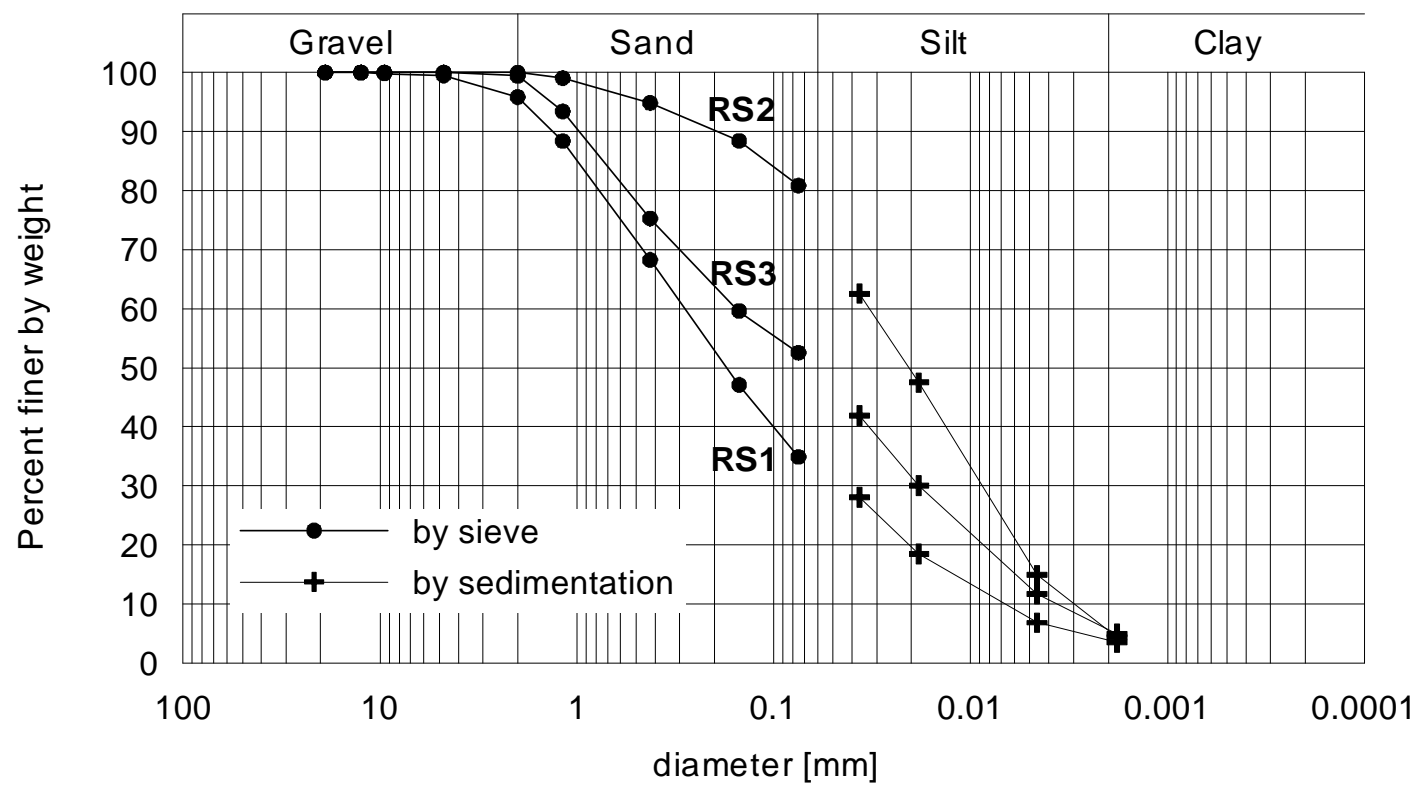

Figure 4.27: Particle size distribution curves of the residual soil samples.

Since the following geotechnical tests have been carried out with the RS1 sample, a short description of its particle size distribution curve is given. The particle size distribution curve indicates that the RS1 sample contains about 5 percent gravel-size particles, almost 60 percent sand-size particles, about 30 percent silt-size particles and less than 5 percent clay-size particles. The sieve test shows that the soil contains about $35 \%$ of fine particles $(\mathrm{d}<0.075 \mathrm{~mm})$. Additionally, three parameters were determined to describe the distribution curve:

$$
\begin{gathered}
\mathrm{D}_{10}=0.007 \mathrm{~mm} \\
\mathrm{D}_{30}=0.065 \mathrm{~mm} \\
\mathrm{D}_{60}=0.28 \mathrm{~mm}
\end{gathered}
$$

Analysing the Atterberg limits of the residual soil has given the result that the sample has no plasticity. So, the liquid limit and the plasticity index value do not apply in this case. However, the determination of Atterberg limits and particle size distributions is a major problem during the analysis of tropical residual soils since the effect of drying can notably change the results (Blight, 1997). Even air-drying at ambient temperature can cause partial or complete dehydration of the clay minerals and can change 
them and their properties irreversibly. The most widely reported effect of drying on the particle size distribution is to reduce the percentage of the clay fraction. Refering to the plasticity, allophane minerals for example, become non-plastic without exception when air-dried or oven-dried (Wallace, 1973).

In the sandy-silty matrix of the soil pumice and some lithic fragments are chaotically plunged. Their size may range from few $\mathrm{mm}$ to several $\mathrm{cm}$. There is no stratification visible and the graduation of the residual soil is poor, which can be explained by the circumstance that the sample is a result of an in-situ weathered phonolitic pyroclastic deposit. Phonolitic pyroclastic deposits always are chaotic formations without internal structure or stratification. This justifies the low value of the uniformity coefficient, $\mathrm{C}_{\mathrm{u}}$, equal to four and the very high value of the coefficient of curvature, $C_{c}$, equal to 2.16 , which indicates the poorly graduation of the soil. Using the USCS (Wagner, 1957) the residual soil sample can be classified as a sandy, silty, no plastic soil with the abbreviation: SM.

The specific gravity of the grains, $G_{s}$, which also represents the density of the solid phase, $\rho_{\mathrm{s}}$, has been studied twice and has given the high values of $\mathrm{G}_{\mathrm{s}}=2.972$ and 2.959 or $\rho_{\mathrm{s}}=2.972$ and 2.959 $\mathrm{g} / \mathrm{cm}^{3}$, respectively. However, this does not surprise regarding the parent rock of the soil sample and the high content of metallic minerals. Residual soils generated form volcanic parent rock such as phonolitic pyroclastic deposits or basalts are characterised by a high specific gravity. Typical $\mathrm{G}_{\mathrm{s}}$ - values of residual soils formed above basalts in Brazil are assumed to be between 2.8 and 3.2 (Vaughan, 1988). The mineralogy of the sample explains the high value, too. Finally, the average density of the grains has been defined as $2.965 \mathrm{~g} / \mathrm{cm}^{3}$.

Table 4.8: Physical properties of the residual soil sample RS1.

\begin{tabular}{|l|c|c|c|c|c|}
\hline specimen & $\begin{array}{c}\text { natural density } \\
{\left[\mathrm{g} / \mathrm{cm}^{3}\right]}\end{array}$ & $\begin{array}{c}\text { water content } \\
{[\%]}\end{array}$ & $\begin{array}{c}\text { dry density } \\
{\left[\mathrm{g} / \mathrm{cm}^{3}\right]}\end{array}$ & $\begin{array}{c}\text { void ratio } \\
{[-]}\end{array}$ & $\begin{array}{c}\text { porosity } \\
{[\%]}\end{array}$ \\
\hline \hline RS1-O-UD1 & 1.52 & 28.75 & 1.18 & 1.52 & 60.31 \\
\hline RS1-O-UD2 & 1.53 & 26.40 & 1.21 & 1.45 & 59.15 \\
\hline RS1-O-UD3 & 1.51 & 23.14 & 1.23 & 1.41 & 58.53 \\
\hline RS1-D-UDI & 1.81 & 28.70 & 1.29 & 1.30 & 56.49 \\
\hline RS1-D-UDIII & 1.60 & 24.91 & 1.28 & 1.32 & 56.80 \\
\hline RS1-D-UDIV & 1.63 & 21.12 & 1.35 & 1.20 & 54.61 \\
\hline RS1-D-UDV & 1.65 & 21.85 & 1.35 & 1.19 & 54.33 \\
\hline RS1-D-UDVI & 1.50 & 30.67 & 1.15 & 1.58 & 61.24 \\
\hline RS1-T-CU1 & 1.60 & 23.12 & 1.30 & 1.28 & 56.14 \\
\hline RS1-T-CU2 & 1.59 & 25.98 & 1.26 & 1.35 & 57.45 \\
\hline RS1-T-CU3 & 1.54 & 29.24 & 1.19 & 1.49 & 59.84 \\
\hline RS1-T-CU4 & 1.53 & 29.58 & 1.18 & 1.52 & 60.32 \\
\hline RS1-T-CUI & 1.40 & 20.01 & 1.17 & 1.53 & 60.47 \\
\hline RS1-T-CUII & 1.51 & 23.95 & 1.26 & 1.35 & 57.45 \\
\hline RS1-T-CD1 & 1.32 & 12.64 & 1.17 & 1.53 & 60.47 \\
\hline RS1-T-CD2 & 1.37 & 12.05 & 1.22 & 1.43 & 58.86 \\
\hline RS1-T-CD3 & 1.40 & 12.76 & 1.24 & 1.39 & 58.16 \\
\hline RS1-T-CD4 & 1.44 & 13.42 & 1.27 & 1.33 & 57.08 \\
\hline RS1-T-CDI & 1.56 & 24.03 & 1.26 & 1.35 & 57.45 \\
\hline average & $\mathbf{1 . 5 3}$ & $\mathbf{2 2 . 7 5}$ & $\mathbf{1 . 2 4}$ & $\mathbf{1 . 4}$ & $\mathbf{5 8 . 1 7}$ \\
\hline
\end{tabular}

The most important characteristics referring to the densities, the water content, the void ratio and the porosity of the undisturbed RS1 samples are given in Table 4.8. Natural densities and the water content of the specimens are not in-situ measurements and may be influenced by the time spent in the humid chamber of the laboratory. However, the natural densities obtained ranging from 1.4 to $1.81 \mathrm{~g} / \mathrm{cm}^{3}$ are realistic looking to the dry densities, which have values between about 1.17 and $1.35 \mathrm{~g} / \mathrm{cm}^{3}$. The void ratios range from 1.19 to 1.58 and are much higher than in sedimentary soils and also higher refering to 
other residual soils. These high values can be explained due to the young stage of the weathering processes, which generally cause a strong increase of void ratios (Blight, 1988). The porosity can be assumed to range from 55 to $60 \%$, which is slightly higher than in other pyroclastic rocks (Moon, 1993; Aversa and Evangelista, 1998), but coincides with measurements on basaltic residual soils in Hawaii (Zhu and Anderson, 1998). Using the average values as listed in Table 4.8, an average degree of saturation can be calculated and gives the value of $54.21 \%$. Summarising these data the RS1 sample can be characterised as a high-porosity residual soil with a low density.

\section{Consolidation tests}

In general, residual soils behave as overconsolidated soils. Their compressibility is relatively low at low stress and increase when the yield stress has been exceeded. Here, the data refering to the consolidation behaviour of the soil has been obtained by two different modes as described in Section 4.2.3: On the one hand using standard oedometer tests and on the other hand by applying a vertical stress during the first step of the direct shear tests. However, only the data of the oedometer tests have been used to define the stress - strain parameters described later in this chapter.

Figure 4.28 shows the behaviour of vertical strain versus time due to different vertical stresses applied to the specimens. These curves, which are represented by a logarithmic scale of time values, have been obtained by first time loading of the specimens and not include data on reloading.

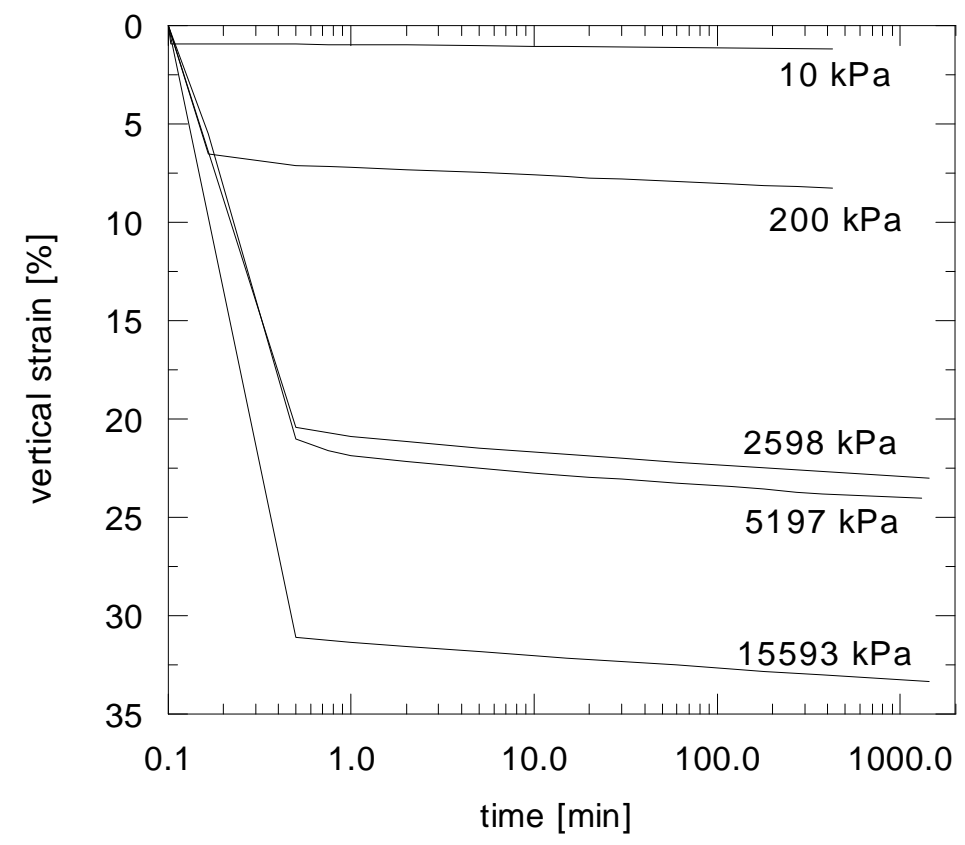

Figure 4.28: Vertical strain - time curves for different vertical stresses due to first time loading.

The plots in Figure 4.28 indicate the particular consolidation behaviour of the residual soil. The curves are characterised by a very fast primary compression at the beginning and a linearly decreasing creep phase. Therefore, the curves can be drawn simplified by two lines of different inclinations. One with a steep slope which represents the primary compression during the first seconds of the test, and a smooth one which indicates the secondary compression. The dissipation of the pore water is completed rapidly and therefore the primary compression lasts only a very small time. This feature can be explained by the high porosity of the sample, which allows the water to dissipate quickly. The secondary compression or creep is characterised by a continuing small increase of vertical strain and may be explained by several processes. A common justification of creep effects in sedimentary soils is the 
ongoing locking of the soil structure after the primary compression or the fracturing of individual sand particles (Lambe and Whitman, 1979). In bonded soils the most common explanation of the creep effect is the failure of the bonds between the particles (Vaughan et al., 1988). A similar, almost instantaneous primary compression and a small creep deformation has been observed in other volcanic bonded soils (Aversa and Evangelista, 1998). However, they detected a significant increase of strain for vertical stresses higher than a certain threshold value due to the total destruction of the bonding.

The behaviour of the particular secondary compression of the soil has been analysed by a long lasting oedometer test with a vertical stress of $2598 \mathrm{kPa}$. The curve of the consolidation is shown in Figure 4.29 and indicates that the creep effect during the secondary compression phase continues till the end of the test, when 90 days have been reached. Similar behaviour has been described in geotechnical studies of other residual soils and of a volcanic clay in Japan (Koizumi and Ito, 1963). They carried out creep measurements of the volcanic clay during more than 4 months and showed that the creep effect continues constantly even after this long time.

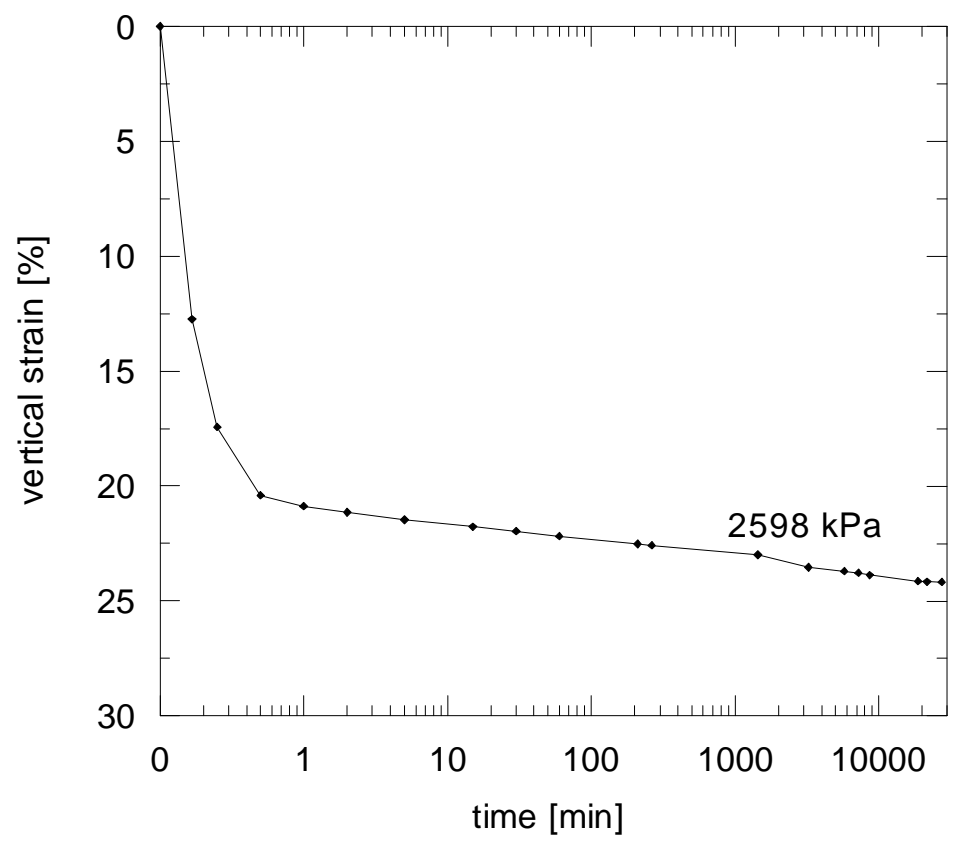

Figure 4.29: Creep effect during the secondary compression phase over an extended duration.

The most characteristic parameters achieved from the consolidation curves are summarised in Table 4.9 including the vertical stress applied to the specimen, $\sigma_{v}$, the vertical strain, $\varepsilon_{\mathrm{v}}$ and the rate of the secondary compression, $\mathrm{C}_{\alpha}$. Moreover, using the consolidation theory of natural soils, the coefficient of consolidation, $\mathrm{c}_{\mathrm{v}}$, and the permeability, $\mathrm{k}$, have been calculated. The permeability values range from $7.00 \times 10^{-5}$ to $1.39 \times 10^{-4} \mathrm{~cm} / \mathrm{sec}$, which can be classified as a low degree of permeability (Terzaghi and Peck, 1967). Additionally, the vertical strain achieved during the primary compression is illustrated in Figure 4.30a and the rate of secondary compression in Figure 4.30b.

Table 4.9: Consolidation parameters for different vertical stress.

\begin{tabular}{|l|c|c|c|c|c|}
\hline specimen & $\begin{array}{c}\sigma_{\mathrm{v}} \\
{[\mathrm{kPa}]}\end{array}$ & $\begin{array}{c}\varepsilon_{\mathrm{v}} \\
{[-]}\end{array}$ & $\begin{array}{c}\mathrm{C}_{\alpha} \\
{[-]}\end{array}$ & $\begin{array}{c}\mathrm{c}_{\mathrm{v}} \\
{\left[\mathrm{cm}^{2} / \mathrm{sec}\right]}\end{array}$ & $\begin{array}{c}\mathrm{k} \\
{[\mathrm{cm} / \mathrm{sec}]}\end{array}$ \\
\hline \hline RS1-O-UD3 & 5 & 0.0013 & 0.0031 & - & - \\
\hline RS1-O-UD1 & 10 & 0.0093 & 0.0875 & 0.078 & $1.97 \times 10^{-4}$ \\
\hline RS1-D-UD0 & 200 & 0.0732 & 0.3843 & 0.055 & $1.39 \times 10^{-4}$ \\
\hline RS1-D-UDVI & 2598 & 0.2041 & 0.6903 & 0.050 & $1.26 \times 10^{-4}$ \\
\hline RS1-D-UDII & 5197 & 0.2214 & 0.7033 & 0.028 & $7.00 \times 10^{-5}$ \\
\hline RS1-D-UDIV & 15593 & 0.3154 & 0.6338 & 0.045 & $1.12 \times 10^{-4}$ \\
\hline
\end{tabular}


Figure 4.30 shows the primary and secondary compression versus vertical stress applied to the specimen. Both graphs indicate a change of the behaviour with increasing vertical stresses. The primary compression increases slightly up to the value of $200 \mathrm{kPa}$ and enlarges significantly for higher vertical stresses. The secondary compression has similar characteristics. For vertical loads up to $200 \mathrm{kPa}$ the $\mathrm{C}_{\alpha}$ - values augment steadily and maintain constant for $\sigma_{\mathrm{v}}$ - values higher than $2500 \mathrm{kPa}$. Therefore, a change of the stress - strain behaviour may occur for both rates at vertical stress between 200 and 2500 $\mathrm{kPa}$. An estimate of the exact yield stress using linearly interpolated lines has given a $\sigma_{\mathrm{v}}$ - value of about $1000 \mathrm{kPa}$ for both parameters. This value represents a critical stress of the soil which produces an increase of the primary compression and a decrease of the secondary compression. An explanation of this phenomenon may be found in the particular bonding of the soil and the assumed yield stress of the bonds at about $1000 \mathrm{kPa}$. The influence of this yield stress or 'critical pressure' on the creep behaviour has also been observed in other residual soils (e.g. Wallace, 1973). In that study, the creep rate of the undisturbed specimens at loads greater than the critical pressure has been measured about ten times the creep rate at loads less than the critical pressure.

a)

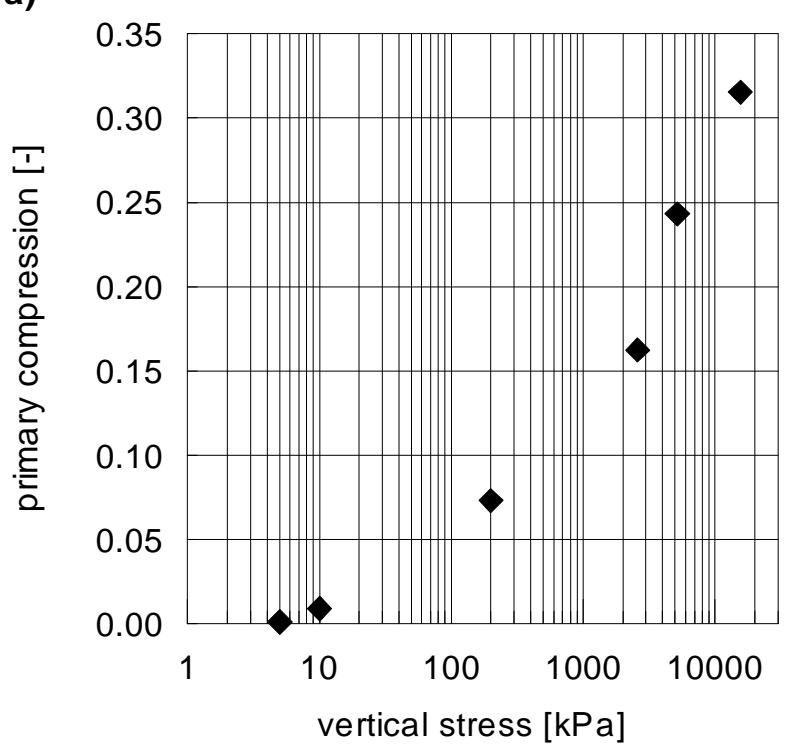

b)

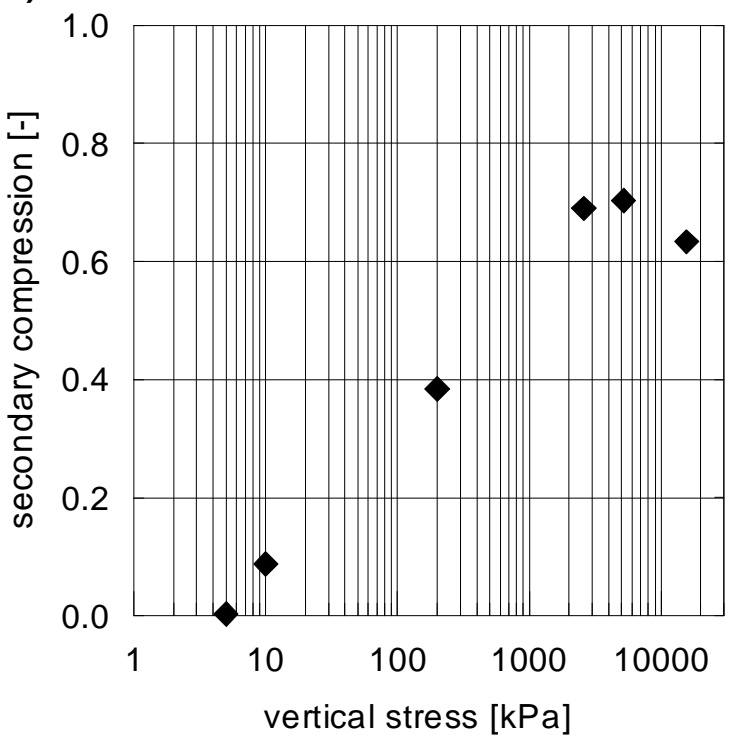

Figure 4.30: Strain achieved during primary compression (a) and secondary compression (b) versus vertical stress.

Finally, the results of the three consolidation tests carried out in the oedometer apparatus will be presented. The stress - void ratio relationship is plotted in Figure 4.31 as void ratio versus applied vertical stress using a semi - logarithmic scale. Due to the high values of the secondary compression and the associated vertical strains, the void ratios have been calculated by the vertical strains including the secondary compression ( $24 \mathrm{~h}$ after loading) and not by the vertical strain related to the primary compression (about $0.5 \mathrm{~min}$ after loading). The curves indicate several interesting points: 1) The saturation does not influence in any form. Neither a collapse effect nor swelling has occurred after soaking. The two specimens, which have been initially loaded in natural condition behave as the specimen soaked initially. 2) The void ratio decreases significantly in each sample and the difference of the initial void ratio and the final void ratio exceeds 0.3 in each curve. 3 ) The yield stress is not very clearly defined. This is quite typical for residual soils and has also been discovered in previous studies (Vaughan et al., 1988; Leroueil and Vaughan, 1990). 4) The normal compression line (NCL) starts at about $800 \mathrm{kPa}$ and indicates the slope for the calculation of the stress-strain parameters. 5) The unloading or recompression line obtained from the three oedometer tests are more or less parallel to the portion of the curves obtained at the beginning of the tests which verify the correctness of the 
measurements. The initial, in-situ stress of the sample in the field has been determined as about $250 \mathrm{kPa}$ which corresponds to an overloading of about $10 \mathrm{~m}$ of volcanic material.

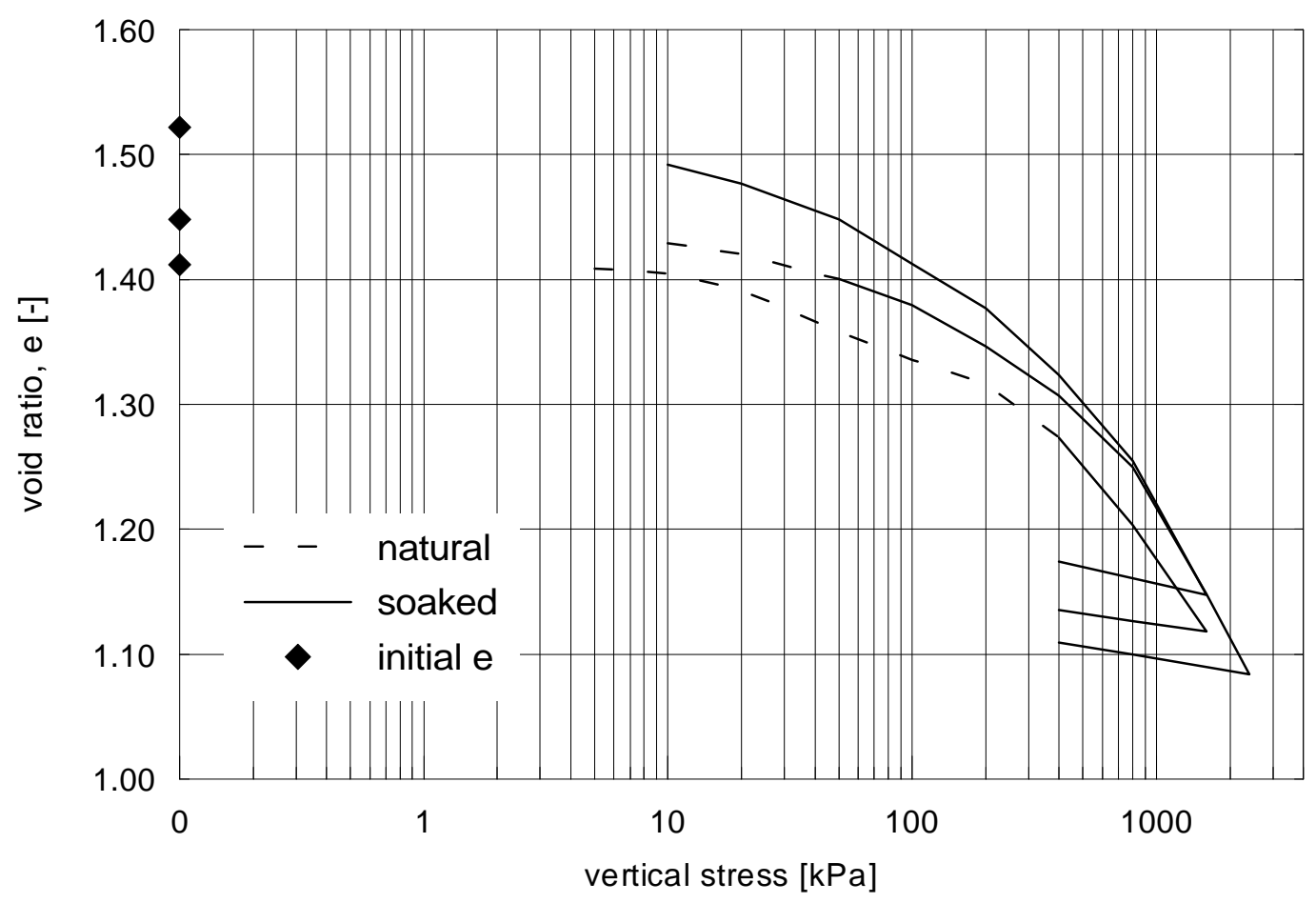

Figure 4.31: Void ratio versus vertical stress from three oedometer tests on undisturbed samples.

The stress-strain parameters have been calculated from the curve obtained from the oedometer test of specimen RS1-O-UD2 (middle curve in Figure 4.31) since the vertical stress for this specimen has been increased up to $2400 \mathrm{kPa}$. The results are illustrated in Table 4.10 and give the values of the coefficient of compressibility, $\mathrm{a}_{\mathrm{v}}$, the compression index, $\mathrm{C}_{\mathrm{c}}$, the coefficient of volume change, $\mathrm{m}_{\mathrm{v}}$, the constrained modulus, $\mathrm{D}$, the Young's modulus, $\mathrm{E}$, and the index of swelling or recompression, $\mathrm{C}_{\mathrm{s}}$. As mentioned above, the secondary compression or creep is characterised by significant values and can not be neglected in the consolidation behaviour of the residual soil analysed. So, the stress - strain parameters are listed in one column including the creep effect and in the other column without it. The results coincide quite well with compressibility data obtained from other residual soils formed above volcanic deposits (e.g. Hobbs et al., 1988). Moreover, the $\mathrm{C}_{\mathrm{c}}-$ value are within the proposed range for residual soils which is defined between 0.2 and 0.4 (Blight, 1997). However, it should be kept in mind that the compression index of residual soils is assumed to correlate with the void ratio and both of them decrease with deeper location (Blight, 1988).

Table 4.10: Stress-strain parameters obtained from the oedometer tests on undisturbed specimens.

\begin{tabular}{|c|c|c|}
\hline parameter & creep included & creep excluded \\
\hline \hline $\mathrm{a}_{\mathrm{v}}\left[\mathrm{MPa}^{-1}\right]$ & 0.0869 & 0.104 \\
\hline $\mathrm{C}_{\mathrm{c}}[-]$ & 0.2875 & 0.35 \\
\hline $\mathrm{m}_{\mathrm{v}}\left[\mathrm{MPa}^{-1}\right]$ & 0.0356 & 0.04 \\
\hline $\mathrm{D}[\mathrm{MPa}]$ & 28.07 & 24.79 \\
\hline $\mathrm{E}[\mathrm{MPa}]^{*}$ & 23.392 & 20.66 \\
\hline $\mathrm{C}_{\mathrm{s}}[-]$ & - & 0.014 \\
\hline
\end{tabular}

*assuming a Poisson ratio of $\mu=0.25$ 
At last, additional oedometer tests have been carried out on remoulded specimens in order to compare the results with the ones obtained from the undisturbed specimens. Consolidation tests are proposed to be the simplest experiments to detect the yield stress of the bonding in residual soils (Vaughan et al., 1988; Blight, 1997). The data obtained from the oedometer tests are illustrated by a semi-logarithmic graph in Figure 4.32a and in order to compare with the model proposed by Vaughan et al. (1988) (see Figure 4.1) by a linear graph in Figure 4.32b. At the beginning both specimens indicate a collapse behaviour due to the porous structure of the soil (Figure 4.32b). However, the volumetric strain is higher for the remoulded specimen and the bond stress (difference between $\mathrm{e}_{\mathrm{UD}}$ and $\mathrm{e}_{\mathrm{RM}}$ ) is continuous increasing up to a vertical stress of about $800 \mathrm{kPa}$. For values higher than about $1000 \mathrm{kPa}$ the bond stress is slightly decreasing which defines the second yield at about $1000 \mathrm{kPa}$.

a)

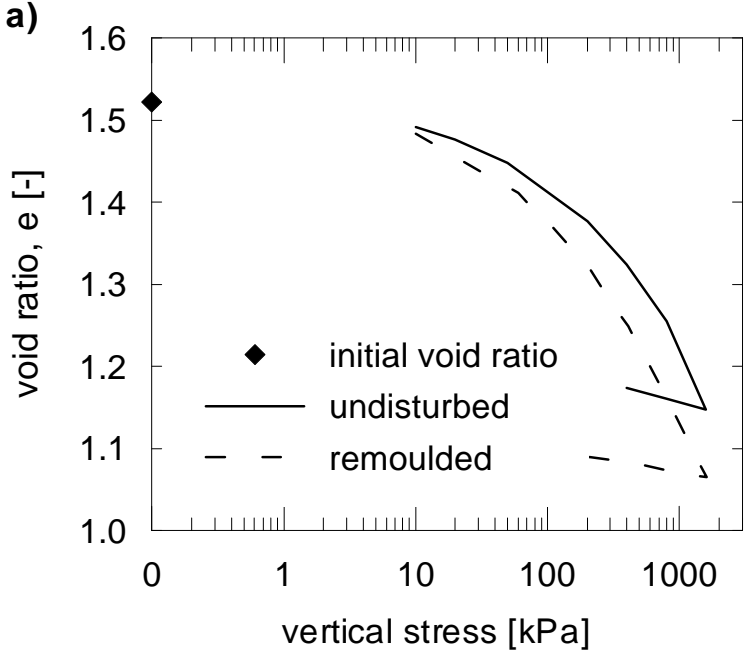

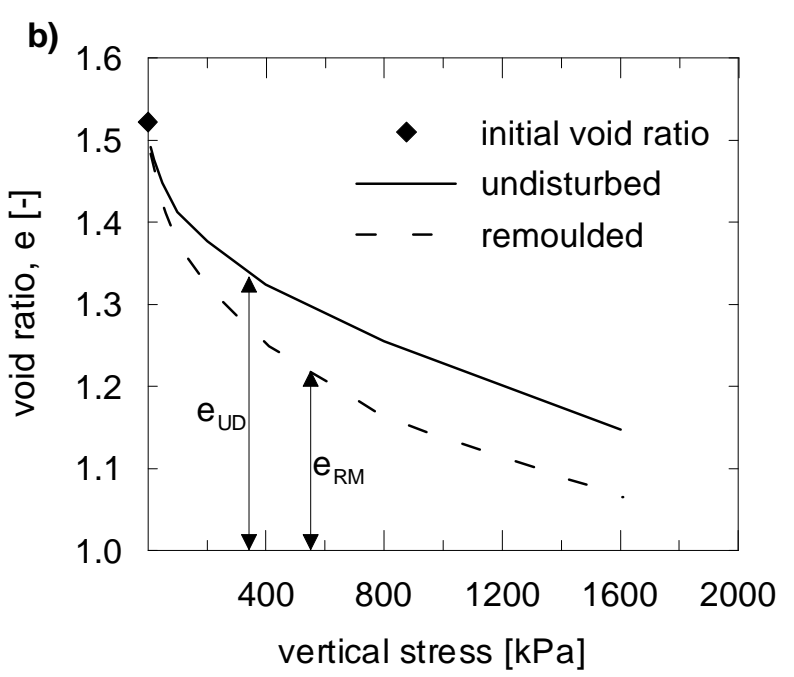

Figure 4.32: Void ratio vs. vertical stress of undisturbed and remoulded specimens using standard oedometer tests. a) Semi-logarithmic scale and b) linear scale. 


\section{Direct shear tests}

The test programme of the direct shear tests can be distinguished into two different parts: 1) the tests carried out using the SHEAR1 apparatus applying low normal stresses; and, 2) the tests carried out by the SHEAR2 apparatus applying high normal stresses. A comparison of the results obtained from the small apparatus SHEAR1 with the ones achieved from the large apparatus SHEAR2 is considered to be possible due to the almost negligible scale or size effects in direct shear testing of specimens with only small differences in diameters (Cheung et al., 1988). All the tests have been carried out strain controlled and in drained conditions with displacement rates between $0.05 \mathrm{~mm} / \mathrm{min}$ and $0.005 \mathrm{~mm} / \mathrm{min}$. First, the data obtained from SHEAR1 and from SHEAR2 apparatus will be presented by means of stress - strain curves refering always to undisturbed specimens. Moreover, a comparison of undisturbed and remoulded specimens will be shown in order to describe the bonding effect. Finally, strength envelopes will illustrate the results related to the shear strength parameters, once again dividing into results obtained from SHEAR1 and SHEAR2 apparatus, respectively.

The shear stress - horizontal strain curves obtained from the analysis of the specimen RS1-D-UD0 in the SHEAR1 apparatus are given in Figure 4.33. Each curve represents the data obtained from a different normal stress, $\sigma_{\mathrm{n}}$. The curves show quite clear peaks with increasing resolution for higher normal stresses and peak shear strength values ranging from about $200 \mathrm{kPa}$ for $\sigma_{\mathrm{n}}=200 \mathrm{kPa}$ to about $600 \mathrm{kPa}$ for $\sigma_{\mathrm{n}}=600 \mathrm{kPa}$. The constant volume shear strength has been selected as the final point of the curve. Looking to the curves of $\sigma_{\mathrm{n}}=400 \mathrm{kPa}$ and $600 \mathrm{kPa}$ the shear strength values still decrease at the end, but the tests had to be stopped at that point due to the limited horizontal displacement of the shear box. So, these two constant volume shear strengths may be slightly higher than in reality. Finally, comparing the peaks of the stress - strain curves a failure of the soil have been assumed to be at strains between 8 and $12 \%$.

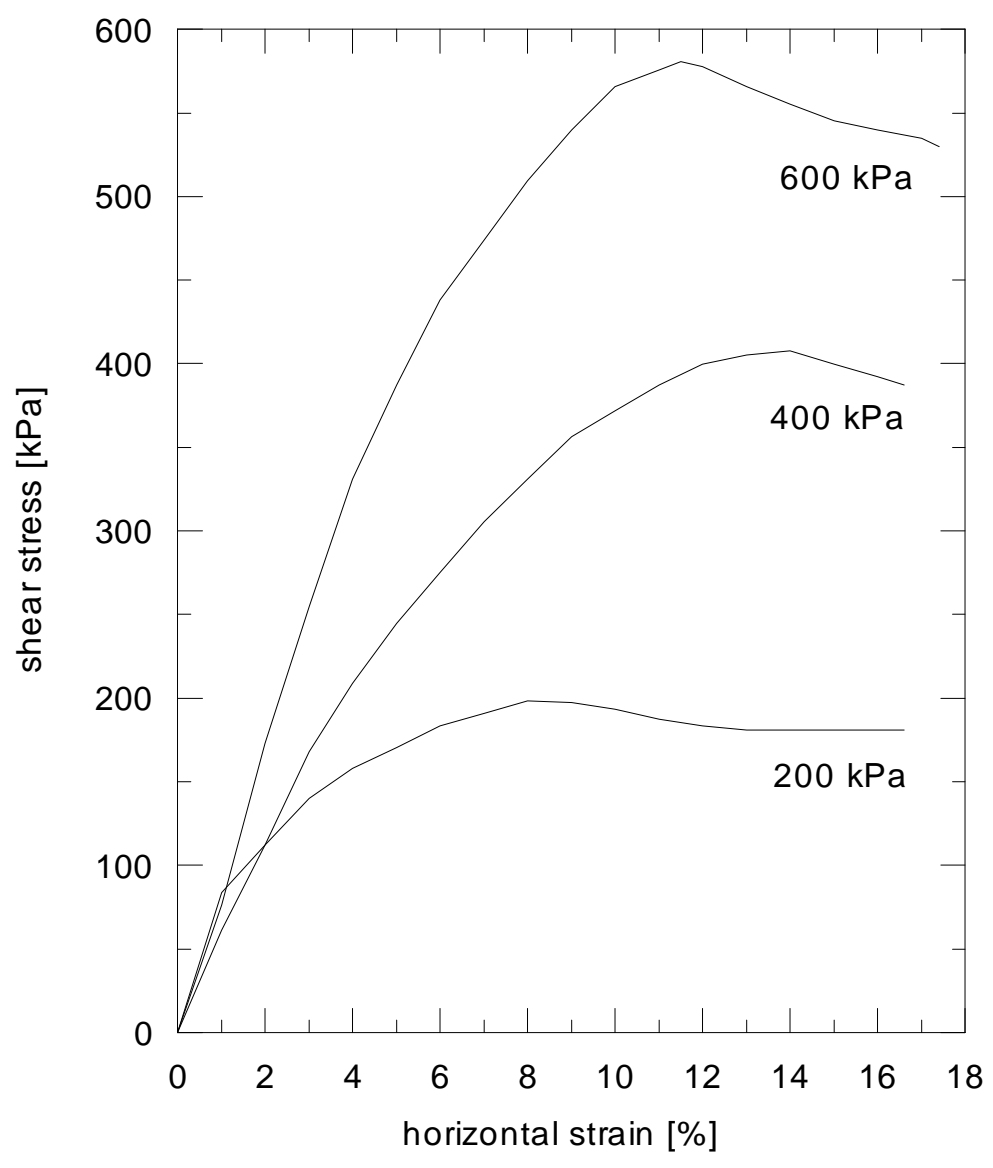


Figure 4.33: Results of direct shear test reloading the same initially undisturbed specimen in apparatus SHEAR1. Numbers indicate the normal stress applied to the specimen.

The residual shear strengths have been determined by returning the upper part of the sheared specimen as explained in Section 4.2.3. A typical curve of shear stress versus displacement including the first run failure and the recycled shearing is shown in Figure 4.34 for specimen RS1-D-UD0 and a normal stress of $200 \mathrm{kPa}$. The solid line indicates the shear stress values for the horizontal displacement into one direction (first run failure occurs) and the dashed line indicates the shear stress values for recycled shearing (returning the sheared part of the specimen to the initial position). The decreasing effect of the shear strengths can be observed easily. The values reduce from about $200 \mathrm{kPa}$ for the peak shear strength down to about $160 \mathrm{kPa}$ for the residual shear strength.

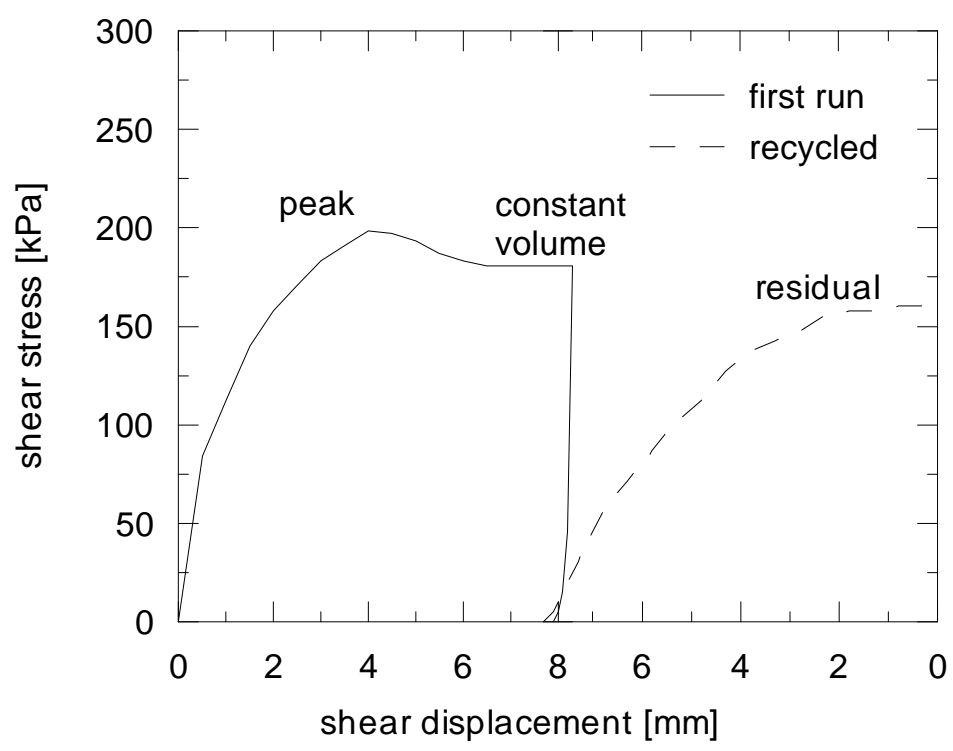

Figure 4.34: Determination of the shear strength values carried out by the drained direct shear test. The graph is shown for a normal stress of $200 \mathrm{kPa}$.

The shear strength values achieved from the three shear tests carried out in the shear box SHEAR1 are listed in Table 4.11. As expected the two following trends have been observed: 1) The shear strength increases constantly for higher normal stresses applied to the specimen; and, 2) the shear strength values decrease from peak shear strength to constant volume shear strength and to residual shear strength.

Table 4.11: Shear strengths for three different normal stresses using SHEAR1.

\begin{tabular}{|c|c|c|c|}
\hline $\begin{array}{c}\text { applied normal stress } \\
{[\mathrm{kPa}]}\end{array}$ & $\begin{array}{c}\text { peak shear strength } \\
{[\mathrm{kPa}]}\end{array}$ & $\begin{array}{c}\text { const. vol. shear strength } \\
{[\mathrm{kPa}]}\end{array}$ & $\begin{array}{c}\text { residual shear strength } \\
{[\mathrm{kPa}]}\end{array}$ \\
\hline \hline 200 & 198.68 & 180.85 & 158 \\
\hline 400 & 407.54 & 387.16 & 321 \\
\hline 600 & 580.74 & 530 & 489 \\
\hline
\end{tabular}


Typical shear stress - horizontal strain curves from the SHEAR2 apparatus are given in Figure 4.35. Each test has been carried out with a new specimen and no recycled tests have been performed. In contrast to the stress - strain behaviour applying low normal stresses, the curves obtained applying high normal stresses do not show clear peaks. The curves applying a normal stress of 2.59 and 5.2 MPa are characterised by a slow increase of the shear stress up to constant value which maintains till a shear displacement of about $10 \mathrm{~mm}$ (equal to a horizontal strain of $14 \%$ ). The curves refering to a normal stress equal to 10.39 and $15.59 \mathrm{MPa}$ show a faster increase of shear stress and don't reach a constant shear stress value even for a final shear displacement of more than $11 \mathrm{~mm}$ (testing a specimen with a diameter of $70 \mathrm{~mm}$ !). Therefore, the shear stress - displacement curves indicate that the stress - strain regime of the soil can be assumed to be ductile applying high normal stresses.

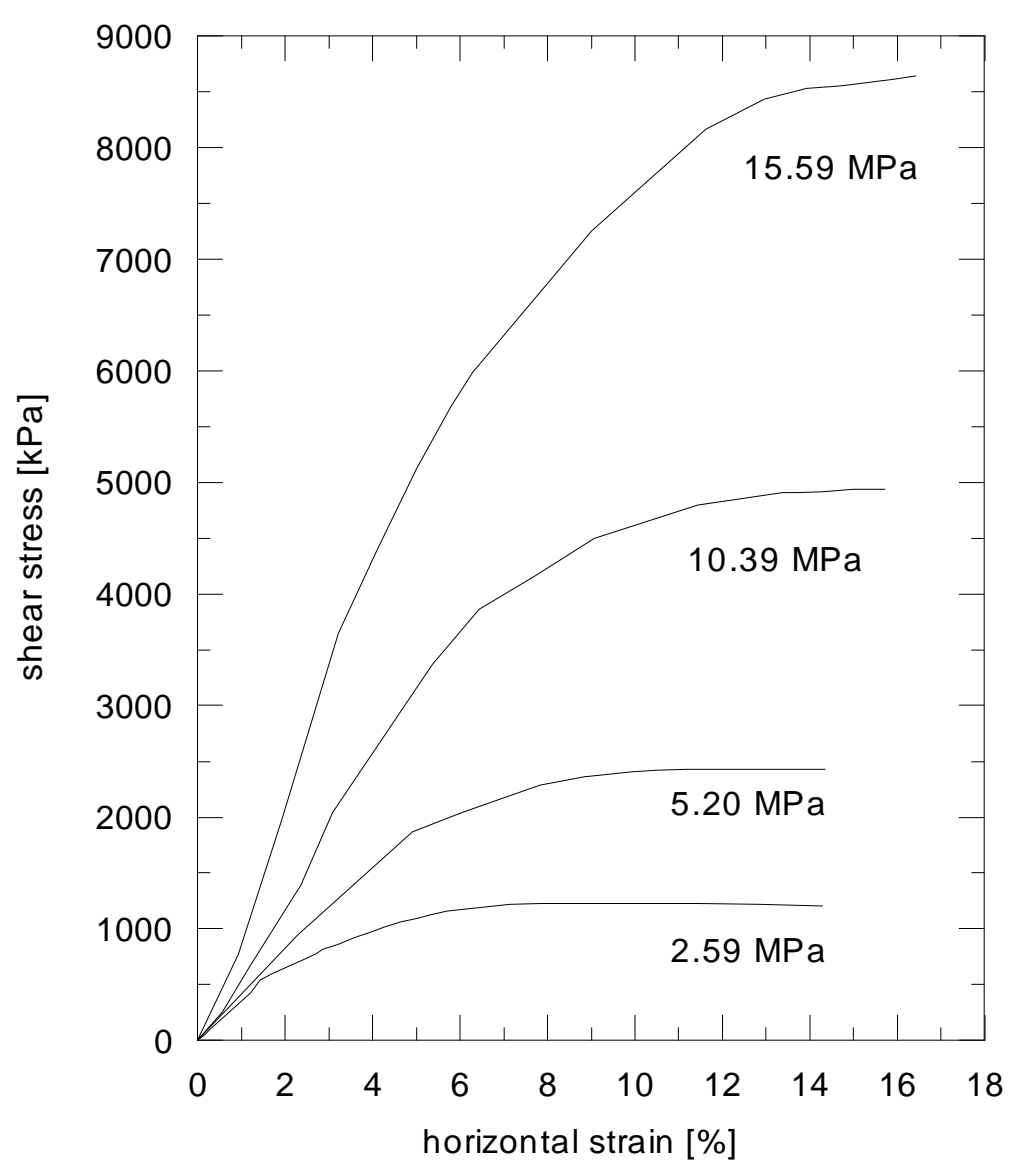

Figure 4.35: Stress - strain curves for undisturbed specimens from direct shear tests using SHEAR2. Numbers indicate the normal stress applied to the specimen.

Finally, the stress - strain curves of Figure 4.33 and Figure 4.35 have shown that the mechanical behaviour of the residual soil during shearing strongly depends on the normal stress applied to the specimen. For low normal stresses the stress - strain regime is preferably brittle and for high normal stresses ductile.

A summary of the shear strength values achieved by the shear box SHEAR2 is listed in Table 4.12 including the results obtained from undisturbed specimens as well as from remoulded specimens. The tests shearing undisturbed specimens give peak shear strengths and the shearing of remoulded, fine grained specimens is assumed to perform an estimate of the residual strength values. However, the residual shear strengths obtained are only insignificantly smaller or slightly higher than the peak shear strengths. For the data achieved from a normal stresses of 5197 and $15591 \mathrm{kPa}$, the shear strength of 
the remoulded, fine - grained specimen is only $6 \%$ smaller than the one of the undisturbed specimen. For a normal stress of $10394 \mathrm{kPa}$, the shear strength of the remoulded, fine - grained specimen is even slightly higher than for the one of the undisturbed specimen. A residual strength higher than the peak strength is theoretically not possible and thus the results obtained from a normal stress of $10394 \mathrm{kPa}$ are not correct. The error can only be explained by the accuracy of the apparatus and the problems with it mentioned in Section 'Methods'. In order to achieve another value of the residual shear strengths of the soil, the upper, sheared part of the undisturbed specimen has been returned to the initial position as done in SHEAR1 (Figure 4.34). In SHEAR2, however, the values obtained from this way are about $20 \%$ higher than the peak shear strength values, which can only be explained by shear box problems explained in the Section 'Methods'. Therefore, these 'residual' shear strength values are not listed in Table 4.12 and have not been incorporated into the calculation of the strength parameters of the soil.

Table 4.12: Shear strengths for different normal stresses using SHEAR2.

\begin{tabular}{|c|c|c|c|}
\hline specimen & $\begin{array}{c}\text { applied normal stress } \\
{[\mathrm{kPa}]}\end{array}$ & $\begin{array}{c}\text { shear strength } \\
{[\mathrm{kPa}]}\end{array}$ & type of shear strength \\
\hline RS1-D-UDVI & 2598 & 1226 & peak \\
\hline RS1-D-UDI & 5197 & 2588 & peak \\
\hline RS1-D-UDII & 5197 & 2431 & peak \\
\hline RS1-D-RMI & 5197 & 2280 & $\begin{array}{c}\text { 'residual' } \\
\text { (remoulded, fine - grained) }\end{array}$ \\
\hline RS1-D-UDIII & 10394 & 5255 & peak \\
\hline RS1-D-UDV & 10394 & 4939 & peak \\
\hline RS1-D-RMII & 10394 & 5435 & $\begin{array}{c}\text { 'residual' } \\
\text { (remoulded, fine - grained) }\end{array}$ \\
\hline RS1-D-UDIV & 15591 & 8707 & peak \\
\hline RS1-D-RMIII & 15591 & 8200 & $\begin{array}{c}\text { 'residual' } \\
\text { (remoulded, fine - grained) }\end{array}$ \\
\hline
\end{tabular}

A comparison of the stress - strain curves obtained from the two apparatuses has also been carried out. This comparison has included the data of remoulded and undisturbed specimens in order to analyse the bonding effect of the soil. Figure 4.36 illustrates four typical stress - strain curves, normalised by dividing the shear stress by the applied normal stress, $\tau / \sigma^{\prime}{ }_{n}$. Both an undisturbed and a remoulded specimen have been sheared applying to each of them on the one hand a low normal stress of $200 \mathrm{kPa}$ using the apparatus SHEAR1 and on the other hand a high normal stress of $15591 \mathrm{kPa}$ using the apparatus SHEAR2. There is no significant difference between the curves obtained from the remoulded and the undisturbed specimens applying high normal stresses. The similar strength values of the two specimens indicate that the bonding has already broken entirely during the normal loading of the consolidation phase and the strength does not differ for undisturbed and remoulded soils. On the other hand, the two curves obtained from the SHEAR1 apparatus applying low normal stresses strongly disagree with the other ones. The shear strengths of the curves increase faster up to a peak value and then lower to a constant volume strength. In contrast to the curves achieved from high normal stresses, the shear strength values of the undisturbed and remoulded specimen applying low normal stresses don't coincide and the values of the undisturbed specimen clearly exceed the ones of the remoulded specimen. The clear difference of these two curves can be justified by the bonding effect. After the consolidation phase applying a normal stress of $200 \mathrm{kPa}$, the bonded structure of the soil maintains intact in the undisturbed specimen and thus strongly differs from the remoulded specimen with a destroyed bonding. A similar behaviour has been revealed by direct shear test on gneissic residual soils in Brazil applying different normal stresses (Maccarini, 1993). 


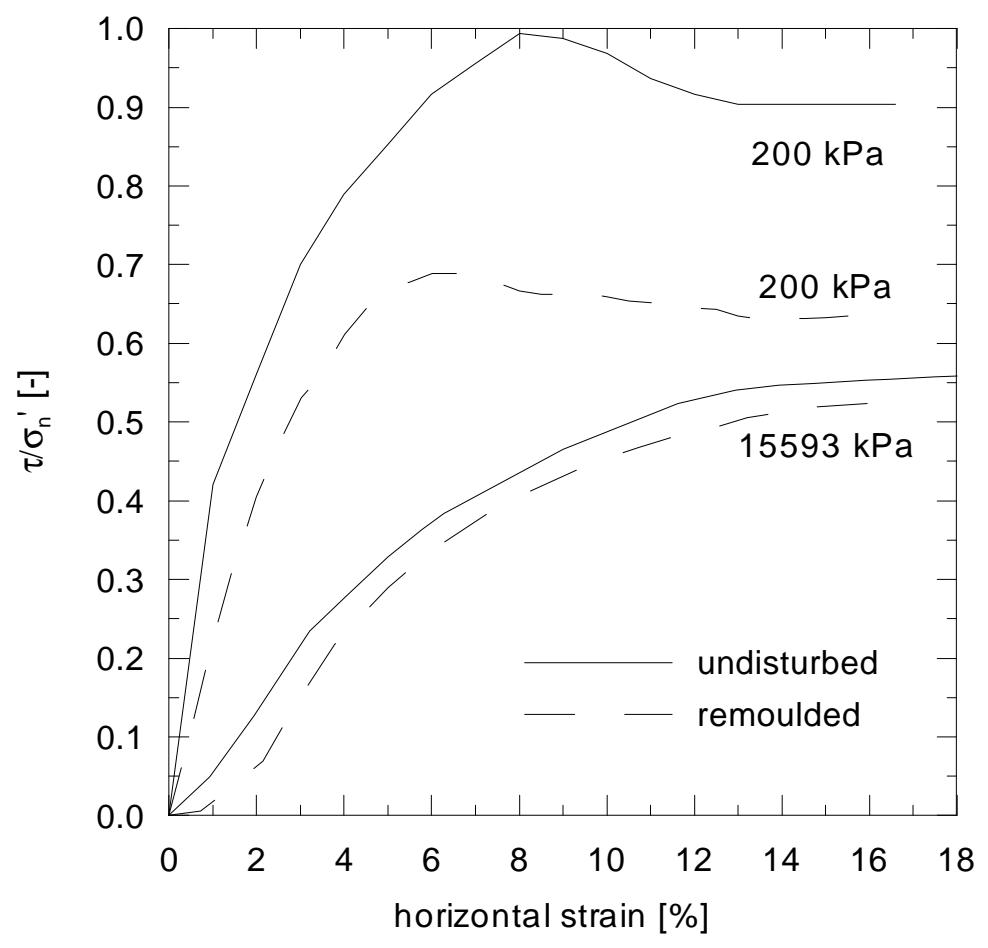

Figure 4.36: Horizontal strain versus $\tau / \sigma_{\mathrm{n}}{ }^{\prime}$ ratio for different normal stresses and both undisturbed and remoulded specimens.

In conclusion, it can be said that the bonding effect in the residual soil depends on two main facts during direct shear tests:

1) The normal stress applied to the soil. If the normal stress exceeds the yield stress of the bonds in an undisturbed soil, the soil acts as a remoulded, 'destructed' soil. Once this yield stress has passed, an initially remoulded and undisturbed specimen behave almost equal.

2) The structure of the soil. An undisturbed soil with an intact bonding clearly surpasses the shear strength of a remoulded soil with destroyed bonds. This characteristic only happens, if the normal stress is lower than the yield stress (see point 1). 
Analysing the volumetric behaviour of the soil during the direct shear tests the results are quite surprising. Figure 4.37 shows the shear stress and the void ratio versus the horizontal strain during the direct shear test of an undisturbed specimen applying a normal stress of 5.197 MPa. The lower graph indicates the large decrease of void ratio during the failure. The maximum volumetric reduction occurs before the peak shear stress is arrived and even continues for large horizontal strains. A dilatant effect which is quite normal for sandy soils, has not been detected in any test carried out during this study. Even applying small normal loads no dilatancy occurs, which distinguishes this residual soil from other residual soils investigated by direct shear tests (Wallace, 1973; Blight, 1997).

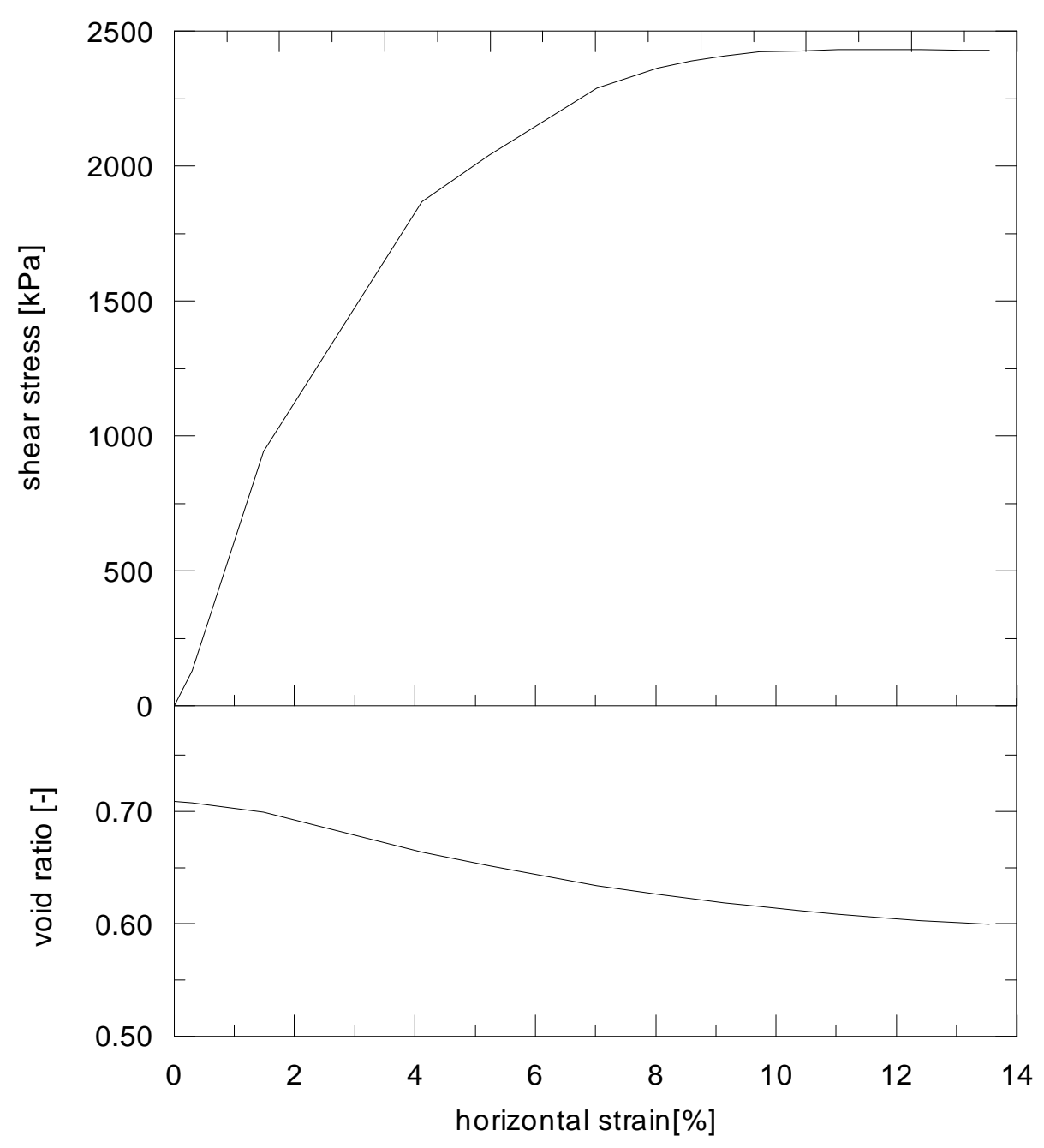

Figure 4.37: Horizontal strain versus shear stress and void ratio during direct shear test of an undisturbed specimen with normal load of 5.197 MPa. 
In the next step, the strength envelopes have been performed for all the data obtained from the direct shear tests, in order to determine the strength parameters of the soil,. Hence, the angle of internal friction, $\phi$, and the cohesion intercept, c , have been calculated using the Mohr-Coulomb failure law, given by

$$
\tau=\mathrm{c}+\sigma_{\mathrm{n}}{ }^{\prime} \tan \phi
$$

, where $\tau$ is the shear stress and $\sigma_{\mathrm{n}}{ }^{\prime}$ is the effective normal stress. The data obtained from SHEAR 1 has first been analysed separately, since the strength behaviour of the soils may be influenced by the application of different normal loads. In a second step the data of both apparatus are presented together.

The results obtained from the tests carried out in the SHEAR1 apparatus are shown graphically in Figure 4.38. The plotted lines indicate the 'best-fit' linear envelopes for each type of shear strength over the range of normal stresses.

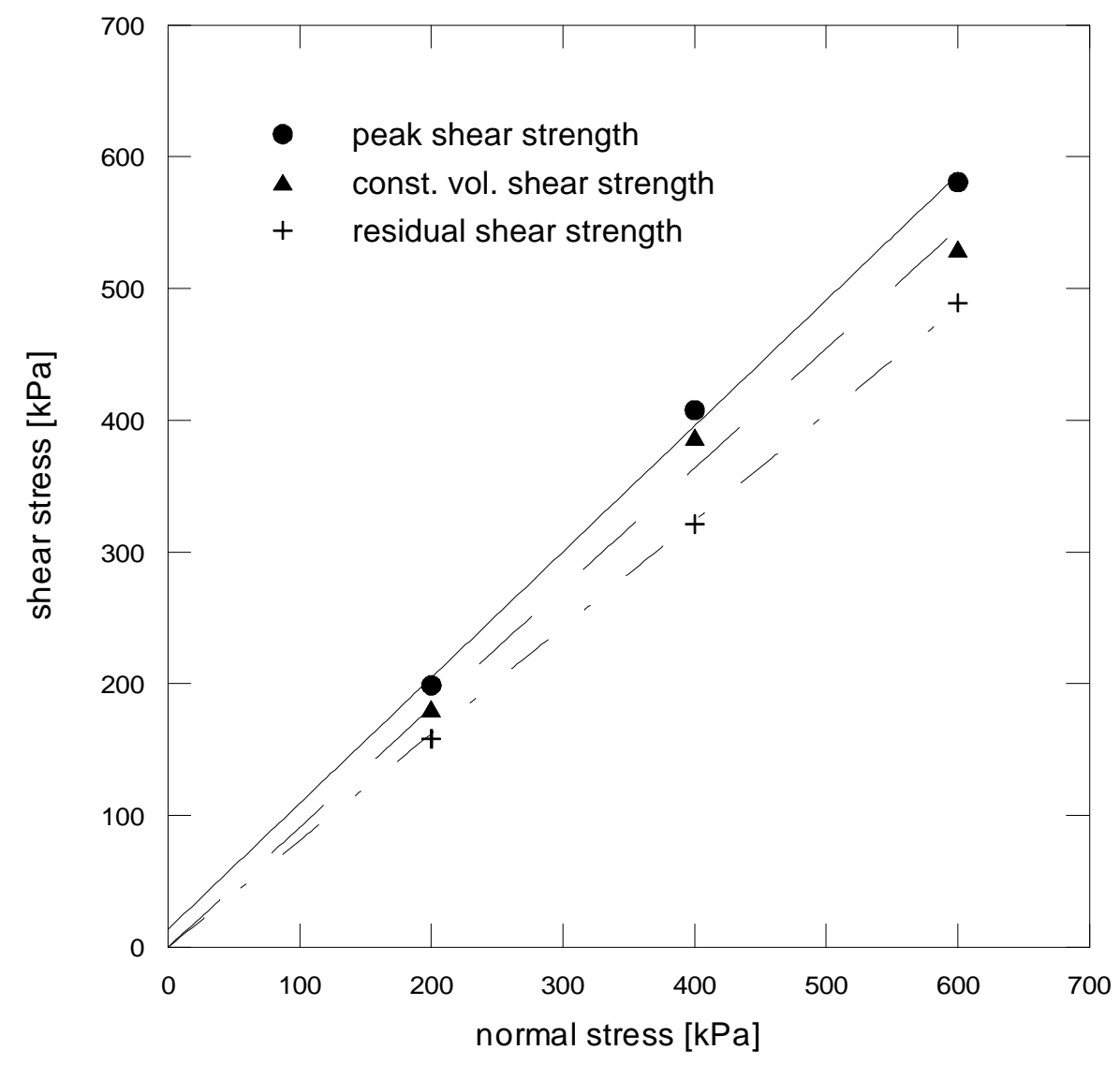

Figure 4.38: Mohr-Coulomb failure planes for different shear strengths obtained from tests in the SHEAR1 apparatus. Straight line for peak shear strength, dashed line for const. vol. shear strength and dashed - doted line for residual shear strength.

Then, the two strength parameters $\phi$ and $\mathrm{c}$ have been calculated. The Mohr-Coulomb failure planes of Figure 4.38 have been represented by mathematical equations of the form of Eq. 4.4 and the resulting expressions for each of the three shear strengths are:

$$
\begin{array}{ll}
\text { peak shear strength : } & \tau=0.955 \sigma_{\mathrm{n}}{ }^{\prime}+13.59 \mathrm{kPa} \\
\text { con. vol. shear strength : } & \tau=0.909 \sigma_{\mathrm{n}}{ }^{\prime} \\
\text { residual shear strength : } & \tau=0.810 \sigma_{\mathrm{n}}{ }^{\prime}
\end{array}
$$


These equations represent the failure envelopes of the residual soil applying low normal stresses and perform the strength parameters listed in Table 4.13.

Table 4.13: Angle of friction and cohesion for the three shear strengths obtained from SHEAR1 applying low normal stresses.

\begin{tabular}{|l|c|c|}
\hline type of shear strength & $\begin{array}{c}\text { angle of friction } \\
\text { [degree] }\end{array}$ & $\begin{array}{c}\text { cohesion } \\
{[\mathrm{kPa}]}\end{array}$ \\
\hline \hline peak shear strength & 45.0 & 13.59 \\
\hline constant volume shear strength & 42.3 & 0 \\
\hline residual shear strength & 39.0 & 0 \\
\hline
\end{tabular}

The results give values of friction angles between 39 and 45 degrees which are higher than for other residual or volcanic soils with friction angles ranging from about 20 to 30 degrees (Ruddock, 1967; Wallace, 1973; Cheung et al., 1988; Hobbs et al., 1988; Kitamura et al., 1988; Sridharan, 1988). The high values can be assumed to the different composition of the youthful residual soil, that contains a large amount of sand fraction instead of the clay rich soils studied in the cited publications. Another explanation may be a stronger bonding effect enforcing the material strength. The calculations of the cohesion achieve small values with both residual and constant volume shear strengths of zero cohesion and values of around $15 \mathrm{kPa}$ for the peak shear strength. These cohesion values support the results obtained from other studies on bonded residual soils (Brenner et al., 1997). They propose that soils with bonded structure are characterised by a cohesion intercept due to the strength of the cementation (peak values). Once the bonding is completely broken the cohesion decreases and may reach zero as in the case of the RS1 sample for the residual cohesion. 
In the following, the shear strength values and envelopes of the data achieved from SHEAR2 apparatus will be presented. The results obtained from undisturbed and remoulded specimen are illustrated in Figure 4.39. Shear strength values and the envelopes of both types of specimens are very similar and do not differ significantly. This behaviour may be explained by the bonding effect of the soil. The cementation of the soil particles already breaks during the consolidation phase of the test applying large normal stresses higher than about $1000 \mathrm{kPa}$. Once the bonds are broken in the undisturbed specimen, it behaves as a non-bonded or 'destructed' soil and has similar characteristics as a remoulded specimen. Another feature supporting the similarity of the two types of specimens may be found in the properties of the soil, which mainly consists of granular and non-plastic material.

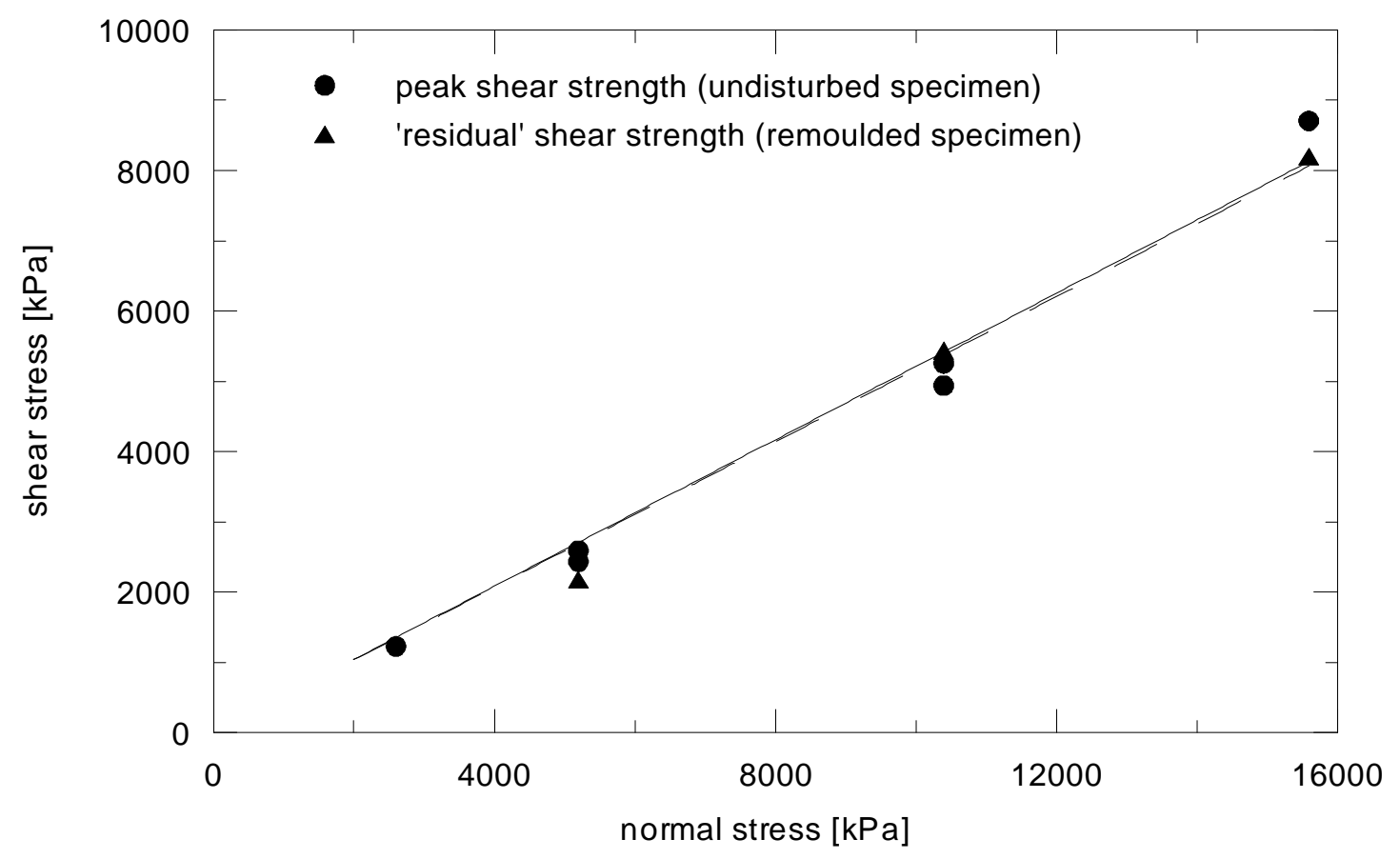

Figure 4.39: Mohr-Coulomb failure planes for the different shear strengths obtained from tests in the SHEAR2 apparatus. Straight line for peak shear strength and dashed line for 'residual' shear strength.

The Mohr-Coulomb failure planes shown in Figure 4.39 can be expressed by the following mathematical expressions:

$$
\begin{array}{ll}
\text { peak shear strength : } & \tau=0.521 \sigma_{\mathrm{n}}, \\
\text { 'residual' shear strength : } & \tau=0.517 \sigma_{\mathrm{n}},
\end{array}
$$

The angles of friction and cohesions calculated by these equations are listed in Table 4.14 and represent the strength parameters of the residual soil applying high normal stresses. The friction angles obtained from the SHEAR2 apparatus are about 27 degrees and the cohesion intercept is zero. The peak shear strength and the 'residual' shear strength don't differ and give almost the same values. Additionally, an overall or average friction angle has been calculated including the data of all specimens (undisturbed and remoulded) and has given an angle of friction of 27.4 degrees.

Table 4.14: Angle of friction and cohesion for the three shear strengths obtained from SHEAR2 applying high normal stresses.

\begin{tabular}{|l|c|c|}
\hline \multicolumn{1}{|c|}{ type of shear strength } & $\begin{array}{c}\text { angle of friction } \\
\text { [degree] }\end{array}$ & $\begin{array}{c}\text { cohesion } \\
{[\mathrm{kPa}]}\end{array}$ \\
\hline \hline peak shear strength (undisturbed specimen) & 27.5 & 0 \\
\hline 'residual' shear strength (remoulded, fine-grained specimen) & 27.3 & 0 \\
\hline
\end{tabular}


Finally, the peak shear strengths obtained from SHEAR2 applying large normal stresses are shown together with the ones obtained from SHEAR1 (Figure 4.40). Two different types of strength behaviour can be distinguished: One represents the results for normal stress up to $600 \mathrm{kPa}$ and the other for normal stress higher than $2500 \mathrm{kPa}$. The fact that different normal stresses produce different shear strength regimes is typical for residual soils due to the bonding effects (Maccarini, 1993; Brenner et al., 1997). Generally, the shear strength parameters within a low normal stress range exceed the ones of higher normal stresses. For small normal stress the bonding of the soil is still intact which produces overestimated shear strength values, whereas increasing normal stress destructs gradually the cementation between the soil particles and gives smaller shear strengths. Figure 4.40 verifies this behaviour performing a friction angle of about $45^{\circ}$ for low normal stresses and one of about $30^{\circ}$ for high normal stresses.

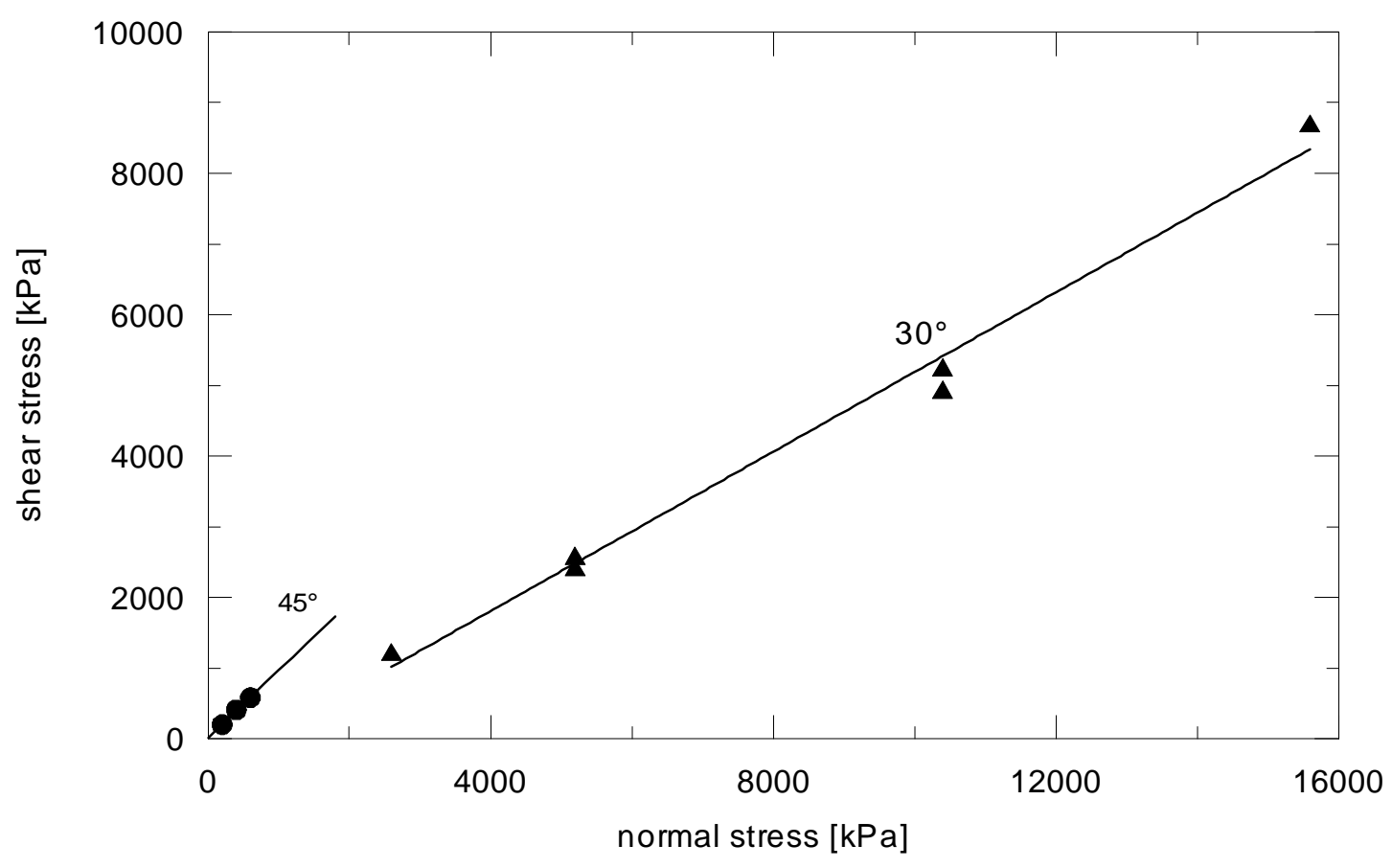

Figure 4.40: Mohr-Coulomb failure planes obtained from peak shear strength values and the calculated angle of friction distinguishing between low normal stress (dots) and high normal stress (triangles).

At last, the broken specimen has been studied after each direct shear test and photographs have been taken in order to determine the mode of failure. The examination of the failure surfaces of the sheared specimens has revealed that the failure takes place along a zone rather than a discrete plane (Figure 4.41). The lack of orientation in the sheared samples of soil RS1 differs from the field observation obtained from sample RS3, which is characterised by several fault planes and typical slickenslides (Figure 4.42). This may be explained by distinct stresses acting on the soils, the influence of preexisting fault planes in the phonolitic pyroclastic deposits or the different mineralogy and grain size distribution of the soils. The weathering stage of RS3 sample is more developed than the one of RS1, and the RS3 soil consists in general of finer particles than RS1. However, direct shear test carried out on allophane soils, which contain a large percentage of clays, revealed similar characteristics as obtained in this study and no discrete failure planes were detected (Rouse et al., 1986). 


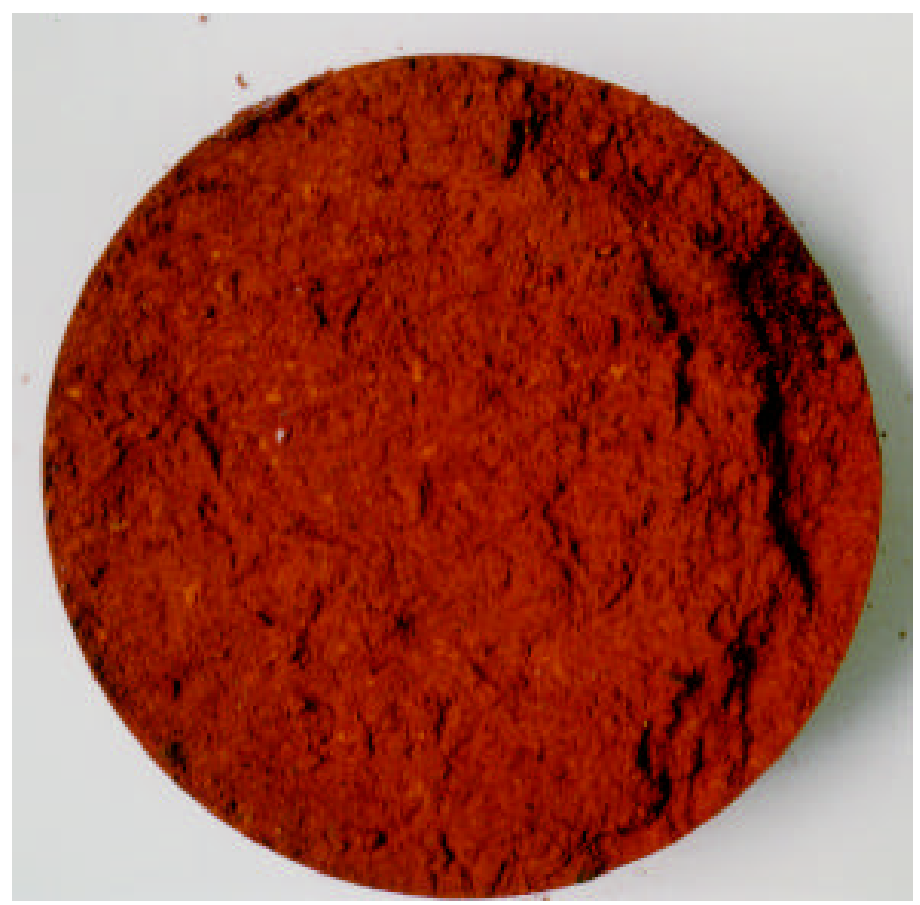

Figure 4.41: Failure zone of undisturbed specimen after a direct shear test applying a vertical stress of $10394 \mathrm{kPa}$. The failure occurs along a zone characterised by a very irregular morphology. The diameter of the specimen is $7 \mathrm{~cm}$.

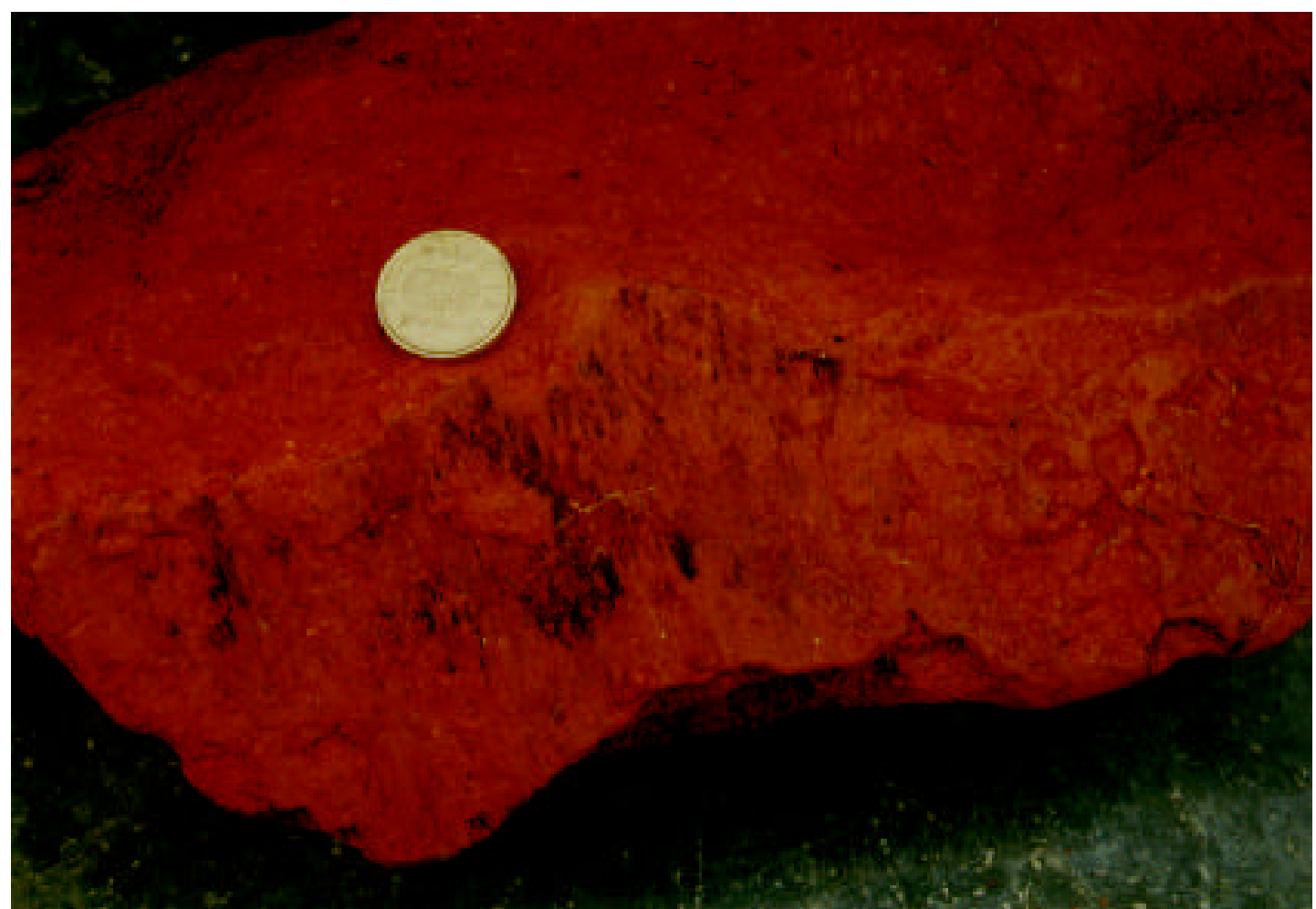

Figure 4.42: Failure zone observed in residual soil RS3. Clear slickenslide features are visible characterised by the black colour. 


\section{Ring shear test}

Five ring shear tests have been carried out in order to achieve the residual shear strength after large displacements. Normal stresses have been applied to the specimens ranging from $200 \mathrm{kPa}$ to $600 \mathrm{kPa}$. After transforming the rotated degrees into displacements with units in $\mathrm{mm}$ the shear stress displacement curves have been plotted as shown in Figure 4.43.

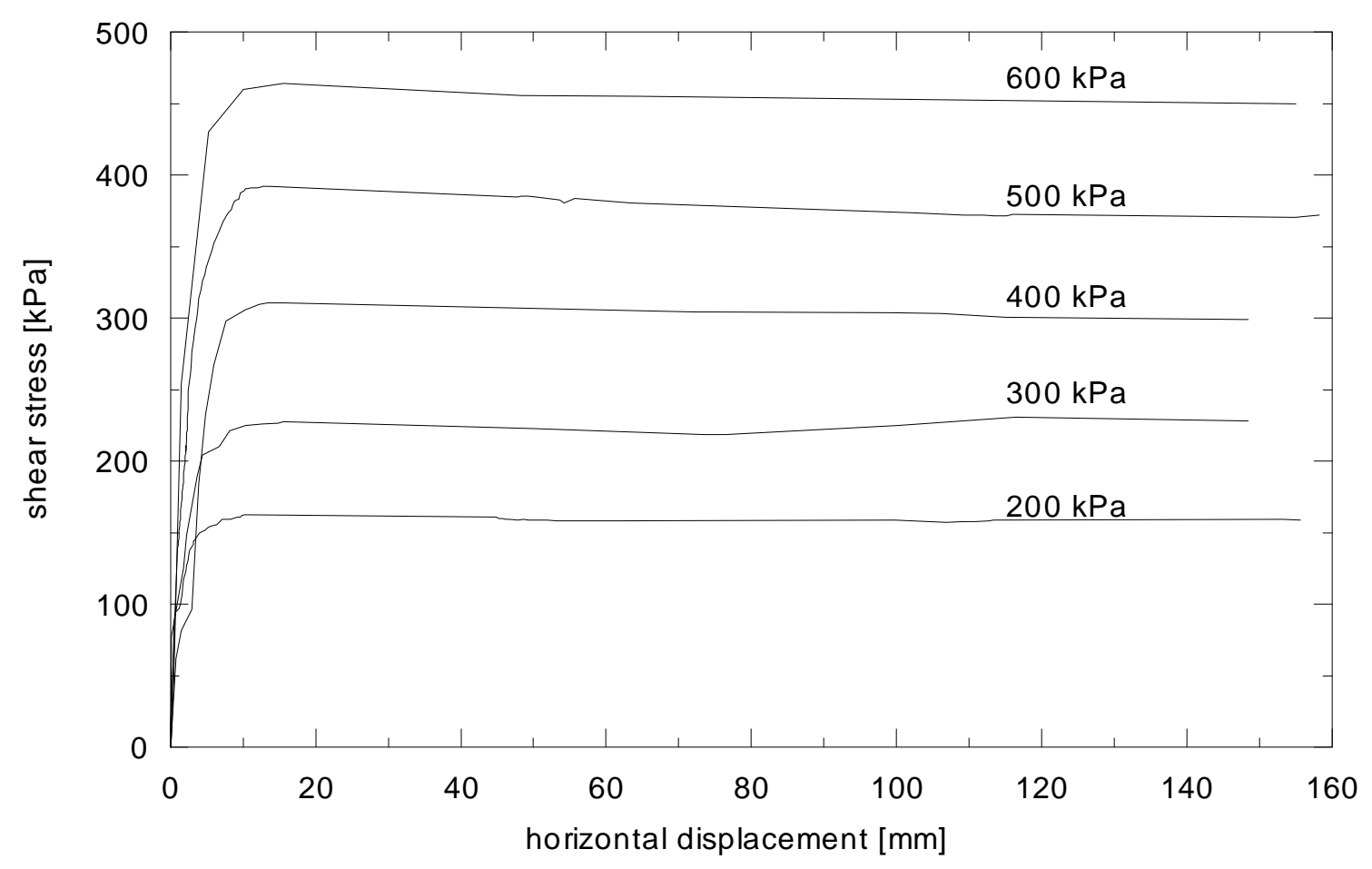

Figure 4.43: Shear strength versus horizontal displacement during ring shear tests applying low normal stresses.

Assuming the cohesion to be zero, the angle of friction can be determined from the minimum values of shear strength during the ring shear test using the expression:

$$
\tau / \sigma_{\mathrm{n}}{ }^{\prime}=\tan \phi
$$

, where $\tau$ is the shear stress and $\sigma_{\mathrm{n}}{ }^{\prime}$ is the effective normal stress. The values of the friction angle calculated by Equation 4.5 range from 36.9 to 38.6 degrees (Table 4.15). The average of these residual friction angles is about 37.5 degrees, which means that it is only insignificantly lower than the residual friction angles obtained from the direct shear tests. The residual friction angle achieved by the direct shear test applying low normal stress has been calculated as 39.5 degrees.

Table 4.15: Residual shear strength and friction angles obtained from the ring shear tests.

\begin{tabular}{|c|c|c|}
\hline $\begin{array}{c}\text { applied normal stress } \\
{[\mathrm{kPa}]}\end{array}$ & $\begin{array}{c}\text { residual shear stress } \\
{[\mathrm{kPa}]}\end{array}$ & $\begin{array}{c}\text { residual angle of friction } \\
{[\text { degree] }}\end{array}$ \\
\hline \hline 200 & 160 & 38.6 \\
\hline 300 & 225 & 36.9 \\
\hline 400 & 300 & 36.9 \\
\hline 500 & 385 & 37.6 \\
\hline 600 & 455 & 37.2 \\
\hline
\end{tabular}




\section{Triaxial tests}

The results obtained during the different triaxial tests can be distinguished in three main groups. Results refering to: 1) the permeability, 2) the volumetric behaviour during the consolidation as well as the failure phase of the test; and, 3) the stress - strain behaviour during failure. In this study, the point 1) and 2) have been studied marginally in order to focus on the stress - strain behaviour of the soil during drained and undrained loading.

Constant flow-rate permeability tests carried out prior to the consolidation of the specimen have provided values of the permeability of the soil (Table 4.16). The permeability, $k$, ranges from $1.04 \times 10^{-4}$ to $4.8 \times 10^{-4} \mathrm{~cm} / \mathrm{sec}$ which does not significantly differ from the values obtained from the oedometer tests ( $\mathrm{k}$ between $0.7 \times 10^{-4}$ and $1.97 \times 10^{-4} \mathrm{~cm} / \mathrm{sec}$ ). Because the geotechnical literature provides very limited information on the permeability of residual soil, a comparison of the data obtained is difficult. However, the values of permeability seem to confirm the results of the soil classification tests, which revealed for example a quite high porosity. Finally, it can be said that the residual soil is characterised by a intermediate permeability according to the classification of soils due to their $\mathrm{k}-$ value (Terzaghi and Peck, 1967). The cell, back and pore pressures applied in each permeability test as well as the measured values are listed in Table 4.16.

Table 4.16: Permeability values obtained in triaxial cells and applied cell pressure, back pressure (inlet) and pore pressure (outlet).

\begin{tabular}{|c|c|c|c|c|}
\hline specimen & $\begin{array}{c}\text { cell pressure } \\
{[\mathrm{kPa}]}\end{array}$ & $\begin{array}{c}\text { back pressure } \\
{[\mathrm{kPa}]}\end{array}$ & $\begin{array}{c}\text { pore pressure } \\
{[\mathrm{kPa}]}\end{array}$ & $\begin{array}{c}\text { permeability } \\
{[\mathrm{cm} / \mathrm{sec}]}\end{array}$ \\
\hline \hline RS1-T-CU1 & 100 & 90 & 80 & $4.6 \times 10^{-4}$ \\
\hline RS1-T-CU2 & 100 & 90 & 80 & $3.5 \times 10^{-4}$ \\
\hline RS1-T-CU3 & 100 & 90 & 80 & $4.8 \times 10^{-4}$ \\
\hline RS1-T-CU4 & 700 & 600 & 570 & $3.1 \times 10^{-4}$ \\
\hline RS1-T-CUI & 50 & 20 & 0 & $2.32 \times 10^{-4}$ \\
\hline RS1-T-CUII & 50 & 30 & 0 & $1.26 \times 10^{-4}$ \\
\hline RS1-T-CD1 & 20 & 10 & 0 & $2.0 \times 10^{-3}$ \\
\hline RS1-T-CD2 & 30 & 10 & 0 & $5.6 \times 10^{-4}$ \\
\hline RS1-T-CD3 & 30 & 10 & 0 & $7.2 \times 10^{-4}$ \\
\hline RS1-T-CD4 & 30 & 10 & 0 & $5.1 \times 10^{-4}$ \\
\hline RS1-T-CDI & 50 & 20 & 0 & $1.04 \times 10^{-4}$ \\
\hline
\end{tabular}

Measurements of the volumetric change have been collected during the confining phase of the triaxial tests. Figure 4.44 shows the void ratio, e, versus the effective confining stress, p', for the three specimens to which a high effective confining pressure have been applied using TRIAX2. As in the results obtained from the oedometer tests, there is no explicit yield stress or collapse visible. However, the consolidation curves seem to change their behaviour at an effective confining stress value of about $700 \mathrm{kPa}$. After this value the e $-\log \left(\mathrm{p}^{\prime}\right)$ curves are parallel to each other and define the normal compression line (NCL) similar to that obtained from the oedometer tests. The slope of the NCL is in this case 0.373 and determines the compression index, $\mathrm{C}_{c}$., which has been calculated as 0.29 and 0.35 in the oedometer tests. A $\mathrm{C}_{\mathrm{c}}$-value of 0.373 agrees with compression indexes achieved from other bonded residual soils (Blight, 1997) and coincides quite well with the value obtained from a volcanic tuff using the same procedures (Aversa and Evangelista, 1998). 


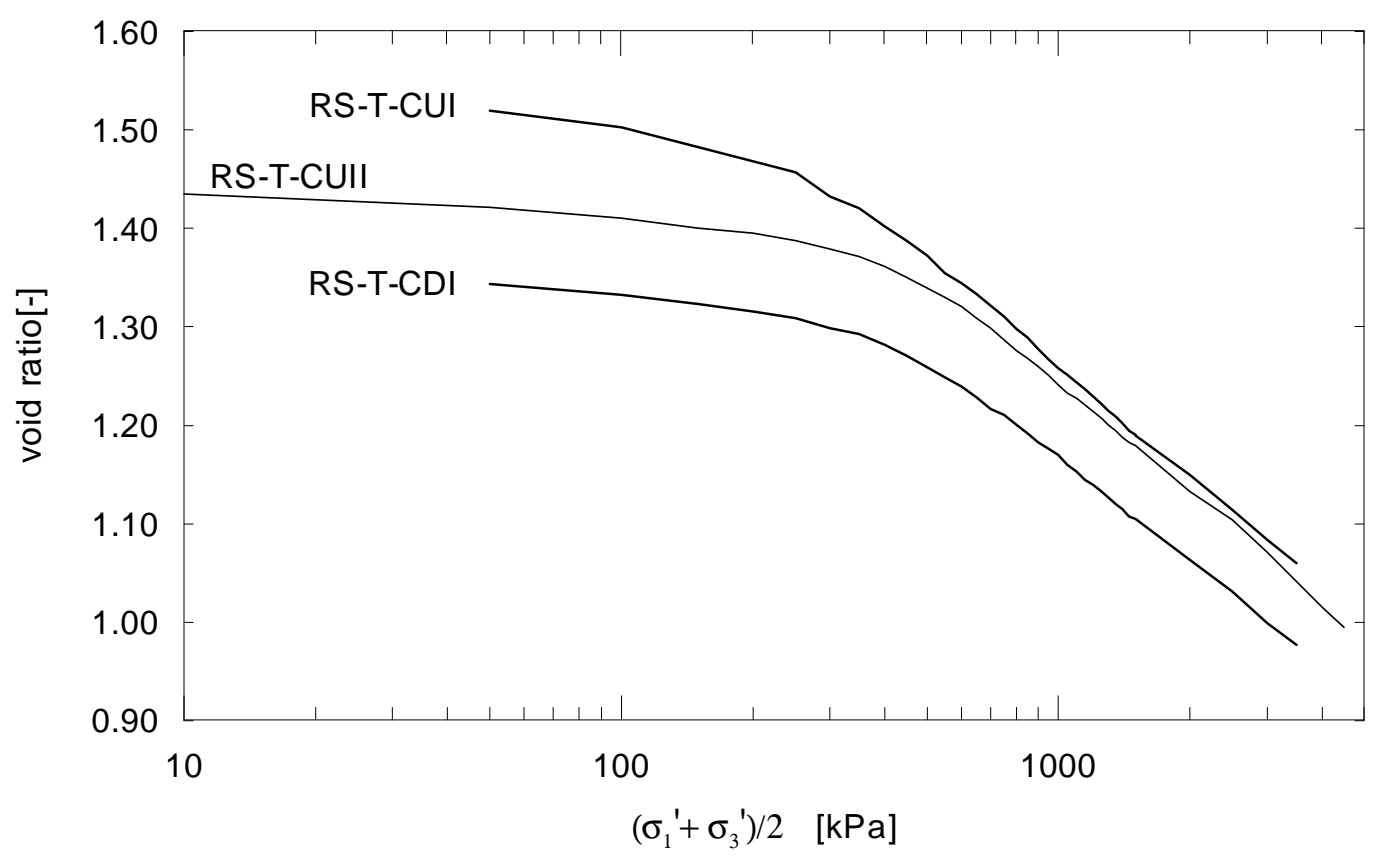

Figure 4.44: Void ratio versus effective confining stress during confining pressure phase of triaxial tests using TRIAX2.

Void ratios of the specimens have been measured before and after the tests and indicate the decrease of volume during the triaxial test. The initial and final values of void ratio as well as the decrease of void ratio achieved from the drained and undrained triaxial tests are listed in Table 4.17. The different effect of undrained and drained tests on the void ratio is clearly visible, and the analysis of the data should thus be separated into two different groups. Generally, the drained triaxial tests are characterised by a much higher decrease of void ratio, since in these tests the reduction of volume is not only limited to the consolidation phase, but also incorporates a significant reduction during failure. This contrasts with the undrained tests, in which the void ratio maintains constant during failure. Moreover, both types of tests represent a decreasing trend of void ratio due to higher effective confining stress.

Table 4.17: Void ratios during triaxial tests.

\begin{tabular}{|c|c|c|c|c|}
\hline specimen & $\begin{array}{c}\text { effective confining } \\
\text { stress } \\
{[\mathrm{kPa}]}\end{array}$ & $\begin{array}{c}\text { initial } \\
\text { void ratio } \\
{[-]}\end{array}$ & $\begin{array}{c}\text { final } \\
\text { void ratio } \\
{[-]}\end{array}$ & $\begin{array}{c}\text { decrease of void } \\
\text { ratio } \\
{[-]}\end{array}$ \\
\hline \hline RS1-T-CU3 & 300 & 1.49 & 1.34 & 0.15 \\
\hline RS1-T-CU1 & 600 & 1.28 & 1.19 & 0.09 \\
\hline RS1-T-CU2 & 900 & 1.35 & 1.21 & 0.14 \\
\hline RS1-T-CU4 & 1550 & 1.52 & 1.28 & 0.23 \\
\hline RS1-T-CUI & 3500 & 1.53 & 1.06 & 0.47 \\
\hline RS1-T-CUII & 4500 & 1.44 & 1.00 & 0.44 \\
\hline RS1-T-CD1 & 300 & 1.53 & 1.16 & 0.37 \\
\hline RS1-T-CD4 & 600 & 1.33 & 0.89 & 0.44 \\
\hline RS1-T-CD2 & 900 & 1.43 & 1.01 & 0.42 \\
\hline RS1-T-CD3 & 1550 & 1.39 & 0.82 & 0.57 \\
\hline RS1-T-CDI & 3500 & 1.35 & 0.74 & 0.61 \\
\hline
\end{tabular}


To improve the understanding of the volumetric behaviour during failure, the void ratio has been plotted versus the mean effective stress. Figure 4.45 indicates the curves obtained from the drained and undrained triaxial tests and additionally shows the critical void ratio (CVR) line interpolated by the yielding points. The concept of the critical void ratio has been introduced by Casagrande and marks the boundary between loose (contractive) and dense (dilative) states. The contractive state is located in the upper right part of the plot and the dilative state in the lower left part. This concept normally applies for sandy soils as for example the one analysed in this study. Since no dilatancy has been detected during any test, all of the curves should start at the right side of the CVR line and then migrate at large strains horizontally (CU - tests) or sub-vertically (CD - tests) towards the line. In particular the curves for low confining stresses contradict this concept of the CVR. This contradiction has also been found in other tests analysing the behaviour of dense and loose samples, where the paths of the tests do not head towards a CVR line but a somewhat diffuse, but clearly pressure dependent, zone of critical void ratios (Wood, 1992). Therefore, the CVR-line computed from all the eleven failure points and drawn in Figure 4.45 only represents an estimation of the centre of a CVR-zone including the failure points of all paths.

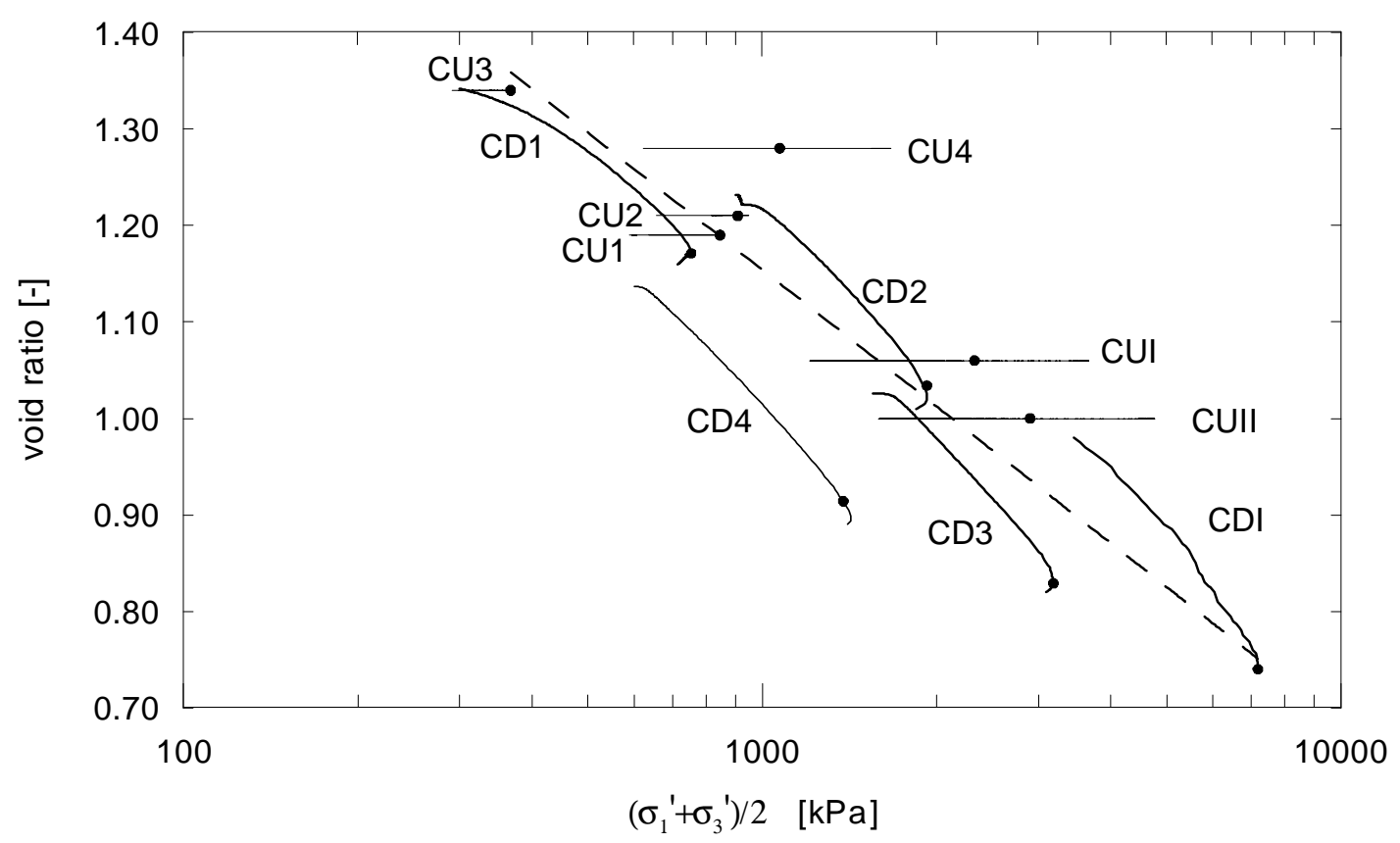

Figure 4.45: Void ratio vs. mean effective stress during failure phase of undrained (thin solid lines) and drained (thick solid lines) triaxial tests. Dots represent yielding point. Dashed line represents the CVR line. Labels are the specimen names as listed in Table 4.17. 
The analysis of the stress-strain behaviour of the soil is divided into two sections. First, the results of the tests carried out by the TRIAX1 apparatus applying low effective confining stresses up to $1550 \mathrm{kPa}$ will be presented. Secondly, the results of the TRIAX2 apparatus applying high effective confining stresses up to $4500 \mathrm{kPa}$ will be shown.

The results of the undrained triaxial tests carried out on the undisturbed specimens in the TRIAX1 apparatus are given in the form of stress-strain curves with additional data referring to the change of the pore water pressure (Figure 4.46). Generally, the deviatoric stress increases rapidly up to the failure, which occurs at an axial strain of between 2 and $5 \%$, and then decreases slightly. The stress-strain behaviour changes again at a strain rate of about $12 \%$. After this point the deviatoric stress decreases stronger than before and the pore pressure starts to augment slightly. These features are stronger developed in the tests with effective confining stresses higher than $300 \mathrm{kPa}$. Such effect may indicate a double mechanism of the soil due to the particle size distribution. Materials of silty-sandy composition often exhibit two different behaviours caused by the different particle sizes.
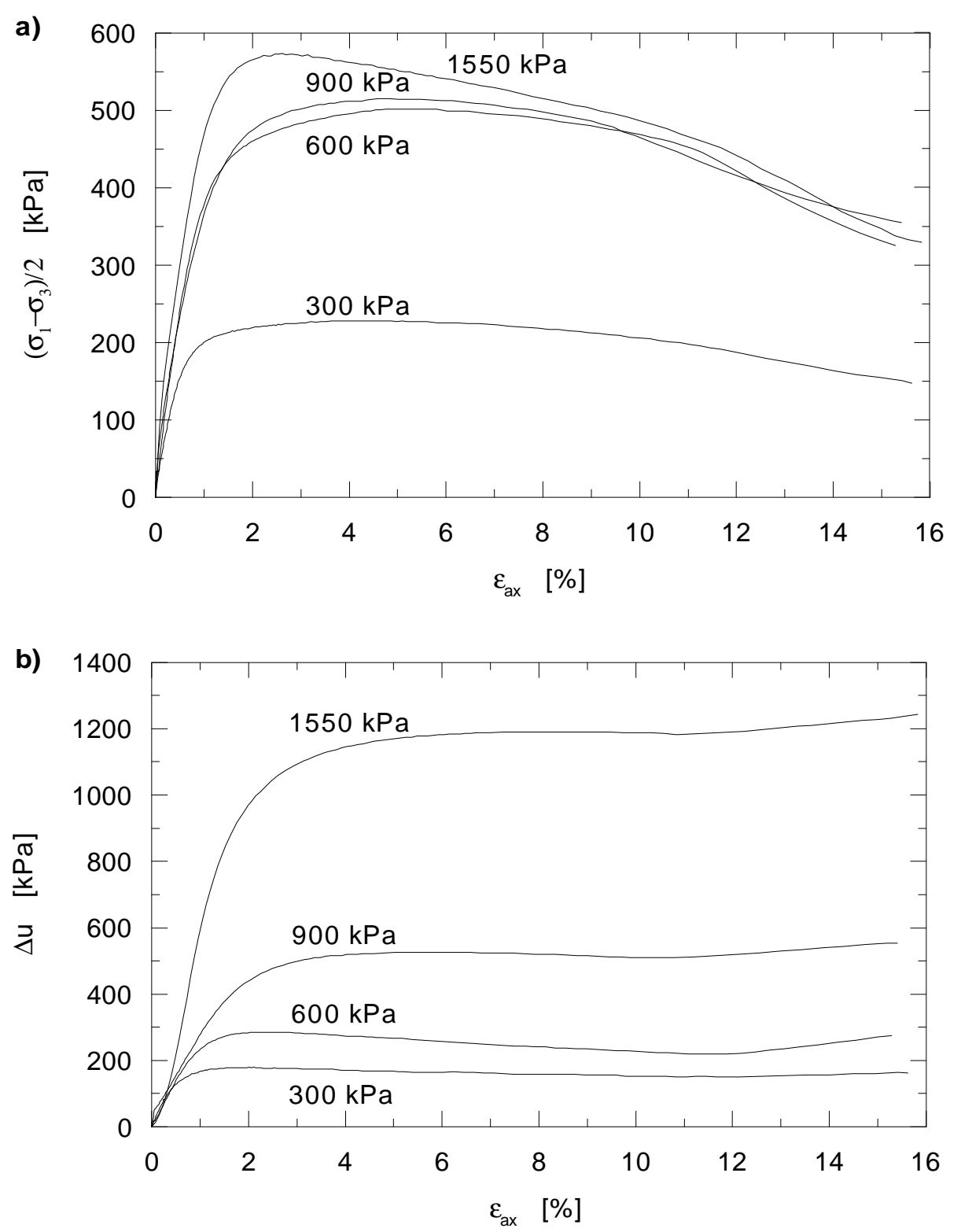

Figure 4.46: Undrained triaxial tests on undisturbed specimens at low effective confining stress obtained from TRIAX1. a) Deviatoric stress vs. axial strain. b) Increase of pore water pressure vs. axial strain. 
The results of the drained triaxial tests are illustrated by curves indicating both the stress-strain behaviour of the soil (deviatoric stress vs. axial strain) and the volumetric behaviour during failure (volumetric strain vs. axial strain). The curves obtained from the test carried out by the TRIAX1 apparatus are shown in Figure 4.47. It can be seen that the slopes of the stress - strain curves are much lower than in the undrained tests and no clear peaks have been developed. The initial tangent stiffness increases for higher effective confining pressures, which coincides with the behaviour of sedimentary soils and also with results obtained from another bonded soil (Maccarini, 1993). The maximum deviatoric stress, which indicates the failure of the material, is reached after axial strain rates higher than $16 \%$. In contrast to other bonded residual soils (Maccarini, 1987; Aversa and Evangelista, 1998; Zhu and Anderson, 1998), no dilatancy occurs and the volumetric strain decreases continuously. The final volumetric strains indicate an enormous reduction of volume during failure. The reduction for an effective confining pressure of $300 \mathrm{kPa}$ has been $8 \%$ and for an effective confining pressure of $600 \mathrm{kPa}$ even $13 \%$ !

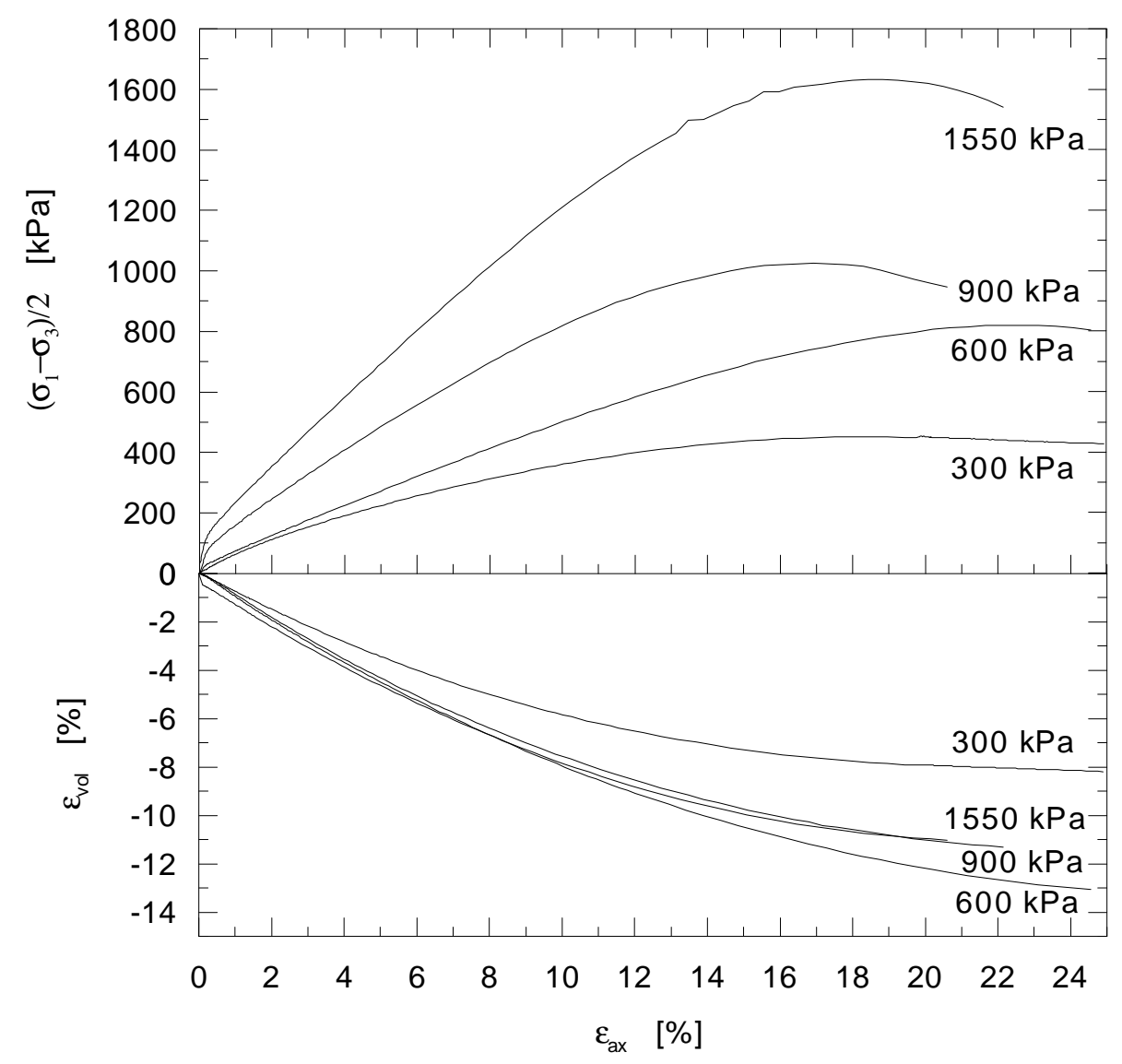

Figure 4.47: Drained triaxial tests on undisturbed specimens at low effective confining stress obtained from TRIAX1. Upper graph: deviatoric stress versus axial strain. Lower graph: volumetric strain versus axial strain. 
Finally, the effective stress path plots are given in Figure 4.48 using the mean effective stress, p', and the deviatoric stress, q, as defined by Lambe and Whitman (1979). The stress paths for low confining pressures are characterised by particular loops at theirs tops, which diminish in the stress paths for higher confining pressures and totally disappear for a confining pressure of $1550 \mathrm{kPa}$. Such loops are quite unusual features and especially occur during failure of bonded soils. Maccarini (1987) detected a similar behaviour for weakly bonded artificial soils applying low confining pressures. Moreover, the stress paths of the CU-tests illustrate the exceptional increase of the pore pressure for high effective confining pressures. Whereas the stress path for low confining pressure is characterised by a sub-vertical curve up to the peak or yield stress, the stress path for a confining pressure of 1550 $\mathrm{kPa}$ initiates similar as a drained one, but then suddenly changes its behaviour decreasing the mean effective stress significantly up to the yield stress. After passing the yield stress, the stress path aims to the origin. This behaviour can also be observed at the other curves with distinct confining pressures migrating all of them to the origin for large strains.

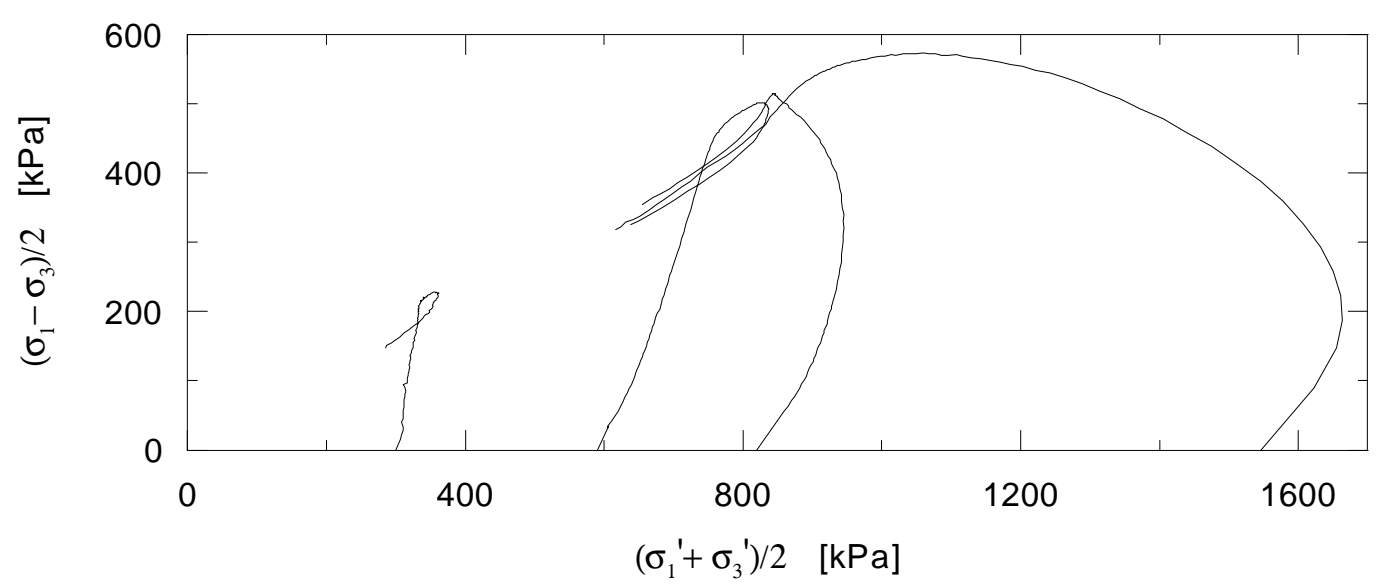

Figure 4.48: Stress paths of undrained triaxial tests on undisturbed specimen using TRIAX1.

In order to compare the undrained with the drained stress paths, both of them have been plotted in the same graph (Figure 4.49).

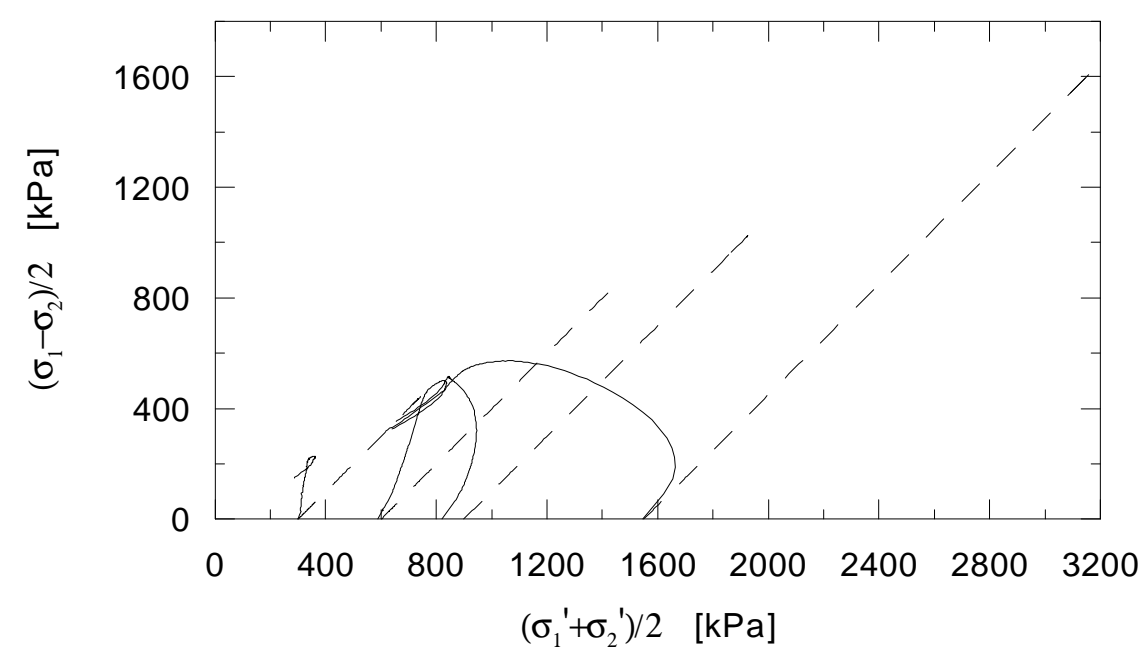

Figure 4.49: Stress paths of drained (dashed lines) and undrained (solid lines) triaxial tests on undisturbed specimen using TRIAX1. 
The triaxial tests carried out by the TRIAX2 apparatus have applied high effective confining stresses of 3500 and $4500 \mathrm{kPa}$, respectively. The results of the undrained triaxial tests are illustrated in Figure 4.50 and show the large increase of pore water pressure due to undrained loading. Maximum pore water pressures reach about $3000 \mathrm{kPa}$ for the effective confining stress of $3500 \mathrm{kPa}$ and about $3750 \mathrm{kPa}$ for the effective confining stress of $4500 \mathrm{kPa}$. The stress - strain curves indicate clear peaks of failures, which occur at axial strain rates between 3 and $4 \%$. Before the failure takes place, the stress-strain relation is linear-elastic. After failure, the strength decrease constantly and a change of behaviour at higher strains as seen in the results obtained from low confining stresses (Figure 4.46) does not occur. Neither the deviatoric stress nor the pore water pressure exhibit such an effect seen in the tests carried out by the TRIAX1 apparatus.
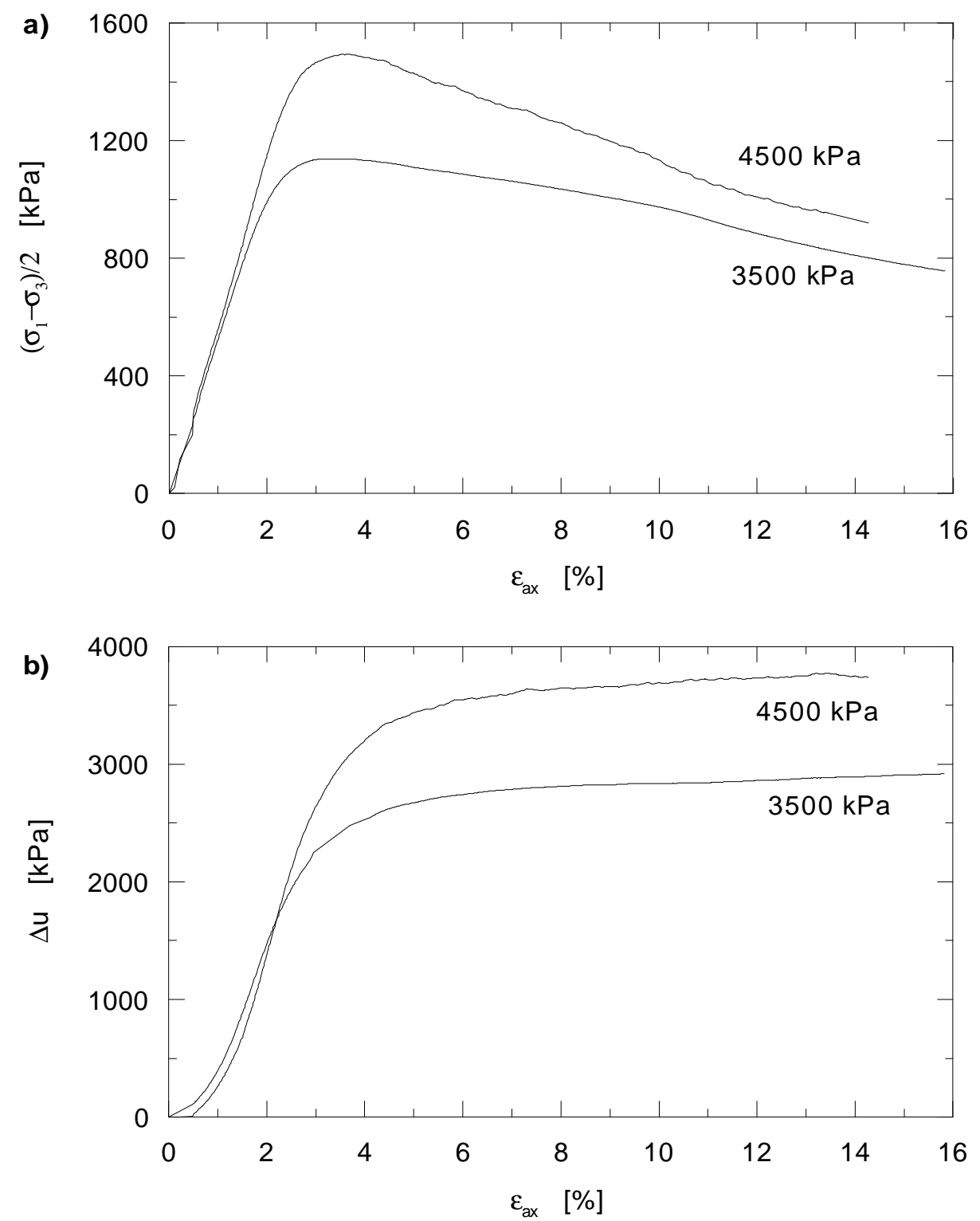

Figure 4.50: Undrained triaxial tests on undisturbed specimens at high effective confining stress obtained from TRIAX2. a) Deviatoric stress vs. axial strain. b) Increase of pore water pressure vs. axial strain. 
During the drained triaxial test carried out in the TRIAX2 apparatus an effective confining stress of $3500 \mathrm{kPa}$ has been applied to the specimen. The stress-strain curve increases continuously with a very smooth slope and the failure does not occur within an axial strain of $24 \%$ (Figure 4.51). However, a maximum deviatoric stress indicating the yield stress may be approximated at about $3750 \mathrm{kPa}$. The volumetric strain of the lower graph indicates a significant, contractant behaviour during failure, as previously seen in the drained direct shear tests. The total volumetric strain at the end of the failure reaches almost $14 \%$.

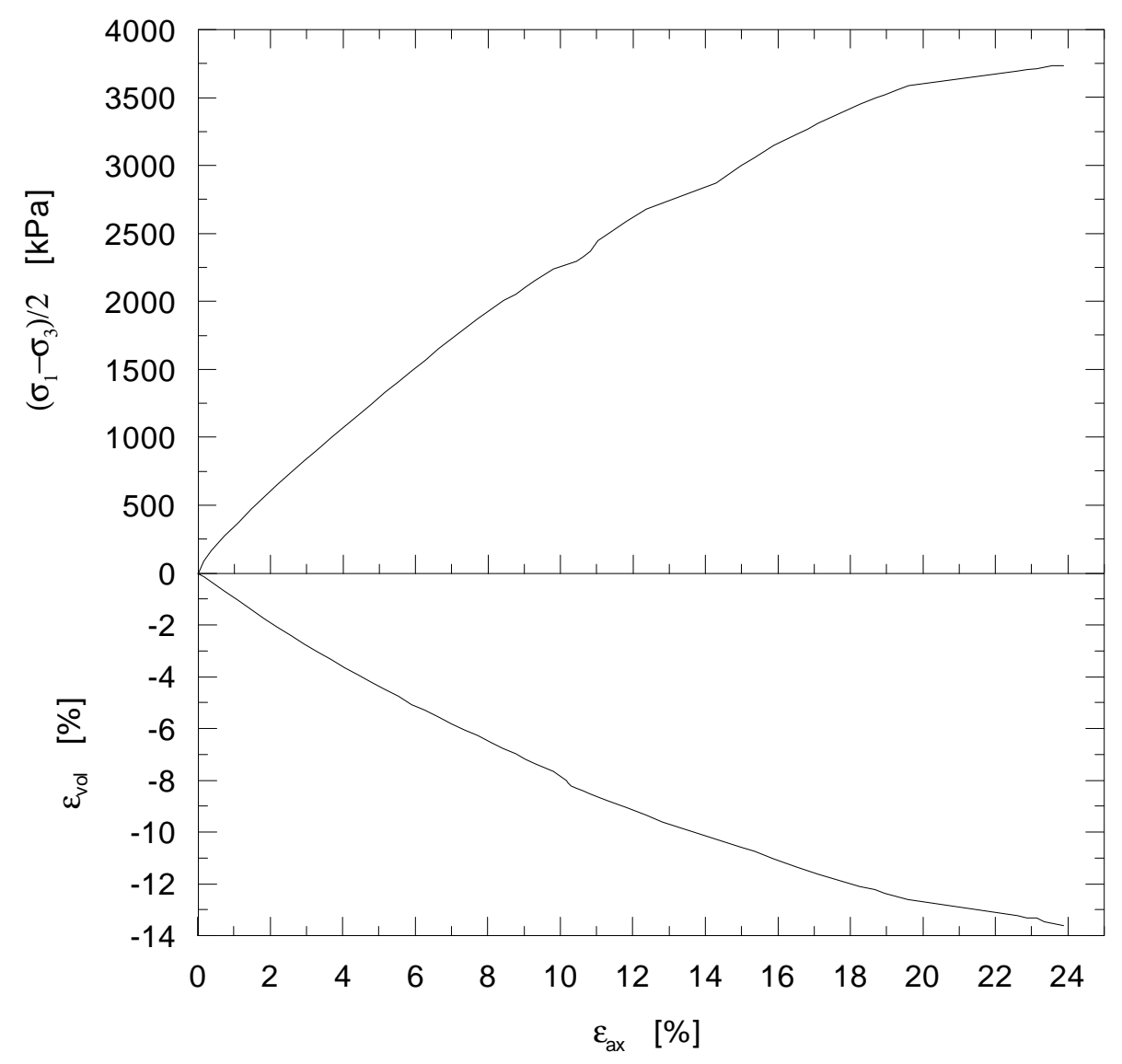

Figure 4.51: Drained triaxial tests on undisturbed specimen at high effective confining stress obtained from TRIAX2. Upper graph: deviatoric stress versus axial strain. Lower graph: volumetric strain versus axial strain. 
The effective stress paths of all undrained triaxial tests on undisturbed specimens are given in Figure 4.52 including results obtained from TRIAX1 and TRIAX2 apparatuses. The general shapes of the stress paths for confining pressures higher than $1500 \mathrm{kPa}$ are almost identical and confirm the strong increase of pore water pressure during undrained loading, whereas the behaviour for low confining pressure is characterised by a loop at the yielding point. After failure, the directions of the stress paths change and the plots are sub-parallel heading all of them to the origin.

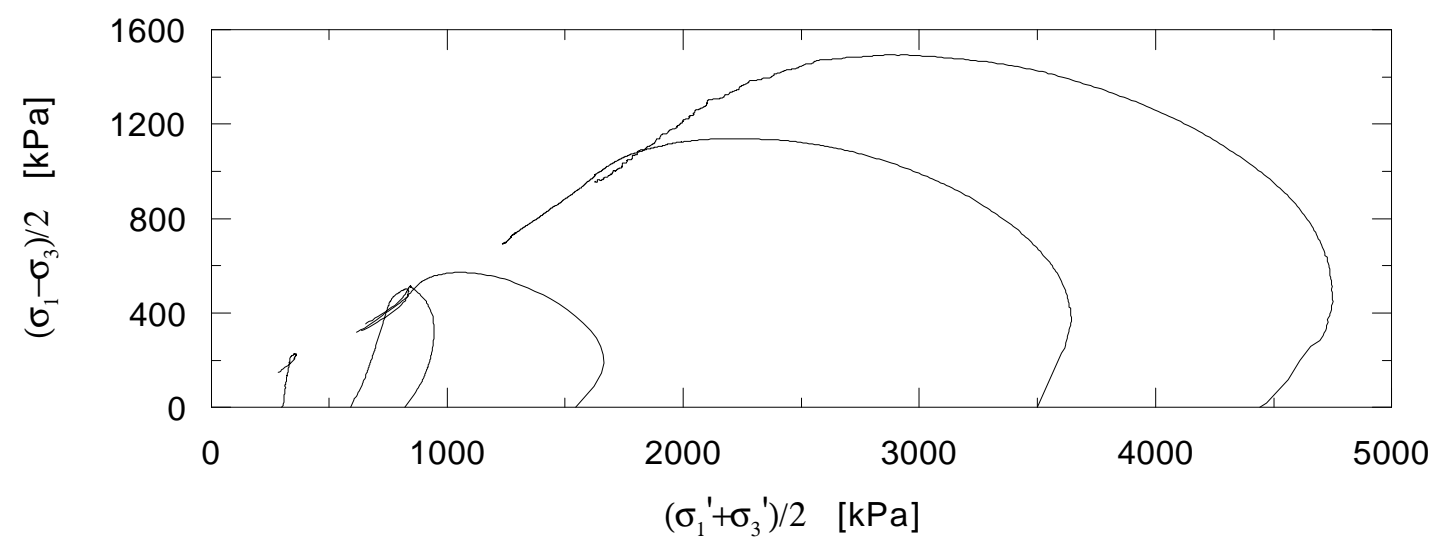

Figure 4.52: Stress paths of undrained triaxial tests on undisturbed specimen applying low and high confining pressures.

Finally, drained and undrained stress paths have been plotted in the same graph (Figure 4.53) to summarise all the results obtained from the triaxial tests carried out during this study.

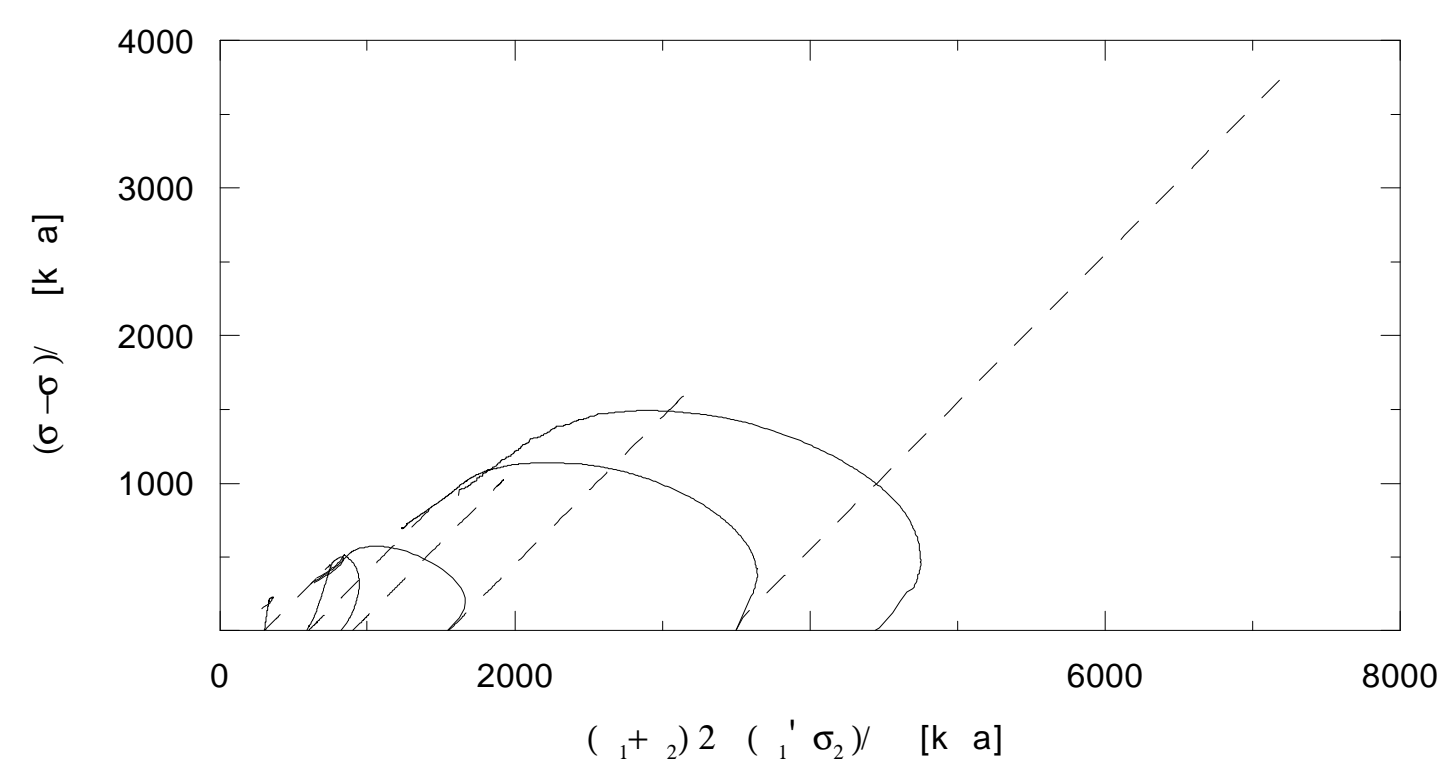

Figure 4.53: Stress paths of drained (dashed line) and undrained (solid line) triaxial tests on undisturbed specimen applying low and high confining pressures 
From the stress paths of Figure 4.49 and Figure 4.53, the strength values of the residual soil can be determined. Table 4.18 lists a summary of the peak and residual stresses obtained from the drained and undrained triaxial tests on undisturbed and remoulded specimens. The data achieved from the remoulded specimens are defined by a ' $r$ ' at the end of the specimen name and will be interpreted later in this section. The peak strength corresponds to the maximum deviatoric stress and the residual strength is assumed to be the minimum deviatoric stress after the failure. Since the deviatoric stress in some tests has remained decreasing even after large axial strains, the final value does not exactly coincide with the residual value and thus indicates in these cases an estimate of the residual strength, slightly higher than the 'true' or correct value. For specimen RS1-T-CDI, no residual strength has been given, because the deviatoric stress has not even passed the peak value.

Table 4.18: Peak and residual stress obtained from drained and undrained triaxial tests for undisturbed and remoulded specimens.

\begin{tabular}{|c|c|c|c|}
\hline specimen & $\begin{array}{c}\text { effective confining stress } \\
{[\mathrm{kPa}]}\end{array}$ & $\begin{array}{c}\text { peak strength } \\
{[\mathrm{kPa}]}\end{array}$ & $\begin{array}{c}\text { residual strength } \\
{[\mathrm{kPa}]}\end{array}$ \\
\hline \hline RS1-T-CU3 & 300 & 236 & 153 \\
\hline RS1-T-CU3r & 300 & 127 & 116 \\
\hline RS1-T-CU1 & 600 & 515 & 355 \\
\hline RS1-T-CU1r & 600 & 223 & 186 \\
\hline RS1-T-CU2 & 900 & 576 & 395 \\
\hline RS1-T-CU4 & 1546 & 585 & 325 \\
\hline RS1-T-CUI & 3500 & 1144 & 635 \\
\hline RS1-T-CUIr & 3500 & 1225 & 982 \\
\hline RS1-T-CUII & 4500 & 1508 & 904 \\
\hline RS1-T-CD1 & 300 & 453 & 415 \\
\hline RS1-T-CD4 & 600 & 821 & 804 \\
\hline RS1-T-CD2 & 900 & 1025 & 947 \\
\hline RS1-T-CD3 & 1550 & 1633 & 1542 \\
\hline RS1-T-CDI & 3500 & 3750 & - \\
\hline
\end{tabular}

The values listed in Table 4.18 can be illustrated graphically in order to compare the different strength values and to define the strength parameter of the residual soil. Figure 4.54 shows the peak and residual strengths obtained from the drained and undrained triaxial tests on undisturbed specimens. At last, the strength values have been divided into four different groups:

1) peak strength obtained from drained triaxial tests

2) peak strength obtained from undrained triaxial tests

3) residual strength obtained from drained triaxial tests

4) residual strength obtained from undrained triaxial tests
(CD peak)

(CU peak)

(CD residual)

(CU residual)

In contrast to the direct shear test, a particular influence of higher confining pressure on the strength behaviour has not been detected. The strength values refering to low and high confining pressure are quite similar and a significant difference between peak and residual strength values is not visible, either. 


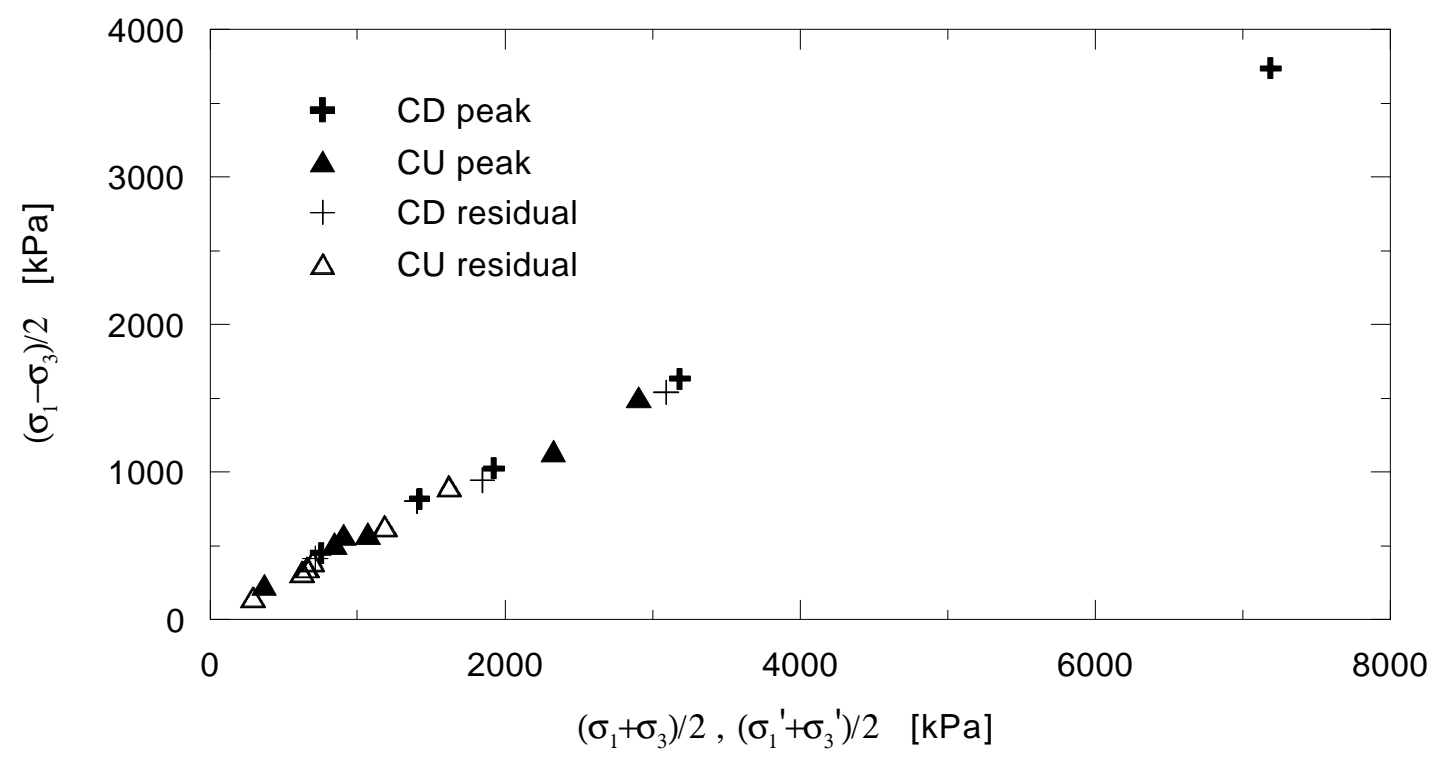

4. : Peak and residual strengths obtained from drained (CD) and undrained (CU) triaxial tests on undisturbed specimen.

Figure 4 54, a distinct behaviour between strength values

data. First, $\mathrm{K}_{\mathrm{f}}$ - lines have been performed for each of the four groups shown in Figure 4.54 using linear interpolation of the strength values. Additionally, the strength data have been divided into values refering to low confining stress and values concerning to high confining stress. Then, the angle of friction of the soil, $\phi$, has been achieved for each group from the $\mathrm{K}_{\mathrm{f}}-$ lines using the equation:

$$
\sin \phi=\tan \theta
$$

, where $\theta$ is the inclination of the $\mathrm{K}_{\mathrm{f}}$ - line to the horizontal. Table 4.19 lists the results of the calculations distinguishing between low confining stresses ranging from 300 to $900 \mathrm{kPa}$ and high confining stresses ranging from 1550 to $4500 \mathrm{kPa}$. Additionally, the results refering to undrained and drained conditions as well as to the peak and residual strength are printed separately. In contrast to Figure 4.54, where the strength values seem to increase linearly, the angle of internal friction indicate a clear difference between low and high confining stress. Especially the friction angle calculated from the peak shear strengths of the undrained triaxial test implies a significant division.

Table 4.19: Peak and residual angles of friction obtained from CU and CD-tests.

\begin{tabular}{|l|c|c|c|c|}
\hline \multirow{2}{*}{$\begin{array}{c}\text { angle of internal friction } \\
\text { [degree] }\end{array}$} & peak & residual & peak & residual \\
\hline \hline Low confining stress $(300-900 \mathrm{kPa})$ & 38.66 & 33.57 & 33.59 & 32.58 \\
\hline High confining stress $(1550-4500 \mathrm{kPa})$ & 30.76 & 33.24 & 31.25 & 29.91 \\
\hline Low and high confining stress & 31.53 & 33.31 & 31.46 & 30.92 \\
\hline
\end{tabular}


In addition to the drained and undrained friction angles, the apparent angle of friction has been calculated for each undrained triaxial test (Table 4.20). The concept of the apparent friction angle, $\phi$ ' ap, was proposed by Sassa $(1988,1992)$ and is similar to the approach using the $\mathrm{K}_{\mathrm{f}}$-line and Eq. 4.6. The apparent friction angle can be expressed as

$$
\mathrm{q}_{\max } / \mathrm{p}^{\prime}{ }_{\text {ini }}=\tan \phi_{\text {ap }}^{\prime}
$$

where $\mathrm{q}_{\max }$ is the maximum deviator stress of a stress path and $\mathrm{p}_{\text {ini }}^{\prime}$ the initial effective stress of the undrained triaxial test. Assuming a fast loading and totally undrained conditions, the apparent friction angle, $\phi_{\text {ap }}^{\prime}$, approximates better the material strength of natural slopes (Sassa, 1988; Sassa, 1992). The resulting apparent friction angles of the soil can be divided into two groups of confining stresses as proposed in Table 4.19. Here, the significant difference between high and low confining stress has been discovered even more clearly. Up to a confining stress of $900 \mathrm{kPa}$, the $\phi$ ' ap - values range from about 34 to 40.5 degrees and decrease significantly for high confining pressures. The values of the apparent friction angle for high confining stresses are between 20.7 and 18.5 degrees. This enormous reduction from the drained friction angle of more than 30 degrees to the apparent friction angle of less than 20 degrees verifies the significant effect of pore water pressure during undrained loading and has to be kept in mind during the stability analyses incorporating such type of soil.

Another parameter, which confirms the important effect of pore water pressure during failure is the pore pressure parameter, A, (Lambe and Whitman, 1979). Again, two different regimes are visible distinguishing between the results obtained from low effective confining stress and the ones from high effective confining stress (Table 4.20). The pore pressure parameter is very high for high effective confining stresses (near unity) and between 0.2 and 0.4 for low stresses up to $900 \mathrm{kPa}$. In sedimentary soils, an A-value greater than one is associated with a loose structure which collapses upon load application. So, the residual soil would act in this mode after fast, undrained loading with an effective confining stress greater than about $1 \mathrm{MPa}$.

Consequently, the results obtained from the triaxial tests indicate the significant influence of both the effective confining stress and of the loading type. The most critical scenario refering to the mechanical stability of the residual soil can be determined as the combination of confining stress higher than the yield stress of the bonds and undrained loading. Once the bonds of the soil are broken after consolidation, the soil acts as a sandy material composed of a loose structure where liquefaction - like processes may occur during undrained loading.

Table 4.20: Calculation of the apparent friction angle and estimate of the pore pressure parameter A for different effective confining stresses.

\begin{tabular}{|c|c|c|}
\hline $\begin{array}{c}\text { effective confining stress } \\
{[\mathrm{kPa}]}\end{array}$ & $\begin{array}{c}\text { apparent friction angle } \\
{[\text { degree] }}\end{array}$ & $\begin{array}{c}\text { pore pressure parameter A } \\
{[-]}\end{array}$ \\
\hline \hline 300 & 38.24 & 0.34 \\
\hline 600 & 40.48 & 0.24 \\
\hline 900 & 33.98 & 0.41 \\
\hline 1550 & 20.68 & 0.97 \\
\hline 3500 & 18.21 & 0.98 \\
\hline 4500 & 18.75 & 0.99 \\
\hline
\end{tabular}


Since the bonding seems to be a very important feature strongly influencing the mechanical behaviour of the residual soil, the final part of this section will focus on this topic. So, the results of the undrained triaxial tests on remoulded specimens will be presented and compared with the data obtained from the undisturbed specimens. As shown in Table 4.18, three remoulded specimens with the same initial void ratio as the undisturbed specimens have been analysed applying effective confining stresses of 300,600 and $3500 \mathrm{kPa}$.

First, the consolidation behaviour will be presented by the data achieved during the isotropic compression in the triaxial cell TRIAX2. The volumetric strain versus the effective confining stress is illustrated in Figure $4.55 \mathrm{a}$ by a semi-logarithmic curve and in Figure $4.55 \mathrm{~b}$ by a linear curve. There are some clear differences to the graphs obtained from the oedometer tests (Figure 4.31). First, a quite clear yield stress can be seen in the triaxial data characterising the failure of the soil structure. This can be attributed to the failure of the bonds and/or to an elastic - plastic limit of the soil. The undisturbed and remoulded specimen contain different values of the yield stress. Figure $4.55 \mathrm{a}$ indicates that the remoulded specimen reaches the yield stress already at about $100 \mathrm{kPa}$, whereas the undisturbed specimen strength support the stress up to about $400 \mathrm{kPa}$. After passing a stress value of about 800 $\mathrm{kPa}$, the curves are sub-parallel and the void ratios decrease similarly. Second, the initial collapse of the remoulded specimen is much larger and significant than the one of the undisturbed specimen (Figure $4.55 \mathrm{~b}$ ). The void ratio of the undisturbed specimen decreases smoothly and shows no clear collapse behaviour.

a)

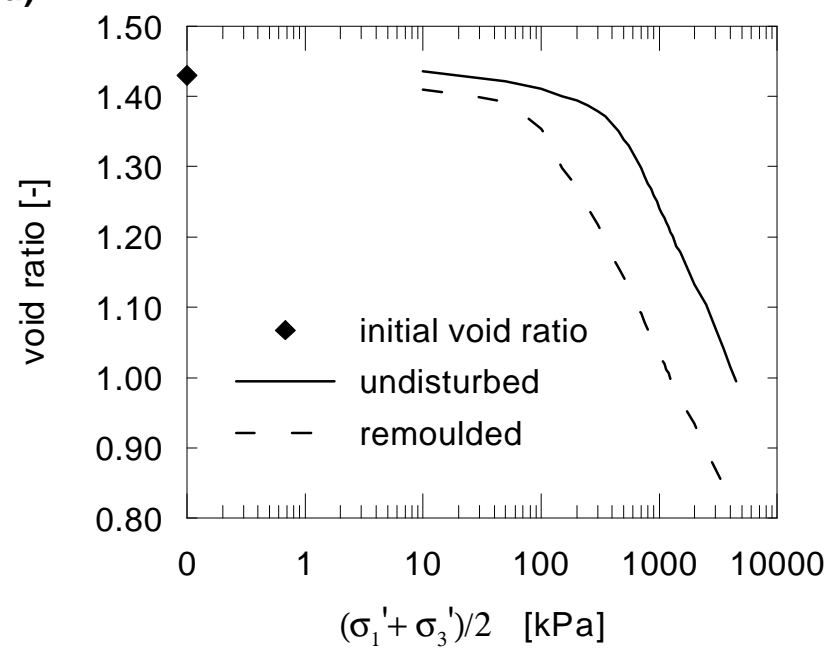

b)

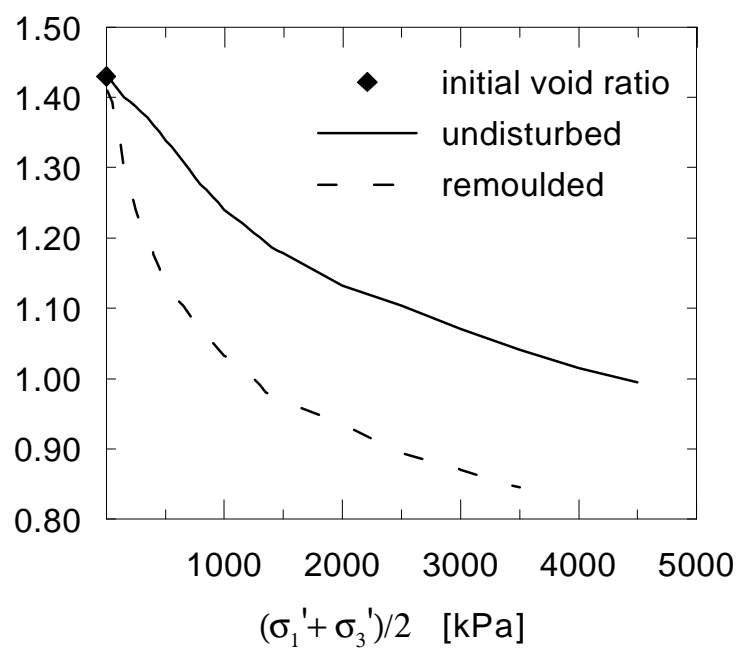

Figure 4.55: Void ratio vs. effective confining stress of undisturbed (RS1-T-CUII) and remoulded (RS1-T-CUIr) specimens during isotropic compression. a) Semi-logarithmic scale and b) linear scale.

In the next step, the stress - strain regimes and the behaviour of pore water pressure during undrained loading have been analysed for the undisturbed and remoulded specimens. The mean deviatoric stress versus the axial strain are plotted in Figure 4.56a and indicate the different mechanical behaviour of specimens confined with a low pressure $(300 \mathrm{kPa}$ and $600 \mathrm{kPa})$ and specimens confined with a high pressure $(3500 \mathrm{kPa})$. Focussing on to the curves with a low effective confining stress, the strength values of the undisturbed specimens are clearly larger than the strengths of the remoulded ones. In contrast applying a high effective stress during the consolidation phase, the strength of the undisturbed specimen is almost equal or even slightly smaller than the strength of the remoulded specimen. Similar characteristics can be observed in Figure $4.56 \mathrm{~b}$ which illustrates the pore water pressure versus horizontal strain. For the curves with low effective confining stress, the pore water pressures increase greater in the remoulded specimens than in the undisturbed ones. This denotes the 
loose structure of the remoulded specimens which collapse during undrained loading, whereas the bonding of the undisturbed specimens supports the soil structure. Looking to the curves with high effective confining stress, the pore water pressure increases almost by the same amount in the remoulded and in the undisturbed specimen, since both of them contain a loose and broken structure.

Generally, the data confirm the results obtained from the previous tests carried out in the shear box. All the data indicate that the structure of the soil (undisturbed or remoulded) plays an important role for low effective stresses and only a very small or any role applying high effective stresses. This can be explained by the fact that the bonding sustains the structure of the undisturbed soil applying stresses less than the yield stress of the bonds. Once the undisturbed soil has been loaded by a high stress surpassing the bond strength, the bonds are broken and the soil acts as a remoulded soil.
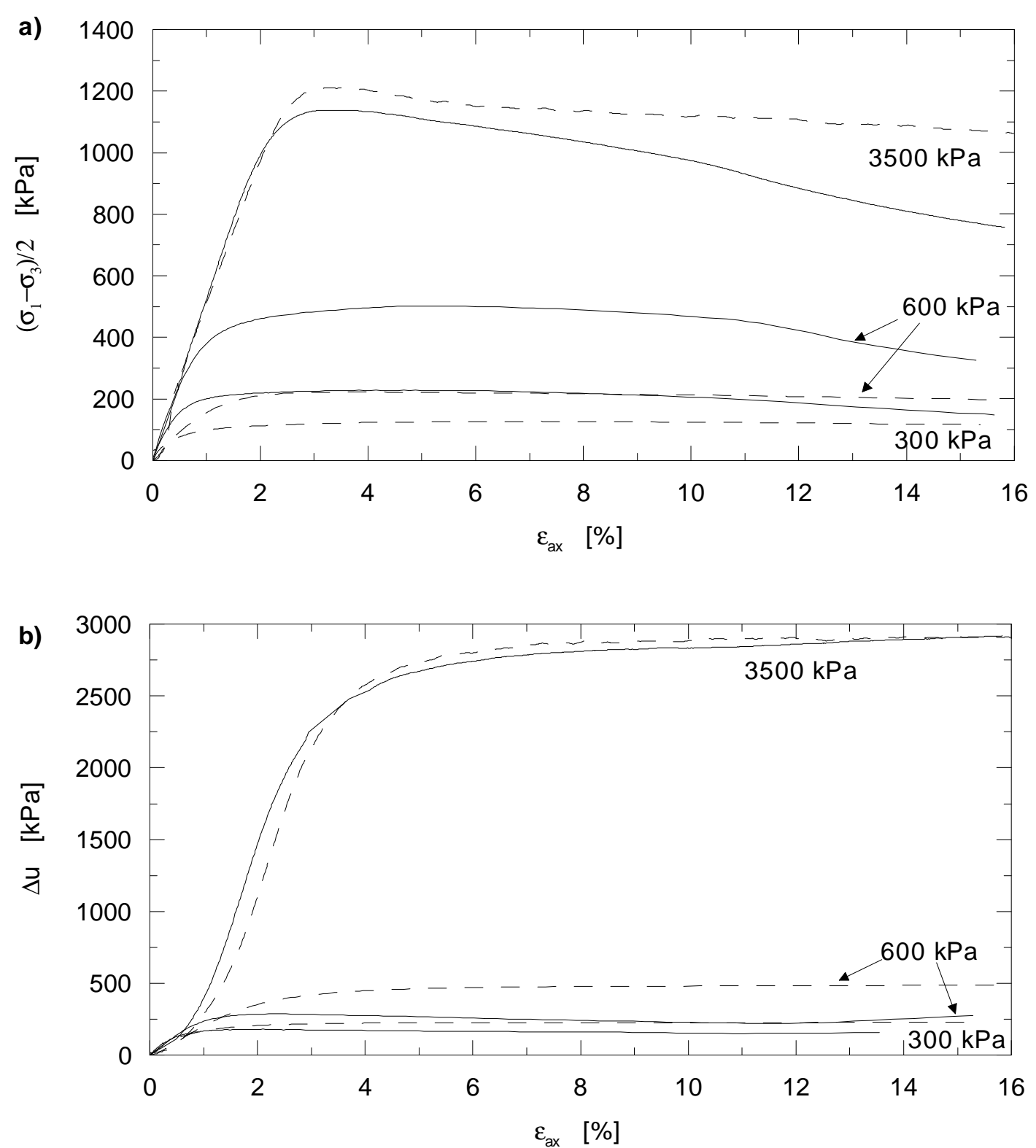

Figure 4.56: Comparison between undrained triaxial tests on undisturbed (straight line) and remoulded (dashed line) specimens. a) Deviatoric stress vs. axial strain. b) Increase of pore water pressure vs. axial strain. 
Finally, the stress paths of the undisturbed and remoulded specimens are shown in Figure 4.57 and confirm the clear difference of mechanical behaviour between soils with an intact bonding and soils with a broken bonding. After the application of the confining stress, the only specimens with an intact bonding are the undisturbed ones with effective confining stress up to $600 \mathrm{kPa}$. The stress paths of these two specimens are characterised by a particular loops at theirs tops and a sub-vertical curve with almost constant deviatoric stresses up to the peak. The specimens with a broken bonding include the three remoulded specimens and the undisturbed specimen confined by a high effective stress. The stress paths of these specimens are very similar in shape. They have no loops and all of them direct to the origin increasing strongly the pore water pressure.

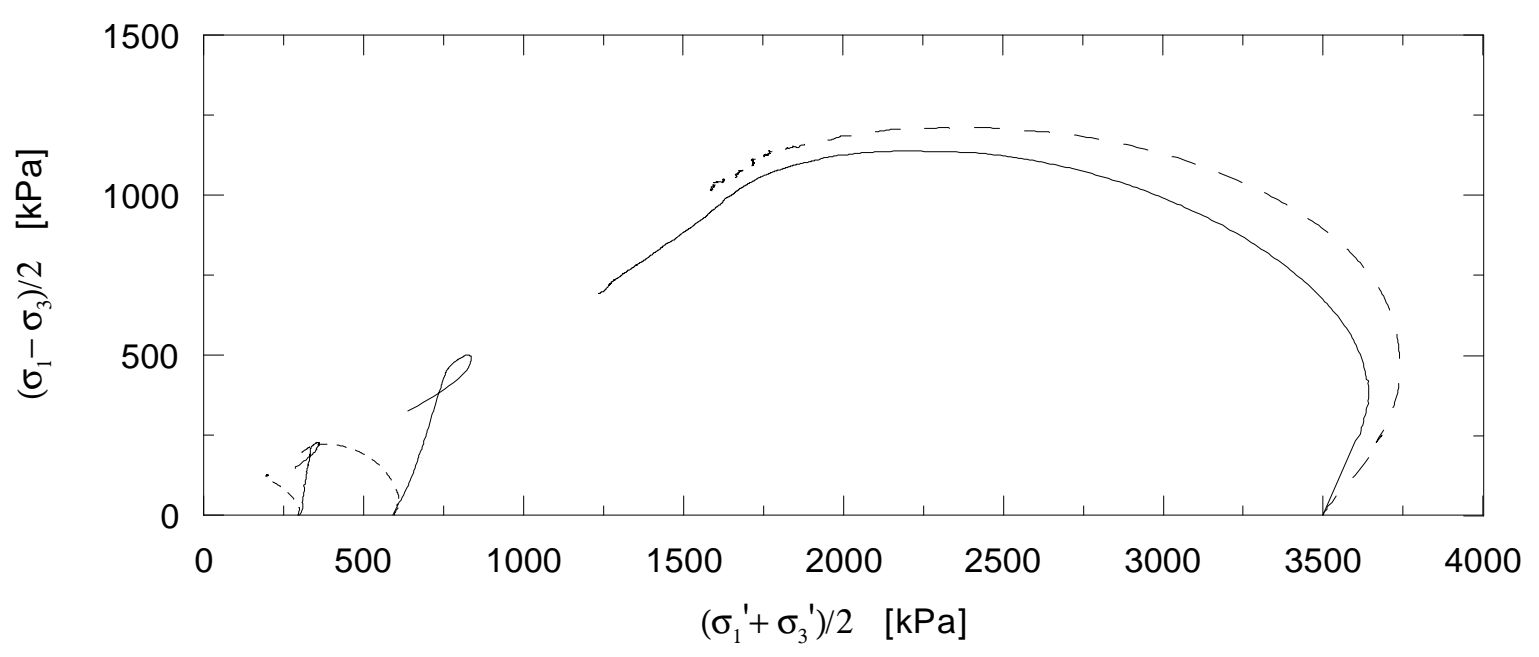

Figure 4.57: Stress path of undrained triaxial tests on undisturbed (straight line) and remoulded (dashed line) specimen.

At last, the study of the failure planes of the broken specimen will be presented. Each specimen has been analysed after taking it out of the triaxial apparatuses, once the drained or undrained test has been terminated. Generally, the study has confirmed the results obtained from the specimens failed during the direct shear tests. No discrete failure plane is visible and the failure has preferably taken place within a zone, which is consistent with the sandy-silty grain size of the soil. This failure zone can be observed quite well in the undisturbed specimens failed during the undrained triaxial tests (Figure 4.58). The failure zone is characterised by an inclination of about 45 degrees and occupies a section of several millimetres thickness. In contrast, the undisturbed specimens failed during drained triaxial tests are generally characterised by horizontal fracturing due to the large vertical compression and don't contain a typical 45 degrees failure (Figure 4.59). Any types of fractures are visible in the remoulded specimens failed during drained or during undrained triaxial tests. 


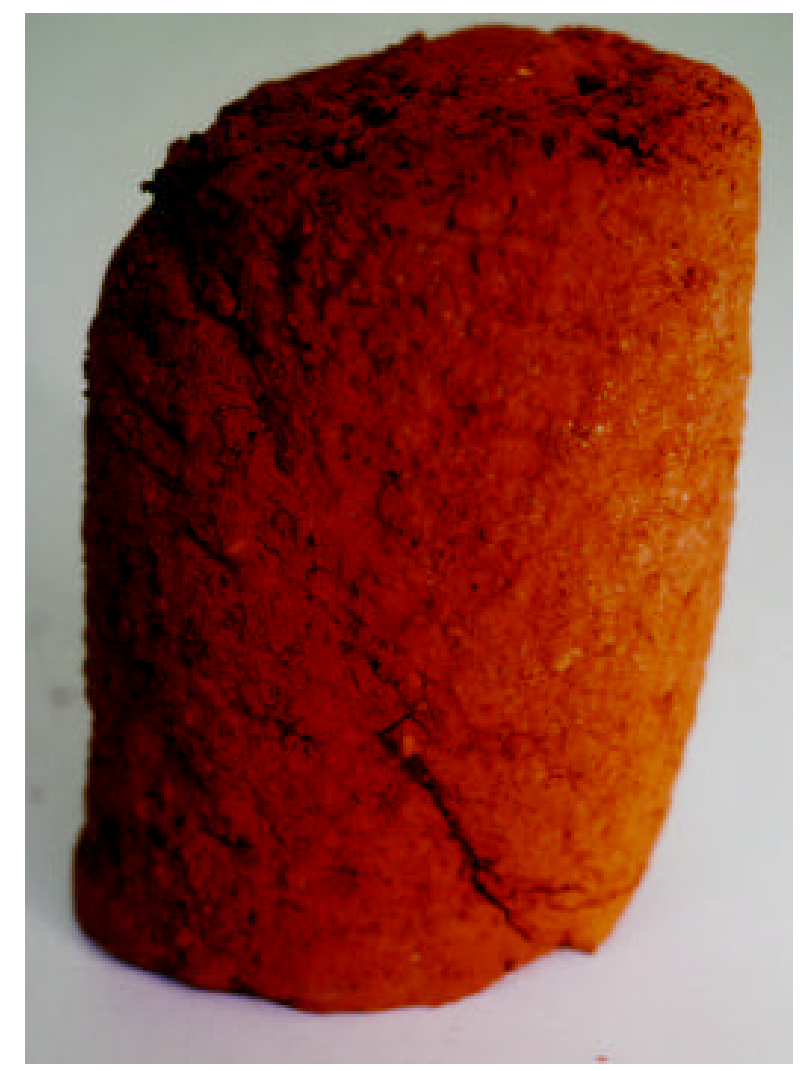

Figure 4.58: Undisturbed specimen after undrained triaxial test with an effective confining stress of $4500 \mathrm{kPa}$.

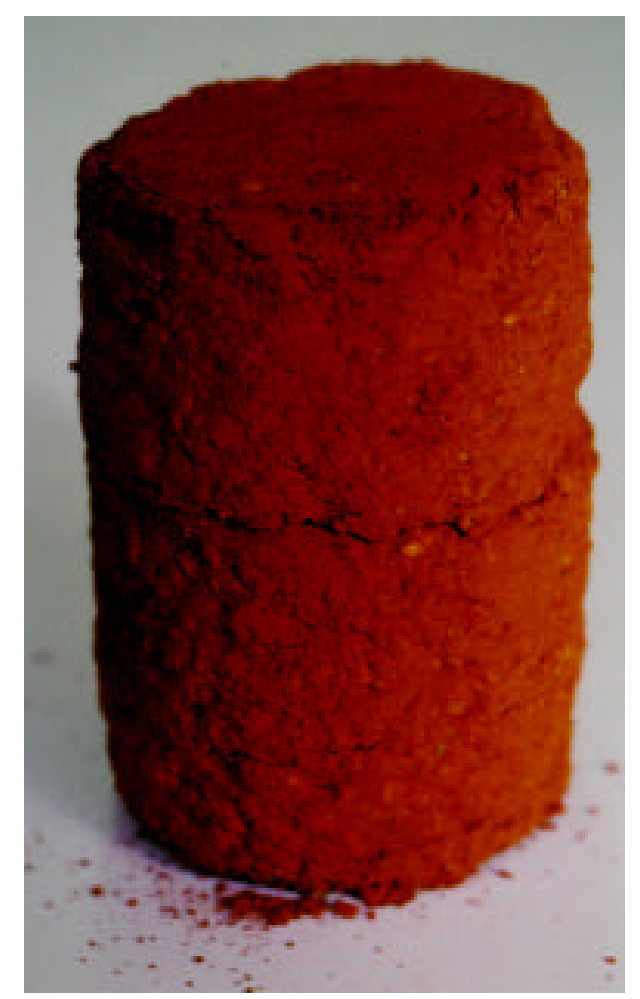

Figure 4.59: Undisturbed specimen after drained triaxial test with an effective confining stress of $3500 \mathrm{kPa}$. 


\subsection{Conclusions}

In this study a residual soil of the La Orotava valley area has been analysed comprehensively. This type of deposit has been selected because the field surveys have revealed that it is the weakest widespread material found on the island, and therefore, a perfect candidate for providing a slip surface. Residual soils commonly vary very widely and their engineering behaviour is difficult to predict. A particular feature of many residual soils is the bonding between the soil particles that strongly influences on the mechanical behaviour of the soils. In this study, the residual soil is characterised by a double bonding: one due to the initial lithification of the parent rock and the other generated by thermal alteration due to the lava flow covering the soil.

The mineralogical study of the soil using X-ray diffraction has revealed the presence of the clay mineral 'halloysite', which is common in youthful soils originated from volcanic deposits. However, the total amount of clay minerals is very small in the residual soil. The analysis of the microstructure has shown for the intact soil an open, porous assemblage of the particles which are often connected by different types of bonds. The broken, destructed soil has shown a compacted, dense microstructure and the bonds failed. Specially, the photographs of both intact and broken bonds are novel and confirm the hypotheses established for bonded residual soils.

The soil characteristics obtained from the first step of the geotechnical analysis indicate that the soil is a weathering product in an early stage along the evolutionary path. At last, the residual soil can be classified as a porous, sandy-silty, no plastic soil with the standard USCS abbreviation, SM.

After vertical loading the residual soil collapses almost instantaneously. Then a small creep effect starts and continues constantly. The compaction of the porous soil structure and the failure of some weak bonds may cause the collapse during the primary compression, whereas the continuing creep effect during the secondary compression may be explained by the persistent and slow failure of stronger bonds. The general consolidation behaviour of the soil obtained from the oedometer tests indicates no particularity, and the water does not influence. There is not a sharp change in the stress-strain curve due to the failure of the bond strength at a well-defined yield stress as detected in other bonded residual soils. This feature is assumed to be caused by the double bonding of the residual soils analysed in this study.

The shear stress - strain curves obtained by the drained direct shear tests are characterised by clear peaks with a further drop for low normal stresses and smooth peaks without a later drop for high normal stresses. On the other hand, all direct shear tests show a volumetric collapse during shearing, even at high confining stresses. The Mohr-Coulomb envelopes performed for the shear strengths indicate the significant effect of the normal stress on the material strength and show the reduction of $\tau^{\prime} / \sigma^{\prime}{ }_{n}$ with increasing values of $\sigma_{\mathrm{n}}^{\prime}$. The peak shear strengths obtained from normal stresses up to $600 \mathrm{kPa}$ give a friction angle of about $45^{\circ}$ and almost zero cohesion. In contrast, the envelope refering to higher normal stresses has a smaller inclination and thus, the resulting friction angle decreases to about 30 degrees and the cohesion to zero. However, all these strength values are higher than the ones of other analysed residual or volcanic soils which are characterised by friction angles ranging from about 20 to 30 degrees. The high value can be assumed to the different composition of the youthful residual soil, that contains a large amount of sand fraction instead of the clay rich soils studied in the mentioned publications. Another explanation may be a stronger bonding effect enforcing the material strength.

The residual shear strength parameters achieved from the ring shear tests indicate that the residual friction angle does not decrease significantly for long horizontal displacements. The residual friction angle obtained from the ring shear test is only slightly lower than the one obtained from the direct shear test.

The results obtained from drained and undrained triaxial tests show the significant influence of the effective confining stress. As in the direct shear tests, two different regimes can be defined: one for low confining stresses and another for high confining stresses. The effective stress paths of the undrained tests show for low confining stress particular loops at theirs tops which are quite unusual features and especially occur in bonded soils. The stress paths for high confining stress contain no loops and are 
characterised by a huge increase of the pore water pressure comparable with a liquefaction-like behaviour. The calculations of the apparent friction angles have verified this specific behaviour of the residual soil and indicate a strong reduction of the material strength of the soil during undrained loading. A drained friction angle of about $35^{\circ}$ has been calculated while for fast loading and undrained conditions the apparent friction angle is only about $20^{\circ}$ applying high confining effective stresses. Therefore, the results of the triaxial tests show the very important effect of undrained loading and pore water pressure. In the case of large volcanic landslides with a high overburden, the residual soil acts similar to sensitive materials, which collapses upon dynamic load application and increases strongly the pore fluid pressure, in consequence reducing significantly the strength of the soil.

The bonding of the residual soil has extensively been analysed. The laboratory tests suggest, that the bond strength of the soil breaks at an effective stress of about $1000 \mathrm{kPa}$ exceeding the strength of common residual soils. This may be explained by the different evolution of the soil. In contrast to ordinary residual soils, the residual soil analysed in this study contains a bonding mainly produced by thermal alteration. During the cooling of the pyroclastic flow deposit with a temperature of hundreds of degrees lithification processes changed the original loose material into a cemented one. Additionally, a lava flow covering the residual soil has caused a second thermal alteration. Once the bonding has broken, the mechanical behaviour of the soil is completely different. If the effective stress applied to the soil exceeds the yield stress of the bonding, the cementation of the soil structure breaks and the soil acts as the remoulded samples analysed in the laboratory. Therefore, no significant difference of the stressstrain regime exists between an intact specimen and a remoulded specimen applying to both of them an effective consolidation stress higher than the bond strength. This fact is important refering to large volcanic landslides with high overburden (hundreds of meters of volcanic material) and dynamic loading (seismic shocks caused by volcanic activity). The confining stress normally higher than the yield stress of the bonds destroys the cementation of the soil and causes a fragile soil structure which collapses during fast, undrained loading as shown in the undrained triaxial tests. 


\section{STABILITY ANALYSIS}

\subsection{Introduction}

After the geological and morphological study of the test site and the laboratory analysis of the residual soil (paleosol), a stability analysis has been carried out. In this Chapter, the results of an extensive stability analysis will be presented focussing on the causes of large volcanic landslides in general and in particular on the events that occurred in the La Orotava valley.

Detailed, comprehensive geotechnical studies analysing the stability of volcano flanks are not common. The publication of numerical models which study the causes of volcanic landslides have started in the eighties after the event at Mount St. Helens (Voight et al., 1983; Paul and Gratier, 1987). Moreover, analyses using finite element methods have been carried out for intraplate volcanoes (Chevallier and Verwoerd, 1988) and at Stromboli and Vesuvius volcano (Russo et al., 1996; Russo et al., 1997) studying the influence of magma pressure and regional stresses on the mechanical stability and the surface deformation. Additionally, the gravitational spreading and associated collapse hazard for idealised stratovolcanoes (Van Wyk de Vries and Merle, 1996; Van Wyk de Vries and Metala, 1998) and the effects of dike intrusion at Hawaiian volcanoes have also been studied (Elsworth and Voight, 1995; Voight and Elsworth, 1997). The majority of these works have improved the general understanding of volcano stability, but a quantitative explanation of the stability problems characterising large volcanic landslides has not yet been found.

In this study, two main types of approaches have been applied to analyse the volcano stability. First, a global limit analysis has been carried out using two simple types of analytical models achieving a Factor of Safety of the volcano slope. On one hand, 2D limit equilibrium method (LEM) has been used. On the other hand, the upper bound method (UBM) has been applied. Second, a continuum analysis has been carried out applying continuum equilibrium and mechanical constitutive laws. The result of such calculations is the stress - strain field of the volcano slope. The continuum analysis has included 2D finite difference (FD) technique and both 2D and 3D finite element methods (FEM).

After a sensitivity analysis of the influence of the slope angle, material properties, hydrogeological conditions and sea water using LEM, three additional mechanisms have been studied. The destabilising effects of seismic acceleration regardless of the origin considered (tectonic, volcano-tectonic or volcanic), horizontal stress due to dike intrusion and vertical shear stress due to caldera collapse events have been analysed using different approaches. An overview of the agents studied in this work is listed in Table 5.1 indicating the approach applied.

Table 5.1: Agents analysed during the stability calculations and approaches applied.

\begin{tabular}{|l|c|c|c|c|}
\hline & LEM & UBM & FD & FEM \\
\hline \hline slope angle & yes & no & no & no \\
\hline material properties & yes & yes & no & no \\
\hline hydrogeological conditions & yes & no & no & no \\
\hline sea water & yes & no & no & no \\
\hline ground acceleration & yes & yes & no & no \\
\hline horizontal stress due to dike intrusion & yes & yes & yes & yes \\
\hline vertical shear stress due to caldera collapse & no & yes & yes & yes \\
\hline
\end{tabular}


Two types of model geometries have been studied. At the beginning, the stability calculations have been carried out for a basic 2D model representing a simple geometry of a common volcano flank. Such a model has been selected in order to allow the application of the results obtained in a general form to other volcano slopes affected by large landslides or with the potential to be affected in the future. On the other hand, more ellaborated 2D and 3D models have been created approximating the preslide morphology of the La Orotava valley. However, the models do not match to all the preslide conditions because exact data refering to the geometry, the material properties and the boundary conditions are not well constrained. In general, the models analysed constitute a first step to understand the processes causing large volcanic landslides and future additional information should be incorporated into the models to improve the accuracy of the predictions.

The principal objectives of the stability analysis include on one hand the evaluation of the significant parameters influencing on the mechanical stability of volcano flanks, and on the other hand the detection of potential failure zones within the volcano slope. These two aims should give answers to the fundamental questions: 'why' and 'where' can take place large volcanic landslides? Another aim of the stability calculations is the improvement of the insights refering to the La Orotava valley events. This test site is characterised by the complexity of the volcanic, volcano-tectonic and tectonic processes influencing on the slope stability. Therefore, the La Orotava valley is a perfect natural example to compare the destabilising effects of each of these processes individually and of a combinations of them.

\subsection{Mechanisms applied}

Volcanic activity can produce many direct and indirect destabilising mechanisms (e.g. Voight and Elsworth, 1997). This study focussed on three mechanisms believed to occur in Tenerife, namely horizontal ground acceleration due to seismic shocks, horizontal stress due to dike intrusion and vertical shear stress due to caldera collapse. Since the influences of these three processes on the volcano stability have been comprehensively evaluated in Chapter 2, this Section only defines how their destabilising mechanisms have been incorporated into the model calculations and which magnitudes have been selected.

\subsubsection{Seismic shocks}

Earthquakes are a common feature in volcanic areas and have triggered many destructive landslides on volcanoes such as e.g. the Nevado Huascarán event (Plafker and Ericksen, 1978) or the Mount St. Helens event (Voight et al., 1981; Voight et al., 1983). Since many seismic shocks adjacent to volcanoes are provoked by a combination of volcanic processes and tectonic activity (see explanations in Chapter 2 ), the mechanism 'seismic shocks' includes ground motion of volcanic, volcano-tectonic as well as tectonic origin. Finally, the destabilising effect of a seismic shock has been incorporated into the stability analysis by a ground acceleration without distinguishing its origin. Because a quantitative evaluation of stability is complex and requires an exact seismic record and detailed dynamic material properties, a pseudostatic approach has been used in this study to calculate the stability of the volcano flanks under dynamic loading (Seed, 1979). In the pseudostatic method, the seismic shocks are applied to the slope by a uniformly distributed effective horizontal acceleration, $a$, as shown in Figure 5.1.

Peak acceleration is the most commonly used ground motion parameter in seismic slope stability analyses and many attenuation relationships have been developed (Kramer, 1996). All of them incorporate the magnitude values of an earthquake and calculate with additional parameters the adequate peak acceleration. The most important of these additional parameters is the epicentre distance 
of the affected slope (see Figure 2.5). This circumstance confirms that seismic shocks adjacent to the volcano are the most dangerous ones refering to failure of the volcano slope. Earthquakes directly associated with the movement or eruption of magma seldom exceed a magnitude of about 5.0 (Hoblitt et al., 1997) and only caldera collapse events can produce seismic shocks with magnitudes reaching high values up to 7.0 (Abe, 1992). However, in recognition to the fact that slopes are not rigid and that peak acceleration exists for only a very short time, the acceleration coefficients used in the analysis should correspond to values well below the peak acceleration. In the stability analysis of dams, it is suggested that appropriate pseudostatic coefficients should correspond to one-third to one-half of the maximum acceleration, including amplification or deamplification effects (Kramer, 1996). Finally, a lateral seismic acceleration up to $0.4 \mathrm{~g}$, where $\mathrm{g}$ is the gravitational acceleration, has been applied. In previous studies about landslides in volcanic zones the seismic loading has been simulated with magnitudes of the order of 0.1 to $0.3 \mathrm{~g}$ for the Mt. St. Helens event (Voight et al., 1983) and a maximum of $0.5 \mathrm{~g}$ for simulations within the focal zone of an earthquake (Belloni and Morris, 1991). Voight and Elsworth (1997) incorporated in theirs calculations for Hawaiian landslides the 1975 Kalapana earthquake with a magnitude of 7.2 and the 1983 Kaoiki earthquake with a magnitude of 6.6. They assumed that these events represented lateral acceleration of the order of $0.1 \mathrm{~g}$ to $0.2 \mathrm{~g}$. Reasonable maximum acceleration of $0.4 \mathrm{~g}$ has been assumed in this study.

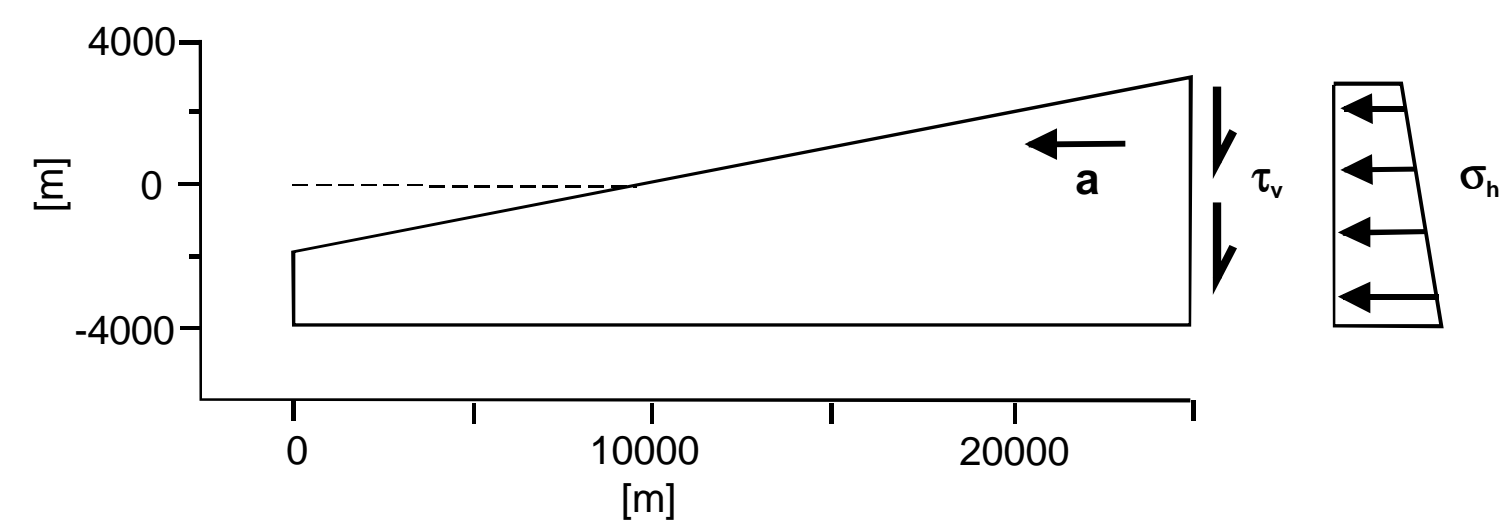

Figure 5.1: Application of the three mechanisms analysed in this study. $\sigma_{h}$ is the horizontal stress due to dike intrusion at the rear of the wedge, $\tau_{v}$ the shear stress caused by a vertical caldera collapse and $a$ is the horizontal acceleration due to seismic shocks.

An additional approach to calculate the dynamic behaviour of natural slopes is the Newmark sliding block analysis (Newmark, 1965). Since earthquake induced accelerations vary with time, the pseudostatic Factor of Safety will vary throughout an earthquake. Therefore, the sliding block analysis provides a prediction of the permanent displacement of a slope subjected to any ground motion. Newmark's method simulates a landslide as a rigid friction block of known critical acceleration on an inclined plane. The analysis calculates the cumulative displacement of the block as it is subjected to the effects of an earthquake acceleration-time history, and the user judges the significance of the displacement.

In the case of Tenerife, the lack of seismic records makes a correct analysis very difficult using the Newmark method. Therefore, only preliminary calculations with a sinusoid acceleration-time history have been carried out. In that case, the assumption of a peak acceleration of $\mathrm{a}=0.3 \mathrm{~g}$ has given displacements of about $5 \mathrm{~cm}$ for the La Orotava geometry (Gründel, 1999). 


\subsubsection{Dike intrusion}

Vertical intrusion of magma (dike intrusion) is characterised by many destabilising effects (see Chapter 2). Here, the stability calculations of this process only refer to the horizontal stress generated by the intruding magma and the related pore pressures changes, without focussing on other effects such as e.g. hydrothermal alteration.

Dike intrusion has been simulated assuming that a planar dike is intruded in an instant at the rear of the model (Figure 5.1). The produced horizontal stress, $\sigma_{h}$, has been applied in the way proposed by Elsworth and Voight (1995) defining it by the sum of magmastatic and overpressured components, $P_{m s}$ and $P_{m o}$,

$$
\sigma_{h}=P_{m s}+P_{m \mathrm{o}}
$$

The magmastatic pressure is given as

$$
P_{m s}=h_{d} \cdot \rho_{m} \cdot \mathrm{g}
$$

where $h_{d}$ is the height of the dike and $\rho_{m}$ the density of the magma. The magma overpressure, $P_{m o}$, during dike intrusion is assumed to exceed lithostatic pressure by values ranging from 2 to $10 \mathrm{MPa}$ (Rubin and Pollard, 1987; Gudmundsson, 1990). Hence, in this study the maximum value of $P_{m o}$ inside an intruding dike has been assumed to be $10 \mathrm{MPa}$.

Additionally, dike intrusion produces a significant increase of the pore fluid pressures by mechanical and thermal straining of the rock-fluid medium. The mechanically generated pore pressure, $P p_{m}$, has been studied by Elsworth and Voight (1992) at the Krafla volcano, Iceland, and defined through the dimensionless pressure, $P_{D m}$, as

$$
P_{D m}=\frac{2 \pi \cdot\left(p_{f l}-p_{f l}^{o}\right)}{U \cdot w} \cdot \frac{k}{\mu}
$$

where $\mathrm{p}_{\mathrm{fl}}$ is the total pore fluid pressure after the intrusion, $p_{f l}{ }^{o}$ the initial pore fluid pressure, $U$ the propagation velocity of the dike front, $w$ the intrusion width of the dike, $k$ the permeability of the porous medium and $\mu$ the dynamic viscosity of the saturating fluid. On the other hand, the thermally generated pore pressure, $P p_{t}$, has been defined by Delaney (1982) and Elsworth and Voight (1995) through the dimensionless pressure, $P_{D t}$, as

$$
P_{D t}=\frac{\left(p_{f l}-p_{f l}^{o}\right)}{K_{b} \cdot A \cdot \sqrt{\kappa n / c}}
$$

where $K_{b}$ is the undrained bulk skeletal modulus of the solid, $A$ the thermal strain, $\kappa$ the thermal diffusivity, $n$ the porosity and $\mathrm{c}$ the hydraulic diffusivity of the porous medium.

An expression to compute $P_{D m}$ was presented by Elsworth and Voight (1992), using the theory of an advancing dislocated front. On the other side, an additional expression to calculate $P_{D t}$ based on a heat diffusion mechanism was proposed by Delaney (1982).

In this study, the stability calculations mainly focus on the influence of the horizontal stress. The two agents refering to the pore pressure changes have only been analysed marginally because of the lack of appropriate data on the material properties. In addition, the magnitudes of the two pore pressures strongly depend on the dike width, $w$, but Elsworth and Voight (1995) had to change this value in their calculations by three orders of magnitude to obtain valuable results. Therefore, the applications of such expressions to actual cases seem to be limited. 


\subsubsection{Caldera collapse event}

Many different processes influence on the mechanical stability of the volcano during a caldera collapse episode. Simplified, the most important mechanisms can be divided into four types: 1) the preeruptive inflation of the magma chamber, 2) the vertical shear stress caused by the friction along the ring faults during the vertical collapse of the volcanic edifice, 3) seismic shocks related to the shear stress or to the explosive eruption; and, 4) the accumulation of eruptive products on steep slopes. The destabilising effect of the inflation of the magma chamber has been calculated numerically elsewhere (Gudmundsson, 1988; Gudmundsson et al., 1997; Hürlimann et al., 1999d) and indicates that the shape of the chamber and of the volcano flank as well as the magmatic overpressure play the major roles in the distribution of the stress field in the adjacent parts of the volcanic edifice. Since the seismic influence has been analysed as described before and point 4 has been included in the preliminary sensitive analysis, we focus in this section on the shear stress due to the vertical collapse of the volcano roof. A vertical shear stress, $\tau_{v}$, has been applied at the rear of the model in order to simulate the frictional stress along the ring fault generated by the volcano roof falling down into the magma chamber (Figure $5.1 \mathrm{~b})$. The only available constrains on this factor come from the seismic recordings and the proposed model of the caldera collapse event in the Galapagos Islands (Filson et al., 1973). Additional data have been found in earthquake literature (Scholz, 1990) and also laboratory data of rock shear strengths have been analysed (Goodman, 1989). Finally, we have applied driving shear stresses of $30 \mathrm{MPa}$ as a maximum value, as proposed by Filson et al. (1973).

\subsection{Approaches}

\subsubsection{Global limit analysis}

There are two basic methods used in geotechnical engineering practice to evaluate quantitatively the stability of natural slopes: the Limit Equilibrium Method (LEM) and the Bound Method (BM). The LEMs consider the equilibrium conditions at a particular line applying the existing forces or momentum, while the BMs calculate the energy equations due to movements. Both methods contain a failure criterion which can be determined as drained or undrained (see Chapter 2, Figure 2.6).

The calculations of slope stability under drained conditions are based on the Mohr-Coulomb failure criterion. The Mohr-Coulomb criterion consists of a linear envelope touching all Mohr circles representing critical combinations of principal effective stresses, $\sigma_{1}^{\prime}$ and $\sigma_{2}^{\prime}$. The Mohr-Coulomb criterion can be illustrated in terms of normal and shear stresses, $\sigma_{n}$ and $\tau$, on the plane represented by the point of tangency of a Mohr circle with the envelope

$$
\tau_{\max }=c+\sigma_{n}{ }^{\prime} \cdot \tan \phi
$$

where $\tau_{\max }$ is the maximum shear strength, $\sigma_{n}^{\prime}$ the effective normal stress, $c$ the shear strength intercept or cohesion and $\phi$ the angle of internal friction. In addition, the effect of water is incorporated as

$$
\sigma_{n}^{\prime}=\sigma_{n}-p_{w}
$$

where $\sigma_{n}$ is the total normal stress and $p_{w}$ the water pressure (Terzaghi and Peck, 1967). However, the water pressure is usually included as a static water pressure, since excess pore water pressure due to dynamic or thermal loading are difficult to compute and thus not able to take into account using the drained failure criterion. 
Therefore, the undrained failure criterion is much more appropriate in the case of excess pore water pressure. The undrained failure criterion has been assumed as

$$
\tau_{\max }=c_{u}
$$

where $c_{u}$ is the undrained strength of the material leaving apart the friction angle (also called the $\phi=0$ - concept; Lambe and Whitman, 1979). During a stability analysis including volcanic mechanisms the selection of undrained conditions is justified because the external loads change at a rate much faster than the rate at which the induced pore pressure can dissipate. This assumption is adequate applying seismic shocks and vertical shear stresses due caldera collapse, but does not match totally refering to the horizontal stress due to dike intrusion, because dike intrusion is usually a slow process. The undrained analysis can be performed using total stresses, because Equation 5.7 is independent of water pressure. Then, the problem becomes to estimate the strength $c_{u}$ which depends on the initial conditions of the material.

In this study, the final stability calculations have been carried out on the one hand using the LEM and the drained failure criterion, and on the other hand using the Upper Bound Method (UBM) and the undrained failure criterion.

It is assumed that these approaches, that are commonly applied to small scale problems, can also be used in these large landslides. The scale effect has not been considered here, as it is not yet well understood, and the works focussing on this topic are still scarce.

\section{Limit Equilibrium Method}

In general, the LEM applied to a sliding block represents the condition at which the forces acting on the block on an inclined plane tending to induce movement are exactly balanced by those resisting sliding. In order to compare the stability of slopes under conditions other than those of limiting equilibrium, some form of index is required and the most commonly used is the Factor of Safety (FS). This is the ratio of the total force available to resist sliding to the total force tending to induce sliding. The calculation of the FS-value is simple for a single sliding block on an inclined plane but is more complex and requires additional assumptions for general slip surfaces. Therefore the most LEM-codes apply the method of slices (Bishop, 1955; Bromhead, 1992). This method divides the mass above the slip surface into wedges or slices and calculates the forces or moments of each slice by imposing equilibrium. Additional assumptions are required since the problem is not fully defined if only equilibrium is considered (Bromhead, 1992). Finally, a FS-value can be estimated as

$$
\mathrm{FS}=\frac{\int \tau_{\max } \mathrm{dl}}{\int \tau \mathrm{dl}}
$$

where $\tau_{\max }$ refers to the strength of the material computed as given in Equation 5.5 or 5.7 and $\tau$ is the shear stress on the slip surface. Both integrals are computed along that slip surface. Thus FS > 1 indicates global safety conditions.

In this study, the commercial LEM-program 'PCSTABL5M' has been used (Achilleos, 1988). The program bases on the two-dimensional LEM and contains the following methods to solve general slope stability problems:

1) simplified Janbu, applicable to failure surfaces of general shape

2) simplified Bishop, applicable to circular shaped failure surfaces

3) Spencer's method of slices, applicable to any type of surface

On the other hand, a second LEM has been applied which has first been introduced by Iverson (1995) and then improved by Elsworth and Voight (1995) and Voight and Elsworth (1997). This specific approach has been developed in order to analyse the influence of dike intrusion on large failures on the Hawaiian Islands incorporating stabilising and destabilising forces. The method is similar to those considered in sliding-wedge problems familiar to geotechnical engineers (e.g. Hoek and Bray, 1981). In the following, the principal ideas of this approach will be explained. 
The slope geometry is defined as a single rigid wedge bounded at the rear by a planar dike and at the base by a potential failure plane of arbitrary inclination (Figure 5.2). The forces acting on the wedge are:

- the forces caused by the block weight

$F_{b l}$

$F_{\text {sea }}$

$F_{g w}$

- the static groundwater pressure

- the forces generated by seismic shocks

- the forces owning to the dike intrusion including:

- the horizontal, seaward force at the rear of the wedge

- the uplift forces due to the mechanically induced pore pressure

- the uplift forces due to the thermally induced pore pressure

$F_{d i}$

$F p_{m}$

$F p_{t}$

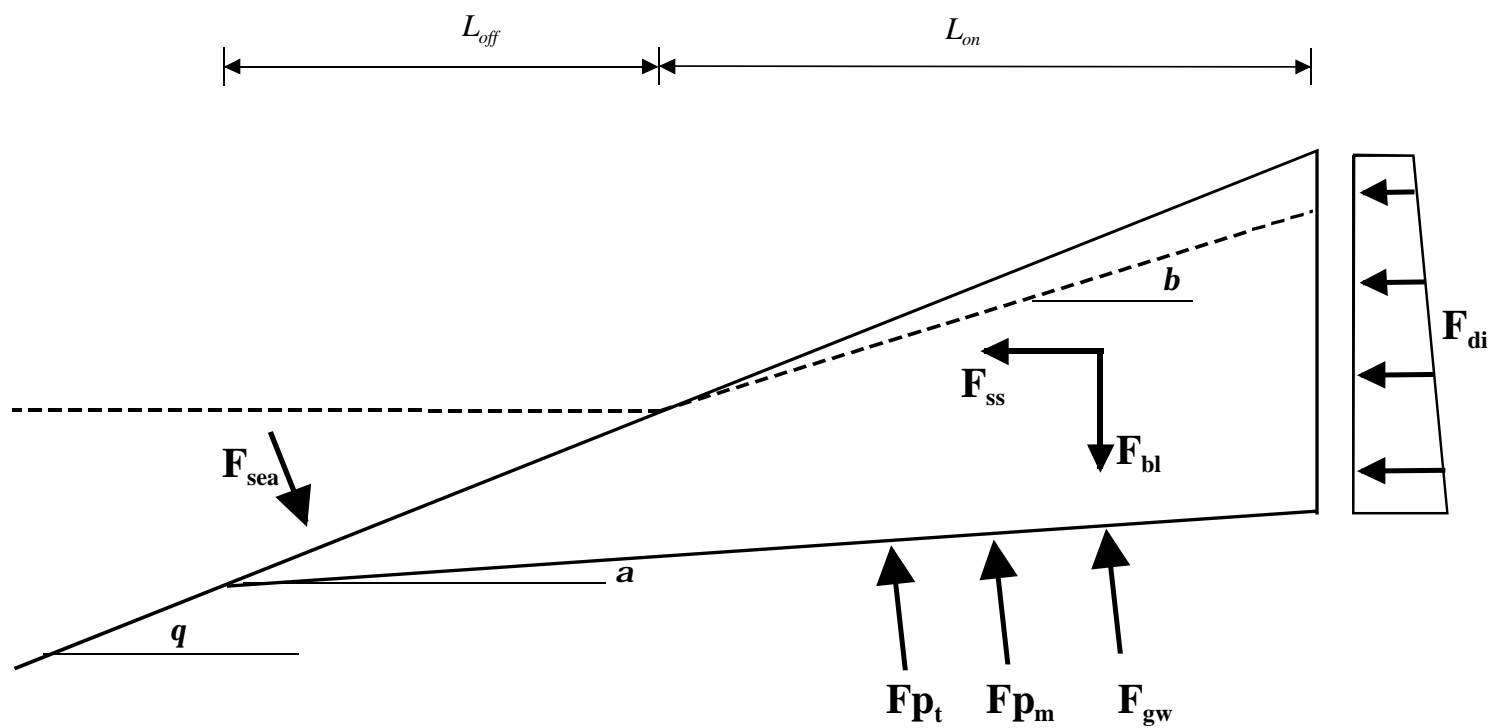

Figure 5.2: External forces and geometric parameters used in LEM. The external forces are indicated by bold letters and geometric parameters by italics. The dashed line shows the sea level/water table.

Besides the parameters referring to the material properties (angle of friction and cohesion) and the external forces, the LEM can be defined by five geometric parameters: three angles including the slope angle, $\theta$, the inclination of the water table, $\beta$, and the angle of slip surface, $\alpha$, and the onshore and offshore lengths of the slipping wedge, $L_{o n}$ and $L_{\text {off }}$.

Since the incorporation of vertical shear stresses is not convenient in the program 'PCSTABL5M', only the destabilising effects of dike intrusion and seismic shocks have been analysed using LEM. The vertical shear stress caused by caldera collapse episodes will therefore be analysed using the UBM.

For the assumptions described above, resolution of forces parallel to the basal failure plane gives the total destabilising forces (shear force), and forces perpendicular to the failure surface contribute to the stabilising forces (effective normal force). Then, Equation 5.8 can be resolved using this concept and selecting drained or undrained conditions (Eq. 5.5 or Eq. 5.7). 
First, drained conditions have been assumed. The resolution of the stabilising and destabilising forces without looking at the forces due to a possible dike intrusion at the rear of the wedge or a seismic shock gives

$$
F S=\frac{c \cdot L_{s p}+\left(F_{b l} \cdot \cos \alpha+F_{\text {sea }} \cdot \cos (\theta-\alpha)-F_{g w}\right) \cdot \tan \phi}{F_{b l} \cdot \sin \alpha-F_{\text {sea }} \cdot \sin (\theta-\alpha)}
$$

where $c$ is the cohesion intercept and $L_{s p}$ the length of the entire failure surface. In order to analyse the seismic influence on the stability of a volcano flank, an average horizontal ground acceleration, $a$, can be incorporated into the model. This process changes Equation 5.9 in the component of the block weight $F_{b l}$ and is given as

$$
F S=\frac{c \cdot L_{s p}+\left(F_{b l} \cdot(\cos \alpha-a \cdot \sin \alpha)+F_{s e a} \cdot \cos (\gamma-\alpha)-F_{g w}\right) \cdot \tan \phi}{F_{b l} \cdot(\sin \alpha-a \cdot \cos \alpha)-F_{s e a} \cdot \sin (\gamma-\alpha)}
$$

Dike intrusion at the rear of the wedge will cause additional forces. These forces are the horizontal force, $F_{d i}$, at the rear of the wedge and the two uplift forces due to mechanically and thermally induced pore pressure, $F p_{m}$ and $F p_{t}$. The additional forces caused by dike intrusion incorporated in Equation 5.9 gives

$$
F S=\frac{c \cdot L_{s p}+\left(F_{b l} \cdot \cos \alpha+F_{s e a} \cdot \cos (\theta-\alpha)-F_{g w}-F_{d i} \cdot \sin \alpha-F p_{m}-F p_{t}\right) \cdot \tan \phi}{F_{b l} \cdot \sin \alpha-F_{s e a} \cdot \sin (\theta-\alpha)+F_{d i} \cdot \cos \alpha}
$$

Finally, a combination of dike intrusion and seismic shock can be calculated. The stability equation for the incorporation of these two processes is given as

$F S=\frac{c \cdot L_{s p}+\left(F_{b l} \cdot(\cos \alpha-a \cdot \sin \alpha)+F_{s e a} \cdot \cos (\theta-\alpha)-F_{g w}-F_{d i} \cdot \sin \alpha-F p_{m}-F p_{t}\right) \cdot \tan \phi}{F_{b l} \cdot(\sin \alpha+a \cdot \cos \alpha)-F_{\text {sea }} \cdot \sin (\theta-\alpha)+F_{d i} \cdot \cos \alpha}$ (Eq. 5.12)

Under undrained condition (Eq. 5.7) the sum of resisting forces at the failure plane can be expressed as

$$
\int \tau_{\max }=c_{u} \cdot L_{s p}
$$

Then, this equation can be incorporated into Eq. 5.8 giving a final equation much easier than the one under drained conditions. At last, the Factor of Safety applying dike intrusion and seismic shocks can be expressed as

$$
F S=\frac{c_{u} \cdot L_{s p}}{F_{b l} \cdot(\sin \alpha+a \cdot \cos \alpha)-F_{s e a} \cdot \sin (\theta-\alpha)+F_{d i} \cdot \cos \alpha}
$$

representing the same conditions as Eq. 5.12 but under undrained conditions. The application of undrained conditions and Equation 5.14 contains the difficulty to estimate the correct magnitude of $c_{u}$. 


\section{Upper Bound Method}

The Bound Method (BM) is a common approach in soil mechanics and permits the incorporation of drained or undrained shear strength of the material. The BM makes use of the important theorems of plastic collapse based on the principle of virtual work, while the LEMs apply the equilibrium of existing forces or momentum (Donald and Chen, 1997).

In this study, only the undrained Upper Bound Method (UBM) has been applied. The UBM is an energy method and implies that by ignoring the equilibrium conditions an upper bound for the collapse load can be calculated. This means that a natural slope loaded to this value must fail. An assumption required for the Upper Bound Method is the perfect plasticity of the material (Chen, 1975). There are several techniques to calculate the upper bound. In this work the increments of movement have been selected as the significant parameter.

The basic idea for the determination of the upper bound consists in the calculation of the work done by both the internal stresses and the external loads during an increment of movement of a compatible mechanism. This theorem can be expressed as

$$
\delta W=\delta E
$$

where $\delta W$ is the increment of work of internal stresses and $\delta E$ is the increment of work due to the external loads. The work done by the internal stresses is the work dissipated by plastic straining in the material in the thin slip surface that make up the compatible mechanism. It can be shown (Chen, 1975) that, the increment of work of internal stresses, $\delta \mathrm{W}$, is given for undrained loading as

$$
\delta W=c_{u} \cdot L_{s p} \cdot \delta w
$$

where $\delta w$ is the relative increment of displacement in the slip surface (Figure 5.3). It is assumed that the sliding block is rigid, and then all the energy is consumed by producing a relative displacement in the slip surface.

If laboratory data on the undrained material strength are available, they can be incorporated into the calculations. In this study, the undrained strength, $c_{u}$, has been approximated by the peak shear stress, $q_{\text {peak }}$, obtained from undrained triaxial tests as proposed by Lambe and Whitman (1979). As the value of the peak shear stress depends on the effective confining stress, $p^{\prime}$ (see Chapter 4), the $c_{u}$-value is directly related to the overburden load. This correlation between $p^{\prime}$ and $q_{\text {peak }}$ as well as between $c_{u}$ and the overburden can be defined by the apparent friction angle, $\phi_{a p p}$, which represents a practical parameter to characterise the material strength during completely undrained loading (Sassa, 1988; Sassa, 1992). Values of $\phi_{a p p}$ are listed in Chapter 4 (Table 4.20) and the relation between $p^{\prime}, q_{\text {peak }}$ and $c_{u}$ can be expressed as

$$
c_{u}=q_{\text {peak }}=\tan \phi_{\text {app }} \cdot p^{\prime}
$$

assuming zero cohesion. In the UBM, the parameter $c_{u}$ determines a global value for the entire failure surface, whereas the $p^{\prime}$-values (overburden) are not constant. Hence, for a single wedge model as used in this study (Figure 5.3) and assuming isotropic stress state ( $\mathrm{p}^{\prime}$ is equal to the effective vertical stress) the global $c_{u}$-value can be estimated as

$$
c_{u}=1 / 2 \cdot \tan \phi_{a p p} \cdot H_{s l} \gamma_{r}^{\prime}
$$

where $H_{s l}$ is the maximum height of the sliding wedge and $\gamma_{r}^{\prime}$ the submerged unit weight of the soil/rock. 
On the other hand, the external loads correspond to all the existing forces acting on the slope including surface stresses, concentrated loads and the self-weight forces. Therefore, the increment of work of the external loads is given as

$$
\delta E=\sum \vec{F} \cdot \delta \vec{w}
$$

where the second hand of the equation represents the sum of the scalar products of external forces and block displacements.

In this study all the external loads are written by forces in order to simplify the understanding of the final equation and to make use of the forces defined during the LEM analysis. Finally, the external forces have been assumed to be (Figure 5.3):

- the self-weight force of the sliding block

- the force of the seawater

$F_{b l}$

- the seismic force acting on the sliding mass

$F_{\text {sea }}$

- the force caused by the horizontal, seaward stress due to dike intrusion

$F_{s s}$

- the force caused by the vertical shear stress due to vertical caldera collapse

$F_{d i}$

$F_{c c}$
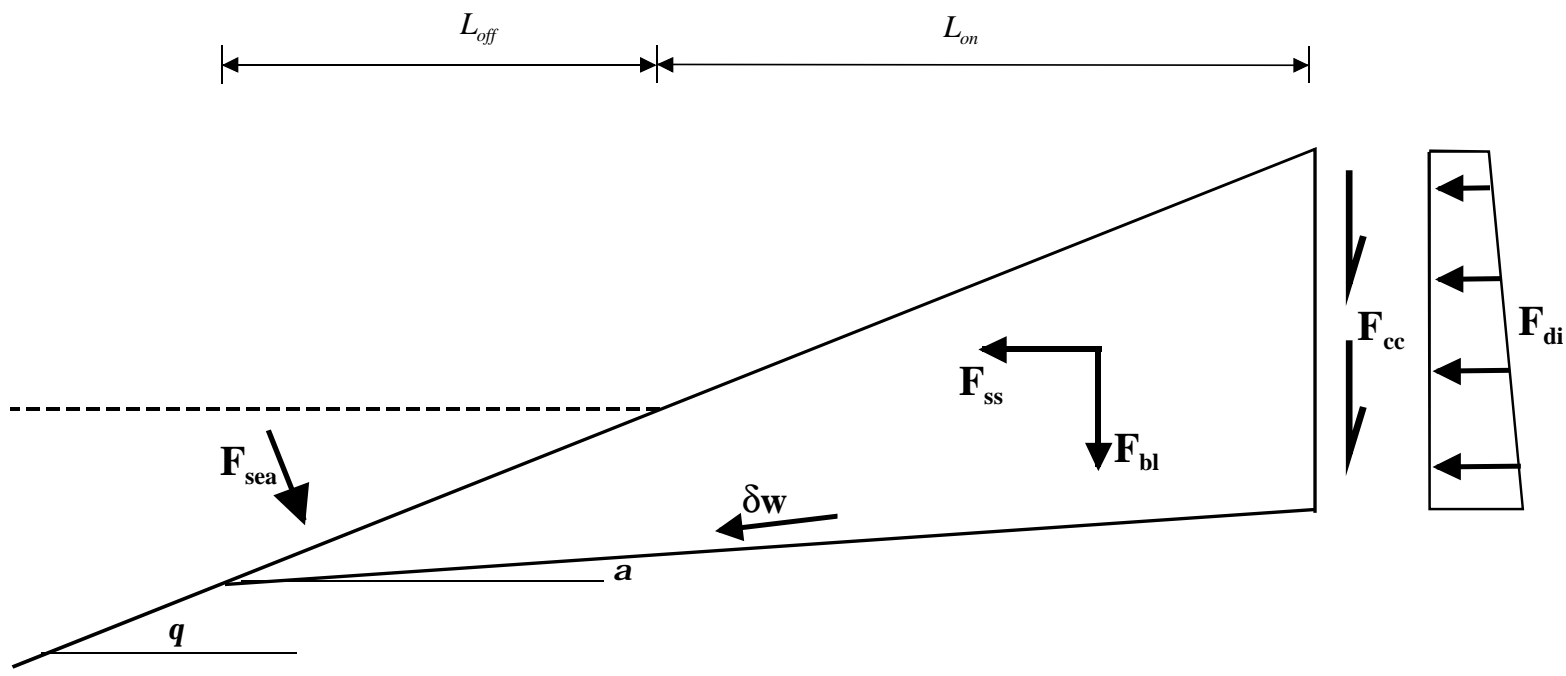

Figure 5.3: External forces and geometric parameters used in UBM. The external forces are indicated by bold letters and geometric parameters by italics. The dashed line shows the sea level.

In contrast to the LEM, the model's geometry using UBM can be defined by four geometric parameters including the slope angle, $\theta$, the angle of the slip surface, $\alpha$, and the onshore and offshore lengths of the slipping wedge, $L_{o n}$ and $L_{o f f}$. Since undrained conditions are considered, a total stress analysis is performed and the position of the water table is not used in the calculations.

Moreover, the UBM enables the incorporation of the vertical shear stress due to caldera collapse episodes, while this process has not been possible to apply correctly when using the PCSTABL program. Here, the force caused by the vertical caldera collapse, $F_{c c}$, is approximated by the product of the shear stress along the ring fault (see Chapter 2) and the length of the rear boundary of the model. In practice, the effect of $F_{c c}$ would be mainly local and concentrated at the lower right edge of the model. Therefore, the formula is less realistic, as it assumes average values of forces distributed along the slip surface. 
The external forces normal to the slip plane $\left(F p_{t}, F p_{m}\right.$ and $F_{g w}$, see Figure 5.2) do not contribute to the external work as $\vec{F} \cdot \delta \vec{w}=0$ for them (Apart from the fact that $F_{g w}$ is not used in undrained conditions). Consequently, the increment of work of internal stresses and of external loads incorporated in Equation 5.15 gives

$$
c_{u} \cdot L_{s p} \cdot \delta w=\vec{F}_{d i} \cdot \delta \vec{w}+\vec{F}_{s s} \cdot \delta \vec{w}+\vec{F}_{c c} \cdot \delta \vec{w}+\vec{F}_{b l} \cdot \delta \vec{w}+\vec{F}_{s e a} \cdot \delta \vec{w}
$$

The division of $\delta W$ and $\delta E$ performs an UBM-ratio or UBM-Factor of Safety, $\mathrm{FS}_{\mathrm{UBM}}$, that can be compared with a Factor of Safety of the slope calculated by LEM. However, it should be considered that the UBM-ratio is either greater than or equal to the actual Factors of Safety (Atkinson, 1993). The UBM assumes that the actual forces which produce failure are smaller than the computed ones, while the LEM assumes that equilibrium conditions are still satisfied at failure.

At last, the incorporation of all external forces into the same equation using the concept of the UBMratio and assuming the undrained failure criterion gives the final equation

$$
F S_{U B M}=\frac{c_{u} \cdot L_{s p}}{F_{b l} \cdot(\sin \alpha+a \cdot \cos \alpha)+F_{d i} \cdot \cos \alpha+F_{c c} \cdot \sin \alpha-F_{s e a} \cdot \sin (\theta-\alpha)}
$$

Note that this equation is the same as (Eq. 5.14 obtained from the LEM approach and undrained failure conditions, only with the additional term concerning the force $F_{c c}$ caused by the caldera collapse episode.

\subsubsection{Continuum analysis}

In this study, two distinct methods have been applied to carry out a comprehensive continuum analysis. On one hand 2D Finite Difference (FD) techniques has been used for the preliminary calculations and on the other hand the Finite Element Method (FEM) has been applied in order to solve 2D/3D simulations. In general, both of these two methods contain three different steps: pre-processing, numerical solution and post-processing (Zienkiewicz and Taylor, 1989). The main function of this preprocessor step is the creation and definition of a suitable model, which has included the following points in this study:

- the definition of the initial geometry of the structure,

- the decomposition of the structure into elements,

- the definition of the material properties of the elements,

- the definition of the loading or the external forces, and

- the definition of the boundary conditions.

During the solution step each element behaves according to the defined linear or non-linear stress-strain law in response to the applied forces and boundary conditions. By this way, the displacements of each node and the stresses of each Gauss point can be computed. The post-processing step is generally facilitated by a post-processing program, which enables to display the results in different ways. 


\section{Finite Difference Method}

In this study, the preliminary calculations of the stability analysis have been performed using the commercial finite difference program package called 'FLAC' (ITASCA, 1995). FLAC is a twodimensional explicit finite difference code, which solves the equilibrium equation

$$
\frac{\partial \sigma_{i j}}{\partial x_{j}}+b_{i}=0
$$

where $\sigma_{i j}$ is the Cauchy stress tensor, $x_{j}$ the coordinate and $b_{i}$ the body forces vector. The FLAC program allows multiple step stability analysis. The calculations have been carried out using different input files including three steps for the analysis of the horizontal stress due to dike intrusion and four steps for the vertical shear stress due to caldera collapse event (Table 5.2). In the first step, the model has been equilibrated applying the gravity forces. In the second step, the seawater loading at the submarine part of the slope as well as the water table has been incorporated. Then, the external mechanisms have been applied using one additional step for the dike intrusion and two additional steps for the caldera collapse event. Before the application of the external forces the displacements computed during the first two steps have been defined as zero.

Before the application of the volcanic processes the material properties have been assumed to be isotropic and linearly elastic. Then, during the analysis of the volcanic processes, the Mohr-Coulomb failure criterion has been introduced in order to detect zones of potential failure. Finally, the results have been plotted assuming the nodes with a Mohr-Coulomb ratio less than 1.0 to be potential failure zones.

The boundary conditions listed in Table 5.2 will be explained in detail in next Section.

Table 5.2: Modelling sequences during the FD analysis indicating the applied stress, material property and boundary conditions (DI for horizontal stress due to dike intrusion, $\mathrm{CC}$ for vertical stress due to caldera collapse).

\begin{tabular}{|c|c|c|c|c|}
\hline model type & step & applied stress & material property & boundary conditions \\
\hline \multirow[t]{3}{*}{ 2D FD DI } & 1 & gravity & elastic & $\begin{array}{l}\text { base } \Delta x=\Delta y=0 \\
\text { sea side } \Delta x=0 \\
\text { volcano side: } \Delta x=0\end{array}$ \\
\hline & 2 & $\begin{array}{c}\text { seawater loading and } \\
\text { hydrostatic pressure } \\
\text { (water table) }\end{array}$ & elastic & $\begin{array}{l}\text { base: } \Delta x=\Delta y=0 \\
\text { sea side: } \Delta x=0 \\
\text { volcano side: } \Delta x=0\end{array}$ \\
\hline & 3 & $\begin{array}{c}\text { horizontal stress due to dike } \\
\text { intrusion }\end{array}$ & $\begin{array}{l}\text { Mohr - Coulomb } \\
\text { plasticity }\end{array}$ & $\begin{array}{l}\text { base: } \Delta \mathrm{x}=\Delta \mathrm{y}=0 \\
\text { sea side: } \Delta \mathrm{x}=0 \\
\text { volcano side: free }\end{array}$ \\
\hline \multirow[t]{4}{*}{ 2D FD CC } & 1 & gravity & elastic & $\begin{array}{l}\text { base } \Delta x=\Delta y=0 \\
\text { sea side } \Delta x=0 \\
\text { volcano side: } \Delta x=0\end{array}$ \\
\hline & 2 & $\begin{array}{l}\text { seawater loading and } \\
\text { hydrostatic pressure } \\
\text { (water table) }\end{array}$ & elastic & $\begin{array}{l}\text { base: } \Delta x=\Delta y=0 \\
\text { sea side: } \Delta x=0 \\
\text { volcano side: } \Delta x=0\end{array}$ \\
\hline & 3 & $\begin{array}{l}\text { horizontal lithostatic stress } \\
\text { at the volcano side }\end{array}$ & elastic & $\begin{array}{l}\text { base: } \Delta \mathrm{x}=\Delta \mathrm{y}=0 \\
\text { sea side: } \Delta \mathrm{x}=0 \\
\text { volcano side: free }\end{array}$ \\
\hline & 4 & $\begin{array}{l}\text { vertical shear stress due to } \\
\text { caldera collapse }\end{array}$ & $\begin{array}{l}\text { Mohr - Coulomb } \\
\text { plasticity }\end{array}$ & $\begin{array}{l}\text { base: } \Delta x=\Delta y=0 \\
\text { sea side: } \Delta x=0 \\
\text { volcano side: } \Delta x=0\end{array}$ \\
\hline
\end{tabular}




\section{Finite Element Method}

The FEM was introduced to the geotechnical engineering at the end of the sixties in order to incorporate non-linear stress-strain relationships in deformation analyses (Duncan, 1992). The basis of FEM is that the medium to be analysed is approximated by an assembly of structural elements connected at their nodal points. The displacement components of these nodes become the unknowns of the problem, when external forces are applied to the model. These displacements are determined by the following equation

$$
F=K \cdot U
$$

where $F$ is the vector that lists the external forces, $U$ is a vector of resulting displacements and $K$ is the stiffness matrix of the structure (Zienkiewicz and Taylor, 1989).

In this work, the commercial computer program 'ABAQUS' has been used (ABAQUS, 1996). During the stability analysis, the final stress - strain field of the models has been calculated in two steps (Table 5.3). First, the equilibrium step has been carried out to obtain an initial state of geostatic stresses in the model including the gravitational force and the seawater loading. After this step the volcanic processes have been incorporated into the model. The material has been assumed to be homogeneous, isotropic and linear elastic during the whole analysis. In contrast to the FD calculations, no water table has been defined in the FEM analysis. To define the mechanical stability of the slope, first the distribution of principal stresses has been analysed and then two different failure criterions have been applied: the Tresca and the Von Mises failure criterion. The Tresca failure criterion suggests that yield would occur when the shear stress reaches a limiting value and is defined as the maximum difference between the principal stresses. The Von Mises failure criterion applies a similar concept and can be expressed in the index notation as

$$
q_{m i s}=\sqrt{\frac{2}{3} S_{i j} S_{i j}}
$$

where $q_{m i s}$ is the Von Mises shear stress and $S_{i j}$ the deviatoric stress tensor, defined as

$$
S_{i j}=\sigma_{i j}-p \delta_{i j}
$$

where $\sigma_{i j}$ is the stress, $p$ the mean stress and $\delta_{i j}$ the Kronecker delta. The mean stress $p$ is given as

$$
p=\frac{1}{3} \sigma_{i i}=\frac{1}{3}\left(\sigma_{x x}+\sigma_{y y}+\sigma_{z z}\right)
$$

Failure occurs when $q_{\text {mis }}$ reaches a critical value.

The two criteria give the same yield stress in tension or compression, whereas the second one predicts a maximum shear stress slightly larger than the first one. Since accurate data on the stress strain behaviour of volcanic material is lacking and this approach mainly has a qualitative purpose, the results of the calculations are presented by the computed Von Mises shear stress values without defining exact yielding zones. However, zones of maximum Von Mises shear stress values can be assumed to be areas of potential failure. 
Table 5.3: Modelling sequences during the FEM analysis indicating the applied stress, material property and boundary conditions (DI for horizontal stress due to dike intrusion, CC for vertical stress due to caldera collapse).

\begin{tabular}{|c|c|c|c|c|}
\hline model type & step & applied stress & material property & boundary conditions \\
\hline \multirow[t]{2}{*}{ 2D FEM DI } & 1 & $\begin{array}{c}\text { gravity } \\
\text { and } \\
\text { seawater loading } \\
\end{array}$ & elastic & $\begin{array}{l}\text { base }: \Delta x=\Delta y=0 \\
\text { sea side } \Delta x=0 \\
\text { volcano side }: \Delta x=0\end{array}$ \\
\hline & 2 & $\begin{array}{l}\text { horizontal stress due to } \\
\text { dike intrusion }\end{array}$ & elastic & $\begin{array}{l}\text { base: } \Delta x=\Delta y=0 \\
\text { sea side: } \Delta x=0 \\
\text { volcano side: free }\end{array}$ \\
\hline \multirow[t]{2}{*}{ 2D FEM CC } & 1 & $\begin{array}{c}\text { gravity } \\
\text { and } \\
\text { seawater loading } \\
\end{array}$ & elastic & $\begin{array}{l}\text { base }: \Delta x=\Delta y=0 \\
\text { sea side } \Delta x=0 \\
\text { volcano side: } \Delta x=0\end{array}$ \\
\hline & 2 & vertical force & elastic & $\begin{array}{l}\text { base } \Delta x=\Delta y=0 \\
\text { sea side } \Delta x=0 \\
\text { volcano side: } \Delta x=0\end{array}$ \\
\hline \multirow[t]{2}{*}{ 3D FEM DI } & 1 & $\begin{array}{c}\text { gravity } \\
\text { and } \\
\text { seawater loading }\end{array}$ & elastic & $\begin{array}{l}\text { base: } \Delta \mathrm{x}=\Delta \mathrm{y}=\Delta \mathrm{z}=0 \\
\text { sea side: } \Delta \mathrm{x}=\Delta \mathrm{y}=0 \\
\text { lateral sides: } \Delta \mathrm{x}=\Delta \mathrm{y}=0 \\
\text { volcano side: } \Delta \mathrm{x}=\Delta \mathrm{y}=0\end{array}$ \\
\hline & 2 & $\begin{array}{l}\text { horizontal stress due to } \\
\text { dike intrusion }\end{array}$ & elastic & $\begin{array}{l}\text { base: } \Delta \mathrm{x}=\Delta \mathrm{y}=\Delta \mathrm{z}=0 \\
\text { sea side: } \Delta \mathrm{x}=\Delta \mathrm{y}=0 \\
\text { lateral sides: } \Delta \mathrm{x}=0 \\
\text { volcano side: free }\end{array}$ \\
\hline
\end{tabular}

\subsection{Model description}

The initial conditions of the northern flank of Tenerife before failure have been estimated using a Geographic Information System (GIS). A simplified preslide morphology of the La Orotava valley has been established by data containing all the geologic and morphologic information available. Additionally, the results of the site investigation have been incorporated including information concerning dike trends, vent locations and the distribution of pyroclastic deposits. Finally, the initial geometric conditions have been approximated in two types of models: 2D models representing a general idealised volcano slope and 2D / 3D models characterising the assumed preslide morphology of the La Orotava valley. The lack of information constraining the exact material properties and the boundary conditions implies that the stability analysis cannot be considered as definite. However, the model results serve to outline the mechanisms controlling the landslide process. 


\subsubsection{Global limit analysis}

During the quantitative analysis only 2D models have been investigated. Two general types of 2D models have been defined. One model type assuming a volcano flank with a very simple geometry and another type approximating the preslide morphology of the La Orotava valley (Figure 5.4). The simple model has been analysed using LEM and UBM, whereas the La Orotava valley model has only been studied using LEM. The simple model represents an idealised volcano flank and is characterised by a wedge-shaped geometry with a constant slope angle and both an offshore and onshore part (Figure 5.4a). The model length has normally been assumed to be $25 \mathrm{~km}$ with a $L_{o n} / L_{\text {off }}$ - ratio of 1.5 and the linear, specified slip surface has been defined as 9 degrees. Such a failure surface includes a vertical head scarp of the landslide that seems to be quite unrealistic. However, this is the only practical manner in the PCSTABL code to apply the horizontal stress caused by dike intrusion to the failing part of the model. During the LEM calculations, the inclination of the water table has been defined as 10 degrees. These five parameters defining the model's geometry have been called the standard geometric model parameters and are listed with the selected magnitudes in Table 5.4. If not explicitly mentioned, these are the values used for the stability calculations presented in this study.

Table 5.4: Definition of the standard geometric parameters used in the preliminary calculations of LEM and UBM analyses.

\begin{tabular}{|l|c|c|c|}
\hline geometric parameter & symbol & magnitude & unit \\
\hline \hline slope angle & $\theta$ & 11 & degree \\
\hline angle of water table & $\beta$ & 10 & degree \\
\hline angle of slip surface & $\alpha$ & 9 & degree \\
\hline total model length & $L$ & 25000 & $\mathrm{~m}$ \\
\hline onshore to offshore ratio & $L_{\text {on }} / L_{\text {off }}$ & 1.5 & - \\
\hline
\end{tabular}

The assumed 2D geometry of the La Orotava valley model is shown in Figure 5.4b. As described in Chapter 3, the La Orotava valley may have been generated by two different failures with distinct characteristics. In this study, the model geometry analysed represents the idealised preslide morphology of the western part adjacent to the Tigaiga massif. The model is characterised by a coastal marine platform, a coastal cliff, a smooth volcano slope and a steep zone adjacent to the centre of the volcano. The model has a total length of about $16 \mathrm{~km}$ at its base and heights ranging from $500 \mathrm{~m}$ b.s.l. at the left boundary to a maximum altitude of $3250 \mathrm{~m}$ a.s.l. at the right boundary. The water table has been difficult to define due to the lack of data refering to hydrogeological conditions in the past and the heterogeneity of volcanic rocks and their hydrogeological parameters. Finally, a quite high water table has been selected based on the studies of the water tunnel network on Tenerife island (Custodio, 1989; Navarro and Braojos, 1991). The hypothetical slip surface has been chosen at a depth between 400 to $700 \mathrm{~m}$ below the preslide surface. 
a)

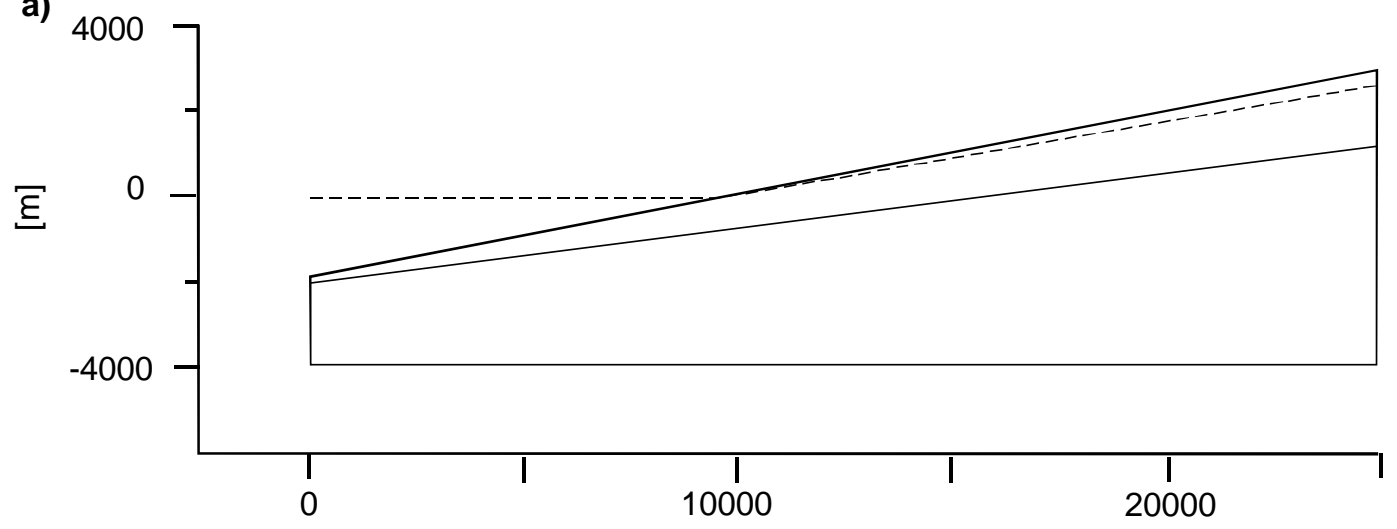

[m]

b)

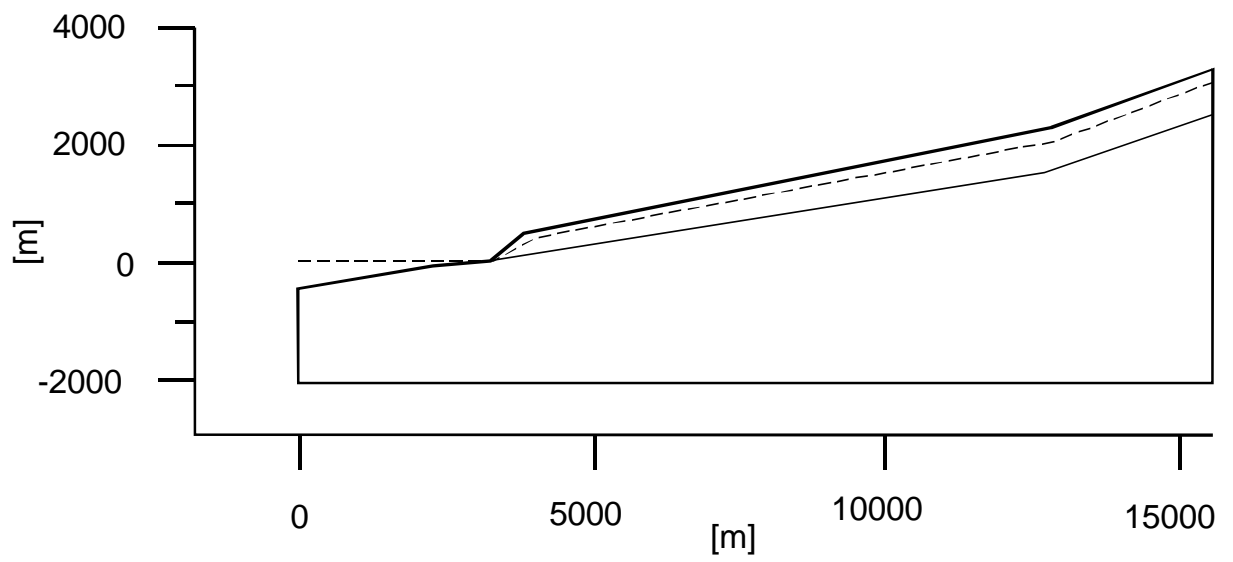

Figure 5.4: Geometry of the 2D models used in the quantitative stability analysis. a) A volcano slope with a very simple model geometry. b) The assumed preslide geometry of the La Orotava valley. Dashed line indicates the sea level / water table and thin line shows specified slip surface.

In all the models used during the quantitative analysis, the material properties have been assumed to be homogeneous with values of fractured lava presented in previous works (Voight et al., 1983; Rubin and Pollard, 1987; Dieterich, 1988; Elsworth and Voight, 1992). The unit weight of the fractured lava as well as that of the magma has been defined as $\gamma_{r}=\gamma_{m}=27 \mathrm{kN} \mathrm{m}^{-3}$. In the LEM analysis, the cohesion has been $c=0 \mathrm{kPa}$ and angle of internal friction $\phi=35^{\circ}$ which could be assumed as conservative. In the UBM calculations refering to the undrained material strengths, the apparent friction angle has been selected as $20^{\circ}$ which corresponds to the value obtained from the laboratory tests performed on residual soil (Chapter 4) and $35^{\circ}$ which represents an upper limit of this value. The standard material parameters used in the LEM and the UBM calculations are listed in Table 5.5.

Table 5.5: Definition of the standard material parameters used for the LEM and UBM.

\begin{tabular}{|l|c|c|c|}
\hline material parameters & symbol & magnitude & unit \\
\hline \hline unit weight of soil/rock & $\gamma_{r}$ & 27 & $\mathrm{kN} / \mathrm{m}^{3}$ \\
\hline unit weight of magma & $\gamma_{m}$ & 27 & $\mathrm{kN} / \mathrm{m}^{3}$ \\
\hline unit weight of water & $\gamma_{w}$ & 10 & $\mathrm{kN} / \mathrm{m}^{3}$ \\
\hline cohesion of soil/rock & $c$ & 0 & $\mathrm{kN} / \mathrm{m}^{2}$ \\
\hline friction angle of soil/rock & $\phi$ & 35 & degree \\
\hline apparent friction angle & $\phi_{a p p}$ & 20 and 35 & degree \\
\hline
\end{tabular}




\subsubsection{Continuum analysis}

In the continuum stability analysis, both $2 \mathrm{D}$ and 3D models have been studied. First, preliminary calculations have been carried out for a simple 2D model using FD. Then, during the FEM analysis 2D and 3D models representing the simplified preslide morphology of the La Orotava valley have been established.

The 2D model for the FD analysis has been defined by the geometry as shown in Figure 5.5a and has been divided into quadrangular elements generating a total of 1296 nodes. The model length is $25 \mathrm{~km}$ and the $L_{o n} / L_{o f f}$-ratio is 1.5 . The water table has been defined by a constant inclination of 10 degrees. In the FEM analysis, the upper boundary of the 2D model has been modified in order to analyse changes of slope inclination at the coast and near the eruptive cone (Figure 5.5b). The model has been dissected into 280 quadrangular 8-node elements considering plane-strain conditions. The total model length has been $25 \mathrm{~km}$ and no hydrogeological conditions have been incorporated.

a)

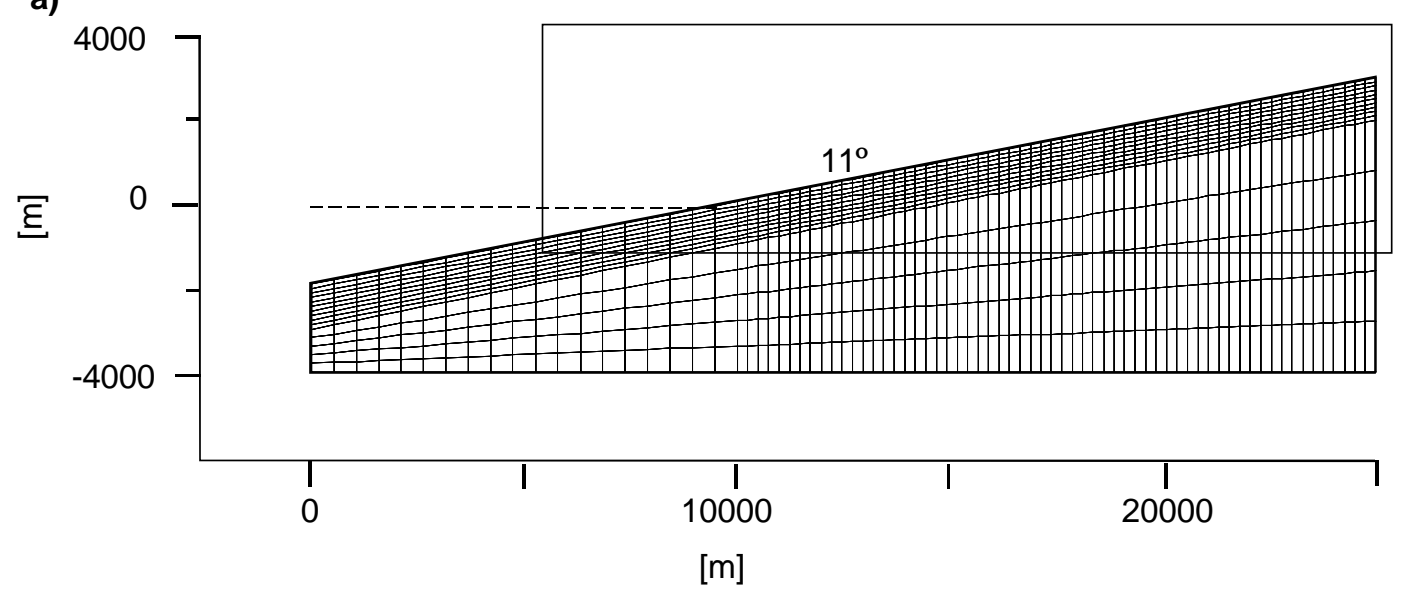

b)

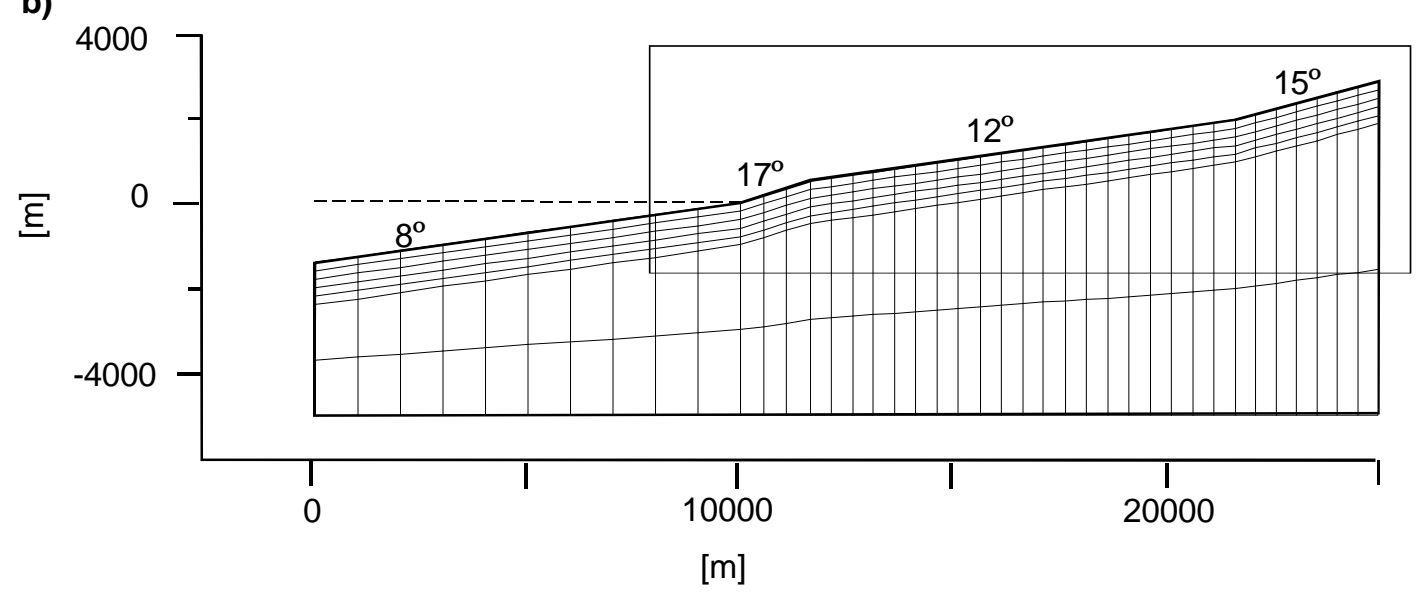

Figure 5.5: Meshes of the 2D models used in the FD (a) and FEM (b) analysis. Dashed lines indicate the sea level. Rectangular areas show the zone of the model presented in the results.

Slope stability is a typical 3D problem and some morphologic features can only be reproduced by a three dimensional modelling. Hence, in the FEM analysis a 3D model composed of 9840 8-node elements has been defined (Figure 5.6). This 3D model approximates the simplified preslide morphology of the La Orotava valley area including several significant morphologic features. A chain of volcanic 
edifices with heights up to $3500 \mathrm{~m}$ a.s.l. has been assumed to be situated at the rear of the model. Supplementary, three narrow canyons with depths of $200 \mathrm{~m}$ and widths of $100 \mathrm{~m}$ have been located at the contact of the volcano edifices starting at the top of the model and going down to the coast line. Major changes of slope inclination have been incorporated into the model at the base of the volcanic cone and at the coast.

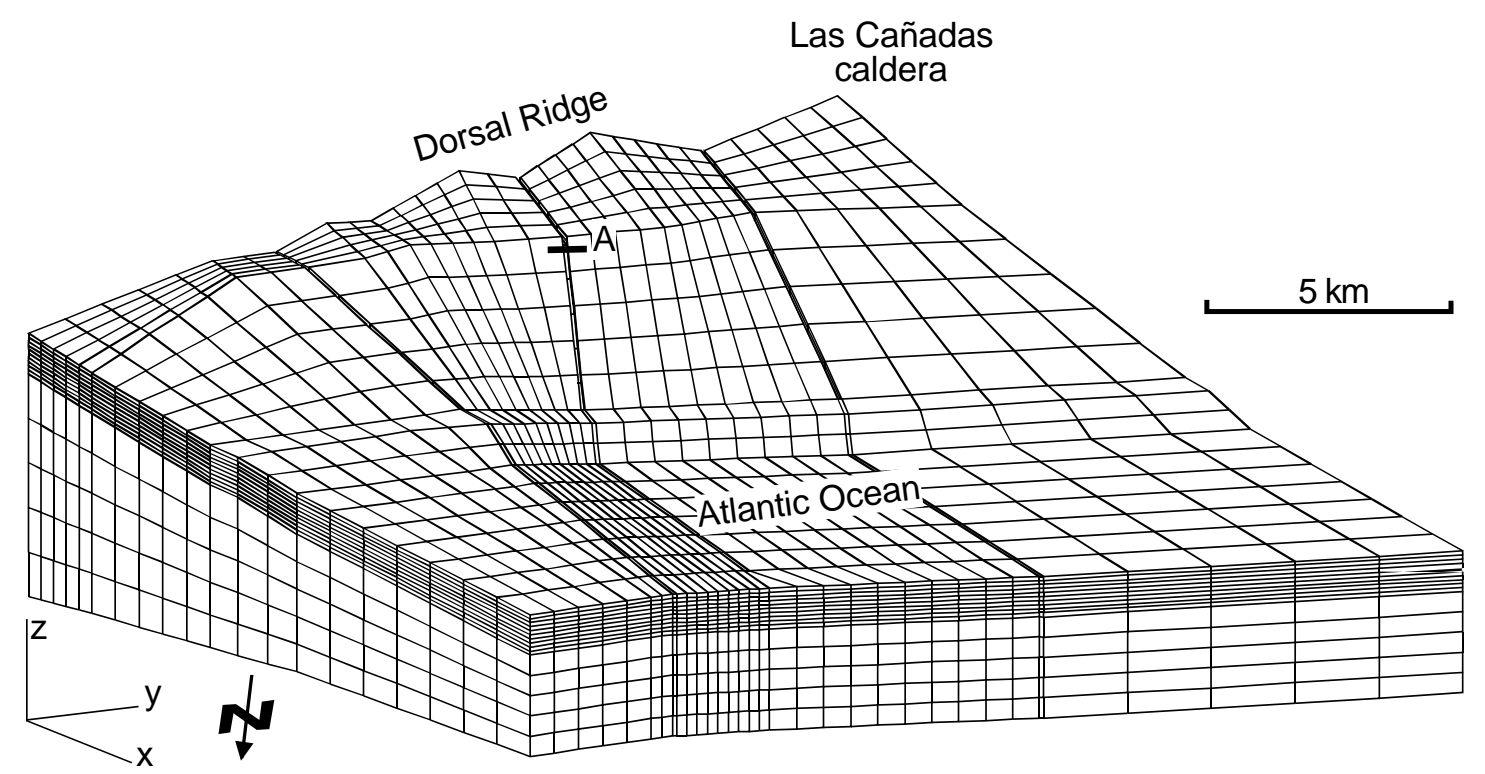

Figure 5.6: Mesh of the 3D FEM-model representing the simplified preslide morphology of the La Orotava valley area. 'A' shows the location of transverse section through a deep, narrow canyon

All the models during the qualitative analysis have been assumed to be homogeneous. Material properties for fractured lava are based on several studies at Krafla volcano, the Hawaiian Islands and the Mount St. Helens rock avalanche (Voight et al., 1983; Rubin and Pollard, 1987; Dieterich, 1988; Elsworth and Voight, 1992). The densities of the fractured lava and of the intruding magma have been given as $\rho_{l}=\rho_{m}=2700 \mathrm{~kg} \mathrm{~m}^{-3}$. During the calculation steps using linear elastic material properties, the Young's modulus has been defined as $E=7.5 \times 10^{3} \mathrm{MPa}$ and the Poisson's ratio as $v=0.25$. The strength parameters for the Mohr-Coulomb failure criterion during the last step of the FD calculations have been chosen as $c=0 \mathrm{kPa}$ and $\phi=35^{\circ}$.

Boundary conditions are difficult to define and can produce unrealistic yielding zones that are artefacts of the model. In this work, attention has been devoted to the potential landslide zones on the volcano flank to avoid such artefacts (rectangular areas in Figure 5.5).

The boundary conditions depend on the applied mechanism as well as on the dimension of the model. A summary of the applied boundary conditions is given for the FD analysis in Table 5.2 and for the FEM analysis in Table 5.3. During the equilibrium steps of all 2D analyses, the lateral boundaries (sea side and volcano side) have been restrained in horizontal direction $(\Delta x=0)$ and the base has been fully restrained in horizontal and vertical direction $(\Delta x=\Delta y=0)$. Then the two volcanic processes have been incorporated into the model. Applying a horizontal stress at the volcano side due to dike intrusion, the right hand side of the model has defined to be free, since $\sigma_{\mathrm{h}}$ includes a magmastatic and overpressure component $(\Delta \mathrm{x}=\Delta \mathrm{y}=$ free $)$. The base has been fully restrained in $\mathrm{x}$ - and $\mathrm{y}$-directions, while the left hand side has been restrained in $\mathrm{x}$-direction. Applying a vertical shear stress at the volcano side due to a caldera collapse, the boundary conditions at the lateral boundaries have been restrained in $\mathrm{x}$-direction, while the base has been fully restrained. 
During the 3D FEM stability analysis, the boundary conditions make use of the same concept only adding the third dimension. In the equilibration step the base has been fully restrained $(\Delta x=\Delta y=\Delta z=$ 0 ) and the four lateral sides have been restrained in the two horizontal directions $(\Delta x=\Delta y=0)$. In the second step applying a horizontal stress at the volcano side due to dike intrusion the lateral boundaries and the side of the dike have been restrained in the y-direction $(\Delta y=0)$ and the boundary opposite to the dike has been restrained in $\mathrm{x}$ - and $\mathrm{y}$-directions $(\Delta \mathrm{x}=\Delta \mathrm{y}=0)$.

The boundary conditions selected during the FEM calculations can produce unrealistic values in the model which should be checked precisely. Hence, a sensitivity analysis of the effects of the boundary conditions has been carried out at the beginning of the FEM computations and the results have revealed that the boundary conditions selected in the calculations are adequate and do not influence on the part of the model on which the stability analysis is focussing. 


\subsection{Results}

\subsubsection{Global limit analysis}

\section{Limit Equilibrium Method}

First, a sensitivity analysis has been carried out for an idealised, homogeneous volcano slope studying the influence of the slope inclination, the sea water level, the groundwater table and the material properties. The Factor of Safety (FS) has been computed assuming drained failure conditions and using both specified linear failure surfaces (Figure 5.4a) and arbitrary circular-shaped failure surfaces.

The influence of the slope angle on the stability of the volcano flank is shown in Figure 5.7a and shows that flanks with an inclination greater than about 25 degrees seem to be unstable. All the results have been calculated using the method looking for the most critical, circular-shaped failure surface. The model length has been defined as $25 \mathrm{~km}$ with the initial point of the failure surface located offshore and the final point located onshore. The inclination of the water table has been assumed to be one degree less than the slope angle and the standard material properties have been assumed as listed in Table 5.5. The FSs calculated coincide quite well with data obtained from the study of collapsed volcanoes over the whole world. The analysis of 55 Quaternary volcanoes affected by sector collapse indicate that slope failure appears most likely when the inclination of the volcano flank exceeds 20 degrees (Siebert, 1984). However, it does not explain the large landslides on volcanic islands such as Hawaii and Canary Islands that are characterised by low, preslide slope angles between 10 and 15 degrees (see Figure 2.4).

a)

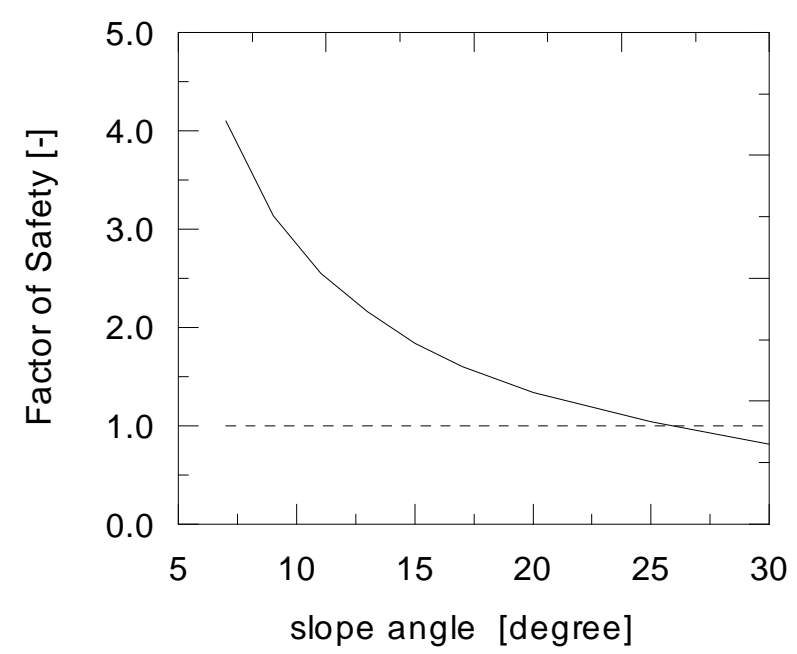

b)

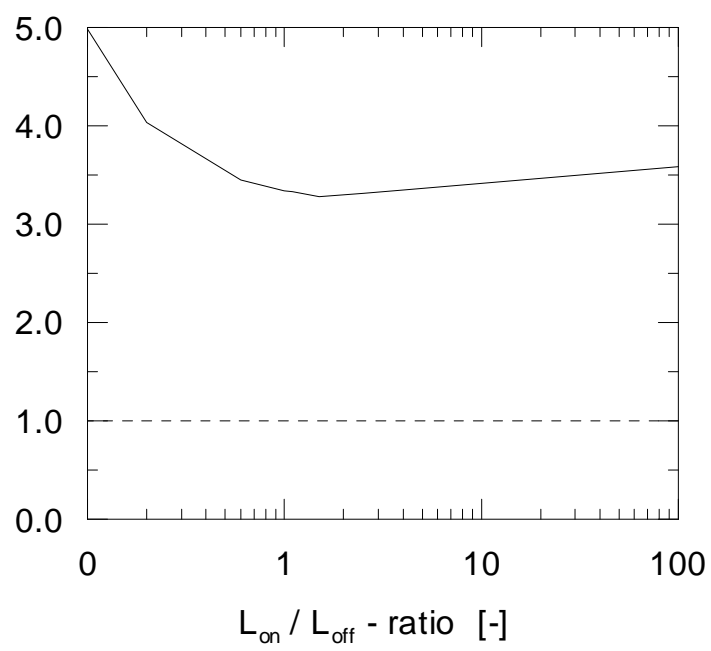

Figure 5.7: Influence of slope angle (a), and $L_{o n} / L_{o f f}$ - ratio (b) on the stability of volcano slopes using LEM. The model conditions are explained in the text.

Then, the effect of the sea water loading has been studied. The ratio between the onshore to the offshore length of the model has changed whereas the model geometry has been defined as $\theta=11^{\circ}, \beta=$ $10^{\circ}$ and $\alpha=9^{\circ}$. The results do not depend on the model length. The FS-values indicate that the most critical $L_{\text {on }} / L_{\text {off }}$ - ratio is about 1.5 (Figure $5.7 \mathrm{~b}$ ). For this condition, the difference between the destabilising uplift force due to the seawater and the stabilising sea water loading (weight of the water) 
reaches its maximum magnitude. Moreover, the graph of Figure $5.7 \mathrm{~b}$ shows that a totally submarine landslide ( $L_{\text {on }} / L_{\text {off }}$ - ratio near zero) seems to be quite unrealistic using model conditions as defined in these calculations. In general, sea level changes within a realistic magnitude do not significantly influence on the stability of volcano flanks, though a sinking of the sea level (a very small $L_{o n} / L_{o f f}-$ ratio moves to about 1.5) may contribute to the mechanical destabilisation of the slope. Additionally, large sea level changes may influence on the volcanic activity and hence indirectly on the slope stability (McGuire, 1996a; McGuire et al., 1997). These arguments are supported by the chronological data of the evolution of Tenerife Island. The relationship between sea level changes, strong volcanic activity such as caldera collapse episodes and large-scale landsliding has already been observed by Ablay and Hürlimann (1999) and can clearly be seen in Figure 3.3.

The influence of the material properties on the slope stability has been analysed changing the magnitudes of the cohesion and the angle of friction. These two parameters have been selected in a quite wide range with cohesion values between 0 and $500 \mathrm{kPa}$ and angle of friction values from 20 to 40 degrees. The calculations have been carried out using both circular and linear failure surfaces and the model's geometry has been defined by the standard geometric parameters listed in Table 5.4. The results indicate that both the friction angle and the cohesion strongly control the slope stability. However, while the friction angle of volcanic materials commonly range from 20 to 40 degrees, the cohesion is normally assumed to be zero (Voight et al., 1983; Rubin and Pollard, 1987; Dieterich, 1988; Elsworth and Voight, 1992). Therefore, Figure 5.8a only shows the effect of the friction angle calculated by the two types of failure surfaces. The minimum FS-values computed for the two different failure surfaces have been obtained for a friction angle of 20 degrees and zero cohesion. The distinct safety conditions comparing the two methods can be explained by the length of the failure surfaces which is longer for the specified one and hence cause more frictional strength.

Typical circular failure surfaces are illustrated in Figure 5.9 including the ten most critical slip surfaces for the standard model parameters and an angle of friction of 35 degrees. The head scarp of the most critical failure with a FS-value of about 2.5 initiates at an altitude of about $2200 \mathrm{~m}$ a.s.l. in the upper part of the volcano slope and the toe of failure is located at about $200 \mathrm{~m}$ b.s.l in the submarine part of the flank. The maximum depth of the landslide exceeds $1000 \mathrm{~m}$ and is situated near the shoreline in the onshore part of the slope.

a)

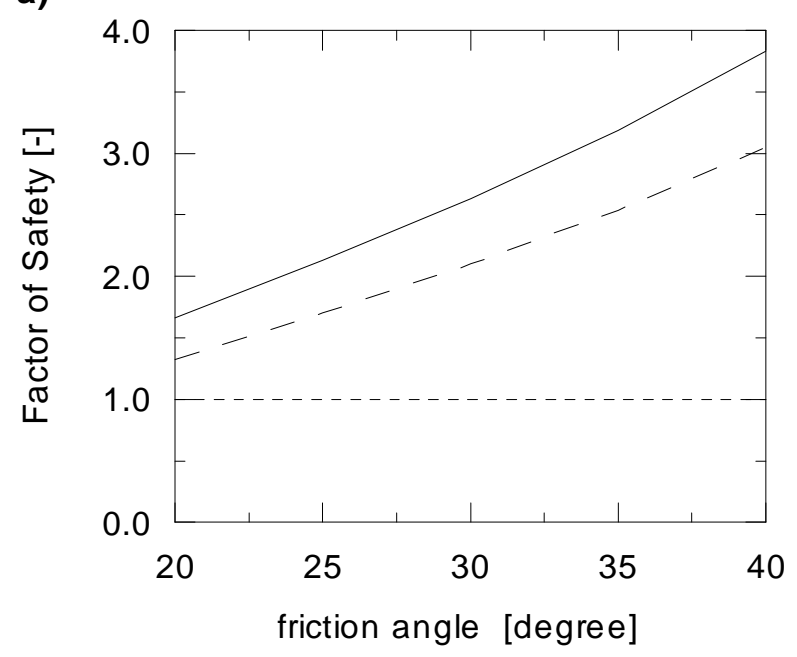

b)

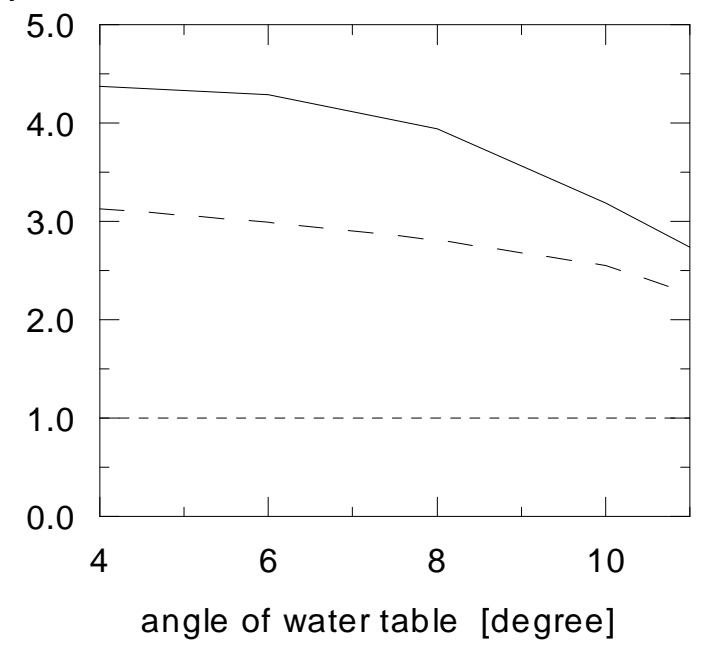

Figure 5.8: Influence of material property (a) and level of water table (b) on the stability of a common volcano slope using circular (dashed line) and specified failure surfaces (straight line) of the LEM. 
On the other hand, the influence of the hydrogeological conditions has been studied changing the inclination of the water table. Figure 5.8b illustrates the FS-values versus different angles of the water table for the two different types of failure surfaces. An extreme situation with a totally saturated volcano slope (inclination of water table is equal to 11 degrees) still has a FS-value exceeding 2.0 refering to the circular failure surface and exceeding 2.5 refering to the specified failure surface. All the results have been computed using the standard material parameters as listed in Table 5.5. However, these calculations refer always to completely drained conditions and static pore water pressures. Excess pore water pressures that often play an important role in the initiation of slope failure have not been incorporated.

The results of the sensitivity analysis have shown that the stability of volcano flanks is related to slope angles, material properties and hydrological conditions, but these factors are not able to destabilise volcano slopes and cause large landslides. The FS calculated for a fully saturated, homogeneous volcano flank with no cohesion and an angle of friction of $20^{\circ}$ is still higher than 1.5 for the linear specified failure surface and 1.2 for circular failures.

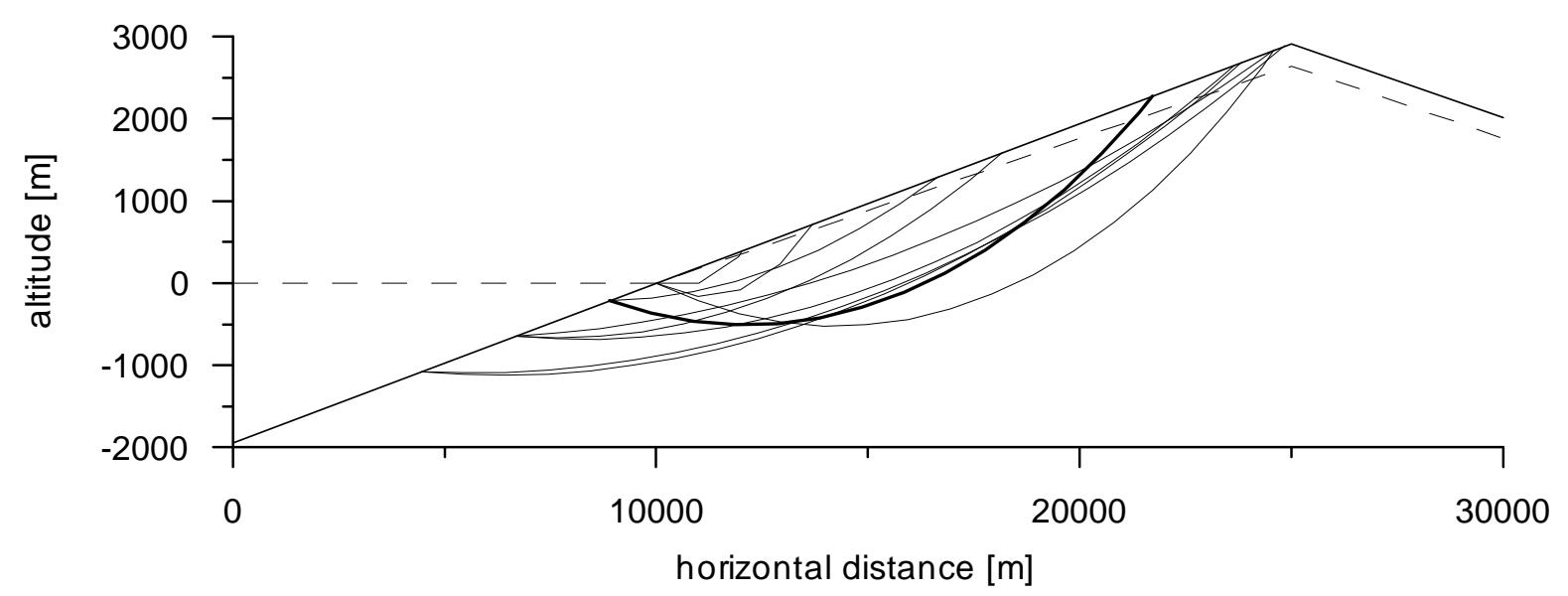

Figure 5.9: Typical circular failure surfaces for a simplified volcano slope using LEM. Thick line indicates the most critical slip surface. Vertical exaggeration: 2x. 
The preliminary results of the sensitivity analysis indicate that additional processes are necessary to initiate large-scale failure of volcano slopes. Hence, external mechanisms such as ground acceleration due to seismic shocks and horizontal stress due to dike intrusion have been incorporated into the model.

First, seismic shocks have been analysed using a pseudostatic approach. The FS-values are plotted versus the horizontal acceleration for three different water tables in Figure 5.10. The model conditions have been defined by the standard model parameters with changing groundwater tables and the FS has been calculated for the specified failure surface. The results indicate the significant influence of seismic shocks on the slope stability. The FS decreases sharply with increasing average ground acceleration whereas the angle of the water table plays a minor role. The metastable limit $(\mathrm{FS}=1.0)$ for a reasonable inclination of the water table of $10^{\circ}$ is located at about $0.3 \mathrm{~g}$. Such a high seismic acceleration uniformly distributed at the same time in the whole volcano flank (pseudostatic conditions) is rather unrealistic. Due to the important scale effect refering to the involved sliding mass, a ground acceleration of this magnitude can only be generated by a strong earthquake $(M>5)$ with an adjacent epicentre (see Figure 2.5).

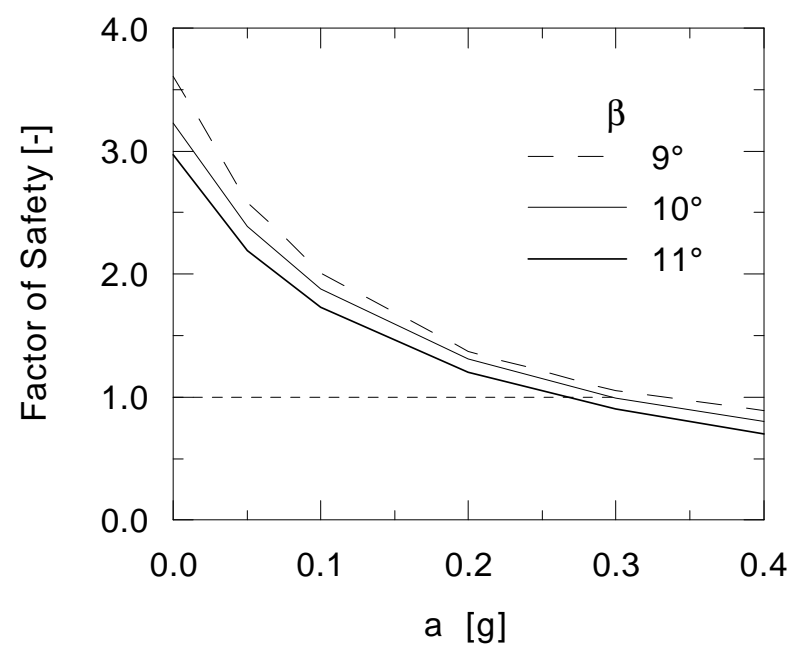

Figure 5.10: Influence of horizontal seismic acceleration, $a$, and, inclination of the water table, $\beta$, on the stability of a simplified volcano slope using linear specified failure surfaces and LEM.

Then, a horizontal stress due to dike intrusion has been applied at the rear of the model in order to analyse its influence on the stability of volcano flanks. The most important parameter studying this mechanism is the magma overpressure, $P_{m o}$. The FS-values presented in Figure 5.11a have been calculated for different $P_{m o}$-values using the specified failure surface. The model has been defined by the standard model parameters and different groundwater tables. The results show that the slope stability decreases insignificantly for a constant model length applying magma overpressures up to $10 \mathrm{MPa}$. The volcano flank maintains very stable even assuming a totally saturated slope and a $\mathrm{P}_{\mathrm{mo}}$-value of $10 \mathrm{MPa}$ (FS = 1.94). On the other hand, Figure 5.11b plots the FS-values versus the model length for four different magma overpressures focussing on the influence of the failure length. The model conditions have been selected as for the previous calculations except the $L$-value, which is free, and the $\beta$-value which is equal to $10^{\circ}$. The graph shows the strong influence of the model length on the slope stability. A maximum $P_{m o}$-value of $10 \mathrm{MPa}$ produces unstable conditions for a model length of about $3 \mathrm{~km}$ and a common $P_{m o}$-value of $5 \mathrm{MPa}$ for a model length of about $2 \mathrm{~km}$. The results obtained coincide with the calculations carried out for the large landslides on the Hawaiian Islands indicating that the slope stability mainly depends on the length of the failure, whereas the magma overpressures plays a minor role (Iverson, 1995). 
An explanation of the minor influence of the magma overpressure in contrast to the strong effect of the model length can be found in the definitions of the forces acting on the sliding mass. Generally, the weight of the sliding mass resisting to failure increases much faster for greater model lengths than the destabilising horizontal stress due to dike intrusion with a constant $P_{m o}$-value. This demonstrates the insignificant influence of magma overpressures studying a large model (Figure 5.11a) and why the influence of dike intrusion strongly increases for smaller model lengths (Figure 5.11b).

a)

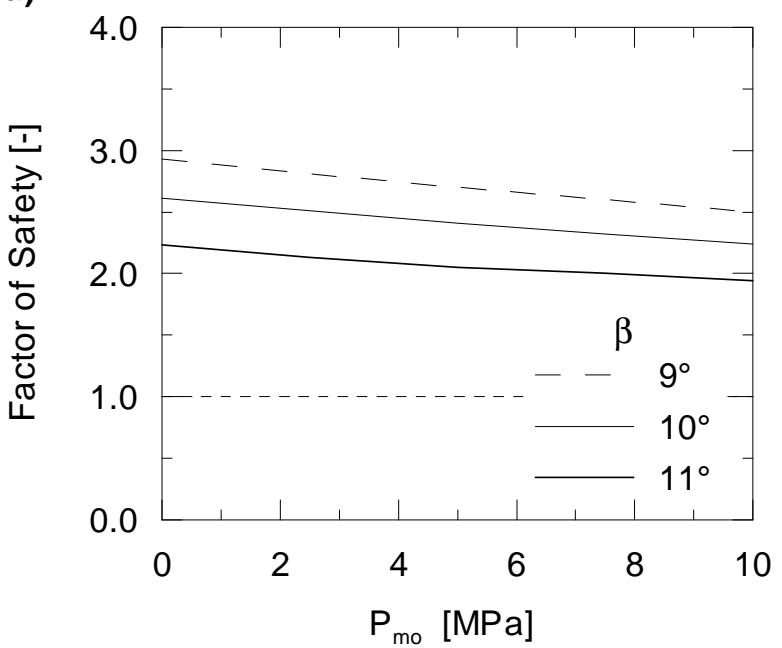

b)

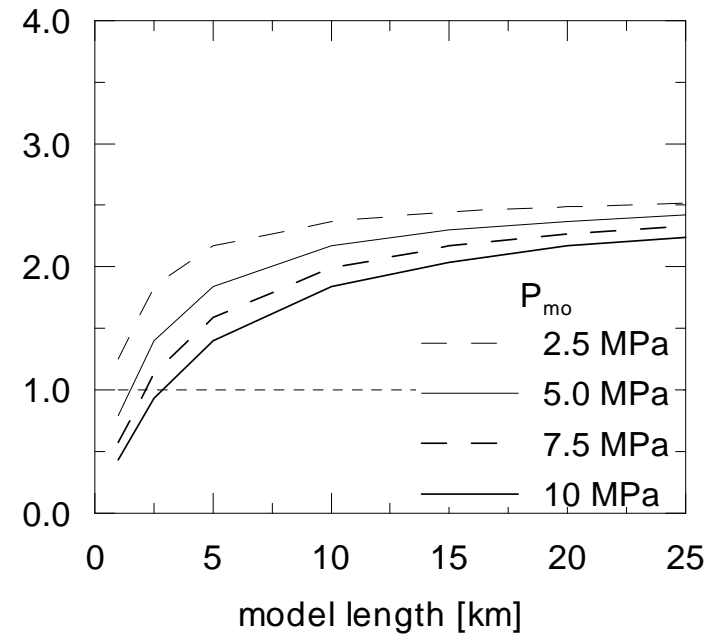

Figure 5.11: Influence of magma overpressure, $P_{m o}$, owning to dike intrusion on the stability of volcano slopes using LEM. a) $P_{m o}$ vs. FS for constant model length of $25 \mathrm{~km}$ and changing water table. b) Model length vs. FS for changing $P_{m o}$.

In addition, some calculations have been carried out incorporating the mechanically and thermally induced pore fluid pressures into the 2D model as proposed by Elsworth and Voight (1995) and Voight and Elsworth (1997). The computations indicate that the results strongly depend on the mechanical and thermal properties selected. However, exact data on these properties are scarce and not well constrained. A sensitivity analysis carried out for the involved parameters indicate that especially the magnitude of the permeability is fundamental and can significantly decrease or increase the Factor of Stability. In volcanic terrains, the permeability may vary more than six orders of magnitude, from values at times in excess of $10^{-2} \mathrm{~m} \cdot \mathrm{s}^{-1}$ in recent scoria, to values well below $10^{-8} \mathrm{~m} \cdot \mathrm{s}^{-1}$ in altered pyroclastic accumulations, massive zones of lava and ignimbrites etc. (Davis, 1969; Custodio, 1989). Therefore, a comprehensive and quantitative stability analysis is quite unrealistic due to the wide range of parameters' magnitudes and the results being very sensitive to some of them.

Finally, no quantitative results will be presented and only some overall comments refering to the destabilising influence of these two pore fluid pressures will be done. The analysis of each pressure shows that the destabilising influence of the mechanically induced pore fluid pressure is much stronger than the one caused by the thermally induced pore pressure (Gründel, 1999). The mechanically induced pore pressure strongly depends on the permeability assumed for the material composing the volcano flank and on the assumed dike width. A small increase of the permeability value - in some case much less than one magnitude - may change a slope characterised by high stability conditions into a slope with a FS well below the metastable limit. On the other hand, the discrepancy between realistic dike widths and the values finally incorporated into the model has already mentioned in the previous Section 5.2.2 and also in the paper by Elsworth and Voight (1995) indicating the limits and difficulties of these calculations. The thermally induced pore pressure is time-dependent and generally affects the slope during a period following the dike intrusion. This period may last weeks or months and hence the results of the stability calculations depend on the value selected for the time period. The FS-value, however, does not significantly reduce even for an unrealistic long period of 10 years (Gründel, 1999). 
In the next step, the geometry of the model has been adapted to the preslide conditions of the La Orotava valley and both ground acceleration due to seismic shocks and horizontal stress due to dike intrusion have been incorporated into the new model. The morphological and hydrological conditions of the model are shown in Figure 5.4b and the standard material parameters have been assumed. First, the influence of the horizontal acceleration caused by seismic shocks has been analysed. The FS-values obtained confirm the significant effect of this agent (Figure 5.12a). The stability of the slope reduces sharply for increasing acceleration and reaches the metastable limit for an average ground acceleration of about $0.26 \mathrm{~g}$. Then, dike intrusion has been applied to the model and the results of these calculations indicate the minor influence of this volcanic process on the slope stability (Figure 5.12b). The FS decreases slightly in a linear mode with increasing magma overpressures, but does not generate unstable conditions applying realistic $P_{m o}$-values up to $10 \mathrm{MPa}$. The volcano slope would not even fail for an exaggerated and unrealistic $P_{m o}$-value of $20 \mathrm{MPa}$. This coincides with the previous results (Figure 5.11) since the length of the La Orotava slide is assumed to have a large value of about $12 \mathrm{~km}$.
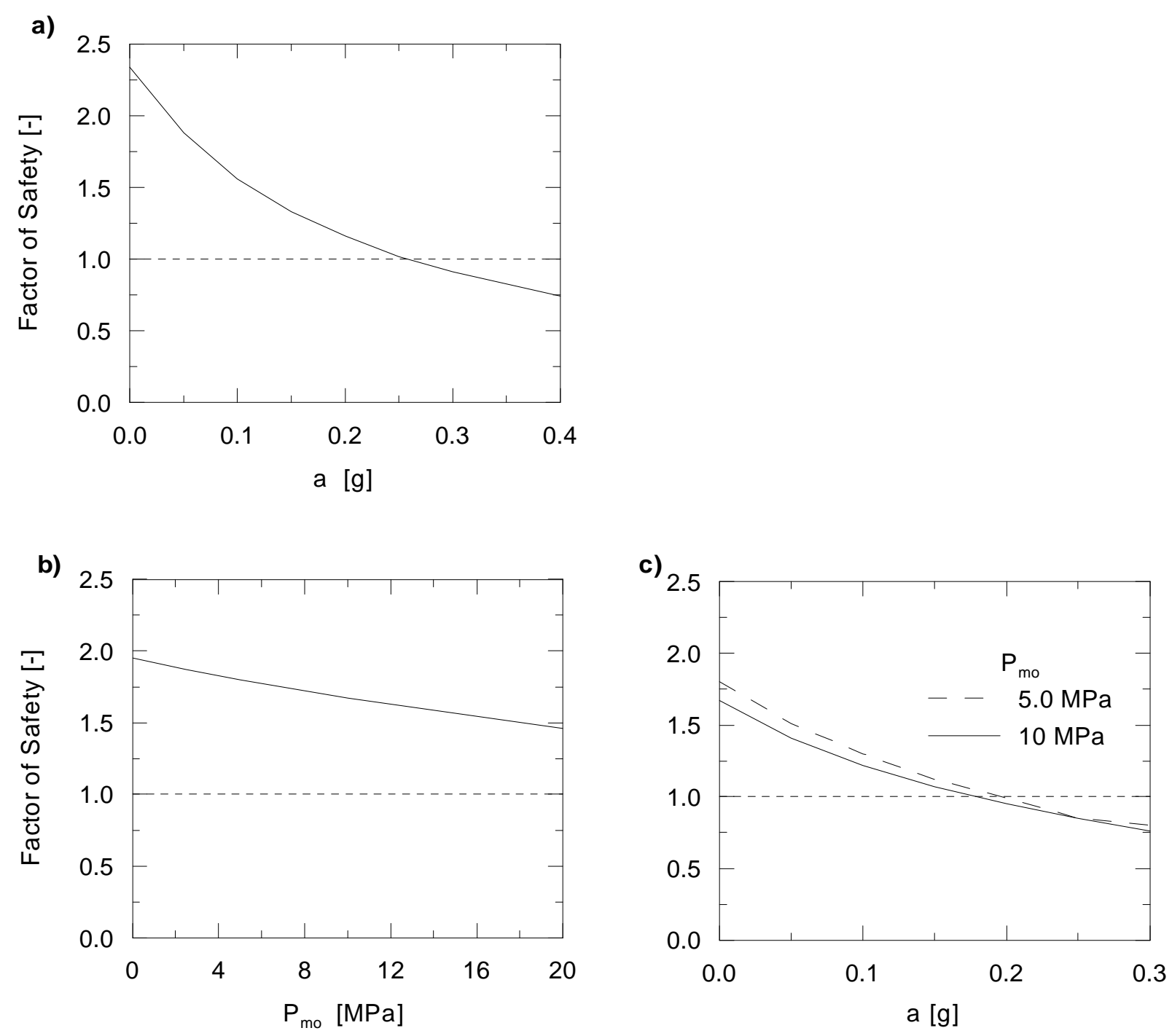

Figure 5.12: Stability analysis for the La Orotava valley using LEM. a) Horizontal acceleration, $a$, due to seismic shocks. b) Magma overpressure, $P_{m o}$, owning to dike intrusion. c) A combination of both processes with numbers indicating the applied magma overpressure. 
Sometimes the forceful movement of magma along rift zones may produce volcano-tectonic earthquakes such as at the Hilina fault system in Hawaii (e.g. Elsworth and Voight, 1995). Thus the horizontal stress due to dike intrusion and the seismic shocks have been coupled and have been simultaneously incorporated into the model. The results of these calculations are illustrated in Figure 5.11c and verify the major influence of horizontal acceleration in contrast to the minor effect of magma overpressure. The FSs applying different combinations of these two processes indicate that a seismic ground acceleration of about $0.18 \mathrm{~g}$ already enables the failure of the volcano flank assuming a value of magma overpressure of $10 \mathrm{MPa}$ due to dike intrusion.

Additionally, the La Orotava model has been studied using circular slip surfaces. The ten most critical failure surfaces have been calculated for the preslide volcano slope characterised by the standard material properties and no external mechanism (Figure 5.13). The toe of the landslide has been defined to be located offshore and the head scarp at an altitude higher than $1500 \mathrm{~m}$. The most critical slip surface with a Factor of Safety of 2.28 terminates just behind the submarine coastal platform within the submarine steep slope and starts close to the top of the volcanic edifice. If the parameters $\phi_{a p p}=20^{\circ}$ and $\mathrm{c}=0$ are used, the same critical slip surface has been found, but the Factor of Safety reduces to FS = 1.19. A toe of the slope failure in this area is supported by the results obtained from a comprehensive morphologic analysis of the bathymetric and topographic data of the northern flank of Tenerife (Ablay and Hürlimann, 1999). They proposed that the large landslide events of the La Orotava valley have intersected the surface of the flank at the base of the present onshore steep zone. Moreover, the LEM calculation has shown that the maximum thickness of the sliding mass is about $1000 \mathrm{~m}$ which coincides quite well with the morphologic and subsurface geologic data of the La Orotava valley (see Chapter 3). However, there are two important facts that must be kept in mind interpreting the results of Figure 5.13. First, the model has been selected as homogeneous without the existence of weak layers that may influence the failure surfaces. Second, no external mechanism has been applied to the model. Especially, the horizontal stress caused by dike intrusion affect the stress field of the volcano flank and therefore the slip surfaces. Third, only circular shaped failure surfaces have been calculated.

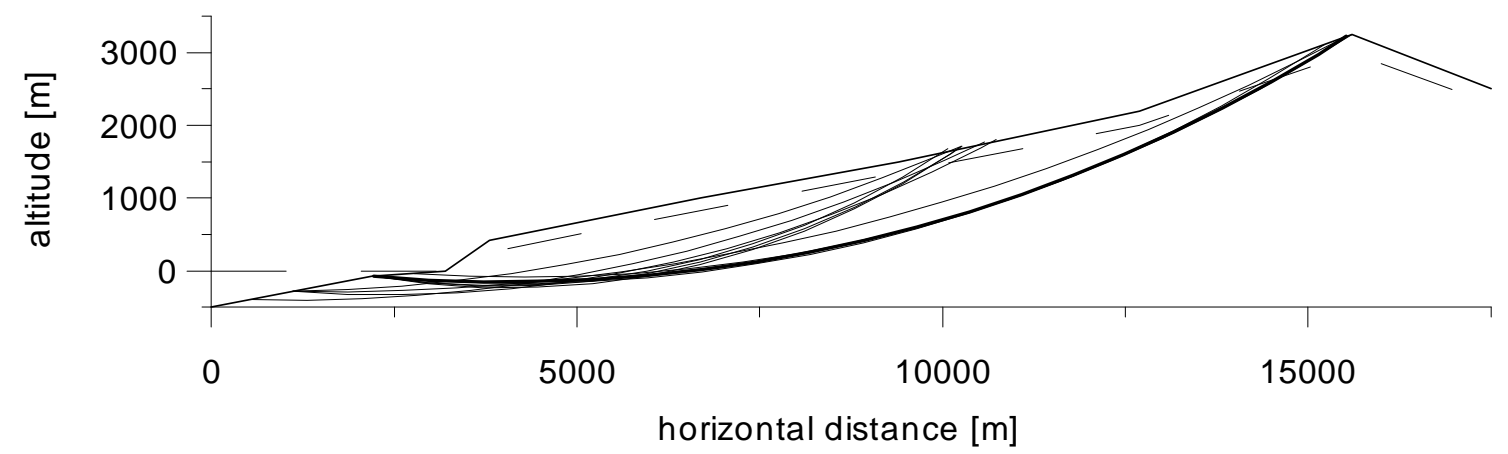

Figure 5.13: Typical circular failure surfaces for the simplified preslide La Orotava model using LEM. Thick line indicates the most critical slip surface. No vertical exaggeration. 


\section{Upper Bound Method}

The second approach applied during the global limit analysis has been the Upper Bound Method (UBM). In contrast to the drained LEM calculations, the UBM has applied the undrained failure criterion. Moreover, the UBM allows the possibility to incorporate shear stresses at the boundaries of the model, which has not been possible with the LEM-program PCSTABL. Therefore, each of the three external mechanisms, ground acceleration due to seismic shocks, horizontal stress due to dike intrusion and vertical shear stress due to caldera collapse, have been analysed.

Two different undrained shear strengths of the material composing the homogeneous volcano flank have been studied. The undrained strength, $c_{u}$, has been estimated using Equation 5.18 and two different apparent friction angles. A low one representing a weak material with an apparent friction angle of about 20 degrees (e.g. the residual soil investigated in this work) and a high one characterising a sound material with an apparent friction angle, $\phi_{a p p}$, of about 35 degrees.

The influence of seismic shocks on the slope stability has been studied using the standard model parameters. Figure 5.14 shows the UBM ratio versus average horizontal ground acceleration for the two different material strengths. The graph matches quite well with the results obtained from the LEM (Figure 5.10) and indicates the significant influence of this agent on the slope stability. The metastable limit is reached at an acceleration of about $0.1 \mathrm{~g}$ refering to the weak slope material and at about $0.3 \mathrm{~g}$ for the strong slope material. The results may theoretically be applied to any scale of slope failure, because the UBM ratios depend for the same material only on the magnitude of the average ground acceleration and not at all on the model length. However, as mentioned in the previous Section refering to the LEM results, it is rather unrealistic that a seismic shock actuates at the same time with the same high acceleration on a failing mass characterised by a large volume.

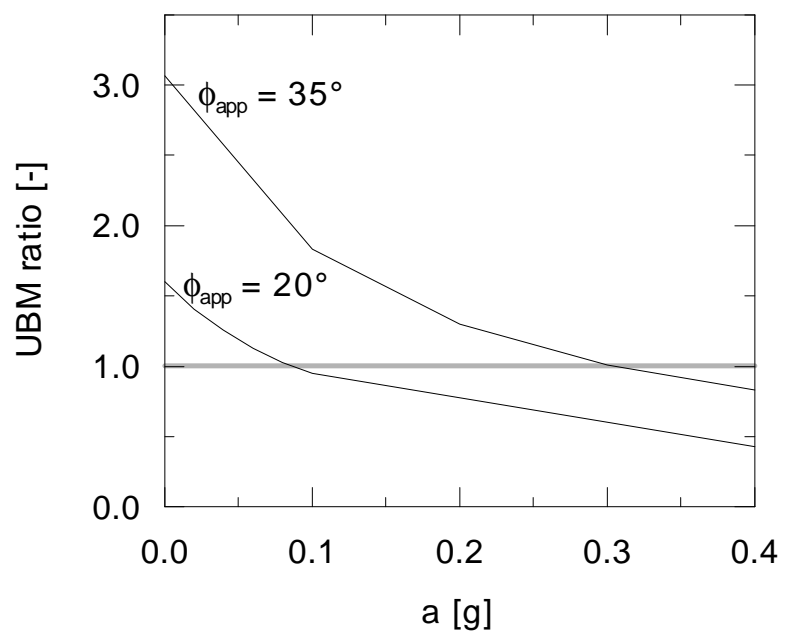

Figure 5.14: Influence of average ground acceleration, $a$, on the stability of a common volcano slope using UBM. Results are given for two different apparent friction angles, $\phi_{a p p}$. 
The destabilising influence of a horizontal stress due to dike intrusion has also been analysed. This horizontal stress has been applied at the rear of the model including a magma overpressure and a magmastatic stress. Magma overpressures ranging up to $10 \mathrm{MPa}$ have been incorporated into the models each of them characterising a volcano flank of different length. The results are shown in Figure 5.15 and indicate the same substantial feature as obtained from the LEM analysis (Figure 5.11). The value of the model length strongly influences on the slope stability. Figure 5.15a and b contain the same results but are plotted with different x-axes. In Figure 5.15a, the $\mathrm{x}$-axis is the magma overpressure and the plots are given for different model lengths and material strengths. The UBM ratios denote that the stability of the volcano slope reduces slightly for a large model length such as $25 \mathrm{~km}$ and stronger for a small length of $5 \mathrm{~km}$. In Figure 5.15b, the x-axis is defined as the model length and the plots are given for different $P_{m o}$-values and material strengths. The results in this figure show that the UBM ratios decrease exponentially for smaller model lengths with a much stronger destabilising effect for the sound material. This clear influence of the material strength is visible in both graphs. The destabilising effect of the dike intrusion is clearly stronger for the higher material strength. However, the UBM ratios concerning to this material do not reach in any calculation the critical value of 1.0 for the model conditions analysed. Only the weak material strength enables slope failure. Critical conditions refering to this weak material are for example a failure length of $5 \mathrm{~km}$ and a magma overpressure of about 3.5 $\mathrm{MPa}$ or a length of about $12 \mathrm{~km}$ and a $P_{m o^{-}}$value of $7.5 \mathrm{MPa}$.

a)

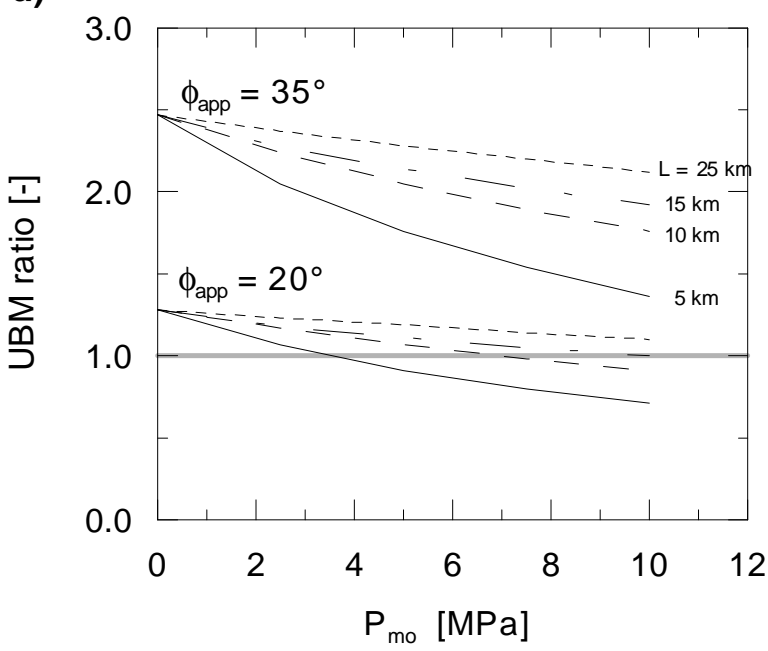

b)

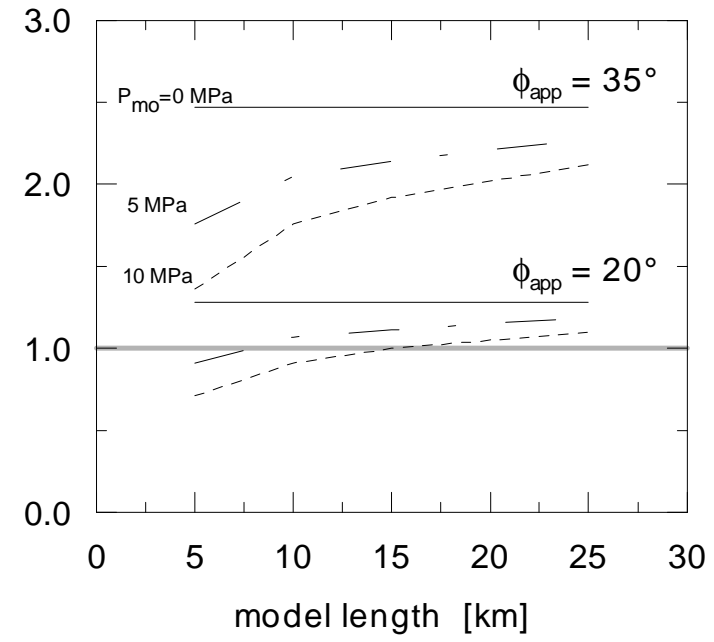

Figure 5.15: Influence of horizontal stress owning to dike intrusion on the stability of volcano slopes using UBM. a) UBM ratio versus magma overpressure, $P_{m o}$, for different model lengths, $L$, and apparent friction angles, $\phi_{a p p}$. b) UBM ratio versus model length for different $P_{m o^{-}}$and $\phi_{a p p^{-}}$values. 
Finally, the destabilising influence of a vertical shear stress due to caldera collapse has been studied. A vertical shear stress, $\tau_{\mathrm{v}}$, has been incorporated at the rear of the model that has been characterised by different material strengths and lengths. The results are illustrated in Figure 5.16 using two distinct ways to plot the graphs: One with the vertical shear stress as the x-axis (Figure 5.16a) and the other with the model length as the $\mathrm{x}$-axis (Figure 5.16b). In general, the shapes of the plots are quite similar to the ones obtained applying a horizontal stress due to dike intrusion (Figure 5.15). However, in contrast to the dike intrusion the destabilising effect of the vertical shear stress due to caldera collapse is not able to produce failure of a volcano slope using the model conditions defined in these calculations. Even a small failure $(L=5 \mathrm{~km})$ and a weak material $\left(\phi_{a p p}=20^{\circ}\right)$ does not reach the unstable state applying a vertical shear stress of $30 \mathrm{MPa}$. The UBM ratio for such conditions has been calculated as 1.08. Hence, it can be concluded that only a vertical shear stress due to a caldera collapse event is unlikely to cause failure of volcano flanks even for weak material strengths. However, it must be said that the important destabilising effects of the seismicity associated with the caldera collapse have not been taken into account in this step. Here, only the influence of the vertical shear stress has been analysed.
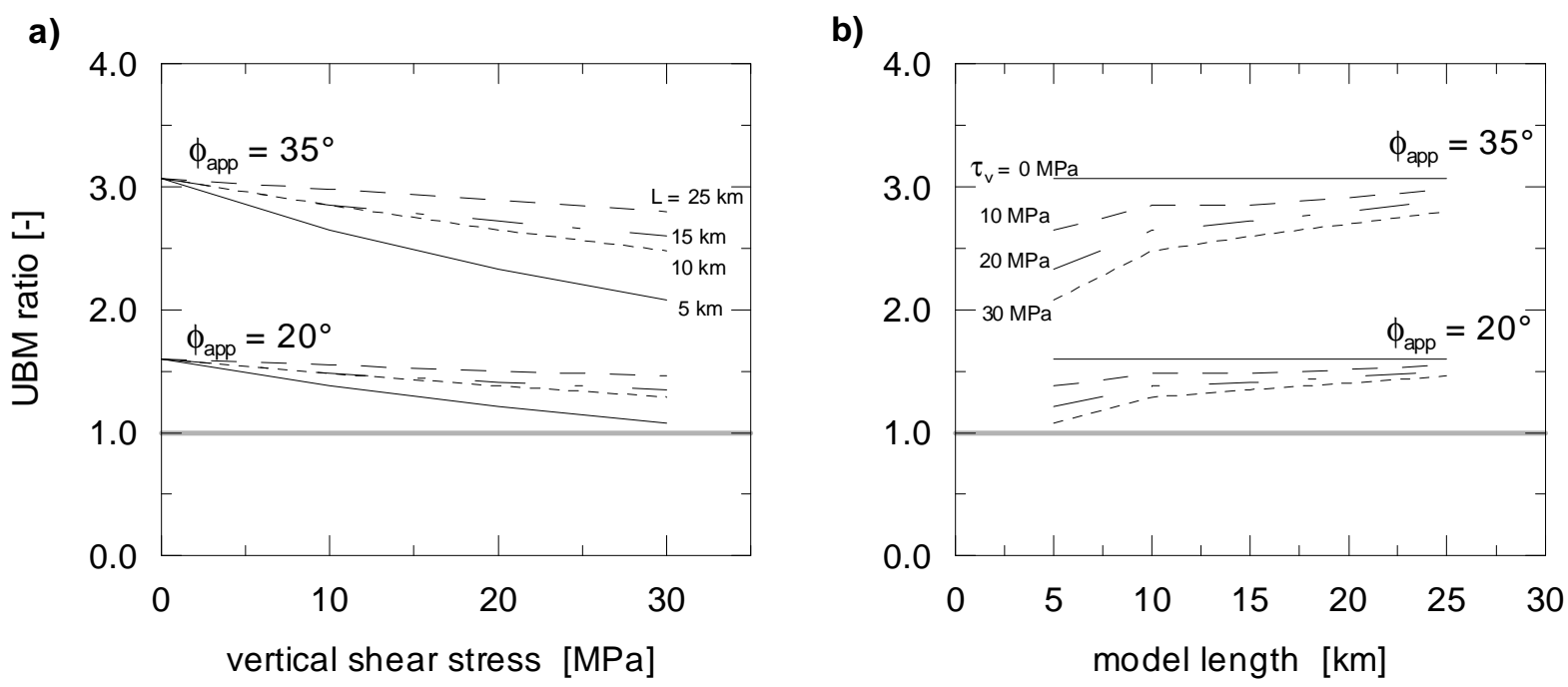

Figure 5.16: Influence of vertical shear stress due to caldera collapse on the stability of volcano flanks using UBM. a) UBM ratio versus vertical shear stress, $\tau_{v}$, for different model lengths, $L$, and apparent friction angles, $\phi_{a p p}$. b) UBM ratio versus model length for different $\tau_{v}-$ and $\phi_{a p p}$-values. 
In addition, the destabilising influence of each of the three external mechanisms has been compared. The destabilising parameters ground acceleration, a, magma overpressure, $P_{m o}$, and vertical shear stress, $\tau$, have been normalised dividing them by the maximum values of each parameter assumed to be realistic. These maximum values have been defined as $a=0.3 \mathrm{~g}, P_{m o}=10 \mathrm{MPa}$ and $\tau_{v}=30 \mathrm{MPa}$ using the available data on each parameter (see Section 5.2). In this way, all of the three mechanisms depend on a normalised destabilising dimensionless parameter and the results can easily be compared. The calculations have been carried out for a model length of $10 \mathrm{~km}$ and two different material strengths. Figure 5.17 illustrates the UBM ratios calculated for each of the three mechanisms versus the normalised destabilising parameter and shows several interesting features. First, the average ground acceleration due to seismic shocks is clearly the most destabilising process, whereas the influence of the vertical shear stress due to caldera collapse and the magma overpressure due to dike intrusion is smaller. A lower UBM ratio for the dike intrusion with a $P_{m o}$-value of $0 \mathrm{MPa}$ in comparison to the two other mechanisms is caused by the fact that the horizontal stress applied to the model includes the magma overpressure and the magmastatic component (Equation 5.1). Whereas the $P_{m o}$-value is zero, the $P_{m s}$-value already affects on the slope due to the stress caused by the weight of the magma column. Moreover, Figure 5.17 verifies the results obtained from previous calculations indicating that the material strength plays an important role. Finally, we can see that only the ground acceleration due to seismic shocks and the horizontal stress due to dike intrusion enable a slope failure applying realistic values (the normalised destabilising parameter equal or less than 1.0). Average seismic accelerations of realistic magnitudes reach the critical stability conditions for both material strength and horizontal stresses due to dike intrusion only for slopes composed of the weak material.

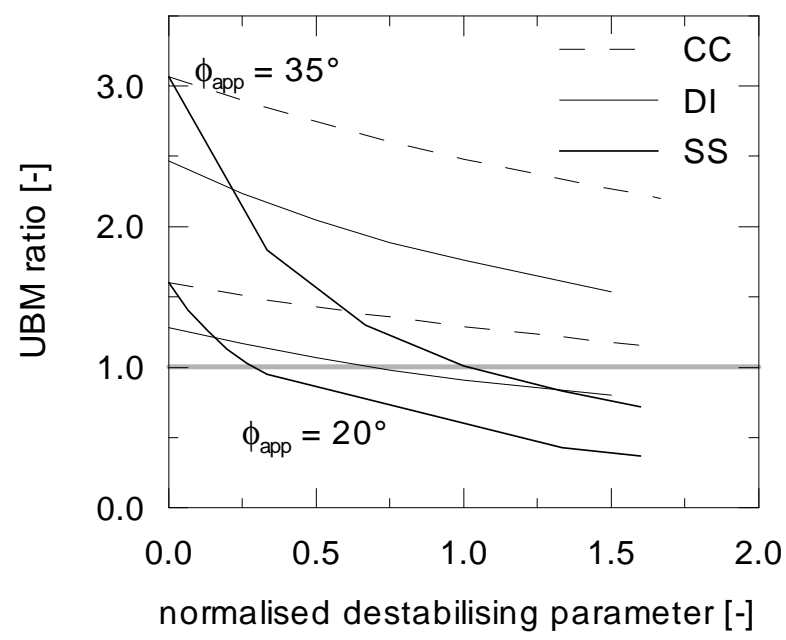

Figure 5.17: Comparison of the destabilising influence of the three mechanisms analysed using UBM: ground acceleration due to seismic shocks (SS), horizontal stress due to dike intrusion (DI) and vertical shear stress due to caldera collapse (CC). 
Two combinations of the destabilising mechanisms have also been analysed. The model conditions have been selected with a model length of $10 \mathrm{~km}$. First, the horizontal stress due to dike intrusion and the ground motion due to seismic shocks have been combined and simultaneously incorporated into the model (Figure 5.18a). The results indicate that a combination of these two mechanisms enables a slope failure applying realistic magnitudes of ground accelerations and magma overpressures. A volcano flank composed of the weak material $\left(\phi_{a p p}=20^{\circ}\right)$ already fails applying for example a magma overpressure of $5 \mathrm{MPa}$ and a average ground acceleration of $0.02 \mathrm{~g}$. On the other side, a volcano slope composed of the sound material fails during a seismic shock characterised by an average acceleration of $0.2 \mathrm{~g}$ applying a magma overpressure of $10 \mathrm{MPa}$ and an acceleration of $0.23 \mathrm{~g}$ applying a $P_{m o}$-value of 5MPa.

Second, the vertical shear stress caused by a caldera collapse has been coupled with seismic acceleration (Figure 5.18b). In this combination seismic accelerations with higher magnitudes are necessary to trigger slope failure. A volcano flank composed of the weak material fails at an average ground acceleration of about 0.05 and $0.07 \mathrm{~g}$ applying $\tau_{v}$-values of 30 and $15 \mathrm{MPa}$, respectively. A volcano slope composed of sound material fails at an acceleration of about $0.28 \mathrm{~g}$ almost independent of the vertical shear stress applied. Hence, as seen in Figure 5.17 the results obtained show that the horizontal stress due to dike intrusion is more effective than the vertical shear stress due to caldera collapse.

However, in the case of Tenerife, the seismic acceleration generated by a caldera collapse may strongly exceed that generated during dike intrusion (see Chapter 2). The first one has a volcanotectonic origin and magnitudes of up to 7.0, while the second one is of volcanic origin and maximum magnitudes of about 5.0 (Okada, 1983; Abe, 1992). Consequently, the initiation of the slope failure is more likely to happen during a caldera collapse episode with strong ground motion than during dike intrusion with associated moderate seismicity.

a)

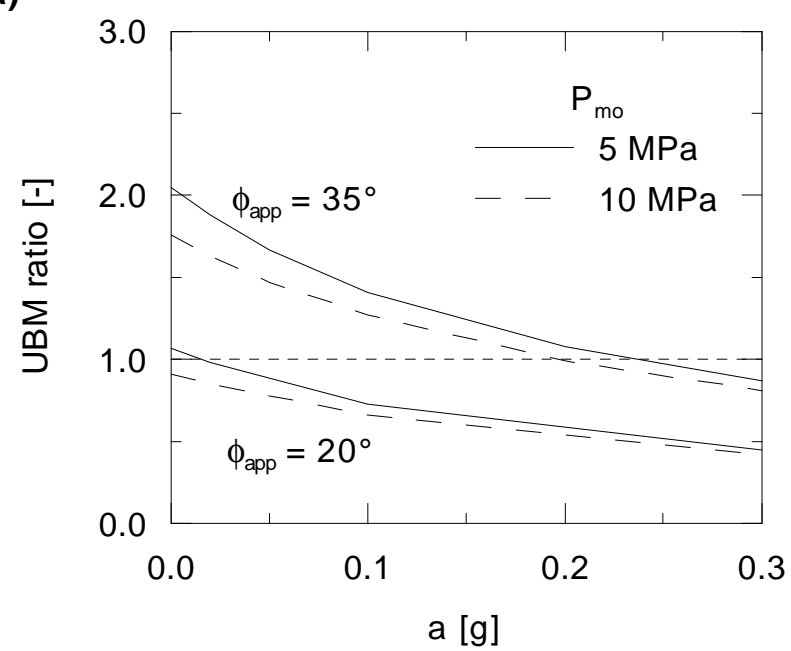

b)

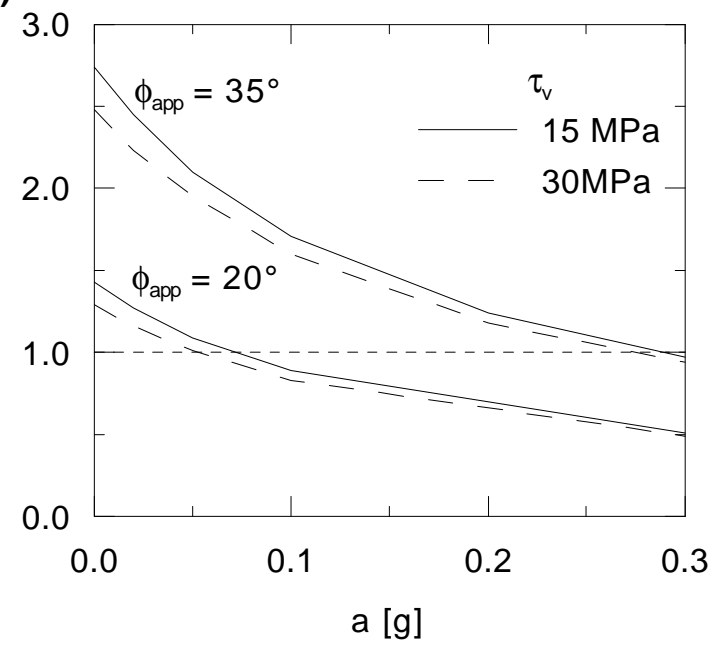

Figure 5.18: Destabilising influence of combinations of external mechanisms using UBM. a) Horizontal stress due to dike intrusion and seismic acceleration. b) Vertical shear stress due to caldera collapse and seismic acceleration. 


\subsubsection{Continuum analysis}

\section{Finite Difference Method}

The two mechanisms, horizontal stress due to dike intrusion and vertical shear stress due to caldera collapse, have been analysed using simple 2D models. First, the distribution of the shear stresses $\left(\sigma_{\mathrm{xy}}\right)$ inside the model has been computed for each mechanism. Figure 5.19a illustrates the shear stress distribution in the whole model after applying a horizontal stress due to dike intrusion with a magma overpressure of $10 \mathrm{MPa}$ at the rear of the model and Figure 5.19b shows the shear stress distribution applying a vertical shear stress of $30 \mathrm{MPa}$ caused by caldera collapse. The significant influence of the boundary conditions can be observed in both models. Especially the maximum shear stresses located adjacent to the lower model limit have been produced by the boundary conditions and are unrealistic. Such artefacts are common features and should be analysed carefully. However, the area of the model studied in this work is located near the upper onshore limit and has been less affected by these artefacts. This fact has been checked by means of a sensitivity analysis varying the boundary conditions.

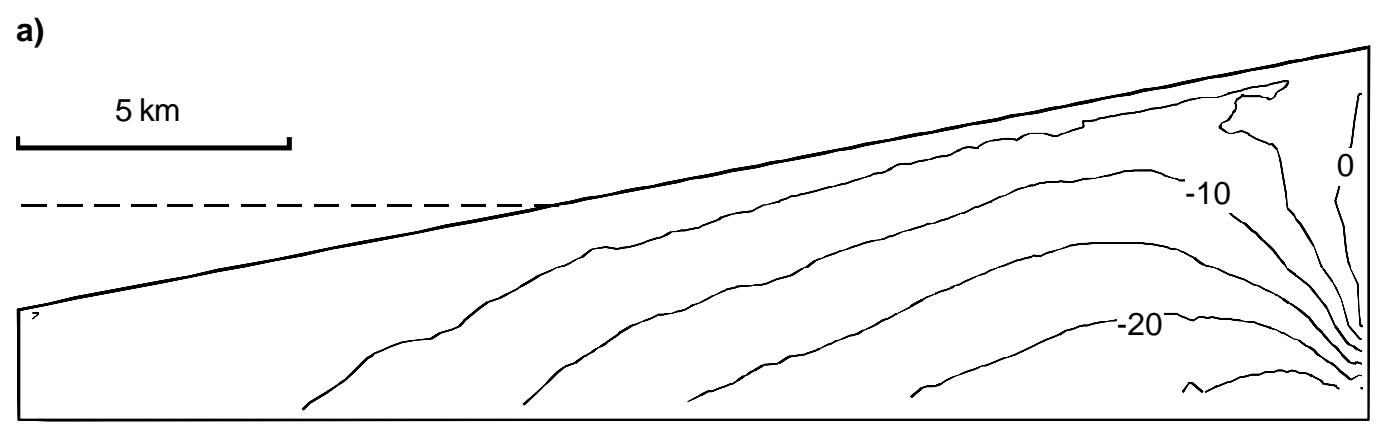

b)

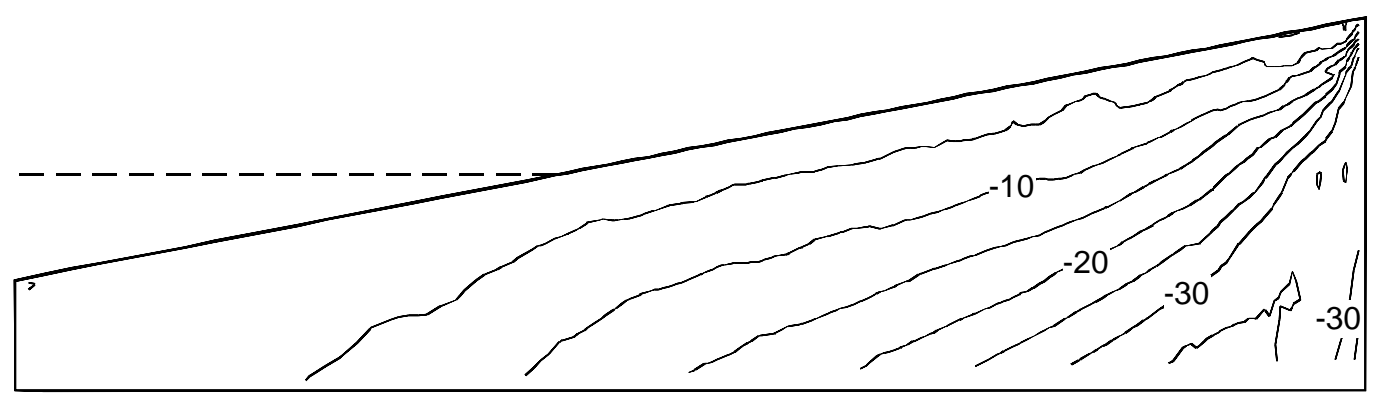

Figure 5.19: Shear stress distribution and intensity corresponding to a horizontal stress due to dike intrusion with a with magma overpressure of $10 \mathrm{MPa}$ (a), and caldera collapse with a vertical shear stress of $30 \mathrm{MPa}(\mathrm{b})$. Contours are at $5 \mathrm{MPa}$ intervals.

In order to visualise the yielding zones in the model, the Mohr-Coulomb strength-stress ratio has been calculated in each node. The nodes containing ratios lower than 1.0 have been assumed to act as potential failure points. The material properties selected for the calculations of the Mohr-Coulomb ratio have been $\mathrm{c}=0 \mathrm{kPa}, \phi=32^{\circ}$. Figure 5.20a shows the conditions for the section of the model indicated in Figure 5.5a applying a horizontal stress due to dike intrusion corresponding to a magma overpressure 
of $10 \mathrm{MPa}$. The yielding area starts in the uppermost part of the idealised volcano flank as a thin layer at a depth of about $200-300 \mathrm{~m}$ and continues down towards the coast as a superficial zone with a thickness of up to $450 \mathrm{~m}$. For a magma overpressure of $5 \mathrm{MPa}$ the results are similar, but the affected zone is thinner. The influence of a caldera collapse event has been analysed applying $3 \mathrm{MPa}$ and 30 MPa driving shear stresses, $\tau_{v}$, at the rear of the model. In contrast to the dike intrusion, the potential yielding zone for a maximum shear stress of $30 \mathrm{MPa}$ is at the subsurface. The failing elements extend to a depth of between 100 and $300 \mathrm{~m}$ from almost the top of the slope down to the coast (Figure 5.20b). A $\tau_{v}$ - value of $3 \mathrm{MPa}$ does not change the stress field significantly thus demonstrating that only large magnitudes of $\tau_{v}$ are able to destabilise volcano flanks.

a)

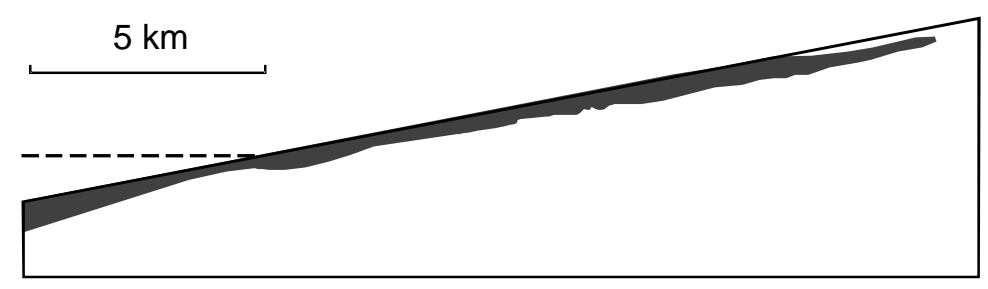

b)

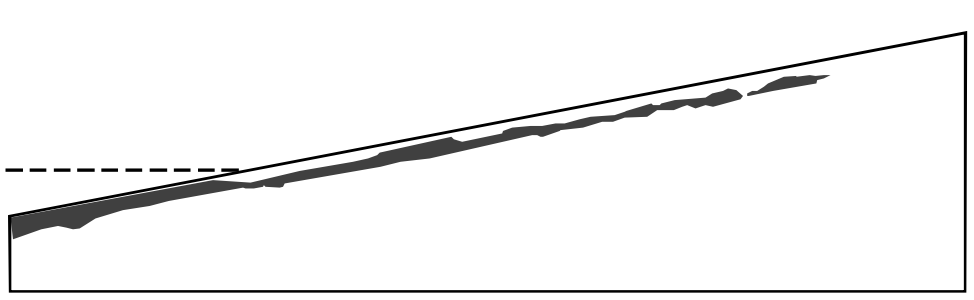

Figure 5.20: Zoom of the zones corresponding to elements in which yielding may occur (Mohr-Coulomb strength-stress ratio less than 1.0). a) Horizontal stress due to dike intrusion with a magma overpressure of $10 \mathrm{MPa}$. b) Caldera collapse with a driving shear stress of $30 \mathrm{MPa}$.

\section{Finite Element Method}

An elaborate analysis of the influence of horizontal stress generated by dike intrusion and vertical shear stress due to caldera collapse on the stability of the volcano flank has been carried out using FEM. First, the distribution and intensity of the principal stresses within the model have been studied after the equilibrium step as well as after applying two additional mechanisms. The distributions of the maximum and minimum stresses, $\sigma_{1}$ and $\sigma_{3}$, are illustrated in Figure 5.21 for the section of the model indicated in Figure 5.5b. The magnitude of stress is proportional to the length of the arrow within one model but not comparable between different models because of altered scales. The results of the equilibrium step applying the gravity and seawater loading show that the principal stresses represent a distribution with generally vertical orientations of $\sigma_{l}$ except near the surface and sub-horizontal orientation of $\sigma_{3}$ both of them increasing with deeper location (Figure 5.21a). The values of principal stresses are negative in the entire model representing compressive conditions. The seawater does not significantly influence on the stress field of the volcano flank. After the application of dike intrusion with a magma overpressure of $10 \mathrm{MPa}$ the principal stress distribution changes completely (Figure 5.21b). Maximum and minimum principal stresses increase and rotate about $90^{\circ}$ which especially occurs adjacent to the intruding dike and near the surface. In the offshore and the lower parts of the 
model the influence of dike intrusion reduces and the stress field changes slightly. After the incorporation of a vertical shear stress of about $30 \mathrm{MPa}$ at the rear of the model the distribution of principal stresses alters only in the zones adjacent to the caldera collapse (Figure 5.21c). The results show that the direct influence of this volcanic process is much smaller than that of dike intrusion. The shear stress applied produces a rotational clockwise movement in the upper right part of the model producing small tensile stresses $\left(\sigma_{3}<0\right)$ in the middle part of the onshore slope near the surface. This may explain small landslides from the caldera wall towards the caldera floor once the vertical collapse has finished which would justify the presence of breccia deposits found inside of many collapse calderas (Lipman, 1976).

a)

$\sigma_{1}$

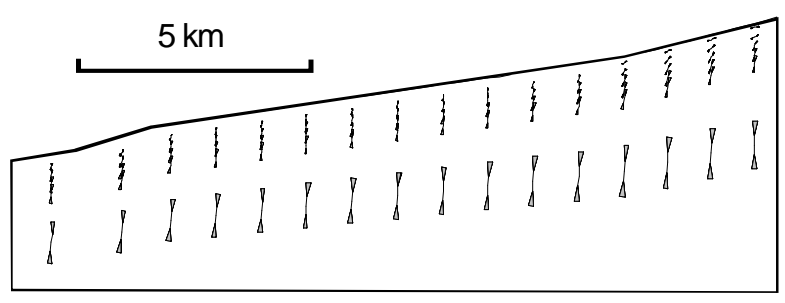

$\triangle$ : - $75 \mathrm{MPa}$ (compressive) $\sigma_{3}$

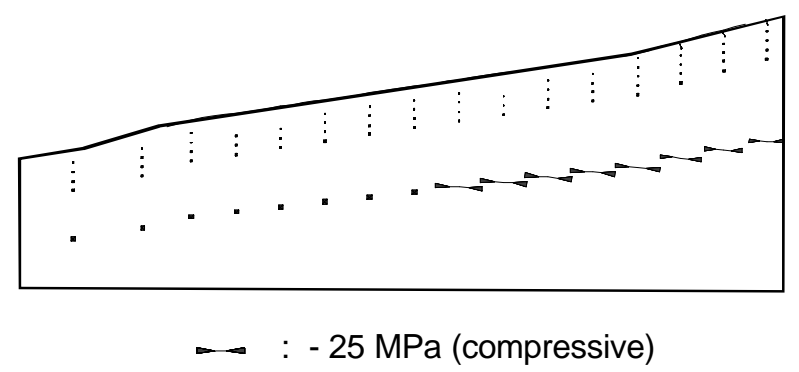

-. : $-25 \mathrm{MPa}$ (compressive)

b)

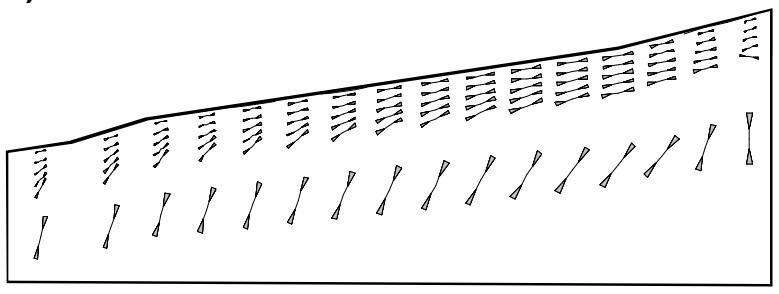

$\triangle:-100 \mathrm{MPa}$ (compressive)

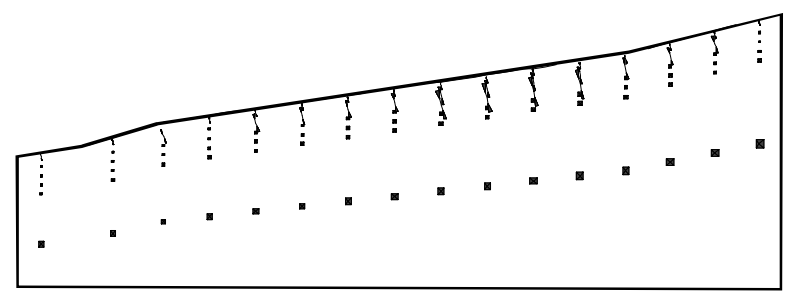

- : - $25 \mathrm{MPa}$ (compressive)

c)

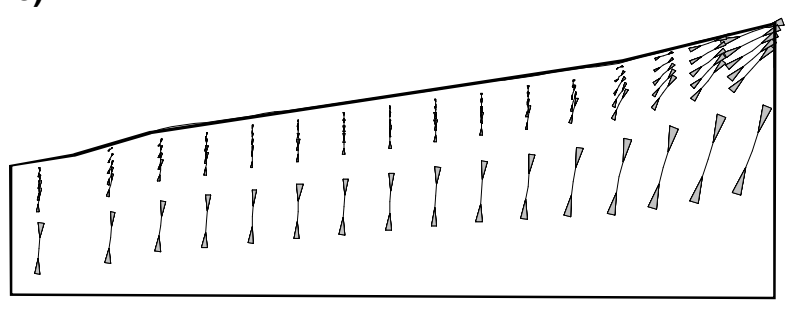

$\triangleright:_{-}-75 \mathrm{MPa}$ (compressive)

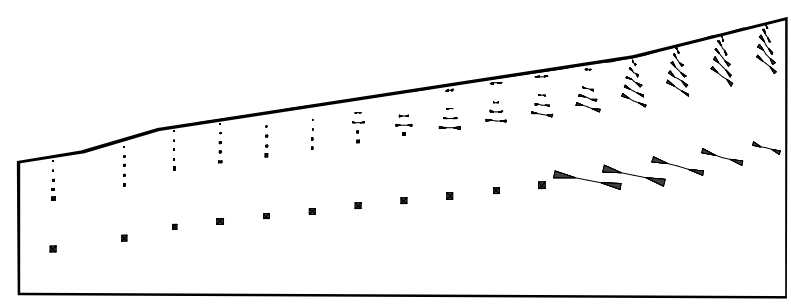

- : - $25 \mathrm{MPa}$ (compressive)

Figure 5.21: Influence of horizontal stress due to dike intrusion and vertical shear stress due to caldera collapse on the stress field of the volcano flank. Orientations of principal stresses are displayed in the area as indicated in Figure 5b. Inward pointing arrows represent compression and outward pointing ones extension. a) Initial conditions of the model applying geostatic stresses. b) Incorporation of a horizontal stress due to dike intrusion with $P_{m o}=10 \mathrm{MPa}$. c) Incorporation of a vertical shear stress due to caldera collapse with $\tau_{v}=30 \mathrm{MPa}$. 
In addition, the Von Mises shear stresses inside the model have been computed for each of the two external mechanisms using the Equations 5.24 to 5.26. To detect potential yielding zones, the distribution of shear stresses have been analysed looking for the maximum values near the surface and avoiding the effects of unrealistic boundary conditions. First, the shear stress distribution of the whole model will be presented (Figure 5.22) and then a zoom of the onshore volcano flank will be shown (Figure 5.23).

The distributions of Von Mises shear stress inside the whole models present similar characteristics as the distribution of standard shear stress using FD. The lower right parts of the models are strongly affected by the boundary conditions of the base and contain unrealistic values. The maximum shear stresses (red shaded areas) are located in both models adjacent to the lower limit of the model. The model refering to the horizontal stress due to dike intrusion has maximum values along the major part of the lower limit (Figure 5.22a), whereas the model affected by a vertical shear stress due to caldera collapse contain maximum values near the lower right corner of the model (Figure 5.22b). On the other hand, the offshore parts of the both models have almost not been affected by the external mechanisms applied.

a)

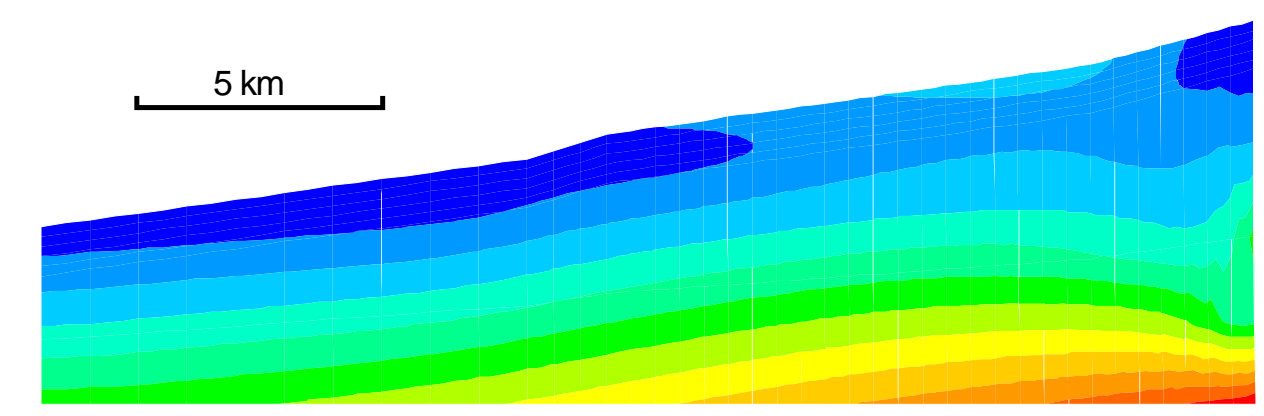

b)
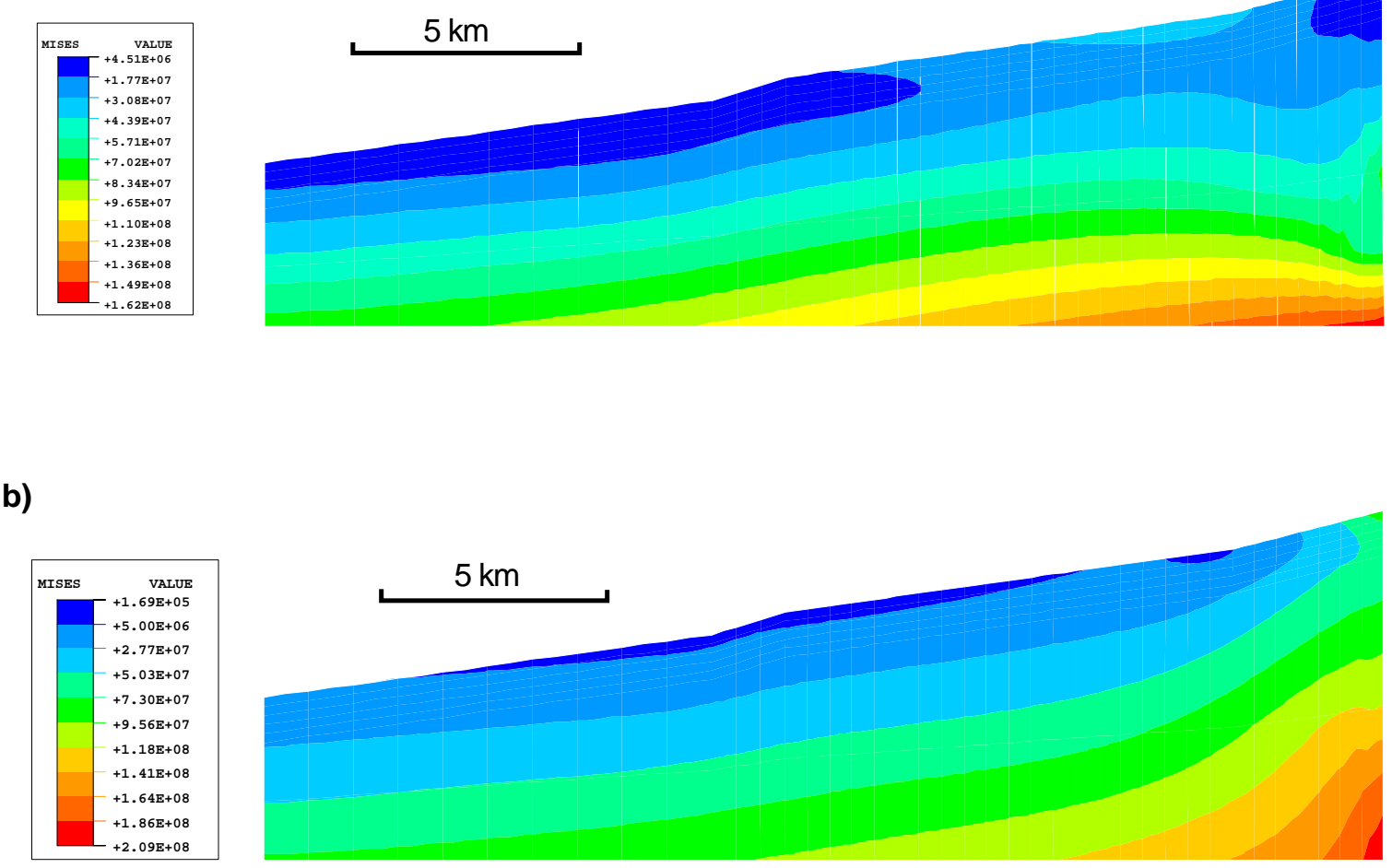

Figure 5.22: Distribution and intensity of Von Mises shear stresses in the entire model after the application of external mechanisms. a) Horizontal stress due to dike intrusion with $P_{m o}=10 \mathrm{MPa}$. b) Vertical shear stress due to caldera collapse with $\tau_{v}=30 \mathrm{MPa}$. 
The following descriptions of the distribution of Von Mises shear stresses refer to the upper onshore part of the model as indicated in Figure 5.5b. The Von Mises shear stress distribution caused by a horizontal stress due to dike intrusion exhibits two zones characterised by unusually high shear stresses (Figure 5.23a). The larger one is located on the higher part of the volcano flank, where the slope inclination changes from the steep cone to the smooth volcano flank, and shear stress values of almost $40 \mathrm{MPa}$ have been calculated. The smaller one is located at the coast, where the marine erosion formed a steep coastal cliff. This is usual, as shear stresses tend to concentrate in areas where the slope profile changes. The vertical shear stress caused by a caldera collapse mainly affects the lower-right part of the model (Figure 5.23b). However, this feature has been affected by the boundary conditions at the bottom base of the model (see Figure 5.22b). Near the surface the Von Mises shear stresses are quite low along the smooth part of the volcano slope and strongly increase closer to the right boundary of the model, where the shear stress has been applied.

Finally, the results of the 2D models indicate that the horizontal stress due to dike intrusion influence much stronger the stress field of the volcano flank than the vertical shear stress caused by caldera collapse which has a more local effect. It can be proposed that multiple dike intrusion along the Dorsal Ridge has significantly destabilised the volcano flank in the upper onshore zone due to high shear stresses preparing the head scarp of the large landslides occurred in the La Orotava valley. This is supported by the actual morphology and underground geology of the La Orotava valley which assumes that the head scarp of the eastern slide may have started in that area of the volcano slope. The vertical walls of the Los Organos area clearly support this hypothesis (see Site Investigation, Figure 3.23).

However, it should be kept in mind, that the destabilising effect of the horizontal stress due to dike intrusion is only a preparing factor and ground acceleration due to a strong seismic shock is still the most potential triggering mechanism finally generating the slope failure.

a)

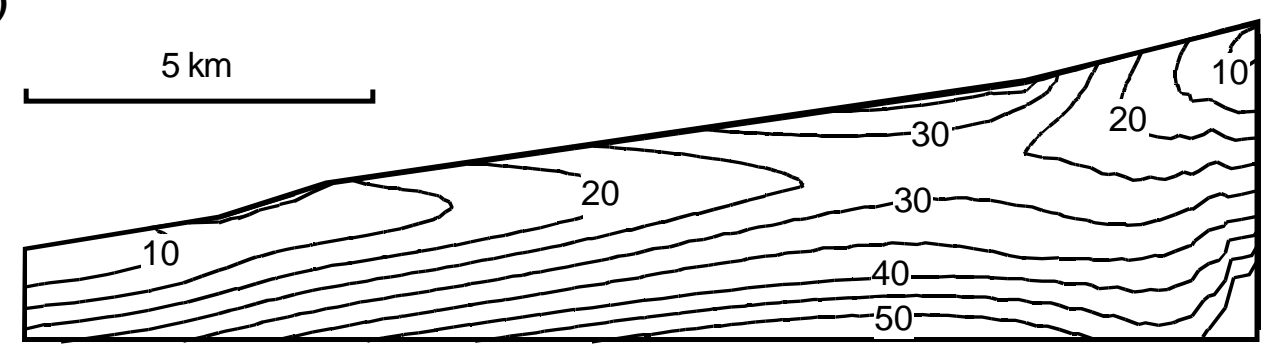

b)

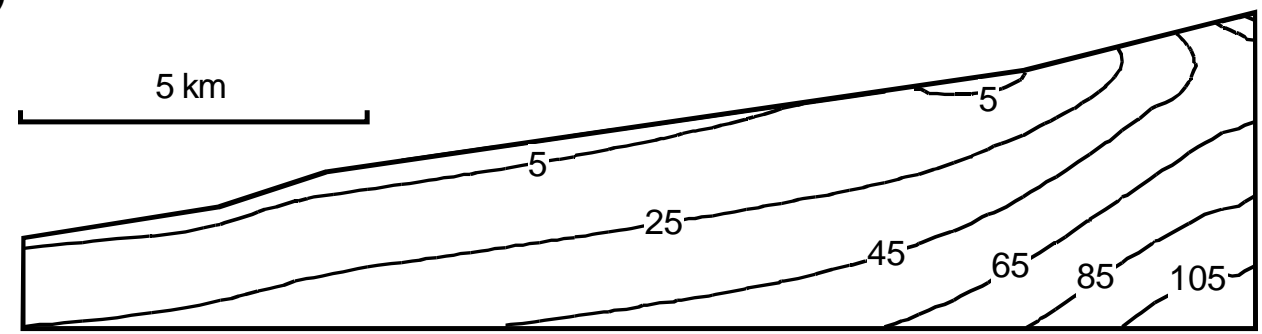

Figure 5.23: Zoom of the distribution and intensity of Von Mises shear stresses after the application of external mechanisms. a) Horizontal stress due to dike intrusion with $P_{m o}=10 \mathrm{MPa}$. Contours are at 5 MPa intervals. b) Vertical shear stress due to caldera collapse with $\tau_{v}=30 \mathrm{MPa}$. Contours are at 20 MPa intervals. 
Finally, the influence of morphologic features has been analysed using the 3D model. Special attention has been drawn on the destabilising effects of deep, narrow canyons. The stress field of the 3D model has been calculated applying at the rear of the model a horizontal stress, which represents the situation of dike intrusion with a $P_{m o}$-value of $10 \mathrm{MPa}$ at the Dorsal Ridge. Again, the potential yielding zones have been approximated by the computation of Von Mises shear stresses. First, the results will be illustrated by a qualitative colour-shaded diagram indicating zones of maximum and minimum shear stresses and then the additional graphics will present the values of Von Mises shear stresses computed in the model.

The colour-shaded diagrams of Figure 5.24 indicate the distribution of the Von Mises shear stresses both in the upper part of the 3D model shown by a view from the north to La Orotava valley and in a transverse section through a deep, narrow canyon. The location of the transverse section is illustrated in Figure $5.24 \mathrm{a}$ by the line named 'A'. The colour scales are only of qualitative purpose where red shaded areas indicate high shear stress values and blue shaded areas show low shear stress values. The results denote two important observations: First, the maximum shear stresses at the surface are situated at the same slope altitude as detected in the 2D model and the lowest values are located in the submarine zone. Second, the deep and narrow canyons influence significantly on the stress field adjacent to these morphologic features. That is usual, as changes in geometry tend to produce stress concentrations. A significant maximum of shear stress has been calculated at the bottom of the canyon.

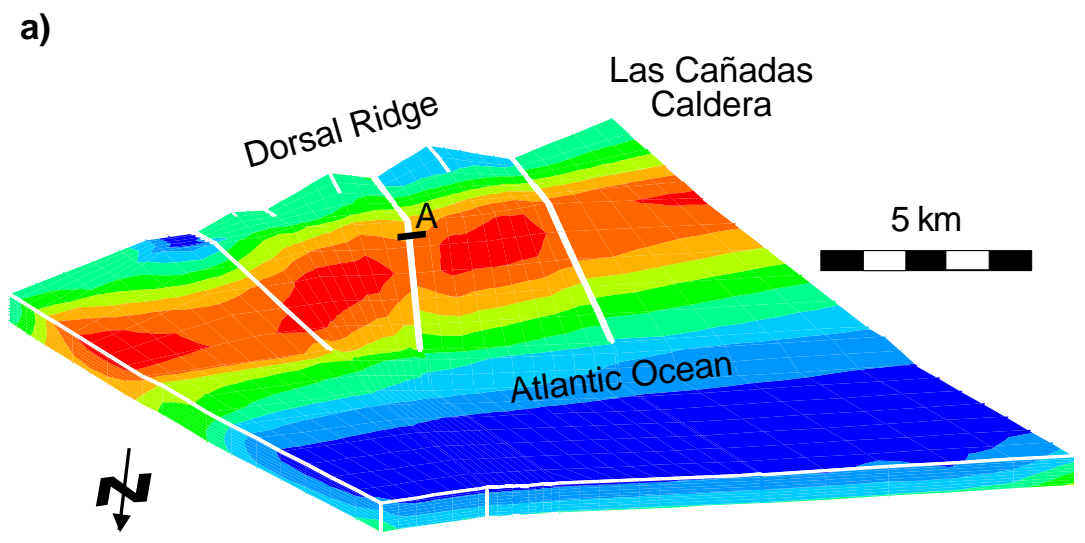

b)

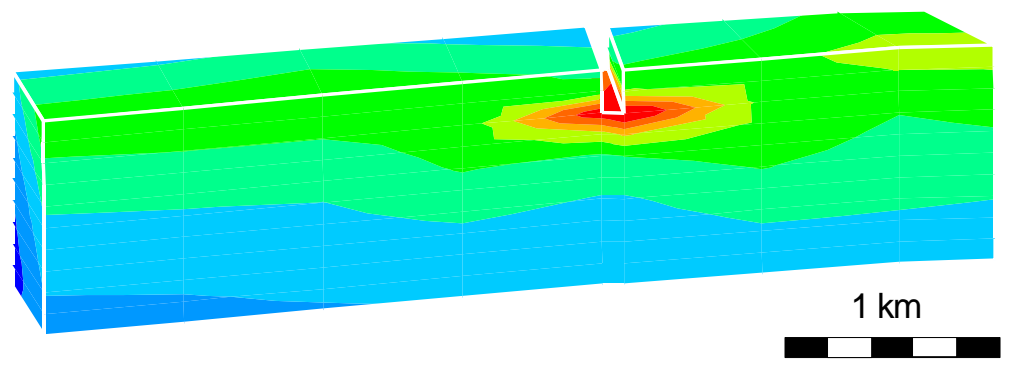

Figure 5.24: Distribution of Von Mises shear stresses in the 3D FEM model applying a horizontal stress due to dike intrusion with $P_{m o}=10 \mathrm{MPa}$. a) Upper part of the model. b) Transverse section trough a deep, narrow canyon along line 'A'. Red coloured areas indicate high shear stress values and blue areas show low shear stress values. Colour scales are different in each figure. 
In the next two diagrams, the upper part of the 3D model and the transverse section through the deep, narrow canyon are given with the Von Mises shear stress values computed during the FEM modelling. Figure 5.25 illustrates the distribution and intensities of the shear stresses in the model that assumes the preslide morphology of the La Orotava valley. The superficial areas of maximum shear stress are located in the upper zones of the smooth onshore parts of the volcano flank and maximum shear stresses exceed $60 \mathrm{MPa}$. The situation of these maximum shear stresses coincides with the proposed location of the head scarp of the eastern landslide. A failure within the areas of maximum shear stresses would correspond to the formation of head scarps as it can be found in the Los Organos area (see Chapter 3: Site Investigation). The different location of the head scarp of the western landslide may be explained by the influence of the processes caused by the Las Cañadas edifice. The inflation of the magma chamber and the vertical shear stress due to the caldera collapse are significant mechanisms influencing on the stress field adjacent to the caldera (Gudmundsson, 1988; Gudmundsson et al., 1997; Hürlimann et al., 1999d). Another interesting result obtained from the shear stress distribution of the 3D model is that the offshore regions have almost not been affected by the influence of dike intrusion and are characterised by small shear stresses.

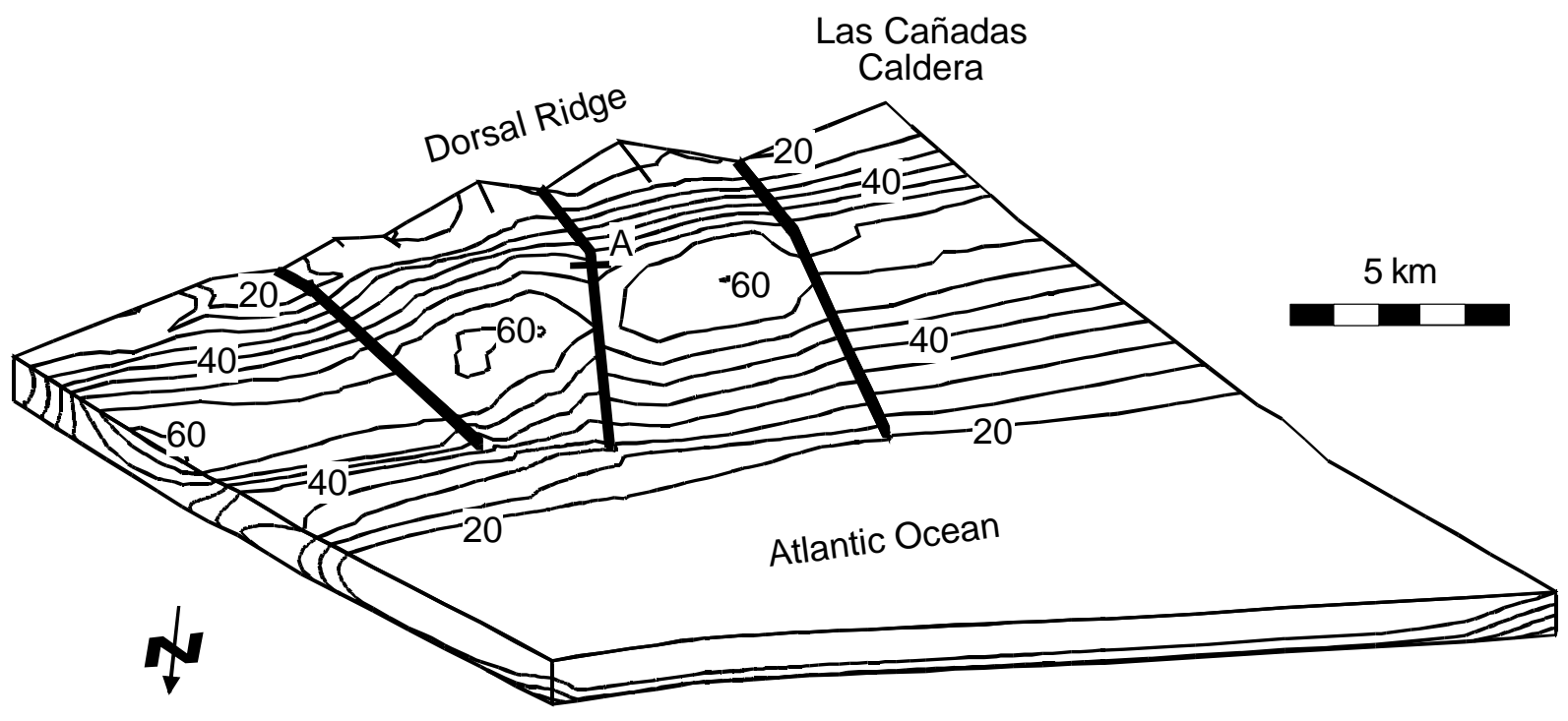

Figure 5.25: Distribution and intensity of Von Mises shear stresses in the upper part of the 3D model applying dike intrusion with $P_{m o}=10 \mathrm{MPa}$. Contours are at 5-MPa intervals. View from the north to the La Orotava valley. 
The distribution and intensity of the Von Mises shear stress in the transverse profile through the canyon along line 'A' (indicated in Figure 5.25) is displayed in Figure 5.26. The shear stresses strongly increase near the canyon and highest values are situated at the base of the canyon reaching maximum values of about $80 \mathrm{MPa}$. This characteristic indicates the importance of such morphologic units as boundaries of landslides. The canyons not only reduce the lateral strength of the slope by their existence, but also create potential yielding zones at their base. Therefore, it can be suggested that the lateral limits of the large volcanic landslides occurred in the La Orotava valley have developed along such canyons. Deep, narrow barrancos are common features on Tenerife. They can erode as deep as hundreds of meters into the volcano flank and are frequently found on slopes not previously affected by slope failure in the humid parts of the island. The 'Barranco de Ruiz' is a typical example in the La Orotava valley area (see Chapter 3) and additional canyons of significant destabilising effects may have also existed along the present limits of the amphitheatre prior to the formation of the valley.

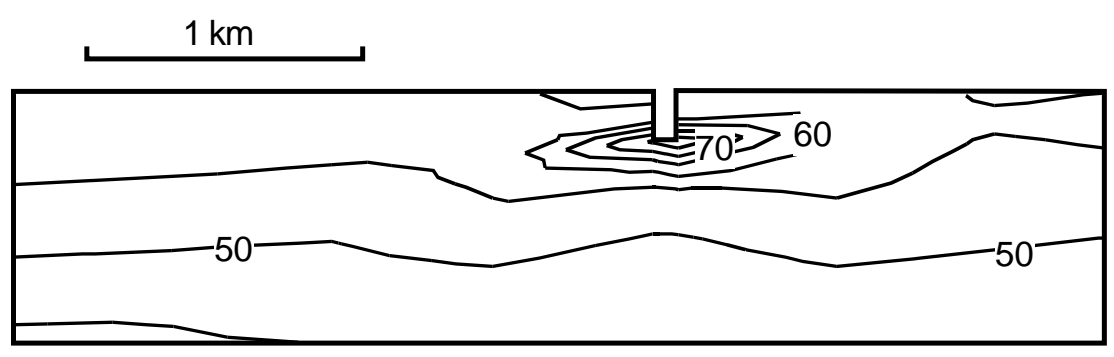

Figure 5.26: Transverse section through deep, narrow canyon with calculated distribution and intensity of Von Mises shear stresses. Contours are at $5 \mathrm{MPa}$ intervals. 


\subsection{Conclusions}

In the last two decades, many advances have been made in understanding the causes of large volcanic landslides. However, comprehensive geotechnical analyses concerning to the destabilising factors of large volcanic landslides are still in a preliminary stage. In this study, the results obtained from different types of stability models including both global limit and continuum approaches have been presented. The destabilising effects of three different mechanisms generated by distinct volcanic and volcano-tectonic processes have been analysed. Average ground accelerations due to seismic shocks, the horizontal tensile stress due to dike intrusion and the vertical shear stress due to caldera collapse have been incorporated into the models. The results are not definitive and have a conceptual purpose, but they give new insights on how seismic shocks, dike intrusion and vertical caldera collapse affect the mechanical stability of volcano flanks.

The results obtained from a sensitivity analysis of the stability of a volcano flank using LEM indicate that the occurrence of weak materials (paleosols, pyroclastic layers, etc.) and pore water pressure increase are insufficient to induce failures of large-scale landslides on volcanic edifices. Also, changes of the sea water level and the associated sea water loading does not influence significantly on the slope stability. Thus, external mechanisms, related to volcanic activity or volcano-tectonic processes, are necessary to cause failure.

During the global limit analysis using both LEM and UBM, the destabilising influences of seismic acceleration, horizontal stress due to dike intrusion and vertical shear stress due to caldera collapse have been studied at a simplified volcano flank and at the assumed preslide morphology of the La Orotava valley. In summary, the results indicate that the average ground acceleration due to seismic shocks is the most important mechanism. The destabilising effects of horizontal stresses due to dike intrusion or vertical shear stresses caused by caldera collapse are of minor magnitude with the vertical shear stress being the less effective. The scale effect plays an important role and each of the three mechanisms strongly depends on the volume of the failing mass. In general, the larger the failure the stronger must be the destabilising influence of the external mechanism. Moreover, it's unrealistic that a seismic shock generates in a volcano slope of several kilometres length in the same moment the same high ground acceleration, since earthquakes generate time-dependent ground motion. The peak accelerations decrease exponentially with epicentre distance and the seismic wave motion affects such a enormous mass at different instants and with different magnitudes. The scale effect refering to the horizontal stress due to dike intrusion and the vertical shear stress caused by caldera collapse is even more significant. The destabilising influence of these two external mechanisms mainly depends on the basal length of the slope failure. At a volcano flank characterised by common drained material strengths realistic magma overpressures up to $10 \mathrm{MPa}$ only enable landsliding for a maximal length of about 3 kilometres and would never be capable to generate failure of a slide with a length exceeding 10 kilometres.

Since many of the volcanic processes occur in a short time and generate undrained conditions, the three external mechanisms have been additionally analysed using the UBM and the undrained failure criterion. The data obtained from the undrained laboratory tests on a residual soil have been used and included into the UBM models. The results indicate the significant destabilising influence of undrained conditions on the slope stability and support the idea that the seismic shocks is the most important process reducing the mechanical stability of volcano flanks.

After the analysis of a common simplified volcano slope, the landslide events occurred in the La Orotava valley have been analysed. Since the assumed length of the slope failure is characterised by about $12 \mathrm{~km}$, the external mechanisms are not able to trigger independently a failure applying realistic magnitudes. Therefore, seismic acceleration and horizontal stress due to dike intrusion have been coupled and incorporated simultaneously into the model. By this way, the assumed failing mass reaches critical stability conditions applying the two external forces with realistic magnitudes of magma overpressure and seismic accelerations. Therefore, it can be proposed that a combination of these two mechanisms may have caused the large volcanic landslide events in the La Orotava valley. Dike intrusion along the Dorsal rift zone may have significantly destabilised the volcano flank generating 
critical stability conditions. Then, ground acceleration generated by a strong and adjacent earthquake has triggered the slope failures. Earthquakes with such features are characterised by a volcano-tectonic origin and generally include processes such as caldera collapse episodes or slumping of the volcano flank adjacent to a rift zone. Slumping due to persistent dike intrusion has been proposed at Kilauea volcano, Hawaii, but is unrealistic on Tenerife. Therefore, the seismic acceleration caused by caldera collapse episode is the most potential triggering mechanism for the La Orotava landslides, since it can easily overcome the critical stability conditions of the slope due to the magnitude and proximity of the earthquake. An additional support of this hypothesis gives the age relationship between the caldera collapse episode at the end of the Guajara cycle at about $0.56 \mathrm{Ma}$ and the formation of the valley.

In addition to the calculations that have studied the Factor of Safety of the volcano slope, the position of the potential slip surface has been searched calculating the most critical failure surfaces. In spite of the simplifications used in this study, the results obtained from the computations analysing the La Orotava events are interesting and coincide with the present morphology of the amphitheatre. The most critical, circular-shaped slip surface calculated for the simplified preslide morphology ends near the coastline in the offshore part and is characterised by an average depth of about 1 kilometre which is consistent with the assumed slip surface obtained form the site investigation (Chapter 3 ). Since the effect of dike intrusion along the Dorsal Ridge could not be included into the LEM model, the starting point calculated at the top of the Dorsal Ridge may have not been estimated correctly.

On the other hand, a continuum analysis has been carried out studying 2D and 3D models by comprehensive numerical modelling. The results obtained from this analysis do not perform exact values refering to stability of the slope, but achieve a global view of the stress field in the volcano flank and hence enable to estimate where may have initiated the failure. Due to the complexity of a coupled dynamic stress displacement analysis, only the influence of horizontal stresses due to dike intrusion and vertical shear stresses caused by caldera collapse have been studied.

The FEM simulations carried out with the 2D models show the different effect of horizontal stresses owning to dike intrusion and vertical shear stresses due to caldera collapse on the mechanical stability of the volcano flank. Dike intrusion significantly affects the stress field of the entire onshore part of the slope, whereas caldera collapse only influences locally and in an inconsiderable magnitude. The distribution of shear stresses indicates that the most potential yielding zone due to dike intrusion is located at the upper part of the smooth volcano flank starting at the surface and going down to a depth of almost 1 kilometre. A failure thickness of up to 1 kilometre is realistic for the La Orotava events and is supported by the results obtained from geological and morphological analysis of the amphitheatre assuming a maximum depth of the failure at about 1 kilometre.

Furthermore, the importance of morphologic features such as deep, narrow canyons has been demonstrated using 3D FEM modelling. Deeply incised canyons are common morphologic features on Tenerife and can preferably be found in the wet areas of the island. The modelling results indicate that these canyons not only reduce the lateral strength of the slope by their existence, but also create potential yielding zones at their base. Thus, it can be proposed that narrow, deep canyons may develop into the lateral limits of the landslides. Otherwise, because of the lack of other discontinuities, development of a lateral failure surface would require much more energy to produce failure.

In addition to the agents studied during this stability analysis, there are other important factors reducing the stability of volcano flanks. Weak layers such as volcanic residual soils may significantly change the stress field and the stability conditions of the volcano flank. In this study, only homogeneous models have been analysed without focussing on the effect of such weak layers. Another important agent only marginally analysed during this work is the pore fluid pressure. Pore fluid pressure enhancement is a significant process in saturated slopes and may strongly increase due to mechanical and thermal effects of intruding magma or due to the presence of volcanic gases. In this work, the pore water pressure increase during undrained conditions has been considered by means of an apparent friction angle in the calculations. Moreover, hydrothermal alteration can affect the stability of volcano flanks weakening the volcanic rocks and reducing chiefly theirs material strengths or augmenting the 
pore fluid pressure. All these processes are difficult to incorporate comprehensively into numerical models but should always be kept in mind during the stability analysis.

In conclusion, the main findings of the geotechnical stability analysis can be divided into two parts. One part responds the question 'Why such large mass movements can occur?' and focuses on the causes of the landslides. The other part answers the question 'Where occurs failure inside the volcano flank?' and studies the location of the potential slip surface. Exact answers to both parts have not been found, but the results have chiefly improved the general understanding of large volcanic landslides.

Refering to the causes, it can be said that the seismic acceleration seems to be the most effective destabilising mechanism. Strong ground motion may be generated by volcano-tectonic tremors caused during caldera collapse events. The calculation results propose that a combination of seismic acceleration and horizontal stress at the rear of the volcano flank due to dike intrusion may have been the most important causes of the large slope failures in the La Orotava valley. Persistent dike intrusion along the structural axis of the Dorsal Ridge may have generated critical stability conditions, while the strong seismicity associated with the caldera collapse episodes has finally triggered the failure. In addition, the laboratory tests performed on a residual soil confirm that undrained loading caused by both seismic shocks and saturated conditions plays a fundamental role in the geotechnical behaviour of this soil (Chapter 4). Therefore, landslides are more probable in wet areas that include large extensions of phonolitic pyroclastic deposits and these residual soil layers. However, it should be kept in mind that large-scale slope failures at volcanoes are very complex processes and many other agents significantly influence the mechanical stability of volcano flanks.

Concerning to the location of the failure surface the stability analysis has revealed some important insights especially for the La Orotava valley events. The LEM calculations have indicated that the most critical slip surface at the assumed preslide volcano flank extends down to a maximum depth of about 1 kilometre. The toe of the failure is located in the offshore part of the volcano slope just behind the coastal shelf. These results coincide very well with the actual morphology of the amphitheatre which exposes lateral scarps of heights up to $500 \mathrm{~m}$ and the underground geology which assumes the failure surface of the landslide events in a depth of about $500-700 \mathrm{~m}$ below the present valley floor. The results obtained from the LEM analysis support a failure surface at a maximum depth of about 1 kilometre. The FEM modelling has indicated that a significant zone of maximum shear stress is located at the upper part of the volcano slope affected by dike intrusion extending down to about the same depth. This area of maximum shear zones may denote the location of the head scarp of the large landslides and coincides with the present situation of the vertical walls found at Los Organos in the La Orotava valley. Consequently, the results obtained from the stability analysis support that the head scarp of the large volcanic landslide is located in the upper part of the smooth volcano slope, the thickness may reach 1000 meters and the toe is situated in the offshore part of the volcano flank near the coast line. 


\section{MOBILITY ANALYSIS}

\subsection{Introduction}

This chapter includes a preliminary analysis of the mobility of large landslides and presents a simple conceptual model, useful for the understanding of these events. The results will be published in Hürlimann et al., 1999.

The travel distance of large landslides generally exceeds the expected values (Figure 2.1) and recent studies demonstrate that for volcanic landslides it may even surpass values for non volcanic landslides (Ui, 1983; Siebert, 1984; Ui et al., 1986; Siebert et al., 1987). Numerous theories have been proposed to account for the mobility of large mass movements including the influence of collisions among individual grains within the sliding mass (Heim, 1932; Hsü, 1975), a layer of compressed air trapped beneath the sliding mass (Shreve, 1968) and mechanical or acoustic fluidisation (Howard, 1973; Goguel, 1978; Melosh, 1979). The enhanced mobility of volcanic landslides has typically been attributed to pore fluid heating by volcanic processes (Ui, 1983; Voight et al., 1983). For subaqueous mass movements, the effect of the fluid medium on their mobility is poorly known, but the runout distance of submarine landslides seems to be greater than for subaerial events (Hampton et al., 1996). Recent laboratory experiments have shown that hydroplaning of the submarine sliding mass may have a strong influence on landslide mobility significantly increasing the runout distance (Mohrig et al., 1998). In this work, to analyse the mobility of landslides on volcanic islands, a single block approach applied to subaerial mass movements has been used. It is based on the works by Ui (1983) and García et al. (1994), which originates from the sliding block model of Heim (1932). Additionally, the change in medium from air to water has been incorporated into the model and the hydroplaning effect of subaqueous sliding masses has been simulated as proposed by Mohrig et al. (1998).

The main objective of this chapter is to analyse the mobility of large landslides focussing on events on volcanic islands. Moreover, the influence of the water on the runout distance of subaqueous mass movements will be studied. The results of the modelling will be compared with available geological, bathymetric and topographic data on the northern flank of Tenerife. The bathymetric data show that landslide material derived from the onshore amphitheatres can now be found at more than 70 kilometres from the shoreline and some large hummocks or megablocks have been inferred to be in depth between 3000 and $-3200 \mathrm{~m}$ (Figure 6.1). 


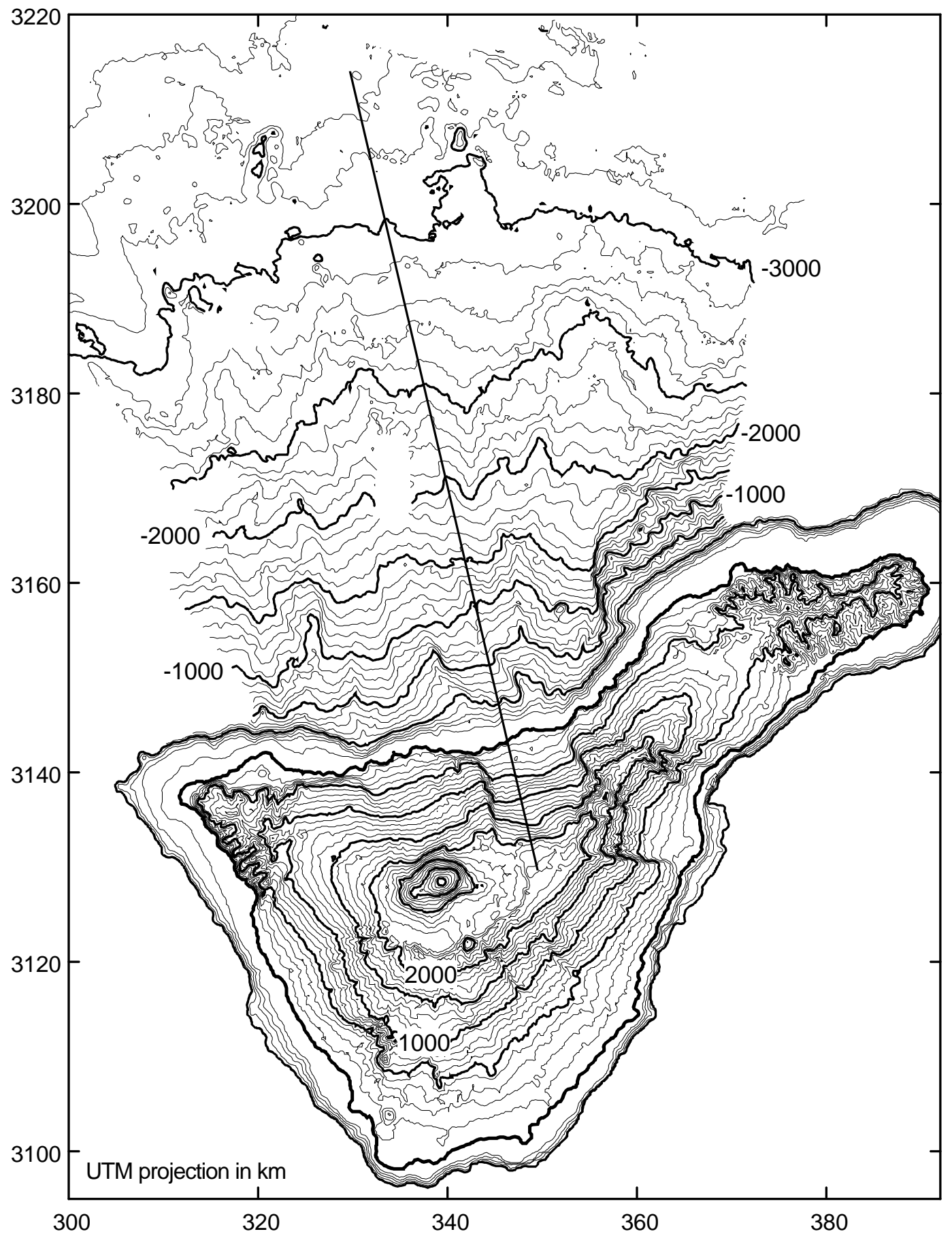

Figure 6.1: Topography of Tenerife and bathymetry of the northern offshore slopes (contour interval is $100 \mathrm{~m}$ ). Bold line indicates the selected profile for the calculations of landslide mobility. 


\subsection{Model description}

The mobility of the La Orotava landslide has been modelled mechanically in order to explain, whether landslide deposits could reach $70 \mathrm{~km}$ from the shoreline, or not. The model analyses the mobility of landslides which start subaerially and are deposited subaqueously. It is an extension of the kinematical approach proposed for completely subaerial events by Ui (1983) and originates from the sliding block model of Heim (1932) which assumes the moving mass to be a rigid solid with constant density and dimensions throughout the sliding path. The final model used in this work is simple, but valid to infer the qualitative behaviour and to check the feasibility of the runout distances.

To simulate the effects of the subaqueous environment on the mobility of landslides, additional forces are incorporated into the model as illustrated in Figure 6.2. Normal and shear stresses on the surface of the sliding mass due to the solid - fluid interaction can be integrated by two forces acting on its centre of gravity: one on the movement direction and another perpendicular. In order to keep the computations simple, the hydrostatic uplift force due to buoyancy and the drag force opposing the movement have been used. The drag force, $F_{D}$ has been determined using a classical fluid mechanics approach (e.g. Streeter and Wylie, 1986) as

$$
\mathrm{F}_{\mathrm{D}}=\frac{1}{2} \mathrm{~K} \rho_{\mathrm{me}} \mathrm{v}^{2} \mathrm{~A}
$$

where $\mathrm{K}$ is a dimensionless shape coefficient, $\rho_{\mathrm{me}}$ is the density of the medium surrounding the sliding body, $\mathrm{v}$ is the velocity and $\mathrm{A}$ is the surface opposing the movement. The hydrodynamic uplift force should be used instead of the hydrostatic force, but this makes the model too complex. The value of $\mathrm{K}$ in $F_{D}$ is constrained by hydraulic experiments to lie between 0 and 2, which keeps the final value of that force well defined. The model does not consider turbulence effects, although an increment of drag forces could be incorporated. It is assumed that the transition from the subaerial to submarine medium is immediate and without energy loss. All forces acting on the moving mass can be described at any point during the slide using Newtons second law and the acceleration of the mass can be expressed as

$$
\frac{d v}{d t}=g \frac{\left(\rho-\rho_{m e}\right)}{\rho}(\sin \theta-\mu \cos \theta)-\frac{K}{L} \frac{\rho_{m e}}{\rho} \frac{v^{2}}{2}
$$

where $t$ is time, $g$ is the gravitational acceleration, $\theta$ is the slope inclination, $\mu$ the coefficient of friction and $\mathrm{L}$ the length of the body. The body density is assumed to be constant during the entire landslide event $\left(\rho=2500 \mathrm{~kg} \mathrm{~m}^{-3}\right)$ and the density of the medium is $\rho_{\mathrm{me}}=0 \mathrm{~kg} \mathrm{~m}^{-3}$ for subaerial conditions and $\rho_{\mathrm{me}}=1000 \mathrm{~kg} \mathrm{~m}^{-3}$ for submarine conditions. Consequently, the analysed parameters in this step are $\mu$, and $\mathrm{K} / \mathrm{L}$. 


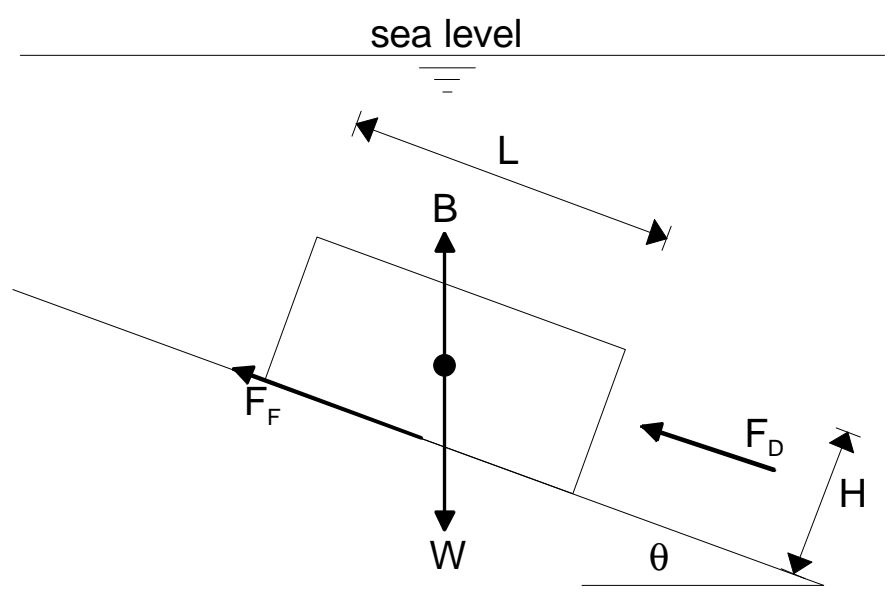

Figure 6.2: Forces acting on a subaqueous sliding mass. The forces incorporated into the computations are the weight of the mass, $\mathrm{W}$, the buoyancy, $\mathrm{B}$, the drag force, $\mathrm{F}_{\mathrm{D}}$, and the frictional force, $\mathrm{F}_{\mathrm{f}} . \theta$ represents the submarine slope inclination.

The hydroplaning effect of subaqueous landslides is also incorporated into the model. For high velocities, it is well known that uplift forces become very important and that a sliding body can loose contact with the slip surface. This phenomenon has recently been reproduced in laboratory analyses of subaqueous debris flows (Mohrig et al., 1998). The experiments indicate that a minimum Froude number, Fr, between 0.3 and 0.4 is necessary for hydroplaning to occur, using the following equation defining the Froude number

$$
\mathrm{Fr}=\frac{\mathrm{v}}{\sqrt{\left(\frac{\rho}{\rho_{\mathrm{me}}}-1\right) \mathrm{gH} \cos \theta}}
$$

where $\mathrm{H}$ is the height of the moving mass. In our model, the Froude number has been calculated at all points during sliding and hydroplaning was assumed to occur for Fr - values greater than 0.4. During the calculations hydroplaning was simulated by neglecting friction forces between the sliding body and submarine slope and setting the friction coefficient, $\mu$, to zero.

The parameters selected for the mobility analysis taking hydroplaning into account are thus the friction coefficient, $\mu$, the ratio, $\mathrm{K} / \mathrm{L}$, and the height, $\mathrm{H}$, of the sliding mass. The friction coefficient has been defined to be equal in subaerial and subaqueous medium with values of 0.05 and 0.08 . The value 0.05 corresponds to a lower, reasonable limit while 0.08 represents the value proposed by Ui et al. (1986) and García et al.(1994) for subaerial volcanic landslides. The shape coefficient and length of the sliding mass are combined and incorporated into the model using the parameter $\mathrm{K} / \mathrm{L}$ with selected values between 0 and $2 \times 10^{-3} \mathrm{~m}^{-1}$. This is because the shape coefficient generally ranges from 1 to 2 , depending on the morphology of the moving body (Streeter and Wylie, 1986), and the length of the sliding mass is assumed to range from $500 \mathrm{~m}$ to infinity. The height of the moving mass is assumed to be between 50 and $200 \mathrm{~m}$. Additionally, Equation 6.2 has been resolved numerically assuming initial conditions with zero velocity at $\mathrm{t}=0$ (Garcia, 1999). 
The topographic profile for the model calculations reflects the fact that the northern flank of Tenerife has undergone recurrent landsliding (Ablay and Hürlimann, 1999) and that the general inclination of the slopes does not vary significantly between parts affected and parts unaffected by landsliding. A profile of the present topography for the sliding path is used starting in the La Orotava valley and finishing 85 kilometres seawards at a depth of about - $3700 \mathrm{~m}$ (Figure 6.3). The centre of the gravity of the sliding mass has been defined at $1500 \mathrm{~m}$ a.s.l. and the starting point of the calculations has been fixed at this height.

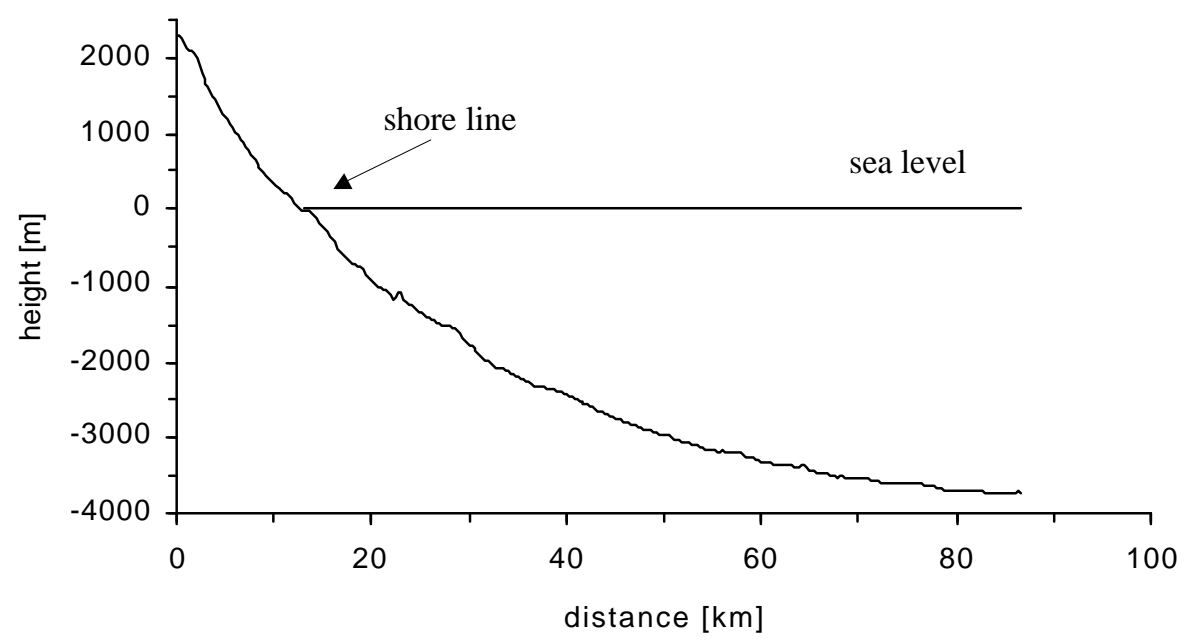

Figure 6.3: Topographic / bathymetric profile indicating the main morphologic sections of the northern slopes of Tenerife. Vertical exaggeration is about $8 \mathrm{x}$.

\subsection{Results}

First, the submarine effects on the mobility of the landslide has been considered including drag forces and the hydrostatic uplift force, using Equation (6.2) regardless of possible hydroplaning. The velocity curves were computed for different values of $\mathrm{K} / \mathrm{L}$ to analyse the influence of the drag forces, using friction coefficients of 0.05 (Figure 6.4a) and 0.08 (Figure 6.4b). The curves indicate a significant effect of drag forces, which decrease the velocity strongly about $10 \mathrm{~km}$ downslope, where the slide enters the subaqueous medium. Only sliding masses with unrealistic low $\mathrm{K} / \mathrm{L}$ values close to zero experience an increase in velocity after entering the water. Slides with more realistic lengths and smaller $\mathrm{K} / \mathrm{L}$ values experience a velocity reduction. The runout distances calculated for the low $\mu$ value of 0.05 are between $35 \mathrm{~km}$ for $\mathrm{K} / \mathrm{L}$ of $2 \times 10^{-3} \mathrm{~m}^{-1}$ and $59 \mathrm{~km}$ for a K/L value of $2 \times 10^{-4} \mathrm{~m}^{-1}$. The calculations of the velocity curves for the smallest and unrealistic $\mathrm{K} / \mathrm{L}$ value could not be terminated since the topographic profile finishes at about $85 \mathrm{~km}$ where the velocity still exceeds $150 \mathrm{~m} / \mathrm{s}$. A smaller K/L value implies a greater mobility of the slide; the longer the block the greater the runout because drag forces are proportional to the surface area of the block opposed to the movement. A large block may break into several smaller blocks, but these will travel together as a single unit. 
a

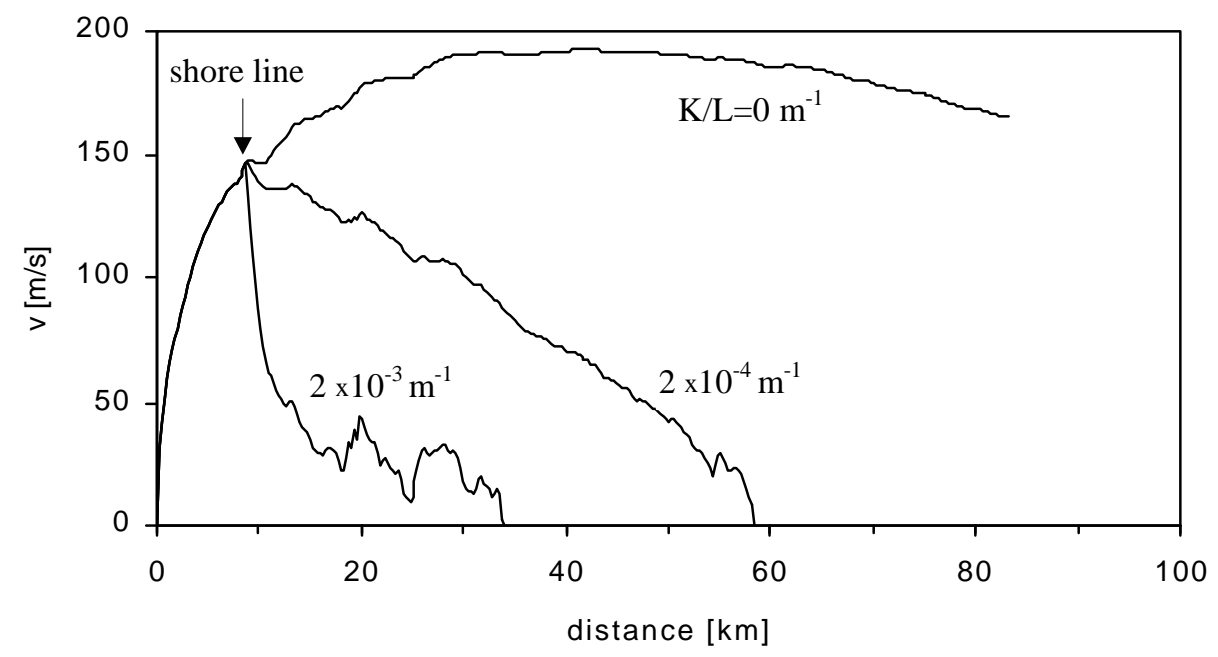

b

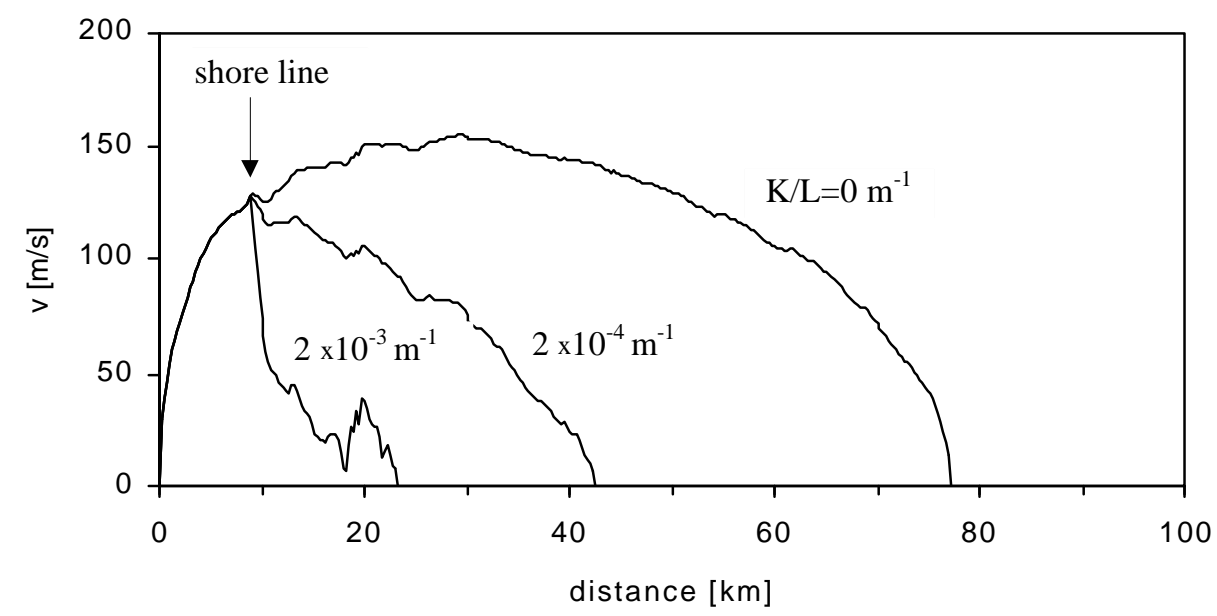

Figure 6.4: The effect of the drag forces on the landslide mobility. The velocity curves for a coefficient of friction of 0.05 (b) and of 0.08 (c) are plotted for three different K/L - values. The selected path for the model calculations is given in Figure 6.3.

The runout distances for a $\mu$ value of 0.08 are generally smaller than those with a $\mu$ value of 0.05 and range from about $23 \mathrm{~km}\left(\mathrm{~K} / \mathrm{L}=2 \times 10^{-3} \mathrm{~m}^{-1}\right)$ to about $78 \mathrm{~km}\left(\mathrm{~K} / \mathrm{L}=0 \mathrm{~m}^{-1}\right)$. Additional calculations show that runout distances are very sensitive to the friction coefficient and even small changes have a significant influence. Some supplementary information about the behaviour of large subaerial landslides can be obtained from the onshore part of the velocity curves. Between the start point and the entrance into the sea at about $10 \mathrm{~km}$ the slides rapidly accelerate and reach calculated velocities of $150 \mathrm{~m} / \mathrm{s}$ for a $\mu$ value of 0.05 and $130 \mathrm{~m} / \mathrm{s}$ for $\mu$ equal to 0.08 . Such velocities are typical of values estimated for large subaerial volcanic landslides (Voight et al., 1983; Ui et al., 1986; García et al., 1994).

These results show a strong reduction in landslide mobility after entering the water suggesting that other processes must exist in order to account for the great runout distances of submarine landslides observed (e.g. Hampton et al., 1996). 
The next step is therefore to analyse the influence of hydroplaning along the subaqueous part of the slide path. For these calculations, the $\mathrm{K} / \mathrm{L}$ value was fixed at $2 \times 10^{-3} \mathrm{~m}^{-1}$ which corresponds to reasonable values of $\mathrm{K}=2$ and $\mathrm{L}=1000 \mathrm{~m}$. Calculations with smaller $\mathrm{K} / \mathrm{L}$ values gave unreasonably long runout distances. As in the previous calculations, the analysed coefficients of friction are 0.05 and 0.08 . Figure 6.5 illustrates the velocity curves for heights of the sliding mass selected at 50, 100 and $200 \mathrm{~m}$.

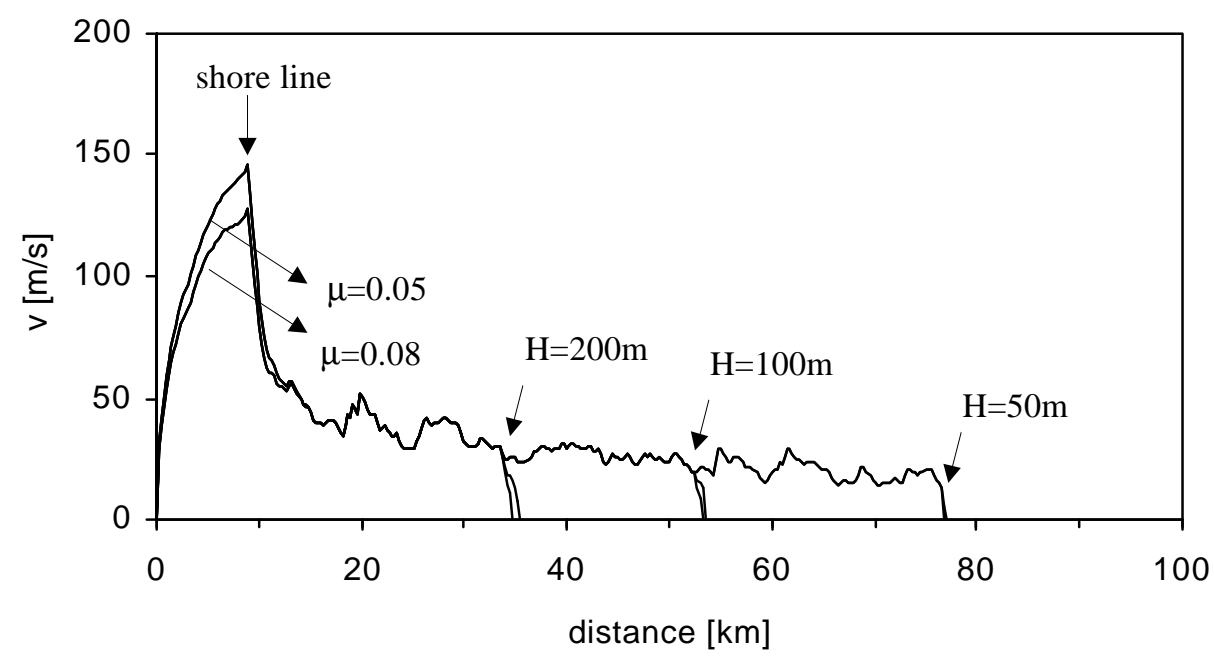

Figure 6.5: The effect of hydroplaning on the landslide mobility. The velocity curves are plotted for the coefficients of friction of 0.05 and 0.08 and sliding mass heights of 50,100 and $200 \mathrm{~m}$. K/L is $2 \times 10^{-3}$ $\mathrm{m}^{-1}$ for all curves. The selected path for the model calculations is given in Figure 6.3.

Subaerially, the landslide velocity depends only on the coefficient of friction. The height of the body does not have any influence as the drag forces due to friction with the air are neglected. At the coast, the entrance into water strongly reduces the landslide velocity due to the effect of drag forces. However, in both cases the velocity of the landslide is sufficiently high for hydroplaning to begin instantaneously. During the first five kilometres of subaqueous transport, the movement is influenced by the subaerial kinematic history and depends mainly on the velocity on entering the water. Thereafter, the calculated cases are characterised by very similar behaviour. This can be attributed to the fact that as long as hydroplaning is acting, only the gravitational driving force and the resisting drag force are in effect, gravity accelerating the slide while drag forces act to retard it. Thus, the subaqueous motion is characterised by a kind of dynamic - stationary movement with an acceleration close to zero. Therefore, the velocity for all calculated cases is the same between 20 and $30 \mathrm{~km}$ runout distance and does not change until reaching the critical velocity for hydroplaning to occur. Since the propensity for hydroplaning at a given velocity depends only on the body height, the slide with the greatest value of $\mathrm{H}$ stops hydroplaning earlier than a slide with lower $\mathrm{H}$ values. Once hydroplaning has stopped, the basal friction and the drag forces begin again to decrease strongly the velocity, the overall effect depending on the $\mu$ value. Hence, the calculated runout distances for a sliding body with a height of $200 \mathrm{~m}$ are about $35 \mathrm{~km}$ for $\mu$ equal to 0.08 and about $36 \mathrm{~km}$ for $\mu$ equal to 0.05 . For bodies with heights of 100 and 50 $\mathrm{m}$ the modelled runout distances reach about $54 \mathrm{~km}(\mathrm{H}=100 \mathrm{~m})$ and $77 \mathrm{~km}(\mathrm{H}=50 \mathrm{~m})$ with only a minor influence of the $\mu$ value.

The simulations performed show that from a physical point of view it is possible to reproduce large runout distances for landslides such as those on the northern flank of Tenerife which include a subaqueous path. The incorporation of the hydroplaning mechanism makes theoretical models consistent with the occurrence of landslide deposits several tens of kilometres from the shore line. 


\subsection{Conclusions}

Once the volcano flank has collapsed, the failed mass generally transforms from a slow moving slide into a fast and mobile debris avalanche (Ui, 1983; Siebert, 1984). The model presented here represents a preliminary effort to simulate the mobility of such large landslides moving down the subaerial slopes of oceanic islands and continuing on the submarine slopes after entering the sea. The calculations include major simplifications but provide some new and important insights, specially regarding the submarine behaviour of the mass movement. The results indicate that the mobility of a landslide changes totally once it has entered a subaqueous medium. On one hand there exist drag forces acting to reduce the velocity and mobility of the sliding mass while on the other hand the hydroplaning effect acts to increase the runout distance. The resistance to sliding induced by drag forces depends chiefly on the length of the moving mass. The longer the block, the more runout will be produced. However, a block can be broken in smaller parts and can move apparently as a single unit. The results obtained from the model incorporating hydroplaning indicate that this effect will increase the runout distance considerably, doubling the mobility for small heights of the moving body. The height of the sliding mass seems to be the most important parameter influencing the propensity for hydroplaning and strongly influences the final runout distance of the slide. In contrast, the friction coefficient plays a minor role during the subaerial part of the slide path and does not significantly affect the mobility.

In addition to hydroplaning there exist other processes which might increase the mobility of large volcanic landslides and which are capable of incorporation into the model. The introduction of pore fluid pressures due to the interaction of ground or sea water, volcanic gases or fluids with the sliding mass should be considered in future calculations. Specially, the incorporation of a pore pressure dissipation term based on the consolidation theory proposed by Hutchinson (1986) may produce interesting insights. Moreover, the incorporation of a mass change during the slide is within the scope of our ongoing studies. Models with a changing landslide mass more accurately simulate the occurrence of depositional processes and yield runout distances several times greater than models with a constant mass (Van Gassen and Cruden, 1989).

In the case of the large volcanic landslides on the northern slopes of Tenerife the model presented provides an interesting framework to interpret the events in a consistent manner. The results indicate that a sliding mass initiated on the subaerial part of the island flank can advance great distances down the submarine slope and stop tens of kilometres away from the island at water depths exceeding $3000 \mathrm{~m}$. At least the model presented suggests that these runout distances are physically possible, and allows to understand the main parameters controlling the problem. However, verification of whether the large, punctual morphologic hights detected on the submarine north flank of Tenerife by bathymetric surveys are megablocks related to giant landslide events (Teide-Group, 1997) or features of submarine volcanism (Romero-Ruiz et al., 1998) requires additional geological and marine geophysical study. 


\section{CONCLUSIONS}

Large volcanic landslides are one of the most hazardous geological processes due to their immense volume and great mobility representing an enormous danger to the neighbouring population. Since the 1980 eruption and the associated debris avalanche of Mount St. Helens, hundreds of similar events have been recognised world-wide, both on continental volcanoes and volcanic islands. Recent studies show that large volcanic landslides are common processes during the evolution of volcanoes and that they have occurred at least 4 times each century during the last 500 years.

In the last two decades, many advances have been made in understanding the causes and mobility of large volcanic landslides. Several hypotheses concerning the potential causes of large volcanic landslides have been proposed, but interactions between the influencing factors and the stability of volcano slopes have not yet been resolved. Many different processes associated with the volcanic activity has been suggested as potential causes of volcano failures including dike intrusion, hydrothermal alteration, volcanic spreading, inflation or deflation of the magma chamber, caldera collapse events, accumulation of eruptive materials or seismic shocks. On the other hand, the slope angle, weak pyroclastic deposits and pore pressure changes have been proposed as additional agents favouring lateral collapses of volcanic edifices. All these assumptions, however, are normally based on qualitative analyses and a geotechnical approach requiring more quantitative information is still unusual.

In this study, a comprehensive geotechnical analysis of the large volcanic landslides occurred in the La Orotava valley has been carried out containing a site investigation, laboratory analysis, stability analysis and mobility analysis. The La Orotava valley is situated on the northern slopes of Tenerife and is the largest landslide amphitheatre on the island. During the last $3 \mathrm{Ma}$ the flanks of Tenerife have experienced several large-scale slope failures. The Orotava valley has been selected for analysis due to the large amount of available data concerning its structure and evolution. The approach used for this test site can be applied to other locations, and thus, general methodologies and results have also been derived in this thesis.

The site investigation has included a general study of the large volcanic landslides around the Canary Islands and an extensive geologic and morphologic analysis of the events that have formed the La Orotava valley. A total of seventeen lateral collapses have been detected around the Canarian archipelago during the last years. The study of these failures concludes that the structural axes and the climate strongly influence on their spatial distribution. Most of the amphitheatres are located perpendicular to the main structural axis or are limited by two axes and are situated in the wettest parts of the islands. Moreover, many landslide ages have been correlated with a significant descent of the sea water level.

On Tenerife, seven large-scale failures have been detected: two during the shield stage and five during the post-shield stage. Most of the events have taken place at the northern flanks generating a huge submarine debris apron with a total estimated volume of about $1000 \mathrm{~km}^{3}$. A temporal relationship between the landslide ages and the caldera collapse episodes in the central part of the island has been observed for at least two events indicating the destabilising influence of this volcanic process on the adjacent slopes.

The La Orotava valley is a huge landslide amphitheatre almost $10 \mathrm{~km}$ wide and up to $14 \mathrm{~km}$ long partly filled by postslide volcanic materials. The valley is bordered by high lateral walls and the Dorsal rift zone at its head. The site investigation has revealed that two different landslide events have generated the valley: one in the eastern sector and the other in the western sector. The thickness of the deposits involved into the failure is difficult to estimate due to the postslide materials filling the amphitheatre, but the analysis suggests a minimum depth of the slip surfaces of at least $500 \mathrm{~m}$ with a maximum value of up to $1000 \mathrm{~m}$. 
The results obtained from the site investigation show that several morphologic and geologic factors have significantly reduced the mechanical stability of the volcano flank prior to failure. A steep coastal cliff up to $500 \mathrm{~m}$ high formed by marine erosion and deep narrow canyons with depths exceeding $200 \mathrm{~m}$ created by fluvial erosion are the most important morphologic features and may have developed into the distal and lateral limits of the failures. The field survey carried out in the La Orotava valley has revealed that widespread residual soils (paleosols) might have been potential slip surfaces for large landslides. Red coloured residual soils are generally located at the top of pyroclastic deposits produced by explosive eruptions of phonolitic magmas. The flat tops of phonolitic pyroclastic deposits represent the only planar surfaces within the deposits composing the volcano slopes and the soil layers characterise the only weak deposit with regional extension. These soils are developed by weathering processes and later 'baked' by additional lava flows creating the particular bonded structure of the soil.

A residual soil sampled in the La Orotava valley has been broadly studied during the laboratory analysis. The mineralogical study of the soil using X-ray diffraction has shown a small amount of clay minerals and the analysis of the microstructure using electron microscopy has revealed a bonded/cemented structure. The soil can be classified as a porous, sandy-silty, no plastic soil with the standard USCS abbreviation, SM. The results of the geotechnical laboratory tests indicate a particular mechanical behaviour of the soil. During normal loading and/or shearing occurs a strong volumetric collapse, and a substantial reduction of the shear strength can be seen applying high normal stresses. However, the most important feature is the significant increase of the pore water pressure during undrained loading which generates a strong decrease of the material strength. Undrained conditions generally require both a fast loading mechanism and saturated conditions. Earthquakes, which are common processes in active volcanic areas, can cause fast loading and saturated soils can be generated by humid climate (e.g. La Orotava valley area is located in the wet part of the island).

The bonding of the residual soil may explain its particular mechanical behaviour. The bonded structure probably originates by a double thermal alteration and breaks at an effective stress of about 1 $\mathrm{MPa}$. Once the bonding is yielded, the soil acts as a sensitive material collapsing during undrained loading.

The laboratory tests have indicated that the residual soil layers are a perfect candidate for developing into slip surfaces of large volcanic landslides and that seismic shocks are the most suitable process triggering the initiation of the failure. Moreover, the distribution of landslide valleys on Tenerife, all of them being located in the humid parts of the island, suggests the importance of water as a destabilising agent.

During the stability analysis 2-dimensional and 3-dimensional models approximating the preslide conditions have been developed using global limit as well as continuum approaches. The sensitivity analyses carried out by the global limit approaches including both Limit Equilibrium Method and Upper Bound Method indicates that the conventional parameters such as the occurrence of weak materials (paleosols, pyroclastic layers, etc.) and hydrostatic pore pressure increments are insufficient to induce failures of large volcanic landslides. Thus, external mechanisms related to volcanic activity or volcanotectonic processes are necessary to cause failure.

The destabilising effects of three different mechanisms have been analysed. Average ground accelerations due to seismic shocks - including both tectonic earthquakes and volcano-tectonic seismic shocks produced along the ring fault during caldera collapse - , the horizontal stress due to dike intrusion and the vertical shear stress due to caldera collapse have been incorporated into the models. The results of the global limit analyses indicate that the average ground acceleration due to seismic shocks is the most important mechanism. The destabilising effects of horizontal stresses due to dike intrusion or vertical shear stresses caused by caldera collapse are of minor magnitude with the vertical shear stress being the less effective. The scale effect plays an important role and each of the three mechanisms strongly depends on the volume of the failing mass. In general, the larger the failure the stronger must be the destabilising influence of the external mechanism. At last, the position of the potential slip surface has been calculated for the assumed preslide conditions of the La Orotava valley. 
The most critical, circular-shaped slip surface calculated ends near the coastline in the offshore part and is characterised by an average depth of about 1 kilometre.

While the global limit analysis performs 'exact' values refering to slope stability, the continuum approaches achieve a global view of the stress field in the volcano flank. The continuum approaches applied in this study have been Finite Element Method and Finite Difference techniques. The results of these two approaches show the distinct effect of horizontal stresses owning to dike intrusion and vertical shear stresses due to caldera collapse on the mechanical stability of the volcano flank. Dike intrusion significantly affects the stress field of the entire onshore part of the slope, whereas caldera collapse only influences locally and in an inconsiderable magnitude. The distribution of shear stresses indicates that the most potential yielding zone due to dike intrusion is located at the upper part of the volcano flank starting at the surface and going down to a depth of almost 1 kilometre. Moreover, the importance of morphologic features such as deep, narrow canyons has been demonstrated using 3D modelling. The results indicate that these canyons not only reduce the lateral strength of the slope, but also create potential yielding zones at their base.

The stability analysis has indicated that ground acceleration due to seismic shocks is the most potential triggering mechanism. However, many other agents such as horizontal stress due to dike intrusion and geologic, morphologic or climatic features are necessary as preparing factors decreasing the global stability of the volcano flank prior to failure. The thickness of the failing mass may have reached $1000 \mathrm{~m}$ which is consistent with the results obtained from the site investigation.

The model presented in the mobility analysis represents a preliminary effort to simulate the mobility of large subaerial/submarine landslides. The great runout distances observed in such mass movements have been studied by the analysis of the friction between the moving mass and the slope, the drag force due to the water and the hydroplaning effect. The results indicate that the mobility of a landslide changes totally once it has entered a subaqueous medium. On one hand, there exist drag forces acting to reduce the velocity and mobility of the sliding mass, while on the other hand the hydroplaning effect acts to increase the runout distance. The results show that especially the hydroplaning strongly influences on the runout distance doubling the mobility for small heights of the moving body.

In the case of the large volcanic landslides on the northern slopes of Tenerife, the results indicate that a sliding mass initiated on the subaerial part of the island flank can advance great distances down the submarine slope and stop tens of kilometres away from the island at water depths exceeding $3000 \mathrm{~m}$. At least the model presented suggests that these runout distances inferred by the bathymetric data are physically possible, and allows to understand the main parameters controlling the problem.

Several key points can be given focussing on the large volcanic landslides occurred in La Orotava valley. The geotechnical analysis shows that a combination of several preparing factors and one final triggering mechanism may have caused the initiation of the large-scale failures. The preparing factors include geologic, morphologic, climatic and volcanological features, while the final triggering mechanisms is assumed to be a strong seismic shock originated by a caldera collapse.

The horizontal seaward stress caused by the active rift 'Dorsal Ridge' may have significantly destabilised the volcano flank. In addition, the existence of weak residual soil layers, deep narrow canyons, a high coastal cliff and a humid climate has strongly influenced on the mechanical stability. Other facts such as pore fluid pressures or hydrothermal alteration may have contributed to the decrease of slope stability. All these preparing factors have not only reduced the stability to critical condition, but have also prepared the limits of the failure.

Finally, strong ground accelerations probably caused during the catastrophic caldera collapse episode at the end of the Guajara cycle at about 0.56 Ma have surpassed the critical stability conditions and have initiated the large landslides. Volcano-tectonic seismic shocks generated by caldera collapse are perfect triggering mechanisms due to their large magnitude and vicinity to the volcano flank.

The results obtained from this study are not definitive, but should be considered in future models for predictions of catastrophic landslides. Many findings can be applied to other landslide events occurred 
on volcanic islands or terrestrial volcanoes, since saturated soils, erosive canyons, dike injection and seismic shocks are common features in many volcanic areas.

This work is preliminary step analysing the mechanisms of large volcanic landslides and the results are not definite. Further investigations concerning causes and mobility are necessary due to the potential danger to the neighbouring population and infrastructure.

The approaches described in this thesis should be applied to other test sites in order to check the validity of the results obtained from this study in a general sense.

Moreover, the geologic and morphologic analysis of the La Orotava valley should be continued and extended to the other amphitheatres on Tenerife. Additional field work would be necessary to improve the preslide conditions. The study of the slip surface is fundamental and efforts should be done to find it and to take samples of the material where failure took place. The slip surface can be found by a vertical drill hole or by an extensive study of the water galleries.

Many mechanisms influencing on the stability of volcano flanks have not been studied in this thesis or have only been analysed marginally. The generation of excess pore pressures due to dynamic loading and magma injection should be analysed numerically, and the laboratory results of this study ought to be incorporated into the calculations. On the other side, pore fluid vaporisation due to frictional heating along the slip surface should be studied in order to take into account the huge scale and overburden stress of large volcanic landslides.

The continuation of the mobility analysis is fundamental for hazard mapping. The model proposed in this study could be improved and a 3-dimensional approach should be worked out. A study of potential hazards caused by landslide induced tsunamis would be an additional inspiration for future investigation work. 


\section{REFERENCES}

ABAQUS (1996): ABAQUS/Standard User's manual. Rhode Island, Hibbit, Karlsson \& Sorensen, Inc.

Abdel-Monem, A., Watkins, N.D., and Gast, P.W. (1972): Potassium-Argon ages, volcanic stratigraphy and geomagnetic polarity history of the Canary Islands: Tenerife, La Palma and Hierro. American Journal of Science, v. 272, p. 805-825.

Abe, K. (1992): Seismicity of the caldera-making eruption of Mount Katmai, Alaska in 1912. Bulletin of the Seismological Society of America, v. 82, p. 175-191.

Ablay, G.J. (1997): Evolution of the Teide-Pico Viejo volcanic complex and magmatic system (Tenerife, Canary Islands). Bristol, University of Bristol, PhD thesis, $336 \mathrm{pp}$.

Ablay, G., and Kearey, P. (1999): Gravity constraints on the structure and volcanic evolution of Tenerife, Canary Islands. Journal of Geophysical Research, in press.

Ablay, G.J., and Hürlimann, M. (1999): Evolution of the north flank of Tenerife by recurrent giant landslides. Journal of Volcanology and Geothermal Research, accepted.

Ablay, G.J., and Martí, J. (1999): Structure, stratigraphy and volcanic evolution of the Pico Teide - Pico Viejo formation, Tenerife, Canary Islands. Journal of Volcanology and Geothermal Research, accepted.

Achilleos, E. (1988): User Guide for PCSTABL5M, Purdue University, Indiana, $131 \mathrm{pp}$.

Aki, K. (1984): Evidence for magma intrusion during the Mammoth Lakes earthquakes of May 1980 and implications of the absence of volcanic (harmonic) tremor. Journal of Geophysical Research, v. 89, p. 7689-7696.

Albini, P., and Vogt, J. (1992): Landslides and earthquakes in historical sources: case histories, French-Italian Conference on Slope Stability in seismic areas, Faccioli, E., and Peyer, E. (eds.), Bordighera, p. 11-24.

Ancochea, E., Fúster, J.M., Ibarrola, E., Cendrero, A., Coello, J., Hernan, F., Cantagrel, J.M., and Jamond, C. (1990): Volcanic evolution of the island of Tenerife (Canary Islands) in the light of new K-Ar data. Journal of Volcanology and Geothermal Research, v. 44, p. 231249.

Ancochea, E., Huertas, M.J., Cantagrel, J.M., Coello, J., Fúster, J.M., Arnaud, N., and Ibarrola, E. (1999): Evolution of the Cañadas edifice and its implications for the origin of the Cañadas Caldera (Tenerife, Canary Islands). Journal of Volcanology and Geothermal Research, v. 88, p. 177-199.

Araña, V. (1971): Litología y estructura del Edificio Cañadas, Tenerife (Islas Canarias). Estudios Geológicos, v. 27, p. 95-135.

in Martí, J., and Mitjavila, J. (eds.), A field guide to the central volcanic complex of Tenerife, Excmo. Cabildo Insular de Lanzarote, p. 3-17.

Atkinson, J. (1993): An Introdution to the Mechanics of Soils and Foundations. London, Mc Graw Hill.

Attewell, P.B., and Farmer, I.W. (1976): Principles of engineering geology. London, Chapman and Hall, 1045 pp.

Aversa, S., and Evangelista, A. (1998): The mechanical behaviour of a pyroclastic rock: yield strength and 'destruction' effects. Rock Mechanics and Rock Engineering, v. 31, p. 25-42.

Bauer, G.R., Fodor, R.V., Husler, J.W., and Keil, K. (1973): Contributions to the mineral chemistry of Hawaiian Rocks. Contributions to Mineralogy and Petrology, v. 40, p. 183194.

Begét, J.E., and Kienle, J. (1992): Cyclic formation of debris avalanches at Mount St. Augustine Volcano, Alaska. Nature, v. 356, p. 701-704.

Belloni, L.C. (1989): Invited contribution: Slope failure on the volcano 'el Reventador' in eastern Ecuador, XII International Conference on Soil Mechanics and Foundation Engineering, Rio de Janeiro, Balkema, v. 5, p. 2851-2852.

Belloni, L., and Morris, D. (1991): Earthquake induced shallow slides in volcanic debris soils. Géotechnique, v. 41, p. 539-551. 
Bishop, A.W. (1955): The use of the slip circle in the stability analysis of earth slopes. Geotechnique, v. 5, p. 7-17.

Blight, G.E. (1988): Construction in tropical soils, Second international conference on geomechanics in tropical soils, ICOTS (ed.), Singapore, Balkema, v. 2, p. 449-467.

Blight, G.E. (1997): Mechanics of residual soils. Rotterdam, Balkema, 237 pp.

BOE (1995): Ministerio de obras publicas, transportes y medio ambiente: Norma Sismorresistente. , p. 3935-3970.

Borgia, A. (1994): Dynamic basis of volcanic spreading. Journal of Geophysical Research, v. 99, p. 17791-17804.

Borgia, A., Burr, J., Montero, W., Morales, L.D., and Alvarado, G.E. (1990): Fault propagation folds induced by gravitational failure and slumping of the central Costa Rica Volcanic Range: implications for large terresrial and martial volcanic edifices. Journal of Geophysical Research, v. 95, p. 14,357-14,382.

Borgia, A., Ferrari, L., and Pasquarè, G. (1992): Importance of gravitational spreading in the tectonic and volcanic evolution of Mount Etna. Nature, v. 357, p. 231-235.

Bravo, T. (1962): El circo de Cañadas y sus dependencias. Boletin de la Real Sociedad Española de Historia Natural, v. 40, p. 93-108.

Bravo Bethencourt, J., and Bravo, T. (1989): Esquema geológico de la pared de Las Cañadas. in Araña, V., and Coello, J. (eds.), Los volcanes y la caldera del Parque nacional del Teide (Tenerife, Islas Canarias), Madrid, I.C.O.N.A, p. 85-100.

Bray, J.R. (1977): Pleistocene volcanism and glacial initiation. Science, v. 197, p. 251-254.

Brenner, R.P., Garga, V.K., and Blight, G.E. (1997): Shear strength behaviour and the measurement of shear strength in residual soils. in Blight, G.E. (ed.), Mechanics of residual soils, Rotterdam, Balkema, p. 237.

Bromhead, E.N. (1992): The stability of slopes, Blackie academic \& professional, $411 \mathrm{pp}$.

Bryan, S.E., Martí, J., and Kas, F.A.F. (1998): Stratigraphy of the Bandas del Sur Formation: an extracaldera record of Quaternary phonolitic explosive eruptions from the Las Cañadas edifice, Tenerife (Canary Islands). Geological Magazine, v. 135, p. 605-636.

Buch, L. (1825): Physikalische Beschreibung der Kanarischen Inseln. Berlin, 201 pp.

Buss, E., and Heim, A. (1882): Der Bergsturz von Elm. Zürich, Würster, 153 pp.

Camacho, A.G., Viera, R., and De Toro, C. (1991): Microgravimetric model of the Las Cañadas caldera (Tenerife). Journal of Volcanology and Geothermal Research, v. 47, p. 75-88.

Campbell, K.W., and Bozorgnia, Y. (1994): Near-source attenuation of peak horizontal acceleration from worldwide accelerograms recorded from 1957 1o 1993, Fifth U.S. National Conference on Earthquake Engineering, Institute, E.E.R. (ed.), Berkeley, California, v. 1, p. 283-292.

Canas, J.A., Pujades, L.G., Blanco, M.J., Soler, V., and Carracedo, J.C. (1995): Coda-Q distribution in the Canary Islands. Tectonophysics, v. 246, p. 245-261.

Cantagrel, J.M., Arnaud, N.O., Ancochea, E., Fúster, J., and Huertas, M.J. (1999): Repeated debris avalanches on Tenerife and genesis of Las Cañadas caldera wall (Canary Island). Geology, v. 27, p. 739-742.

Carracedo, J.C. (1975): Estudio paleomagnético de la Isla de Tenerife, PhD Thesis, Univ. Compultense de Madrid.

Carracedo, J.C. (1994): The Canary Island: an example of structural control on the growth of large oceanic-island volcanoes. Journal of Volcanology and Geothermal Research, v. 60, p. $225-241$.

Carracedo, J.C., Day, S.J., Guillou, H., and Gravestock, P. (1999): Later stages of volcanic evolution of La Palma, Canary Islands: Rift evolution, giant landslides, and the genesis of the Caldera de Taburiente. Geological Society of America Bulletin, v. 111, p. 755-768.

Chen, W.F. (1975): Limit analysis and soil plasticity. New York, Elsevier.

Cheung, C.K., Greenway, D.R., and Massey, J.B. (1988): Direct shear testing of a completely decomposed granite, Second international conference on geomechanics in tropical soils, ICOTS (ed.), Singapore, Balkema, v. 1, p. 109-117. 
Chevallier, L., and Bachelery, P. (1981): Evolution structurale du volcan actif du Piton de la Fournaise, Ile de la Réunion - Océan indien occidental. Bulletin of Volcanology, v. 44, p. 723-741.

Chevallier, L., and Verwoerd, W.J. (1988): A numerical model for the mechanical behavior of intraplate volcanoes. Journal of Geophysical Research, v. 93, p. 4182-4198.

Chorley, R.J. (1984): Geomorphology. London, Methuen \& Co. Ltd.

Clague, D.A., and Denlinger, R.P. (1994): Role of olivine cumulates in destabilizing the flanks of Hawaiian volcanoes. Bulletin of Volcanology, v. 56, p. 425-434.

Coello, J. (1973): Las series volcánicas de los subsuelos de Tenerife. Estudios Geologicos, v. 27, p. 95-137.

Coello, J., and Bravo, T. (1989): Correlación lito-estratigráfica de perforaciones (galerías) en la región central de Tenerife. in Araña, V., and Coello, J. (eds.), Los volcanes y la caldera del Parque nacional del Teide (Tenerife, Islas Canarias), Madrid, I.C.O.N.A, p. 359-383.

Corominas, J. (1995): Evidence of basal erosion and shearing as mechanisms contributing the development of lateral ridges in mudslides, flow-slides and other flow-like gravitational movements. Engineering Geology, v. 39, p. 45-70.

Corominas, J. (1996): The angle of reach as a mobility index for small and large landslides. Canadian Geotechnical Journal, v. 33, p. 260-271.

Crandell, D.R. (1971): Postglacial lahars from Mount Rainier volcano, Washington, U.S. Geological Survey Professional Paper 677, 73 pp.

Crowley, J.K., and Zimbelman, D.R. (1997): Mapping hydrothermally altered rocks on Mount Rainier, Washington, with Airborne Visible/Infrared Imaging Spectrometer (AVIRIS) data. Geology, v. 25, p. 559-562.

Crozier, M.J. (1992): Determination of palaeosesmicity from landslides, Landslides, Bell, D.H. (ed.), Christchurch, Balkema, v. 2, p. 1173-1180.

Custodio, E. (1989): Groundwater characteristics and problems in volcanic rock terrains, Isotope techniques in the study of the hydrology of fractured and fissured rocks, International Atomic Energy Agency, Panel Proceedings Series, v. 2, p. 87-137.

Davis, R.O., Smith, N.R., and Salt, G. (1990): Pore fluid frictional heating and stability of creeping landslides. Int. J. Numer. Analyt. Meth. Geomech., v. 14, p. 427-443.

Davis, S.N. (1969): Porosity and permeability of natural materials. in deWiest, J.R.M. (ed.), Flow through porous media, New York, Academic Press, p. 53-100.

Day, S.J. (1996): Hydrothermal pore fluid pressure and the stability of porous, permeable volcanoes. in McGuire, W.J., Jones, A.P., and Neuberg, J. (eds.), Volcano Instability on the Earth and Other Planets, Volume 110, London, Geological Society Special Publication, p. 77-93.

Day, S.J. (1997): unpublished data on the dike distribution along the Dorsal Ridge. .

Day, S.J., Carracedo, J.C., and Guillou, H. (1997): Age and geometry of an aborted rift flank collapse: the San Andres fault system, El Hierro, Canary Islands. Geological Magazine, v. 134, p. 523-537.

Delaney, P. (1982): Rapid intrusion of magma into wet rock:groundwater flow due to pore pressure increases. Journal of Geophysical Research, v. 87, p. 7739-7756.

Denlinger, R.P., and Okubo, P. (1995): Structure of the mobile south flank of Kilauea Volcano, Hawaii. Journal of Volcanology and Geothermal Researches, v. 100, p. 24499-24507.

Dieterich, J.H. (1988): Growth and persistence of Hawaiian volcanic rift zones. Journal of Geophysical Research, v. 93, p. 4258-4270.

Dikau, R., Brunsden, D., Schrott, L., and Ibsen, M.L. (1996): Landslide recognition: Identification, movement and causes. Chichester.

Dixon, J.B., and Weed, S.B. (1989): Minerals in soil environments. Madison,Wisconsin, Soil Science Society of America.

Donald, I.B., and Chen, Z. (1997): Slope stability analysis by the upper bound approach: fundamentals and methods. Canadian Geotechnical Journal, v. 34, p. 853-862.

Druitt, T., and Sparks, R.S.J. (1984): On the formation of calderas during ignimbrite eruptions. Nature, v. 310, p. 679-681. 
Duffield, W.A., Stieltjes, L., and Varet, J. (1982): Huge landslide blocks in the growth of Piton de la Fournaise, La Réunion, and Kilauea, Hawaii. Journal of Volcanology and Geothermal Research, v. 12, p. 147-160.

Duncan, M. (1992): State-of-the-art: Static stability and deformation analysis, Stability and performance of slopes and embarkments - II, Seed, R.B., and Boulanger, R.W. (eds.), v. 1, p. 222-266.

Dvorak, J.J., Okamura, A.T., English, T.T., Koyanagi, R.Y., Nakata, J.S., Sako, M.K., Tanigawa, W.T., and Yamashita, K.M. (1986): Mechanical response of the south flank of Kilauea volcano, Hawaii. Tectonophysics, v. 124, p. 193-209.

Dvorak, J.J., and Berrino, G. (1991): Recent ground movement and seismic activity in Campi Flegrei, Southern Italy: episodic growth of a resurgent dome. Journal of Geophysical Research, v. 96, p. 2309-2323.

Ecker, A. (1976): Groundwater behaviour in Tenerife, volcanic island (Canary Islands, Spain). Journal of Hydrology, v. 28, p. 73-86.

Eisbacher, G.H., and Clague, J.J. (1984): Destructive mass movements in high mountains: Hazard and management. Geological Survey of Canada, p. 84-16.

Eissler, H.K., and Kanamori, H. (1987): A single-force model for the 1975 Kalapana, Hawaii, earthquake. Journal of Geophysical Research, v. 92, p. 4827-4836.

Ekström, G. (1994): Anomalous earthquakes on volcano ring-fault structures. Earth and Planetary Science Letters, v. 128, p. 707-712.

Elsworth, D., and Voight, B. (1992): Theory of dike intrusion in a saturated porous solid. Journal of Geophysical Research, v. 96, p. 9105-9117.

Elsworth, D., and Voight, B. (1995): Dike intrusion as a trigger for large earthquakes and the failure of volcano flanks. Journal of Geophysical Research, v. 100, p. 6005-6024.

Elsworth, D., and Day, S.J. (1999): Flank collapse triggered by intrusion: The Canarian and Cape Verde archipelagoes. Journal of Volcanology and Geothermal Research, v. in press.

Endo, E.T., Malone, S.D., Noson, L.L., and Weaver, C.S. (1981): Locations, magnitudes and statistics of the march 20 - may 18 earthquake sequence. in Lipman, P.W., and Mullineaux, D.R. (eds.), The 1980 eruptions of Mount St. Helens, Washington, U. S. Geol. Survey Prof. 1250, p. 93-106.

ESRI (1998): User Manual Arc/Info, Version 7.2.1. Redlands.

Féraud, G., Giannérini, G., Campredon, R., and Stillman, C.J. (1985): Geochronology of some canarian dike swarms: contribution to the volcano-tectonic evolution of the archipelago. Journal of Geophysical Research, v. 25, p. 29-52.

Ferrucci, F. (1995): Seismic monitoring at active volcanoes. in McGuire, B., Kilburn, C.R.J., and Murray, J. (eds.), Monitoring active volcanoes, p. 60-92.

Filson, J., Simkin, T., and Leu, L.K. (1973): Seismicity of a caldera collapse: Galapagos Islands 1968. Journal of Geophysical Research, v. 78, p. 8591-8621.

Firth, C., Stewart, I., McGuire, W.J., Kershaw, S., and Vita-Finzi, C. (1996): Coastal elevation changes in eastern Sicily: implications for volcano instability at Mount Etna. in McGuire, W.J., Jones, A.P., and Neuberg, J. (eds.), Volcano Instability on the Earth and Other Planets, Volume 110, London, Geological Society Special Publication, p. 153-167.

Francis, P.W. (1994): Large volcanic debris avalanches in the central Andes., International conference on vocanic instability on the earth and other planets, Geological Society of London.

Frank, D. (1995): Surficial extent and conceptual model of hydrothermal system at Mount Rainier, Washington. Journal of Volcanology and Geothermal Research, v. 65, p. 51-80.

Fritsch, K., and Reiss, W. (1868): Geologische Beschreibung der Insel Tenerife. Winterthur, Switzerland, Wurster, $496 \mathrm{pp}$.

Funck, T., and Schmincke, H.U. (1998): Growth and destruction of Gran Canaria deduced from seismic reflection and bathymetric data. Journal of Geophysical Research, v. 103, p. 15393-15407.

Fúster, J.M., Araña, V., Brandle, J.L., Navarro, M., Alonso, U., and Aparicio, A. (1968): Geología y volcanología de las islas Canarias: Tenerife. Madrid, Instituto 'Lucas Mallada', CSIC, 218 pp. 
Fúster, J.M., Ibarrola, E., Snelling, N.J., Cantagrel, J.M., Huertas, M.J., Coello, J., and Ancochea, E. (1994): Cronología K-Ar de la Formación Cañadas en el sector Suroeste de Tenerife: Implicaciones de los episodios piroclásticos en la evolución volcánica. Boletin de la Real Sociedad Española de Historia Natural, v. 89, p. 25-41.

Garcia, M.O., and Hull, D.M. (1994): Turbidites from giant Hawaiian landslides: Results from Ocean Drilling Program Site 842. Geology, v. 22, p. 159-162.

García, L., Díez-Gil, J.L., and Araña, V. (1994): A large volcanic debris avalanche in the Pliocene Roque Nublo Stratovolcano, Gran Canaria, Canary Islands. Journal of Volcanology and Geothermal Research, v. 63, p. 217-229.

Garcia, J.O. (1999): Estudi de grans esllavissaments produïts en zones volcàniques. Aplicació a l'illa de Tenerife. Barcelona, Ms.Thesis, Technical University of Catalonia, $139 \mathrm{pp}$.

Gardner, C.A., Scott, K.M., Miller, C.D., Myers, B., Heldreth, W., and Pringle, P.T. (1995): Potential volcanic hazards from future activity of Mount Baker, Washington, USGS OpenFile Report 95-498.

Gee, M.J.R., Watts, A.B., Masson, D.G., and Mitchell, N.C. (1999): Seismic and sonar evidence for the catastrophic collapse of Hierro in the Canary Islands, EGS 1999, The Haag, p. Poster.

Gerrard, J. (1988): Rocks and landforms. London, Unwin Hyman Ltd.

Giresse, P. (1987): Quaternary sea-level changes on the Atlantic coast of Africa. in Tooley, M.J., and Shennan, I. (eds.), Sea-level changes, Oxford, Blackwell, p. 249-275.

Glicken, H. (1996): Rockslide-Debris Avalanche of May 18, 1980, Mount St. Helens Volcano, Washington, USGS Open-File Report 96-677.

Goguel, J. (1978): Scale-dependent rockslide mechanisms, with emphasis on the role of pore fluid vaporization. in Voight, B. (ed.), Rockslides and avalanches - 1: Natural phenomena, Amsterdam, Elsevier, p. 693-705.

Gonzalez de Vallejo, L.I., Jiménez Salas, J.A., and Leguey Jiménez, S. (1981): Engineering geology of the tropical volcanic soils of La Laguna, Tenerife. Engeneering Geology, v. 17, p. 1-17.

Goodman, R.E. (1989): Introduction to rock mechanics, John Wiley \& Sons, 562 pp.

Gorshkov, G.S. (1959): Gigantic eruption of the volcano Banzymianny, Bulletin of Volcanology, v. 21, p. 77-109 .

Gorshkov, G.S., and Dubik, Y.M. (1970): Gigantic directed blast at Shiveluch Volcano (Kamchatka). Bulletin of Volcanology, v. 34, p. 261-288.

Gründel, S. (1999): Geotechnical hazards shown by the example of large landslides on a volcanic island like Tenerife. Ms. thesis, Technical University of Catalonia, $55 \mathrm{pp}$.

Gudmundsson, A. (1988): Effect of tensile stress concentration around magma chambers on intrusion and extrusion. Journal of Volcanology and Geothermal Research, v. 35, p. 179194.

Gudmundsson, A. (1990): Emplacement of dikes, sills and crustal magma chambers at divergent plate boundaries. Tectonophysics, v. 176, p. 257-275.

Gudmundsson, A., Martí, J., and Turon, E. (1997): Stress fields generating ring faults in volcanoes. Geophysical research letters, v. 24, p. 1559-1526.

Gudmundsson, A., Marinoni, L.B., and Martí, J. (1999): Injection and arrest of dykes: implications for volcanic hazards. Journal of Volcanology and Geothermal Research, v. 88, p. $1-13$.

Habib, P. (1976): Production of gaseous pore pressure during rock slides. Rock Mechanics, v. 7, p. 193-197.

Hampton, M.A., Lee, H.J., and Locat, J. (1996): Submarine landslides. Review of Geophysics, v. 34, p. 33-59.

Haq, B.U., Hardenbol, J., and Vail, P.R. (1987): Chronology of fluctuating sea levels since the Triassic. Science, v. 235, p. 1156-1167.

Harp, E.L., and Jipson, R.W. (1996): Landslides triggered by the 1994 Northridge, California, Earthquake. Bulletin of the Seismological Society of America, v. 86, p. S319-S332.

Harrison, J.V., and Falcon, N.L. (1937): The Saidmarreh landslip, southwest Iran. Geogr. J., v. 89, p. 42-47. 
Hausen, H. (1956): Contributions to the geology of Tenerife. Soc. Sci. Fennica Com. Phys. Math., v. 18, p. 1-247.

Heiken, G., and Wohletz, K. (1985): Volcanic ash. Berkeley, University of California Press, 246 pp.

Heim, A. (1932): Bergsturz und Menschenleben. Zürich, Fretz \& Wasmuth Verlag, 218 pp.

Hermanns, R.L., and Strecker, M.R. (1999): Structural and lithological controls on large Quarternary rock avalanches (sturzstroms) in arid northwestern Argentina. Geological Society of America Bulletin, v. 111, p. 934-948.

Hildreth, W. (1983): The compositionally zoned eruption of 1912 in the Valley of Ten Thousand Smokes, Katmai National Park, Alaska. Journal of Volcanology and Geothermal Research, v. 18, p. 1-56.

Hirn, A., Lépine, J.C., Sapin, M., and Delorme, H. (1991): Episodes of pit-crater collapse documented by seismology at Piton de la Fournaise. Journal of Volcanology and Geothermal Research, v. 47, p. 89-104.

Hobbs, P.R., Culshaw, M.G., Northmore, K.J., Rachlan, A., and Entwisle, D.C. (1988): Preliminary consolidation and triaxial test results for some undisturbed tropical red clay soils from West Java, Indonesia, Second international conference on geomechanics in tropical soils, ICOTS (ed.), Singapore, Balkema, v. 1, p. 149-156.

Hoblitt, R.P., Miller, C.D., and Scott, W.E. (1997): Volcanic Hazards with Regard to Siting Nuclear-Power Plants in the Pacific Northwest, USGS Open-File Report 87-297.

Hoek, E., and Bray, J.W. (1981): Rock slope engineering. London, E \& FN Spon, 358 pp.

Holcomb, R.T., and Searle, R.C. (1991): Large landslides from oceanic volcanoes. Marine Geotechnology, v. 10, p. 19-32.

Howard, K. (1973): Avalanche mode of motion. implications from lunar examples. Science, v. 108, p. 1052-1055.

Hsü, K. (1975): Catastrophic debris streams (Sturzstroms) generated by rock falls. Geological Society of America Bulletin, v. 86, p. 129-140.

Huertas, M.J., Ancochea, E., Cantagrel, J.M., Coello, J., Fúster, J.M., and Ibarrola, E. (1994): Un episodio volcánico pre-Cañadas en la Isla de Tenerife. Geogaceta, v. 15, p. 113-116.

Hürlimann, M., Ledesma, A., and Martí, J. (1997): Analysis of large landslides triggered by volcanic activity. Application to Tenerife (Canary Islands), III Conf. of IAMG, Pawlowsky-Glahn, V. (ed.), Barcelona, CIMNE, p. 274-279.

Hürlimann, M., Garcia, J.O., and Ledesma, A. (1999a): Causes and mobility of large volcanic landslides: Application to Tenerife, Canary Islands. Journal of Volcanology and Geothermal Research, v. in press.

Hürlimann, M., Ledesma, A., and Martí, J. (1999b): Conditions favouring catastrophic landslides on Tenerife (Canary Islands). Terra Nova, v. in press.

Hürlimann, M., Martí, J., and Ledesma, A. (1999c): Catastrophic volcanic landslides triggered by caldera collapse. Geology, v. submitted.

Hürlimann, M., Turon, E., and Martí, J. (1999d): Large landslides triggered by caldera collapse events in Tenerife, Canary Islands. Physics and Chemistry of the Earth, v. in press.

Hutchinson, J.N. (1986): A sliding-consolidation model for flow slides. Canadian Geotechnical Journal, v. 23, p. 115-126.

Ibarrola, E., Ancochea, E., Fúster, J.M., Cantagrel, J.M., Coello, J., Snelling, N.J., and Huertal, M.J. (1993): Cronoestratigrafía del Macizo de Tigaiga: Evolución de un sector del edificio Cañadas (Tenerife, Islas Canarias). Bol. R. Soc. Esp. Hist. Nat., v. 88, p. 57-72.

IGME (1988a): Geological maps of Spain 1:25.000. Sheets 1103-II, 1103-III, 1104-III, 1110-I, 1110-II, 1110-IV, 1111-IV/I. Madrid, IGME.

IGME (1988b): Mapa Geológico de España 1:25.000. Puerto de la Cruz (hoja 1103-II). Madrid, IGME, $90 \mathrm{pp}$.

Inokuchi, T. (1988): Gigantic landslides and debris avalanches on volcanoes in Japan, Kagoshima International conference on Volcanoes, Japan, National Institute for Research Administartion, p. 456-459.

Instituto Geográfico Nacional (1988): Satellite Image of the Canary Islands. 
ITASCA (1995): FLAC - Fast lagrangian analysis of continua. Minneapolis, USA, ITASCA Consulting Group, INC.

Iverson, R.M. (1995): Can magma-injection and groundwater forces cause massive landslides on Hawaiian volcanoes? Journal of Volcanology and Geothermal Research, v. 66, p. 295308.

Iverson, R.M., Reid, M.E., and LaHusen, R.G. (1997): Debris-flow mobilization from landslides. Annual Rev. Earth Planet. Sci., v. 25, p. 85-138.

Jibson, R.W., and Keefer, D.K. (1993): Analysis of the seismic origin of landslides: Examples from the New Madrid seismic zone. Geological Society of America Bulletin, v. 105, p. 521-536.

Jiménez, J.A. (1963): Note on a halloysite red clay from Fernando Poo Island, III Regional Conference Africa on Soil Mechanics, Salisbury, v. 1, p. 85-88.

Johnson, R. (1987): Large-scale volcanic cone collapse: the 1888 slope failure of Ritter volcano, and other examples from Papua New Guinea. Bulletin of Volcanology, v. 49, p. 669-679.

Julian, B.R. (1983): Evidence for dyke intrusion earthquake mechanisms near Long Valley caldera, California. Nature, v. 303, p. 323-325.

Keefer, D.K. (1984): Landslides caused by earthquakes. Geological Society of America Bulletin, v. 95, p. 406-421.

Kitamura, R., Haruyama, M., Jitousono, T., and Nakamura, J. (1988): Slope stability in volcanic soil based on its mechanical and physico-chemical characteristics, $\mathrm{X}$ Conference on Landslides, Bonnard, C. (ed.), Lausanne, Balkema, v. 1, p. 199-203.

Koizumi, Y., and Ito, K. (1963): Compressibility of a certain volcanic clay. Soils and foundations, v. 3, p. 37-48.

Kokelaar, P., and Romagnoli, C. (1995): Sector collapse, sedimentation and clast population evolution at an active island-arc volcano: Stromboli, Italy. Bulletin of Volcanology, v. 57, p. 240-262.

Kramer, S.L. (1996): Geotechnical earthquake engineering. New Jersey, Prentice-Hall, 653 pp.

Labazuy, P. (1996): Recurrent landslides events on the submarine flank of Piton de la Fournaise volcano (Reunion Island). in McGuire, W.J., Jones, A.P., and Neuberg, J. (eds.), Volcano Instability on the Earth and Other Planets, Volume 110, London, Geological Society Special Publication, p. 295-306.

Lambe, T.W., and Whitman, R.V. (1979): Soil mechanics. New York, Wiley, 553 pp.

Lénat, J.F., Vincent, P., and Bachèlery, P. (1989): The off-shore continuation of an active basaltic volcano: Piton de la Fournaise (Réunion Island, Indian Ocean); structural and geomorphological interpretation from sea beam mapping. Journal of Volcanology and Geothermal Research, v. 36, p. 1-36.

Leroueil, S., and Vaughan, P.R. (1990): The general and congruent effects of structure in natural soils and weak rocks. Géotechnique, v. 40, p. 467-488.

Lietz, J., and Schmincke, H.U. (1975): Miocene-Pliocene sea-level changes and volcanic phases on Gran Canaria (Canary Islands) in the light of new K-Ar ages. Paleogeography, Paleoclimatology, Paleoecology, v. 18, p. 213-239.

Lipman, P.W. (1976): Caldera-Collapse breccias in the western San juan Mountains, Colorado. Geological Society of America Bulletin, v. 87, p. 1397-1410.

Lipman, P.W., and Mullineaux, D.R. (1981): The 1980 eruptions of Mount St. Helens, Washington, U. S. Geol. Survey Prof. 1250, 844 pp.

Lipman, P.W., Normark, W.R., Moore, J.G., Wilson, J.B., and Gutmacher, C.E. (1988): The giant submarine Alika debris slide, Mauna Loa, Hawaii. Journal of Geophysical Research, v. 93, p. 4279-4299.

Lo Giudice, E., and Rasa, R. (1992): Very shallow earthquakes and brittle deformation in active volcanic areas. The Etnean region as an example. Tectonophysics, v. 202, p. 257-268.

Lomoschitz, A. (1995): Análisis del origen y evolución de la depresión de Tirajana, Gran Canaria. Barcelona, Technical University of Catalonia, PhD thesis, $203 \mathrm{pp}$.

López, D.L., and Williams, S.N. (1993): Catastrophic volcanic collapse: Relation to hydrothermal processes. Science, v. 260, p. 1794-1796.

Lyell, C.H. (1855): A manual of elementary geology. London, Murray, 655 pp. 
Maccarini, M. (1987): Laboratory studies of a weakly bonded artificial soil. $\mathrm{PhD}$ thesis, Imperial College, University of London.

Maccarini, M. (1993): A comparison of direct shear box tests with triaxial compression tests for a residual soil. Geotechnical and Geological Engineering, v. 11, p. 69-80.

Maccarini, M., Teixeira, V.H., and Triches, G. (1989): Bonding properties of a residual soil derived from diabase, XII International Conference on Soil Mechanics and Foundation Engineering, Rio de Janeiro, Balkema, v. 1, p. 525-528.

Mark, R.K., and Moore, J. (1987): Slopes of the Hawaiian ridge. U.S.Geol.Surv.,Prof.Pap., v. 1350, p. 101-107.

Martí, J. (1998): Comment on 'A giant landslide on the north flank of Tenerife, Canary Islands' by A. B. Watts and D. G. Masson. Journal of Geophysical Research, v. 103, p. 9945-9947.

Martí, J., Mitjavila, J., and Araña, V. (1994): Stratigraphy, structure and geochronology of the Geological Magazine, v. 131, p. 715-727.

Martí, J., Ablay, G.J., and Bryan, S. (1996): Comment on " The Canary Islands : an example of structural control on the growth of large oceanic-island volcanoes" by J.C. Carracedo. Journal of Volcanology and Geothermal Research, v. 72, p. 143-149.

Martí, J., Hürlimann, M., Ablay, G.J., and Gudmundsson, A. (1997): Vertical and lateral collapses on Tenerife (Canary Islands) and other volcanic ocean islands. Geology, v. 25, p. 879-882.

Marzol, J. (1988): La lluvia, un recurso natural para Canarias, Confederación de Cajas de Ahorros, Caja Canaria, 220 pp.

Masson, D.G. (1996): Catastrophic collapse of the volcanic island of Hierro $15 \mathrm{Ka}$ ago and the history of landslides in the canary Islands. Geology, v. 24, p. 231-234.

Mathews, W.H., and McTaggart, K.C. (1978): Hope rockslides, British Columbia, Canada. in Voight, B. (ed.), Rockslides and avalanches - 1: Natural phenomena, Amsterdam, Elsevier, p. 259-275.

McGuire, W.J. (1996a): Sea-level change and the stability and activity of coastal and island volcanoes. in Barberi, F., Casale, R., and Fantechi, R. (eds.), The mitigation of volcanic hazards, Brussels, Office for Official Publication of the European Communities, p. 341363.

McGuire, W.J. (1996b): Volcano instability: a review of contemporary themes. in McGuire, W.J., Jones, A.P., and Neuberg, J. (eds.), Volcano Instability on the Earth and Other Planets, Volume 110, London, Geological Society Special Publication, p. 1-23.

McGuire, W.J., and Pullen, A.D. (1989): Location and orientation of eruptive fissures and feeder-dykes at Mount Etna; influence of gravitational and regional tectonic stress regimes. Journal of Volcanology and Geothermal Research, v. 38, p. 325-344.

McGuire, W.J., Pullen, A.D., and Saunders, S.J. (1990): Recent dyke-induced large-scale block movement at Mount Etna and potential slope failure. Nature, v. 343, p. 357-359.

McGuire, W.J., Murray, J.B., Pullen, A.D., and Saunders, S.J. (1991): Ground deformation monitoring at Mt Etna evidence for dyke emplacement and slope instability. Journal Geological Society London, v. 148, p. 557-583.

McGuire, W.J., Howarth, R.J., Firth, C.R., Solow, A.R., Pullen, A.D., Saunders, S.J., Stewart, I.S., and Vita-Finzi, C. (1997): Correlation between rate of sea-level change and frequency of explosive volcanism in the Mediterranean. Nature, v. 389, p. 473-476.

Meco, J., Petit-Maire, N., and Reyss, J.L. (1992): The Canary Islands current during isotopic stage 5 , as implied by fauna of a marine terrace at Fuerteventura. C. R. Acad. Sci. Paris, v. 314 , p. 203-208.

Melosh, H.J. (1979): Acoustic fluidization: a new geologic process? Journal of Geophysical Research, v. 84, p. 8097-8113.

Mezcua, J., Buforn, E., Udías, A., and Rueda, J. (1992): Seismotectonics of the Canary Islands. Tectonophysics, v. 208, p. 447-452.

Millot, G. (1970): Geology of clays. New York, Springer-Verlag, 429 pp.

Mitjavila, J.M., and Villa, I.M. (1993): Temporal evolution of Diego Hernández formation (Las Cañadas, Tenerife) and confirmation of the age of the Caldera using the ${ }^{40} \mathrm{Ar} /{ }^{39} \mathrm{Ar}$ method. Revista de la Sociedad Geológica de España, v. 6, p. 61-65. 
Mohrig, D., Whipple, K.X., Hondzo, M., Ellis, C., and Parker, G. (1998): Hydroplaning of subaqueous debris flows. Geological Society of America Bulletin, v. 110, p. 387-394.

Montalto, A., Vicinguerra, S., Menza, S., and Patane, G. (1996): Recent seismicity of Mount Etna: implications for flank instability. in McGuire, W.J., Jones, A.P., and Neuberg, J. (eds.), Volcano Instability on the Earth and Other Planets, Volume 110, London, Geological Society Special Publication, p. 169-177.

Moon, V.G. (1993a): Geotechnical characteristics of ignimbrite: A soft pyroclastic rock type. Engineering Geology, v. 35, p. 33-48.

Moon, V.G. (1993b): Microstructural control on the geomechanical behaviour of ignimbrite. Engineering Geology, v. 35, p. 19-31.

Moore, J.G. (1964): Giant submarine landslides on the Hawaian Ridge, U.S. Geol. Surv. Prof. Pap., 501D, D95-D98.

Moore, J.G., and Albee, W.C. (1981): Topographic and structural changes, March-July 1980 photogrammetric data. U.S. Geol. Surf. Prof. Pap., v. 1250, p. 123-134.

Moore, J.G., Clague, D.A., Holcomb, R.T., Lipman, P.W., Normark, W.R., and Torresan, M.E. (1989): Prodigious submarine landslides on the Hawaiian Ridge. Journal of Geophysical Research, v. 94, p. 17465-17484.

Moore, J.G., Normark, W.R., and Holcomb, R.T. (1994): Giant Hawaiian landslides. Annual Review Earth Planet, v. 22, p. 119-144.

Moore, J.G., Bryan, W.B., Beeson, M.H., and Normark, W.R. (1995): Giant blocks in the South Kona landslide, Hawaii. Geology, v. 23, p. 125-128.

Moriya, I. (1980): 'Bandaian eruption' and landforms associated with it. Collection of articles in memory of retirement of Prof. K. Nishimura from Tohoku Univ., p. 214-219.

Mothes, P.A., Hall, M.L., and Janda, R.J. (1998): The enormous Cillos Valley Lahar: an ashflow-generated debris flow from the Cotopaxi Volcano, Ecuador. Bulletin of Volcanology, v. 59 , p. $233-244$.

Navarro, J.M. (1998): personal communication. .

Navarro, J.M., and Coello, J. (1989): Depressions originated by landslide processes in Tenerife. Abstract ESF Meeting on Canarian Volcanism, p. 150-152.

Navarro, J.M., and Braojos, J.J. (1991): Criteria for hydraulic resources planning, Tenerife Island. Tenerife, Gobierno de Canarias, $66 \mathrm{pp}$.

Newmark, N.M. (1965): Effects of earthquakes on dams and embankments. Géotechnique, v. 15 , p. $139-160$.

Nicoletti, P.G. (1991): Rock-avalanche risk at Platí, Southern Italy, Landslides, Bell (ed.), Christchurch, Balkema, p. 1031-1036.

Nunn, P.D. (1995): Oceanic islands. Oxford, Blackwell Publishers, 413 pp.

Okada, H. (1983): Comparative study of earthquake swarms associated with major volcanic activities. in Shimozurur, D., and Yokoyama, I. (eds.), Arc Volcanism, Tokyo, Terra Scientific Publishing Company, p. 43-61.

Okamoto, S. (1984): Intoduction to earthquake engineering. University of Tokyo Press, $629 \mathrm{pp}$.

Okimura, T., Yamagami, T., and Ugai, K. (1996): Slope failures during the 1995 Southern Hyogo Earthquake in Japan, Landslides, Senneset, K. (ed.), Trondheim, alkema, A. A., Rotterdam, v. 2, p. 1013-1018.

O'Leary, D.W. (1991): Structure and morphology of submarine slab slides: Clues to origin and behaviour. Marine Geotechnology, v. 10, p. 53-69.

O'Rourke, T.D., and Crespo, E. (1988): Geotechnical properties of cemented volcanic soil. Journal of Geotechnical Engineering, ASCE, v. 114, p. 1126-1147.

Palacios, D. (1989): Caracteres geomórfologicos del sector occidental del macizo de Tigaiga (Tenerife). Anales Geogr. Univ. Compultense, v. 9, p. 169-184.

Palacios, D. (1990): Depósitos torrenciales y caracteres geomorphológicos generales en el Socorro, Los Realejos, Tenerife. Boletin de la Real Sociedad Española de Historia Natural, p. 69-82.

Palacios, D. (1994): The origin of certain wide valleys in the Canary Islands. Geomorphology, v. 9 , p. 1-18. 
Paul, A., and Gratier, J.P. (1987): A Numerical Model for Simulating Deformation of Mount St.Helens Volcano. Journal of Geophysical Research, v. 92, p. 10299-10312.

Pearce, A.J., and O'Loughlin, C.L. (1985): Landsliding during a M 7.7 earthquake: Influence of geology and topography. Geology, v. 13, p. 855-858.

Petley, D.N., and Allison, R.J. (1997): The mechanics of deep-seated landslides. Earth surface processes and landforms, v. 22, p. 747-758.

Pierson, T.C., and Janda, R.J. (1994): Volcanic mixed avalanches: A distinct eruption-triggered mass-flow process at snow-clad volcanoes. Geological Society of America Bulletin, v. 106, p. 1351-1358.

Plafker, G., and Ericksen, G.E. (1978): Nevados Huascarán avalanches, Peru. in Voigt, B. (ed.), Rockslides and avalanches - 1: Natural phenomena, Amsterdam, Elsevier, p. 277-314.

Ridley, W.I. (1971): The origin of some collapse structures in the Canary Islands. Geology Magazine, v. 108, p. 477-184.

Rippa, F. (1997): A description of pyroclastic soils that buried Pompeii and Herculaneum in A.D. 79, Geotechnical Engineering for the Preservation of Monuments and Historic Sites, Viggiani (ed.), Balkema, p. 261-270.

Romagnoli, C., and Tibaldi, A. (1994): Volcanic collapse in different tectonic setting: an example from the Aeolian Arc, Italy, International conference on vocanic instability on the earth and other planets, Geological Society of London.

Romero-Ruiz, C., García-Cacho, L., Araña, V., and Yanes-Luque, A. (1998): Submarine volcanism surrounding Tenerife, Canary Islands, Geology and Geophysics of Tenerife, p. 18.

Roobol, M.J., Wright, J.V., and Smith, A.L. (1983): Calderas or gravity-slide structures in the Lesser Antilles island arc? Journal of Volcanology and Geothermal Research, v. 19, p. 121134.

Rouse, W.C., Reading, A.J., and Walsh, R.P.D. (1986): Volcanic soil properties in Dominica, West Indies. Engineering Geology, v. 23, p. 1-28.

Rubin, A., and Pollard, D. (1987): Origins of blade-like dikes in volcanic rift zones. in Decker, R.W., Wright, T.L., and Stauffer, P.H. (eds.), Volcanism in Hawaii, U.S.Geol.Surv. Prof. Paper 1350, p. 1449-1470.

Ruddock, E.C. (1967): Residual soils of the Kumasi district in Ghana. Géotechnique, v. 17, p. 359-377.

Russo, G., Gilberti, G., and Sartoris, G. (1996): The influence of regional stresses on the mechanical stability of volcanoes: Stromboli (Italy). in McGuire, W.J., Jones, A.P., and Neuberg, J. (eds.), Volcano Instability on the Earth and Other Planets, Volume 110, London, Geological Society Special Publication, p. 65-75.

Russo, G., Giberti, G., and Sartoris, G. (1997): Numerical modeling of surface deformation and mechanical stability of Vesuvius volcano, Italy. Journal of Geophysical Research, v. 102, p. 24785-24800.

Sassa, K. (1988): Special lecture: Geotechnical model for the motion of landslides, International Symposium on Landslides, Bonnard, C. (ed.), Lausanne, Balkema, v. 1, p. 37-55.

Sassa, K. (1992): Landslide volume - Apparent friction relationship in the case of rapid loading on alluvial deposits. Landslides News, v. 6, p. 16-18.

Scholz, C.H. (1990): The mechanics of earthquakes and faulting. Cambridge, Cambridge University Press, $439 \mathrm{pp}$.

Schuster, R.L., Logan, R.L., and Pringle, P.T. (1992): Prehistoric rock avalanches in the Olympic Mountains, Washington. Science, v. 258, p. 1620-1621.

Seed, H.B. (1979): Considerations in the earthquake-resistant design of earth and rockfill dams. Géotechnique, v. 29, p. 213-263.

Selby, M.J. (1985): Landforms of the Subtropics and Tropics, Earth's Changing Surface, Oxford, Clarendon, p. 547-575.

Semet, M.P., and Boudon, G. (1994): Large scale collapse sructure at Piton du Carbet, Martinique: geological and petrological constraints, International conference on vocanic instability on the earth and other planets, Geological Society of London. 
Serrano, A. (1976): Aglomerados volcánicos en las Islas Canarias, Simposio Nacional sobre rocas blandas, Madrid, SRB, v. 2, p. 47-53.

Servicio de Planificación Hidráulica (1991): Plan hidrológico insular de Tenerife. Tenerife, Gobierno de Canarias, unpublished data.

Servicio de Planificación Hidráulica (1992): Ejecución de dos Sondeos de gran diámetro en Las Cañadas del Teide, Informe No. 2, Cabildo Insular de Tenerife.

Servicio de Planificación Hidráulica (1994): Zona Las Cañadas del Teide, Sondeos C-1, C-2 \& C-3. Obra: SPA-15, Cabildo Insular de Tenerife.

Shreve, R.L. (1968): The Blackhawk landslide. Geological Society of America, Special Paper, v. 108.

Siebert, L. (1984): Large volcanic debris avalanches: characteristics of source areas, deposits, and associated eruptions. Journal of Volcanology and Geothermal Research, v. 22, p. 163197.

Siebert, L. (1992): Threats from debris avalanches. Nature, v. 356, p. 658-659.

Siebert, L., Glicken, H., and Ui, T. (1987): Volcanic hazards from Bezymianny and Bandai-type eruptions. Bulletin of Volcanology, v. 49, p. 435-459.

Siebert, L., Begét, J.E., and Glicken, H. (1995): The 1883 and late-prehistoric eruptions of Augustine volcano, Alaska. Journal of Volcanology and Geothermal Research, v. 66, p. 367-395.

Skempton, A.W. (1966): Bedding-plane slip, residual strength and the Vaiont landslide. Géotechnique, v. 16, p. 82-84.

Skempton, A.W. (1985): Residual strength of clays in landslides, folded strata and the laboratory. Géotechnique, v. 35, p. 3-18.

Soler, C. (1997): Gigantescos deslizamientos en islas volcánicas y su repercusión en la hidrogeología insular, IV Simposio nacional sobre taludes y laderas inestables, Granada, p. 325-337.

Sridharan, A. (1988): Engineering properties of tropical soils, Second international conference on geomechanics in tropical soils, ICOTS (ed.), Singapore, Balkema, v. 2, p. 527-535.

Streeter, V., and Wylie, B. (1986): Fluid mechanics. USA, McGraw-Hill, Inc., 595 pp.

Sudhakar, R.M. (1995): Mechanistic approach to the shear strength behaviour of allophanic soils. Engineering Geology, v. 40, p. 215-221.

Teide-Group (1997): Morphometric interpretation of the northwest and southeast slopes of Tenerife, Canary Islands. Journal of Geophysical Research, v. 102, p. 20325-20342.

Terzaghi, K., and Peck, R.B. (1967): Soil mechanics in engineering practice. New York, John Wiley and Sons.

Thrall, F.G., and Bell, J.R. (1989): Predicting properties of young volcanic soils, XII International Conference on Soil Mechanics and Foundation Engineering, Rio de Janeiro, Balkema, v. 1, p. 555-558.

Tibaldi, A., Ferrari, L., and Pasquarè, G. (1995): Landslides triggered by earthquakes and their relations with faults and mountain slope geometry: an example from Ecuador. Geomorphology, v. 11, p. 215-226.

Tika, T.A., and Hutchinson, J.N. (1999): Ring shear tests on soil from the Vaiont landslide slip surface. Géotechnique, v. 49, p. 59-74.

Turner, A.K., and Schuster, R.L. (1996): Landslides: investigation and mitigration, National academy of Sciences, USA.

Ui, T. (1983): Volcanic dry avalanche deposits - identification and comparison with non volcanic debris stream deposits. Journal of Volcanology and Geothermal Research, v. 18, p. $135-150$.

Ui, T., Yamamoto, H., and Suzuki-Kamata, K. (1986): Characterization of debris avalanche deposits in Japan. Journal of Volcanology and Geothermal Research, v. 29, p. 231-243.

Urgeles, R., Canals, M., Baraza, J., Alonso, B., and Masson, D. (1997): The most recent megalandslides of the Canary Islands: El Golfo debris avalanche and Canary debris flow, west El Hierro Island. Journal of Geophysical Research, v. 102, p. 20305-20323. 
Urgeles, R., Masson, D.G., Canals, M., Watts, T., and Le Bas, T. (1999): Recurrent giant landslides on the west flank of La Palma, Canary Island. Journal of Geophysical Research, v. in press.

Uriel, S., and Serrano, A.A. (1973): Geotechnical properties of two collapsable soils of low bulk density at the site of two dams in Canary Islands, Spain, Eight International Conference on Soil Mechanics and Foundation Engineering, Moscow, v. 2.2, p. 257-264.

Uriel, S., and Serrano, A. (1974): Propiedades geotécnicas de dos suelos volcánicos colapsibles de baja densidad en la cimentación de dos presas en las Islas Canarias (España). Boletín de información laboratorio del transporte y mecánica del suelo, v. 105, p. 21-28.

Vallance, J.W., and Scott, K.M. (1997): The Osceola mudflow from Mount Rainier: Sedimentology and hazards implications of a huge clay-rich debris flow. Geological Society of America Bulletin, v. 109, p. 143-163.

Van Gassen, W., and Cruden, D.M. (1989): Momentum transfer and friction in the debris of rock avalanches. Canadian Geotechnical Journal, v. 26, p. 623-628.

Van Wyk de Vries, B., and Merle, O. (1996): The effect of volcanic constructs on rift fault patterns. Geology, v. 24, p. 643-646.

Van Wyk de Vries, B., and Francis, P.W. (1997): Catastrophic collapse at stratovolcanoes induced by gradual volcano spreading. Nature, v. 387, p. 387-390.

Van Wyk de Vries, B., and Metala, R. (1998): Styles of volcano-induced deformation: numerical models of substratum flexure, spreading and extrusion. Journal of Volcanology and Geothermal Research, v. 81, p. 1-18.

Varnes, D.J. (1978): Slope movement types and processes. in Schuster, R.L. (ed.), Landslides: Analysis and control, National Academy of sciences, p. 11-33.

Vaughan, P.R. (1988): Characterising the mechanical properties of in-situ residual soil, Second international conference on geomechanics in tropical soils, ICOTS (ed.), Singapore, Balkema, v. 2, p. 469-487.

Vaughan, P.R., Maccarini, M., and Mokhtar, S.M. (1988): Indexing the engineering properties of residual soil. Quarterly Journal of Engineering Geology, v. 21, p. 69-84.

Voight, B. (1978a): Lower Gros Ventre slide, Wyoming, U.S.A. in Voight, B. (ed.), Rockslides and avalanches - 1: Natural phenomena, Amsterdam, Elsevier, p. 111-161.

Voight, B. (1978b): Rockslides and avalanches - 1: Natural phenomena. Amsterdam, Elsevier, $833 \mathrm{pp}$.

Voight, B. (1978c): Rockslides and avalanches: an introduction. in Voight, B. (ed.), Rockslides and avalanches - 1: Natural phenomena, Amsterdam, Elsevier, p. 1-67.

Voight, B., Glicken, H., Janda, R.J., and Douglas, P.M. (1981): Catastrophic rockslide avalanche of may 18. in Lipman, P.W., and Mullineaux, D.R. (eds.), The 1980 eruptions of Mount St. Helens, Washington, U. S. Geol. Survey Prof. 1250, p. 347-377.

Voight, B., and Faust, C. (1982): Frictional heat and strength loss in some rapid landslides. Géotechnique, v. 32, p. 43-54.

Voight, B., Janda, R.J., Glicken, H., and Douglass, P.M. (1983): Nature and mechanics of the Mount St Helens rockslide-avalanche of 18 May 1980. Géotechnique, v. 33, p. 243-273.

Voight, B., Janda, R.J., Glicken, H., and Douglass, P.M. (1985): Discussion on: Nature and mechanics of the Mount St Helens rockslide-avalanche of 18 May 1980. Géotechnique, v. 35, p. 357-368.

Voight, B., and Elsworth, D. (1997): Failure of volcano slopes. Géotechnique, v. 47, p. 1-31.

Von Humboldt, A. (1814): Voyages aux régions equinoxiales du nouveau continent, 1799-1804. Paris, Dufour et Cie., 200 pp.

Wagner, A.A. (1957): The use of the unified soil classification system by the bureau of reclamation, Proc. 4th Inter. Conf. Soil. Mech. Found. Eng., London, v. 1, p. 125.

Wallace, K.B. (1973): Structural behaviour of residual soils of the continually wet Highlands of Papua New Guinea. Géotechnique, v. 23, p. 203-218.

Watson, R.A., and Wright, H.E. (1967): The Saidmarreh landslide, Iran. Geological Society of America, Special Paper, v. 123, p. 115-139.

Watts, A.B., and Masson, D.G. (1995): A giant landslide on the north flank of Tenerife, Canary Islands. Journal of Geophysical Research, v. 100, p. 24,487-24,498. 
Watts, A.B., and Masson, D.G. (1998): Reply to Comment on ' A giant landslide on the north flank of Tenerife, Canary Islands'. Journal of Geophysical Research, v. 103, p. 9949-9952.

Watts, A.B., Peirce, C., Collier, J., Dalwood, R., Canales, J.P., and Henstock, T.J. (1997): A seismic study of lithosperic flexure in the vicinity of Tenerife, Canary Islands. Earth and Planetary Science Letters, v. 146, p. 431-447.

Waythomas, C.F. (1997): Debris-avalanche-initiated tsunamis at Augustine Volcano, Alaska, reexiamined. Geol. Soc. Am. Abstracts with Programs, v. 29, p. 73.

Wesley, L.D. (1990): Influence of structure and composition on residual soils. Journal of Geotechnical Engineering, ASCE, v. 116, p. 589-603.

Williams, H., and McBirney, A.R. (1979): Volcanology. San Francisco, Freeman, Cooper, 397 $\mathrm{pp}$.

Winograd, I.J., Coplen, T.B., Landwehr, J.M., Riggs, A.C., Ludwig, K.R., Szabo, B.J., Kolesar, P.T., and Revesz, K.M. (1992): Continuous 500000 year climate record from vein calcite in Devils Hole, Nevada. Science, v. 258, p. 255-260.

Winograd, I.J., Landwehr, J.M., Ludwig, K.R., Coplen, T.B., and Riggs, A.C. (1997): Duration and structure of he past four interglaciations. Quaternary Research, v. 48, p. 141-154.

Wood, D.M. (1992): Soil behaviour and critical state soil mechanics, Cambridge University Press, 462 pp.

Zehnder, J.N. (1988): Der Goldauer Bergsturz. Goldau, Stiftung Bergsturzmuseum Goldau, 272 $\mathrm{pp}$.

Zhu, J.H., and Anderson, A. (1998): Determination of shear strength of Hawaiian residual soil subjected to rainfall-induced landslides. Géotechnique, v. 48, p. 73-82.

Zienkiewicz, O.C., and Taylor, R.L. (1989): The finite element method, McGraw-Hill Book Company, $648 \mathrm{pp}$.

Zlotnicki, J., Boudon, G., Viodé, J.P., Delarue, J.F., Mille, A., and Bruère, F. (1998): Hydrothermal circulation beneath Mount Pelée inferred by self potential surveying. Structural and tectonic implication. Journal of Volcanology and Geothermal Research, v. 84, p. 73-91. 